Galla Daniella Dominika:

GYEREKEK. OTTHON. EGYÜTTMÜKÖDÉS. KREATIVITÁS. A designkommunikáció, mint a soft készségek fejlesztését támogató oktatásmódszertani eszköz 
Marketing-, Média - és Designkommunikáció Tanszék

Témavezetők:

Dr. Horváth Dóra

Dr. Cosovan Attila Róbert

(C) Galla Daniella Dominika, 2021 
GYEREKEK. OTTHON. EGYÜTTMÜKÖDÉS. KREATIVITÁS. A designkommunikáció, mint a soft készségek fejlesztését támogató oktatásmódszertani eszköz

\author{
Doktori értekezés \\ Galla Daniella Dominika
}





\section{TARTALOMJEGYZÉK}

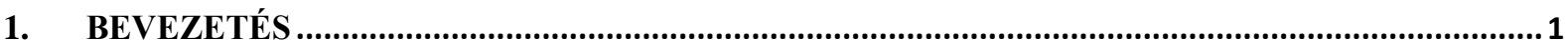

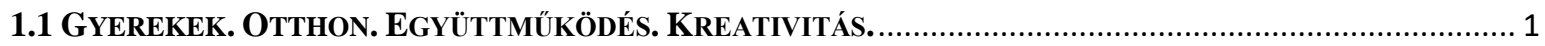

1.2 KITEKINTÉS, POZÍCIONÁLÁS: NEVELÉSTUDOMÁNY ÉS PEDAGógIA .............................................. 2

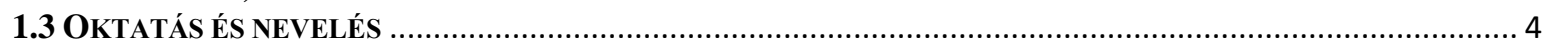

1.4 A TÉMAVÁLASZTÁS INDOKLÁSA, A DÖNTÉS HÁTTERÉBEN HÚZÓDÓ SZEMÉLYES MOTIVÁCIÓ................... 6

1.5 A TÉMAVÁLASZTÁS AKTUALITÁSA, GAZDASÁGI, TÁRSADALMI, KÖRNYEZETI RELEVANCIÁJA................ 7

1.6 A DISSZERTÁCIÓT MEGHATÁROZÓ TUDOMÁNYFILOZÓFIAI MEGKÖZELÍTÉSEM .................................. 9

1.7 AZ INTERDISZCIPLINÁRIS MEGKÖZELÍTÉS ÉS A KÜLÖNBÖZŐSÉGBEN REJLŐ EGYSÉG LEHETŐSÉGE..... 12

2. AZ ELMÉLETI KERET ÁTTEKINTÉSE, FÓKUSZBAN AZ OKTATÁS...................................14

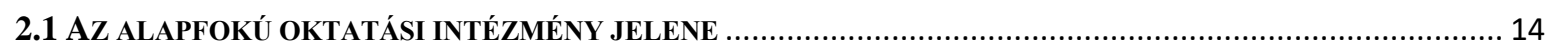

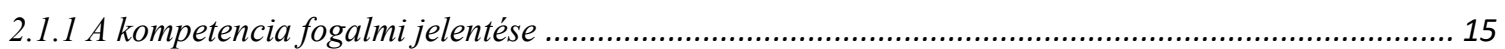

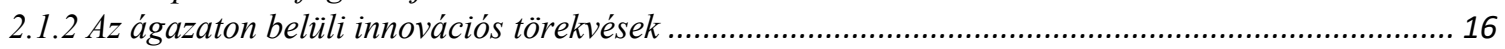

2.1.3 A jelen közoktatási helyzetben felsorakozó kutatói dilemmák a neveléstudomány területén .............. 17

2.2 A KREATIVITÁS JELENLÉTE A SZABÁLYOKKAL TERHELT ÁLTALÁNOS ISKOLÁBAN ............................ 18

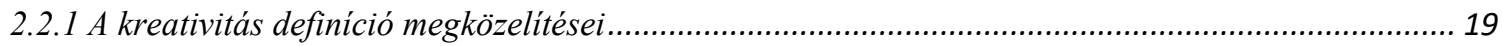

2.2.2 A kreativitást támogató és gátló környezeti tényezök ......................................................... 21

2.2.3 A fejlödésre képes kreativitás ...................................................................................................... 23

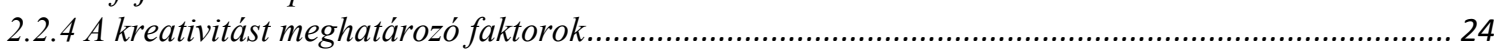

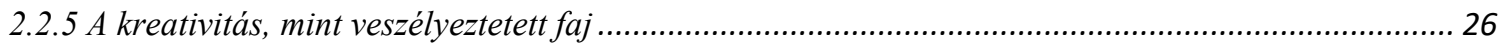

$2.3 \mathrm{AZ}$ EGYÜTTMÜKÖDÉSBEN REJLŐ LEGFONTOSABB OKTATÁS-MÓDSZERTANI LEHETŐSÉGEK ............... 27

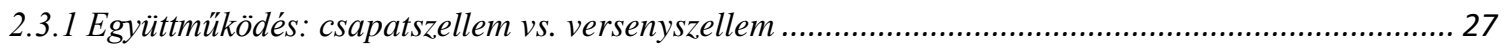

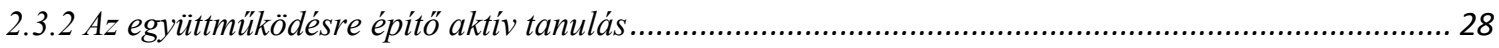

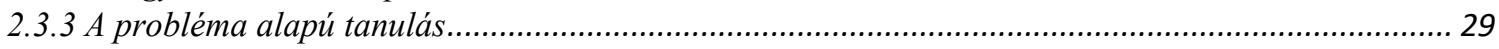

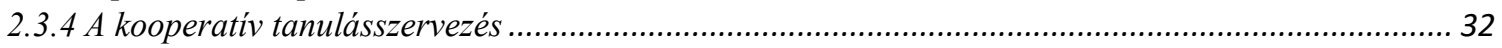

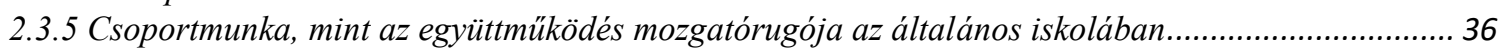

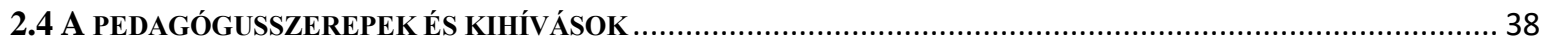

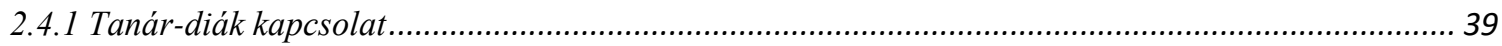

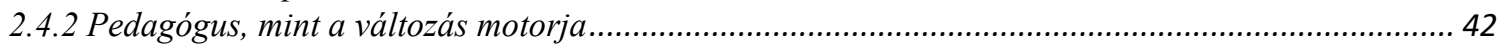

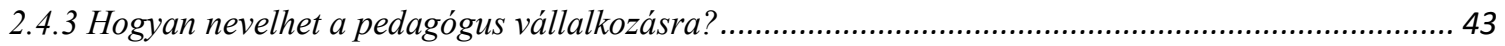

2.4.4 Kreativ pedagógus, kreatív környezet, kreativ gyermek ...................................................... 45

$2.4 .5 \mathrm{Az}$ együttmüködés katalizátora: pedagógusszerep a csoportmunkában ............................................ 48

2.5 DIÁKOK: ÚJ OKTATÁSI IGÉNYEKKEL RENDELKEZŐ Z GENERÁCIÓ ...................................................5 50

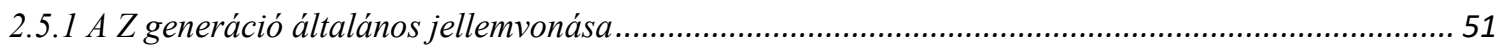

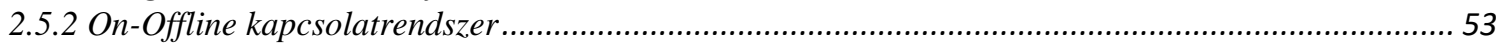

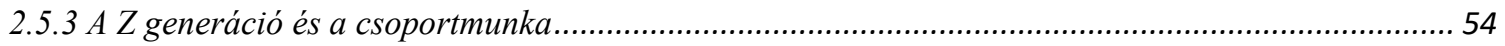

2.5.4 A formális hatalmi viszonyokat elutasító nemzedék..............................................................5 55

3. AZ OKTATÁS ÉS A GAZDASÁG POTENCIÁLIS KAPCSOLÓDÁSI PONTJAI ........................57

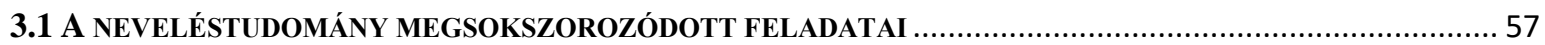

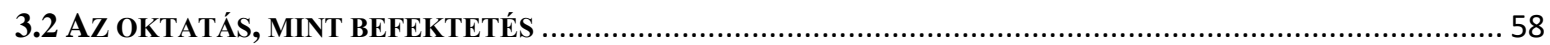

3.3 SOFT KÉSZSÉGEK, MINT A LEGFONTOSABB MUNKAVÁLLALÓI ELVÁRÁSOK? .........................................59

3.3.1 Soft készségek: a fogalom és a benne rejlö üzleti potenciál .......................................................6 60

3.3.2 A fiatal munkavállaló felé támasztott követelmények ..................................................................63

3.3.3 A soft skillek fejlesztésére irányuló törekvések az oktatásban és azon túl .....................................67 67

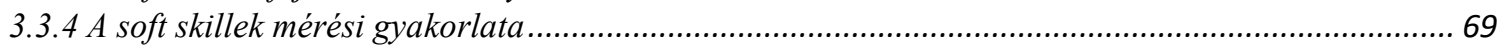

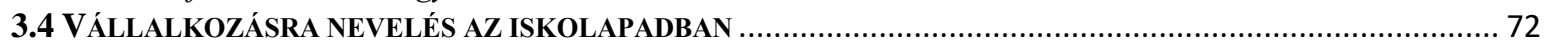

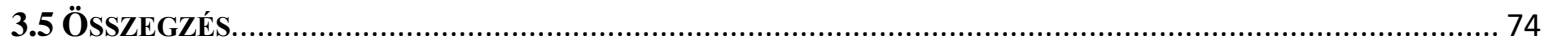

4. A DESIGNKOMMUNIKÁCIÓ, MINT MÓDSZERTANI KIINDULÓPONT ..................................76

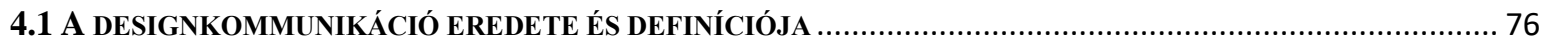

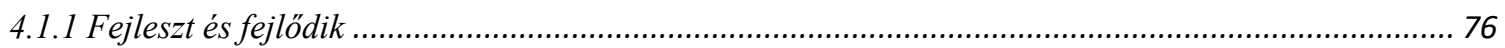

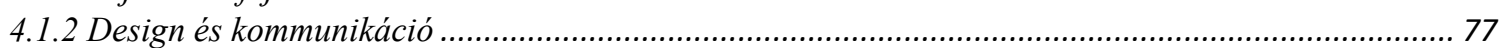




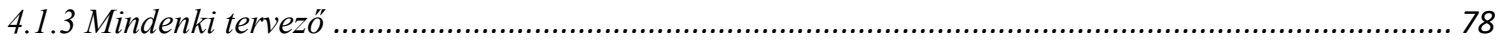

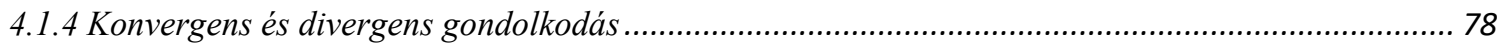

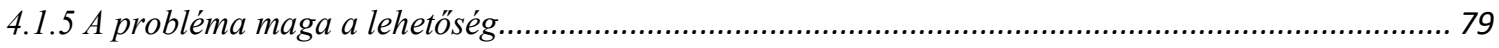

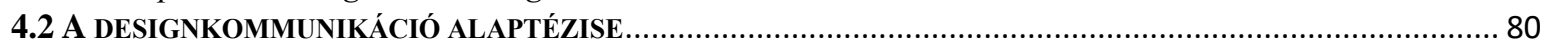

4.3 A DESIGNKOMMUNIKÁCIÓ ÉRTÉKKATEGÓRIÁJA ÉS FENNTARTHATÓ JELLEGE ..................................81

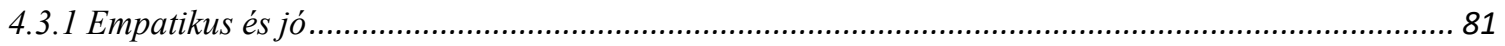

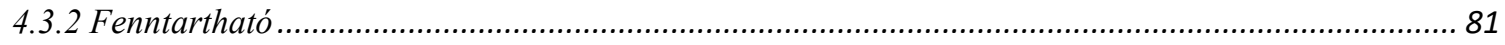

4.3.3 A megismerésen túl a felismerésre ösztönöz ........................................................................ 82

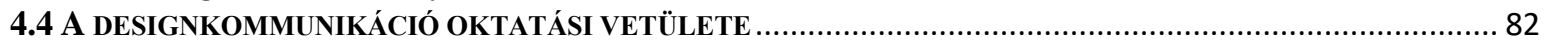

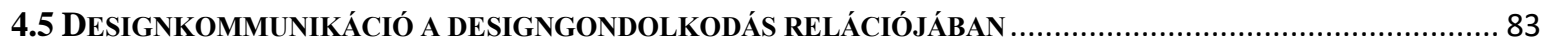

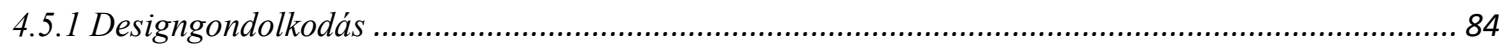

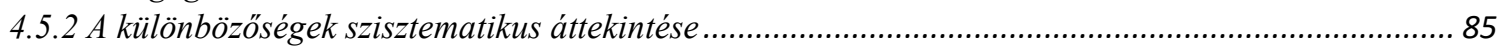

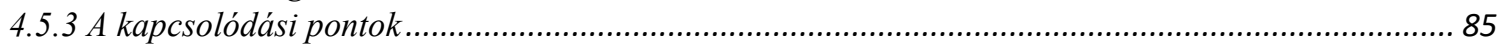

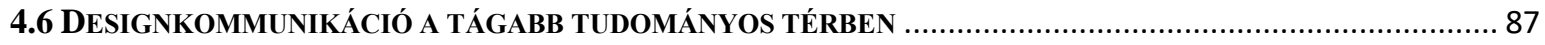

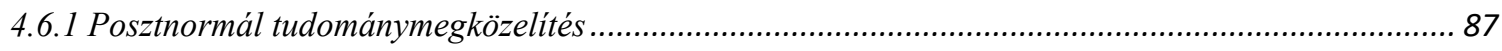

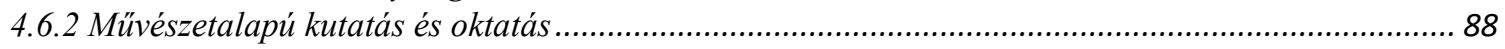

4.7 A WIKINOMIKUS EGYÜTTMÜKÖDÉS, MINT A DESIGNKOMMUNIKÁCIÓ FONTOS KATALIZÁTORA ...........90

5. KUTATOTT TÉMÁM MÓDSZERTANI MEGKÖZELÍTÉSE, A KUTATÁSI TERV ..................93

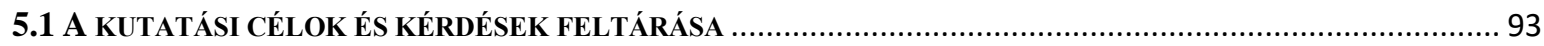

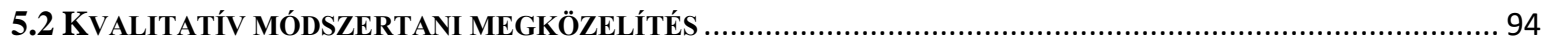

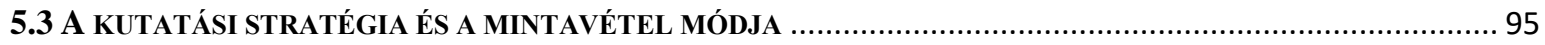

5.3.1 Multimethods, a több-módszertanú kutatási stratégia ............................................................ 96

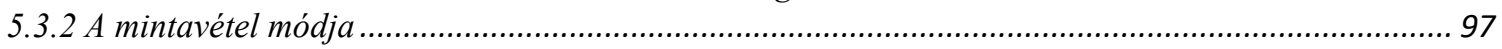

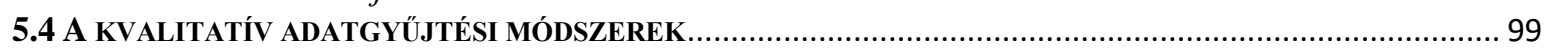

5.4.1 Mélyinterjú: a keretek meghatározása, a problémák azonosítása .................................................. 100

5.4.2 A kutatás kiemelt adatgyüjtési módszere - résztvevö megfigyelés ............................................. 101

5.4.3 Emlékkönyv: a diákok által írt reflexiók ........................................................................... 105

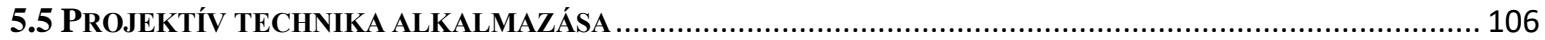

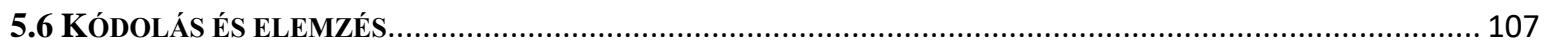

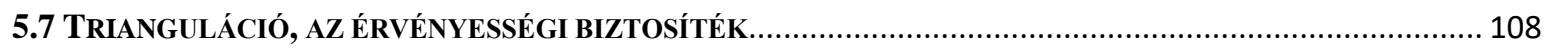

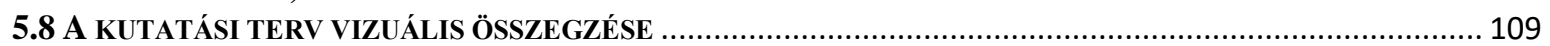

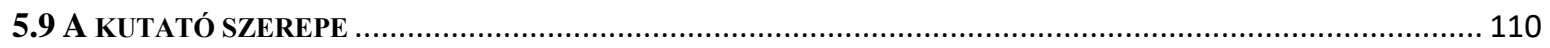

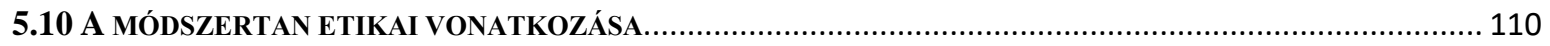

6. AZ EMPIRIKUS KUTATÁSHOZ VEZETŐ ELSŐ LÉPÉSEK ÉS EREDMÉNYEIK - AZ AKCIÓ TÁRGYA: „AZ OTTHONOM JOBBÁ TÉTELÉRE VÁLLALKOZOM” CÍMÜ WORKSHOP

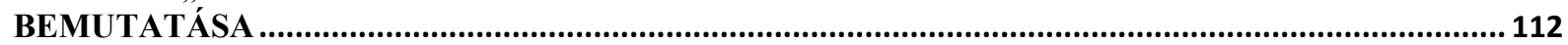

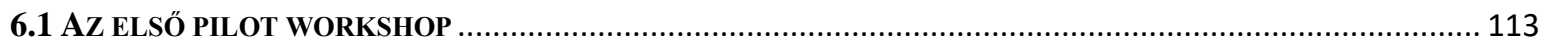

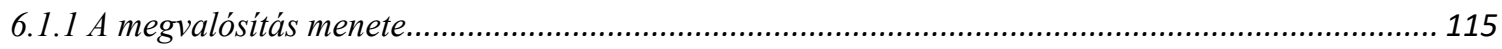

6.1 .2 A , Boldog Város " projekt ............................................................................................. 116

6.1 .3 A reflexiók és a mélyinterjúk elemzésének összefoglalása .......................................................117

6.1.4 Tanári/pedagógus szerepek értelmezése - tanári mélyinterjúk ............................................... 119

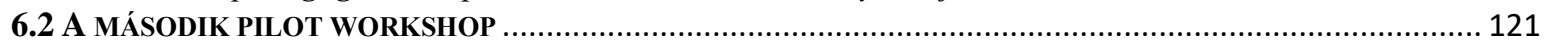

6.2.1 A.R.T.: Aktív Rendezvény Tapolcáért ............................................................................................ 122

6.2.2 Gyerekszáj - a workshop záró akkordjaként elkészült reflexiók elemzése................................... 123

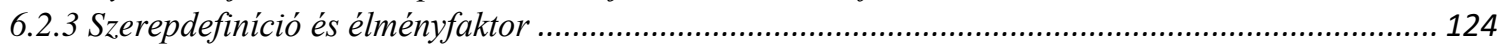

6.2.4 A designkommmunikáció módszerét ismertető prezentáció és a tréner szerepe .............................. 124

6.2.5 A csoportmunka, a közösségi alkotás nehézségei, és az eredmény, mint központi motívum ............. 125

7. AZ ELMÉLETI MEGALAPOZÁS ÉS A KUTATÁSI TERV ÖSSZEGZÉSE ............................. 127

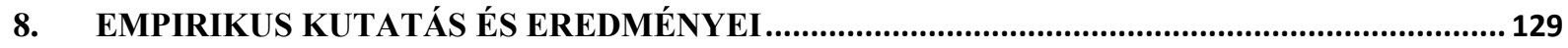

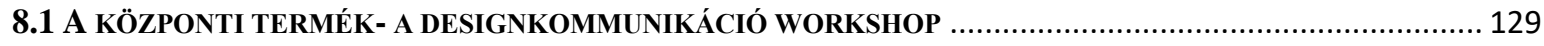

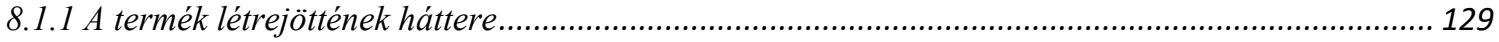

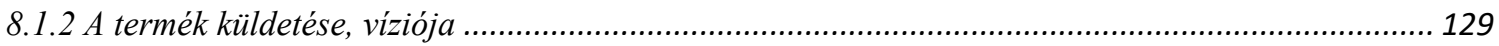

8.1.3 Elsödleges és másodlagos célcsoport ................................................................................. 130

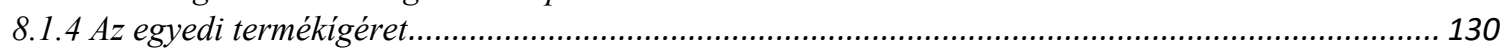


8.1.5 A termékleírás.................................................................................................................... 130

8.1.6 A termék elérhetösége, bevezetése az iskolai környezetbe ......................................................... 133

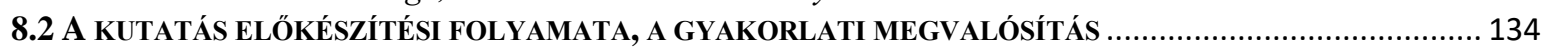

8.3 A KUTATÁSI EREDMÉNYEK BEMUTATÁSÁNAK MENETE ÉS KERETRENDSZERE ................................ 137

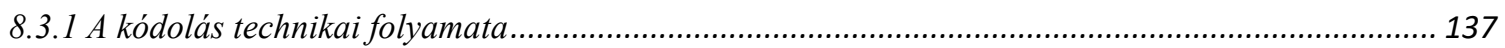

8.4 HELYSZÍNI EREDMÉNYEK STRUKTURÁLT PREZENTÁLÁSA ............................................................ 138

8.4.1 Bács-Kiskun megye, Kalocsa ............................................................................................... 138

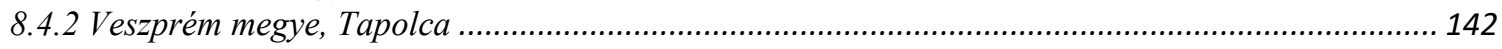

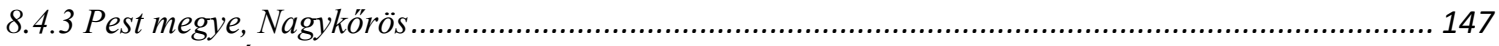

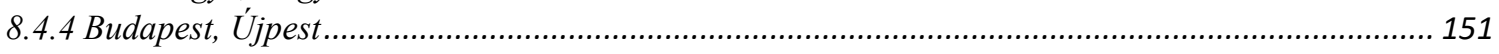

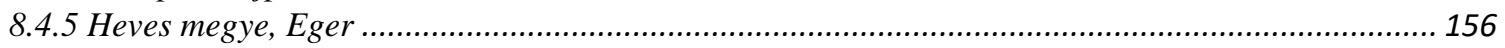

8.4.6 Borsod-Abaúj-Zemplén megye, Bodrogkeresztúr ................................................................... 161

8.4.7 Csongrád megye, Hódmezövásárhely ........................................................................................ 165

8.4.8 Borsod-Abaúj-Zemplén megye, Sajószentpéter ...................................................................... 168

8.4.9 Tolna megye, Tamási ................................................................................................ 171

8.4.10 Szabolcs-Szatmár-Bereg megye, Baktalórántháza ......................................................... 175

8.4.11 Jász-Nagykun-Szolnok megye, Besenyeszög .................................................................. 178

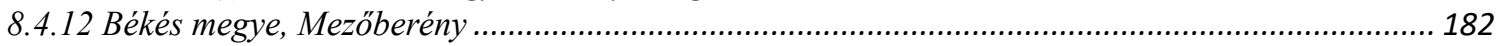

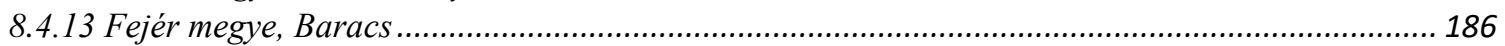

8.4.14 Komárom-Esztergom megye, Dorog................................................................................. 189

8.4.15 Hajdú-Bihar megye, Debrecen ............................................................................................. 193

8.4.16 Györ-Moson-Sopron megye, Tápszentmiklós ...................................................................... 197

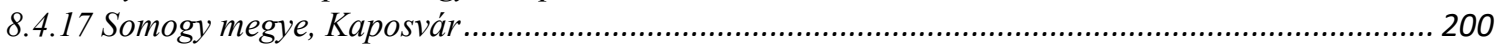

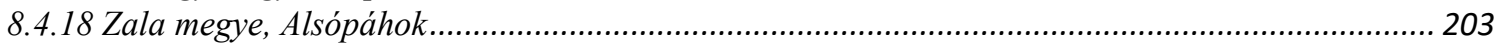

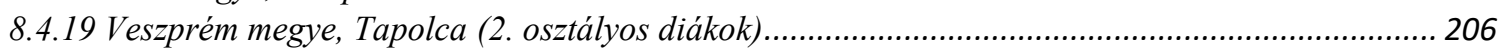

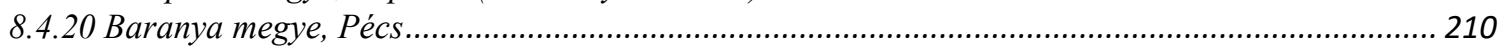

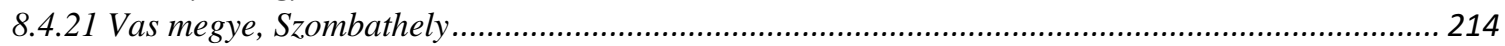

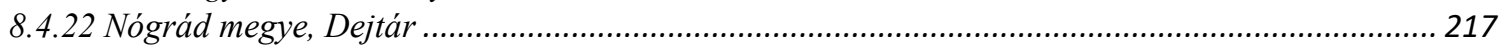

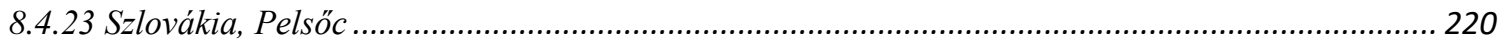

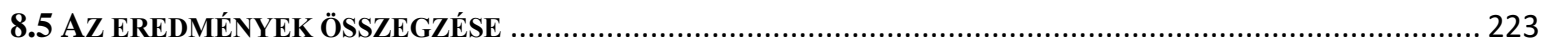

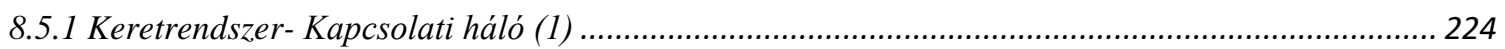

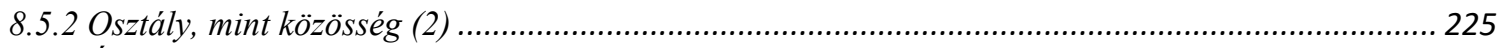

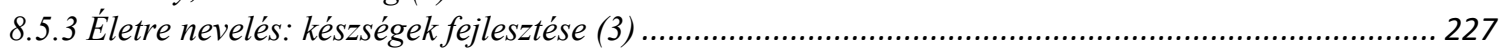

8.5.4 Fejlödésre törekvés, a fejlödés dimenziói (4) ............................................................................ 229

8.5.5 Hivatásom és felelösségem: pedagógus vagyok (5)............................................................... 230

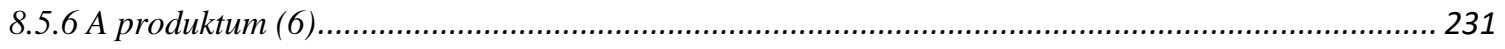

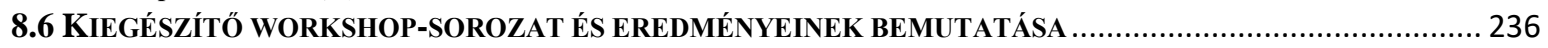

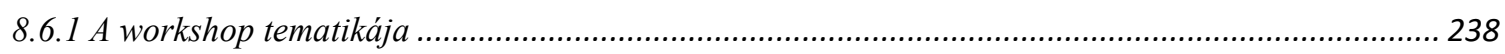

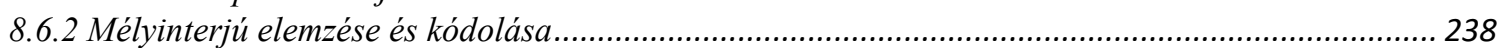

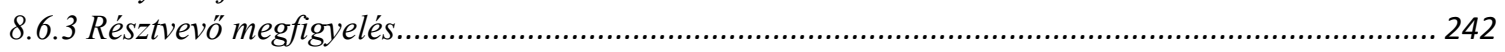

8.6.4 A diák reflexiók elemzése ...................................................................................................... 246

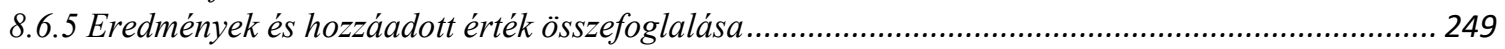

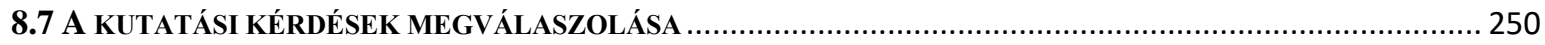

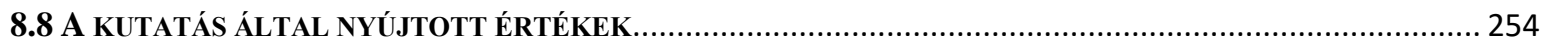

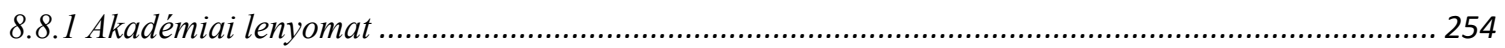

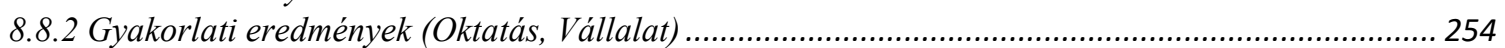

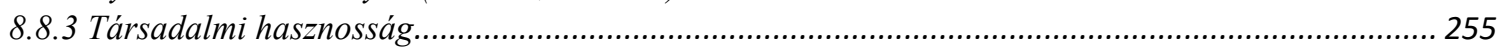

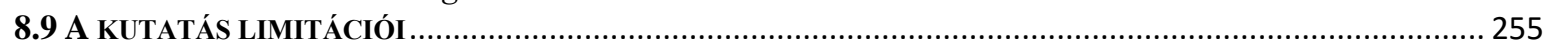

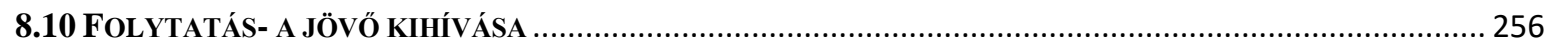

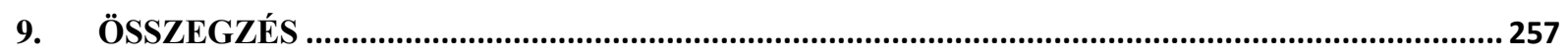

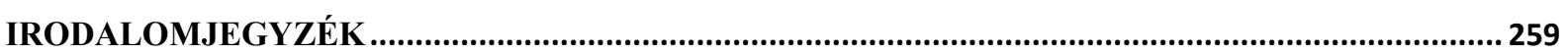

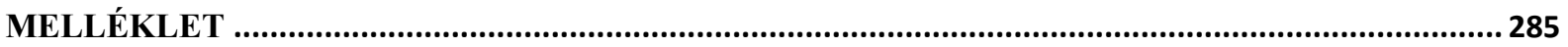

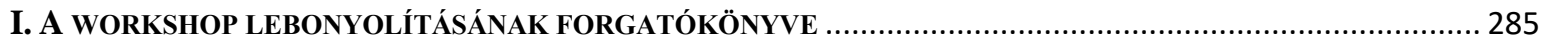

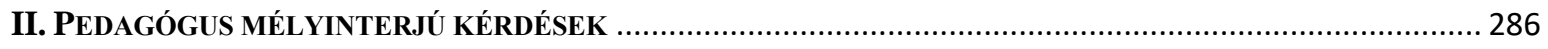

III. A WORKSHOP SORÁN BEMUTATOTT DESIGNKOMMUNIKÁCIÓ PREZENTÁCIÓ ................................... 287 


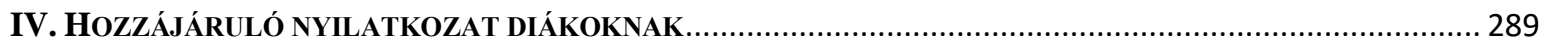

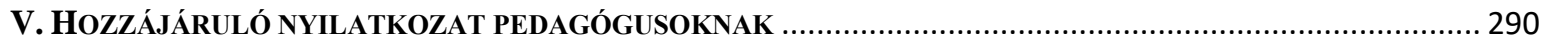

A SZERZŐ TÉMÁBAN MEGJELENT PUBLIKÁCIÓI .......................................................................... 291

\section{ÁBRAJEGYZÉK}

1. ábra: A soft készségek üzleti sikerhez történő hozzájárulása ........................................... 62

2. ábra: Az elméleti összefoglaló térképe a legfontosabb kapcsolódások tükrében................. 75

3. ábra: A kutatási stratégia és az adatgyüjtési módszerek ................................................... 95

4. ábra: A kutatási terv vizuális térképe a központi termék viszonyában ............................. 109

5. ábra: A tréning folyamatának bemutatása a résztvevői szerepek dimenziójából............... 115

6. ábra: A tréning 5 lépéses folyamata a tréner és a résztvevők relációjában ........................ 122

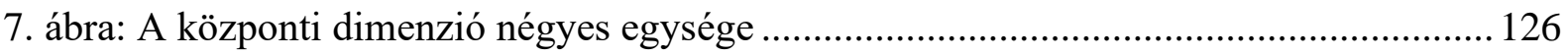

8. ábra: A dolgozat elméleti háttere és a kapcsolódó kutatási terv strukturált összefoglalója127

9. ábra: Pedagógus mélyinterjú kódjegyzék - Kalocsa ...................................................... 139

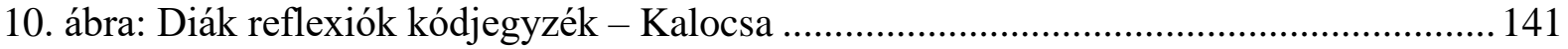

11. ábra: Pedagógus mélyinterjú kódjegyzék - Tapolca..................................................... 144

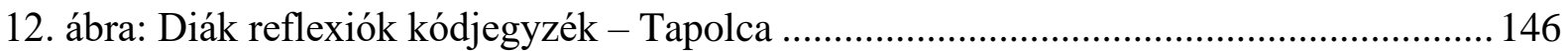

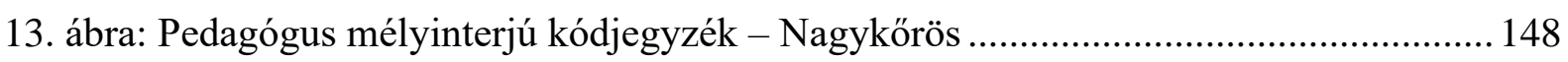

14. ábra: Diák reflexiók kódjegyzék - Nagykőrös ............................................................ 150

15. ábra: Pedagógus mélyinterjú kódjegyzék - Budapest.................................................... 153

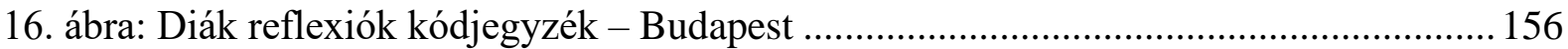

17. ábra: Pedagógus mélyinterjú kódjegyzék - Eger .......................................................... 157

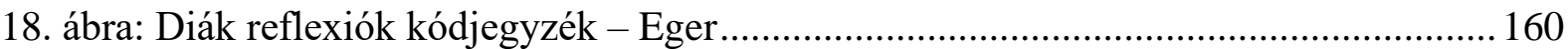

19. ábra: Pedagógus mélyinterjú kódjegyzék - Bodrogkeresztúr ......................................... 162

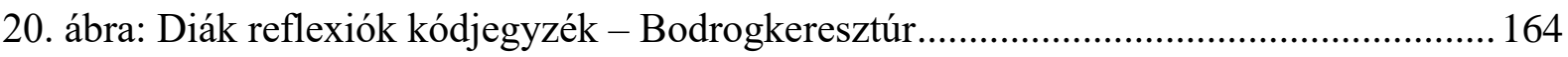

21. ábra: Pedagógus mélyinterjú kódjegyzék - Hódmezővásárhely ..................................... 165

22. ábra: Diák reflexiók kódjegyzék - Hódmezővásárhely …............................................. 168

23. ábra: Pedagógus mélyinterjú kódjegyzék - Sajószentpéter ........................................... 168

24. ábra: Diák reflexiók kódjegyzék - Sajószentpéter ......................................................... 171

25. ábra: Pedagógus mélyinterjú kódjegyzék - Tamási ........................................................ 172

26. ábra: Diák reflexiók kódjegyzék - Tamási .................................................................. 175

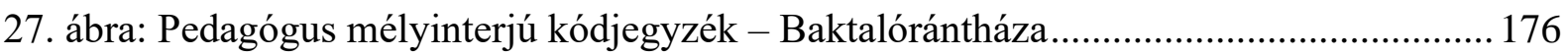

28. ábra: Diák reflexiók kódjegyzék - Baktalórántháza …................................................. 178

29. ábra: Pedagógus mélyinterjú kódjegyzék - Besenyeszög .............................................. 179 
30. ábra: Diák reflexiók kódjegyzék - Besenyeszög

31. ábra: Pedagógus mélyinterjú kódjegyzék - Mezőberény.

32. ábra: Diák reflexiók kódjegyzék - Mezőberény 186

33. ábra: Pedagógus mélyinterjú kódjegyzék - Baracs

34. ábra: Diák reflexiók kódjegyzék - Baracs 188

35. ábra: Pedagógus mélyinterjú kódjegyzék - Dorog 190

36. ábra: Diák reflexiók kódjegyzék - Dorog 192

37. ábra: Pedagógus mélyinterjú kódjegyzék - Debrecen 194

38. ábra: Diák reflexiók kódjegyzék - Debrecen 196

39. ábra: Pedagógus mélyinterjú kódjegyzék - Tápszentmiklós 197

40. ábra: Diák reflexiók kódjegyzék - Tápszentmiklós . 200

41. ábra: Pedagógus mélyinterjú kódjegyzék -Kaposvár 201

42. ábra: Diák reflexiók kódjegyzék - Kaposvár 203

43. ábra: Pedagógus mélyinterjú kódjegyzék -Alsópáhok 204

44. ábra: Diák reflexiók kódjegyzék - Alsópáhok 206

45. ábra: Pedagógus mélyinterjú kódjegyzék -Tapolca (2. osztályos diákok) 207

46. ábra: Diák reflexiók kódjegyzék - Tapolca (2. osztályos diákok). 210

47. ábra: Pedagógus mélyinterjú kódjegyzék -Pécs

48. ábra: Diák reflexiók kódjegyzék -Pécs

49. ábra: Pedagógus mélyinterjú kódjegyzék -Szombathely

50. ábra: Diák reflexiók kódjegyzék - Szombathely

51. ábra: Pedagógus mélyinterjú kódjegyzék -Dejtár.

52. ábra: Diák reflexiók kódjegyzék - Dejtár 220

53. ábra: Pedagógus mélyinterjú kódjegyzék -Pelsőc

54. ábra: Diák reflexiók kódjegyzék - Pelsőc

55. ábra: Az empirikus kutatás eredményeinek összegzése 253 


\section{TÁBLÁZATOK JEGYZÉKE}

1. táblázat: A designkommunikáció alaptéziseinek magyarázata ......................................... 80

2. táblázat: Az adatgyüjtési módszerek és az általuk rögzített adatok útja a kutatás során ... 100

3. táblázat: A megvalósult iskolai foglalkozások összegzése időpont és helyszín szerint rendezve

4. táblázat: A designkommunikáció workshop során létrehozott produktumok sajátosságai //

1. rész

5. táblázat: A designkommunikáció workshop során létrehozott produktumok sajátosságai //

2. rész

\section{ILLUSZTRÁCIÓK JEGYZÉKE}

1. illusztráció: Közös rajz-Mezőberény 184

2. illusztráció: Közös rajz-Debrecen 195

3. illusztráció: Közös rajz-Tápszentmiklós 199

4. illusztráció: Közös rajz-Tapolca. 209

5. illusztráció: Közös rajz-Pécs 212 


\section{Köszönetnyilvánítás}

Szerencsés vagyok, mert doktori disszertációm létrejöttét sokan és sokféleképpen segítették. Volt, aki nap, mint nap támogatott, biztatott és erőt adott a nehéz helyzetekben, de olyan is, aki jószándékú kritikával próbált segíteni a fejlődésemben. A legfontosabbaknak szeretném itt is megköszönni a hozzájárulást.

Köszönet és hála jár a két témavezetőmnek, Horváth Dórának és Cosovan Attilának, akikre a 4 év alatt mindig és mindenben számíthattam. Szakmailag és emberileg, mentorként és vezetőként is jelen voltak. Segítségük és hozzájárulásuk nélkül ez a disszertáció nem született volna meg.

Köszönöm a Férjemnek, aki nap, mint nap erőt adott, segített átlendülni a holtpontokon és türelmes volt velem akkor is, amikor én magammal már nem.

Köszönöm Anyukámnak és Apukámnak, akik a felbecsülhetetlen értékü lelki támogatáson túl pedagógusként is nagyon nagy szerepet vállaltak abban, hogy az empirikus kutatásom ilyen zökkenőmentesen megvalósulhatott.

Köszönöm azoknak a Tanároknak és Diákoknak, akik közvetve vagy közvetlenül részt vettek a kutatásomban, nagyban hozzájárulva ezzel disszertációm létrejöttéhez.

Végül, de nem utolsó sorban köszönöm a Kollégáimnak, akik mellettem álltak ebben az időszakban. Szeretném kiemelni a Marketing PhD csoportot, akikkel minden nap segítettük egymást az úton a szakirodalmak, pontok, publikációk és követelmények útvesztőjében. Köszönöm, hogy nem hagytatok eltévedni, vagy kerülöúton jutni a célhoz. 


\section{BEVEZETÉS}

\subsection{Gyerekek. Otthon. Együttmüködés. Kreativitás.}

Gyerekek

A címben is kiemelt kulcsszavak, melyek a kutatásom valódi esszenciáját jelentik. Egy saját fejlesztésű, kreatív oktatás-módszertani eszköz általános iskolába történő integrálását szeretném megvalósítani, ahol a vizsgálat alanyai, a kutatás főszereplői a 10-12 éves gyerekek. Ök azok, akik jelen pillanatban a Z generációt erősítik. Nem titkolt cél, hogy ez a módszertan generációkon átívelve, mindig a gyerekeket szolgálja. A mai általános iskolákban, melyek alapvetően még nem tervezői és nem is kreativitás fókuszú intézmények, a 12 éves gyerekek nyitottsága kihagyhatatlan lehetőséget biztosít a tervezői kapcsolatteremtés (A. Cosovan, 2009) megvalósítására.

Otthon

Az oktatás-módszertani eszköz implementálásához, azonnali hozzáadott értékének méréséhez a világra nyitott gyerekek középpontba állítása mellett szükség volt egy olyan központi motívumra, mellyel a gyerekek társadalmi és gazdasági háttértől függetlenül azonosulni tudnak. Ez nem más, mint az otthon, amit alapvetően a kutatás során a saját közvetlen lakóhelyük, a település szintjén determinálok, hiszen az mindannyiuk számára közös pont, amit a gyerekek ismernek, amiröl van véleményük, melynek elönyeit és hátrányait nemcsak tudják, hallják, de nap, mint nap tapasztalják saját szemüvegükön keresztül. Az oktatásmódszertani eszköz az „otthonom jobbá tételére vállalkozom” címet kapta, melynek alkalmazása során a közvetlen lakóhelytől indulva megjelenik a kiterjesztett otthon értelmezése is, ami így egy újabb dimenziót nyit a kutatásban. 
Együttmüködés

Együtt. Közösen. Talán a legfontosabb pillér... A közösség összehangolása egy tervezői folyamat megvalósításán keresztül egy közösen megvalósított produktum létrehozásának céljából. Ez lehet a valódi eredmény, mely menedzseri implikációja során a legértékesebbnek vélt munkavállalói képességek fejlesztését támogatja.

\section{Kreativitás}

A negyedik kulcsszó a kreativitás. Ennek a kifejezésnek ma különleges hozzáadott értéke van, ezzel pedig kezd a szó elhasználódni, eredeti jelentésétől eltávolodni. Csíkszentmihályi, (2008) szerint nem számít mennyire kreatív és tehetséges az egyén, ha a környezet nem értő és elfogadó, akkor nincs esély az eredményre. Itt fogalmazódik meg az alkalmazott módszertan és a disszertáció hozzáállása a kreativitáshoz: a módszerrel a támogató és befogadást segítő körülmény megteremtésére vállalkozik.

\section{Összességében a cél, hogy nyitottá tegyem a gyerekeket az alkotásra, teret engedjek} a kibontakozásukhoz az otthon, mint kézzel fogható tematika köré szerveződően, egy nem (csak) kézzelfogható kreatív, tervezői szemléletre építő oktatásmódszertani eszközön keresztül, más nézőpontot mutatni számukra a zárt iskolai rendszerben, mely egyszerre a munkavállalói léthez is támogatást nyújt.

\subsection{Kitekintés, pozícionálás: Neveléstudomány és pedagógia}

A téma tudományterületeken átível és ezzel párhuzamosan tudományterületeket kapcsol össze. Tudományos és gyakorlati jelentősége pontosan ebben ragadható meg. A Gazdálkodástani Doktori Iskolában készült disszertáció a menedzsment irodalomhoz történő kapcsolódása mellett szorosan köthető a neveléstudomány tudományterületéhez, erre alapoz, ebből inspirálódik és a tudományterület eredményeit felhasználja a holisztikus (Jarvis \& Parker, 2006) elemzés érdekében. Ennélfogva a bevezetés részeként a tudományterülethez köthető fogalmi keretek tisztázására is sor kerül. A neveléstudománynak nincs egy egyértelmü és jól körülhatárolható definíciója. Müvelői és képviselői eltérő módon értik és interpretálják, végeláthatatlan szakmai vitát és diskurzust indítva ezáltal. Ezek a viták egyfajta önmeghatározási kísérleteknek is tekinthetők a neveléstudományi kutatók között, akik helyük, 
szerepük rögzítésére törekednek egy látszatra strukturált ám a szereplők nézőpontjából ingoványosnak tünő színtéren (Furlong, 2013; Kozma, 2013). A neveléstudomány mellett a pedagógia fogalma is hasonlóan sok értelmezéssel bír. A pedagógia alapvetően egy olyan kifejezés, amelyet széles körben használnak az oktatás vonatkozásában, és éppen az a túl gyakori és általános használat feltételezi annak magától értetődő jelentéstartamát, pedig nem minden esetben egyértelmü, gyakori a nem megfelelő alkalmazása (Murphy, 2008).

A hazai neveléstudományos gondolkozás kibontakozása a 19. század második felére tehető, ekkorra datálja a szakirodalom a pedagógia, mint tudomány intézményesülésének kezdetét is (Németh, 2002). Ahhoz, hogy egy terület tudománnyá váljon sok feltételnek kell eleget tenni. Ezek között a feltételek között tartják számon a területhez kapcsolódó tudományos folyóirat létrehozását is, mely folyóirat hazánkban Magyar Pedagógia néven 1892-ben került megalapításra. Ez a pont tekinthető a neveléstudomány modern empirikus tudománnyá válásának Magyarországon (Csapó, 2005). Ezidőtájt valójában a német megközelítés átvételével, majd meghonosításával volt jellemezhető a hazai neveléstudományhoz kapcsolódó szellemi áramlat. A 20. század utolsó harmadában azonban megjelent, majd idővel mértékadóvá vált a nyugati tudományosság hatása is, ezt az időszakot az angolszász, angolamerikai tudomány recepciója jellemezte, mely irányokban erőteljesen felfedezhető a neveléstudomány interdiszciplináris jellege (Németh, 2013).

Bemutatom a disszertáció megközelítését legjobban kifejező definíciót. A neveléstudomány tehát egy olyan tudományterületként rögzíthető, amely a pedagógiai ismeretek és törvényszerüségek tudományos értelmezését hivatott elvégezni. Az emberi személyiség fejlesztésére törekvő ismeretek határozzák meg a neveléstudomány tárgyát és egyben egyediségét, melynek komplexitása már önmagában szükségessé teszi multidiszciplináris tudományként történő rögzítését. A neveléstudomány egyesíti és összegezi egyéb kapcsolódó tudományterületek módszereit és fogalmait is. A pedagógia a neveléstudományhoz kapcsolódóan egy gyakorlati tevékenységként értelmezhető, mely a neveléstudomány kutatási eredményeire épül, példaként megragadva az orvostudomány és a gyógyítás kapcsolati jellegét (Csíkos, 2020). Ezt a fogalmi keretrendszert erősíti Žogla is tanulmányában. A neveléstudományt egy integrált humanisztikus és társadalomtudományként rögzíti, amely azokat a kombinált és egyedülálló törvényszerüségeket vizsgálja, amelyek a folyamat során előforduló tanulási interakciókra, a kommunikáció és kölcsönös kapcsolatok tartalmára összpontosítanak és melyek összessége egy meghatározott kutatási objektumot alkot. A pedagógiai gyakorlati aspektusát pedig elsősorban a szervezett pedagógiai folyamatok reprezentálásában definiálja, amelyek a neveléstudományi 
elméletekre építenek, annak alapján jönnek létre, konkrét célkitủzésként azonban egy oktatási cél elérését rögzítik (Žogla, 2018). Ezek a didaktikai célok leírhatók, azonban azzal kalkulálni kell, hogy az egyedi interaktív aspektusok okán a pedagógiai tapasztalatokat nem lehet könnyen teoretizálni. Ezt a pedagógia neveléstudománytól történő eltávolodásaként is értelmezhetjük, egy új gyakorlati ismeretelmélet létrejöttével egyidőben. Egy olyan ismeretelmélet, melyben a praxis fogalma (az elmélet és a gyakorlat közötti dialektikus viszony leírására használt kifejezés a tanításban) központi szerepet játszik (Murphy, 2008).

Disszertációmban ezt az értelmezési keretet alkalmazom. Fontosnak tartom ezt rögzíteni annak okán is, hogy a pedagógia szó fogalmi jelentése és a neveléstudományhoz kapcsolódó kommunikációs viszonya sem egyértelmủen dekódolható (Biró, 2009). Vannak értelmezések, melyek a pedagógia fogalmának összetettségét hangsúlyozzák, az elméleti tudomány (neveléstudomány) és annak gyakorlati aspektusának komplex értelmezéseként tartják számon (Golnhofer, 2004). A fogalmi tisztázásra tett kommunikációs kísérletek között említhető, hogy a tudományos diszciplína képviselői magukat „neveléstudós”, majd még egy szükebb kör magát „oktatáskutatóként” aposztrofálja, míg a „pedagógus” kifejezés az intézményes oktatás/nevelés feladatát ellátó szakemberek privilégiuma maradt (Biró, 2009). Ez is rögzíti a neveléstudomány elméleti, és a pedagógia tudományhoz kapcsolódó, annak alapjaira építő, tudományos validálásához a mindennapokban hozzájáruló gyakorlati dimenzióját.

A doktori disszertációmban a neveléstudomány és a pedagógia egyaránt fontos szerepet kap, hiszen a neveléstudomány alapjaiból és kutatási eredményeiből táplálkozik a szakirodalmi elemzés, ugyanakkor a primer kutatás során a gyakorló pedagógusok jelentik a kvalitatív kutatás alanyainak egy kiemelt csoportját, ami pedig már a pedagógia gyakorlati megközelítését hivatott vizsgálni. A disszertáció célkitüzései között tartom számon, hogy megszólítsam az oktatás szereplőit és rávilágítsak, hogy a neveléstudomány elméletét kutató neveléstudósok, valamint a kutatási eredményeket a gyakorlatba átültető pedagógusok együttes munkája eredményezheti csak a tudományos diszciplína fejlődését. Az így generált fejlődés egyúttal folyamatos változást, kritikai szemléletet és rugalmasságot is kíván, ami ugyanakkor megteremti és biztosítja a tudományterület fenntarthatóságát is (Žogla, 2018).

\subsection{Oktatás és nevelés}

Az oktatás és a nevelés folyamatát szétválasztani az iskolai kereteken belül nem tudom, a kettő áthatja egymást (Fürjné Nyeste, 2017) Ez determinálja az iskola feladatkörét is. A pedagógia szerepét a szakirodalom az életen át tartó tanulásra fókuszáló felkészítésben 
rögzíti. A cél, hogy az iskola megtanítsa a diákoknak, hogy a folyamatosan változó társadalmi és gazdasági környezetben hogyan tudnak helyt állni az életben, és hogyan tudják alkalmazni a folyamatosan elsajátított tudáshalmazt (De Corte, 2001). Ehhez a legfontosabb képesség: a tanulás szeretetének, a tanulás élmény-jellegének átadása, vagyis meg kell tanítani a gyerekeket tanulni, hogy a diákot hajtsa a tudásvágy, és tudatosuljon benne, hogy tanulni jó dolog. Ezzel szemben megérkezik a diák az óvodából az iskolába, és lassan már az iskolatáskát sem bírja $\mathrm{el}^{1}$. Szigorodó követelményrendszer, sokasodó óraszám, önálló feladatok, számonkérések sorozata, teljesítményértékelés. Nem csoda, ha a felfedezés élményét nyújtó tanulási módszerekre nem, vagy alig jut idő. A diákoknak az élményt, - különösen serdülökorban- barátaik, és a közösség jelentik, iskolai közérzetük alakulásában jelentős szerepe van osztálytársaiknak, és a közöttük jellemezhető kapcsolatnak (Balogh és mtsai., 2000).

A közösségi, társas tanulás jelentősége megkérdőjelezhetetlen, integrálhatósága az általános iskolai keretrendszerbe már sokkal inkább kérdéseket és bizonytalanságot hordoz. A tanulás lehet nem csupán egyéni, hanem közös, megosztott tevékenység. A tanulás eredményesebbé tehető, ha biztosított a lehetőség a diákoknak az együttműködésre, eszmecserén, vitán, megoldási stratégiák összevetésén keresztül. A tradicionálisan túlmisztifikált egyéni tanulás helyett el kell mozdulni a szociális interakció felé az osztályteremben is, ez növeli a tanulás hasznosságát, és a közösséget is építi (De Corte, 2001).

Az oktatási reformok újra értelmezésének szükségessége nem vitatott. A gondolkodási mód megváltoztatására van szükség, egyéb esetben a reformtörekvés kudarcba fullad. Az oktatás egyre inkább tolódik el a szolgáltatás irányába, ahol a verseny kiélezett. A tudás megfoghatatlan jellege, az oktatási, nevelési szolgáltatás eredménye azt jelenti (a tanuló nézőpontjából), hogy milyen többletet tudhat magáénak az adott oktatási szakasz/képzés teljesítését követően, milyen munkavállalói értékkel gazdagodik. Az oktatás magas minősége tehát azt a hozzáadott többletértéket jelenti, ami nem egyéb nevelési forrásból származó tényezőknek, hanem tisztán az iskolai tevékenységnek az eredménye (Tosifescu, 2009).

„Az oktatást azáltal tehetjük jobban tanuló szervezetté, hogy sok-sok jó minőségü visszajelzést, visszacsatoló kört építünk a rendszerbe. Visszacsatoló köröket alakítunk ki ott is,

\footnotetext{
${ }^{1}$ http://www.ajbh.hu/-/az-ombudsman-az-iskolataska-sulyarol-es-a-gyermekekgerincproblemairol
} 
ahol eddig nem voltak ilyenek, és a visszajelzések technikáját, finomságát javítjuk, gyakoriságát növeljük ott, ahol már léteznek ilyenek, csak nem müködnek elég hatékonyan” (Csapó, 2007: 14). Kutatásomban az „otthonom jobbá tételére vállalkozom” kreatív oktatásmódszertani eszköz fejlesztésére vállalkozom, mely azonnali visszajelzést nyújt a workshopot tartó trénernek és pedagógusnak is. A visszajelzés nem csupán a workshop eredményeire hagyatkozik, maga a folyamat is egy tükröt állít a pedagógus elé. Az iskola, mint tanuló szervezet (T. Baráth, 2014; Beke, 2001; Gelei, 2002) jelenik meg, a workshop a diákok és a tréner egyidejü, közös tanulását szorgalmazza, ami az egyéni fejlödésen túl a szervezeti tudás gyarapításához is hozzájárul. A cél az oktatás szereplői szempontjából azonos: az oktatást szolgáltató intézmény és/vagy pedagógus hozzáadott többletértékének maximalizálása, oly módon, hogy az az elvárt és legfontosabb munkavállalói készségek fejlesztését is elősegítse. Ehhez az értéknöveléshez kívánok kutatásommal hozzájárulni.

\subsection{A témaválasztás indoklása, a döntés hátterében húzódó személyes motiváció}

A témaválasztásban meghatározó szerepet töltöttek be a bevezetésben megfogalmazott gondolatok, problémák, és az oktatásban rejlő kiaknázatlan fejlesztési lehetőségek. A kutatás témaválasztása a saját jövőmről szól, miközben ezzel párhuzamosan diákok jövőjére próbálok hatással lenni, az oktatásra fókuszáló reformtörekvéseken keresztül. $\mathrm{PhD}$ tanulmányaim megkezdését az oktatás iránti vágy motiválta, az a személyes attitüd, mely arra hivatott, hogy diákok számára értékes és hasznos tudást adjon át, miközben a szemléletüket is formálja, az oktatás és nevelés szétválaszthatatlan egységeként.

Pedagógus családban szocializálódtam, így nevelésemre hatással volt az adott oktatási helyzet, a fennálló problémák, az új tanulási és oktatási módszerek, valamint a pedagógusok törekvései az oktatásban fellelhető problémák megoldására. Ez mind inspirációként szolgált abban a törekvésemben, hogy kutatásom olyan irányba tereljem, melynek egyéni céljaim megvalósításán túl társadalmi haszna, akár azonnali hozzáadott értéke lehet pedagógusok és diákok számára. Ezen a ponton találkoztam a designkommunikáció, mint a kreatív alkotói kapcsolatteremtésre építő módszertannal (A. Cosovan, 2009) mely kiindulási pontként jelent meg az oktatás fejlesztésére irányuló alkotói munka során. PhD tanulmányaim eddigi szakaszáig is több kutatási projektben vehettem részt, ahol többnyire kutatócsoportban dolgoztam, így az együttmüködésben rejlő erőt és a közösségi alkotásban tapintható energiákat nap, mint nap tapasztalom én magam is. Ez inspirál, segíti a fejlödést és megerősít abban, hogy kutatásom egyik fő fókusza mennyire aktuális az oktatás relációjában. 
Az alapvető cél egy olyan kreatív oktatási gyakorlat kidolgozása, megvalósíthatóságának feltérképezése, tesztelése és eredményeinek bemutatása, mely a pedagógusokat és diákokat egyaránt aktív, egyenrangú közreműködésre sarkallja, valamint a fennálló általános iskolai oktatási keretrendszerbe gond nélkül illeszthető, és a következő kiemelt elemeket integrálja magába: (1) közösségi tanulás, (2) (tömeges) együttmüködés, a (3) csoportmunka, a (4) hierarchiamentes, egyenrangú kapcsolatok, (5) tervezői, alkotói szemléletmód, (6) vállalkozói attitüd és mindezt áthatva jelentős szerepet kap a (7) kreativitás.

\subsection{A témaválasztás aktualitása, gazdasági, társadalmi, környezeti relevanciája}

Az oktatás és az oktatáshoz kapcsolódó reformtörekvések nem tudják aktualitásukat veszíteni. Az oktatásban egyre több az érintett szereplö, az élethosszig tartó tanulás jelensége meghosszabbította az iskolapadban eltöltött évek számát, még akkor is, ha ez az iskolapad sok esetben már egy digitális tudásátadásra épít. A digitális bennszülöttek, a tanulmányunk főszereplőit meghatározó $\mathrm{Z}$ generáció már egészen másként fogadja be az információt, más módszerek müködnek, ami a tanulás átszervezését indukálhatja (Fodorné Tóth, 2018), így minden olyan módszertan, mely az oktatási rendszer reformtörekvéseit támogatja, annak társadalmi relevanciája adott. Fodorné (2018) rávilágít, hogy ez nem csak a Z generációt érintő változás, hiszen a globális-digitális hétköznapokban való túlélés, fennmaradás és fejlődés (A. Cosovan, 2009) más képességeket és készségeket kíván meg, így ehhez igazodni kell a köz-és felsőoktatásnak egyaránt.

Adódik a kérdés, hogy valójában egy, az oktatást középpontba helyező, és annak fejlesztésére irányuló kutatás hogyan kapcsolódik a gazdasági és menedzsment irodalomhoz. A legszorosabb kapcsolat abban manifesztálódik, hogy a jövő munkavállalói, az oktatás outputjaként tekinthető diákok, akik a vállalatok igényeihez, elvárásaihoz igazodó készségek elsajátításával lehetnek a jövő hatékony és sikeres dolgozói a vállalati input oldalon. Vagyis a diák, a jövő munkavállalója akkor lehet sikeres, ha az oktatásban megszerzett tudása átfedésben van azokkal a követelményekkel, melyet a vállalat és a modern gazdaság támaszt szakemberei felé. Nem meglepő, hogy az ehhez a témához kapcsolható kutatási aktivitás erős, hiszen az iskolapadból a munkába való folyamat során mind a kiindulási pont (maga az oktatási, képzési rendszer), mind a végpont, a célállomás (vagyis a munkaerőpiac) folyamatos átalakulásban van, ami állandó kutatási kérdést generál (Bartus \& Róbert, 2019). 
A disszertációban megvalósuló kutatásommal fontosnak tartom az oktatás és a munkahelyek megteremtői, a vállalatok, a gazdaság legfontosabb szereplői közötti párbeszéd fenntartását, a párbeszéd intenzitásának növelését, ahol szükséges ott hatékonyabbá tételét.

$\mathrm{Az}$ akadémiai lenyomat, a társadalmi hozzáadott érték, az oktatás fejlesztéséhez történő hozzájárulás mellett doktori tanulmányom kiemelten fontos célkitüzése a párbeszéd elmélyítése és hatékonyabbá tétele a felsorakoztatott tudományterületek mellett, elsősorban az oktatás és a vállalkozás között. Értékelve a szakirodalmi elemzés során tapasztaltakat szükséges egy erősebb, közvetlenebb és operatív szinten is realizálódó (tervezői) kapcsolatteremtés az oktatás és innováció motorját jelentő pedagógusok és a gazdaság munkavállalói elvárásait megfogalmazó és alkalmazó szereplöi között. Szükséges ez annak érdekében, hogy egy olyan generációt nevelhessünk, aki azt a tudást kapja, ami számára elvárt, hiánypótló és hasznosítható, és amely tudás felhasználása egyben a gazdaság motorjaként is funkcionál, ezzel párhuzamosan pedig előre lendíti a személyes és társadalmi fejlődést. Ezt a gondolatot számos kutatási eredmény alátámasztja (Archer \& Davison, 2008; Hurrell, 2016; Sin \& Neave, 2016; Succi \& Canovi, 2020). Ha csak a jelen disszertáció által középpontba helyezendő soft készségek relációjából vizsgáljuk, akkor egyrészt a munkáltatóknak aktívan részt kell venniük a hallgatók, valamint a diplomások soft képességeinek fejlesztésében; másrészt az akadémiának erősebb partnerségeket kell kiépítenie az iparral, és hatékonyan kell együttműködnie a munkahelyre kész diplomások garantálása érdekében (Succi \& Canovi, 2020). A doktori tanulmányaim során, a disszertáció részeként fejlesztett oktatásmódszertani eszköz többmódszertanú kvalitatív kutatás során kapott eredményei ennek a párbeszédnek az elmélyítéséhez, újragondolásához kívánnak hozzájárulni.

A téma aktualitását tovább erősíti az együttmüködés, a kreativitás és az oktatás kapcsolatának vizsgálata, a két képesség oktatási keretek között megvalósuló fejlesztésének nem elhanyagolható jelentősége. Az együttműködés egy, az általunk fejlesztett oktatásmódszertani eszköz kulcseleme, mindamellett a sikeres vállalatok müködésének egyik alappillére, aminek eredményeképpen a vállalkozók számára kiemelkedő fontosságúvá vált ez a tulajdonság a legújabb munkatársak alkalmazásának tekintetében. Így azok a frissen végzett hallgatók, akik ezen képesség birtokában állnak, nagyobb előnnyel lépnek ki a munkavállalók világába. A másik hangzatos, ám valóban egyre fontosabb és meghatározó tulajdonság a kreativitás, mely az együttmüködés mellett napjaink álláshirdetéseinek kiírásában, függetlenül a pozíció jellegétől szinte kivétel nélkül elvárt tulajdonságként jelenik meg. A kreativitás az emberi lét része, átélésének folyamata meghatározó: „az alakító kíváncsiság, $\mathbf{s}$ az így végrehajtott helyzetmegoldás, melynek kísérő élménye az önmegvalósítás” (Landau, 1974) 
A kreativitás, mint megkerülhetetlen emberi tulajdonság fontosságát hangsúlyozni kell azzal is, hogy a mesterséges intelligenciát maga az emberi kreativitás hozta létre (Boden, 1998), belőle ugyanakkor ez a tulajdonság hiányzik. A kreativitás oktatásban betöltött szerepének vizsgálata a mesterséges intelligencia jelenléte mellett is megkerülhetetlen. Elemzése kifejezetten hasznos lehet egy olyan csoport fókuszba állításával, amelynek nyitottsága lehetővé teszi személyiségük és hozzáállásuk formálását.

A téma aktualitása nem megkérdőjelezhető, gazdasági relevanciája bizonyított, de a választott téma és a hozzá kapcsolódó kutatás társadalmi haszna és környezeti jelentősége sem elhanyagolható. A témához kapcsolódóan megvalósított kvalitatív kutatás során $\mathbf{5 0 0}$ diák vehetett részt egy innovatív foglalkozáson, mely foglalkozás nemcsak a gyerekek számára jelent egy új élményt és tapasztalást, de a kutatási koncepció kialakítása során a legfontosabb szempontok között tartottam számon, hogy egy olyan kutatás valósuljon meg, melynek eredménye az oktatás szereplői számára pozitív hozadékot jelent, mellyel hozzájárulok az oktatási reformtörekvések támogatásához. A foglalkozás valós problémára épül, mely valós probléma az otthon, környezet jobbá tételét jelenti, lehetőséget adva arra, hogy a diákokat támogassa, a diákoknak teret adjon egy környezettudatos és általánosságban gondoskodó alkotói megoldás létrehozásában.

\subsection{A disszertációt meghatározó tudományfilozófiai megközelítésem}

Tudományfilozófiai megközelítésem kifejtését azzal érdemes kezdenem, hogy az itt leírt és kutatásomat determináló tudományfilozófiai elméletek mellett rávilágítok azokra az egyéb szubjektív szürő elemekre, melyek formáltak és hatással voltak rám, mint kutatóra. Ide tartozik az előképzettségem, a személyiségem, a kutatás tárgya felé kialakult attitüdöm, a feldolgozott szakirodalom interpretálása a gondolkodásmódomba, a megértésére irányuló képességem. Tudományfilozófiai megközelítésem kialakítása tehát mindenekelőtt egy hermeneutikai feladattal kezdődött, melynek során a felderítés, a kutató belső szubjektív, elemi összetevőinek megértése és értelmezése jelentette a kiindulási pontot.

A marketingkutatás területén jellemzőnek tekinthetők a pozitivista megközelítések (Malhotra, Peterson, \& Kleiser, 1999). A marketingben a domináns paradigma tehát a pozitivizmus (logikai pozitivizmus vagy logikai empirizmus), amely magába foglalja a kvantitatív módszerek alkalmazását, a realizmus elfogadását, az okság keresését és a determinizmus feltételezését (Hunt, 1994). A pozitivista kutatók úgy vélik, hogy a kísérleteken és a megfigyeléseken keresztül a teljes megértéshez juthatnak (A. B. Ryan, 2006). 
Összességében elmondható, hogy a pozitivista nézet dominál a legtöbb tudományterületen, különösen jelen van ott, ahol a szubjektív humán faktor kevésbé, mint például a müszaki vagy természettudományok terén. Egyetlen számszerüsíthető valóságot feltételez, az adatok változását a megfigyelések hatására elveti (Guba \& Lincoln, 1994). A pozitivista kutatásban az eredmény a hipotézisek, vagy tesztelendő modell formájában megfogalmazott tudás megerősítése vagy elutasítása (Kock, McQueen, \& John, 1997). A tudomány immanens megközelítése azt jelenti, hogy eltekintünk tőle, vagyis eleve figyelmen kívül hagyjuk a tudományos megismerés szélesebb, társadalmi összefüggéseinek vizsgálatát. Ez a megközelítés a pozitivizmus valamennyi árnyalatára jellemző. A pozitivizmus feladatának csupán a tudományos kutatás folyamatán, a tudományos elmélet felépítésén belüli, főként logikai és metodológiai problémák elemzését tekinti (Kocsondi, 1982). Összefoglalva „, a pozitivizmus a tudományt önálló, a társadalmi totalitás más formáitól függetlenül létező szféraként fogja fel, s ezáltal tagadja társadalmi jellegét és társadalmi meghatározottságát."(Kocsondi, 1982, o. 17) Valójában a két fő pozitivista tétel - az a meggyőződés, hogy vannak egyetemes és állandó törvények vagy elvek, amelyek egyirányú oksági kapcsolatokat képviselnek, és az a meggyőződés, hogy csak egyetlen igazi "tudományos" módszer létezik e kapcsolatok feltárására (Guba \& Lincoln, 1994). A pozitivista kutatások dominanciája arra a feltételezésre késztet, hogy ha a társadalmi kutatás megfelelő módon történik, akkor az a természettudományok mintáját követi, és világos, egyértelmű utat biztosít bizonyos társadalmi vagy pszichológiai jelenségek okaihoz. Ez azonban korántsem mondható el olyan kérdésekre irányuló kutatás során, amikor például arra keressük a választ, hogy az emberek hogyan élnek vagy hogyan gondolkoznak a világról (A. B. Ryan, 2006). Fentiekből adódik, hogy a pozitivista megközelítés nem alkalmazható jól olyan társadalomtudományi jelenségek vizsgálata során, ami bevonja az emberi tényezőt és a valós tapasztalatokat. Ennek oka, hogy figyelmen kívül hagyja, hogy képesek reflektálni független módon a problémákra. Tudományfilozófiai megközelítésem pozícionálásának, meghatározásának lényege a pozitivista szemlélettől történő megkülönböztetésben realizálódik, hiszen kutatásomat pontosan az emberi tényező és a benne rejlő potenciális változás mozgatja.

A 19. század második felében az antipozitivisták bekerültek a kutatási színtérre, és azzal a feltételezéssel éltek, hogy az egyének nem léteznek elszigetelten, és ezért őket olyan kulturális és társadalmi környezet szerves elemeként kell megérteni, amelynek részét képezik. Az 1920as évek második felében teret nyertek tehát olyan új tudásépítési paradigmák és ismeretelméletek, mint a poszt-pozitivizmus, a kritikai elmélet, az interpretatív megközelítés és a konstruktivizmus (Kock és mtsai., 1997). Az interpretatív és konstruktivista 
megközelítés közé nem tehető egyenlőségjel, azonban „közös intellektuális hagyományt” képeznek, így az együttes kezelés elfogadott (Gelei, 2006, o. 87). A posztpozitivista kutatások karakter jellemzői között már feltünik, hogy a kutatás inkább széleskörü, mintsem speciális, sokféle dolog minősül tehát kutatásnak. Az elmélet és a gyakorlat nem különíthető el egymástól, továbbá nem megengedhető az elmélet figyelmen kívül hagyása „csak a tények” érdekében. A kutató motivációja és elkötelezettsége a kutatás szempontjából központi és döntő fontosságú a vállalkozás számára. Az az elképzelés, hogy a kutatás csak az információk gyüjtésének és kategorizálásának helyes technikáival foglalkozik a posztpozitivista felfogásban már nem releváns (A. B. Ryan, 2006). A kutató és a kutatási téma elválaszthatatlan, a közöttük fellépő kölcsönhatás magától értetődik. Az ok-okozati kapcsolatra jellemző a pozitivista paradigmától eltérően, hogy minden egyes egység kölcsönhatásban fejlődik, ezért lehetetlen elkülöníteni az okokat és következményeket (Guba \& Lincoln, 1994).

Jelen kutatásomban a kritikai gondolkodás egyéni reflexióit, az önmegvalósítást helyezem a figyelem középpontjába. Tudományfilozófiai megközelítésem konstruktivista, ahol a valóság relatív és az emberi szubjektivitás kiemelt szerepet kap a jelentés megalkotásában (Baxter \& Jack, 2008). A konstruktivizmus, legalábbis a társadalomtudományokban, újabb keletű, mint az interpretivista gondolkodás, bár gyökerei a tudás racionális megalapozásával kapcsolatos legkorábbi filozófiai érvekig nyúlnak vissza. A konstruktivisták mélyen elkötelezettek amellett a nézet mellett, miszerint amit objektív tudásnak és igazságnak tekintünk, az az adott perspektíva eredménye (Schwandt, 1994). Nemcsak a tudás, hanem a megismert valóság társadalmi konstitúcióját is egyaránt tételezi, valamint azt, hogy nincs az emberi szellemi tevékenységtől és az emberi szimbolikus nyelvtől független létező valós világ (Schwandt, 1994; Zemplén, 2006). Hangsúlyozza a valóság pluralisztikus és plasztikus jellegét. Pluralisztikus abban az értelemben, hogy a valóság különféle szimbólum- és nyelvi rendszerekben fejezhető ki; plasztikus jellege pedig abban ragadható meg, hogy a valóságot kinyújtják és úgy alakítják, hogy illeszkedjenek a szándékos emberi tényezők céltudatos cselekedeteihez. (Schwandt, 1994). A konstruktivizmus az értékek és ideológiák mögött potenciálisan meghúzódó következtetésekre fókuszál (Healy \& Perry, 2000). Az alapfeltevés az, hogy a kutatónak aktívan kell építenie az ismereteket és készségeket, valamint hogy az információ ezekben az épített konstrukciókban létezik, nem pedig a külső környezetben (Huitt, 2003). A konstruált valóság feltérképezését az interjúztató és a válaszadó interakciója jelenti, a kutató így egy elszánt és aktív résztvevőként van jelen a saját terepmunkája során (Guba \& Lincoln, 1994). Kutatóként hasonló elszántság és aktív jelenlét jellemezte a személyes terepmunkámat is, a disszertációm 
során készített több módszertanú kvalitatív kutatás során mind a résztvevői megfigyelések, mind a 26 darab mélyinterjú esetében.

A kutató tudományfilozófiai megközelítésének komplex rendszerében az egyes paradigmákhoz kapcsolódóan három elemi összetevőt is vizsgálunk. Ide tartozik a filozófiai irányvonalhoz leggyakrabban kapcsolódó módszertani elem, mely a kvalitatív módszertani megközelítéseket jelenti. Erre már a kutató hozzáállására irányuló leírás engedett következtetni. Az episztemológia a kutató és a valóság kapcsolatát vizsgálja (Healy \& Perry, 2000). Az episztemológia/ ismeretelmélet egy tanulmány arról, hogy az emberek vagy az emberi közösségek hogyan ismernek meg dolgokat, és hogyan gondolkoznak erröl az ismeretröl (Keeney, 1983). Ennek értelmében a valóság létezését nem vetem el, csupán beismerem, hogy nem létezik objektív megismerés, ezért az egyének szubjektíven interpretált saját valóságának vizsgálatára összpontosítok. Ennek értelmében ontológiailag (a valóság, melyben a kutató vizsgálódik) a valóságot az egyének együttesen kreált/felépített szubjektív konstrukciójaként feltételezem jelen doktori disszertációmban alkalmazott kutatásom során (Healy \& Perry, 2000).

\subsection{Az interdiszciplináris megközelítés és a különbözőségben rejlő egység lehetősége}

Az „interdiszciplináris” egy latin eredetű szó, melynek definíciója az online Idegen Szavak Gyüjteménye alapján: „Több tudományt, szakterületet érintő (a tudományterületek közötti kapcsolatra értendő)" kifejezés ${ }^{2}$. Interdiszciplináris megközelítésröl beszélünk tehát, amikor egy kutató tudományos munkája készítéséhez különböző tudományterületekről származó ismereteket, elméleteket és szemléletmódot egységesít, kutatási tevékenységét ennek szellemében készíti el egy meghatározott cél elérése érdekében. Ez a fajta szemléletmód megköveteli, hogy a résztvevők a saját, fö kutatási irányukat meghatározó diszciplínán túlmenően a kapcsolódó tudományterületekben is elmélyedjenek, megismerjék a szakterminológiát, a tudományfelfogásban rejlö különbségeket. Fontos, hogy az egyes tudományterületek határán zajló interdiszciplináris kutatási megközelítés abban különbözik a multidiszciplináris felfogástól, hogy itt a kutató átlép saját tudományterületének határán és az eredmény a határok átlépése során tapasztalt, összeadódott tudás konstruálásából fakad (Bognár, 2016).

\footnotetext{
${ }^{2}$ Idegen szavak gyüjteménye (https://idegen-szavak.hu/interdiszciplin\%C3\%A1ris), Letöltés dátuma: 2021. 01. 30.
} 
Az Egyesült Államok már 2005-ben felismerte az interdiszciplináris kutatások jelentőségét. Egy, a Nemzeti Tudományos Akadémia (NAS) által publikált hivatalos tanulmány rávilágít, hogy az interdiszciplináris megközelítés jelentős tényezőként kap szerepet a tudományos kutatásban. A tanulmány többek között az olyan problémák meglétére alapozza az interdiszciplináris gondolkodás előre törését, melyek nem oldhatók meg egyetlen szakterületen belül, de a társadalmi problémák megoldásához szükséges hozzájárulást is ide sorolja (D. D. Horváth, Csordás, Horváth, \& Cosovan, 2020). 


\section{AZ ELMÉLETI KERET ÁTTEKINTÉSE, FÓKUSZBAN AZ OKTATÁS}

Ahhoz, hogy egy valóban hasznos és hatékony, a későbbiekben rendszer szinten, akár tantervi keretrendszerbe illeszthető oktatási modul valósulhasson meg, a fennálló határok alapos megismerésére volt szükség. Ez a keretrendszer - a szakirodalom alapján - hat dimenzió mentén került elemzésre. Ez a hat dimenzió a következőket foglalja magába: (1) az a szabályegyüttes és keretrendszer, mely az általános iskolát, mint oktatási intézményt jellemzi a jelenkorban, (2) a kreativitás jelenléte a szabályokkal terhelt általános iskolában, (3) a kooperációban rejlő oktatás-módszertani lehetőségek, a csoportmunka probléma-alapú tanulásban történő megmutatkozása (4) a pedagógusszerepek és az őket terhelö/motiváló kihívások, (5) a kutatás kiemelt résztvevőit jelentő diáksereg, a Z generáció, valamint (6) az oktatás és a gazdaság szereplőinek kapcsolata és a kapcsolatban rejlő lehetőségek feltárása kerül fókuszba az elméleti áttekintés során. A következőkben az elméleti keret első részének bemutatása kap helyet a disszertációmban, amit a feltüntetett dimenziók mentén ismertetek.

\subsection{Az alapfokú oktatási intézmény jelene}

Globalizáció, technológiai innováció, digitális és információs írástudás. Csak néhány azok közül az elmúlt évtizedben megtörtént változások közül, melyek komoly hatást gyakoroltak az alapfokú oktatási rendszer tanulásban és személyiségfejlődésben betöltött szerepének helyzetére és felfogására is (Radó, 2017). Vannak tanulmányok, melyek kérdöre vonják az országosan egységes és követendő iránymutatásként szolgáló kerettantervek alkalmazási prioritását az elsajátítandó kompetenciák javára (ld.pl. Seikkula-Leino, 2011; So \& Kang, 2014; Szebeni, 2010). A merev, tantárgyakra épülő szigorú oktatási kereteket pedig sokkal inkább az egységkép megértését támogató, tapasztalásalapú oktatási módszerekkel írnák felül (Penuel, Turner, Jacobs, Van Horne, \& Sumner, 2019).

Az oktatási gyakorlat csak lassan igazodik a fenti változásokhoz. 45 perces tanórák, heti kötelező óraszám, melyek tantárgyakra lebontott mennyiségét a kerettanterv írja elö, az óraszám tekintetében minimális teret engedve az iskolának, még kevesebbet a pedagógusnak. A tankötelezettség ma Magyarországon 6-16 éves korig tart, a gyermeknek kötelező megkezdeni a közoktatásban tanulmányait legkésőbb az azt követő naptári évben, melyben a hatodik életévét betöltötte. Az óvodától a középiskoláig biztosított az ingyenes oktatás minden magyar állampolgár számára. A közoktatás 12 összefüggő évfolyamon valósul meg, mely 3 
szakaszra bontható. Az alapfokú nevelés-oktatás szakaszban elkülönítünk alsó (1-4. osztály) és felső (5-8. osztály) tagozatot, a 9-12.osztály, napjainkban sok esetben egy előkészítő évfolyammal kiegészítve jelenti a középfokú oktatás-nevelés szakaszát (Racskó, 2017). Jelen tanulmány számára a kiemelt fókuszt az alapfokú oktatás határozza meg.

A hazai oktatás meghatározó tartalmi-szabályozó dokumentuma a Köznevelési törvény és a Nemzeti Alaptanterv, melynek 1995-ben valósult meg első bevezetése (Vilmos, 2008). A jelenleg hatályos Nemzeti Alaptanterv teljes szövegét a 110/2012. (VI. 4.) Kormány rendelet tartalmazza. Fontos rögzíteni, hogy a 5/2020. (I. 31.) Kormány rendelete alapján a módosított Nemzeti Alaptanterv lesz az irányadó. Bevezetése a 2020/2021-es tanév első félévében történt, a bevezetés felmenő rendszerben valósul meg, elsőként az általános iskola első és ötödik osztályában, a 5/2020. (I. 31.) Kormány Rendelet 4. § alapján. A Nemzeti Alaptantervhez illeszkedő tartalmi szabályozók között sorakozó tantárgyakra és évfolyamokra (1-4./5-8. osztályos diákok) lebontott kerettantervek alapján az oktató pedagógusok számára egyértelmüen rögzített a törzsanyag, a diákok számára területekre lebontva az elsajátítandó készségek. Kijelöli továbbá, hogy a NAT-ban rögzített kulcskompetenciákhoz az adott tantárgy hogyan járul hozzá, miként fejleszti a vonatkozó készséget. Meghatározza az adott tantárgy oktatása során érinteni szükséges témákat és az arra javasolt óraszámokat is feltünteti, melytől persze a pedagógus minimálisan eltérhet, de az éves szinten elvárt követelményeknek meg kell felelni (www.oktatas.hu). A NAT iránymutatást ad az alapfokú oktatásban érintett diákok egységes, vagy legalábbis egységesnek tünő haladására. A követelmények szigorúak, feszített tempót követelnek meg, így a fejlesztési célként kijelölt és 2020-ban módosított tanulói kompetenciák, úgy mint a kutatásom szempontjából is kiemelt jelentőségü kreativitás és munkavállalói, vállalkozói készségek (Petróczi, 2020) csak a tantárgyakba integráltan tudnak megvalósulni, az egyéb szabad mozgástér minimális, szigorú keretek közé szorítja az amúgy is redukált lehetőségeket (Z. Fodor, 2018).

2.1.1 A kompetencia fogalmi jelentése

Kiemelten fontosnak tartom, hogy már a dolgozat kezdeti szakaszában rögzítsem a kompetencia fogalmát, mely fogalomra a későbbiek során is építek. A kompetencia, mint egy gyűjtőfogalomként magába integrálja a készségek, ismeretek, adottságok és attitűdök együttesét, valamint magában hordozza a tanulásra való képességet is. A kompetencia segítségével képessé válunk egy összetett feladat sikeres megoldására adott helyzetben (K. Demeter, 2013). A fogalom utal az ismeretek mobilizálásának képességére egyaránt, a kognitív és gyakorlati aspektusokat is előtérbe helyezi. 
A kulcskompetencia ehhez képest döntő fontosságú a (1) kulturális tőke kapcsán, hiszen az egyén életében fontos, hogy célokat határozzon meg, melyeknek eléréséért dolgozik. A kulcskompetencia hajtóerőként jelenik meg úgy a kulturális tőke, mint a (2) társadalmi tőke vonatkozásában, segít a társadalmi életbe történő aktív beilleszkedésben. Az (3) emberi tőkéhez való hozzájárulása a kulcskompetenciáknak pedig abban nyilvánul meg, hogy képessé teszi az embert arra, hogy a munkaerőpiacon képességeihez igazodó munkát vállalhasson (C. M. Szabó \& Balázs, 2020).

\subsubsection{Az ágazaton belüli innovációs törekvések}

Az oktatási innovációs törekvések folyamatosak, egyre inkább elötérbe kerülnek a kreatív módszereket a mindennapi oktatásukba integráló alternatív iskolák, de az új NAT törekvései is ebbe az irányba mutatnak. Kutatásommal is az oktatás reformtörekvéseihez szeretnék csatlakozni. Az oktatás és innováció kapcsolata több dimenzióban értelmezhető, szerepe a nemzeti innovációs stratégiákon belül kiemelt. Az oktatás a gazdaságban és a társadalomban megvalósuló innovációs folyamatok motorja, hiszen az iskolában, az oktatás rendszerében valósul meg azoknak a képességeknek a fejlesztése, melyek nélkülözhetetlenek az innovációs folyamatokhoz, mint például a kreativitás és a tervezői attitűd, vagy a vállalkozói képesség. Ezen képességek fejlesztése pedagógiai innovációt követel, hiszen a régi berögzült módszerek erre csak korlátozottan vagy egyáltalán nem lesznek alkalmasak. Éppen ennek okán is kiemelten fontos az ágazaton belüli innovációs törekvés, hogy aztán majd hatékonyan és eredményesen legyen képes az oktatás támogatni a többi területen zajló innovációs folyamatokat is. Egy tanulmányban bemutatott kutatás eredményei alapján a hazai oktatásban magas szintű innovációs aktivitás jellemző, bár ez az aktivitás nem egyforma az oktatás egyes alrendszereiben, a kutatásom szempontjából fókuszt kapó közoktatás a sor végén áll (Á. Fazekas, Halász, \& Horváth, 2018). A kutatás alapján az újítások nagy része a pedagógusoktól indul, melynek egy kisebb része valósul meg leírható és átadható formában. A modern innovációs gondolkodás során a gyakorlati szakemberektől érkező innováció pedig egyre inkább a figyelem középpontjába kerül (Lippke \& Wegener, 2014), az innovációs folyamatok sikerének zálogát a pedagógusok birtokolják, a jövőben az igazi áttörést az alulról induló kezdeményezések jelenthetik (Jánosy, 2018), ehhez próbálok kutatásommal kapcsolódni. 
2.1.3 A jelen közoktatási helyzetben felsorakozó kutatói dilemmák a neveléstudomány területén

Az oktatás fejlesztésére vonatkozó innovációs törekvések és a hozzájuk szorosan köthető kutatások kapcsán is ismert probléma, hogy az alapkutatásban létrehozott eredmények igazolásától míg eljut a kutató a gyakorlati implementációig az egy nagyon hosszú, erőforrás orientált folyamatot jelent. A pedagógiai kísérletekre jellemző, hogy kisebb mintán kerülnek megvalósításra, csupán néhány osztály vagy iskola részvételével és a sokszor nem szokványos kísérleti feltételek megvalósítása nem, vagy nehezen kivitelezhető, továbbá a közoktatás fejlesztését szolgáló empirikus kutatások igen költségigényesek, így ritkán szolgálhatnak az oktatáspolitikai döntés megalapozásaként. Ehhez társulhat a kutatás elutasításának jelensége, amennyiben az nem áll egységben a közvélemény és a döntéshozók feltevéseivel (Csapó, 2020). Ettől függetlenül a kutató feladata nem változik, az innováció motorjaként kell jelen lenni, a tudomány eszközeit használva vizsgálni a jelenséget, bízva az áttörésben (Á. Fazekas és mtsai., 2018). Csapó (2020) tanulmánya is rögzíti, hogy az Európai Unió támogatja és inspirálja a tagországok egyéni, az oktatás és neveléstudomány fejlesztésére irányuló törekvéseit. Fontos rögzíteni, hogy az oktatás a nemzeti szuverenitás körébe tartozik, a tudományosan megalapozott és bizonyított fejlesztésre nincs, vagy csak minimális tér áll rendelkezésre. Az Európai Unió támogatásához hozzájárulnak az összehasonlító statisztikák, ilyen a kétévente megrendezésre kerülő nemzetközi PISA felmérés is, melynek legfrissebb, 2018-as eredményei (OECD, 2019) rávilágíthatnak az oktatásban rejlő hiányosságra, teret és lehetőséget engedve így a tudományosan alátámasztott eredmények gyakorlati alkalmazásának. Nem ez az egyetlen kompetenciákat vizsgáló felmérés, de ez az, amit az országok komoly visszajelzésként tartanak számon nemzetük oktatási rendszerének vonatkozásában. Kiemelt jelentősége okán a főként intézményi visszajelzést nyújtó PISA felmérési program mindenkori eredménye hatással van az oktatás és neveléstudomány területén megvalósuló tudományos kutatási törekvésekre, hozzájárul a bizonyítékokra támaszkodó döntéshozatalhoz, és kiváló visszacsatolást ad a beavatkozás hatásainak vizsgálatához egyaránt (Csapó, Csíkos, Korom, Molnár, \& Vidákovich, 2017).

Az bizonyos, hogy ahhoz, hogy a hazai oktatási rendszer nemzetközi szinten is versenyképes maradjon, továbbá versenyképességét képes legyen növelni a neveléstudományi kutatás fejlesztésére van szükség. Ennek két meghatározó kritériuma biztosan létezik. Az egyik, hogy minél több fiatal kutató számára vonzóvá kell tenni a kutatói életpályát, kiemelten az oktatás és neveléstudományt érintő területekhez kapcsolódóan, mindemellett kiemelt képzési 
minőségre van szükség, mely minőség javítását érdemes már a közoktatásban elkezdeni. Jelen doktori disszertáció szorosan kapcsolódik az oktatás versenyképességének megőrzéséhez azáltal, hogy mindkét fent említett dimenzió előre lendítésében aktív szerepet vállal.

\subsection{A kreativitás jelenléte a szabályokkal terhelt általános iskolában}

Az előző bekezdésben rávilágítottam arra, hogy a kutató, és sok esetben a pedagógus is az innováció motorja kell, hogy legyen az oktatás fejlesztésére irányuló törekvésekben. Ehhez fontos meghatározni azt, hogy az innováció miként kapcsolódik tanulmányom egyik központi kulcsdimenziójához, a jelen fejezet fókuszát is jelentő kreativitáshoz. Az innováció és a kreativitás kapcsolatát sokan, sokféleképpen közelítették már meg, szakirodalmi elemzésem során Amabile (1996) megközelítésére támaszkodom. Ö a kreativitást hasznos újításként definiálja, az innovációt pedig a kreatív ötlet szervezeten belüli megvalósításaként értelmezi. A kreativitást tekinthetjük tehát az innováció kiindulópontjának, mely annak szükséges, de nem elegendő feltételeként realizálódik (Derecskei \& Zoltayné Paprika, 2012). Ha valaki kreatív, akkor ezen képessége és motivációja az innovációt indukálja, így a sikeres innováció receptje alapján kreatív egyének képzésére majd az ő képességeik hatékony alkalmazására van szükség. Erre pedig kiemelt hatással lehet a család mellett az oktatás és az oktatás során az egyént körülvevő társak. Így érkezünk el a kreativitás oktatáson belüli kiemelt szerepéhez (Iványi \& Hoffer, 1999)

A kiindulási pont az a fentiekben is rögzített keretrendszer és szabály-együttes, ami az általános iskolát, mint oktatási intézményt jellemzi. Cél, hogy a kreativitás definícióinak egyes megközelítésének elemzésén keresztül tanulmányozzam az oktatás és a kreativitás kapcsolatát, megvilágítva azokat a sarokpontokat, melyeken keresztül az oktatás a kreativitás fejlesztését támogatni hivatott. Vizsgálom a fennálló hazai alapfokú közoktatási rendszerben a kreativitás potenciális megjelenési formáit, valamint a kapcsolódó elvárásokat. Feltérképezem, hogy a kreativitás, mint tanulói készség fejlesztésére irányuló törekvés megjelenik-e a mindennapi oktatási gyakorlat részeként. A kreativitás jelentősége és hozzáadott értéke a tudomány jelentős számú területén vitathatatlan. A vizsgált tudományterület kapcsán a fő kérdés, hogy lehetségese a kreativitás valódi, eredményekkel alátámasztott fejlesztése egy olyan oktatási rendszerben, ahol rögzített a tanóra hossza, a követelmény folyamatosan nö, így a tanmenet szerinti feladatokat is nehéz teljesíteni a 45 perces órák keretein belül? A kreativitás hasznossága, jelentősége nem kérdés, szerepe felértékelődött, és egyre több ország tekinti a kreativitás 
fejlesztését a gazdaság motorjaként, a jólét potenciális megalapozójaként (Beghetto, 2010). „A munkaerőpiac követelményei, a társadalom és gazdaság gyors ütemü fejlődése egyre több kreativitást és problémamegoldást vár el a felnövekvő generációktól” (K.Nagy \& Pálfi, 2017, p.76).

\subsubsection{A kreativitás definíció megközelítései}

A kreativitás jelentése nehezen definiálható, a megfogalmazások jellemzően szerteágazóak. Már az ókori görögök számára is minden esetben vitaindító volt a fogalom precíz leírása, definiálását igen bonyolultnak ítélték meg (Crimmins-Crocker, 2018). PéterSzarka és szerzőtársai (2015) nyomán Mumford (2003) definícióját emelem ki, ami szerint a kreativitás „újszerű és hasznos”. Mumford definíciója nemcsak önmagában állja meg a helyét, de a kreativitás definíciók egy igen jelentős számának összefoglaló irányát is jelöli. A szakirodalmi viták általános megállapodásaként rögzíthetem, hogy a kreativitás magába foglalja a létrehozott termék/ötlet eredetiségét, valamint a kreativitás eredményeként megvalósult ötlet/termék hasznos jellegét (Walia, 2019). A legtöbb modern kutatás a kreativitás vonatkozásában ragaszkodik az ötlet újszerüségéhez és hasznosságához, ezt tekinti a kreativitás viszonyítási pontjaként. Az újdonság az eredetiségre utal, azaz valami új előállítására, a hasznosság pedig egy ötlet megfelelöségére, a probléma megoldására törekszik (Amabile \& Pratt, 2016). Ez a megközelítés elsősorban eredményfókuszú, esetemben, a Z generáció kapcsán a folyamat - a kreatív alkotói folyamat - elemzését kell a középpontba állítani, gyakorlatilag az újszerüség a folyamat kialakítása során is helyet kaphat, nemcsak a megoldás, de a megoldáshoz vezető út, mint eredmény is jelentheti a kreativitást. A gyerekektől nem elvárható, és az objektív kritériumok mentén legtöbb esetben nem is nevezhető a gyermeki produktum kreatívnak, az addig végbemenő folyamat már annál inkább (Péter-Szarka és mtsai., 2015). Mumford definíciójához kapcsolható Kaszás kreativitás értelmezése is, aki arra világít rá, hogy egy gondolat akkor nevezhető kreatívnak, ha eredeti és egyben használható (Kaszás, 2014). Az eredetiség és a hatékonyság fogalma hosszú múltra vezet vissza, így segítségükkel a sztenderd kreativitás definíció kiválóan értelmezhető Runco és Jaeger (2012) megfogalmazása alapján, mely szintén szoros összhangban áll a fentiekkel.

Kutatásom sajátosságait szem előtt tartva a kreativitás definíciók közül még két irányt érdemes górcső alá venni. Megemlíteném Landau kreativitás definícióját, ami Mumford fogalmával szemben az eredmény helyett a belső folyamat jellegre fókuszál, mely a megszerzett és az egyén birtokában lévő ismeretektől és az intelligenciától nem függetleníthető, ezen mégis 
túllépő önálló alkotó tevékenység (Landau, 1974). Ez a definíció közvetve rögzíti a kreativitás fejleszthetőségét is, hiszen azt mondja ki, hogy az egyéni ismeretek befolyásolhatják a kreativitást, és ezen egyéni ismeretek pedig az oktatás során javíthatók, kiterjeszthetők. A másik fontos irány Csíkszentmihályi nevéhez kötődik, aki a kreativitást a probléma felismerésének képességében értelmezi (Csíkszentmihályi, 1988). A kreativitás értelmezése 3 fö összetevő rendszereként kerül értelmezésre. Az első összetevő a tartomány, ami nem más, mint szabályok és folyamatok együttese, a második összevető az a szakértői kör, aki azokat jelenti, akik arról döntenek, hogy a kreatív folyamat során létrejött eredmény bekerülhet-e ebbe a tartományba. A harmadik dimenzió pedig nem más, mint maga az egyén és az egyént meghatározó képességek (Csíkszentmihályi, 2018) A kreativitás tehát vagy megváltoztatja a létező tartományokat, vagy új tartományt valósít meg. A kreativitás nem csupán az egyéni kreativitástól, képességektől függ, hanem attól, hogy az adott tartomány és a hozzá tartozó szakértői kör mennyire látja az ötletet befogadhatónak, mennyire képesek felismerni az adott ötlet újdonság értékét. Szükséges még továbbá egy olyan infrastruktúra, mely segíti a szakértők, a tartományok és az egyének összekapcsolódását, hogy aztán a kreativitás eredményei az innovációs folyamatokban is felhasználásra kerüljenek (Székely, 2013). Az oktatásban minden tényező adott, csak azok megfelelő és hatékony összehangolására lenne szükség.

A későbbiekben bemutatásra kerülő alkalmazott módszertan, a designkommunikáció kreativitás felfogása a túlélési ösztön emberi manifesztációjaként kerül rögzítésre (A. Cosovan \& Horváth, 2016). Itt egy olyan kreativitás definícióval állok szemben, melynek eredményéért az alkotó felelősséget vállal, és ahol a kreativitás és az innováció közötti szakaszt a tervezői képesség fedi le. A jelenség rögzíthető cselekvő kreativitásként, ahol a kreatív elme ötlete nem csak a gondolat, hanem a cselekvés szintjén is értelmezhető, ahol a cselekvés egyúttal egy felelősségvállalást is jelent a saját kreatív produktum felé.

Összességében látható, hogy ha leegyszerüsítem, akkor a sztenderd kreativitás definíciók során a jelenség két dimenzióban manifesztálódik: adott egy új(szerü), eredeti ötlet mely ötlet önmagában értékes, vagy olyan termékek előállításához járul hozzá, melyek értékesek. Fontos látni, hogy új és értékes ötlet létrejöhet véletlenszerűen is, például egy folyamat melléktermékeként, amikor nem a kreatív elme indukálja az eredményt. Hills és Bird (2019) tanulmányában arra vállalkozott, hogy a kreativitás megszokott definícióját tovább gondolja, a kreativitással társított és berögzült értékítéletet megkérdőjelezze és egy olyan meghatározást alkosson, mely az értékalkotást háttérbe szorítja- azt fenntartja, hogy bár a kreativitás alapvetően nem az érték objektumának előállítására irányul, ennek ellenére erősen elősegíti 
azok létrejöttét-, az eredetiséget előtérbe helyezi (Hills \& Bird, 2019). Az eredetiséghez három kapcsolódó feltételt állítanak, melyek általában nem találhatóak meg a hagyományos kreativitás definíciókban, ez a képzelet, a termékenység és a motiváció. A kreativitás a tanulmányban megfogalmazottak szerint az egyén diszpozíciója vagy összekapcsolt diszpozícióinak halmaza, melynek során az eredeti új ötlet a képzelet felhasználásával generálódik rendkívül változatos és produktív formában, és ez az ötlet a belső motiváció által a megvalósításig jut. Egy kreatív egyedben ennek a három egységnek a kombinációja egyszerre van jelen, vagyis a kreatív cselekedetek és produktumok ezen diszpozíciók manifesztációjaként jönnek létre. A definíció nem zárja ki azt, hogy a kreativitás hozzájárulhat az értékalkotáshoz is, ehhez további két feltétel teljesülését szorgalmazza, miszerint építeni kell korábbi, megalapozott már működő példákra és modellekre és a jó megítélés, és jó megítélőkészség/felismerés, hogy kiderüljön, mely, a képzelet által generált új ötletek azok, amik valóban értékesek (Hills \& Bird, 2019). Az oktatás és kreativitás kapcsolatának vizsgálata szempontjából a kreativitás definiálásának ez az aspektusa azért lehet jelentőségteljes, mert az iskolában az értékalkotás a nevelési alapelv részét képezi (Mátés, 2019). A kreativitás fejlesztése egyre inkább az oktatás feladata (Molnár, Turcsányi-Szabó, \& Kárpáti., 2019). Ezt a feladatot érdemes összehangolni a jóra való törekvéssel. Ha a diák a kreativitás fejlesztésére irányuló képzés során elsajátított, továbbfejlesztett készséget, a kreativitását arra használja fel, hogy megtervezze, hogy hogyan lógja el a tanórát, akkor a fejlesztésre irányuló oktatásmódszertani eszköz a nevelés dimenzióját tekintve nem biztos, hogy a legideálisabb, de a kreativitásra gyakorolt hatása nem vonható kétségbe. Amikor tehát módszertant választok, ami a kreativitás fejlesztését segíti, akkor több komponens összhangjára kell törekednem. Saját fejlesztésű designkommunikáció workshopom a kreativitás hagyományos definícióira épít, és a kreativitás kibontakozásával párhuzamosan, attól elválaszthatatlanul az értékalkotásra is hangsúlyt helyez, ösztönözni próbálja ezzel a diákokat arra, hogy a bennük rejlő képességeket pozitív célok megvalósítására használják.

\subsubsection{A kreativitást támogató és gátló környezeti tényezők}

A kreativitás csak úgy magától nem történik meg. A csoda létrejöttéhez egy támogató környezetre van szükség, ami közvetve az innováció esélyét is növeli (Derecskei \& Zoltayné Paprika, 2012). A kreativitás iskolában történő kibontakozása szempontjából igen lényeges elem a támogató és gátló környezeti tényezők felismerése. Sahlberg (2009) tanulmányában 3 a kreativitást segítő, és 3 azt gátló tényezőt rögzít és részletez. Környezeti akadályként 
definiálja a versenyt. Érthető, hogy a szülők iskolaválasztását segíti, az összehasonlítást megkönnyíti, sokszor ez a verseny pontosan, és kizárólag erről szól. Nem feltétlen az oktatás színvonala nő, az erőfeszítés többnyire csupán a marketingcélokat szolgálja. A folyamatok standardizálása, és a tesztalapú, könnyen mérhető számonkérés ugyancsak nem támogatja a kreativitást.

Három támogató tényező ismertetése is helyet kap Sahlberg (2009) értekezésében. Ide soroljuk az együttműködés jelentőségét, a kockázatvállalást, és a hibázást is. Az iskola feladata az, hogy megtanítsa, hogyan legyenek képesek a diákok jól megoldani a feladatot. A kreativitásnak sokszor pont a félelem szab gátat: a félelem attól, hogy valamit rosszul csinálunk. A hibázás lehetőségének elismerése lebontja ezt a falat, egy olyan környezet megteremtése, mely elfogadja a hibákat biztonságot, és bizalmat nyújt a diákoknak, ami teret enged a kreativitásnak. Amikor a kreativitás fejlesztésére irányuló módszertan kialakítására és alkalmazására törekszünk, akkor érdemes a támogató tényezőket előtérbe helyezni, míg a kreativitást gátló tényezőket a lehetőségekhez képest a leginkább visszaszorítani. Korábbi vizsgálódások rámutattak, hogy a kreativitás és az innováció megtörténtének valószínüsége nagyobb, ha a támogató tényezők jelen vannak. Fontos kiemelni, hogy ez önmagában nem elegendő, szükséges hozzá a megfelelő tanár-diák kapcsolat és a bevonódás (Ferrari, Cachia, \& Punie, 2009), valamint egy kreatív attitűddel rendelkező, nyitott pedagógus is .

Csíkszentmihályi a kreativitást 3 fő dimenzióban értelmezi, mely rendszeregyüttest már korábban ismertettem. Itt visszautalok arra, hogy az a tartomány, amiben a szakértői kör által elfogadásra vagy elutasításra kerül az egyén kreatív gondolata nagyon erősen rávilágít arra, hogy a környezetnek milyen intenzív szerepe van a kreativitás kibontakozásában (Csíkszentmihályi, 2018). Ennek a környezetnek a befolyása gyerekeknél, az oktatási keretek között, ahol jellemzően a hierarchikus tanár-diák kapcsolat egyértelműen determinálja, hogy ki az a személy, aki a döntést hozza, még intenzívebb. Nem véletlen, hogy más kutatók is elötérbe helyezik a környezeti tényezőket a kreativitás kapcsán. Amabile arra világít rá, hogy (1) a kreatív megoldások nagyobb valószínüséggel születnek, ha az egyének olyan terület kapcsán alkotnak valami újat, melyet ismernek, amivel sokat foglalkoznak (Amabile, 1996). Az oktatásban ez kiaknázható oly módon, hogy a kreativitás fejlesztésére irányuló oktatásmódszertani eszközök által feldolgozott témákat a gyerekek kifogástalanul ismerik, így nem szab gátat kreativitásuk kiteljesedésében a bizonytalanság, hanem tudnak meglévő ismereteikre építeni. A kreativitás megjelenését tovább fokozza, (2) ha valóban alkalmazásra kerülnek a kreativitás fejlesztésére irányuló módszerek, vagyis az iskolákban, a tanórák 
keretein belül irányítottan meg kell jelennie és tudatosan alkalmazni kell ezeket az eszközöket. A kreativitás megfoghatatlan jellege (Kaufmann, 2003), mérhetőségének bizonytalansága (Harsányi \& Szántó, 2018) miatt sok esetben annak fejlesztésére irányuló törekvés nem elsődleges szempont az oktatásban érintettek számára, napjainkban egyre inkább kezd a kreativitás, mint elsajátítandó/fejleszthető (Sternberg, 2006) képesség nagyobb teret kapni, mérhetőségére egyre több eredményes próbálkozás születik (DeHaan, 2009), így jelentősége körüli kétségek fokozatosan háttérbe szorulnak. Amabile (1996) megközelítése alapján az utolsó támogató környezeti tényező az (3) erős belső motiváció, mely szintén intenzíven függ a validáló szakértôi csoporttól, az oktatásban a pedagógustól, a lelkesedésétől, valamint a kreativitásnak helyet adó tartományi keretektől.

\subsubsection{A fejlődésre képes kreativitás}

A kreativitást az egyik legösszetettebb és egyben legfontosabb emberi viselkedések között tartják számon. Alapvető személyiségbeli képesség, melynek jelentősége, szociális fontossága egyértelművé válik, ha csak arra a számtalan tudományos és technikai vívmányra, az emberi életminőséget magasabb szintre emelő termékekre, müvészeti alkotásra gondolunk, melyek ugyancsak az emberi kreativitás manifesztációjaként realizálódtak. A pedagógia oldaláról tekintve kialakítása, fenntartása és fejlesztése prioritást kell, hogy élvezzen a nevelésoktatás során, hiszen a kreativitás alapvető humánértéket képvisel. Korábbi kreativitás nézőpontok alapján a kreativitás kiváltságot jelentett és csak kivételes képességű személyek birtokolhatták-e jelzőt. Ma ez a szemléletmód meglehetősen átalakult, a kreativitás lehetősége közkincesé vált, mely magával hordozza a különösen kiskorban megvalósítható fejleszthetőséget, mely nézőpont fokozott pedagógiai jelentőségéhez nem fér kétség (L. Fodor, 2015). Hatása egyértelmű és széles körben tetten érhető, a mindennapi élet problémáin átívelve egészen a müvészetek és a tudomány területein keresztül. A fentieket erősíti, hogy a kreatív képességet inkább a normatív emberi kognitív müködés szerves részének tekintik, mint egy velünk született adottság, mely csak néhányaknak adatik meg. Így tehát a kreatív gondolkodás függ az alapvető kognitív folyamatoktól, ami a kreativitás egyéni eltérő minőségére is választ ad. A kreatív problémamegoldási folyamatok során alkalmazott mentális müveletek fejlődése és alakíthatósága arra utal, hogy az egyéni kreativitás fejlődni képes az életkorral és a megfelelően alkalmazott fejlesztési módszerekkel (Stevenson, Kleibeuker, de Dreu, \& Crone, 2014). Valójában számos tanulmány (Sowden, Pringle, \& Gabora, 2015) bizonyította már a kreativitás fejlesztésére irányuló célzott tréningek hatékonyságát, úgy, mint a divergens 
gondolkodás javítására való törekvések, melyek kifejezetten jó hatással voltak a teljesítmény növelésére, de hatásuk a fogékonyságban és a rugalmasságban is tetten érhető. Stevenson és szerzőtársai (2014) kutatása során serdülő korú gyerekek és felnőttek relációjában figyelte, hogy 3 különböző típusú tréning -melyek közül egy közvetlenül a kreativitás fejlesztésére irányult- milyen hatással van a résztvevők fejlődésére. A kutatás során az bizonyosodott be, hogy a serdülők számára több hasznot jelentett a tréning, függetlenül annak típusától. Eredménye többek között arra világított rá, hogy a serdülőkör egy előnyös időszak, egy hasznos életkor a „dobozon kívüli” gondolkozás (thinking outside the box) fokozására és a kreatív folyamatok elsajátítására (Stevenson és mtsai., 2014). Tekintettel a kreatív gondolkodás fontosságára az egyéni sikerek és a társadalmi fejlődés lehetőségének biztosítása érdekében a pedagógusoknak ki kell használni ezt az érzékeny és fogékony időszakot a divergens gondolkodás fejlesztésére, mely hosszú távon a kreativitás képességét fejleszti. A szakemberek alapvetően azt a kutatási eredményt tekintik irányadónak, mely a kreatív viselkedést tekinti természetesnek, a nem kreatív viselkedést ezzel szemben tanult viselkedésként rögzíti (Higgins, 1996). Ez a kutatási eredmény még inkább az iskolák felelősségét helyezi reflektorfénybe, hiszen közvetve azt jelentheti, hogy nem is elsődlegesen a kreativitás fejlesztése a cél, hanem az, hogy ne adjunk teret a kreativitás háttérbe szorulásának, megrekedésének és visszafejlődésének. További vizsgálatok is elemzik a kreativitást az életkor viszonyában, melynek eredménye szintén arra enged következtetni, hogy a kor és a kreativitás szintje nem szétválasztható, ebből kifolyólag fejlesztését (szinten tartását) minél fiatalabb korban kell megkezdeni. Az eredmények számokban azt mutatták, hogy míg az óvodásoknál vizsgált kreativitásszint kifejezetten magasnak tekinthető (90-95\%), addig az öket korosztályban követő általános iskolásoké 70-75\%-ra tehető. A középiskolában tanulóknál a szint lecsökken 40-50\% közé, a felsőoktatásban tanuló hallgatók esetében pedig 20-25\%-ot mértek. A felnőttek esetén jelentős a csökkenés, esetükben a kreativitás szintje a kutatás alapján $10 \%$ alá tehető (Buzan, 2006).

\subsubsection{A kreativitást meghatározó faktorok}

A kreativitás fejlesztése kapcsán gyakori az általánosítás, egyre több pedagógiai foglalkozásra, játékra használják a „kreativitás fejlesztését segíti” jelzőt anélkül, hogy bizonyítottan ez volna az elsődleges célja. Ahhoz, hogy az iskola valóban képes legyen hatékonyan fejleszteni a kreativitást és kiválasztani az ezt leginkább támogató oktatásmódszertani eszközt meg kell határoznia azt, hogy mi a cél, milyen tulajdonságokkal 
írható le egy kreatív elme, mi jelenti egy kreatív személy megkülönböztető jegyeit. Ezt követően már könnyebbé válhat a fejlesztésre irányuló eszközök differenciálása is, hiszen így a kreativitás, mint tulajdonság további tényezőkre, összetevőkre bontható, mely elemek fejlesztésére irányuló törekvések ilyen módon sokkal pontosabban meghatározhatók az egyes oktatásmódszertani eszközök, foglalkozások esetében.

A kreativitás faktorai, a kreatív személy megkülönböztető jegyei a terület két jelentős kutatója által összegzett eredmények alapján kerülnek ismertetésre (J P Guilford, 1950; Torrance, 1974). A szakirodalomban ma is általános érvényüek és széles körben elfogadottak az általuk vizsgált kreativitás tényezők. A tíz tényező bemutatását az (1) általános problémaérzékenységgel kezdem. Az egyén észreveszi, felismeri a problémákat még akkor is, ha maga a probléma nem egyértelmü és/vagy rejtett. (2) Az eredetiség a kreatív gondolkodás központi sajátosságaként arra utal, hogy a személy szokatlan, innovatív, új vagy újszerü, a többiek válaszaitól nagyban eltérő és meghökkentő megoldásokat ad a felismert problémára. A (3) fluencia, mint folyékonyság arra utal, hogy az egyén folyamatosan képes az ötletek generálására, számtalan ötlettel rendelkezik, mindig mindenröl eszébe jut valami új, játszi könnyedséggel asszociál. Az (4) elaboráció, a kidolgozás képessége szintén egy jelentős megkülönböztető jegyet jelent, mely faktor képessé teszi a személyt a részletek alapján a struktúra, az egész meghatározására, segít a részletek kitöltésében. A (5) flexibilitás, vagyis rugalmasság ugyancsak egy kiemelt tényező, ami lehetőséget teremt arra, hogy a probléma megoldása során az egyén változatos megközelítést alkalmazzon, amikor az egymásnak olykor ellentmondó elemek nem a problémát, hanem a lehetőséget jelentik. Az (6) analízis egy olyan gondolkodási müveletet jelöl, melynek során a meglévő struktúrák szétbontásra kerülnek, hogy aztán egy új rendszerben kerüljenek összeillesztésre, ami az előzőhöz képest új jelentést, többletértéket is kaphat. A következő faktor a (7) szintetizálás, mely segíti a gondolatok egységesebb, egyre átfogóbb rendszerekbe, hálózatokba rendezését. A (8) komplexitás a szintetizálással összefügg, azt egy magasabb szintre emeli. Arra vonatkozik, hogy egyszerre, egy időben az egyén elbánik és képes operálni sok és sokféle egymással összefüggő gondolattal. $\mathrm{Az}$ (9) újradefiniálás az egyén azon személyiségjegyét világítja meg, mint a kreativitás újabb fontos faktora, hogy az egyén képes az egyes tárgyak szokásostól eltérő felhasználására, melynek során az is előfordul, hogy ez ellentmond a hagyományos, rendeltetés szerü használatának. Végül, az (10) értékelés jelenik meg, mint a kreativitás faktora, mely lehetőséget biztosít arra, hogy felmérjük az új gondolatok, ötletek értékét, meghatározzuk relevanciáját. Ez a tíz jellemző vonás előfordulási aránya természetesen egyedi, személyenként eltérő, felmérését követően az oktatásban egy értékes információt ad a pedagógusnak, hogy a 
kreativitás fejlesztésére irányuló módszertanok közül, mely részterületre fókuszálót érdemes akár egyénileg, akár közösség szintjén alkalmazni (Szarka, é. n.). Ezek a faktorok tehát hozzájárulnak a pedagógus munkájához, hatékonyan irányíthatják azt, különösen olyan helyzetekben, amikor a cél a kreativitás fejlesztése. A pedagógus számára sok esetben egyértelmübb, a tantárgyak órai kereteibe könnyebben integrálható, ha a kreativitás egyes részterületeire, elemeire fókuszál. Ha már csak egy faktorra irányuló fejlesztés megtörténik, akkor már hozzájárult a pedagógus a kreativitás fejlesztésére irányuló globális pedagógiai feladathoz (L. Fodor, 2015).

\subsubsection{A kreativitás, mint veszélyeztetett faj}

Összegezve a fentieket a kreativitás kétségkívül egy olyan képesség, melynek fókuszba helyezése elengedhetetlen. Alapvetően ez a fókusz tudományterülettől függetleníthető az oktatás-nevelés területén ignorálása komoly következményeket vonhat maga után. A kreativitáscsökkenési trend eltérő aspektusokban jelentkezik, a kreatív ember egyre inkább a „veszélyeztetett fajok” között kap helyet (Kaszás, 2011). Kreatívnak lenni mindenki számára adott lehetőség. Kutatások bizonyítják, hogy a kor előre haladtával a kreativitás szintje csökkenő tendenciát mutat, így az oktatás legfontosabb feladatai között kell, hogy helyet kapjon annak fejlesztése, a megfelelő faktorokra irányuló fókuszpont mellett. Kaszás (2011) idézetével zárom a fejezetet, mely ugyancsak bizonyosságot állít arról, hogy kutatásom célja és a célhoz segítő központi eleme, a kreativitás fejlesztésére irányuló foglalkozás mindenképpen fontos és hiánypótló. Nem lehet elég figyelmet fordítani arra, hogy a pedagógusok számára minél inkább diverz csatornákon juttassunk el megoldási módszereket, hogy a leterhelt hétköznapok mellett ne maradjon el a figyelem egy olyan képességről, mely az élet minden területén nélkülözhetetlen a sikeres boldoguláshoz. „Nagyon fontos lenne, hogy az oktatás teljes folyamatában érvényesüljön az a szemlélet, amely a kreativitást értékként kezeli. Nem szabadna, hogy ez a hasznos látásmód vagy megközelítés elitiskolák, haladó pedagógiai rendszerekkel dolgozó intézmények privilégiuma legyen, hanem valamennyi iskolában, mindenki számára érvényesülnie kellene. Lényeges, hogy az iskolai oktatás ne kész »ismeretkonzervek" átadásában merüljön ki, hanem sokkal inkább az ismeretek megszerzésének és használatának technikáit tanitsa, illetve fejlessze a képességeket." (Kaszás, 2011, o. 23) 


\subsection{Az együttmúködésben rejlő legfontosabb oktatás-módszertani lehetőségek}

\subsubsection{Együttmüködés: csapatszellem vs. versenyszellem}

A Darwinizmus felemelkedésével egyidős az emberekbe vetett hit, hogy a túlélésért bizony küzdeni kell, és csak a legerősebb éli túl a kihívásokat. Az együttmüködésen alapuló nézet elutasítja ezt, és azt álltja, hogy az emberiség a kooperációnak köszönheti az elért fejlettségi szintet (Apicella \& Silk, 2019), ezt támogatja az is, hogy az együttmüködés az előző fejezetben elemzett kreativitás támogató tényezői között jelenik meg (Sahlberg, 2009). Régen, valakivel együtt tanulni azt jelentette, hogy az illető nem képes mások segítsége nélkül „felkészülni”, ma pedig ez az egyik legjobb stratégia arra, hogy megtanuljunk tanulni (Chen, 2002). A legtöbb magyar fiatal jobban ismeri a versenyszellem fogalmát, mintsem a csapatszellemét, hiszen egymással versenyeznek a jobb jegyekért, bejutásért a legjobb gimnáziumokba, de ma már a legtöbb általános iskola is felvételihez köti az iskolakezdést. Bizonyított, hogy az oktatás során alkalmazott együttmüködésre építő módszerek megerősítik a közösséget, növelik a munka értékét, segítik a diákokat az új dolgok megértésében és elfogadásában (Robbins, 1994) és egyéb szociális készségeket kommunikációs készség, konfliktuskezelés - is fejleszteni képesek (Altun, 2017). Az együttmüködésre épülő módszerek, úgy mint a csoportmunka egyes előfordulásai tehát számtalan egyéb készség fejlesztését támogatják, a heterogén csoportok kialakítása például lehetővé teszi, hogy a diákok egymást motiválják a feladat megoldása során (Szücs, 2018). Iskolákban végzett vizsgálatok eredményei azt is igazolják, hogy a versengést támogató környezettel szemben azok a módszerek, melyek együttműködést eredményeznek alkalmasabbak az önjutalmazó (intrinzik) motiváció megteremtésére (Kim, 1998). A kutatók 20, nemrégiben közzétett, magas színvonalú, az együttmüködésre építő tanulás témáját taglaló tanulmány alapján készítettek egy összefoglaló szintézist a módszer hatékonyságáról. E tanulmányok mindegyike kísérleti terveket és kifinomult statisztikai technikákat alkalmazott az adatok elemzésére. Ebből a munkából a kutatók megállapították, hogy a jól megtervezett együttmúködésre építő oktatásnak következetesen pozitív hatása van, amely átlagosan 17 százalékpont nyereséget jelent a hallgatók tanulásában. Más szavakkal élve, egy hagyományos körülmények között 50 százalékot teljesítő hallgató 67 százalék elérésére is képes, amennyiben egy jól strukturált és tervezett feltételek mellett kialakított együttmüködésre építő feladaton keresztül vállalkozunk a tudásátadásra (Averianova, 2014). Jelen fejezet módszertani kiindulási pontjaként az együttműködés széles és szerteágazó szakirodalmi 
összefüggéseinek elemzését követően két fontos aspektusát vizsgálom meg. Elemzésem kereszttüzébe az aktív tanulási módszerek alapjaira építő problémaalapú tanulás, valamint a kooperatív tanulásszervezés kerül.

\subsubsection{Az együttmüködésre építő aktív tanulás}

Felsőoktatási keretek között már érződik - föként az orvostudományi és gazdálkodástudományi egyetemek esetében -, hogy különböző módszerek alkalmazásával serkentik e kulcsfontosságú készség, az együttmüködés elsajátítását. Ismeretes, hogy egyes egyetemek például teljesen átálltak a probléma alapú tanításra -amely során kis csoportokban, együttes erővel keresik a megoldást az adott problémára- éppen azért, hogy a végzett hallgatók ezáltal is nagyobb előnnyel lépjenek ki a munka világába (Cohen-Schotanus, Muijtjens, Schönrock-Adema, Geertsma, \& Van Der Vleuten, 2008). Az együttmüködésre építő aktív tanulás szerepe az oktatásban egyre inkább felértékelődik, fogalmi definíciója már a 20. század elején ismert volt a pedagógusok előtt. A diákok egyaránt tanulhatnak passzív és aktív módon.

Passzív tanulásról beszélünk, amikor a diákok részvétele a tanulási folyamatban mindössze a hallgatásban manifesztálódik. Az aktív tanulás ezzel szemben a hallgatáson túli cselekedetet vár el a diáktól (M. P. Ryan \& Martens, 1989). A gyerekek kíváncsiságának felkeltése kulcsfontosságú tényező, a hatékony tanulás alappilléreként van jelen, és az önálló ismeretszerzés fenntartásához is hozzájárul (Á. Baráth, 2017), esszenciája az alkotó munkára nevelésben összegezhető (Lechnitzky, 1912). Az aktív tanulás közoktatásba történő bevezetése John Dewey nevéhez társítható (Dewey, 1923), számos tanítási módszer gyüjtőneveként is szolgál.

A legfontosabb közös pont a tanuló, aki, mint cselekvő-alkotó alany kerül a tanítási folyamat középpontjába (Bonwell \& Eison, 1991). A diákok feladatok helyett a kreatív gondolkodást igénylő problémákkal való szembesítést kapják, ahol a feladat a megoldás, és az ahhoz vezető út felderítése, megalkotása (Bús, 2015). Kérdésekre felelnek, s ezzel párhuzamosan saját kérdéseket fogalmaznak meg, személyes tapasztalatokat gyüjtenek, és segítik egymást a tanulásban (Vastagh, 1999).

Összevetve a fogalmi meghatározásokat, a következők emelhetők ki, mint közös kapcsolódási pontok az egyes megfogalmazások metszetében: a diákok bevonása több, mint puszta figyelem, kevesebb hangsúly helyeződik az információ egyirányú szállítására és sokkal több a képességek, készségek fejlesztésére. A hallgatók bevonásra kerülnek a gondolkodás az elemzés, a szintézis, az értékelés szintjén egyarát, a diákok tevékenységeket folytatnak, mint az 
olvasás, az írás vagy éppen a vita. Nagyobb hangsúly kerül a hallgatói értékekre, az attitűdök feltérképezésére. Az aktív tanulás egyes stratégiái, mint a kutatás, eset, felfedezés, projekt vagy probléma alapú tanulás (L. Nagy, 2010) gyakran építenek a csoport együtt tanulására is. A sikeres és eredményes csoportmunka megvalósítása nem könnyü. Szükséges, hogy a csoporttagok megosszák egymás között a munkát, legyenek érvek felsorakoztatva, és képesek legyenek egymás hozzászólását kiegészíteni, majd egy egységes álláspontot kialakítani. Ez az aktív tanulásra építő oktatásban is tapasztalható (Kissné Gera, 2016). Összefoglalva tehát az aktív tanulás során a diákok bevonásra kerülnek a cselekvési folyamatba és gondolkodásra késztetik őket arról a cselekvési folyamatról, melynek aktív részeseivé váltak (Bonwell \& Eison, 1991).

A közoktatás és a felsőoktatás szemüvegén keresztül elemezve, a pedagógiai szakirodalomban legtöbbször előtérbe kerülő didaktikai, oktatáselméleti modelljei az aktív tanulásnak a következők: felfedezésen alapuló tanulás, a tanulással tanítás, a projekt alapú tanulás, a probléma alapú tanulás és a kooperatív tanulás (Á. Baráth, 2017). Jelen dolgozat részeként a tanulóközpontú aktív tanítás megközelítésmódjai közül ez utolsó két modell, a probléma alapú tanulás és a kooperatív tanulás kerül tanulmányozásra, melynek magyarázata, hogy az aktív tanulásra építő módszerek közül e kettő kapcsán fedeztem fel fontos kapcsolódási pontokat a kutatási szakaszban ismertetésre kerülő, saját fejlesztésű oktatásmódszertani eszközömmel.

\subsubsection{A probléma alapú tanulás}

A probléma alapú tanulás, a PBL módszer (Problem Based Learning nemzetközi betűjele), a hetvenes, nyolcvanas évek terméke, mely elsőként az észak-amerikai orvosi egyetemeken honosodott meg, ahol a fő indok abban volt felfedezhető, hogy az orvosképzés mozduljon el a tanár központúság irányából a tanuló-központúság felé, így a passzív tanulás szerepét az aktív tanulásszervezés vegye át (Á. Baráth, 2017). A probléma alapú tanulás definiálására rengeteg kísérlet született, így Howard S. Barrows tollából, aki egy amerikai orvos és orvos-kutató volt, és akinek nevéhez kötődik a PBL módszer középiskolába történő bevezetése is. Kutatásuk során rávilágítottak arra, hogy az orvostanhallgatók csak egy töredéke volt képes a tudományos tudását összekapcsolni a betegek által prezentált problémákkal, mely felismerés teret engedett és nyitottságot teremtett az újszerü oktatási, tanulásszervezési megközelítéseknek, így a probléma alapú tanulásnak is (Barrows \& Tamblyn, 1980). Barrows (1984) meghatározása a tanuló-központúság, a tanár facilitátor szerepe (feladata a 
beszélgetések ösztönzése), a probléma középpontba helyezése és a tanulói csoportmunka köré épül.

Egy másik meghatározás arra épít, hogy a PBL egy olyan aktív tanulási módszer, melynek során a tanulók egy tantárgyat, egy a témához és tudásanyaghoz kapcsolódó valós probléma relációjában vizsgálják (Boud \& Feletti, 1998), a tanulásszervezés és kompetenciafejlesztés sajátos paradigmájaként is értelmezhető (Arató, 2008). Ez az a módszer, mely a tanári szerepfelfogást és nézőpontot nagy mértékben alakítja át (Molnár, 2004). A tanár nem formális előadást tart, helyette egy megoldásra váró problémát vázol fel. A tanulásra vonatkozó követelmény nincs konkrétan meghatározva, ezt a tanulók fedezik fel, nekik kell rájönni arra, hogy milyen ismeretanyag elsajátítására van szükség adott probléma megoldásához (Gardner, 2011). Ez sok esetben megköveteli a hiányzó adatok begyüjtését és ennek mikéntjének megtervezését (Á. Baráth, 2017).

Látható tehát, hogy a probléma alapú tanulás számos megközelítésben értelmezhető (Tóth, 2017). Tekinthetjük oktatási módszernek, ahol a csoportban, közösen dolgozás, és az életszerü probléma keresése megváltoztatja a diákok tanulását. Pozitívan hat a kritikai és az analitikus gondolkodásra (Duch, 1996). A PBL értelmezhető fejlesztési-oktatási megközelítésként is, ami olyan problémákra épít, melyek esetében nincs egy egyszerü, állandó helyes megoldást, nem is biztos, hogy egyáltalán létezik legjobb megoldás (Finkle \& Torp, 1995). Divergens gondolkodást feltételez, és vár el a diákoktól, nyílt problémamegoldó helyzetet teremt (Dorst, 2011).

A probléma alapú tanulás egy transzkurrikuláris oktatási megközelítés, ahol a tanulási folyamat kiindulási pontja maga a probléma. A probléma típusa és meghatározása az oktatási intézmény sajátosságaitól függ. Egy probléma lehet jól és rosszul definiált. Ennek lényege abban rejlik, hogy a probléma milyensége már önmagában előrevetíti azokat a gondolkodási folyamatokat, melyek várhatóan a megoldás során végbe mennek majd. A mindennapokban gyakran kerülünk szembe rosszul definiált problémákkal, amelyek esetében sokszor a cél sem tisztázott, így ezekre a típusú problémákra kell felkészülni és felkészíteni (PásztorKovács, 2015). Ebben a kontextusban elkerülendő, hogy olyan probléma kerüljön meghatározásra, mely kapcsán a megoldáshoz rutinszerü algoritmus alkalmazható, mert ekkor pont a tanulásszervezés lényegi eleme veszik el. A PBL során rosszul definiált problémát kapnak a diákok, így azt először meg kell határozni, később akár az újra definiálására is sor kerül. A rosszul definiált probléma további információk szükségességét is feltételezi, mely a diákok aktivizációját, proaktivitását indítványozza. A fókusz a probléma természetére kerül. Az ilyen jellegü problémák hatékonyabban motiválják a diákokat (Molnár, 2005). A problémák 
általában a valós életre alapozva fogalmazódnak meg, olyan formában, mely találkozik az oktatási céllal és követelményrendszerrel. Lehetnek ezek fiktív problémák, de alapvető, hogy ez az oktatási célokat is szolgálja, hiszen ez meghatározza a tanulási folyamat irányát is (De Graaf \& Kolmos, 2003). A problémahelyzet komplex és változatos, de a már fentebb is rögzített fontos sajátossága, hogy nincsenek kész receptek a megoldáshoz (Á. Baráth, 2017).

A problémaalapú tanulás nem csak egy didaktikai módszer, lehetőséget nyújt olyan tanulói készségek fejlesztésében, melyek a hagyományos oktatási mindennapokban háttérbe szorulnak, vagy teljesen kiesnek a fókuszból (Á. Baráth, 2017). A PBL során olyan specifikus kompetenciák szisztematikus fejlesztésén van a hangsúly, mint az alkalmazkodás, a találékonyság, a problémák holisztikus áttekintése, a tanulási hiányosságok és erôsségek felismerése, az önálló tanulás, a hatékony kommunikációs készségek fejlesztése, vagy akár az együttműködés (Baráth, 2017 in Savin-Baden, 2000). Felsőoktatási keretek között már érződik - a művészeti és mérnöki területek mellett föként az orvostudományi és gazdálkodástudományi egyetemek esetében -, hogy különböző módszerek, köztük a PBL alkalmazásával serkentik sok kulcsfontosságú készség, például az együttmüködés elsajátítását is. Ismeretes, hogy egyes egyetemek például teljesen átálltak a probléma alapú tanításra -amely során kis csoportokban, együttes erővel keresik a megoldást az adott problémára- éppen azért, hogy a végzett hallgatók ezáltal is nagyobb előnnyel lépjenek ki a munka világába (CohenSchotanus és mtsai., 2008).

A kreatív és kritikus gondolkodás szisztematikus fejlesztésére is törekszik a PBL módszer, ennek eredményét már több kutatás is alátámasztja (Ersoy \& Başer, 2014; Yeo, 2008). Ersoy \& Başer (2014) kutatása során elsőéves, statisztika szakos egyetemistákat vizsgált, ahol az alkalmazott PBL-folyamat végén az az eredmény látható, hogy a hallgatók saját ötleteikkel és képességeikkel azonosítják és megoldják a problémákat, így fejleszthetik kreatív gondolkodásukat, amely az egyik legmagasabb szintű készség. Ez a konklúzió párhuzamba állítható például Yeo (2008) kutatásával is, aki kifejezi, hogy a hallgatók vállalják a felelősséget a rugalmasabb gondolkodásmódú tanulásért a PBL-módszer minden szakaszában. Ezenkívül bizonyítja, hogy a kreatív problémamegoldás, a probléma azonosítása, az értékelés fázisa és a következtetés a PBL-módszerrel fejleszthető.

A PBL a fentiekhez nagy mértékben hozzájáruló, kiemelt jelentőségü eleme a csoportmunka, de nem a hagyományos értelemben. A tanulók mentori iránymutatással dolgoznak, együttmüködő kiscsoportban, mely együttmüködést ösztönzi a tanulás aktív, integrált és közös tapasztalatszerzésre fókuszáló jellege (Á. Baráth, 2017). Segít kialakítani egy biztonságos közeget, ahol a diákok jól érzik magukat, és nem félnek kérdezni. Fejleszti a 
kommunikációs képességet. A csoportmunkában a tanulók aktív részesei a munkának, ami egy felelősségteljes feladat, így fontosnak érezhetik magukat, a csoport számít rájuk. Összességében elmondható, hogy a PBL alkalmazásába állított csoportmunka is növeli a diákok teljesítményét, a társadalmi beilleszkedéshez elengedhetetlen képességeket fejleszt, a többi csoporttag meghallgatásán keresztül hatással van az empátiára, támogatja a probléma gazdagabb, több, eltérő nézőpontból való megértését is (Molnár, 2004).

Összegzésként fontos tehát rögzíteni, hogy annak ellenére, hogy a probléma alapú tanulás számos előnyt jelent az oktatás szereplőinek, a tanulóknak és a munkáltatóknak egyaránt a megközelítés az oktatás nézőpontjából tekintve egyelőre alul értékelt. Gondoljunk csak bele, hogy a probléma alapú tanulás lehetőséget kínál a diákok számára a tanulás, mint folyamat elsajátítására, hozzájárul a kulcsfontosságú készségek, az önálló vizsgálat, valamint a verseny és vita képességének fejlesztéséhez. A pedagógusoknak, oktatásban érintetteknek egy eszközkészletet nyújt, megoldást a tantervhez kapcsolódó egyre növekvő nyomás feloldására, a szakmaközi oktatás és fejlődés lehetőségére, valamint egy olyan oktatás megvalósítására, mely összhangban van a munkahelyi elvárásokkal. A diákokat arra ösztönözheti, hogy vegyenek részt a mindennapi problémás helyzetek megoldásában, összetettségük és sokféleségük ellenére. A probléma alapú tanulás eszközt nyújt a sokféleség kezelésében, választást biztosít oktatónak és tanulónak egyaránt (Savin-Baden, 2000).

\subsubsection{A kooperatív tanulásszervezés}

A kooperatív tanulásszervezés (Arató \& Varga, 2005) kifejezés az angol „cooperative learning" kifejezésből származtatható, a hazai neveléstudományi diskurzusban többféle fordításban is találkozhatunk vele. (Arató, 2011) A kooperatív tanulásszervezés a kooperatív tanulásnál pontosabban adja vissza a kifejezés jelentéstartamát, azt a jelentéstartalmat, mely a tanulás szervezésének módjára utal, előtérbe helyezve a folyamatok strukturális keretbe rendezését, hiszen itt elsősorban nem egy tanítási módszertanról beszélünk (Arató, 2011). A kooperatív tanulásszervezés tehát nem egy újabb módszer, sokkal inkább egy olyan tanulás- és oktatásszervezési keret, amelyben minden alternatívnak mondott pedagógiai gyakorlat valódi együttmüködésre építve valósítható meg (Arató, 2011).

A kooperatív tanulásszervezés az aktív tanulás egyik megközelítése, de nem minden aktív tanulás kooperatív (Keyser, 2000). A kooperatív tanulásszervezés a kis csoportok oktatási felhasználását jelenti, így a hallgatók együtt dolgoznak a saját és egymás tanulásának maximalizálása érdekében (Johnson \& Johnson, 2008). A jó működéshez az együttmüködésen 
alapuló tanulást meg kell tervezni, figyelembe véve a csoport megfelelő méretét, az egyes hallgatók csoporton belüli szerepét, valamint azt, hogy az eredményeket hogyan értékelik és használják fel az osztályban. Minden kooperatív tanulási csoportban részt vevő hallgatónak szerepet kell vállalnia a feladat elvégzésében. Több ez tehát, mint egy egyszerű csoportmunka (Keyser, 2000), annak ellenére, hogy a mindennapi pedagógiai köznyelvben gyakran azonosítják vele (Arató, 2011).

A kooperatív tanulással szemben több követelményt támaszt a szakirodalom (PapSzigeti, 2007). Annak érdekében, hogy a kooperatív tanulásszervezés sajátosságait, alapelveit pontosan értelmezni lehessen, érdemes röviden összefoglalni, hogy a hagyományos csoportmunkához viszonyítva a kooperatív tanulásszervezés miben jelent mást, melyek a legfontosabb megkülönböztető jegyek. A hagyományos csoportmunka és a kooperatív tanulásszervezés összehasonlítása Arató (2011) munkája alapján került elemzésre.

A hagyományos csoportmunka megvalósulásakor a csoport összetétele jellemzően homogén, vagy véletlenszerü, a kooperatív tanulásszervezés során minden esetben heterogén összetételü csoportok dolgoznak. A hagyományos csoportmunkában az együttmüködés nem garantált, ennek oka, hogy a nem egymásra épülő feladatok okán előfordulhatnak potyautasok és igavonók. A kialakult szerepkörök többnyire hierarchikusak, ez a tanári szerepre is jellemző, csupán látszatautonómia áll fenn, szemben a kooperatív tanulásszervezés során, amikor a tanár is egyenrangú partnerként van jelen, biztosítja a csoport számára az autonómiát a szerepe valódi átadásával.

Az egyéni felelősség és számonkérés a csoporttagok önállóságával biztosított, így az egymásrautaltság is erőteljesebben megjelenik, tervezett és szervezett a kooperatív tanulásszervezés során, míg a hagyományos csoportmunka esetében a számonkérés a legtöbb esetben a pedagógusnál marad, az egymásrautaltság kimenetele többnyire negatív. A nyilvánosság a hagyományos csoportmunkánál frontális helyzetben valósul csak meg, míg a kooperatív tanulásszervezés során strukturálisan biztosított kooperatív nyilvánosságról beszélhetünk, amire kiváló példát jelent a mozaik-struktúra, mely a kooperatív tanulásszervezés (Arató \& Varga, 2005) kiindulópontjának is tekinthető, megalapozta az együttmüködésre építő tanulást.

A mozaik-struktúrára épülő tanulásszervezés posztmodern szülőatyjaként Aronsont, az amerikai szociálpszichológust tartják számon (Arató, 2010). Aronson nem egy új pedagógiai programot, nem új módszertant alkot, hanem olyan strukturális elveket vezet be, melyek szociálpedagógiai szempontból is indokolt együttmüködési helyzeteket alakítanak ki, ezekre a helyzetekre építenek (Arató, 2010). A mozaik-módszer lényege abban rejlik, hogy az osztályba 
járó gyerekeket heterogén csoportokba osztjuk. A heterogenitás értelmezésre kerül a kulturális hovatartozás, a szociális helyzet, a képességek fejlettsége tekintetében. Az adott óra tananyagát a pedagógus felosztja annyi részre, ahány csoporttag alkot egy csoportot, így mindenkinek jut egy anyagrész, melyet önállóan és/vagy konzultálva a másik csoport ugyanazon témát feldolgozó tagjával értelmezik, majd közösen megtanulják, megtanítják egymásnak az anyagrészeket. A tudás mozaikszerüen áll össze, melyet a tanulás során, azzal egyidőben ki is kérdeznek a diákok egymástól. A tanár feladata és felelőssége az előkészítésre, a csoportok kialakítására és egyéni érdeklődés esetén az addicionális anyagok biztosítására korlátozódik, mely korlát sokkal inkább kulcsfontosságú szerepet ad a pedagógusoknak (Aronson \& Bridgeman, 1979).

A nevelés-oktatás területén ez a csoportmunkára építő módszer paradigmaváltást eredményezett a tudás konstruálásának szemléletében, az elsők között alakult ki hierarchikus tanulásszervezési eljárás helyett ahierarchikus, kooperatív struktúra (Arató, 2010), melynek eredményét kutatás is alátámasztotta. Valóban az attitűdök változását idézte elö, az elfogadás és empátia növekedett a különböző gyermekcsoportok között, mely igazolta létrejöttének okát is (Aronson \& Blaney, 1978). Aronson mozaikmodellje a mai, szigorúbb alapelvekre építkező, kooperatív tanulásszervezés szempontjából szubkooperatív jellegünek tekinthető csupán. Ez annyit tesz, hogy a pozitív egymásrautaltság, az egyéni felelősségvállalás, mint fontos alapelv már érvényesül benne. Van néhány további meghatározó alaptézis, mely még hiányzik ebből a modellből, így napjaink távlatából ez a tanulásszervezési eljárás nem tekinthető kooperatívnak. Nem kétséges, hogy az együttműködésre építő tanulásszervezés a mozaik módszeren keresztül fejlödött és szilárdította meg a mindmáig tartó erös pozícióját a neveléstudomány-oktatás területén. Aronson úttörőként, a mindennapi gyakorlat szintjén elemezve nyitotta meg a tudomány számára a kooperatív strukturális nézőpontot (Arató, 2010).

A kooperatív tanulásszervezés szakirodalmát tanulmányozva a különböző szerzők eltérő számosságú és elnevezésű alapelveivel kerülünk szembe a téma feldolgozása során, a megközelítés bázisa alapvetően ugyanazon alaptételekre épül (Johnson \& Johnson, 1987; Kagan, 2001). Jelen dolgozatban az alapelvek közül azt a négyet emeltem ki, amely a legtöbb kutatónál átfedésben van, és a megnevezés kapcsán az Arató \& Varga (2005) féle terminust alkalmazom.

A kooperatív, az együttmúködésre építő tanulásszervezés során egy új tanulásszervezési megközelítésről beszélünk, mely bizonyítottan serkenti a diákok saját élményen keresztül szerzett tanulási motivációját. Oly módon javasolja az iskolai oktatás 
átalakítását, hogy a diákok közötti egymásrautaltságra épít, saját élményekre alapoz és az állandó versengő hangulat helyett egy együttműködő közeg megalapozására fókuszál.

A hagyományos csoportmunkával szemben ez egy olyan tanulásszervezési forma, melynek müködését több alapelv határozza meg. A kiscsoportos munkaformát alkalmazza, ez a kooperáció alapegysége. Teszi ezt nagyfokú tudatossággal, alapelveire következetesen támaszkodva, melynek hátterében tudatos tanári tevékenység húzódik meg. A nagy csoporton belül irányítottan jönnek létre a heterogén mini közösségek, melyek önálló egységként funkcionálnak, de együttmüködésre lép(het)nek a többi csoporttal is.

A kooperatív tanulásszervezés 4 alapelve között tartjuk számon az (a) építő és ösztönző egymásrautaltságot, az (b) egyenlő részvétel és hozzáférés lehetőségét, a (c) személyes felelősségvállalást és az egyéni számon kérhetőséget, valamint a $(\mathrm{d})$ mindenkire kiterjedő interakciót (Aranka Varga, 2015). Varga (2015) magyarázata alapján az (c) egyéni felelősségvállalás és számonkérhetőség alapelvéhez igazodva világos és jól körülírt feladatokat vállalnak a résztvevők, melynek stratégiai kialakításában a tanár szerepe jelentős, a számonkérés már a csoport szintjén valósul meg, a csoport felé történő megfelelés iránti vágy mozgatja. A csoport felé adnak számot tudásukról, feladataik elvégzéséről, a pozitív egymásrautaltság frusztráló számonkérések helyett motiválóan hat, a visszajelzés azonnal megvalósul, erősítve így a felelősségvállalást és a bevonódást.

A mindenkire kiterjedő interakció megvalósítása a tanórákon szinte elképzelhetetlen, a kevésbé extrovertált, visszahúzódó diákok megszólalásra kényszerítése pedig kifejezetten ellenjavalt pedagógus reakció, mely bizonytalan viselkedési folyamatot indíthat el a diákban (Zétényi, 1998). A kooperatív tanulásszervezés során a csoportok feladatai úgy kerülnek meghatározásra, hogy minden résztvevő diák aktivitására szükség van a közös megoldáshoz, a passzív befogadás helyett cselekvő részvételt tanúsítanak. A (d) párhuzamos és mindenkire kiterjedő interakció alapelve a kiscsoportos munkaszervezés eszközével cselekvő bevonódást eredményez. Vagyis ezen alapelv mentén a pedagógus olyan tanulási keretet alkalmaz, ahol a diákoknak nem csak lehetősége van a cselekvésre, hanem a kooperatívan strukturált munkaforma révén minden diák aktív részvétele szükséges ahhoz, hogy a kiadott közös feladat valóban elkészüljön. Az egy időben párhuzamosan dolgozó kis csoportok megsokszorozzák a hozzászólási és cselekvő részvételi alkalmakat a diákok számára, a személyes interakciók elősegítik, hogy a passzív befogadásnál mélyebben bevonódó tanulási folyamat realizálódjon.

Az (a) építő és ösztönző egymásrautaltság abban teljesedik ki, hogy a tanár a feladatokat oly módon osztja szét, hogy a megoldás csak akkor jön létre, ha mindenki elkészíti a rá 
szabott feladatot. A feladatok során a differenciálás megvalósul, így az egyéni fejlődés lehetősége is megfelelő arányban biztosított. Ez nem változtat azon a jelenségen, hogy csak úgy áll össze az egész, ha a saját részét mindenki hozzáteszi. Valódi eredmény csak úgy jön létre, ha a rá szabott feladatot mindenki sikeresen elvégzi, mely jelenség további ösztönzőként szolgál.

Az (b) egyenlő részvétel és hozzáférés lehetősége is biztosított a jól megtervezett struktúra által. Mindenki számára képességei és igényei, elvárásai mentén kerülnek a feladatok differenciálásra, a tudás megosztása, a hozzáférés biztosítása a közös megoldás létrehozásához elengedhetetlen, az esélyegyenlőség dimenzióinak szem előtt tartása minden esetben prioritás (Aranka Varga, 2015). A kooperatív tanulásszervezés alapja az együttmüködés, a tudásanyag elsajátítása ezen készségre alapoz, így folyamatos fejlesztése elengedhetetlen. Arató (2010) tanulmányából kiindulva a tanulási elképzelések sikeres megvalósításának esélye egy együttmüködően strukturált tanulási helyzetben nagyobb. Az utóbbi évtizedekben bizonyítást nyert, hogy az együttmúködés inkluzív garantálása fejleszti a gyerekek szociális képességein túl a tudáshoz való individuális hozzáférést is.

\subsubsection{Csoportmunka, mint az együttműködés mozgatórugója az általános iskolában}

Mindezeket figyelembe véve nemcsak a felsőoktatásban, de már egészen kicsi korban is kritikus jelentőséggel bír az együttmüködésre tanító foglalkozások jelenléte, illetve az ehhez szükséges környezet megléte. Bár ezen tények mindenki számára ismertek, mégis kevés tanár él az órákon megvalósítható csoportmunka lehetőségével, hiszen nemcsak időigényesek, de fennáll a társas lógás lehetősége is, illetve a tantervben szereplő tananyag mennyisége és az idő hiánya is korlátozza őket. Ez még inkább igaz az általános iskolákra, ahol közismerten feszített tempóval haladnak a tananyaggal. Be kell látnunk, hogy igenis fontos megtanítani már az általános iskolás diákoknak is, hogy hogyan tudnak együttmüködni, ezen képesség hiánya ugyanis gyenge teljesítményhez is vezethet (Vargas és mtsai., 2018). A csoportmunka valamely válfaja tehát ma már általánosan elfogadott részét kell, hogy képezze az általános iskolai oktatási ideológiának is (M. Galton \& Williamson, 2003). A legtöbben ennek fényében is leginkább csak felső tagozaton kezdenek megismerkedni ezzel a tanulási módszerrel.

A csoportos tanulás a csoporton belüli interakciókban testesül meg. A tanulás alanya nemcsak az egyén, hanem a csoport egésze (Knight, 2002). Beszélhetünk korábbi nevén hagyományos, újabban kollaboratív (A. Horváth, 1994) elnevezésű csoportmunkáról az aktív 
tanulási folyamat részeként. Emellett a probléma alapú tanulás is felhasználhatja a csoportmunkát, mint eszközt a probléma feldolgozására (és teszi is ezt rendszeresen), továbbá a kooperatív tanulásszervezésnek is egy kulcseleme a csoportba rendeződés. A csoportfoglalkozások során a problémaközpontú gondolkodás fejlesztése zajlik. A cselekvésre alapozó tanulási tevékenységformák, mint az önálló információszerzés vagy a kooperatív tanulási technikák is eredményesebben valósulnak meg a csoportfoglalkozások alkalmazásával. Az elsajátítás tehát eredményesebb, maradandóbb és szórakoztatóbb, hiszen a tanulás valódi élményét nyújtja a diákoknak (K Nagy, 2012).

A fejezet során kiemelten taglalt aktív tanulási módszerekben közös, hogy a csoporttagok együttműködésére építenek és az ehhez szükséges attitüdök fejlesztése nem titkolt szándék. A csoportmunka jótékony hatása nem jelenti az egyéni úton szerzett tudás fontosságának tagadását. A legjobb eredmény eléréséhez, a két tanulástípus harmonikus viszonya szükséges (Csíkos, 2010). A kooperatív személetmód szerint a tanulás eredményessége nő, ha lehetőséget biztosítunk a diákoknak az együttmüködésre, ahol összehasonlíthatják, megvitathatják a stratégiákat és megoldásokat, esetleg közösen hozhatják létre azokat. A kooperatív tanulást és tanulásszervezést már ismertettük, de a téma teljessé tétele még megkívánja, hogy a kollaboratív tanulást is elhelyezzük a taglalt szakirodalmi síkon.

A PBL és a kooperatív tanulásszervezés alaposabb megértéséhez már szemléltettük a különbözőségeket az adott témát taglaló alfejezetekben. Itt pedig a hagyományos csoportmunka sajátosságaira fókuszálva, annak szemszögéből értelmezve kerül elő. A kooperatív tanulásszervezés és a hagyományos csoportmunka szociálpszichológiai és pedagógiai alapvetései meglehetősen közel esnek egymáshoz a szakirodalomban.

A kollaboratív tanulás annak ellenére, hogy még mindig nem eléggé elterjedt a közoktatási gyakorlatban, a tanárok elméleti-ismereti szintjén jelentősen befolyásolja a kooperatív tanulásszervezés adaptációját, integrálását az oktatás mindennapjaiba (Arató, 2011). A kooperatív tanulás tekinthető a kollaboratív tanulás egy kategóriájaként, alfajaként, ahol a tagokat a kollaboratív tanulással szemben egyéni és közös felelősség egyaránt terheli (PásztorKovács, 2015). Csoportdinamikai szempontból ez jelenti a legfontosabb különbséget. Kollaboratív tanulás során a csoporttagoknak nincs saját feladata, szerepe, ahogy kölcsönös felelősség sincs. A nyomás, hogy ha nem vesznek részt a munkában, akkor nem lesz megfelelő a végkifejlet és/vagy eredmény elmarad. A csoportszerepek hiánya társas lazsáláshoz (Latané, Williams, \& Harkins, 1979; Pásztor-Kovács, 2015), erőteljes státuszharchoz (Bonebright, 2010) vezet, de az is előfordulhat, hogy a csoportnak csupán egy tagja vállalja magára a 
vezetést. A kollaboratív helyzet természeténél fogva lehetővé teszi egy csoporttag teljes passzivitását és uralkodását is ugyanabban a feladatban (Pásztor-Kovács, 2015).

A hagyományos csoportmunka alkalmazása során a csoportfejlesztésre jellemző, hogy a csoport kialakítását követően azonnal elkezdődik a csoportmunka (Arató, 2011), ami teret enged a spontaneitásnak, mely sajátosság megkönnyítheti a pedagógusoknak az alkalmazhatóságot. Függetlenül a csoportmunka kooperatív/kollaboratív jellegétől bizonyítottan pozitív hatással van az együttmüködés egyes szintjeire, az oktatási-nevelési folyamatban jelentősége nem kérdés, ahogy az sem, hogy ezt már alsó tagozatban érdemes a pedagógusnak a mindennapi iskolai keretekbe illeszteni. A csoportmunka támogatja a lelkiismeretes feladatvégzést és hozzájárul a mélyreható tanulási stílus erősítéséhez. Ceglédi (2009) kutatása során arra világít rá, hogy azoknál az osztályoknál, ahol rendszeresen végeznek csoportmunkára épülő feladatokat, ott a tudásszerzésre vonatkozó igény (kompetencia) és a dolgozatok eredményei között összefüggés mutatható ki. A kompetenciaalapú oktatás egyre intenzívebb elöretörése is a csoportmunka egyre gyakoribb és szélesebb körben történő felhasználására ösztönzi az oktatás szereplöit (Ceglédi, 2009)

Nem szabad tehát megfeledkezni a tényről, hogy maga az együttmüködés is tanulható készség. Ezt bizonyítja Reinke (2001) kutatása is, amelyből kiderül, hogy az olyan kollaboratív metódusok alkalmazása, amelyek a csoportmunkán alapszanak, már rövid időn belül is képesek fejleszteni az együttmüködő képességet, és ráadásul nemcsak a diák-diák, de a diák-tanár kapcsolatokat is megerősítik. Különösképpen igaz ez egy olyan kooperatív tanulásszervezési folyamat során, ahol a tanár ezt kiegészítve, hagyományos hierarchikus szerepét félretéve, a háttérből irányítja, rögzíti és ellenőrzi az együttmüködés sarokpontjait.

\subsection{A pedagógusszerepek és kihívások}

Vezesd öket, utat ne tévessz, S magadhoz mindig hü maradj,

Mert élen állsz, és messze látszol,

Sose feledd: példa vagy!

- Nagy László -

Az emberi erőforrás növekvő jelentősége a gazdaság speciális ágazatában, a ma már szervezetként értelmezett iskola esetében is láthatóvá vált (Serfőző, 2005). A pedagógusok hozzáállása, nyitottsága, rugalmassága, a kihívások, melyekkel szembe néznek mérvadó a 
befogadás/elfogadás nézőpontjából. Habár a középpontban a diákok vannak, az iskolát mozgató motort a tudást átadó pedagógusok, valamint a kialakított tanár-diák kapcsolat/interakció/együttmüködés jelentik (S. Horváth, 2018).

$\mathrm{Az}$ oktatási rendszer minőségét, legfontosabb elemét a benne helyet kapó és értéket, tudást átadó pedagógusok jelentik (Barber \& Mourshed, 2007). Pedagógusnak lenni nem csupán egy szakma, sokkal inkább hivatás. Amikor kérdésként felmerül, hogy mitől lehet vonzó a pedagógus életpálya, akkor gyakran a döntő érveket az egyedi értékrend és az elhivatottság adja, megelőzve a társadalmi tényezőket is (Jancsák, 2012; V. Wilson, Powney, Hall, \& Davidson, 2006).

Magas szakmai tudás, kifogástalan pedagógia érzék, gyakorlati tapasztalat, hitelesség. Ma már ez nem elég ahhoz, hogy egy pedagógus megnyerje diákjai figyelmét. A vizsgálatunk fókuszát jelentő $Z$ generáció egy felgyorsult közegben éli az életét, a felesleges időtöltést elutasítja, hatékony tudásátadást követel meg. Annyi, és olyan minőségü információt szeretne kapni, amire neki éppen abban a pillanatban szüksége van, adott szakaszban illeszkedik érdeklődéséhez és kielégíti a felmerült tudásszomját. A képességek és készségek fejlesztését a Z generáció a korábban megszokott módszerektől eltérő módon is igényli, mely jelenség a pedagógusok nyitottságára tud csak építeni. A digitális bennszülött generáció figyelmének megragadásához elengedhetetlen a digitális eszközök ismerete a pedagógus oldaláról, a nyitottságnak ezen a területen is realizálódnia kell. A képesség jellegü tudás szerepe felértékelödött, egyre inkább nélkülözhetetlenné válnak azok a gondolkodási műveletek, melyek támogatják az ismeretek rendszerezését, és segítséget nyújtanak adott problémák megoldására (Pásztor, 2014). A tantervi követelmények teljesítése, az egyre nagyobb leterheltség mellett minimális a pedagógusok mozgástere, így a gondolkodási képességek fejlesztése operatív és elméleti szinten is kihívást jelent.

\subsubsection{Tanár-diák kapcsolat}

A korábbi tekintélyelvü, hierarchikusnak definiálható tanár-diák kapcsolat dimenziói megváltoztak, generációs szerepcsere észlelhető. A kutatásom tapasztalata alapján ez mindaddig fennáll, míg egy valós szituációban nem kerülnek egy ilyen helyzetbe (D. Horváth, Cosovan, Horváth, \& Lachin, 2018). Az egyéni szükségletek megkövetelik a kreatív, tervezői folyamatokat, valamint a tanár-diák kapcsolat új alapokra helyezett, partnerségre és kölcsönösségre építő újra értelmezését (Fullan, 2013). 
Amióta bevezetésre került a pedagógus-életpályamodell azóta növekvő elvárás a pedagógusokkal szemben, hogy értsék, hogyan tanulnak a diákok. Ez nem érthető meg másképp, csak ha más formában, más környezetben is találkoznak a diákokkal, ami alátámasztja a megváltozott dimenziókat (Nagy-Czirok, 2017). A tanárok egyre inkább alkalmatlanná válnak a diákokkal való kapcsolatfelvételre, hiszen a rugalmatlan oktatási koncepciók és az eszközválasztás szabályozott keretek közé szorítása nem teremti meg erre a lehetőséget. Csökken az autonómia, nő a kontroll, a kimenetek standardizálása lesz a jellemző, hiszen a nemzetközi tendencia is ezt követeli meg. Észlelhető a változás szükségessége, mely változásban az eredményt a tanárok és diákok együttműködésre építő, közös teljesítménye hozza, melynek kiindulópontja a köztük lévő kapcsolat minősége (Zolnai és mtsai., 2016). A más forma, a más környezet jelentősége és szerepe nem kérdés, hiszen a hagyományos hétköznapi iskolai oktatás nagy részében a tanár ma már/még nem igazán nevezhető mesternek. Mester az, akivel lehetőség van együtt dolgozni egy probléma, kérdés, gyakorlatorientált feladat valódi létrehozásán. Többnyire inkább az információ közvetítőjeként jellemezhető. Az így kapott információ személytelen, az egyirányú folyamat korántsem kedvez az együttmüködés kialakításának, a bizalom megteremtésének (Csíkszentmihályi, Rathunde, Whalen, Wong, \& Halmos, 2010).

A diák és pedagógus közötti jó kapcsolat kialakítása a nevelés egyik kulcsfontosságú céljaként jelenik meg a szakirodalomban. A nevelő, szemléletformáló, a gyerekek személyiségét alakító hatást a pedagógus a személyes kapcsolaton keresztül tudja érvényesíteni (Sallay, 1995). A tanár-diák kapcsolat jelentőségét növeli és gyakorlatilag megkérdőjelezhetetlenné teszi, hogy egy vizsgálat során kiderült, hogy a tanár és a diák kapcsolata párhuzamba állítható az anya-gyermek kapcsolattal, azáltal, hogy egy gondoskodó és támogató tanár hasonlóan jelentőségteljes formálást hozhat a gyerekek személyiségfejlődésében, mint amilyen hatást az anya-gyermek kapcsolat jelent (B. A. Mason, Hajovsky, McCune, \& Turek, 2017).

Szabó Éva kutatásában ugyancsak egy igen érdekes jelenségre világít rá, miszerint az iskolai élmények meghatározó része a pedagógusokhoz köthető, és csak másodsorban társítják a diákok a társaikhoz, vagy egyéb más összetevőhöz (É. Szabó, 1999). Itt fontos megemlíteni, hogy a pedagógus egyszerre minta, példa, követendő személy is a gyermekek számára, ami a fejezet elején rögzített idézet eszenciája is egyben. Felnéznek rá, ha szakmai felkészültsége és tudása széleskörü és kifogástalan, de emellett még nagyobb jelentőséget tulajdonítanak annak, hogy teljes személyiségével jelen legyen a tanár az oktatói, nevelői tevékenységben. Ezek összessége hozzájárul ahhoz, hogy példaképpé váljon a tanár a diákok számára, ami már 
önmagában egy lépés a bizalom elmélyítése felé (Lévai, 2013). Ezt erősíti, hogy a hatékony pedagógusnak az oktatói szerepkörön túl, modellként kell szolgálnia, mely hatáskört a státusz, szakértelem, pozíció mellett a személyes vonzerő adja, mely vonzerő a tanár-diák kapcsolat megalapozásához is nélkülözhetetlen (Sallay, 1995).

A kisiskolás gyermekek hétköznapjaik meghatározó részét töltik tanítóik társaságában, gyakran több időt töltenek egy nap az iskolában a pedagógusokkal, mint a családi környezetben. A tanárral kialakított kapcsolat pozitív vagy negatív jellege értelemszerüen hatással van a diákok iskolához füződő viszonyához is (Huszka \& Kinyó, 2019).

Az a tanuló, aki tanítójával pozitív, szoros és jó kapcsolatot ápol, jobban végzi iskolai feladatait, és szociális készségeik rendre fejlettebbek kortársaiknál (Ladd \& Burgess, 2001). Két amerikai kutató 500 tanár és 3700 tanítási óra lejegyzését elemezte kutatása során. Az eredmények arra a jelenségre hívták fel a figyelmet, hogy ha a pedagógus oldaláról a megértést, a törődést és az őszinteséget kapták, akkor viselkedésük pozitív irányba változott. Arra világítottak rá, hogy ha egy olyan tanári attitüdre törekednek, mely empatikus, elfogadó, a diákok személyiségfejlesztésére irányul, akkor az eredmény nem marad el: redukálódnak a hiányzások, javulnak az intellektuális teljesítmények, fejlődik az önértékelés és csökken a fegyelmezési probléma, így tehát a megértés, a bizalom, a jó kapcsolathoz vezető viselkedési normákat előtérbe helyező pedagógus számára a pozitív megerősítésben kifejezett hála, viszonzás sem marad el a diákok oldaláról (Aspy \& Roebuck, 1974).

A tanár diák kapcsolat minősége befolyásolja a diákok egymás közötti viselkedését, együttmúködését is. A pedagógusok tekintélyt képviselnek, pozitív viselkedésük hatása magával vonzza a tanulók egymás felé nyújtott elfogadásra törekvő viselkedését, ez ugyanúgy igaz fordított irányban is. Az elutasító, negatív tanári magatartás hátráltatja az elfogadást és a közösség formálódását (Torgyik, 2004).

Jó kapcsolat nem alakul ki magától, ez még olykor a sokéves tapasztalattal rendelkező pedagógusoknak is igen nagy kihívást jelent, magas szakértelmet igényel. A pozitív érzelmi viszony a jó kapcsolat alapfeltétele, ez nem lehet egyoldalú. Kialakítását, megteremtését a pedagógusnak kell kezdeményezni, méghozzá oly módon, hogy a diákot elfogadják, és teszik ezt úgy, hogy nem feladatként rögzítik maguknak (Füzi, 2012). A kapcsolat fejlesztésére, a jó kapcsolat kialakítására számtalan lehetőség adott, úgy az adekvát motivációs technikák alkalmazása, a több minőségi, gyerekekkel töltött idő, valamint az érzelmi támogatás biztosítása. Ide tartozik a támogató tantermi közeg kialakítása és a pedagógus nyitott hozzáállása is (Cicchetti \& Lynch, 1993 in Huszka \& Kinyó, 2019). Érdemes kihasználni a diákoktól érkező inputokat is a kapcsolat fejlesztése érdekében, hiszen a gyerekek egyedi 
ismeretekkel és perspektívákkal rendelkeznek az iskoláikról, a környezetröl amelyeket a felnőttek nem tudnak teljes mértékben ezen a sajátos nézőponton keresztül értelmezni, ennek ellenére értékes és a kapcsolat fejlődését serkentő meglátásokat is jelenthet (Levin, 2000).

A fenti fejezetek során részletesen bemutatott kooperatív tanulásszervezés alkalmazása a tanulók számtalan képességére pozitív hatással van, úgy a kommunikációs készségük is fejlődik, ami segíti a megfelelő minőségű információáramlást, nemcsak diák-diák, de diáktanár között is, ami ugyancsak a jó kapcsolat megalapozására hivatott eszközkészletként szolgálhat a pedagógus számára (Szücs, 2018). Az összehangolt tanár-diák kapcsolat bizalmat épít úgy, hogy a mindennapokban a kudarc kockázatának kitett tanulókat támogatja azáltal is, hogy a tanítást és az értékelést szétválasztja, az átfedést minimalizálja (Gillespie, 2005). Ezt a törekvést, az ezirányú bizalomépítést a kooperatív csoportmunkára építő aktív tanulási módszerek azáltal támogatják, hogy az értékelést sok esetben nem a tanár végzi, hanem maga a csoport értékeli saját munkáját (Arató, 2011), így egyfajta önreflexióként realizálódik az eredmény értékelése, nem keveredik a pedagógussal és a tanár tudás-átadó szerepétől szétválasztható. A jó tanár-diák kapcsolat törödést igényel. A pedagógustól induló ötletekkel, innovatív, vagy már régi, jól bevált gyakorlatok alkalmazásával. Ez csak akkor működik, ha a pedagógus motivált, aktív és a kapcsolat fejlesztésére irányuló törekvés, ahogy egyéb újító ötletek oktatásban történő alkalmazása is, egy belső indíttatás eredménye, nem pedig egy vezetői nyomás/utasítás.

\subsubsection{Pedagógus, mint a változás motorja}

Zolnai és szerzőtársai (2016) a magyarországi közoktatási helyzetképet nemzetközi viszonylatban vizsgáló tanulmányukban állítják, hogy a felülröl induló reformtörekvések tovább növelhetik a bizonytalanságot, ami segítő szándéka ellenére hátráltató tényező lehet (Zolnai és mtsai., 2016). Mi több, a folyamatos reformtörekvések hatására a „pedagógusközösségben évek óta él egyfajta kétség a felülről érkező, újabb és újabb reformokkal szemben" (Veres, 2016, o. 43). Az igazi változáshoz ugyanis elengedhetetlen, hogy jelen legyen a rendszerben a belső indíttatás és akarat, valamint az együttmüködési készség is, vagyis a központosított reformok sikeréhez az alulról induló kezdeményezés lehet a kulcstényező (Halász, 2008).

Az intézményi szakmai autonómiára és az adott erőforrásokra építő szerves innováció a pedagógusok kezdeményezéséből fakad és a fentiekre építő pedagógiai innovációt reprezentálja (Becze, 2011). Az oktatáspolitikai döntések átfutása lassú folyamat, hiszen 
nagyon sok döntéshozó és jóváhagyó szerv szükséges az esetek nagy számában. Az iskolában dolgozó pedagógusok ezeket a döntéseket -túl azon, hogy kétséget ébresztenek bennük (Veres, 2016),- nyomásként, olykor teherként élik meg, mint egy kívülröl, vagy felsőbb utasításra megvalósuló újítást. Már maga a döntés váltja ki ezt a reakciót függetlenül annak minőségétől vagy hasznosságától. Ezek a döntések az alapvetően innovatív szemléletü pedagógusra is negatív hatással lehetnek, érdektelenné válhatnak. A kulcs a partnerségben rejlik. Amennyiben a döntéshozók együttmüködve, az oktatás szereplöinek tapasztalatára és véleményére támaszkodva, szakmai tudásukban rejlő lehetőségeket kihasználva törekednek az innovációk, reformtörekvések tervezésében és kivitelezésében, úgy nemcsak maga az ötlet, de a megvalósítás is gördülékenyebbé válhat, a legfontosabb szereplök involválódnak, elkötelezettségük fokozódik. A folyamatos közös tanulás és tapasztalás pedig hosszú távon is eredményes kollaborációt jelenthet (Saly, 2016).

A szakirodalom ilyen irányú álláspontja okán vélem igazoltnak, hogy oktatásmódszertani eszközömet a pedagógusokon keresztül szeretném eljuttatni és integrálni az alapfokú oktatási intézményekbe (D. D. Horváth és mtsai., 2020). Sok esetben azonnali bevonódást és bizalmat eredményezhet, ha a reformtörekvések során a legfontosabb szereplőket sikerül meggyőzni a módszer előremutató jellegéről (Zolnai és mtsai., 2016). A cél valóban a tanulás eredményesebbé tétele (D. Molnár, 2019). Érdemes lenne a lineáris modell helyett olyan új irányokat találni, mely a változásra alkalmas környezet megteremtését tartja szem előtt, ahol a probléma barát, a segítségkérés pedig az erőt és a bátorságot jelenti (Halász, 2008), az együttmüködés pedig maga a kiindulási pont.

\subsubsection{Hogyan nevelhet a pedagógus vállalkozásra?}

A vállalkozói ismeretek oktatása az első és vitathatatlanul a legfontosabb lépés az innovatív kultúra megszilárdításához Európában. A vállalkozói ismeretek oktatása a tapasztalati tanulás, a készségfejlesztés és - ami a legfontosabb - a gondolkodásmód változását ötvözi. Minél kisebb korban és minél szélesebb körben valósul meg a vállalkozói szellem és az innovatív attitüd expozíciója, annál valószínűbb egy vállalkozói hajlandóság a diákok oldalán (K. Wilson, 2008).

A 21. század általános elfogadott / elvárt attitüdje a vállalkozói attitüd, ami nem csak a gazdasági szinten jelenik meg, hanem annak megtalálásában is, hogy mivé váljon, ami egyúttal a vállalkozásra nevelés célkitüzésére is rávilágít, és a foglalkoztatás növelésében jelentkezik elsődlegesen. Mindehhez az oktatás nagy mértékben hozzá tudna járulni a szakmai ismeretek 
mellett a vállalkozói ismeretek beépítésével (S Gubik \& Farkas, 2016). Nincs egyértelmü konszenzus arra vonatkozóan, hogy a folyamatban mi lenne pontosan az iskola és mi a tanárok feladata, mi az, amit a mindennapi oktatás szintjén érdemes átadni, amire a társadalomnak és a gazdaságnak egyaránt szüksége lehet.

Ez a szükséglet megragadható olyan vállalkozók nevelésében, akik kötelességtudók, jó felfogású diákok tulajdonságait hordozzák, és saját egyéni sikereik mellett a társadalmi felelősséget is szem elött tartják. Ma még nem teljesen egyértelmű az a szerepdefiníció sem, hogy a pedagógus ehhez a folyamathoz hogyan járulhat hozzá (Fülöp \& Pressing, 2012). További kétséget és bizonytalanságot ébreszt az a kutatási eredmény, mely arra világít rá, hogy az iskolai versengés és a vállalkozásra nevelés összhangban van. Vagyis az iskolán belül, a diákok között kialakult versenyhelyzetek intenzitása pozitívan befolyásolja a vállalkozói kedvet és lendületet (Falck \& Woessmann, 2013).

A béke, a nyugalom, az összhang és a harmonikus iskolai atmoszféra és közösség kialakítására törekvő pedagógusok számára ez ellentmondó érzéseket kelt és kérdéseket vet fel. Képes-e egy pedagógus motivált lenni a vállalkozásra nevelésben, amennyiben az, akár azt is jelenti, hogy szembe kell mennie az általa prioritásként tartott -és más szempontok mentén ugyancsak kiemelt jelentőségü- elvekkel (Fülöp \& Pressing, 2012). A szerepvállalás körüli bizonytalanság mellett nem elhanyagolható az a robbanásszerű növekedés sem, mely a vállalkozásra nevelés érdeklődésének intenzitásában mutatkozik meg és az oktatás érintettjei mellett a tudományos kutatásban résztvevők között egyaránt megfigyelhető (Fülöp \& Pressing, 2012 in Rizza \& Varum, 2011).

Adott egy versenyre épülő társadalom. Ebben a környezetben a gazdaságot a profitábilis vállalkozások mozgatják, és ez az a környezet, ahol a flexibilitás, a vállalkozókészség és a mobilitás értékei kerülnek előtérbe. Ebben a közegben a diákoknak más kompetenciákra és készségekre van szükségük ahhoz, hogy érvényesüljenek és sikeressé váljanak (Mihály, 2001).

Ezzel összhangban a tanári szerepek egyik ma még kevésbé elemzett, ám annál inkább prioritást érdemlő területe a vállalkozói példamutatás, a vállalkozói kedv integrálása a hétköznapi oktatásba a pedagógus iránymutatásával, valós szituációkon keresztül. A Nemzeti Alaptanterv (110/2012. (VI. 4.) Kormány rendelet alapján) és egyúttal a 2020/2021-es tanévtől bevezetésre került módosított Nemzeti Alaptanterv már sokkal nagyobb hangsúllyal helyezi a pedagógus vállalkozói példamutatását a középpontba, és ezzel igyekszik a szerepvállalás körüli bizonytalanságot mérsékelni.

A tanár feladatai közé tartozik a vállalkozó szellem ösztönzése, ami a kihívásokkal történő szembenézést, a kreativitást, a sokoldalúságot egyaránt támogatja. A NAT 
kiindulva az Európai Unió által javasolt kulcskompetenciákból, figyelembe véve és integrálva a hazai sajátosságokat fogalmazza meg a 7 kulcskompetenciát. Sajátosságaik, hogy kizárólagosan egyetlen tanulási területhez sem köthetők, változó mértékben és összetételben alapoznak és építenek a megszerzett tudásra, a tanulási-tanítási folyamatban fejlődnek. A tantárgyak során pedig elvárás a kulcskompetenciákhoz történő kapcsolódás. A kulcskompetenciák sorában a munkavállalói, innovációs és vállalkozói kompetenciák is helyet kaptak, ezzel is alátámasztva a méltán fontos és napjainkban egyre kiemeltebb helyet kivívó vállalkozói attitűd fejlesztésére irányuló törekvés létjogosultságát az oktatásban is.

A szakirodalomban fellelhető kutatások alapján ez más európai országokban sokkal inkább az oktatás szerves részét képezi. A vállalkozás oktatásba integrálása kapcsán nem a speciálisan ilyen ismeretekre fókuszáló tantárgyak kidolgozását és tanrendbe illesztését értjük csak, hanem a valós tapasztalatot, hogy miképpen lehetnek a diákok képesek új javak (termékek, szolgáltatások, módszerek, rendszerek, megközelítések) előállítására. A konstruktív jellegü, a szabályok betartására építő vállalkozói készségek szocializálása elengedhetetlen, és ebben a folyamatban a pedagógusok kell, hogy a kulcsszereplővé váljanak (Fülöp \& Pressing, 2012). Ide tartozik az az ugyancsak fejleszteni kívánt aspektus, hogy miképpen lehetnek képesek a diákok saját innovativitásuk, hozzáállásuk új nézőpontból történő megvilágítására. Ez az új nézőpont hatással lehet arra, hogy a munka világába kikerülve hogyan állják meg a helyüket. Utóbbit a fennmaradás érdekében elsajátított eszközkészlet is befolyásolja. Ehhez az oktatási megközelítéshez egy egészen nyitott hozzáállás szükséges a pedagógus oldaláról is, hogy felismerje ennek későbbi gazdasági életre gyakorolt katalizátor hatásán túl a tanuló egyéni fejlődésében, az attitűd befolyásolásában az életre nevelésben mért pozitív hozadékait. Fülöp és Pressing kutatásuk alapján elismerik a vállalkozásra nevelés fontosságát, a gyakorlati megvalósítás már láthatóan sokkal nehezebben kivitelezhető (Fülöp \& Pressing, 2012), fókuszba helyezése tendencia szerűen érzékelhető.

\subsubsection{Kreatív pedagógus, kreatív környezet, kreatív gyermek}

A legtöbb, a kreatív egyénekre fókuszáló kutatás a kiemelkedő „nagy C” kreativitást helyezi a fókuszba, mely kreatív folyamat során létrejön egy nagyívü termék, ami újszerü és hasznos a társadalomnak, vagy a társadalom egy pontosan szegmentálható, jól körül írható részének (Ruth, 2008). Az utóbbi időben egyre nagyobb figyelem fordul a „kis C” (Craft, 2001), azaz a mindennapi (Ruth, 2008) kreativitás jelenségére. A mindennapi kreativitás definíciója szerint kreativitás az, amikor a hétköznapi ember az adott élethelyzetből adódó 
problémához a megoldást egy azonosíthatóan egyedi gondolkodásmódból származtatja. Amikor a kreatív pedagógus karakterjegyeit tanulmányozom, akkor legtöbbször a mindennapi kreativitás jelenségére összpontosítok ( Ripple, 1989 in Anderson, 2002; Bramwell, Reilly, Lilly, Kronish, \& Chennabathni). Rendkívül nehéz meghatározni a kreatív egyének személyiségjegyeit, bár egyes kutatók igyekeztek felsorolni a jellemzőket, ideértve például: kíváncsiság, az ítélet és a gondolkodás függetlensége, az intuíció, az idealizmus, a kockázatvállalás és a feladatok elvégzésére irányuló kapacitás (Torrance, 1965). Ez a korábbi fejezetben taglalt szakirodalmi megközelítéssel (J P Guilford, 1950; Torrance, 1974) is erőteljes átfedést mutat, valamint kiindulási alapot teremt a kreatív tanár személyiségjegyeinek pontos kirajzolódásához.

Az oktatási kontextusban végzett kutatások azt mutatják, hogy a kreatív tanárok közös tulajdonságai a bizalom, ezen keresztül az önbizalomtól szétválaszthatatlan megalapozott tárgyi tudás, a lelkesedés és az elkötelezettség, valamint az én, mint kreatív lény megértése és elfogadása is hozzájárul a kreatív oktatói személyiséghez (Cremin, 2001). A kreatív pedagógus nem fél a kockázatvállalástól sem szakmai, sem magánéletében, sőt ösztönzi az észszerü kockázatokat. (Craft, 2001 in Cremin, 2009; Morais \& Azevedo, 2011). Vitathatatlanul könnyedén megmutatja saját kreatív elkötelezettségét, és felfedi a kreatív törekvésekhez kapcsolódó kétértelmüséget és bizonytalanságot, a kudarcot pedig a tanulási folyamat részeként értelmezi. Ez utóbbi jelenség összekapcsolható az önbizalommal.

Ki kell emelni, hogy a kreatív pedagógus nem fél az érzelmei és érzései kimutatásától sem, mindemellett a mindennapi munkáját megsokszorozza a rengeteg erkölcsi és politikai invesztíció (Woods \& Jeffrey, 1996). A kreatív tanár így tehát jellemzően a tanár-diák kapcsolat formálására is több időt fordít, ami így közelebbi, erősebb és harmonikusabbnak tekinthető kapcsolatot eredményez (Morais \& Azevedo, 2001).

A kreatív tanár egyik legértékesebb tulajdonsága önbevallás alapján, hogy képes a diákok autonómiájának megteremtésére, és az önbizalmuk pozitív irányú elmozdítására (Morais \& Azevedo, 2001). Az autonómia megjelenik a kreatív tanár saját kvalitásaként, valamint az iskolai rendszer, a tanmenet tervezésének önállóságára is utal (D. R. Anderson, 2002), mely összhangba hozható a korábban elemzett pedagógiai innováció esszenciájával. Kiemelendő, hogy a tanár kreativitása nem mindig csak individuálisan értelmezhető, erős a kollaboráció jelenléte, hiszen számtalanszor származhat az ötlet egy közös gondolkodási, együttműködésre építő munkából, folyamatból (John-Steiner, 2000 in Cremin, 2009).

A kreativitás fejlesztése már nem csak egyéni érdek, a társadalom egésze számára prioritás. A fejlődés kézenfekvő terét a köznevelésben töltött évek jelentik, így a kreativitás 
támogatását, térnyerését az oktatási folyamatokban biztosítani szükséges (Mező, Mező, \& Varga, 2019). Az ezt segítő kreatív környezet megteremtésének facilitátora kell, hogy legyen a pedagógus, ez a szerep megköveteli, hogy ő maga rendelkezzen a kreatív tanárt meghatározó tulajdonságok jelentős hányadával. Ugyanis, ha a tanár nem látja fontosnak a diákok kreativitásának előmozdítását, nem valószínü, hogy a kreativitás fejlődését elősegítő környezetet megteremtése létfontosságú feladat lesz számára, nem fogja prioritásként kezelni (Beghetto, 2006).

Ma társadalmi elvárásként realizálódik a sokféle pedagógusszerep egyidejü létezése. A diákok kreativitásának kibontakozásához nem elég néhány technika, fejlesztő módszer, kreatív tanítás alkalmazása. Sokkal inkább szükséges, hogy a pedagógus stílusát holisztikusan átjárja a kreativitást támogató attitűd (Ambrose, 2005). A tanórán kívüli kreativitásfejlesztés, a kifejezetten erre célzottan fókuszáló kurzusok lehetnek hasznosak, de igazán eredményes akkor lesz, ha ez a mindennapokba beépítésre kerül (Péter-Szarka és mtsai., 2015). Ehhez nélkülözhetetlen elem a motiválás és az önálló munka. Bátorítani kell a tanulókat a kérdésfelvetésre, és a nyílt problémamegoldó helyzetekre épülö feladatok megoldására, melyeket aztán érdemes eddig ritkán alkalmazott nézőpontból is tárgyalni. Itt jelenik meg a pedagógus katalizátor szerepe a kreatív környezeti tényezők támogatása kapcsán, mely szerep kiteljesedését is segítheti az általam kidolgozott kreatív workshop (Fryer, 2009; Péter-Szarka és mtsai., 2015).

Fontos tanulmányozni, hogy amennyiben adott egy kreatív pedagógus, aki képes a kreatív környezet megteremtésének facilitátoraként is müködni, úgy mennyire lehet ez hatással a gyermekek kreativitás nevelésének hatékonyságára. Vajon a kreatív pedagógus egy kreatív környezetben kreatívabb gyermekeket nevel?

\section{A pedagógus feladata nemcsak a kreativitásra nevelés, hanem a kreatív, tehetséges} diákban rejlő lehetőség felismerése az adott diák személyes fejlődése érdekében. Feladata az alkotómunkához szükséges tulajdonságok és képességek fejlesztése, és az ennek teret adó feltételek biztosítása (Detre, 2015). Egyáltalán nem elhanyagolható, hogy a diák kreativitása a köznevelésben töltött évek alatt kibontakozik, fejlődik, vagy háttérbe szorul, elnyomásra kerül. Ahhoz, hogy képes legyen az ötlet, a gondolat szárnyra kelni, a kreativitás teret kapni nyitott hozzáállás szükséges az iskola, a pedagógus oldaláról, nem pedig egy olyan keretes rendszer, mely dobozba zárja az innovatív elmét (Buda \& Péter-Szarka, 2014; Detre, 2015).

Ez a nyitottság sokkal nagyobb valószínüséggel van jelen egy kreatív pedagógus személyiségében, ahogy azt korábban is alátámasztottuk. A tanárok közvetlen és közvetett módon is képesek hatást gyakorolni a diákokban rejlő kreatív potenciálra. A pedagógusok 
hozzáállása, nézőpontja befolyásolja a diákokban rejlő kreatív potenciál felismerését, de ami ennél is fontosabb, hogy a tanárok észlelései és kreativitáshoz köthető elvárásai közvetetten befolyásolhatják a hallgatók jövőbeli saját kreatív potenciáljának felfogását (Gralewski \& Karwowski, 2018 in Paek \& Sumners, 2019). Az oktató magatartása előmozdítja vagy blokkolja (Beghetto, 2006) a kreativitás ösztönzését, mely ösztönző erő értelemszerủen sokkal intenzívebb, amennyiben a pedagógus is hordozza a kreativitás személyiségjegyeit.

A gátló hatást eredményezheti akár egy negatív tanári visszajelzés egy kreatívnak vélt produktum kapcsán, mely következményeként a diák érdeklődését és törekvését a kreativitásra elveszíti, a széthulló kreativitás jelenségét eredményezve (Beghetto, 2014). A partneri kapcsolat a kreatív tanulás sikerét is magában hordozza, növeli a tanulásra irányuló törekvéseket, valamint a munkákban a kreativitás előre törését (Horng, Hong, ChanLin, Chang, \& Chu, 2005). A kapcsolódó szakirodalom alapján a pedagógus kreativitása és az ezt támogató közeg, melyet megteremt egyértelműen indukálhatja a gyerekek kreativitásának felszínre kerülését, fejlesztését. Mindezen túl a pedagógus együttműködést támogató szerepe is igen jelentőségteljes úgy a kreativitás, mint egyéb, a kutatásunk aspektusából kiemelten lényeges attribútumok fejlesztésében, melynek elemzésére a következő alfejezet vállalkozik.

\subsubsection{Az együttmüködés katalizátora: pedagógusszerep a csoportmunkában}

A tanári pálya egy olyan foglalkozás, melyben a visszacsatoló információk nagyon rossz minőségűek. Az igazán fontos és meghatározó eredmény csak nagyon hosszú idő után lesz elérhető a pedagógus számára. Fejlődni ennélfogva nehéz, előfordul, hogy éveken keresztül ugyanúgy tanítanak, és nem is jut tudomásukra, hogy adott esetben az a módszer, amit alkalmaznak nem a jó irányba vezet (Csapó, 2007). A csoportmunka ezt nem engedi, hiszen a visszacsatolás képezi az alapját. A csoportmunka során az eredmények egyértelmúek, és azonnal láthatóak, amennyiben adott egy kellő mértékben motivált pedagógus és egy együttmüködésre képes közösség. A motivált pedagógus képes a közösséget pozitívan befolyásolni. Kutatások rávilágítottak, hogy amennyiben egy lelkes tanár áll a katedrán úgy a diákok érdeklődése nagyobb arányban van jelen, energikusabbak, sokkal inkább jellemzi őket a kíváncsiság és az izgatottság a tanulás kapcsán (Patrick, Hisley, \& Kempler, 2000).

A csoportmunka sok esetben, mint rejtett eszköz jelenik meg a pedagógus kezében, ami a tanuló számára tudattalanul müködik, hatással van a hatékony munkavégzésre és a motivációra is (Pajor, 2015). Nem elhanyagolható szempont az sem, hogy eredménye látható, a visszajelzés azonnal eljut pedagógushoz és diákhoz egyaránt, egyidőben. 
Sok pedagógus felvetése, hogy a csoportmunka alapvetően felnőtt feladat, nem várható el, hogy egy ilyen módszertani megközelítést a kisgyermekek jól megoldjanak. Nagy az egyetértés a pedagógusok között abban is, hogy a kisgyermekek együtt dolgozása nem könnyü feladat. Ebből kifolyólag szükség van bizonyosságra, hogy az erőfeszítések mind az érintett tanulási folyamatok, mind a tanulási eredmények szempontjából megérik az erőn felüli energiabefektetést (M. Galton \& Williamson, 2003).

Az együttmüködésre való nyitottságot már maga az ültetési rend determinálja a gyerekekben. Galton és Williamson szerint (2003) ha a diákokat csoportokba ülteti a pedagógus, akkor sokkal hamarabb késztetést éreznek -nem csak eszközeik - de véleményeik megosztására, cseréjére is, az egyéni eredményekért folyó versengést felváltja a közös munka lehetőségében rejlő örömök kiaknázása.

Számtalan általános iskolákban megvalósult megfigyelés bizonyította, hogy a beszélgetés a gyerekek között az osztályteremben sokkal kisebb mértékü, mint a feltételezett ilyen irányú cselekvés (M. J. Galton, Simon, \& Croll, 1980; Mortimore, Sammons, Stoll, \& Ecob, 1988).

Látható, hogy a pedagógus szerepe már az osztályterem berendezésével, az együttmüködésre lehetőséget biztosító tér kialakításával elkezdődik. Általánosságban elmondható, hogy a tanár szerepe a kooperatív tanulásban magában foglalja (1) a célok meghatározását, (2) a hallgatók csoportosítását, (3) a feladatok magyarázatát, (4) a csoportmunka nyomon követését, ami közvetlenül kapcsolható a hallgatók kognitív teljesítményéhez (Deering \& Meloth, 1993 in Ding, Li, Piccolo, \& Kulm, 2007), és (5) az eredmények és az együttmüködés értékelését (Bettenhausen, 2002). A tanár aktív figyelemmel kíséri a tanulási csoportok müködését, amikor szükséges beavatkozik, tanácsokat ad, kérdésfelvetéssel támogatja az együttműködési készségek kialakulását, fejlődését és a feladatok megoldásával kapcsolatos kérdések megválaszolása kapcsán is rendelkezésre áll, ha ezt a diákok igénylik. A tanár szerepe a folyamatban leginkább tanácsadóként jellemezhető. Fontos, hogy teret engedjen a diákok kibontakozásának, a csoport önálló és hatékony müködésének, hátrahagyva a frontális oktatás során beidegződött szokásokat, ami nem kis feladatot támaszt a pedagógus felé (Johnson \& Johnson, 1987 in Ding et al., 2007).

A sikeres tanár definíciója a következőkben meghatározott tulajdonságokra épül (Füzi, 2012; Tímár, 2006). Ezen tulajdonságok párhuzamba állíthatók egy csoportmunka folyamata során előtérbe kerülő attribútumok mentén, így világítunk rá a kollaboráció által a pedagógus csoportmunka során betöltött szerepére és a fejlödés kétoldalú (tanár-diák) lehetőségére. A csoportmunka minden résztvevőnek fejlődési lehetőséget biztosít. 
A sikeres tanárnak (1) jó kapcsolata van diákjaival. A kapcsolat erősítésében a csoportmunka segít, hiszen egy hierarchiamentes kapcsolat kialakításához fontos, hogy eltérő helyzetekben is kapcsolódjanak a diákok és tanárok, így a helyzet akár csak ideiglenes megváltozásával is egy idöre más kontextusba kerül a diák és a tanár, ami katalizátorként hat a társas kapcsolatukra, építi a bizalmat (K Nagy, 2012), de a kreativitás fejlesztésében is helyet érdemel (Horng és mtsai., 2005). A sikeres tanár (2) képes a konfliktuskezelésre és irányításra. A csoportmunka ezen tulajdonságok elöre törését megköveteli. Egy csoportmunka esetén a tanár, mint tréner van jelen, a háttérből ugyan, de irányítania kell a folyamatokat, átlendíteni a diákokat a konfliktuson, amennyiben felmerül, egyfajta facilitátor-mediátor szerepet is betölt (Buchs, Filippou, Pulfrey, \& Volpé, 2017), úgy, hogy a diákoknak önállóságot biztosít. A hagyományos csoportmunkák során ez az autonómia csupán látszat jellegű, de a kooperatív csoportmunka során valóban a diákok önállóságára építkeznek (Arató, 2011). A (3) változásra való képesség szintén a sikeres pedagógus egyik jellemzője. A csoportmunka ehhez akképpen járul hozzá, hogy a folyamatos alkalmazkodásról szól, az új ötletek megjelenéséről, elvetéséről vagy integrálásáról (K Nagy, 2005). Nemcsak a diákoknak, de a tanárnak is követnie kell ezt a változást a saját szerepében, és ezekhez a változásokhoz alkalmazkodni kell, ha a csoport sikeres müködését hivatott segíteni. Végül egy pedagógus akkor lehet igazán sikeres, ha (4) kreatív. Itt kapcsolódik össze és erősíti elválaszthatatlan jellegét az együttműködés és a kreativitás, valamint itt visszautalok az előző fejezetre is, megerősítve annak szakirodalmi megalapozottságát. Kreativitás hiányában a pedagógus nem tudja a diákokat sem kreativitásra ösztönözni, elmarad a példamutatás. A csoportmunka során a kreativitás fejlesztése a közös ötletgeneráláson keresztül realizálódik (Martinez, Gonzalez, Campoy, García-Sánchez, \& Ortega-Mier, 2014), teret adva így a kreatív gondolatok elöre törésének (Füzi, 2012; Tímár, 2006).

\subsection{Diákok: új oktatási igényekkel rendelkező Z generáció}

Ha egy gyerek nem tud úgy tanulni, ahogy tanitjuk, akkor úgy kell tanitanunk, ahogy ö tanulni tud.

\section{- Ignacio Estrada-}

Amikor egy terméket készítünk, akkor az egyik legfontosabb kritérium a sikerhez, hogy kifogástalanul ismerjük azt, akinek a termék szól (Bauer, Berács, \& Kenesei, 2007). 
Szakirodalmi áttekintésem első részének záró szakaszában azt a generációt veszem tehát górcső alá, aki a kutatásom részeként létrehozott oktatásmódszertani eszköz elsődleges célcsoportját alkotja, akit fontos volt megismerni ahhoz, hogy egy számukra is elfogadható, hasznos, újszerü terméket hozzak létre. Generációnak nevezzük azoknak a megközelítőleg azonos életkorral rendelkező személyeknek a csoportját, akik számára a kollektív személyiséget az egyazon történelmi idő és tér biztosítja (Howe \& Strauss, 2000).

Jelen kutatásom fő fókuszát képező csoport az általános iskolába járó, főként már inkább a felső tagozaton tanuló 10-14 év közötti gyerekek. Ök a Z generációt képviselő korosztály, akiket a szakirodalom a digitális bennszülött társadalom képviselőjeként tart számon (Pál, 2013). A korosztály sajátosságait, az új generáció születését elsőként Tapscott ismerte fel (Csobanka, 2016). Amikor elsődleges célcsoportomról elmélkedek, akkor generációs tulajdonságokra is hivatkozom, ezért a dolgozatban a $\mathrm{Z}$ generáció vizsgálatára helyeztem a hangsúlyt.

A Z generációhoz a hozzávetőlegesen 1995 és 2012 között született gyermekeket soroljuk (C. Juhász, 2017), a dolgozat során ehhez a generációs definícióhoz igazodom. Érdemes kiemelni, hogy a Z generáció kapcsán többnyire egyetértenek a különböző szakirodalmi nézetek, a kezdőpontot illetően mindenképpen (Schroer, 2008). Fontos megjegyezni, hogy a Z generáció egy nagyobb korosztályos halmazt fed le, mint a kutatásom fókuszpontját jelentő, elsősorban az általános iskola felső tagozatába járó diákok. A leginkább egységes képet viselkedésükről a generációs jellemzők elemzésén keresztül sajátíthatjuk el. Természetesen nem mindenki képviseli ugyanazokat az értékeket vagy rendelkezik és éli meg egyazon tapasztalatokat az egy generációba foglalt korosztályos társaival. Adott egy közös társadalmi, történelmi és szociális kontextus, mely hasonlóan alakítja világképüket. Ennélfogva tehát a generációs kutatás értékes információkat szolgáltathat az intézményeknek a hatékony oktatási politikák, programok és gyakorlatok megtervezéséhez (Seemiller \& Grace, 2017).

\subsubsection{A Z generáció általános jellemvonása}

A Z generáció szocializációjában alapos szerepet játszott a technológia rohamos fejlődése és térnyerése, az ingatag gazdaság és a társadalmi igazságosság mozgalmai. Sokkal nyitottabb és elfogadóbb a nem megszokottra, arra, ami eltér az átlagostól (Shatto \& Erwin, 2016). A 9/11es terrortámadást követően nőttek fel, így az erőszakhoz való kapcsolódásuk egy teljesen más szintet mutat, tudják, hogy gyakorlatilag a nap bármely szakaszában megtörténhet egy ehhez hasonló esemény. A félelem jelen van, de nem szab gátat annak, hogy érezzék magukban az 
erőt és képességet, mely lehetőséget teremt számukra a világ megváltoztatására. Ezek a jelenségek természetesen a többi generáció formálódásához is hozzájárulnak. A Z generációnak nincs összehasonlítási alapja (Seemiller \& Grace, 2017). Számukra az internet, az online kapcsolódás egyazon világ része, amiben élnek, szétválaszthatatlan egységben formálódik életük a digitális technológiával és az irányítása alá kerülö folyamatokkal. Ők az ,interneten felnövő, annak képi és nyelvi világát ismerő generáció tagjai, akik rövid, képekkel ellátott, naprakész, igazából real time információkat kezelnek" (Törőcsik, Szücs, \& Kehl, 2014, o. 6).

Már a korai életkortól kezdve a $\mathrm{Z}$ generáció szinte bármit megszerezhet egy gombnyomásra az interneten keresztül, ez a jelenség beágyazódott a kultúrájukba, és gyakorlatilag ezt veszik természetesnek, így a türelem háttérbe szorul (O’Connor, 2016), szemben az azonnali tudás iránti vággyal, ami prioritásként kap helyet (Mendoza, 2018). Az internetet tekinthetjük az első tanáruknak, hiszen a digitális világgal és az ott rejlő információkkal már a formális oktatás előtt megismerkedtek, így nem volt kérdés, hogy tanulásuk fő alkotóelemévé válik majd (Geck, 2007).

Ők az a generáció, akiket a legidősebb átlagéletkorú anyák gyermekeiként tartanak számon, a családmodellre jellemző a kis létszám, ebben az időszakban az egy anyára jutó gyermekek száma 2 alá csökkent. Ez is befolyásolhatja azt, hogy ők az a generáció, akik oktatására a legtöbb figyelem fordult, ezen túlmenően a becslések alapján várható életkoruk is nekik a leghosszabb (Pais, 2013).

Jellemző rájuk az élethosszig tartó tanulás (Ferincz \& Szabó, 2012) és a munkamagánélet egyensúlyára való törekvés (Krajcsák, 2018). A generáció mibenlétét, fő jellemvonásait már az elnevezés is igen erősen szemlélteti, amivel ezt a generációt a szakirodalom felruházza (Pais, 2013): bedrótozott nemzedék, net generáció, dotcom gyerekek, Facebook generáció vagy éppen digitális őslakosok név jelzi a korosztályos sajátosságot (Prensky, 2001). Rendkívül jól kezelik az online térhez kapcsolódni képes eszközöket, egyszerre több platformon vannak jelen, számukra a multitasking tartalomfogyasztás magától értetődő, jellemzően nem 1-2, hanem 4-5 képernyőn keresztül (Glum, 2015) valósul meg. A nagy online nyilvánosságban való megjelenés is természetes, megszokott jelenség számukra, legtöbb esetben ők generálják azt, emellett a közösségi média főszereplői. A Z generáció szociális, ez nem megkérdőjelezhető, ahogy az sem, hogy ennek ellenére az írásban történő kommunikációt a szóbeli kapcsolattartás elé helyezik (Igel \& Urquhart, 2012).

A világ első globális nemzedékeként tartjuk őket számon, a kultúra, a gasztronómia fogyasztása, az öltözködési trendek, a szórakozási szokások nagyon nagy átfedésben vannak, nincsenek markáns földrajzi határok, és számukra nem is voltak, az online egység a kezdetektől 
biztosította a generáció számára azt, hogy nyelvtől és tartózkodási helytől függetlenül alakíthassa ki a globális generációs sajátosságokat, és megélje a kultúrák aktív találkozásában és a folyamatos kapcsolattartásban rejlő lehetőségeket (McCrindle \& Wolfinger, 2010). Ezt erősíti, hogy olyan szavakat, kifejezéseket alakítottak ki maguknak a Z generáció tagjai, amit a többi generáció már nem ért (Tari, 2011).

\subsubsection{On-Offline kapcsolatrendszer}

A kapcsolatok fontosak számukra, de a kapcsolat online/offline jellege diverz képet mutat. Kezdetben az online teret az offline kapcsolat ápolására, építésére használják, építenek arra, hogy bárhol, bármikor bárkit elérnek és maguk mellett érezhetnek a digitális eszközök és az internet biztosította lehetőségeken keresztül, de aztán szépen lassan észlelhető a tendencia, hogy az online kapcsolattartás elötérbe és túlsúlyba kerül (Turkle, 2017). Az ismerkedésre hangsúlyt fektetnek, fontos számukra. Ami igazán jellemző rájuk az az online platformon megvalósuló kapcsolatteremtés, majd a kapcsolat fenntartása a digitális térben, amihez a fó csatornát az online üzenetküldő applikációk jelentik számukra. Nem ritka az sem, hogy fizikailag velük egy légtérben tartózkodó társukkal is az online dimenzióban zajlik a kommunikációs párbeszéd (Ruzsa, 2018). Az online világ identitásuk alakulásának jelentős befolyásoló tényezőjévé válik, az online világ az én határokat kiszélesíti számukra (Pais, 2013). Szabadságigényük éppen ebből kifolyólag is magas. Az online világban igencsak otthonosan mozgó Z generáció számára komoly kihívást jelent az online és az offline élet összekapcsolása, mely szinergia kialakításában az oktatásnak is meghatározó szerepe lehet (Bencsik, HorváthCsikós, \& Juhász, 2017).

Mivel a technológia az egyének interakciójának átjárójaként müködik, a társadalom hozzászokott már ahhoz, hogy az egyén egyre inkább hálózatba kerül, semmint társadalmilag beágyazódjon csoportokba. A társadalmi érdeklődés és csoporthoz kapcsolódás befolyásolhatja a Z generációs fiatalokat, segítené őket abban, hogy a szóbeli kifejezőkészségük árnyaltabbá, szóhasználatuk választékosabbá váljon. A személyes kapcsolat hiánya potenciálisan gátolhatja a társadalmi és személyes kapcsolatfelvételi képességeik fejlesztését (Turner, 2015). Az a Z generációs gyermek, akinek nincs lehetősége részt venni az akadályok kezelésében és azok leküzdésében a személyes interakción keresztül, felnőttként potenciálisan küzd a kapcsolatok fejlesztésével. Ennek orvoslása, a személyes kapcsolat erösítése ugyancsak az iskola 
felelőssége is (Turner, 2015), melynek egyik eszközeként szolgálhatnak a kollaborációra, kooperációra építő módszerek..

\subsubsection{A Z generáció és a csoportmunka}

A Z generáció a tanulási módszer aktív szereplőjévé szeretne válni oly módon, hogy az elsajátított tudást azonnal tudja alkalmazni a való életben (Seemiller \& Grace, 2017). A dotcom nemzedék alapvetően türelmetlen és elsősorban a gyakorlati tudás elsajátítására törekszik. Észlelése szerint minden információt megtalál az online térben, az erre specializálódott keresőoldalakat készség szinten használja, a talált információ validitását nem kérdőjelezi meg (Shatto \& Erwin, 2016).

A fejlett problémamegoldó képességgel rendelkező $Z$ generációnak szüksége van a megfigyelő szerepre. Gyakran fogyaszt videós tartalmakat, a tudás elsajátításának első lépéseként azonosítja a megfigyelő szerepet. A szakirodalomban egyes kutatók úgy vélik, hogy a Z generáció tagjai okosabbak, jobban képesek önmaguk irányítására, így az önállóságra és az információk gyorsabb feldolgozására. Van valami, amiben biztosan nem haladják meg az őket megelőző generációkat. Ez pedig nem más, mint az együttmüködés, valamint az erre építő tanulási módszerek. A Z generáció a csoportmunkára elsősorban online formában nyitott, de ez a nyitottság is csak erős nyomás hatására valósul meg. Fontos, hogy a többi generációhoz képest a tudás megosztása teljesen természetes számukra, tét nélkül, nyíltan vállalják tudásuk publikussá tételét (Bencsik \& Machova, 2016).

Az együttmüködésre való nyitottság és képesség tehát nem nevezhető generációs sajátosságnak, sokkal inkább egy generációkon átívelő tulajdonságként kap helyet, mely halmaznak az összetétele diverz képet tár elénk a korosztály tekintetében. Nevezhetjük őket Co-generációnak. Amikor Co-generácóról beszélünk, akkor az együttmüködés hierarchiamentes megvalósítását megvalósítani képes közösségről beszélünk, amit értelmezhetünk akár a korábban már felvezetett tanár-diák relációban is. Ök az a „generáció”, akiknek a leginkább fejlett az együttmüködési képessége, akik a legerőteljesebben alkalmazzák a kooperációt úgy a mindennapi életben, mint egy munkahelyi probléma megoldása érdekében. Az együttműködésben a lehetőséget látják, ahol a tudás spektruma megsokszorozódik, így hozzájárul a probléma hatékony és gyors megoldásához.

A társadalmi és konstruktivista tanulási elméletek állítják, hogy az ismeretek megszerzése és kiterjesztése nem valósulhat meg az emberek közötti kölcsönhatás, az interperszonális kommunikáció eszköze nélkül, a pszichológia pedig a társas tanulás érzelmi 
előnyeiről ír, kifejezetten azok számára, akik izoláltan küzdenek a tananyag elsajátításával. (Igel \& Urquhart, 2012). Éppen ezért is kiemelten fontos és több kutatás is alátámasztja, hogy a kooperációra építő tanulási módszerek alkalmazása a fiatalok körében kiemelt szerepet játszik, hatékony alkalmazása a Z generáció körében nagyfokú tudatosságot követel meg. Körültekintéssel kell tehát a netgeneráció számára a kollaborációra építő feladatokat tervezni, hiszen elötérbe helyezik az intraperszonális kommunikációt. Ez adódik abból a sok attribútumra visszavezethető generációs adottságból, hogy a digitális lét teret ad, mi több támogatja az intraperszonális tanulási folyamatokat. Ennek ellenére a dotcom generáció értékes forrásként tartja számon a társakat és az instruktorokat, de szüksége van arra a döntésre, hogy másokkal a saját szabályai és meglátásai mellett dolgozhasson együtt, és az együttmüködést megelőzően nélkülözhetetlen számára, hogy a problémát megismerje, a koncepciót, a megoldási javaslatokat önállóan végiggondolja (Seemiller \& Grace, 2017).

\subsubsection{A formális hatalmi viszonyokat elutasító nemzedék}

Kutatásom szempontjából fontos kiemelni e generáció tekintélyhez való viszonyának módosulását. A szabályok betartására nem mutatnak hajlandóságot. A gyors változásra, megújuló impulzusokra, és a folyamatos fejlödésre szükségük van, jól is kezelik, hiszen ebbe a környezetbe születtek bele, a felpörgött életritmus már a lételemüknek tekinthető (Pais, 2013). Ezt igazolja, hogy a $\mathrm{Z}$ generáció tagjainak hozzáállása a formális hatalmi viszonyokra építő vezetéssel szemben elutasító. Az egyén szabadsága kiemelten fontos számukra, ahogy az önmegvalósítás, mindemellett a formalitásokat, úgy az alá-fölérendeltséget elutasítják (SzabóSzentgróti, Gelencsér, Szabó-Szentgróti, \& Berke, 2019).

A szakmai fejlődés igénye a munkahelyi célok és a karrierépítés fölött áll. A csapatmunkának azt az aspektusát különösen élvezik, hogy ott teret kapnak a hierarchiamentes fejlődésre. Fontos tehát, hogy erre már az általános iskolában építsünk (Wey Smola \& Sutton, 2002). Ez alátámasztja, hogy egy rendkívül szabad, keretektől, szabályoktól mentes módszertanra van szükség, ha azt akarjuk, hogy pozitív fogadtatásban részesüljön, és valóban elérje a célt a módszertan, vagyis kizökkentve őket a formális keretrendszerből egy új irányt mutatva fejlődhessen a kreativitásuk, megvalósuljon a látókörbővítés a világ első globális generációjánál (Pál, 2013).

Mivel ezek a fiatalok nem vesznek tudomást más valóságról, mint az internet-alapú világuk, valószínűleg megnövelték a technikai elvárásokat, hozzáállást és meggyőződést úgy egymás, mint az őket körülvevő környezet, így tanáraik felé is (Geck, 2007). A Z generáció 
megszokta, megtanulta az „új” technológiákat, nem is tehetett mást, hiszen ebben szocializálódott, nem is ismer mást, nem tolerálja azt, ha valaki (akár egy másik generáció) nem képes elsajátítani a folyamatosan változó új digitális infrastruktúrát (Gale, 2015).

A pedagógus és a $Z$ generációs diák közötti szakadékot növeli, hogy a Facebook generáció által kialakított párbeszédet, a sajátos nyelvezetet a másik generációhoz tartozó pedagógus nem, vagy csak hiányosan érti, ami nem tudatosan, de ugyanúgy a hatalmi hierarchia, a távolság fokozásának érzését és a bizalom hiányát keltheti a diákban (Besenyei, 2016). Ennek mérséklésére megoldást jelenthet, ha a pedagógus is képes nyitottá válni és elsajátítani a Z generáció szókincsét, fejleszti a digitális tudását, nem utasítja el, hogy ő tanuljon a diákoktól. Ez a korábbi fejezetben taglalt pozitív tanár-diák kapcsolat kialakulását és a vele járó pozitív hozadékot jelenti a dotcom nemzedéknek, hozzájárul az offline kapcsolatok, az interperszonális kommunikáció erősödéséhez. Ez utóbbihoz tartozik a másokkal való jó együttműködéshez szükséges készségek kialakítása, például aktív hallgatás, konstruktív kritika biztosítása és a képesség arra vonatkozóan, hogy mások, sok esetben eltérő nézőpontját tiszteljük, elfogadjuk (Frey, Fisher, \& Everlove, 2009).

A Z generációt oktató pedagógusok felé és felől rengeteg kérdés felmerül az oktatásitanulási folyamatok kapcsán. Egy bizonyos: meglepően hangzik, de a Z generáció bevonódása csak úgy érhető el, ha az oktatást igazítjuk saját igényeikhez (Shatto \& Erwin, 2016). A diák elkötelezetté válik a tananyag felé, ha az személyes életéhez, érdekeihez kapcsolódik, ha aktív részesei a folyamatnak, valamint, ha a figyelem a hallgató fejlesztésére irányul és nem a pontszám és az érdemjegy megszerzésére fókuszál (Pletka, 2007). Csak a dinamikus tanulási környezet megteremtésével lesznek képesek az oktatók elérni azt, hogy a Facebook generáció hatékony tanulóvá és a társadalom aktív tagjává váljon kezelve a felmerülő konfliktusokat és tanúsítva a megértést, amennyiben az éppen szükséges.

Van egy generációs szakadék, amihez hozzáadódik az ezzel párhuzamosan futó, kötelezően az oktatásba illesztett digitális tudás, mint kulcskompetencia elsajátítása, a technológiahasználat integrálása a mindennapi oktatási gyakorlatba, a megváltozott szociális normák, melyek rengeteg még megválaszolatlan kérdést hordoznak magukban. Egy dolog bizonyos: a tanár-diák távolság minimalizálása érdekében a pedagógusok képzésébe integrálni kell a Z generációs sajátosságokat, így a közös szókincsen túl a digitális és technológiai ismereteket, hiszen a kapcsolat ezen tudásátfedés hiányában párhuzamos, nem egy irányba haladó kommunikációs folyamatokat indít el, ami hosszabb távon az oktatás minőségében is visszaütközhet (Cruz \& Díaz, 2016). 


\section{AZ OKTATÁS ÉS A GAZDASÁG POTENCIÁLIS KAPCSOLÓDÁSI PONTJAI}

Ha csak azért tanulunk, hogy jól teljesítsünk egy vizsgán, akkor elfelejtettük, mi is a tanulás valódi célja. - Jeannie Fulbright -

A közoktatás hazánkban állami feladat, így magától értetődő, hogy a neveléstudomány fejlődése szétválaszthatatlan egységben van jelen az adott társadalom politikai és gazdasági fejlődésével (Csapó, 2011). Az oktatás és a gazdaság között a legerősebb kapcsolódási pontot maguk a szereplők jelentik. Azok a fentiekben bemutatott és megismert $Z$ generációs diákok, akik jelenleg még az iskolapadban ülnek néhány éven belül kikerülnek a munkaeröpiacra és a gazdaság motorjaként meghatározó szereplőkké válnak. Olyan szereplőkké, akik felé elvárásként realizálódik az élethosszig tartó tanulás, akik számára hasznosítható, a társadalmi és gazdasági igényekhez igazodó tudást kell átadni (Csapó, 2011).

$\mathrm{Az}$ oktatás-és neveléstudomány területét behatóan vizsgáló jelen dolgozat fontos célkitüzéseként tartja számon, hogy kapcsolatot teremtsen, valamint párbeszédet indítson az oktatás és a gazdaság szereplői között. A cél, hogy rávilágítsak, hogy a két terület szoros együttmüködése, összehangolt kommunikációja elengedhetetlen, az oktatási szektor feladatai közé kell, hogy tartozzon a gazdasági szféra által támasztott igény kiszolgálása, de ez csak akkor kivitelezhető, ha a gazdaság oldaláról is folyamatos a párbeszéd a munkavállalói elvárások tekintetében.

Ha a munkaerő termelésre, folyamatként tekintünk, akkor az, ami az oktatásnak az eredménye vagy „outputja”, az a vállalati közeg ,inputja” lesz. A felmerülő kérdés az, hogy vajon egy iskolába kerülő kisgyereket mikor és milyen formában kell elkezdeni felkészíteni a munkavállalói létre? Milyen előnyei származhatnak a diáknak és milyenek a gazdaságnak abból, ha az iskola tudatosan, tantervbe integráltan készíti fel a tanulókat az iskola utáni életre már az iskolakezdéssel egyidőben?

\subsection{A neveléstudomány megsokszorozódott feladatai}

A közösség által felhalmozott tudás, annak továbbadása a következő generációk számára, vagyis a tanítás gyakorlatilag egyidősnek tekinthető a civilizációval. Az oktatás egyre intenzívebb és szélesebb körü terjedése a 19. század végére vezethető vissza, amikor jelentős 
növekedés vette kezdetét, megsokszorozódott az igény a képzett munkavállalók iránt. A tudás felértékelődése a 20. század második felében minden eddiginél nagyobb méreteket öltött, ezzel párhuzamosan a munkaerővel szembeni elvárások is intenzív növekedésnek indultak. A neveléstudomány feladatai tehát megsokszorozódtak: használható, hasznosítható tudás átadására vállalkozik (Csapó, 2011).

A gazdasági szektor állandóan változó elvárásai mellett a társadalmi, technológiai és kulturális változások konstans jelenével is meg kell birkóznia a képzési intézményeknek, mi több, állandóan igazodni, alkalmazkodni, reagálni szükséges ezekre a változásokra. Ez a válasz, a reakcióidő, a tanúsított rugalmasság pozitív irányba billent az oktatási intézmények esetében, de a távolság még mindig nagy a gazdaság és az oktatás között (C. M. Szabó \& Balázs, 2020). Szakirodalmi kutatások is rávilágítanak, hogy mennyire fontos lenne az ipar és az oktatás tantervi szintü összekapcsolása, ahol az oktatás szereplői kezdeményezik az ipar szereplőinek meghívását, ennek rendszerszintű megjelenését a tantermi mindennapokban (Mei, 2019).

\subsection{Az oktatás, mint befektetés}

A közoktatás fejlesztése a legjobb beruházások egyikeként tartható számon. Számtalan szakirodalom (Hanushek \& Woessmann, 2010; Krisztina \& Pál, 2015; List \& Horn, 1940; K. Nagy, 2016) megerősíti az elméleti és gyakorlati oktatás gazdasági növekedésre mért pozitív hatását. Azzal már kevesebb tanulmány foglalkozik, hogy ehhez a növekedéshez pontosan milyen oktatási fejlesztésre, bővítésre van szükség. (Keller, 2006). Csapó szavait idézve: Kiemelt feladat annak az attitüdnek az elsajátítása, ,hogy az oktatásra ne mint fogyasztásra, egyfajta luxus kiadásra tekintsünk, amelyre majd akkor lehet költeni, ha az egyéb igények már ki vannak elégítve, hanem (gazdasági szempontból) olyan befektetésre, amit érdemes mások elé helyezni, mert az erre forditott kiadások más alternativ beruházásokhoz viszonyitva jobban megtérülnek" (Csapó, 2011, o. 1068).

Az oktatást úgy tekintik, hogy a különféle fejlődési mechanizmusok révén kedvezően befolyásolja a növekedési rátákat, ideértve a teljesség igénye nélkül a megnövekedett termelékenységet és írástudást (Schultz, 1963), a közösség átlagos iskolai végzettségének átterjedő hatásait (Lucas, 1989) vagy az új technológia elfogadását (Keller, 2006). Fontos rögzíteni, hogy az oktatás célja nem redukálható a gazdaság produktivitásának növelésére, ugyanakkor a tanulmányi és a gazdasági teljesítmény kapcsolata közötti összefüggés nem függetleníthető egymástól. Fél évszázados múltja van azoknak a közgazdaságtani 
elméleteknek, melyek az emberi erőforrást, a megszerzett készségeket és képességeket, a felhalmozott társadalmi tudást tekintik a gazdaság katalizátoraként.

A háromévenként mért, életkoralapú felmérésre építő PISA eredmények rendkívül hasznos tükröt tartanak az oktatás és gazdaság szereplői, véleményformálói, fejlesztői elé. A mérések során felhalmozott adatok pontos kimutatásokat, precíz modelleket állítanak fel annak szemléltetésére, hogy amennyiben az oktatási rendszerek hatékonyságát fokozzuk, úgy az milyen gazdasági hozamot jelenthet (Csapó, 2011). A PISA eredmények mellett az OECD (Gazdasági Együttmüködési és Fejlesztési Szervezet) egyéb statisztikai adatait integrálta az a kimutatás, melynek során azt elemezték, hogy amennyiben egy ország oktatása 20 év alatt elérné a finn oktatás színvonalát, akkor az a becslések alapján a most született generációnak az éves jövedelmünk öt-hatszorosát jelentené többletként (OECD, 2010). Rávilágít arra is, hogy mennyit veszít az az ország, aki nem reagál időben a közoktatás fennálló problémáira, és a benne rejlő lehetőségekre (Csapó, 2018). Egy másik kutatás eredménye kiemeli, hogy globális szinten, a vizsgált időszakot tekintve, azokban az országokban gyorsabb gazdasági növekedés volt tetten érhető, ahol a közép és felsőoktatás kapcsán a beiratkozási ráta is emelkedett. Mindemellett ugyancsak növekedést mutattak ki ott, ahol az alap-és középfokú oktatásban az egy főre jutó oktatási közkiadás magasabb volt, illetve ahol általánosságban több invesztíció zajlott az általános iskolában (Keller, 2006).

Nem véletlen, hogy az akadémiai irodalom egyértelmüen pozitív összefüggést bizonyít az emberi tőke és a gazdasági növekedés között. Azok a befektetések és üzletágak, melyek munkavállalói több készséggel, magasabb képzettséggel rendelkeznek nagyobb innovációs és teljesítményrátát tudhatnak magukénak. A lexikális, technikai tudás, a magas kvalifikáció csupán egy a modern munkavállalói elvárások sokaságában. Az úgynevezett soft skillek és személyes tulajdonságok éppúgy hozzáadódnak a sikerhez. A Világgazdasági Fórum szerint meghatározott tizenhat kritikus jártassági tényező közül tíz a soft skillekre alapoz. A soft skilleket nevezhetjük foglalkoztatási vagy vállalkozói készségeknek is, sajátosságuk, hogy nem iparág vagy foglalkozásspecifikusak (Deloitte Access Economics, 2017).

\subsection{Soft készségek, mint a legfontosabb munkavállalói elvárások?}

Az üzleti siker és a nemzeti jólét megkívánja, hogy a legfontosabb munkaerőt jelentő társadalmi közeg képességek széles skálájával rendelkezzen (Deloitte Access Economics, 2017). Ennélfogva a mai fiatalok, serdülök számára az iskolai, később a munkahelyi siker megköveteli a kritikus gondolkodói képességeket, és azt, hogy képesek legyenek csapatként 
müködni ebben a sokszor igen összetett társadalmi rendszerben (Igel \& Urquhart, 2012). Azok a diákok, akik rendszeresen egy jól strukturált kooperatív környezetben tanulnak sokkal jobban felkészülnek az iskola utáni életre, így a munkaerőpiaci elvárásokra is (Igel \& Urquhart, 2012). A munkahelyi rugalmas, fejlesztésre irányuló csoportok, szerveződések a sikeres iskolák számára mintát adnak, ahol ugyancsak alkalmazzák ezeket a kötetlen munkacsoportokat, használatuk egyre több helyen kerül bevezetésre az oktatásban (DuFour, 2004).

3.3.1 Soft készségek: a fogalom és a benne rejlő üzleti potenciál

$\mathrm{Az}$ általános bevezetést és áttekintést követően, ha a fogalom pontos definícióját vizsgálom, akkor a készségek a következőképpen határozhatók meg: „A készségek öröklött és tanult rutinokból, valamint egyszerübb készségekböl, ismeretekböl szervezödö pszichikus rendszerek, amelyek a képességek, a kompetenciák komponenseiként aktiválódnak a személyiség müködésében, viselkedésében”(J. Nagy, 2000, o. 255) A hierarchiát és az elemek egymáshoz való kapcsolódását tekintve tehát a több tízezer rutin és a többezer készség képességekké kovácsolódik, majd ezek a képességek 3 általános és néhány speciális kompetenciává állnak össze (J. Nagy, 2000). Ennélfogva a korábbi fejezetben már érintett kompetencia, készségek, képességek, ismeretek, adottságok és attitüdök együttese (Gőgh \& Kővari, 2019), mely biztosítja ismereteink mobilizálását, magába integrálja a tanulásra való képességet is. Úgy is fogalmazhatunk, hogy a készségeket a kompetencia alcsoportjaként tartjuk számon. A szakirodalom elismeri, hogy a kompetencia és a készség között felfedezhető átfedés, ám a kifejezések fogalmi különbsége valós (Rychen \& Salganik, 2000).

Az együttmüködés, a problémamegoldás és a konfliktuskezelés olyan kompetenciák, melyekre a munkaeröpiac igényt tart, függetlenül a pontos végzettségtől, és egyre több iskola építi be az ezeket a kompetenciákat támogató tanulási készségeket az alaptantervbe (Aronowitz, 2010). Közvetlenül egy tantárgyhoz sem kapcsolhatók, (Kovári, 2019) a soft készségek csoportjába soroljuk őket.

A soft készségek elnevezése változó képet mutat a szakirodalomban, olvashatjuk definíciójukat úgy, mint szociális készségek/kompetenciák, általános kompetenciák, transzverzális kompetenciák, non-kognitív készségek, de nagy nemzetközi kutatási projektek és szervezetek 21. századi készségként (Ananiadou \& Claro, 2009) és kulcskompetenciaként említik a soft készségeket (Cinque, 2016). Fontos rögzíteni, hogy az eltérő megnevezésekhez eltérő definíciók is társulnak, melyek átfedésben vannak és kiegészítik egymást. 
Tanulmányomban a soft készségek megnevezést és a hozzá társított és elfogadott definíciót alkalmazom.

A soft készségek alapvetően inkább a viselkedés, hozzáállás és a gondolkodás, a személyes tulajdonságok halmazát jelentik, melyek lehetővé teszik az emberek számára környezetük hatékony irányítását, együttmüködésüket embertársaikkal. A soft készségek két nagy csoportba sorolhatók annak függvényében, hogy intraperszonális, azaz személyen belüli, vagy interperszonális, vagyis személyek közötti készségekhez kapcsolható az attribútum.

Az intraperszonális készségek az egyén képességeire vonatkoznak arra, hogy miképp menedzseli magát és munkahelyi fejlődését, lásd időmenedzsment, stressz menedzsment vagy kreatív gondolkodás. Mindeközben az interperszonális képesség definíciója szerint arra utal, hogy az ember hogyan képes a kapcsolatainak a kezelésére az optimális fejlődés érdekében, mint például a motiválókészség vagy épp a tárgyalókészség (Sunarto, 2015).

A soft készségek, mint belső és személyközi interakciót támogató készségek nélkülözhetetlenek a személyes fejlődéshez, a társadalmi részvételhez és a munkahelyi sikerhez (Kechagias, 2011; Lippman, Ryberg, Carney, \& Moore, 2015). Támogatják a pozitív teljesítményt és a célok elérését. Alkalmazásuk széles körben lehetséges, a müszaki, szakmai és tudományos készségek kiegészítő elemeiként is funkcionálnak. A soft skillek egy életciklus során változhatnak, sőt változnak is, de az intenzitás, és a változás könnyedsége különböző mechanizmusok mentén megy végbe az egyes életszakaszokban (Kautz, Heckman, Diris, Ter Weel, \& Borghans, 2014). Növekvő bizonyítékbázis utal rá, hogy az akadémiai és technikai készségeket nemcsak kiegészítik, de felveszik velük a versenyt, a tulajdonságok birtokában megjósolható a várható kereset és a foglalkoztatási arány (Kautz és mtsai., 2014).

A soft készségek bizonyítottan növelik a vállalat értékét, és pozitív hatásuk közvetetten tetten érhető az üzleti eredményekben. A Deloitte Access Economics kutatására alapozva készített egy ábrát, mely kiválóan szemlélteti, hogy a magas szintű soft készségekkel rendelkező alkalmazottak hogyan járulhatnak hozzá az üzleti sikerhez vezető kulcsfontosságú mutatók jobb teljesítményéhez. Az ábra elemzésem fókusza szempontjából leginkább relevánsnak ítélt elemeit apróbb kiegészítésekkel mutatom be az értekezésben. 
1. ábra: A soft készségek üzleti sikerhez történő hozzájárulása

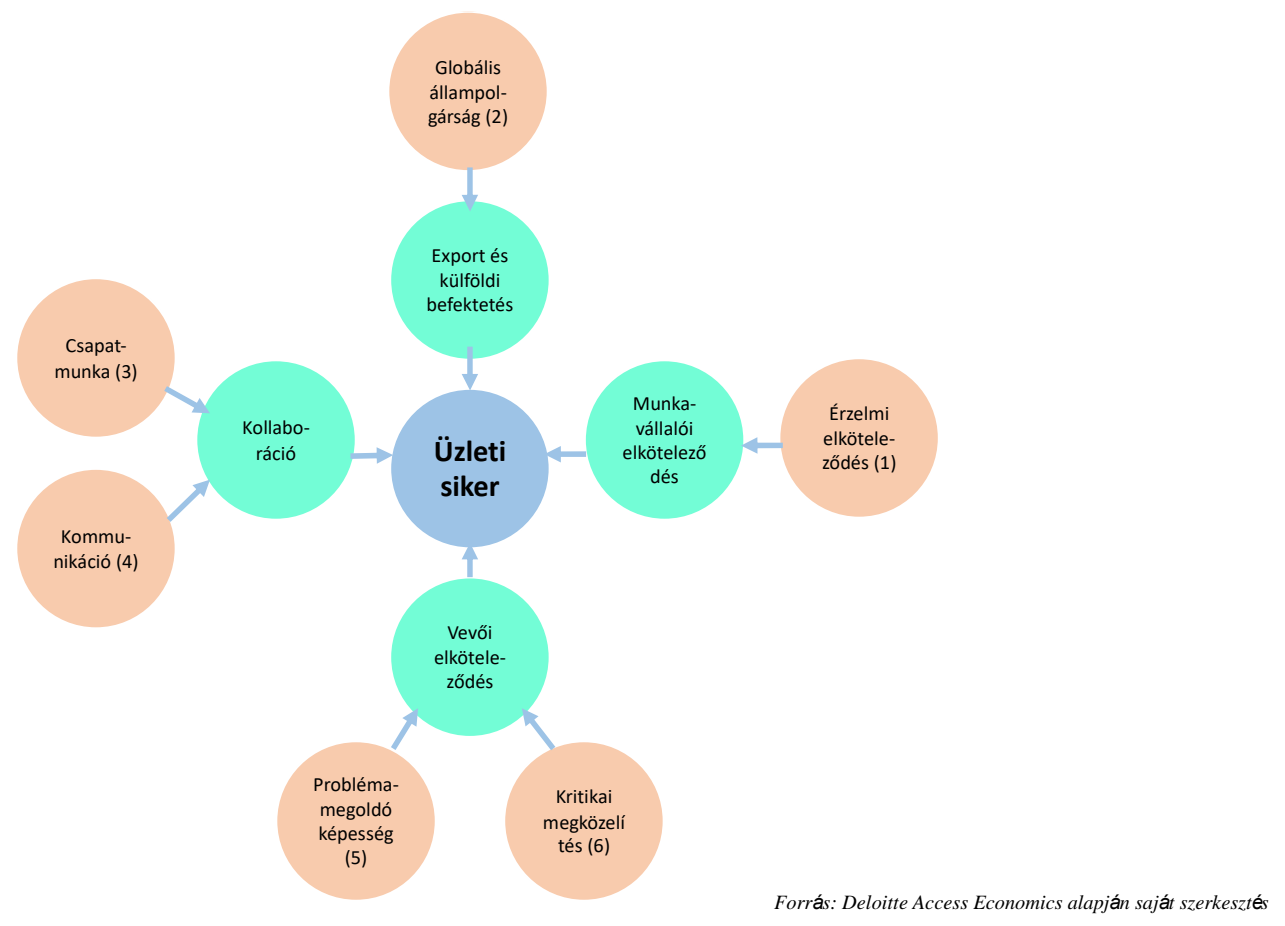

Az erős érzelmi elköteleződés (1) alacsony fluktuációhoz vezet. Ezt megerősíti egy közel 600 munkavállaló bevonásával készült kutatás, mely alapján az önértékeléssel mért érzelmi intelligencia szintje erősen korrelál a munkahelyen maradással (Jordan \& Troth, 2011), ami a vállalatnak érdeke, hiszen a munkavállaló betanítására az első évben igen jelentős összeget fordít, ami abban az esetben, ha a munkavállaló a megtérülési idő előtt elhagyja a vállalatot, akkor az veszteségként realizálódik (P. Juhász, 2005). A tanulmány arra is rávilágít, hogy amennyiben egy munkavállalóban erősen jelen van a globális állampolgárság (2) nézete, akkor az export tevékenységet is végző vállalat felé a partnerek nagyobb bizalommal fordulnak, a kulturális érzékenység ugyancsak segít ennek támogatásában. Hazánkban a globális állampolgárság (Abdullahi, 2010) helyett a globális felelősségvállalás kifejezést használjuk. Ennek oka, hogy az oktatásban a diákok ilyen irányú képzése és ösztönzése nem arról szól, hogy a globalizáció előnyeinek kihasználására készítse fel őket az oktatási intézmény. Sokkal inkább arról, hogy együtt, egy globális közösség részeként képessé váljunk felelősséget vállalni a Föld jövőjéért (Varga, 2018). Az együttmüködést tárgyaló fejezetben kitértem a kooperációt támogató tényezőkre, mint a csapatmunka (3) és a tagok között a megfelelő kommunikáció (4). Az együttmüködésnek kiemelt szerepe van, a vállalati siker kulcstényezőjeként tartják számon, hiánya olyan következményeket hordoz, mint a piaci erő és a hatékonyság csökkenése (Takácsné Prof Dr György \& Benedek, 2016). Az ábrában további két igen lényeges soft skill jelenik meg, mint az üzleti siker közvetett mozgatórugója. A problémamegoldó képesség (5) és 
a kritikai megközelítés (6). Mindkét készség a vevőorientációt támogatja, mely a vállalati siker legérzékenyebb összetevője. A fentiekben taglalt elemzés kimondja tehát, hogy a soft készségek jelentős haszonnal járhatnak, még azokban az iparágakban is, ahol ezeket nem feltétlenül a leginkább kritikus fejlesztendő pontok között tartják számon a vállalatok (Deloitte Access Economics, 2017). Látható tehát, hogy a soft készségek üzleti sikerhez történő hozzájárulása egyre inkább teret kap a vállalati menedzsment gondolkodásban, így ezzel egyidőben nemcsak a meglévő munkavállalók soft készségeinek fejlesztése kerül előtérbe, hanem az újonnan belépő munkavállalók felé támasztott követelmények is egy magasabb szintre kerülhetnek.

\subsubsection{A fiatal munkavállaló felé támasztott követelmények}

A munkáltató oldaláról az elvárás a megfelelő szakmai felkészültség tekintetében alapvetés. Ahogy az előző fejezetben is rávilágítottam, egyre nagyobb hangsúly kerül a soft skillek jelenlétére is. A Deloitte Access Economics előrejelzése szerint a munkavállalók által birtokolt soft skillek 2030-ra a munkahelyek kétharmada számára döntő tényezővé válnak, összehasonlítva a 2000-ben mért eredményekkel, ahol ez csupán a munkahelyek felére volt elmondható (Deloitte Access Economics, 2017). Egyre jellemzőbb a felsőoktatás felé megfogalmazott kritika is a munkaadók részéről, amiért nézeteik szerint nem készítik fel megfelelően a hallgatókat a jelenlegi munkaerőpiacra (Hurrell, 2016). A szakirodalmi áttekintés is arra világít rá, hogy egyre inkább növekszik az érdeklődés a puha készségek iránt, a fejlesztésükre szánt akadémiai programok hiánya, valamint annak szükségessége, hogy a vállalatok / munkaadók hatékonyabb és eredményesebb kommunikációt, együttműködést és partnerséget folytassanak az egyetemekkel az ügy kezelése érdekében (Succi \& Canovi, 2020). Ez az a hiányzó párbeszéd, melynek jelentőségére jelen disszertáció is rávilágít.

A LinkedIn szakmai portál gyüjtése alapján évről évre felsorolásra kerülnek a legfontosabb soft skillek, melyek munkavállalói elvárásként jelennek meg a munkavállaló felé. A leginkább elvárt készségek meghatározásának módszere során megvizsgálják azokat a készségeket, melyekre a legnagyobb a kereslet. A kereslet meghatározása a legmagasabb arányban felvett munkavállalók LinkedIn profiljában rögzített tulajdonságok alapján történik (B. Anderson, 2020; Petrone, 2019). Azon készségek kerültek a lista élére, melyek a cégvezetők értékelése alapján a legértékesebbnek számítanak, melyeket legnehezebb megtalálni a munkavállalókban, és melyek támogatják az ügyfelek magasabb szintü kiszolgálását. A soft 
skillek felértékelődését támogatja az is, hogy ezek azok a kompetenciák, melyeket a robotok nem képesek automatikusan előállítani, ehhez az emberi elme nélkülözhetetlen.

2019-ben az 5 legfontosabb soft skill között kapott helyet a kreativitás, a meggyőzés, az együttmúködés, a rugalmasság, valamint az időmenedzsment (Petrone, 2019 in C. M. Szabó \& Balázs, 2020). 2020-ban ugyancsak a kreativitás került az első helyre, majd a meggyőzés és az együttmüködés hasonlóan a 2019-es évhez dobogós helyet tudhat magáénak. A rugalmasság is változatlan helyet ért el, az időmenedzsment helyett pedig az érzelmi intelligencia kapott jelentősebb szerepet a vállalatok által elvárt legfontosabb soft skillek munkavállalói tulajdonlása kapcsán (B. Anderson, 2020). A LinkedIn kutatás eredményét erősíti Péter-Szarka szakmai véleménye is, miszerint a tanulás és innováció készségei közé tartozik a kreativitás, a kritikai gondolkodás, a kommunikáció és az együttműködési képesség, melyek alapján eldől, hogy ki tud sikeresen helytállni a jövőben az élet és a munka egyre összetettebbé váló világában (Péter-Szarka és mtsai., 2015).

A tudományos szakirodalom is egyre többet foglalkozik a soft skillekkel szemben támasztott elvárásokkal. Egy hazai kutatás például a frissdiplomás, egyetemi hallgatókkal szemben a munkaerőpiac oldaláról támasztott, kreativitáshoz kapcsolódó elvárásokat vizsgálta, amihez középiskolai tanárok, HR szakemberek és egyetemi hallgatók válaszait dolgozták fel. A kutatás eredménye rámutatott, hogy a kreativitás a leginkább a marketing, a vezetés és menedzsment, a $\mathrm{K}+\mathrm{F}$ és tervezés valamint a design területen prioritás a munkáltatóknak és a mérését leginkább a próbaidő alatt valósítják meg, hiszen úgy gondolják, hogy akkor derül fény a valódi munkavállalói kreativitásra (Zoltayné Paprika \& Nagy, 2013).

Az általam fejlesztett workshop pontosan a fentiekre épít: kritikus tervezői megközelítés és együttmüködés, mint a kreativitás két fő motorja biztosítja a bázist, ami a bizonyítottan fontos soft skillek fejlesztését is lehetővé teszi. Ha a fiatal pályakezdők rendelkeznek azokkal a kompetenciákkal, melyek összhangban vannak a munkáltatói szféra által támasztott elvárásokkal, akkor képesek jól beilleszkedni a munkahelyi környezetbe. Nem elhanyagolható az sem, hogy ezek lesznek azok a kiinduló személyes kompetenciák, melyek biztos alapot nyújtanak, amire aztán a szakmai kompetenciák támaszkodni tudnak (C. M. Szabó \& Balázs, 2020). A fentiekkel párhuzamba állítható egy 2018-ban végzett National Association of Colleges and Employers (USA) felmérés, melynek során 172 vállalat vezetőjét kérték meg, hogy sorolják fel azokat a készségeket/tulajdonságokat, amelyeket egy potenciális, frissen végzett munkavállalóval szemben a legfontosabbnak tartanak. A felmérésben olyan nagy vállalatok vezetői vettek részt, mint az GE Appliances vagy a National Instruments. Ennek 
eredményeként az együttmüködés -a kommunikációs képesség és a probléma-megoldó képesség mögött- a harmadik helyet kapta a listán (NACE, 2018).

Bár az összefüggés és átfedés látható, a szakirodalomban teljesen egybehangzó konszenzus nincs a kérdésben, miszerint, pontosan melyek azok a soft skillek, amik a leginkább hozzájárulnak az elsősorban fiatalok munkaerőpiaci sikeréhez. Disszertációmban egy kapcsolódó tanulmányt (Lippman és mtsai., 2015) tekintek irányadónak, ami több, mint 380, a témához köthető, de számos tudományterületet lefedő, azokon átívelő szakirodalmat tekintett át és elemzett a világ minden tájáról. A szakirodalmak között helyet kaptak empirikus tanulmányok, munkaadói elemzések, nemzetközi konszenzusos projektek eredményei egyaránt. A kutatás módszertana a kiterjedt és szisztematikus irodalmi áttekintésen túl magába foglalt konzultációkat és fókuszcsoportos interjúkat az érdekelt felekkel, beleértve a kutatókat, a témához szorosan köthető programok vezetőit, a munkáltatókat és magát az érintett ifjúság szereplőit is. Az irodalomfeldolgozás során kritériumként szerepelt többek között, hogy a tanulmány nem lehet 20 évnél régebbi, és eredményeit tekintve mindenképpen a munkaerőpiacra reflektál. A kutatás során elemezték a soft skillek és a munkaerő kulcsfontosságú eredményei közötti kapcsolatot, ideértve a foglalkoztatást, a munkahelyi teljesítményt, a béreket és a vállalkozói sikert (Lippman és mtsai., 2015).

Azok az álláskereső fiatalok, akik rendelkeznek soft skillekkel előnyre tehetnek szert az álláskeresés során és nagyobb arányban jutnak a pozíciókhoz. A lelkiismeretesség bizonyítottan pozitívan hat a keresés sikerére (Uysal \& Pohlmeier, 2011). A sikeres állás megtalálását követően a pozíció megtartása is jelentősebb azoknál a munkavállalóknál, akik magasabb soft képességekkel rendelkeznek, a kutatás szerzői az önbizalmat említik példaként, mely elengedhetetlen képesség a pozíció megtartásához. Ezen túlmenően direkt és indirekt hatásuk egyaránt van a puha képességeknek a fizetés mértékére. A tanulmány a vállalkozói kedv és a vállalkozás sikerét is összekapcsolja a soft skillekkel, kulcseredményeként tartja számon a köztük kimutatható pozitív összefüggést (Lippman és mtsai., 2015). A fentebb említett előnyökön túl a munkaadóknak is hozadékot jelentenek azok a munkavállalók, akik sok soft skillel rendelkeznek, hiszen produktívabbak. Azok, akik kellő kritikai gondolkodással és problémamegoldó attitüddel rendelkeznek sokkal pontosabb kérdések feltételére képesek, ami a folyamat végén egy jobb végeredmény megvalósítására enged teret (Soland, Hamilton, \& Stecher, 2013).

A soft skillek sajátos tulajdonságai okán kezelhetők egy csoportként. Az elemzés rávilágított saját kutatásom nézőpontjából is egy igen fontos eredményre. A tanulmány leírja, hogy mely az az 5, egymással szoros összefüggésben álló kulcsfontosságú soft skill csoport, 
melyek a leginkább hozzájárulnak a fiatalok munkaerőpiaci sikeréhez, melyek a legnagyobb támogatást nyújtják. Lippman és munkatársai kutatása alapján ezek azok a készségek, melyekre a leginkább érdemes fókuszálni, melyek fejlesztésére optimális esetben már minél fiatalabb korban hangsúlyt kell fektetni.

Az első csoportot alkotják a (1) szociális készségek, szerepük a társas interakciók kapcsán a legjelentősebb. Magukba foglalják az egymás iránti tiszteletet, azt, hogy a megfelelő helyzetben a megfelelő viselkedést vagyunk képesek alkalmazni és a konfliktusok megoldásában is kiemelt szerepet kapnak.

A második csoportba tartoznak a (2) kommunikációs készségek, melyek a megértést, a kommunikáció hatékony átadását, a kifejezésmódot, valamint a tudás és ötletek átadását jelentik. A kommunikációs készségeket jelen tanulmány relációjában a munkahelyi közegben, nem pedig általánosságban értelmezzük.

A következő készség a (3) magasabb rendű gondolkodás, mely a problémamegoldást, a kritikai megközelítést és a döntésképességet foglalja magába. Ezen készségcsoport a probléma azonosítását és több forrásból származó információ begyűjtését teszi lehetővé, annak érdekében, hogy a felmerülő opciók értékelését követően a legészszerübb következtetés realizálódjon (Stein, 2000 in Lippman et al., 2015 ).

Kiemelt készségcsoportként rögzíti a kutatás az (4) önkontrollt, melynek értelmében az egyén képes érzelmeit és benyomásait irányítani, viselkedését szabályozni, így minden fentebb említett munkaeröpiaci tényező kapcsán jobb eredményt érnek el. Ez különösen a fiatalabb korosztály esetén kerül előtérbe. Az álláskeresés, az állás megszerzése és megtartása is kiemelkedőbb azoknál a személyeknél, akik kellő önkontrollal rendelkeznek.

A (5) pozitív önkoncepció ugyancsak az 5 kulcskompetencia tagjaként jelenik meg, mely magába foglalja az önbizalmat, az önhatékonyságot, az öntudatot, a hitet önmagunkban, az önbecsülést úgy, mint a büszkeséget.

A felsorolt 5 készség kapcsolódik egymáshoz. Az önkontroll intraperszonális készségei és a pozitív önkoncepció hozzájárulnak a másik három interperszonális készség jártasságának szintjéhez, és viszont. A szociális készségek, a kommunikáció és a magasabb rendü gondolkodás magasabb szintü ismerete hozzájárul a jobb önkontroll és a pozitív önkép kialakulásához. Ezt az öt, a munkahelyen is bizonyíthatóan jelen lévő készséget az irodalom és az érdekelt felek támogatták, az áttekintés során egyértelműen az ifjúsági munkaerő sikerének kiemelt prioritásává vált (Lippman és mtsai., 2015). 
3.3.3 A soft skillek fejlesztésére irányuló törekvések az oktatásban és azon túl

A soft készségek jelentőségét felismerték, nemzetközi szervezetek, célzottan erre alakult projektek törekszenek fejlesztésükre és integrálásukra (Cinque, 2016). A ModES ${ }^{3}$ projekt 20092012 között a soft készségek akkreditációján keresztül vállalkozott a felsőoktatás modernizálására (Perez, Haselberger, Oberhuemer, Cinque, \& Capasso, 2010). A projekt célja a soft készségekkel kapcsolatos közös európai program integrálása az akadémiai tantervekbe. Célkitüzései között szerepel továbbá a kutatásom fókusza szempontjából is igen jelentőségteljes kezdeményezés, mely a diplomások profiljai és a munkaerő-piaci igények közötti nagyobb illeszkedést hivatott megvalósítani. A fejlődés érdekében a projekt hosszútávú, fokozott kapcsolat kialakítására törekszik az egyetemek és a vállalkozások között. A projekt eredményeként több nyelven felállításra került egy új tanterv, mely a hallgatók profilját foglalkoztatás-orientált kompetenciákkal, mint például vezetés, vállalkozói szellem, új ötletek generálására való képesség, kreativitás bővíti. Az ilyen jellegü törekvések segíthetik a soft készségek megfelelő minőségü fejlesztését, amit a felsőoktatás mellett érdemes a közép és alapfokú oktatási intézményekbe is beépíteni.

Ennek alátámasztását jelentheti, hogy számos tanulmányban nyert empirikus igazolást, hogy a soft készségek is változnak, fejleszthetők, nem egyforma intenzitással és minőségben vannak jelen az egyes életszakaszokban. A fejlesztésükre fordított energia tehát fontos, a leginkább fontos időszakot a kisgyermekkorban megvalósuló iskolai fejlesztés jelenti (K. Fazekas, 2018; Schulz, 2008). A nem kognitív képességek fejlődésére a leginkább ideális környezet az az iskola, de ennek szükséges feltétele egy motivált pedagógus, hiszen a soft képességek fejlesztése eltérő kompetenciákat kíván meg a pedagógustól (J. J. Heckman, Humphries, \& Kautz, 2014 in K. Fazekas, 2018).

A motiváció mellett fontos első lépések egyike, hogy mind a tanulók, mind a tanárok tisztában legyenek a soft készségek fontosságával, hiszen ennek az ismeretnek a hiányában a fejlesztésre irányuló motiváció is elmarad (Schulz, 2008). A nem kognitív képességek komplexitása nem elhanyagolható, fejlesztésük hosszú távon a kognitív képességek fejlődését is jelenti (K. Fazekas, 2018) és fordítva. Az ideális oktatás során a kognitív képességek elsajátítása sem történik anélkül, hogy a diákok soft képességei elkerülhetetlenül és tudattalanul fejlődjenek, mindez persze a pedagógus oldaláról tudatos felkészülést igényel (Schulz, 2008).

\footnotetext{
${ }^{3}$ https://www.euca.eu/modes
} 
A soft készségek fejlesztésére irányuló szakpolitikai iránymutatás és összegzés magabiztosan levonta az erre vonatkozó következtetést, miszerint a leghatékonyabban úgy lehet őket elsajátítani, ha kezdetben kis mennyiségre koncentráltan fókuszálunk releváns formális input mellett. Továbbá szükséges egy nagyfokú élettapasztalat. Nem elhanyagolható az sem, hogy az egyén a gyakorló szakasz folyamán a komfortzónáján belül és kívül is mozogjon, és időnként fontos a releváns és építő jellegű visszajelzés a közösség tagjaitól. A közösség azért is segíti a fejlődést, hiszen ők képesek az egyén megfigyelésére, megértésére (McGurk, 2010).

Ebben a fejezetben tehát arra próbálok választ keresni, hogy melyik a legjobb, leghatékonyabb módja a soft készségek fejlesztésének. Ehhez első lépésként szükséges az emberi lény fejlődésének meghatározása. Ha ezt megértettük, akkor az már egy kiindulópontot jelenthet a konkrétumok szintjéhez, az egyes soft képességek fejlesztésének lehetőségeire (Levasseur, 2013).

Levasseur (2013) tanulmányában Lewin (1951) és Bronfenbrenner (1979) modelljeit taglalja, mely írás alapján jelen értekezésben én is rávilágítok a modell legfontosabb elemeire, hiszen úttörő szerepe a soft készségek fejlesztési lehetőségei kapcsán nem megkérdőjelezhető.

A viselkedés tekinthető egy interakció eredményének, mely az ember és környezete között valósul meg. Mivel a készségek képesek a viselkedés fejlesztésére, ebből következik, hogy az ember és környezete meghatározza a készségek fejlődését is. Vagyis emberi oldalról az akarat, a vágy a fejlödésre szükséges, de nem elegendő feltétel, kell még hozzá egy támogató környezet. Ha valaki szeretne megtanulni valamit, ám annak feltételei nem adottak, akkor nem elég az egyéni akarat és fordítva (Lewin, 1951).

Ezt az irányt vitte tovább Bronfenbrenner is kutatása során. Az emberi környezet, mint kritikus tényező jelenik meg a soft készségek fejlesztésére irányuló törekvések során, mely a környezetet struktúrákra bontja. A legbelső környezet jelenti magát az egyént és az azonnali környezetét, mint például az otthon és a gyermek nézöpontjából tekintve a szülei. A következő szintben az egyén mellé csatlakozik az a környezet, akivel az egyénnek jelentős és gyakori kapcsolata van, a gyermek kapcsán ez lehet az iskola és a tanárok. A következő szintet az a környezet jelenti, mely az egyénre hatással van, de ez fordítva már nem releváns. A gyermeki nézőpontnál maradva ezt jelenti például a szülők munkahelye. Utolsó szinten jelenik meg az a kultúra, vagy szélesebb társadalmi közeg, mely körülveszi az egyént. Hatása tetten érhető ugyan az egyénre nézve, de nem feltétlenül napi szinten. Példaként említhetjük az egész oktatási rendszert (Bronfenbrenner, 1979 in Levasseur, 2013). 
Az elmélet alapját az ökológiai átmenet fogalma jelenti, ami akkor következik be, amikor az egyén környezeti helyzete, az ahhoz való viszonya, kapcsolódása megváltozik, és ez a változás teret enged a fejlődésre. Ennélfogva, ha az emberi fejlődést katalizálni szeretnénk, akkor a környezetben egy pozitív irányú változásra, tovább lépésre van szükség. A környezet és az ember közötti megfelelő interakció megváltozik, ez ökológiai átmenetet eredményez a magasabb rendủ környezetre. Ha fennáll a személyes motiváció is a változáshoz, az eredmény az egyéni növekedés és fejlődés lesz.

Levasseur (2013) ezt egy olyan példával szemlélteti, mely igen relevánsnak tekinthető saját empirikus kutatásom nézőpontjából. Ha az a cél, hogy egy gyermek megtanuljon jobban és gyorsabban olvasni, akkor azt számára élvezetessé kell tenni. Egy bekövetkező szerepvállalás ökológiai átmenetet fog eredményezni, egy másik szintre lép, ha passzív befogadóból egy aktív szerepvállaló feladatkörhöz jut. Példának okáért a kollaboratív tanulási folyamat alkalmazása egy új szinten kap helyet, mely nagy valószínűséggel őt magát is motiválttá teszi az egyéni fejlődésre (itt kap helyet a korábban Lewin kapcsán ismertetett emberi tényező). Az eredmény a fejlődést hozza magával (Levasseur, 2013).

A soft készségek fejlesztése kapcsán ez az elméletegyüttes arra világít rá, hogy a kognitív képességek fejlesztésénél ez egy sokkal összetettebb feladat. A soft készségek fejlesztése megköveteli a folyamatos aktív kölcsönhatást másokkal, valamint az ebből következő visszajelzések elfogadására vonatkozó hajlandóságot. A valódi fejlődés a készségek folyamatos gyakorlásából és a teljesítmény-visszacsatolás feldolgozásából származik, amely önreflexión vagy másoktól kapott konstruktív bemeneten alapul, és elősegíti ezen készségek folyamatos fejlesztését. A soft készségek fejlesztéséhez nem elég csupán egy könyv, más emberekre és a velük történő interakcióra van a legnagyobb szükség (Levasseur, 2013).

\subsubsection{A soft skillek mérési gyakorlata}

Egy jelentős mennyiségü bizonyíték sugallja, hogy a nem kognitív készségek az élet kimeneteleinek széles skáláját jósolják, ideértve az oktatási eredményeket, az egészséget, a bűnözést és a kutatásom szempontjából igen kiemelt fontosságú munkaerő-piaci eredményeket (Kautz és mtsai., 2014). A vállalkozások felismerték ezen jellegü képességek fontosságát és azt, hogy a szélesebb körü előnyök kiaknázásához a soft skillek fejlesztésére fordított erőforrás nem lehet elhanyagolható léptékü. Becslések szerint a vállalkozások évente 4 milliárd dollárt költenek a képzésre, és további 7 milliárd dollárt költenek a megfelelő személyzet toborzására. A soft készségek objektív és átfogó mérése nélkül nehéz megbecsülni ennek a beruházásnak a 
hatását (Deloitte Access Economics, 2017), értékelésük és mérésük egyre több területen kap növekvő figyelmet (Gibb, 2014).

A soft készségek jelentősége, a gazdaságban betöltött indikátor szerepük tehát nem vitatott, így az sem, hogy már az oktatás során is egyre inkább fókuszt kell erre helyezni. A Deloitte Access Economics Ausztráliában végzett kutatása már pozitív példaként említi a Deakini Egyetemet, ahol a diplomaszerzés kritériumaként szerepel adott soft skillek, mint kulcsfontosságú készségek megszerzése, továbbá az, aki a soft készségekben teljesít kiemelkedően hallgatótársaihoz képest ugyanolyan díjban részesül, mint a kognitív képességekért járó elismerés (Deloitte Access Economics, 2017).

Annak érdekében tehát, hogy hitele és jelentősége általános érvényü legyen a vállalati oldal mellett az oktatás szereplöi körében is, referenciapontokra, a fejlődés mérésére van szükség. A non-kognitív képességek mérhetősége sok kihívást rejt magában és korántsem kézzelfogható minden esetben, szemben az elfogadott és számtalan mérési metódust lehetővé tevő kognitív tulajdonságokkal. Kutatások eredménye arra enged következtetni, hogy a tanárok által történő értékelés jó megközelítésként szolgálhat. Az általános iskolás gyerekek viselkedésének vizsgálata és értékelése során tanáraik elöre tudták jelezni felnőttkori viselkedésüket, valamint fontos eredményként rögzítették, hogy a kisgyermekkorban megvalósuló, a soft skillek fejlesztésére irányuló interakciók elősegítik ezen képességek kibontakozását (J. Heckman, Pinto, \& Savelyev, 2013).

A személyiségpszichológiában általánosan elfogadott a „Big Five” (McCrae \& Costa, 1987) néven elhíresült csoportosítás, mely 5 csoportba sorolja az emberek nem kognitív készségcsoportjait és ezen belül az egyes csoportokhoz tartozó készségeket. Ez az 5 csoport nem más, mint az extrovertáltság, barátságosság, lelkiismeretesség, érzelmi stabilitás és nyitottság. A Big Five nem azt jelenti, hogy a személyiségjegyekben rejlö különbségek csupán 5 jellemző alapján redukálhatók sztenderd csoportokba. Sokkal inkább ez az öt dimenzió a legszélesebb absztrakciós szint, és mindegyik dimenzió sok különálló, konkrétabb személyiségjellemzőt foglal össze (John \& Srivastava, 1999). Alapvetően angol nyelvű szövegeken elvégzett szemantikai statisztikai elemzések eredményeképpen került meghatározásra ez az 5 soft skill csoport, de igazolásra került, hogy más kultúrákban is megállja a helyét. Érdekes megjegyezni, hogy átfedés van, de jelentős különbségek is fellelhetők a soft készségek csoportosítása kapcsán a szakirodalomban annak függvényében, hogy a munkavállalói sikerhez történő hozzájárulást, az általános csoportosítást, vagy a mérhetőséget tartjuk szem előtt (K. Fazekas, 2018). A mérhetőség kapcsán a Big Five abban segíti a kutatókat, hogy a készségcsoport értelmezése mindenki számára egyértelmű, így lehetőséget 


\section{teremt arra, hogy sztenderdizált módszerek segítségével mérhetővé váljanak a soft skillek}

(K. Fazekas, 2018; Roberts, Martin, \& Olaru, 2015).

A soft skillek felismerése könnyü, a mérésük már annál összetettebb folyamat. Az osztályterem falait, ha tekintjük, akkor is az tapasztalható, hogy a pedagógusok a soft képességek meglétét hamar konstatálják, ám azok megítélése intuitív, szubjektív és tudatalatti módon valósul meg. A törekvés a benchmarkok kialakítására adott, ezt támogatja a GRASS ${ }^{4}$ (Grading Soft Skills, vagyis a soft készségek osztályozása) projekt is, melyet a következőkben röviden ismertetek. A GRASS projekt arra összpontosított, hogy a különféle korú és különbözö oktatási szinteken élö tanulók soft képességeit mennyiségi, mérhető módon reprezentálja, hogy ezek a készségek formális érvényesítés és elismerés tárgyát képezhessék, összességében a soft készségek részben számszerüsíthető mérésére és sztenderdizálására vállalkozik (Cinque, 2016). A projekt egy hároméves kutatást tud maga mögött, mely az EU által került finanszírozásra és legfontosabb célkitüzéseként szerepelt a soft készségek kvantitatív mérhetőségének kialakítása, valamint a nyitott jelvények rendszere, mely az értékelést segíti.

A GRASS projekt során megvalósult egy elméleti sorozat, mely a soft készségek értékelésére konkrét mutatókat dolgozott ki. Ez az eszközkészlet minden pedagógus számára nyitva áll és szabadon felhasználható, valamint az aktuális oktatási környezethez igazítható, személyre szabása megengedett. A projekt már tucatnyi különféle oktatási környezetben sikeresen alkalmazta teljesítménymutatóit (Devedzic és mtsai., 2018). A mutatók egy része kvantitatív. Gondolok itt arra, hogy a csapatmunka képességeinek mérése úgy történik, hogy az egyes hallgatók hány értelmes és hasznosítható hozzájárulást adtak az adott együttmüködési projektben. Másik részük kvalitatív jellegü, minőségi mutató, és sok esetben integrálják a tanárok, társak, szakértők véleményét, megfigyeléseit. Ide tartozhat az, ha valakinek a másokkal történő kommunikációs képzettségét elemezzük és értékeljük. Az indikátoroknak jellegüktől függetlenül tartalmazniuk kell egy mért változót, mely egy adott soft készség egy bizonyos alkotóelemére vonatkozik. Emellett szükséges még a mért változóhoz tartozó osztályozási skála rögzítése, mely igazodik az előre meghatározott teljesítményszintekhez. A változó és a skála kiválasztása úgy kell, hogy megvalósuljon, hogy az kellően konkrét legyen ahhoz, hogy a megfigyelést elősegítse. Mindezen túl ezek a mutatók tartalmazhatják a vonatkozó mérési eljárások leírását, a minimális teljesítményszintek vagy meghatározott teljesítményszabályok elérésének küszöbértékeit, továbbá azon funkciók leírását, amelyek a

\footnotetext{
${ }^{4}$ https://sites.google.com/site/llpgrassproject/project-description
} 
megfigyelt értékeket esetleg a megfelelő teljesítményszintekké alakíthatják át, így a mérés már önmagában lehetőséget teremt a fejlődésre (Devedzic és mtsai., 2018). A GRASS mérési módszer segítségével a diákok soft készségei felértékelődnek, hiszen így van lehetőség arra, hogy a kognitív képességek szintje mellett megbízható eredmény szülessen a soft készségek kapcsán is, az eredmények összehasonlíthatóvá válnak, a kritériumszintek meghatározási folyamata egyszerüsödik.

\subsection{Vállalkozásra nevelés az iskolapadban}

Az oktatás és vállalkozás, az oktatás és a gazdasági szereplők kapcsolatának vizsgálata során nem lehet elmenni a valós vállalkozási kompetenciák oktatása, fejlesztése mellett sem, melynek kiemelt szerepe egyre intenzívebben jelenik meg már az alapfokú oktatás során is. A vállalkozói kompetencia az Európai Unió ajánlása szerint (Council of the European Union, 2002) a kulcskompetenciák között kap helyet. Ezt figyelembe véve és erre építve a hatályos Nemzeti Alaptanterv is kulcskompetenciaként rögzíti a munkavállalói, innovációs és vállalkozói kompetenciákat, melyek a tanulási területeken átívelő kompetenciák között sorakoznak fel (NAT, 2020). Jellegzetessége, hogy nem feltétlenül köthető konkrét tantárgyhoz, tanulási területhez, fejlődése a tanulási -tanítási folyamatban történik, épp ezért a pedagógus személye, motiváltsága kiemelten fontos, ahogy azt már a korábbi fejezetben részletesen rögzítettem. Létezik pénzügyi és vállalkozási ismeretek tantárgy, mely a szabadon tervezhető órakeret terhére beépíthető az oktatásba, ennek az órakeretnek a felhasználásáról az iskola vezetösége, az egyes területek pedagógus munkaközössége dönt, ennélfogva adott esetben ez egy alulról induló kezdeményezés eredményeként a vállalkozói kompetencia oktatása, fejlesztése önálló tantárgy keretein belül is megvalósulhat. A kulcskompetenciák tantárgyakon átívelő jellege pedig abban manifesztálódik, hogy a kapcsolódó területeket feldolgozó tantárgyak, mint például egy szöveges matematika feladat vagy egy állampolgári ismeretek, technika és tervezés óra miként és milyen gyakorisággal dolgozza fel az adott tudományág gazdasági vetületeit. A földrajz tantárgy kapcsán a tantárgy tanítási céljai között rögzíti például a NAT, hogy „a globális világ pénzügyi-gazdasági folyamatainak megismerésével a gazdasági élet eseményeiben eligazodó aktív, kreativ és rugalmas állampolgári gondolkodás és vállalkozásra kész attitüd kialakulását fejlessze” („A Nemzeti alaptanterv kiadásáról, bevezetéséről és alkalmazásáról szóló 110/2012. (VI. 4.) Korm. rendelet módosításáról”, 2020, o. 400). Ezek a törekvések fontosak, de nem szabad, hogy a tantárgy egyéb elsődleges céljai mögött elsikkadjon. 
Erre a problémára megoldást jelenthet, ha a vállalkozói kompetencia fejlesztése az oktatási intézmény egészében kiemelt hangsúlyt kap, így a pedagógusok is nagyobb eséllyel építik be a mindennapi oktatási gyakorlat vonatkozó és releváns tantárgyi kereteibe. Ezt támasztja alá egy kvantitatív kérdőíves kutatás is, mely bár a felsőoktatást helyezi górcső alá, mégis a folyamat eredményét tekintve kiválóan szemlélteti az alapfokú oktatásban is megfigyelhető aktuális trendeket és gyakorlatot. A kutatásnak a Dunaújvárosi Egyetem adott otthont 2019 tavaszán és a kutatás során a vállalati szektor elvárásai kerültek összevetésre a felsőoktatás kimeneteli kompetenciáival (C. M. Szabó \& Balázs, 2020). Az eredmények között kimutatható, hogy a vállalatok számára az elvárások között a prioritást a soft készségek megléte jelenti, mint az együttmüködési és a jó kommunikációs készség, vagy a proaktív hozzáállás, melyet, ha egy kulcskompetenciával szeretnénk azonosítani, akkor nehéz feladatunk lenne, de talán a legközelebb a vállalkozói kompetenciákhoz állnak. Mivel ez nem kapcsolható egyetlen konkrét tantárgyhoz sem, így a kutatás is arra világít rá, hogy a fejlesztés csak a kollaboratív módszerek alkalmazásával válik megvalósíthatóvá, melyben az egyetemi oktatók felelőssége vitathatatlan (C. M. Szabó \& Balázs, 2020).

Korábbi fejezetben, amikor a pedagógus szerepét vizsgáltam a vállalkozásra nevelésben, akkor már kitértem rá, hogy a 21. század emberére alapvetően jellemző a vállalkozói attitűd, ami túlmutat a gazdasági szinten egészen az egyéni önmegvalósításig, mely a vállalkozásra nevelés közvetett céljait és fontosságát is determinálja, valamint soft készség jellegére is rávilágít. A mai oktatási gyakorlat tudatában van annak a folyamatnak, hogy a frontális munka, a tárgyi tudás, a lexikális ismeretek átadása mellett helyet kell adni a kompetenciaalapú nevelési irányzatnak is. Ez nem azt jelenti, hogy a tudatosságnak háttérbe kell szorulni, a kompetenciaalapú oktatáson az elöre definiált és rögzített kompetencia átadásán és fejlesztésén van a figyelem. A vállalkozásra nevelés is egy kompetenciakészlet átadására tesz tehát kísérletet (Galambos, 2005). Bamford (2000) arra mutat rá, hogy a vállalkozóinak tekintett kompetenciakészlet napjainkban valójában már a munkavállalókkal szemben felállított általános követelmény, így gyakorlatilag kikerülhetetlen a vállalkozásra nevelés a közoktatásban (Fülöp \& Pressing, 2012). Értekezésem kapcsán azért is van jelentősége a vállalkozói kompetenciának, hiszen a fentiekben részletesen taglalt soft készségek között kap helyet a szakirodalomban (Devedzic és mtsai., 2018).

A vállalkozói kompetencia egy komplex fogalmat jelöl, melynek összetevői további egyéb soft készségeket is magukba foglalnak, mely magyarázza és igazolja az előző fejezetekben bemutatott készség és kompetencia fogalmi és jelentés béli eltéréseit. A vállalkozói kompetencia támogatja az egyént a mindennapi életben, segít a kínálkozó 
lehetőségek felismerésében és azok tudatos kihasználásában. Magába integrálja azt tudást, mely a gazdasági tevékenység során nélkülözhetetlen, ide sorolandó a vezetés, szervezés, elemzés, irányítás képessége. Továbbá a kreativitás, az innovációra való törekvés, a csapatban való dolgozás, a kommunikáció képessége is a vállalkozói kompetencia összetevőiként kapnak helyet a szakirodalomban (Mihalkovné Szakács, 2014). Látható tehát, hogy a vállalkozói kompetencia fejlesztése az oktatásban azért is kiemelten fontos, hiszen összetettsége révén további egyéb soft készség fejlesztését is támogatja. A jelenlegi pedagógiai gyakorlatban jellemzően a kompetencia ismereti és tudás komponense kap jelentős szerepet (ez utóbbi is inkább a közép- és felsőoktatásban) a többi összetevő háttérbe szorul. Mihalkovné (2014) ezt a problémát úgy oldaná fel, hogy a már újszerü, a személyiség fejlesztésére is alapozó kompetenciafókuszú pedagógiai módszertanokat két csoportba sorolná aszerint, hogy melyek azok, amelyek támogatják a gyakorlatorientáltságot és melyek azok, amik inkább a készségek fejlesztésére összpontosítanak (Mihalkovné Szakács, 2014). A két csoportosítás között természetesen található átfedés, ahogy ezt Mihalkovné is említi tanulmányában. Gyakorlati példaként szolgálhat jelen értekezés empirikus kutatásának központi elemét jelentő, saját fejlesztésű oktatási eszközöm is, melynek ezt az irányt támogató módszertani alapjait a következő fejezetben ismertetem.

\section{5 Összegzés}

A szakirodalmi összefoglaló első részét egy összegző ábrával zárom, ami egyúttal egy átvezetést is jelent a designkommunikáció módszertan felé, hiszen elhelyezi annak alkalmazási keretét is az elméleti relációban. Az ábra rávilágít a fenti két fejezet során ismertetett jelenségekre, azok kapcsolódási pontjaira az oktatás- és neveléstudomány jelenkori vonatkozásában, a kiemelt szereplők nézőpontjának beépítésével. Az elméleti összefoglalóban is helyet kapó kulcsdimenziók, mint a soft készségek, valamint az oktatás és gazdaság kapcsolódási pontjai is szemléltetésre kerülnek, ami a kutatási kérdések megfogalmazásának meghatározó elemeiként szolgálnak. 
2. ábra: Az elméleti összefoglaló térképe a legfontosabb kapcsolódások tükrében

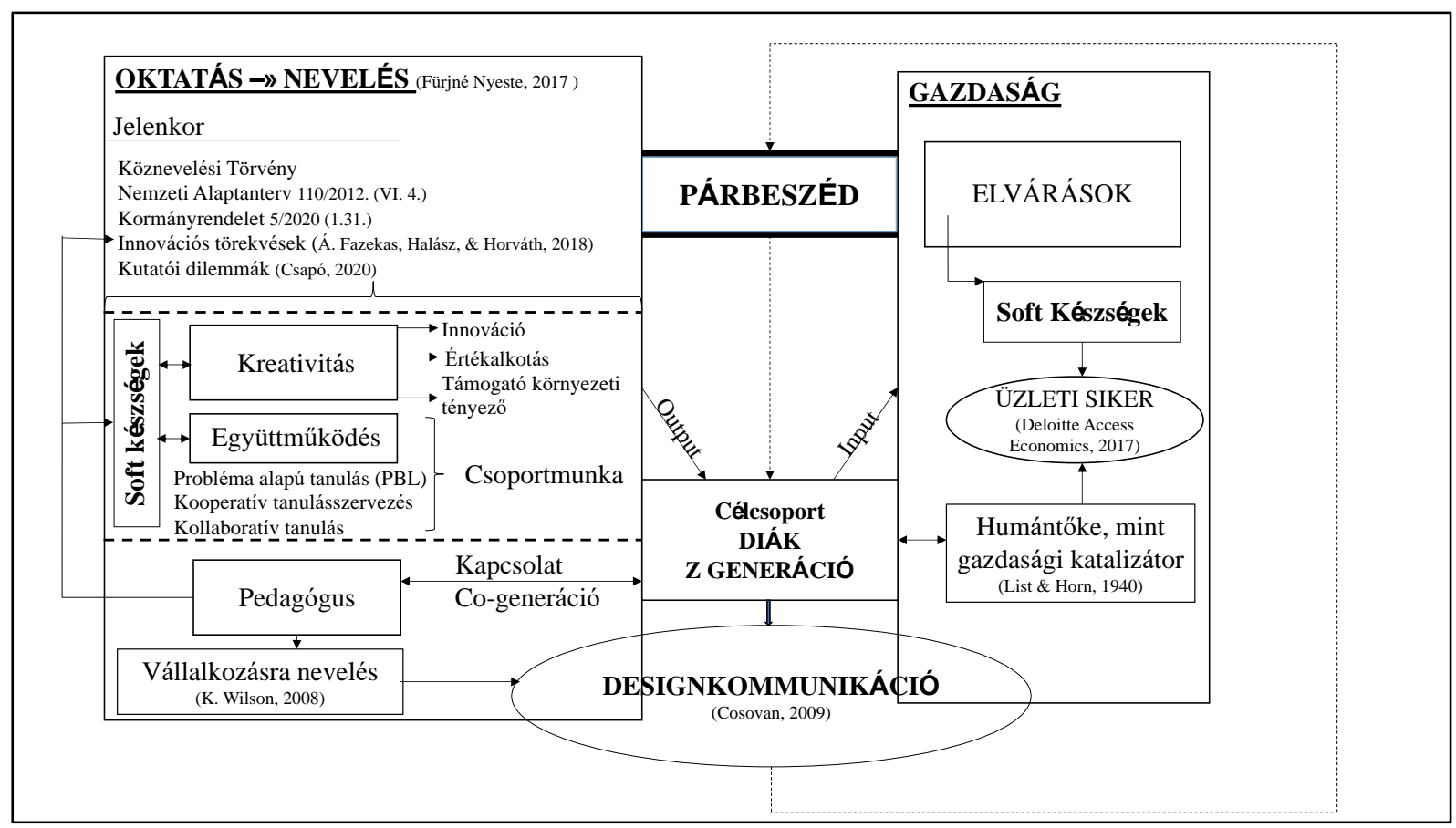

Forrás: A szakirodalmi összegzés alapján saját szerkesztés 


\section{A DESIGNKOMMUNIKÁCIÓ, MINT MÓDSZERTANI KIINDULÓPONT}

A szakirodalmi összefoglaló következő részében a saját fejlesztésű oktatásmódszertani eszközöm legfontosabb építőelemét, a designkommunikáció (A. Cosovan, 2009) módszertanát mutatom be. A designkommunikáció módszertana egy kreatív, akadémiai alapokon álló módszertan, ami az elméleti alapok és a gyakorlati tapasztalat lehető legjobb összehangolására törekszik. A soft készségek fejlesztését lehetővé tevő és támogató designkommunikáció módszertan rendkívül rugalmas keretek mellett biztosítja azt a megalapozott módszertani hátteret, mely a korábbi megszokott, ismert és elismert eszközkészleten túlmenően egy újszerű látásmódot tár az alkalmazók köre elé. Ahogy az értekezés is tudományterületeken átívelő témát dolgoz fel, hiszen érinti az oktatás és neveléstudomány, az üzleti kommunikáció, valamint a menedzsment területeit, úgy a módszertan is a tervezés és az üzleti kommunikáció tudományterületének tudatos találkoztatása.

\subsection{A designkommunikáció eredete és definíciója}

A designkommunikáció egy 15 éves múltra visszatekintő, egyedi, dinamikus, hazai, védjegyoltalom alatt álló know-how, mely egy doktori munka eredményeként született a design és a kommunikáció tudományterületeken átívelő módszertani párosításával. A mára már DIS.CO címmel könyv formájában (A. Cosovan, 2009) megjelent, valamint hazai (A. Cosovan \& Horváth, 2016; A. R. Cosovan, Horváth, \& Mitev Ariel, 2018; D. Horváth, Cosovan, Horváth, és mtsai., 2018; D. D. Horváth és mtsai., 2020) és nemzetközi publikációban (D. Horváth, Cosovan, Csordás, Horváth, \& Mitev, 2018) is elérhető megközelítés Cosovan Attila tervezőmüvész és egyetemi tanár nevéhez köthető. A módszertan felsőoktatási gyakorlatba történő integrálása 2015-től kezdődött meg a Budapesti Corvinus Egyetemen, ahol azóta is töretlenül zajlik a -mára már nevében is rögzített- Marketing-, Média- és Designkommunikáció Tanszéken.

\subsubsection{Fejleszt és fejlődik}

A designkommunikáció egy tervezői, alkotói szemlélet. Arra épít, hogy nem minden ember tervező, de mindannyian képesek vagyunk a kreatív alkotói kapcsolatteremtésre. A 
designkommunikáció definíció szerint fejlesztésbe, fejlődésbe integrált kommunikációt jelent (A. Cosovan, 2009). Fontos rögzíteni a fejlesztés és fejlödés közötti fogalmi különbözőségeket, mely a módszertan és a meghatározás egyik fontos eszenciájára is rávilágít. A Magyar Értelmező Kéziszótár (József Juhász, Szőke, O.Nagy, \& Kovalovszky, 1972, o. 365) megfogalmazása alapján a fejlesztés az a cselekvés, hogy valamit fejlesztenek. A fejlesztés tehát kifejezetten az ember által alkotott környezetre, tárgyra vonatkozik. A fejlödést pedig egy olyan folyamatként rögzíti a Magyar Értelmező Kéziszótár (József Juhász és mtsai., 1972, o. 366), amikor valaki vagy valami fejlödik, változik a teljesebb, bonyolultabb, magasabb rendü minőségi változás felé. A környezetünk felé irányuló fejlesztési törekvésünkkel párhuzamosan, maga a fejlesztő, az alkotó egyén is fejlődik, a fejlesztés által egy magasabb minőségbe kerül. A designkommunikáció során a tervező olyan módon fejleszt, hogy közben fejlődést generál. Teszi ezt saját magával és a folyamatban résztvevő környezetével szemben egyaránt. A designkommunikáció középpontjába magát az embert helyezi. Egy olyan módszertan, mely „a tervezői eszköztárat használja arra, hogy alkalmazói az emberi szükségleteket, a technológiai lehetőségeket és az üzleti siker kritériumait integrálják a stratégia-, a szervezet- és a termékfejlesztésbe" ((A. R. Cosovan és mtsai., 2018, o. 233)).

\subsubsection{Design és kommunikáció}

„A design; tervezömüvészet, kreativ tervezés, alkotói magatartás. Ehhez társul a kommunikáció; a tervezői, alkotói, kreatív kapcsolatteremtés, úgy az önreflexió (belső párbeszéd), mint az interhumánus fenomén szintjén. Így tehát a designkommunikáció egy olyan kapcsolatteremtési szemléletet képvisel, amely HÍD- ként jelenik meg a különbözö diszciplínák és diskurzusok, a társadalom és a gazdaság jelenségei között. Interdiszciplináris és interprofesszionális módszerével valós idejü kapcsolatot lehet teremteni oktatás, kutatás és vállalkozás között”'(A. Cosovan \& Horváth, 2016, o. 43).

A designkommunikáció a szakirodalomban fellelhető összetett és sokrétü design és kommunikáció fogalmakat újraértelmezi és reduktív módon közelíti meg. A módszertan a design fogalmát a ,jót csinálni” kifejezéssel azonosítja, míg a kommunikáció a ,jót mondani” jelentéstartalmat kapja. A designkommunikáció design fogalom meghatározása alapvetően Papanek (1971) definíciójából indul ki: „A formatervezés, a design jelenti egy epikus vers összeállitását, egy falfestmény kivitelezését, egy remekmü festését, de egy koncert dalszerzését egyaránt. Ugyanakkor a tervezés az asztali fiókok tisztítását és átszervezését, az ütött fogak húzását, az almás pite sütését, a hátsó tételü baseball játék oldalának kiválasztását és a gyermek oktatását is szolgálja” (Papanek, 1971, o. 3-4). Teszi ezt a design fogalmához 
szorosan kapcsolódva a designkommunikáció is. A fentieket összegezve a designkommunikációs szemlélet elsajátítása intenzív és sokrétü bevonódást igényel, az elméleti ismeret, a tapasztalatszerzés kiemelt jelentőségű, ami időigényes folyamat.

\subsubsection{Mindenki tervező}

A designkommunikáció tehát egy tervezői szemléletmód, mely definíciója szerint nem minden ember tervező, de minden ember képes kreatív alkotói kapcsolatteremtésre (A. Cosovan, 2009). A mindenki tervező elv megjelenése Papanek (1971) nevéhez köthető, aki szerint a tervezés alapvető fontosságú az összes emberi tevékenység szempontjából. A tervezési folyamatot képezi minden cselekedet megtervezése a kívánt, előrelátható cél felé (Papanek \& Fuller, 1972). Ehhez kapcsolódik a designkommunikáció is, ami azt rögzíti, hogy a kreatív üzenet vagy kapcsolatteremtés nem egy utólagos sallang, hanem a problémakereséssel, feltárással, - megoldással együtt születik és kódolódik a termék, szolgáltatás vagy éppen eljárás fejlödésébe, tehát tudatos tervezés eredménye. A tervezés, az alkotás és az ebböl fakadó kapcsolatteremtési szándék az emberi faj egyik legfontosabb adottsága, lehetösége, kötelessége és egyben felelössége - figyelembe véve a társadalmi állandó(k) és változó(k) kölcsönhatását (A. Cosovan, 2009). A tervezői attitüd elsajátítása is könnyebbé válik és maradandóbb tudással ruházza fel az alkalmazót, amennyiben az az ösztönös kreatív kapcsolatteremtésen keresztül valósul meg, szemben azzal, ha ez egy racionális gondolkodás eredményeként realizálódik. (A. Cosovan, 2009).

\subsubsection{Konvergens és divergens gondolkodás}

A designkommunikáció módszertana úgy segít megoldani a problémákat, hogy közben magát a problémát megoldó személyt/személyeket egy tervezői attitüd elsajátítására ösztönzi, a fentiek szerint a „mindenki tervező” elvre épít. Az elénk kerülő problémák többféle sajátossággal rendelkezhetnek, melyek megoldása más-más gondolati formát követel meg, vagyis a probléma megoldásához vezető utat többféleképpen differenciálhatjuk.

Beszélhetünk konvergens gondolkodási (Joy Paul Guilford, 1950) folyamatról, ami többnyire a már meglévő tudás felhasználásán alapul. Adott egy pontosan meghatározható, jól körül írható probléma, amelyre létezik megoldás, ami a memóriánkban felhalmozódó információk alapján megoldható. 
A divergens gondolkodás (Joy Paul Guilford, 1950) ezzel szemben egy összetett megoldást igénylö feladat eredményeként jön létre, ahol már szükség van a kreativitásra, ahol nem egyértelmű a megoldáshoz vezető út, a problémamegoldás divergens jellegét a problémaszituációkra adott újszerü válaszok jelentik (Tóth, 2015). A designkommunikációt igen hatékonyan tudjuk alkalmazni az ilyen jellegü problémafelvetések kapcsán. Kész módszerek, viszonyítási pontok nincsenek. Nem tudjuk, hogy van-e jó megoldás, vagy éppen több jó megoldás is elérhető. Az eredmény és a hozzá vezető út egyszerre, egy időben alakul és teljesedik ki, fejlesztésbe, fejlödésbe integrált kommunikáció valósul meg (A. Cosovan, 2009), ezzel az előrehaladást, a pozitív elmozdulást tekinti természetesnek, mely az eredmény hozadékát jelenti.

\subsubsection{A probléma maga a lehetőség}

A designkommunikáció értelmezhető terméktervezési, kutatási, oktatási, feladatmegoldási helyzetekben egyaránt, ahol a divergens gondolkodás és a kreativitás nélkülözhetetlen. Alapvetően (de nem kizárólag) nyílt problémamegoldó (Dorst, 2011) helyzetekre építő szemlélet. Kiemelten fontos, hogy a feladatot nem problémaként determinálja, hanem lehetőségként értelmezi, ami oktatási gyakorlata során is egy pozitív, támogató, megoldásra ösztönző ugyanakkor nem csak eredményfókuszú értékítéletet feltételez, hiszen sok esetben az eredmény maga az odavezető út lesz.

Zárt problémamegoldással állunk szemben, amikor ismerjük a probléma összetevőit. Tudjuk, hogy mi az elérni kívánt cél, ismeretünk között szerepel, hogy a célt meghatározó összetevők milyen relációban vannak, hogyan hatnak egymásra, hogyan befolyásolják együttmüködéseik a megoldást, így egyszerüen megoldható a feladvány (Dorst, 2011). Amennyiben egy összetevő hiányzik, úgy az a másik két elemből kikövetkeztethető, mint egy egyismeretlenes egyenlet esetében. Ehhez képest a nyílt problémamegoldás helyzetben sokkal több az ismeretlen.

Többnyire csupán az elérni kívánt érték ismert számunkra, a megoldás formája, a megoldást támogató összetevők szinergiája nem szolgál támpontként (A. R. Cosovan és mtsai., 2018; Dorst, 2011). Ilyen esetekben a megoldás és a hozzá vezető út egyszerre, egy időben van jelen, az eredmény és a módszer egyidőben, egyszerre valósul meg. A definíció kapcsán taglalt fejlesztés és fejlődés elválaszthatatlan kapcsolata a designkommunikáció módszertanában a nyílt problémafelvetésen keresztül is igazolódik. 


\subsection{A designkommunikáció alaptézise}

Az alkotói, tervezői kapcsolatteremtési képességünk fajunk létezése óta determinálja integrált és differenciált, azaz komplex emberi gondolkodásunkat, amely a minimum és maximum szabályokat figyelembe véve - a megismerés fenomenológiájában - egy holisztikus viszonyrendszerben fogalmazódik meg; ezzel segítve a tervezői, alkotói optimum megtalálását (A. Cosovan, 2009). Ez a viszonyrendszer az (1) anyag-anyagtalan, a (2) túlélés-fennmaradásfejlödés és az (3) állandó-változó(k) viszonyában rögzül (A. R. Cosovan, 2015).

A három viszonyrendszer bármilyen kontextusban, így az oktatás és a tervezési feladatok során is értelmezhető. E viszonyrendszer az, amit vizsgálni kell egy problémamegoldás megkezdése elött, a tervezés során és végül az értékeléskor (D. Horváth, Cosovan, Csordás, és mtsai., 2018), annak érdekében, hogy a hibázás lehetőségét a minimálisra redukálhassuk. Az értékelési szempontrendszert és jelentésének azonosítását az 1. táblázat foglalja össze.

\section{1. táblázat: A designkommunikáció alaptéziseinek magyarázata}

\begin{tabular}{|l|l|}
\hline Designkommunikációalaptézise & Fogalmak definiálása \\
\hline túlélés-fennmaradás-fejlődés & $\begin{array}{l}\text { A környezetre nézve is tudatos, a múltból alakul és a } \\
\text { jövőre nézve előremutató. }\end{array}$ \\
\hline állandó-változó & $\begin{array}{l}\text { A létrehozott produktum kortalan, időtálló, a folyamatosan } \\
\text { változó környezet és trend ellenére is. }\end{array}$ \\
\hline anyag-anyagtalan & Tárgyi jelentésén túl mögöttes üzenete is értéket képvisel \\
\hline
\end{tabular}

Forrás: Saját szerkesztésü táblázat, szerzői interpretáció a Designkommunikációt feldolgozó szakirodalom alapján

A táblázat alapján a túlélés-fennmaradás fejlődés viszonyrendszere arra világít rá, hogy a tervezői folyamat során szem elött kell tartani, hogy a létrejövő produktum a múlt eredményeit magába foglalja, ugyanakkor innovatív jelleggel ne csak a jelenben legyen értékes, hanem olyan tulajdonságokkal rendelkezzen, melynek hosszú távon is van létjogosultsága, amivel a fenntartható fejlődés és gazdasági versenyképesség kettősségéhez is kapcsolódunk (Málovics \& Ván, 2008). Az állandó-változó viszonyrendszere megköveteli, hogy a folyamatosan változó környezetben is időtálló érték valósuljon meg, mely az új trendekhez is képes eredményesen kapcsolódni. Az anyag-anyagtalan viszonyában a tervezői folyamat eredménye kézzel fogható 
vonatkozásai mellett szimbolikus jelentéssel is bír. Kiemelt jelentőségü, hogy a mögöttes üzenet összhangban legyen a termék tárgyi jellemzőivel és funkciójával egyaránt.

\subsection{A designkommunikáció értékkategóriája és fenntartható jellege}

\subsubsection{Empatikus és jó}

A designkommunikáció egy mindenki számára elérhető, empátiára építő szemlélet, mely az objektív jó megvalósítására törekszik, így a designkommunikáció megjeleníti a ,jó” értékkategóriáját és teszi ezt két értelemben (A. R. Cosovan és mtsai., 2018). Egyrészt utalást tesz arra, hogy a jó jelenti a termék, tér, szervezet és közösség igényeihez illeszkedőt. Jelent mindent, ami megfelelő, ami hasznos, vagyis jó. Ugyanakkor a morális szempontokat és a társadalmi felelősség elvét is közvetíti a design tudományán keresztül (A. Cosovan, 2009). Ez azt jelenti tehát, hogy a tervezői folyamatba azt a szemléletet integrálja, melynek során a saját érdekünkké kell, hogy váljon, hogy másnak az érdekeit figyelembe vegyük. Ha a vállalatvezetők is hasonló szemléletben, a tervezői nézőpontot integrálva közelítenek egy problémához, akkor a létrehozott megoldások funkcionalitásuk mellett a társadalom számára is értéket képviselnek, legyen szó termékek, szolgáltatások létrehozásáról vagy épp munkafolyamatok átszervezéséről (Boland \& Collopy, 2004).

\subsubsection{Fenntartható}

A designkommunikáció fenntartható jellege az oktatási alkalmazásában is helyet kap. A fenntartható fejlődés oktatási gyakorlata az interkulturális együttmüködés, melynek során a cél szintén hasonló: felhívják a gyerekek figyelmét arra, hogy a fenntarthatóság globális megvalósulásához (melynek ők maguk is részei) egyaránt érdekünk a kevésbé fejlett országok helyzetének megismerése, majd támogatása (Huggins, Siraj, Dékány, Fekszi, \& Szabad, 2018). Így értelmezi a designkommunikáció is a jó minimum szabályát. A módszertan fenntartható fejlődéshez történő kapcsolódása a designkommunikáció előző fejezetben ismertetett alaptézisének hármas viszonyrendszerében is helyet kap. A szakirodalom kihangsúlyozza, hogy nem csak a megismerés, hanem a felismerés és az aktív, cselekvő, problémamegoldó magatartás is szükséges a kreatív, probléma megoldására képes, fenntartható központú oktatás során 
(Lesku, 2010). A designkommunikáció pontosan ezt az innovatív szemléletet rögzíti módszertanába.

\subsubsection{A megismerésen túl a felismerésre ösztönöz}

A designkommunikáció a tudás megszerzését, a probléma megoldását nem kizárólag a megismerésben, hanem inkább a felismerésben rögzíti, ami valami olyanra történő rádöbbenés, ami nem feltétlenül jár lineáris megismerhetőséggel. Felismerni nem csak azt lehet, amit már korábban megismertünk. A felismerés különbözik a megismeréstől, amely épp a tudás megszerzésére törekszik (M. Demeter, 2015). A designkommunikáció alapjaként szolgáló megismerés és felismerés közötti kapcsolatrendszert jól mintázza Angyal Ádám tanulmánya: „A megismerés az ismeretszerzés, a felismerés az ismeret-, a tudásalkotás. Amíg a megismerés lényege a tapasztalás, addig a felismerés legfontosabb módszere a gondolkodás. A tapasztalás és a gondolkodás egyaránt a tudás kialakitásának alapvetö módszerei, de éppen eltérö voltukból következöen lehet megkülönböztetni „termékeiket” is. A tapasztalás terméke a megismerés, a gondolkodás terméke pedig a felismerés. Ugyanakkor tudni lehet, hogy a tapasztalás és a gondolkodás nem szembeállitható, hiszen kölcsönösen építenek egymásra. A felismerés a megismerésen túli gondolkodás és kísérletezés következménye, barangolás a nem megismert vagy még nem is megismerhetö világba, az ismeretlenbe. "(Angyal, 2007, o. 7-8) A designkommunikáció módszertana által is alkalmazott nyílt problémamegoldásra alapozó kérdésfelvetés is a felismerésre épít.

A designkommunikáció a felismerés előtérbe helyezésével arra is rávilágít, hogy nem egy kész tudáscsomag átadására tesz kísérletet, sokkal inkább arra épít, hogy az alkalmazók maguk alkossanak egy tudáscsomagot a folyamat során tapasztalt felismeréseken keresztül. Hasonlóan az iménti gondolatmenethez, a kreativitást sem keretezi, nem szisztematikus, hanem tartományokon átívelő kreativitásra épít, ami megfelelő pedagógiai alkalmazása mellett a fenntartható fejlődés oktatási katalizátoraként is szolgálhat.

\subsection{A designkommunikáció oktatási vetülete}

A jelenkor oktatási gyakorlatában a leginkább megválaszolásra váró kérdés, hogy miképpen lehet úgy igazodni a minden tekintetben és minden résztvevő nézőpontjából megváltozott elvárásokhoz, a digitális világ szabta személyiségváltozáshoz, hogy az új 
módszertan egy állandó értéket (D. Horváth, Cosovan, Horváth, és mtsai., 2018) hordozzon magában. Vizsgálatom és az empirikus kutatás során e fenti gondolat kapcsán a designkommunikáció oktatási vetülete került előtérbe, így a továbbiakban a módszertan oktatási-nevelési irányvonalait prezentálom. A designkommunikáció módszertan alkalmazása az oktatásban azért is egyedülálló, mert ahogy a bevezetésben már megfogalmaztuk egy összeköttetést képez a különböző tudományterületek, a társadalom és a gazdaság jelenségei között. Támogatja a valós idejü kapcsolat létrehozását az oktatás, kutatás és vállalkozás között (A. Cosovan \& Horváth, 2016, o. 36). Értekezésem fő célját, az oktatás és a vállalkozás közötti párbeszéd elindítását, a célok és elvárások összehangolását nagy mértékben támogatja egy kifejezetten erre a célra irányuló módszertani kiindulópont.

A designkommunikáció alkalmazása, cselekvő kreatív oktatás-módszertani eszközként arra épít, hogy tudatosítja a résztvevőkben, hogy képesek értéket alkotni. Támpontokat ad, segítséget az eligazodáshoz, kész megoldási modult azonban nem nyújt. A designkommunikációs szemléletben a tervező számára tehát nem áll rendelkezésre egy elöre meghatározott lépés sorozat, hanem a problémamegoldás, és a hozzá vezető út egyszerre, egy időben valósul meg. (A. Cosovan, 2009)

A kezdeti káosz a megoldás formálódásával párhuzamosan tisztul, az eredmény, a sikerélmény pedig flow élményhez (Csíkszentmihályi, 2001) vezethet, amit empirikus kutatásom során a vizsgált osztályok esetében is tapasztaltam. A designkommunikáció a partnerkapcsolatra, a mindenki egyenrangú elvre épít (Benkler, 2006), valós problémákat helyez a középpontba, elsősorban nyílt végü kérdésekre keresi a választ, a csoportmunkára épít, ami hozzájárul az iskolai kreatív környezet megteremtéséhez is (Péter-Szarka, 2014).

\subsection{Designkommunikáció a designgondolkodás relációjában}

A designkommunikáció a napjaink üzleti és menedzseri gyakorlatában igen elterjedt design gondolkodás kortárs alternatívájaként szolgál, de kihívójaként is tekinthető (A. R. Cosovan és mtsai., 2018), miközben tartalmuk és küldetésük hasonlóságokat mutatnak. A designkommunikáció megértése, jelentősége és oktatásban kihasználható szerepe a design gondolkodás relációjából még könnyebben ismertethető, a módszertan mélyebb megértéséhez járul hozzá. 


\subsubsection{Designgondolkodás}

A design gondolkodás fogalma az idő során formálódott, jelenleg használatos definíciója az IDEO innovációs tanácsadó céghez és vezetőihez kötődik. Az IDEO vállalati stratégiája tükrözi magának a tervezési gondolkodásnak a fejlődését: eredetileg a termékfejlesztésre összpontosított, később a tervezés fókuszát kibővítette a szolgáltatások, stratégiák, sőt az oktatási és egyéb társadalmi rendszerek tervezésére is (Liedtka, 2015). A design gondolkodás a tervezői alapelveket, módszereket, megközelítéseket és eszközöket kapcsolja össze a problémamegoldás érdekében (Brown, 2009).

Egy másik definíció értelmezésében az emberközpontúságon és az innovációs folyamatokon van a hangsúly, ami a megfigyelés az együttműködés a gyors tanulás, az ötletek vizualizációja, a prototípusok azonnali megalkotása, valamint az ezzel párhuzamosan futó üzleti elemzés egyidejü létrejöttében látja a design gondolkodás fogalmi keretét (Lockwood, 2010).

Összefoglalva a design gondolkodás egy szisztematikus kreativitásra építő gyakorlati módszer, mely elöre meghatározott lépések sorozatát jelenti. Folyamatát a sorrendileg kötött rutin lépések sora határozza meg. A probléma megoldása három egymást követő lépcsőn keresztül valósul meg, melyek között visszacsatolás is lehet, ezek sorrendben (1) a fókuszban lévő kérdés feltárása, felfogása (inspiration), (2) adott szituációhoz igazodó tervek, megoldási módszerek összefogása (ideation), (3) a megvalósítás szintje (implementation) (Brown, 2008).

A design gondolkodást számos helyzetben alkalmazzák sikerrel, egymást követő lépései tovább bonthatók. Fehér és Varga (2017) cikkében számos gyakorlatot, alkalmazást hasonlított össze, ahol a következő lépések valamely kombinációját használják: (1.) definiálás; (2.) kutatás; (3.) értelmezés; (4.) ötletek gyüjtése; (5.) prototípusok előállítása; (6.) különböző változatok keresése; (7.) kontextusba illesztés; (8.) a javítás lehetőségeinek feltárása. Az előre meghatározott, egymást követő lépésekből álló tervezési lépéssor támogató sorvezetőként szolgál a megoldások keresésében. A design gondolkodás különösen hatékony megközelítés lehet, a már ismertetett zárt probléma megoldási helyzetekben. A lehetőség azonban, hogy egy megadott sorrendre épülö eljárásra támaszkodunk be is határolhatja a tervezési folyamat kimenetelét, így, ami a támogatást nyújtja egyidőben az újítás, akár az innováció megakadályozója is lehet. A design gondolkodás mindazonáltal a tervezői megközelítésnek csak egy nézőpontja. A lényeglátás, a felismerés a müvészi értelmezés, mint dimenziók már a design gondolkodást megelőzően megjelentek a szakirodalomban (Buchanan, 1992 in A. R. Cosovan et al., 2018). 


\subsubsection{A különbözőségek szisztematikus áttekintése}

A két módszertan adott szempontrendszer szerinti áttekintése, összehasonlítása Cosovan és munkatársai (2018) elemzése alapján valósul meg, kiemelt fókuszba helyezve a cikkben található táblázatot. (3. táblázat. A design thinking és a DIS.CO összehasonlítása) (A. R. Cosovan és mtsai., 2018). A design gondolkodás alapvetően a szisztematikus kreativitást támogatja, ami sokkal inkább rutinszerü, ám egy könnyebben szabályozható és rendszerezhető metódust jelent a kreatvitás alkalmazásában. Ezt támasztja alá, hogy amikor egy design gondolkodásra építő helyzetben a résztvevők úgy érzik, hogy kiléptek komfortzónájukból, akkor voltaképpen csak egy másik, rendszerint a facilitátor által kontrollált zónába lépnek át, ahol a facilitátor számára egy kiszámítható közegbe kerülnek, így továbbra is alkalmazhatók a megtanult módszerek és technikák, ők maguk a megszokott, jól ismert szerepekben maradnak.

Ezzel szemben a designkommunikációra építő helyzetekben, mind a résztvevők, mind a folyamatot részben instruáló facilitátorok is kikerülhetnek a komfortzónájukból, melynek során a nagyfokú bizonytalanság következtében a kreativitás új dimenziói nyílnak meg az alkalmazók előtt, mint a tartományokon átívelő, tartományokat befolyásoló és mozgató kreativitás (Csíkszentmihályi, 2018), amit korábban cselekvő kreativitásként is rögzítettem. A rutin helyett az organikus rítus veszi át a föszerepet. A tudásszerzés jellegét tekintve a design gondolkodás a megismerésre épít, míg a designkommunikáció a felismerésre alapoz, ebből is következik, hogy míg előbbi kapcsán a fejlődés jellege lineáris, úgy a designkommunikáció esetében a fejlődés exponenciális természete kerül előtérbe (A. R. Cosovan és mtsai., 2018).

\subsubsection{A kapcsolódási pontok}

A különbözőségek mellett számos hasonlóság is felfedezhető. Mindkét módszertan emberközpontú, a probléma megfogalmazása és megoldása is az érintettek bevonásával zajlik a tervezői és alkalmazói szerepek összemosódnak, erőteljes átfedésben vannak. A megoldási folyamatokban más-más arányban ugyan de az analitikus és az intuitív gondolkodás, a szubjektív meglátások és az érzések is helyet kapnak. Míg a design gondolkodás esetében ezek egyenlő arányban jelentkeznek (Martin \& Martin, 2009), addig a designkommunikáció esetében ez az intuitív gondolkodás javára tolódik. Martin (2009) tanulmányában arra világít rá, hogy az elkövetkező évek legsikeresebb vállalkozásai egyensúlyba hozzák az analitikus készségeket és az intuitív eredetiséget egy dinamikus kölcsönhatásban, amit ő a design 
gondolkodás módszerével azonosít. Az utóbbi évek során tapasztalt soft készségek felértékelődése azonban már árnyalja ezeket az arányokat.

Valójában ki a tervező? Abból a nézőpontból indult ki a szakirodalom, ahogy ezt Buchanan is felismeri (Buchanan, 1992), hogy a szakértők azok, akik részt vesznek a tervezési folyamatban, akik képesek arra, hogy olyan eredményeket hozzanak létre, melyek társadalmilag elfogadhatók. A közönség aktív szerepe később megjelenik, olyan formában, hogy ők lesznek azok, akik létező és releváns következtetéseket levonnak. Később az új szervezetek és a hozzájuk kapcsolható szervezeti formák, mint például a Wikipédia 2001-es megjelenése (Rosenzweig, 2006) további gondolatokat hívott elö annak kapcsán, hogy ki is valójában a tervező. A környezet bizonytalansága miatt a felhasználók egyfajta generációs elkötelezettséget igényeltek, amelyben a tervezők és a felhasználók közötti különbség elmosódik, amelynek eredményeként társ-tervezők közössége alakult ki (Liedtka, 2015). Ez az orientáció már sokkal inkább integrálja a társadalmi fókuszt, a hangsúly az együttmüködésre helyeződik, ami a korábbi elméletekböl hiányzott. Már nem csak a tervező kizárólagos privilégiuma lesz a terméktervezés. A design gondolkodás, úgy a designkommunikáció is másmás mértékben, de teret ad arra, hogy az adott problémamegoldásban részt vevők megcsillogtathassák tervezői attitüdjüket és nem csak utólagos véleményformálóként, hanem tervezőként cselekedjenek a probléma megoldása során.

Az empátia, mint kulcsjelenség esszenciális motívumként kap helyet az összehasonlításban, különösképpen a hasonlóságok tekintetében. A korábbi menedzsment elméletekben egyáltalán nem jelenik meg az empátia, így a design gondolkodás kapcsán úttörő színben tünik fel (Patnaik, 2009 in Liedtka, 2015) . Az empátia túlmutat a tervezési terület szubjektivitásának puszta elismerésén; gyakorlatilag a folyamat minden jelenlegi leírása hangsúlyozza a formatervezési gondolkodást, mint emberi központú és felhasználói alapú alapvető értéket. Ez összecseng a designkommunikáció definíciójával, mely a szemlélet empátiára építő jellegét (A. Cosovan, 2009) helyezi középpontba. Látjuk tehát, hogy a design gondolkodás alapvetően meghatározta a designkommunikáció kialakulását, belőle formálódott, legfontosabb építő kövei újra gondolva, a fókuszpontok átértékelésével, de helyet kaptak. A design gondolkodás módszertana jelenti a legszorosabb kapcsolatot, azonban a designkommunikáció átfogó megismeréséhez érdemes kitekintést tenni, hogy a tágabb tudományos térben hol helyezkedik el az alkalmazott módszertan. 


\subsection{Designkommunikáció a tágabb tudományos térben}

\subsubsection{Posztnormál tudománymegközelítés}

A posztnormál tudománymegközelítés vizsgálja a tudomány és a társadalom megváltozott kapcsolatát és azt, hogy ennek a kapcsolatnak a legfontosabb résztvevői a kutatók, valamint az állampolgárok miképp változtatták hozzáállásukat a tudomány müvelése kapcsán. A tudomány komplex, nehezen megoldható, átfogó, sok esetben még fel nem derített problémákra keresi a választ és az ahhoz vezető utat. A problémák összetettsége okán, a tudomány a megoldást számos kérdés kapcsán csak a transzdiszciplinaritás segítségével képes megtalálni (Köves, Gáspár, \& Matolay, 2020).

A transzdiszciplináris kutatás a tudományterületek közötti átjárhatóság és integráció jelenségével definiálható (Dúll, 2017). A folyamatban nem nélkülözhető a kölcsönös tanulás, a transzdiszciplinaritás számos esetben a különböző értékek, tudásterületek, tudásszintek összehangolására kényszerül a probléma megoldása érdekében. A tudásterületek határai közötti átjárás mellett az is fontos, hogy a transzdiszciplinaritás egy olyan új tudást hoz létre, mely nem korlátozódik csupán a résztvevő tudományterületekre, hanem egy teljesen új elméleti keretben értelmezhető (Dúll, Somogyi, Hülber, Brózik, \& Szabó, 2018). Ez nagyon összecseng a következő fejezetrészben bemutatásra kerülő, a designkommunikációs tervezési folyamat egyik jellegzetes, elsősorban az oktatási gyakorlatban alkalmazott együttmüködési formájával, a wikinomikus együttműködés sajátosságaival. Amikor egy egész osztály vagy nagyobb csoport dolgozik együtt egy projekt vagy probléma megoldásán, akkor a megoldáshoz vezető út részét képezi az eltérő személyiségjegyekkel, attitüddel, érdeklődéssel és tudásszinttel rendelkező egyedek véleményének, meglátásainak, hozzászólásainak összehangolása az eredmény érdekében. A tudásszintek összeadódnak, az új tudás pedig értelemszerüen sokkal több és komplexebb, mint az egyéni tudások egyszerü összege.

A posztnormál tudományfelfogás számára a kutatók véleménye mellett fontos az érintettek bevonása, a kutatott téma kapcsán kiterjesztett közösség véleménye. Az egyre inkább összefonódó társadalmi és gazdasági problémák megoldására a tudományágak közötti kapcsolódás jelenti a megoldást, a szakirodalom ezt tekinti az előremutató tudományfelfogásnak, mely alapelvet a designkommunikáció is alaptézisének értelmezi. A posztnormál tudományfelfogás megközelítése tehát a következő: „természeténél fogva összetett rendszerekben vizsgál összetett problémákat" (Réti \& Varga, 2008, p. 7 in Köves et al., 2020). A posztnormál tudományfelfogás támogatja a fenntarthatóságra nevelést, ami szintén 
összecseng a designkommunikáció által hordozott értékkategóriával. Továbbá a posztmodern tudományfelfogás fontos szerepet tulajdonít a tágabb és nem kutató szakértők tudásbázisának és véleményhalmazának (Köves és mtsai., 2020), mely elem saját empirikus kutatásunk során is esszenciális összetevőként van jelen.

\subsubsection{Müvészetalapú kutatás és oktatás}

A posztnormál tudománymegközelítés teret enged a müvészet és tudomány összekapcsolódásának is (Köves és mtsai., 2020). A designkommunikáció is szoros kapcsolatban áll a müvészetalapú kutatás, kiemelten annak oktatásban alkalmazott irányaival (Judit Juhász, 2019). A művészet alapú kutatás egy feltörekvő kvalitatív kutatási megközelítés; utal bármilyen müvészeti forma (vagy ezek kombinációinak) a kutatási folyamat bármely pontján történő felhasználására (Cole \& Knowles, 2001). A müvészet alapú kutatás úgy is meghatározható, mint a mủvészeti folyamat szisztematikus felhasználása, a művészi kifejezések tényleges megvalósítása a művészet összes különféle formájában, mint elsődleges módszer a kutatók és a kutatók által a tanulmányba integrált és a kutatásba bevont résztvevő emberek tapasztalatainak megértésére és megvizsgálására (McNiff, 2008).

A múvészetekben megtalálható lehetőségek a tudományos megismerés szempontjából azért is lehetnek kifejezetten fontosak, mert támogatják a tudás és megismerés dimenzióinak bővítését és lehetővé teszik a tudás előállításának egyéb formáinak előretörését is (Boydell, Gladstone, Volpe, Allemang, \& Stasiulis, 2012 in J. Juhász, 2019). A müvészetalapú kutatás nem tekinthető egy konkrét módszernek, sokkal inkább kutatási megközelítések halmaza. A művészetalapú kutatás a legtöbb esetben sokkal többet jelent, mint csupán azt, hogy a művészet a kutatás tárgya. A müvészet az ilyen jellegü kutatási eljárásokban helyet kap a kutatás több fázisában is, mint az elemzés, az értelmezés vagy a tudás előállítása (Judit Juhász, 2019).

A múvészetalapú kutatás egyik leggyakoribb alkalmazási területeként tartják számon az oktatást. A művészetalapú kutatás során nem csupán egy kreatív tevékenységben vesznek részt a kutatás alanyai, a közös alkotói élményen keresztül hatékonyabbá válhat az együttmúködés és a kommunikáció. Az alkotói folyamat formálja a gondolkodás alakítását, megkönnyíti az interakciót az egyének között, megszünik a kényszeresség, minimalizálódik a kontroll. A mủvészeti kutatás során létrehozott környezet pedig a kreatív környezet megvalósulásának motorjaként is funkcionál, teret adva így a szárnyaló kreativitásnak (McNiff, 2008). 
Designkommunikáció workshopomra építő empirikus kutatásom során is a fentieket feltételezem, a vizsgálat során a kutatási kérdések megválaszolásával az értekezés céljai között szerepel ennek bizonyítása, így amennyiben az igazolást nyer, úgy az alkalmazott módszertannak is helye lehet a művészet alapú kutatási módszerek között.

A föiskolák és egyetemek egyre több olyan képzést és programot kínálnak, amelyek összekapcsolják a mủvészetet más tudományágakkal, ezzel párhuzamosan a művészek kutatói képességeik kihasználásának módját keresik, így a tudományos környezet is egyre jobban reagál az új vizsgálati módszerekre (McNiff, 2008). Néhány példa, a teljesség igénye nélkül, mely egyetemeken ilyen mix jellegü képzési programokkal találkozhatunk: SAIC ${ }^{5}$, Stanford $^{6}$, University Arts London ${ }^{7}$, University of Toronto ${ }^{8}$, Case Western Reserve University ${ }^{9}$. Az elfogadás irányába mutató trendek nagyban köszönhetők Rudolf Arnheim és Susanne Langer munkásságának, akik a müvészetek kognitív vonatkozásait validálták a nagy tudományos közönség számára az 1950-es években. Ezzel megalapozták a művészet alapú kutatási megközelítés érvényességét a komoly tudományos vizsgálatok között (McNiff, 2008).

A mủvészetpedagógiát az oktatás egy müvészetalapú módszereként tartják számon, melynek fogalmi jelentése két részre bontható. Jelenti egyrészt a müvészeti tantárgyak oktatását, a müvészetre nevelést ((Trencsényi, 2000), ahol a cél a müvészet megismerése, emellett egyaránt jelentéséhez társítjuk azokat a módszertani eszközöket, melyek a művészetet alkalmazzák különféle pedagógiai gyakorlatok megvalósításához. Itt művészettel nevelésről (Trencsényi, 2000) beszélünk, ahol a müvészet a nevelési folyamat eszközeként szolgál. A müvészetpedagógia jellemzőihez soroljuk továbbá, hogy alkalmazza a pedagógia eszköztárát, céljai összhangban vannak az oktatási környezet által kitüzött célokkal, megvalósítható pedagógiai kereteken belül és kívül egyaránt (Kiss, 2017).

Amikor a müvészet fogalma pedagógiai és terápiás kontextusban kerül értelmezésre, akkor a fogalom lényege a funkció a nyelvezet és a kifejezésmód. Maga az esztétikum ezekben az esetekben csupán másodlagos. Ehhez kapcsolódóan a müvészetterápia definíciója is több pillérre építve jellemezhető, két egymástól nem függetleníthető aspektusa, a művészet, mint szublimáció és a művészet, mint kommunikáció a szakirodalomban leginkább elterjedt megközelítése a művészet terápiás módszerének bemutatásához (Kiss, 2010). Amikor a

\footnotetext{
${ }^{5}$ https://www.saic.edu/academics/areas-of-study/art-science

6 https://arts.stanford.edu/for-faculty/art-science/

${ }^{7}$ https://www.arts.ac.uk/subjects/fine-art/postgraduate/ma-art-and-science-csm

${ }^{8} \mathrm{https}$ ://www.artsci.utoronto.ca/future/ready-apply/programs-study

9 https://weatherhead.case.edu/degrees/doctorate/phd-management/design-and-innovation/
} 
mủvészet szublimációs jellege élvez prioritást, akkor maga az alkotói folyamat kerül fókuszba. Az alkotás átélése, az ezzel párhuzamosan megvalósuló szorongás, stressz és feszültség levezetése történik. Amikor a müvészet kommunikációs jellege kerül előtérbe, akkor a vizsgálat az alkotás folyamata helyett, az alkotás eredményére, és az abban rejlő üzenetekre összpontosít. Ide tartoznak többek között a projektív technikák, mint oktatásban is alkalmazott módszerek (Kiss, 2010).

A müvészettel nevelés megközelítése állítható leginkább párhuzamba a designkommunikáció módszertanával. A művészettel nevelés a mủvészetre nevelés és a művészetterápia közös metszeteként is értelmezhető. A művészettel nevelés módszerének jellemzőiként tartja számon a szakirodalom, hogy maga a müvészet eszközként kerül elő, és nem célként határozható meg. A designkommunikációhoz hasonlóan támogatja a problémamegoldást, és segíti a szocializációt. A személyes és művészeti kontextust együtt értelmezi, és a társadalmi szerepvállalás integrálása a művészettel nevelés folyamatának igencsak szerves részét képezi (Kiss, 2017). Ez a jellemvonás, a társadalmi szerepvállalás (Bodóczky, 2012 in Kiss, 2017), a globális állampolgárságra nevelés ugyancsak megjelenik az általam vizsgált és alkalmazott designkommunikáció módszertanában. A művészettel nevelés alkalmazási területeiként tartjuk számon a készség- és személyiségfejlesztést, de a hatékony kommunikációra nevelést is (Illés, 2009), ami többek között a soft készségek fejlesztésének megvalósulását is jelenti, így ez is egy jelentőségteljes kapcsolódási pont a müvészettel történő nevelés és a designkommunikáció között.

\subsection{A wikinomikus együttmüködés, mint a designkommunikáció fontos katalizátora}

Nem hagyható figyelmen kívül az a feltörekvő üzleti és egyre inkább a tudományos világot is megmozdító trend miszerint az egyének megosztják az ismereteket, a számítási teljesítményt, a sávszélességet és az egyéb erőforrásokat, hogy széles skáláját hozzák létre ingyenes és nyílt forráskódú termékek és szolgáltatások számára, amelyeket bárki felhasználhat vagy módosíthat. Csak egy számítógépre, egy hálózati kapcsolatra, valamint a kezdeményezés és a kreativitás élénk szikrájára van szükség a gazdasághoz való csatlakozáshoz. A tömeges együttmüködés kinyitotta az árvízkapukat, és átalakuló özönváltássá változtatta az innováció áramlását, amelyben bárki, aki ötlettel és számítógéppel rendelkezik, szabadon úszhat, vagy örömmel szállíthatja azt tovább. (Fuchs, 2008).

„A korszerü felfogásban a tanuló kliens és munkatárs is, aki az iskola dolgozóival együttműködve hozza létre az iskola „termékét”: saját fejlődését” (Buda \& Péter-Szarka, 2015, 
o. 11). Erre a tételmondatra is építek, amikor az együtt gondolkodás, együtt dolgozás lehetőségét a saját fejlesztésű designkommunikáció módszertanára építő, kutatásom központi elemét jelentő workshop kiindulópontjaként értelmezem. Azt, hogy jó alapokra építek megerősíti, hogy a világ legbefolyásosabb vállalatainak egyre növekvő hányada a tömeges együttmüködést, mint nyerő fegyver tartja számon az innovatív hatalom előmozdítása érdekében (Rinaldi, 2009).

A designkommunikáció tervezői szemléletet wikinomikus együttmüködéssel együtt, egyidőben, eszközkészletét felhasználva építettem bele a kreatív oktatás-módszertani workshop termékfejlesztési folyamatába, gyakorlatilag a designkommunikáció katalizátoraként müködik. Legfontosabb összetevőinek bemutatása ezért is kiemelt fejezete az értekezésnek.

A wikinómia definíció szerint tömeges együttmüködést jelent (Tapscott, Williams, \& Garamvölgyi, 2007). Arra az elvre épít, hogy az igényelt, szükséges tudást mindenki számára átadja, azonban ennek a tudásnak a forrását a többi résztvevő tudáshalmaza jelenti (Fuchs, 2008). Alkalmazása a tudomány egyre több területét érinti. Amikor a tudományról és a „wiki” világ kapcsolatáról beszélünk, akkor az együttmüködések olyan formáiról beszélünk, melyek körülbelül egy évtizede zajlanak és amelyekben a közvélemény tagjai adományozzák szellemi forrásaikat a tudományos haladás érdekében (Rinaldi, 2009). Használata oktatási és offline környezetben sem ritka, korábbi hazai kutatásokban is alkalmazásra került, ott azonban az alkalmazói környezet egyetemista diákokat jelentett. (D. Horváth, Cosovan, Horváth, és mtsai., 2018).

Jelen empirikus kutatásomban a wikinomikus együttmüködés integrálása a workshop részeként a határok feszegetését jelentette, célzottan a diákok komfortzónából történő kimozgatására fókuszált. A tömeges együttmüködés az oktatási gyakorlatban azt jelenti, hogy az adott projektben részt vevő alanyok egymás felé nyitottak, a tudást szívesen megosztják, közösen dolgoznak annak érdekében, hogy együtt az adott célt teljesítsék, valamint, hogy a cél elérésén keresztül az adott közösség életét előre mozdítsák.

A wikinómia az egyenrangúak együttműködéseként is definiálható (Benkler, 2006), ami a designkommunikációra építő workshopok esszenciája. Ezt a tételt kutatásomban közvetlenül átültettem a gyakorlatba: diákok és tanárok, valamint a workshopot tartó tréner is egyenrangú félként vett részt, ami egy nyitott, barátságos, befogadó környezetet feltételez. Ez az atmoszféra biztonságot nyújt a diákoknak, kapaszkodót jelent a bizonytalan helyzetben. A vállalati életben zajló folyamatok is párhuzamot mutatnak: a hatékony vezetők pozitív kapcsolatokat alakítanak ki az összes érdekelt féllel, így segítik elő a horizontális bizalmat, ösztönzik a szakmai tiszteletet, ami pozitív hatással van az együttmüködésre. Ez történik akkor is, amikor a 
hierarchikus viszony tanár és diák között átmenetileg lebomlik, és új értelmezést nyer egy együttmüködés során (Raelin, 2016). A wikinomikus kooperáció általánosságban a fentiekhez, majd a konkrétumok szintjén saját designkommunikáció foglalkozásomhoz a következő négy alappillérén keresztül járul hozzá (Tapscott és mtsai., 2007):

1. Nyíltság: Az új helyzet befogadása. Egy osztályteremnyi ember dolgozik együtt, és alkot egy közös projektet, ráadásul egy heterogén résztvevői összetételben.

2. Egyenrangúak együttmüködése: Nincs alá-fölé rendeltség, érdemes tudatosítani a résztvevőkben, hogy mindegyikőjük gondolata egyformán értékes. Nem számít, hogy kitől származik, csak az az érdekes, hogy milyen hozzáadott értéke van a nyílt probléma-megoldási helyzetekben (Dorst, 2011).

3. Megosztás: A munka során minden ötlet, javaslat mindenki rendelkezésére áll. A létrejött, megformált közösségi tudás mindenkié, megosztásra kerül online és offline eszközökön egyaránt.

4. Globális cselekvés: A cselekvésbe, megoldásba kódolt jó, és annak kommunikációja, kiterjesztése a projektben nem résztvevőkre is. 


\section{KUTATOTT TÉMÁM MÓDSZERTANI MEGKÖZELÍTÉSE, A KUTATÁSI TERV}

\subsection{A kutatási célok és kérdések feltárása}

A szakirodalom áttekintését követően a kutatási célok és a kutatási kérdések meghatározására összpontosítok. A kutatás céljai között szerepel egy olyan oktatásban alkalmazható produktum fejlesztése, mely könnyen integrálható a zárt, általános iskolai keretrendszerbe, használatával a diákok csoportban, együttmüködve, egy kreatív, tervezői nézőpontot elsajátítva alkothatnak, tervezhetnek. Egy olyan oktatási modul, mely a soft készségek fejlesztésére törekszik, kiemelt fókuszt helyezve a kreativitásra, az együttmüködésre és a vállalkozói attitüdre. A kutatás egyes fázisai, mint például az adatgyüjtés, valamint a termékfejlesztési folyamat egy időben, egyszerre van jelen, így a designkommunikáció nemcsak az oktatási modul, de a termékfejlesztési folyamat módszertani alapját is szolgáltatja. A design, a tervezés számos aspektusa együtt jár a kereséssel és a kutatással, ami a tervezői folyamat és kutatás egyidejü megtörténtében fellelhető összhangot erősíti (Friedman, 2003). Az „otthonom jobbá tételére vállalkozom” kreatív oktatás-módszertani eszköz fejlesztése a designkommunikáció módszertani alapjaira építve valósult meg, és került a kutatás során kialakításra. Kutatásom során az általam fejlesztett terméket helyeztem a vizsgálat középpontjába. A központi (fö) kutatási kérdést a következőképpen fogalmaztam meg:

A designkommunikáció (tervezői kapcsolatteremtés), mint kreatív oktatásmódszertan alkalmazása egy workshopon keresztül hogyan alakítja, milyen módon formálja a részt vevő közösséget (diákok, pedagógusok)? Hogyan járul hozzá a nyílt végü problémamegoldás a vizsgált csoporton belüli kommunikációhoz? Hozzájárulását és befolyását a következő dimenziókban feltételezem: (I) közösségépítés, (II) soft készségek fejlesztése, (III) tervezői, alkotói identitás kialakulása, (IV) vállalkozói kompetencia térnyerése. A rögzített dimenziók által felvetett kérdésekre a következő kutatási alkérdéseken keresztül keresem a választ.

(I): Hogyan segíti a workshop a közösség építését?

(II): Milyen módon, milyen irányba alakítja a workshop a diákok soft készségeit?

(III): Hogyan formálódik, alakul a workshop által a diákok tervezői identitása? 
(IV): Hogyan alakítja a workshop és a közösség a vállalkozói attitüd és kedv megjelenésének intenzitását?

A kutatással a legfontosabb célkitüzés a tudományos irodalomhoz történő hozzájárulás mellett a kutatásban rejlő társadalmi hasznosság. Túl ezen, szeretnék egy mélyebb párbeszédet indítani a vállalati szférával az oktatott és elvárt készségek és képességek összehangolása érdekében. Cél továbbá, hogy feltárjam és leírjam, hogy a nyílt végü problémamegoldási helyzet ebben a korosztályban mire és milyen módon hat. Kiemelt jelentőséget tulajdonítok annak, hogy akadémiai munkásságom a kutatás tárgyában leginkább érdekelt közösséghez gyakorlati szinten is eljusson, ahol valós terepen tapasztalható eredményeket kutathatok, és azonnali hozzáadott értéket hozhatok létre a kutatásban részt vevő közösségnek. Kutatásom társadalmi célja a termék fejlesztésével egy időben az egyén és a vizsgált szervezet támogatása, fejlesztése, a gyerekek számára egy olyan egyedi tapasztalat, élmény biztosítása, ami meghatározó elem lehet a gondolkodásuk formálódásában, így a workshop mind a teszt fázisban, mind a későbbi kutatási lépcsők során az adott szervezethez alakítva került megtervezésre, igazításra. A kutatás távolabbi célkitüzése a módszertan tantervbe történő integrálása, a workshop marketingkommunikációs stratégiájának tervezése és eljuttatása az oktatás fejlesztésében érdekelt, és/vagy az oktatás fejlesztésére nyitott szakmai és civil közösségeknek.

\subsection{Kvalitatív módszertani megközelítés}

A fenti kutatási kérdésekhez és célokhoz igazítva doktori disszertációm tisztán kvalitatív kutatásmódszertanra alapozom. Vizsgálódásom középpontjában a soft készségek és az oktatás relációja áll, így fontosnak láttam, hogy egy minden elemében a témaválasztásomhoz illeszthető módszertanra támaszkodhassak. A kvalitatív módszertani megközelítés esetében nincs pontosan kijelölt út, az újra definiálás, a módszertan sajátossága, fejlődési lépcsőfok. A kutató az útvonal tervezője, a tájékozódási pontok kijelöléséért is ő felel, ami ugyancsak nagyfokú kreativitást igényel. Az út, a kijelölt terep, a határvonalak, és a nézőpont sokszor, sokféleképpen változik, míg kitisztul, és láthatóvá válik az a rendszer, amit a kutató létrehozott. Ehhez türelem, elhivatottság és kitartás szükséges (D. Horváth \& Mitev, 2015) .

A kvalitatív módszertan definíciója dinamikusan változik, tudományterületenként eltérő, így pontos megfogalmazása kapcsán nehézségekbe ütköztem. Saját kutatásomhoz leginkább közel álló definíció Van Maanen (1988) nevéhez köthető, akinek megfogalmazása alapján a kvalitatív kutatás egy vita részeként értelmezhető, nem nevezhető rögzített igazságnak (Van 
Maanen, 2011). A mélyben rejlő értelem megragadására tesz kísérletet, és ez keretezi és összegzi mindazt, amit leírok arról, amit valójában csinálok. Sajnos a kvalitatív kutatás, folyamatosan növekvő szerepe és erősödő elfogadottsága ellenére sem maradéktalanul akceptált a tudományos közegben. Az eredmények a legtöbb esetben nem számszerüsíthetők, a kutatás egzaktsága nem úgy, és olyan formában érhető tetten, mint egy kvantitatív módszertan esetén, így a kézzelfoghatóság hiánya sokszor kevésbé tudományos színben tüntetheti fel a kvalitatív módszertannal készült kutatás eredményeit. A kézzelfoghatóság hiánya egy egyértelmüen beazonosítható szolgáltatásmarketing problémává redukálja a fenti kérdést, mely terület egyedi, specializált helyzete a marketingtudományban nem vitatott, ellenkezőleg: teljességgel elfogadott jelenség (D. Horváth \& Mitev, 2015).

\subsection{A kutatási stratégia és a mintavétel módja}

A kvalitatív módszertani megközelítések, stratégiai irányok közül, kutatásom stratégiáját a multimethods, azaz a több módszertanú kutatási stratégia (Morse, 2003) határozza meg, melynek keretein belül háromféle kvalitatív adatgyüjtési módszert alkalmaztam, amit a

\section{3. ábra: A kutatási stratégia és az adatgyüjtési módszerek}

következő ábrán szemléltetek, és a későbbi fejezetekben részletezek.
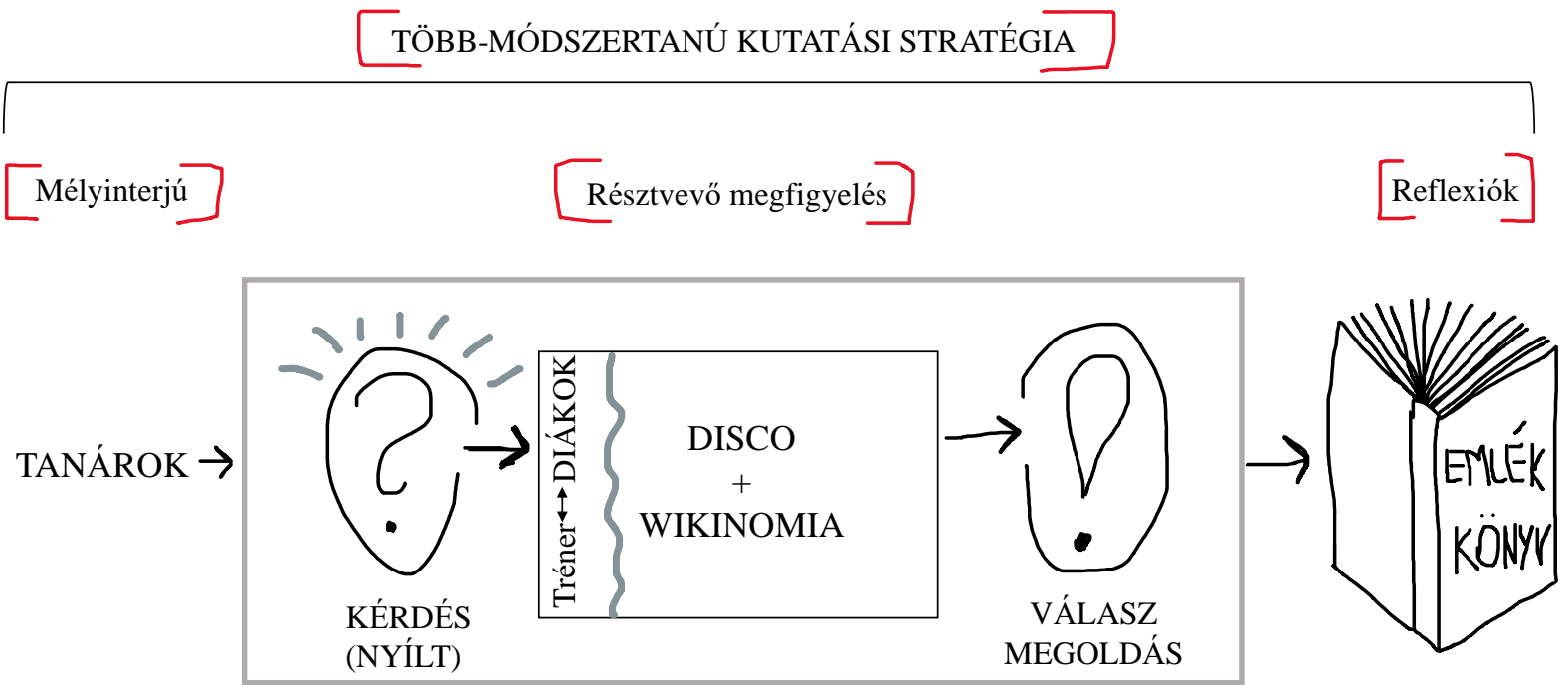

Forrás: Saját szerkesztés a rögzített kutatási terv alapján 
A téma sajátosságain túl, a kutatás menetének pontos kialakításában segítséget jelentett a későbbiekben bemutatásra kerülő pilot kutatások megvalósítása, így állt össze a most ismertetendő kutatási terv.

\subsubsection{Multimethods, a több-módszertanú kutatási stratégia}

\section{Kutatásom módszertani keretét, a kutatási stratégiát, a multhimethods, magyarul a} több-módszertanú kutatási stratégia határozza meg.

A szakirodalomban a fogalmak eltérő használata és definíciója jellemző a hibrid kutatási megközelítések kapcsán. A hibrid kutatás egyedi jellemzője, hogy több lábon áll, így lehetőséget teremt a nehezen elérhető csoportok és adatok hozzáféréséhez. A részben vagy egészében eltérő, rugalmasan kombinálható kutatási módszerek, feszegetik a megismerés határainak korlátait (Neulinger, 2016). A hibrid kutatási stratégiát alapvetően különböző kutatási módszertanok együttes alkalmazásaként értelmezzük. Megvalósulása történhet kizárólag kvantitatív vagy kvalitatív megközelítés/adatfelvétel kombinációjával, valamint e kettő tudatos és jól szervezett összekapcsolásával egyaránt. Szekvenciális megoldásról beszélünk, ha ezek az adatfelvételek egymást követik, míg párhuzamos megoldásként értelmezzük az egymással egyidőben lezajló adatfelvételi folyamatot (Neulinger, 2016). A marketing területén a leggyakrabban több-módszertanú (multhimethod) és a tőle eltérö alapokra építő vegyes módszertanú (mixed method) kutatásként címkézik a hibrid módszerek két fő irányát, ezért fontos tisztázni a két irány közötti legfontosabb különbségeket (Harrison \& Reilly, 2011). Ezzel egyidőben saját kutatási stratégiámat is nevén nevezem, a szakirodalomban fellelhető definíciós különbségek tisztázása és egyértelmüsítése okán Morse (2003) meghatározására hivatkozom, a kutatás során az ő definícióját követem (Morse, 2003).

(1): Vegyes módszertanú megközelítés (mixed method): Lényege, hogy magába foglalja a két típusú adatfelvételi módszer keverését. A különféle adatok tudatos, szervezett kombinálása kapcsán realizálódik a kutatás eredménye.

(2): Több-módszertanú megközelítés (multhimethod): Többféle adatfelvételi módszert alkalmaz, de vagy tisztán kvalitatív, vagy tisztán kvantitatív módszertani megközelítésen belül, a kettőt egymással nem keveri.

A két megközelítés tehát valójában eltér egymástól. Több szerző, például Fielding (2012), nem tesz határozott különbséget a két stratégiai irány között, így tágabban értelmezi a vegyes módszertanú megközelítést (Fielding, 2012). Nincs tehát egyértelmű magyarázat arra vonatkozóan, hogy egy tisztán kvalitatív módszertani megközelítéseket egyesítő kutatás miért 
ne tartozhatna a vegyes módszertanú megközelítés körébe (Fielding, 2012). Ezt támasztja alá, hogy a vegyes módszertan tekinthető egy központi és egy kiegészítő módszertan együttes alkalmazásának, ahol a központi eredmények segítik a kiegészítő eredmények értelmezését. (Morse, 2010) A QUAL-QUAL vegyes módszertant tehát egy központi adatfelvételi módszer, és kisebb kérdésekre választ adó, a fő irányt alátámasztó, kiegészítő elemek jellemzik, melyek önmagukban nem lennének elegendőek (Morse, 2010). Ezen definíció szerint, ha kutatásom stratégiáját vegyes módszertanú stratégiaként rögzíteném, akkor a fö komponenst a résztvevő megfigyelés, a kiegészítő komponenseket pedig a reflexiók és a mélyinterjúk jelentenék.

Olyan is fellelhető, amikor a több-módszertanú (multimethod) kutatási stratégiaként rögzített megközelítés egyaránt tartalmaz kvalitatív és kvantitatív adatfelvételi módszereket (Budai, 2004). Ez nem csak alkalmazott módszerként, de módszertani szakirodalomban is megtalálható (Schutz, Chambless, \& DeCuir, 2004). Neulinger (2016) arra is hoz példát, amikor olyan hibrid megoldás születik, melyben a több módszertanú és a vegyes módszertanú megközelítés egyszerre kerül alkalmazásra (Neulinger, 2016).

A többféle szinten, eltérő keretek mentén értelmezett megközelítések közül a korábban rögzített, és egyértelműen definiált több-módszertanú megközelítést veszem alapul, így kutatásomban különbséget teszek a hibrid megközelítések között is, és a Morse (2003) féle irányt tekintem alapvetésnek (Morse, 2003). Így tehát tisztán kvalitatív adatfelvételi módszerek kapnak helyet a több-módszertanú kutatási stratégiában. Ezek az adatfelvételi módszerek szekvenciálisan követik egymást. Először a mélyinterjú, majd a résztvevő megfigyelés végül a reflexiók kerülnek megvalósításra. Az első esetben az alanyok, a helyszín és az időpont eltérőek, a résztvevő megfigyelés és a reflexiók esetében egyidőben, ugyanazon a helyen, ugyanazoktól az alanyoktól más jellegü adatfelvételi módszerrel kerülnek rögzítésre az információk. A több-módszertanú kutatás során olyan hibrid mérést alkalmazok, melynek során van olyan, hogy ugyanazon válaszadó (diák) többféle adatfelvételi módszerrel (résztvevő megfigyelés, reflexió) találkozik, de van olyan válaszadó is (pedagógus), akit csak egy módon kérdezek (mélyinterjú).

\subsubsection{A mintavétel módja}

A kutatás ismétlése nem csak az elméleti telítődésig (Mitev, 2012) történik, minden magyar megyébe, Budapestre és egy határon túli magyar településre is elvittem a workshopot. Ezzel a cél a helyi szinten feltételezett hozzáadott érték, amit a résztvevők számára az általam fejlesztett kreatív oktatás-módszertani eszköz biztosít, miközben folyamatosan fejlődik és 
tökéletesedik a termék a résztvevők hozzáadott véleményének beépítésén keresztül. Így 19 megyében, Budapesten és egy határon túli magyar településen került megvalósításra a workshop, a pilot foglalkozásokon felül, mindösszesen 24 alkalommal.

Az iskolák kiválasztása során arra törekedtem, hogy olyan állami intézményekben valósítsam meg a kutatást, melyek a nemzeti alaptantervet irányadónak tekintő, aszerint működő reguláris képzésủ általános tanrendủ iskolák. Mindenképpen fontosnak tartottam elkerülni a kutatás első szakaszában a magánintézmények vizsgálatát, melyek speciális tantervet követnek, és nyíltan megfogalmazzák a kreativitás fejlesztésére vonatkozó törekvéseiket. A kutatás szempontjából egy nyolc osztályos, államilag támogatott körzeti iskola jelenti az ideális mintát, ahol a csoportmunkát, az innovatív, hagyományostól eltérő aktív tanulási módszereket ritkán, vagy nem alkalmazzák, és az alkalmazása nem tanrendi kötelezettség, hanem a pedagógusok hozzáállásától függ. Azt feltételeztem, hogy a kutatás kezdeti szakaszában olyan iskolákban tudom igazán vizsgálni a módszer hatékonyságát, ahol ez ismeretlen még a diákok számára, ahol a csoportmunka nem a mindennapi rutin része, nem volt korábban jelentős számú hasonló tanulási módszerben részük, mely befolyásolná az eredményt, így minimálisra redukálhattam a zavaró tényezőket.

A kiválasztási szempontokat összegezve, a következőket tekintettem irányadónak:

(1): 8 osztályos általános iskola

(2): állami támogatású intézmény

(3): normál tanrendü, a nemzeti alaptantervet követő,

(4): minden megyét, Budapestet és egy határon túli magyar települést érintő magyar nyelvü általános iskola

(5): az iskola és a pedagógusok nyitottsága, rugalmassága, a tudomány iránti fokozott érdeklődés hozzáadott érték, de nem elsődleges kiválasztási kritérium

A mintavétel a fenti kiválasztási szempontokat figyelembe véve valósult meg az iskolák tekintetében, alkalmazva a Horváth-Mitev (2015) által is ismertetett hólabda vagy lánc elnevezésü kvalitatív mintavételi technikát (D. Horváth \& Mitev, 2015). A kiindulópontot a pilot workshopnak is helyet biztosító Bárdos Lajos Általános Iskola Kazinczy Ferenc Tagintézménye jelentette, aki partnerintézményei, kapcsolati hálója révén segítette az elindulást.

A mintavétel két szinten került értelmezésre. Egyrészt minden esetben kiválasztásra került az iskola, valamint az iskolán belül az osztály, akire a kutatás fókuszál. Az iskolán belül 
a vizsgált korosztályt a hatodik osztályos tanulók jelentik. Ebben az esetben a mintavételi technika elméletalapú, egy korábbi kutatásom eredménye alapján választottam ezt a korosztályt. 4., 6. és 8 . osztályos tanulókat vizsgáltam, a designkommunikáció módszertanára irányuló nyitottságuk került a vizsgálat középpontjába. Az itt feltárt eredmény arra engedett következtetni, hogy a határozott tervekkel, szabad, merész gondolatokkal rendelkező 6. osztály a legalkalmasabbnak vélt, a Z generációt erősítő célcsoport jelen kutatásomhoz (D. D. Horváth és mtsai., 2020). Azokban az iskolákban, ahol egy évfolyamon összesen egy osztály van, ott a mintavétel adott volt. Ott, ahol egy évfolyamon belül több hatodik osztály is található a választott iskolán belül, ott az iskola igazgatójára, az iskolában oktató pedagógusokra bíztam a választást. A választás indoka minden esetben rögzítésre kerül írásban is, de azt szem előtt kell tartani, hogy ebben az esetben feltehetően számolni kell a kutatást torzító hatásokkal is. A tanár/igazgató elfogultsága, tudományos ambíciója befolyásolhatja a választást, és így a kutatás eredményét. Előfordulhat, hogy torzítást okoz az a törekvés, hogy a tehetségesebb, jobb képességű osztályt választják, hiszen a kutató, a kutató mögött álló egyetem felé jobb képet szeretnének mutatni az iskoláról. Árnyalja a képet a kutatás célkitüzése, miszerint a pedagógusok alkalmazni fogják a módszertant, így közvetetten ugyan, de a kevésbé jó képességü, a kutatás vizsgálati fókuszába nem kerülő diákok is lehetőséget kaphatnak a jövőben a workshopon való részvételre.

\subsection{A kvalitatív adatgyüjtési módszerek}

A több-módszertanú kvalitatív kutatási stratégia részeként több kvalitatív adatgyüjtési módszert alkalmaztam, ezek a megvalósítás sorrendjében a következők:

(1) mélyinterjú a vizsgált osztály osztályfőnökével, hiszen ő a csoport hivatalosan kinevezett vezetője (Mészáros, 1998)

(2) résztvevő megfigyelés, a workshop megvalósításán keresztül,

(3) a résztvevő diákok által írt reflexiók és elemzésük. A mélyinterjú és a reflexiók kapcsán projektív technikákat is alkalmaztam.

Mielőtt részletesen ismertetem az egyes adatfelvételi módszereket egy táblázat formájában összegzésre kerültek az adatgyüjtési módszerek, melyben ismertetem az adatok eredetét, típusát, a rögzített kritériumokat, valamint a kutatás során megvalósított adatelemzési módszereket, és a lehetséges limitációit is a kutatásnak. 
2. táblázat: Az adatgyüjtési módszerek és az általuk rögzített adatok útja a kutatás során

\begin{tabular}{|c|c|c|c|c|c|c|c|}
\hline Kutatási stratégia & A kutatás elemszáma & $\begin{array}{l}\text { Adatgyújtési } \\
\text { módszerek, } \\
\text { Adatfelvétel }\end{array}$ & $\begin{array}{c}\text { Az adat származása, } \\
\text { honnan jön létre az } \\
\text { adat? }\end{array}$ & \begin{tabular}{|c|} 
Kutatási folyamatot \\
meghatározó sarokpontok, \\
adott instrukciók
\end{tabular} & Adat & $\begin{array}{l}\text { Adatelemzési } \\
\text { módszer }\end{array}$ & Limitáció, Nehézség \\
\hline \multirow{3}{*}{ 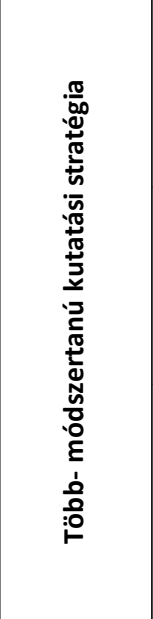 } & $\begin{array}{c}24 \\
\text { (19 megye+Budapest+határon } \\
\text { túli magyar település) }\end{array}$ & $\begin{array}{l}\text { 1. Elözetes interjú a } \\
\text { vizsgált osztályhoz } \\
\text { legközelebb álló } \\
\text { pedagógussal } \\
\text { MÉLYINTERJú }\end{array}$ & $\begin{array}{c}\text {-Hangfelvétel } \\
\text {-Kérdezó jegyzete } \\
\text {-projektív technikát } \\
\text { alkalmazó feladatok } \\
\text { vizualizációja }\end{array}$ & $\begin{array}{l}\text { Pedagógus meglátásai, } \\
\text { elözetes ismeretek } \\
\text { feltérképezése a hatások } \\
\text { pontos rögzítéséhez, } \\
\text { mélyinterjú-vezérfonal, } \\
\text { felkészült kérdezőbiztos }\end{array}$ & $\begin{array}{l}\text {-narratíva } \\
\text {-rajz, ábra, egyéb } \\
\text { vizualizáció }\end{array}$ & $\begin{array}{l}\text { Tartalom- és } \\
\text { ábraelemzés }\end{array}$ & $\begin{array}{c}\text {-Pedagógus } \\
\text { hozzáállása } \\
\text { - Vélt és valós viszony } \\
\text { a pedagógus és a } \\
\text { diákok között }\end{array}$ \\
\hline & $\begin{array}{c}24 \\
\text { (19 megye+Budapest+határon } \\
\text { túli magyar település) }\end{array}$ & $\begin{array}{l}\text { 2. Workshop a vizsgált } \\
\text { osztályközösség részét } \\
\text { képező diákokkal } \\
\text { RÉSZTVEVŐ } \\
\text { MEGFIGYELÉs }\end{array}$ & $\begin{array}{l}\text {-A workshop során a } \\
\text { résztvevő́k által } \\
\text { létrehozott output } \\
\text {-Résztvevőí } \\
\text { megfigyelés során a } \\
\text { megfigyelö(k) } \\
\text { (tréner)jegyzete }\end{array}$ & \begin{tabular}{|c|} 
A változás, az eredmény, a \\
kiindulási ponthoz történő \\
viszonyitás lehetősége, a \\
diákok workshophoz történő \\
alkalmazkodása
\end{tabular} & $\begin{array}{c}\text {-output szöveges } \\
\text { leírása } \\
\text {-naplóbejegyzés } \\
\text {-rajz }\end{array}$ & Tartalomelemzés & $\begin{array}{l}\text { - Workshop kimenete } \\
\text {-Résztvevőḱ aktivitása, } \\
\text { együttmüködése } \\
\text { - Kiskorúak bevonása a } \\
\text { kutatási folyamatba }\end{array}$ \\
\hline & \begin{tabular}{|c|}
24 \\
(19 megye+Budapest+határon \\
túli magyar település) *22 diák \\
(átlagos osztálylétszám)
\end{tabular} & \begin{tabular}{|c|} 
3. A workshop \\
befejezését követően a \\
diákok reflexiót írnak a \\
workshop során szerzett \\
tapasztalataikról \\
REFLEXIÓ
\end{tabular} & $\begin{array}{l}\text { - A diákok által írt } \\
\text { fogalmazások } \\
\text {-projektív technikát } \\
\text { alkalmazó feladatok } \\
\text { vizualizációja }\end{array}$ & \begin{tabular}{|} 
Egy fehér, üres lapra, a \\
vendégkönyvbe írják le \\
gondolataikat a diákok az \\
átélt tapasztalatokat \\
fogalmazzák meg, megadott \\
szempontok mentén, \\
véleményük szerint mi \\
változott
\end{tabular} & $\begin{array}{c}\text {-reflexió szövege } \\
\text { - rajz }\end{array}$ & $\begin{array}{l}\text { Tartalom- és } \\
\text { ábraelemzés }\end{array}$ & $\begin{array}{l}\text { - A diákok hozzáállása } \\
\text { a feladathoz } \\
\text { - Öszinteség kérdése } \\
\text { - Kiskorúak bevonása a } \\
\text { kutatási folyamatba } \\
\text { - Írástudás és } \\
\text { kifejezőkészség, } \\
\text { szókincs }\end{array}$ \\
\hline
\end{tabular}

Forrás: Saját szerkesztés a kutatási terv lépéseinek szem elött tartásával

5.4.1 Mélyinterjú: a keretek meghatározása, a problémák azonosítása

Az empirikus kutatás első adatfelvételi lépése egy félig strukturált mélyinterjú (J. Mason \& Tóth, 2005), a vizsgálat fókuszát képező osztályt leginkább ismerő pedagógussal, aki valószínüsíthetően a diákok osztályfőnöke is, ő az, aki hasznos információt biztosít a kutatás alanyairól, elsősorban, mint közösségről. A felkészültség kiemelten fontos a kérdező részéről, hiszen ez az interjú az, mely segíti majd az empirikus kutatás következő lépéseinek sikeres formálását. Éppen ezért az interjú vezérfonalának összeállítására kiemelt figyelmet kell szánni (Pervez \& Kjell, 2011).

Az interjúkérdések a fő kutatási kérdés és az ahhoz kapcsolódó alkérdések ismertetése során meghatározott és vizsgálni kívánt dimenziókra épülnek, a cél, hogy megismerjem azokat a kihívásokat, amivel az osztályközösség szembesül, a diákok egymáshoz, és pedagógusokhoz való viszonyát. Az interjú során információt szerettem volna kapni az osztály pedagógus által felismert kreativitásáról, a csoportmunka, illetve egyéb alternatív és aktív tanulási módszerek alkalmazásáról, a pedagógus nyitottságáról, tapasztalatairól.

Az adatfelvétel a mélyinterjúkkal kezdődött adott vizsgálati helyszínen, így a kutatássorozat végére 24 pedagógussal készített mélyinterjú, és abból származtatható adat áll 
rendelkezésre. Az időzítés jelentősége nem elhanyagolható, nagyon fontos, hogy a résztvevő megfigyelést megelőzze, hogy megfelelő legyen a felkészültség, és az interjú eredményei alapján szükség esetén finomítani lehessen a workshop menetét.

Az interjú során a kérdések sorába szerkesztettem projektív technikákat is. A pedagógusokat a kreativitás megszemélyesítésére kértem: milyen ember/állat maga a kreativitás, valamint a jelenség iskolában való megjelenésének rajzos vizualizációja is feladat volt. A projektív technikákról és használatuk jelentőségéről egy későbbi fejezetben részletesen beszámolok.

\subsubsection{A kutatás kiemelt adatgyüjtési módszere - résztvevő megfigyelés}

A kutatás központi egységét a létrehozott oktatásmódszertani eszköz, a bevezetésben is rögzített az „otthonom jobbá tételére vállalkozom” workshop jelenti. Ez egy, a designkommunikáció elméletét alkalmazó oktatás-módszertani termék. Kifejezetten általános iskolás korosztály számára fejlesztett. Kialakítása során rendkívül nagy jelentőséget tulajdonítottam annak, hogy a termék alkalmazható legyen az iskolák zárt, szabályokkal és kötelezettségekkel terhelt rendszerében is. A saját fejlesztésű oktatásmódszertani eszköz (workshop), mint termék részletes bemutatása a primer kutatást taglaló fejezetben valósul meg, a workshop forgatókönyve pedig a mellékletben elérhető az olvasónak. A kutatás tervezett és megvalósult időzítése a 2019/2020-as iskolai tanév első fele, mely időzítés nagyon szerencsésnek mondható, utólag kiváló döntésnek bizonyult, hiszen a menetközben kialakult pandémia okán később már nem lett volna lehetőség a teljes adatfelvételre, ami jelentősen limitálta volna a kutatás eredményeit. A kutatás aktív előkészítése, a kapcsolatfelvétel a részt vevő intézményekkel már 2019 tavaszán elkezdődött. A workshop vizsgálata, az adatgyűjtés egy résztvevő megfigyelésen keresztül valósult meg, ahol a kutatást végző személy, és a workshop trénere ugyanaz a személy.

A résztvevő megfigyelés a kvalitatív kutatások egyik legrégebben alkalmazott adatfelvételi módszere, mely tágabb értelemben kutatási stratégiaként is szolgálhat, de esetemben adatgyüjtési módszerként jelenik meg (Schleicher, 2007). Alkalmazása akkor igazán informatív, ha az emberek viselkedésére vagyunk kíváncsiak egy adott természetes környezetben, a saját közegükben. A közöttük lévő interakciók kereszttüzében van jelen a kutató. A résztvevő megfigyelés során a megfigyelő belép a vizsgálni kívánt világ keretrendszerébe, részvétele a vizsgált keretben, a nézőpont megváltozása (a megfigyeltek szemszögéből tekint) lehetővé teszi a szubjektivitás redukálását (Kapitány \& Kapitány, 2002). 
A résztvevő megfigyelés lényegét Malinowski (1972) munkái foglalják össze, az antropológiai kutatásokból eredeztethető: a kutatónak, megfigyelőnek mindent le kell jegyzetelnie, még az akkor, abban a pillanatban nem lényegesnek tünő momentumokat is, a viselkedések pontos megfigyelése sem elhanyagolható. Törekedni kell a befogadásra a közösség által, irányított kérdésekkel biztosítani kell azt, hogy a kutatott téma középpontba kerüljön, de mindezt befolyásolás nélkül kell megvalósítani (Kapitány \& Kapitány, 2002). A résztvevő megfigyelés klasszikusan, az antropológusok által megfigyelt idegen kultúrák esetében nagyon hosszú terepen töltött idöt követel meg, akár éveket. Mióta a szervezetkutatásokban is elkezdték használni, azóta rövidült ez az idö. Ide tartozik az általam is alkalmazott iskolai osztály megfigyelése, azzal az aktív tevékenységgel kiegészítve, hogy itt a workshop megvalósítása közben került megfigyelésre a közösség, ahol a kutató és a workshop vezetője ugyanaz a személy.

Terepkutatóként fontos a kutatói identitás meghatározása, mely nagy hatással lehet az adatgyűjtésre. A résztvevő, mint megfigyelő, van jelen saját kutatásomban. A diákok tudnak a kutatási folyamatról, hiszen ez az az irány, mellyel etikai oldalról is a leginkább azonosulni lehet (Schleicher, 2007). Ha nem is teljes aktivitással, de a workshopban a kutató részt vesz, hiszen a tréner személyét is ő tölti be, a nyitó előadást is ő tartja. Ez növeli ugyan a szubjektivitás faktorát, de a befogadást nagy mértékben elősegíti. A validitási kockázat csökkentése érdekében a workshopról kép -, és hangfelvétel készült, így ellenőrizhető és finomítható a kutató által készített jegyzet és a kutatói reflexió, a megfigyelés pontosítható. Tovább segíti a kutatás valid eredményeit, hogy több alkalommal vett részt második kutató is a workshopokon, aki kizárólag megfigyelő szerepben volt jelen. Az általa készített jegyzetek kettős ellenőrzést tettek lehetővé.

A szervezeten belüli résztvevő megfigyelés során jellemző ez a kettős szerepfelfogás, mely a saját kutatásban is helyet kap. A workshop során a munkában részt vevő személy, és a megfigyelő szerep konstans változása jellemző. Adott egy prezentáció, amit a kutató, mint aktív résztvevő megtart, majd, ha úgy ítéli, akkor megfigyelő szerepre vált, a lényeg, hogy a kutatás szempontjából előnyös lehet a szerepváltás. Egy prezentáció esetében például rögzítheti, hogy az ott elhangzottakat hogyan építi be a csoport a munkájába (Oborni, 2017). 
A résztvevő megfigyelés során alkalmazott megfigyelési szempontok a következőképpen alakultak:

(1): A workshopot indító prezentációval kapcsolatban a diákok figyelmének rögzítése (hallgatás, kérdezés, jegyzetelés, beszélgetés megléte és intenzitása)

(2): Az elhangzott kérdések mennyisége és jellege

(3): A diákok önálló feladatmegoldási folyamatának megfigyelése: szerepek, kommunikáció, fordulópontok, passzív szereplők

(4): A diákok magatartása az egyéni feladat időtartama alatt

(5): Az önálló feladatmegoldás folyamata, lépései, szerepek, kommunikáció

(6): A feladat során kialakult konfliktusok száma, befolyása a munkára, a konfliktus rendezésének menete

(7): A feladat során azonosítható nehézségek, melyek nem vezettek konfliktushoz, hanem megoldásra kerültek.

(8): A megoldáshoz vezető út mérföldkövei, a diákok eredményhez füződő kapcsolata

(9): A létrehozott eredmény/produktum elemzése

A megfigyelési szempontok formálódása, fejlődése volt tapasztalható a kutatás időbeni elöre haladtával. Minden egyes workshopot követően a kapott kész válaszok beépítésre kerültek a következő foglalkozás menetébe, a fö kutatási irány vonalától nem eltérve, azt kiegészítendő jelleggel, tehát úgy történt meg, hogy az összehasonlíthatóság lehetősége megmaradt.

Bár az alkalmazott kutatási stratégia nem definiálható szüken értelmezett akciókutatásként, ez az a kvalitatív stratégiai megközelítés, mely iránymutatást jelentett a résztvevő megfigyelés során alkalmazott kutatói szerep kialakításában, így fontosnak tartottam rövid jellemzését, és az inspirációt jelentő legfontosabbnak vélt sarokkövek definiálását. Míg a hagyományos kutatási módszertanok esetében a fókuszban álló szervezet passzív, addig a kutató az akciókutatás során dinamikus ismeretet sajátít el, aktív kölcsönhatásba léphet a vizsgált szervezettel (Grasselli, 2009). A beavatkozás szembesítheti a kutatót a valósággal, ami nem mindig, illetve nem pontosan úgy tükrözi a szakirodalomban foglaltakat, ahogy az várható, így menetközben formálódhat a kutatási kérdés is.

Az akciókutatás, azon belül is a részvételi akciókutatás jelentette az iránymutatást, ahol a közösség, a vizsgált szervezet jelentősége felértékelődik, ahol a kutató tevékenyen integrálódik a kutatási folyamatba, nemcsak a megfigyelö, hanem tervezö, elemzö szerephez jut. 
Az akciókutatás sokkal inkább jellemezhető tudományos megközelítésként, mint módszerként (Grasselli, 2009) Az akciókutatás definíciójának ismertetését egy alternatív paradigma nézőpontjából végzem: Reason és Bradbury meghatározása, akik a „részvételi kutatás” és az „,akciókutatás” fogalmakat azonos értelemben, gyüjtőfogalomként határozzák meg: „,..olyan demokratikus, részvételen alapuló folyamat, amelynek célja az emberek és az emberiség javát szolgáló gyakorlati tudás létrehozása... és amely egyesiti magában a cselekvést és a reflexiót, az elméletet és a gyakorlatot, célja az emberek számára jelentöséggel bíró problémák közös megoldása, tágabb értelemben pedig az egyének és közösségeik felvirágoztatása, fejlödésének támogatása” (Reason \& Bradbury, 2001, o. 2). Ez a definíció teljes mértékben párhuzamba állítható az általam felvázolt kutatási célokkal.

Az akciókutatás kapcsán a másik fontos iránymutatást Lewin (1946) funkcionális fejlesztésre irányuló megközelítése jelentette, ahol az eredmények mérhetővé válnak, és a kutatás mind gyakorlati, mind teoretikus nézőpontból értéket teremt (Kaukko \& Fertig, 2016). A lépések a következőképpen definiálhatók:

1) diagnosztizálás

2) tervezés

3) az első etap megindítása

4) a tervek alkalmazása

5) megfigyelés

6) az új szakasz megtervezése az előző eredményeinek elemzése alapján, a megfigyelés eredményeinek beépítésével (Vámos, 2013).

Az akciókutatásnak számtalan variációja létezik, bizonyosan az egyik leginkább gyakorlati eredményre és tudásra fókuszáló módszertan, mely az elméleti tudáson túl a gyakorlatban bekövetkező változást is szeretne felmutatni. Célja egy olyan tudás létrehozása, mely a mindennapi gyakorlatban támogatja az embereket (Csillag, 2016). A pedagógiai gyakorlat akciókutatása adott oktatási tevékenység/eszköz célját és az ehhez képest realizálódó eredményt hasonlítja és elemzi. Az akciókutatás a pedagógiában azt jelenti, hogy mindennapi dolgokat integrálunk az oktatási gyakorlatba, ahol azt kibontjuk, és megvizsgáljuk a jelentőségét. Sajátossága, hogy nemcsak a folyamat kimenete kerül a vizsgálat fókuszába, hanem önmagában a folyamat is hangsúlyossá válik. Lehetőséget teremt, hogy a diákok teljesítménye mellett maga a tanulási folyamat is kiemelt helyet kapjon a megfigyelésben, ezzel párhuzamosan nem lehet elégszer hangsúlyozni az akciókutatás közösségfejlesztő szerepét (Havas, 2004). 
Ha tudományos paradigmáról beszélünk, akkor az a kutató alapvető meggyőződéseit fókuszba helyező tudományelméleti hozzáállásán alapul. Ide tartoznak a (1) célok, melyeket a tudomány szolgál, (2) a kutatók által felhasznált eszközök és a (3) lételméleti választások (Csillag, 2016).

Csillag (2016) tanulmánya alapján a részvételi paradigma legjellemzőbb sajátosságain keresztül választ ad a társadalomtudományban fennálló hármas „képviselet, érvényesség és gyakorlat jelenlegi” kutatási krízisére (Lincoln \& Denzin, 1994, p. 28 in Csillag, 2016 ):

A kutatásban résztvevők nemcsak a kutatás alanyai, hanem kutatótársak, a kutatás eredménye közös alkotómunka eredménye

1. A kutató maga is a kutatás alanya, tudása a valós tapasztalatain alapszik, amihez persze a megfelelő kritikai szubjektivitás elengedhetetlen

2. Az elmélet és a gyakorlat integrálása egy, a gyakorlat számára is érvényes tudást hoz létre.

A részvételi akciókutatásban észrevételezik a kutatók a legteljesebb demokráciát (Lajos, 2018). Ez így ebben a formában már önmagában determinálja, hogy egy ennyire az egyenrangú szerepekre építő elméleti alap, mint a designkommunikáció miért inspirálódik az akciókutatás elméleti keretéből. Az akciókutatás meghatározásával szemben a részvételi akciókutatás a következőképpen definiálható: ,, a részvételt és a hatalmi viszonyok változását, a közösségeket érintö döntéshozatali folyamatokban való részvételt helyezi középpontjába” (Bodorkós, 2010, o. 37), valamint „a lehetöségek szerint az összes releváns szereplöt bevonja a valamilyen szempontból problémásnak itélt helyzet értékelésének folyamatába abból a célból, hogy változásokat és konkrét cselekvéseket hozzon létre” (Bodorkós, 2010, o. 37). A részvételi akciókutatás a tudományos kutatás egy sajátos megközelítése. A kutató a helyi közösség tudására épít, a közös tanulás folyamatát helyezi fókuszba, ahol ennek a tanulásnak az eredményét a csoport a saját fejlődésére, adott probléma megoldására hasznosítja. Ez a közös tanulási folyamat elvárja az akció és reflexió állandó, aktív jelenlétét. A részvételi kutatás célja a problémák mélyebb megértésén túl a társadalmi tudás megteremtése és a különböző tudástípusok (szakértői/tréneri és az osztályközösség tudása) szinergikus összekapcsolása (Pataki \& Vári, 2011).

\subsubsection{Emlékkönyv: a diákok által írt reflexiók}

A résztvevő megfigyelés (workshop) záró szakaszában kerül sor a résztvevők véleményének írásos összegzésére. Minimális iránymutatás mentén, a kutatásban 
résztvevőknek össze kell foglalniuk gondolataikat írásban egy tiszta, fehér lapra. Egy a kvalitatív megközelítésben sokszor alkalmazott metafora jelenségével élve, emlékkönyv /vendégkönyv jelleggel. Fontos, hogy saját szerepüket, jó és rossz élményeiket, javaslataikat is rögzítsék, mi az, ami tetszett nekik, és mi az, ami nem. A reflexiók során projektív technika is alkalmazásra került, a diákoknak meg kell határozni a designkommunikáció, az alkotói és tervezői szemléletre építő workshop megszemélyesítésének eredményét. Pontos külső és belső tulajdonságokkal szükséges ábrázolni, hogy milyen ember, illetve milyen állat lenne maga a workshop. A projektív technika vizualizációval is összekötésre kerül, a diákoknak le kell rajzolni a kreativitás jelenségét minden segítség vagy hozzáadott információ nélkül. Maga a diákok által írt reflexiók tartalomelemzése egy igen jelentős szerepét adja az adatgyüjtésnek, és a kutatási eredményekre meghatározó befolyást gyakorolt.

\subsection{Projektív technika alkalmazása}

Mind a mélyinterjú, mind a diákok reflexiói kapcsán alkalmazásra kerülnek projektív technikák. A projektív technikák, vagyis a közvetett, indirekt kutatási módszerek hozzásegítenek a fogyasztói attitüdök, gondolatok, érzések megértéséhez ( Steinman, 2009 in D. Horváth \& Mitev, 2015). Képesek oldani a zárkózottságot, a feszültséget, pozitívabb hozzáállást eredményeznek (Gyulavári és mtsai., 2012). A projektív technikák fontos jellemzője a strukturálatlanság, és a válaszok lehető legnagyobb fokú változatosságának biztosítása (Gordon, Pál, \& Langmaid, 1997). Marketingkutatásban történő alkalmazásuk mély és gazdag információt biztosít. A motivációk és magatartásformák, a személyiségjegyek olyan aspektusait tárja elénk, melyet egy direkt kutatási technika sajátos jellemzői okán nem tudna (D. Horváth \& Mitev, 2015). A projektív technikát a szakirodalom álcázott technikaként rögzíti. Ennek oka, hogy a kutatásban részt vevő alanyok tisztában vannak azzal, hogy ők egy kutatási folyamat részesei, de a kutatás pontos orientációja ismeretlen marad előttük. Ebből következik a projektív technika fent említett strukturálatlan jellege is. Kutatásom alanyai, a gyerekek tudják, hogy egy kutatási folyamat részesei, de arról nincs információjuk, hogy mi a vizsgálat pontos tárgya, nem tudják, hogy miért kérem a designkommunikáció workshop megszemélyesítését. Rendszerint arra ösztönözzük a kutatás alanyait a projektív technika során, hogy alkossanak valamit (Gordon és mtsai., 1997). A kutatás alanyai nincsenek tisztában azzal, hogy melyek azok a válaszok, amelyek helyesek, nem ismerik a társadalmilag elvárt, kész modulválaszokat (D. Horváth \& Mitev, 2015), ami szintén redukálhatja a kutatás limitációit . 
A kvalitatív adatgyüjtési módszer részeként kerül a projektív technika a kutatási tervbe. A projektív technika a gyerekek ösztönös reakcióját, nem tudatos, keretezett válaszait hivatott a felszínre hozni a workshop során. Kutatási célként fogalmazódik meg az ösztönös kreativitás felszínre törése, az ötletek szabad áramlása, és a flow élmény megvalósulása (Csíkszentmihályi, 2010). Ezt segíti elő az indirekt kérdések alkalmazása, ami támogatja a nagyfokú szabadság és az ösztönös kreativitásuk kibontakozását. A projektív technikák alkalmazása csoportban nehezebb, minimális fokú mélységvesztés érheti a kutatás eredményét, ám ez nem jelenti azt, hogy a projektív technikák alkalmazása csoportdinamikai megfigyelések esetén ne lehetne eredményes. Nagyon fontos, hogy a projektív technikák és kérdésfeltevés csoportos alkalmazására pontos, definiált szabályok nincsenek, ám ahhoz, hogy eredményes legyen bizonyos folyamatokat körültekintően kell kezelni (Gordon és mtsai., 1997).

Kutatásom szempontjából kiemelt szerepet kap a „nincs rossz válasz” elv. Fontos, hogy a gyerekek számára amúgy is szokatlan helyzetet ne fokozzam a csoport előtti megfelelési kényszerrel. Már a workshop kezdeti szakaszában biztosítom őket arról, hogy nincs helytelen kifejezés, nincs rossz válasz, és kérdezni szabad. Nyomatékosan kifejezésre juttatom, hogy ez egy szabad, szabályoktól mentes néhány óra, ahol minden, amit mondanak az egyaránt értékes és egyenértékü. A projektív technika csoportban történő helyes alkalmazásához hozzá tartozik, hogy a résztvevők ne érezzék magukat olyan helyzetben, ahol mindenáron a megfelelés a cél, mint például az iskola (Gordon és mtsai., 1997). Ezt nem segíti elő az iskola/osztályterem, mint helyszín. A probléma a terem átrendezésével, a kutató és résztvevők közötti barátságos, laza, tegező viszony kialakításával kerül feloldásra.

\subsection{Kódolás és elemzés}

A reflexiók és mélyinterjúk kódolása a grounded theory Strauss és Corbin által képviselt irányzatára épül (Strauss \& Corbin, 1994), amit a következőkben 3 lépcsőben ismertetek (D. Horváth \& Mitev, 2015):

1. Elsőként a nyílt kódolás folyamata zajlik, melynek során a szöveg nyitott, szabad olvasását követően viszonylag nagy mennyiségü kategória beazonosítására kerül sor. A kódolás jelen fázisa strukturálatlan. Keresem a hasonlóságokat és különbözőségeket, miközben folyamatosan kérdést teszek fel a felismert jelenségekről. Ebben a szakaszban lebontom az adatokat, címkézek és kategorizálok.

2. Az axiális kódolás szakaszában megtörténik a kategóriák összevonása. Nagyon fontos, hogy a kutató csökkentse a nyílt kódolás során azonosított, akár megszámlálhatatlan 
mennyiségü kategóriát, hogy kirajzolódjanak az azonosított témák és a minták közötti potenciális kapcsolatok. A hasonló fogalmak csoportosítása valósul meg ebben a fázisban, és a legfontosabb különbséget a nyílt kódolással szemben az jelenti, hogy itt a hangsúly a kategóriák közötti kapcsolat vizsgálatára kerül. Ez az elméletalkotás kiindulópontja.

3. Zárásként a szelektív kódolás során a kulcskategória is meghatározásra kerül, kialakul a központi dimenzió, mely aztán összevetésre kerül a résztvevő megfigyelés során zajló folyamatokkal, a megvalósult produktummal, és a mélyinterjú során a közösséggel azonosított problémákkal, az ehhez kapcsolható dimenziók feltárásával.

\subsection{Trianguláció, az érvényességi biztosíték}

A kvalitatív kutatás validitálásának, érvényességi biztosítékának leghatékonyabb eszköze a trianguláció (Sántha, 2009). A trianguláció egy, a kvalitatív vizsgálatokra kifejlesztett kritériumrendszer, mely nem hagyja figyelmen kívül a kvalitatív paradigma sajátosságait, a problémafelvetést egy másik nézőpontból közelíti meg, így biztosítja a vizsgálatok egyedi metodológiai elveit (Sántha, 2010). A kombinált módszertan szerepe felértékelődik. Ugyan a pedagógiai kutatások eredményei ritkán szolgáltathatók direkt matematikai úton, a problémák több nézőpontból történő megvilágítása közelebb vihet az eredmény valid értelmezéséhez.

A trianguláció több típusának diverz alkalmazása teheti teljessé a folyamatot. Az alkalmazott több-módszertanú kutatási stratégia során 3 különböző adatgyüjtési módszer kerül alkalmazásra, mely az azonos komponensü adatgyüjtési módszerek triangulációját eredményezi (mélyinterjú, résztvevő megfigyelés, reflexiók, illetve a hozzájuk kapcsolódó projektív technikák alkalmazása), ami a módszertani (módszeren belüli altípus) triangulációtipológiának feleltethető meg (Sántha, 2017). A módszertani trianguláció a különböző tipológiák központi koncepciója, alkalmazása esetén minél több adatgyüjtési módszert érdemes felhasználni ugyanazon probléma vizsgálatára, megválaszolására (Sántha, 2015).

A módszer mellett az adatok triangulációja is megjelenik. „Általános értelmezés szerint az adatok triangulációja eltérö időpontban és helyen, különbözö forrásból, eltérö személyektől, valamint más technikai megvalósitással gyüjtött adatokkal való munkát jelenti. Így időbeli, térbeli és személyi dimenziók különithetök el” (Sántha, 2017, o. 36). Az időbeli és térbeli dimenzió is helyet kap, hiszen összesen 24 alkalommal, 22 különböző helyszínen és időpontban valósult meg az adatfelvétel. Az adatok triangulációjának személyi komponense pedig ott realizálódik, hogy adott helyszínen különböző személyektől (pedagógusok, diákok), és az 
eltérő helyszínek (iskolák minden megyében) nem visszatérő alkalmat jelentenek, így mindig új kutatási alanyokat vizsgálok.

A személyi trianguláció jelenléte is rendkívül fontos a folyamatban. Egy ilyen intenzív, hosszú időt magába foglaló empirikus kutatás felemésztheti a kutatót, amennyiben egyedül dolgozik és egyedül elemzi az adatokat. Személyi trianguláció megvalósul, ha ugyanaz az adathalmaz, ugyanazon jelenség esetében több személy által is vizsgált, mely jelen kutatás során realizálódik, hiszen több kutatási csoport részvételi tagjaként lehetőség nyílik az ilyen jellegü közös munkára, együttmüködésre, ennek eredményeképpen az adatfelvétel során rögzített adatok több kutató által elemzésre kerülnek, keresztvalidálás történik. A pedagógiai kutatások során gyakran használt trianguláció szerves részét, központi elemét képezi az empirikus vizsgálatoknak, többek között hozzájárul a kvalitatív folyamatok szisztematikus rendezéséhez is (Sántha, 2015).

\subsection{A kutatási terv vizuális összegzése}

A kutatási terv legfontosabb lépéseinek vizuális megjelenítésére készítettem egy térképet, mely tartalmazza a fenti fejezetekben ismertetett kutatási terv legfontosabb elemeit a kutatási stratégia nézőpontjából, a központi termék viszonyában.

\section{4. ábra: A kutatási terv vizuális térképe a központi termék viszonyában}

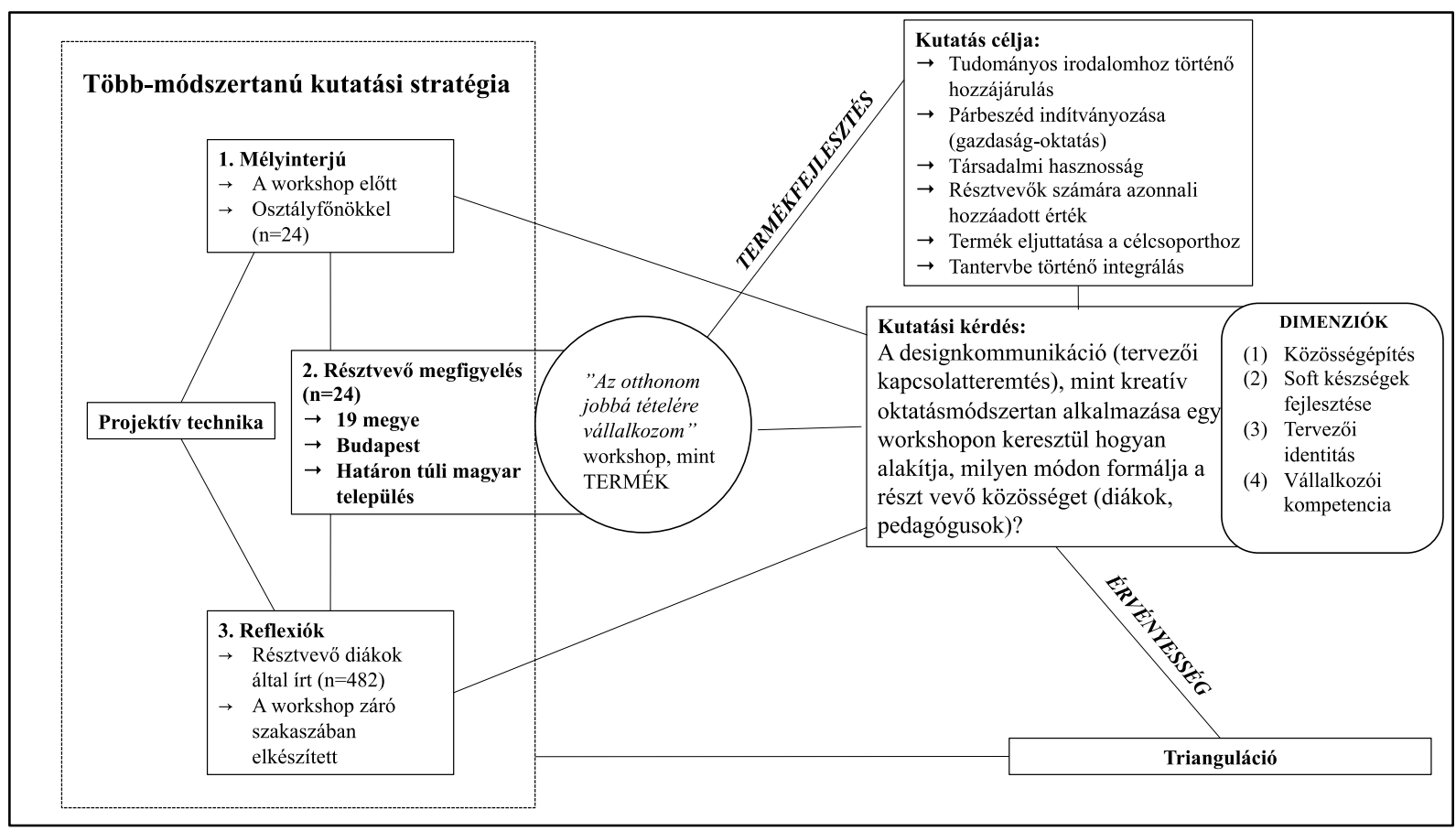

Forrás: Saját szerkesztés a kialakitott kutatási terv mentén 


\subsection{A kutató szerepe}

A kvalitatív kutatás során a kutató szerepe esszenciális. Kvalitatív kutatói szerepkört betölteni nagy felelösség, és még nagyobb, ha a kutatás alanyai kiskorúak. Amit a kvalitatív kutató keres a kutatás során az a ,szellemi megvilágosodás”, a ,jelentésalkotás”, a folyamatok és eredményeik mögöttes megértése (D. Horváth \& Mitev, 2015). A megértés elősegítésére a kvalitatív kutatások előszeretettel alkalmazzák a metaforákat. A szakirodalom, a kvalitatív kutató szereplehetőségeit is metaforákkal azonosítja, melyek közül jelen kutatás során a kutató a rendező szerepfelfogással azonosul. A kutatás maga nem más, mint egy kortárs színházi előadás, ahol a kutató választja ki a kutatás témáját, a workshop tematikáját, központi elemét, jelen esetben az otthon jobbá tételének lehetőségét. A társulat tagjaiért, vagyis a kutatásban részt vevő gyerekekért ő felel, de a színházi társulat közösen hozza létre a darabot, a workshop eredményét, a környezetük jobbá tételét segítő koncepciót (D. Horváth \& Mitev, 2015). Fontos, hogy a darab szereplői egyben a közönséget is jelentik, a szerepek váltakoznak, egymás előtt kell bizonyítaniuk. Az eredmény, a közösen létrehozott, a rendező váltakozó aktív és passzív szerepének eredményeképpen megvalósult produktum a társulat tagjaiban tovább él, azt később formálni képesek, és a lehetőség adott is a további cselekvésre. Az eredmény újragondolása és a megvalósítás felé mutató lépések megtétele a tagok által a kutatás egyik célkitűzéseként szerepel. A kutató a workshop során kettős szerepben van jelen, ahogy erre már a résztvevő megfigyelés során is kitértem. Egyrészt a workshop teljes körü lebonyolítója, másrészt résztvevő megfigyelő. Trénerként a háttérből alakítania kell a folyamatokat, mindezt úgy, hogy a gyerekek gondolatait ne befolyásolja. Szem elött kell tartani továbbá azt is, hogy a jó ötletek teret nyerjenek, és helyet kapjanak. A kutatás nézőpontjából pedig résztvevő megfigyelőként van jelen, elemzi a folyamatokat, a reakciókat, a csoportdinamika alakulását, az ötletek megvalósulását.

\subsection{A módszertan etikai vonatkozása}

A kutatás során az etikai vonatkozásnak igen jelentős szerepe van. Empirikus kutatásom résztvevő alanyai kiskorúak, így fokozottan körültekintően kell a kutatást megtervezni és lebonyolítani. Az iskola igazgatója már a megkeresés pillanatában tudja, hogy egy doktori disszertációhoz kapcsolódó kutatásban vesznek részt a gyerekek. A pedagógusok felveszik a szülőkkel a kapcsolatot, és aláírásra kerül egy, a kutatás hozzájárulásáról szóló dokumentum. 
A dokumentum létrehozása jogi szakemberrel egyeztetve került kialakításra. A diákok szülei mellett az osztályfőnök (vagy az osztályt legjobban ismerő pedagógus) is aláírja a beleegyezést az interjú elkészítésére vonatkozóan. A workshop megkezdése előtt a kutatásban részt vevő diákok számára is kommunikálásra kerül, hogy ők most egy kutatás alanyai. A kutatás során kép- és hangfelvétel a vonatkozó GDPR szabályok betartásával történik a szülök beleegyezésével, melyben rögzítésre kerül, hogy felhasználásuk csak és kizárólag az elemzést segíti, valamint a doktori munkához szorosan kapcsolható publikációkban a vizualizációt támogatja, szemléltetési eszköz. A GDPR vonatkozó rendelkezései a kutatás hozzájárulásával egy időben, egy dokumentumként került aláírásra a szülők és a pedagógusok által. A diákok által a workshop végén írt reflexió névtelen, a kutatás alanyai így nem beazonosíthatók. A csopordinamika és az egyén szerepe egyaránt fontos, ezt a névtelenség nem korlátozza. A workshopban a tanulók önkéntesen vesznek részt, ha valaki úgy dönt, hogy neki ez nem tetszik, vagy nem szeretne a kutatásban részt venni, akkor ezt mind az osztályfőnök, mind a kutató elfogadja, ezzel is biztosítva a kutatás megfelelő etikai keretét. 


\section{AZ EMPIRIKUS KUTATÁSHOZ VEZETŐ ELSŐ LÉPÉSEK ÉS EREDMÉNYEIK - AZ AKCIÓ TÁRGYA: „AZ OTTHONOM JOBBÁ TÉTELÉRE VÁLLALKOZOM” CÍMÜ WORKSHOP BEMUTATÁSA}

A sikeres termékfejlesztési folyamat érdekében, valamint a kutatási kérdés és módszertan pontos meghatározása, tesztelése okán két alkalommal valósítottam meg pilot kutatást. Ezeknek a pilot workshopoknak a célja a termék folyamatos fejlesztése, hibáinak korrigálása, valamint a kutatás módszertani alapjainak felmérése, a workshop gyakorlati tesztelése, a szükséges idő, eszközállomány ellenőrzése, valamint a felmerülő problémák kiküszöbölése volt. A két pilot workshop menetét és eredményeit ismertetem jelen fejezetben. Teszem mindezt úgy, hogy ezzel összekapcsolva magát a fejlesztett és a későbbiekben a kutatásban alkalmazott workshop pontos menetét és sajátosságait is bemutatom. A pilot workshopok teszt jellege sem a résztvevő diákoknak, sem a pedagógusoknak nem került kommunikálásra, hiszen kiemelt szerepet tulajdonítottam annak, hogy valós szituációban dolgozhassak, és a pilot jelleg ne hozzon egy komolytalan vetületet. Ez mind a kutatónak, mind a résztvevőknek fontos tényező volt. Mindkét workshop a fentiekben már részletesen ismertetett két pilléren alapszik. Egyrészt a kialakítás során a választott kreatív módszertant a designkommunikációs szemléletet jelentette, a wikinomikus együttmüködés pedig egyfajta társadalmi együttmüködés átélését biztosította.

A kiindulási pont, melyhez mindvégig tartottam magam az a soft készségek, kiemelten a kreativitás az együttmüködés és a kommunikáció fejlesztésére való törekvés, valamint egy olyan oktatási eszköz kialakítása mely viszonylag könnyedén, minimális anyagi ráfordítással beilleszthető az általános iskolák zárt, szabályokkal terhelt rendszerébe. A foglalkozás a tömeges együttmüködésen keresztül nem mellékesen a csoportkohéziót is formálni hivatott. Egy szokatlan helyzetben, szokatlan összetételben, közösen kell megoldásra jutni a diákoknak, ami egy, a komfortzónájukon túlmutató szituációba helyezi őket, mindannyian tervezőkké válnak. Az iskolában, nem, vagy alig oldanak meg csoportban feladatokat, ha erre mégis sor kerül, akkor kis csoportokban teszik ezt. Így nemcsak a szokatlan „tanóra”, a tréner személye, a feldolgozott téma, de az együttmüködés módja, az interaktív tanulás is újszerủ élmény a diákoknak.

Korábbi megfigyeléseim arra engedtek következtetni, hogy ha ez egy életszerü, a korosztály érdeklődési köréhez igazodó témán keresztül kerül megvalósításra, akkor a valós tapasztalat támogatja, erősíti a workshop sikerességét, a helyzet komolysága felelősséget 
ébreszt a résztvevőkben (Rudnák, Komor, \& Józsa, 2015). Ez volt az alapgondolat, amikor a workshop témáját az „otthonom jobbá tételére vállalkozom” tematika köré szerveztem. A saját, közvetlen környezet, az otthon, hatással van mindenkire, az általa keltett inger, befolyásolja a költözési szándékot, így a helymarketing egyre kiemeltebb szerepet kap (Marien, 2013), mindez az egy városban élő diákok és tanárok számára pedig egy közös kiindulási pont lehet. A helymarketing fogalma nincs definiálva a résztvevőknek, de a feladat arra vonatkozik, hogy ök maguk mivel tudnák vonzóbbá tenni a közvetlen környezetüket, lakóhelyüket, otthonukat. Más-más jellegű nehézségekkel, problémákkal, fejlesztendő területekkel találkoznak, de van közös nevező, amivel mindenki azonosulni képes. A téma kialakításánál szerepet kapott az a kritérium is, hogy több irányból megközelíthető legyen a problémafelvetés, mind piaci, gazdasági, mind társadalmi oldalról. A döntés, hogy az otthonuk jobbá tételét profitorientált alapokra helyezve, vagy jótékony jellegü, társadalmi kezdeményezés oldaláról közelítik meg determinálhatja a csoport vállalkozói attitüdjét is.

A pilot workshopok helyszíne Veszprém megyében, Tapolcán volt. A választás a Tapolcai Bárdos Lajos Általános Iskola Kazinczy Ferenc tagintézményére esett. A kiválasztásban meghatározó tényezőként szolgáltak a korábban rögzített kritériumok. Fontos szempont volt, hogy egy minden értelemben átlagos intézmény kerüljön kiválasztásra. Az iskola nem magánintézmény, nem egyházi vagy alapítványi támogatású oktatóközpont. 8 osztályos tanrendben tanulnak a diákok, 1-2. osztályban egy osztályfönök tanítja őket, majd 34. osztályban új pedagógus érkezik az osztály élére, és egy harmadik osztályfőnök kíséri végig az osztályokat a felső tagozatban. Az iskola egy nyugodt, kertvárosi övezetben fekszik, és jelenleg 558 tanuló látogatja.

\subsection{Az első pilot workshop}

Az első workshop 2018. november 30-án, pénteken zajlott, 13:00-kor. Egy olyan időpont választását tüztem ki célként, amikor a diákok leterheltsége lehetővé tett egy délutáni elfoglaltságot. Tanórán kívüli tanulásként megnevezett oktatási formához hasonlítható (Imre, 2018). Ez az időzítés a pilot jelleg miatt került így kialakításra, hiszen azt is célként tüztem ki, hogy megvizsgálom, hogy miképpen válik alkalmassá a foglalkozás arra, hogy a délelőtti tanrendi keretbe illeszthetővé váljon. Egy korábbi kutatásom eredményeire építve választottam ki azt a két korosztályt, akivel érdemes lehet már egy ilyen jellegü projektben együtt dolgozni (D. D. Horváth, Cosovan, Csordás, Horváth, \& Mitev, 2018). 
A kutatás során a cél annak a releváns célcsoportnak a kiválasztása volt (a vizsgált 3. 6. és 8. osztály közül), akivel a résztvevő megfigyelés megvalósítható. Az empirikus kutatás eredményeként arra a következtetésre jutottam, hogy a designkommunikáció, mint vállalkozói attitüd fejlesztésére alkalmas módszertan a vizsgált legfiatalabb korosztály eseten kevésbé alkalmas, hiszen itt nem jelenik meg olyan intenzíven az a fajta érdeklődési kör (munka, hivatás), amire egy ilyen módszertan alkalmazásakor építeni szükséges. A kutatás első fázisában egy osztály kiválasztását találtam indokoltnak, a kutatás eredményei alapján mind a vizsgált 6 . mind a vizsgált 8 . osztály további elemzése új aspektusokat nyithat a kutatásban. Az eredmények azt mutatják, hogy az érdeklődés más-más szinten realizálódik. Míg a fiatalabbaknál kevésbé konkrét, ám határozott, magabiztos tervek vannak, addig a végzős osztály tudja mi lenne a jó, tudja mi érdekeli, de a megvalósítást illetően kétségeik, félelmeik vannak, a bizonytalansági tényezők fokozottan jelentkeznek. Végül arra a döntésre jutottam a kialakított termék sajátosságait szem előtt tartva, hogy a félelmektől még mentesebb, ám kellő magabiztossággal rendelkező hatodik osztályosok alkotják majd a homogén összetételü pilot csoportot. Emellett kiválasztásra került egy heterogén csoport is, ahol hatodik és nyolcadikos diákok a pedagógusokkal együtt létrehozott pilot kutatásban vettek részt, így a résztvevő csoportok korosztályos jellegzetességei is megfigyelhetők voltak, és a jövőre nézve tanulsággal szolgáltak, formálták a kutatási tervet.

Mindezek alapján hatodik és nyolcadik osztályos diákok vettek részt az első pilot workshopon. A workshopról sem a diákok, sem a tanárok nem kaptak konkrét információt, annyit tudtak, hogy egy kreatív, közös együtt alkotásban fognak részt venni, kötelezettségek és hagyományos teljesítményértékelés nélkül. Tekintve, hogy péntek délután, a diákok szabadidejében szerveződött a projekt nem volt cél a részvétel erőltetése, kötelezővé tétele. A projekt szempontjából kiemelkedően fontos volt, hogy érdeklődő, aktívan részt vevő diákok legyenek ott, ne olyan tanulók, akik esetleg egy adott tárgyból jobb jegyet remélve jönnek el. A workshopon így 8 fö nyolcadik osztályos és 7 fö hatodik osztályos diák vett részt.

A két legnagyobb kérdést az jelentette, hogy a diákoknak külön workshopot tartsak-e, illetve a velük egy iskolában dolgozó, korábbi években, vagy jelenleg őket tanító pedagógusokat bevonjam-e a workshop folyamatába. Ha bevonom őket, akkor egy nagyon sokrétü, diverz résztvevői állománnyal valósul meg a korábbiaktól eltérően, amikor a korosztály tekintetében homogén összetételü wikinomikus együttmüködés megvalósítása történt meg a gyakorlatban (D. D. Horváth és mtsai., 2018). Végül az első pilot workshop során a korábbi tapasztalatok beépítésével, és tovább gondolásával megnéztem, hogy egy ilyen hierarchia, korosztály, életszakasz szempontjából is különböző csoport hogyan képes együtt 
interpretálni egy, a designkommunikációs szemléletre építő kreatív workshopot. Végül, a 15 diák mellé csatlakozott 7 pedagógus is. A workshop kialakítása lehetővé teszi, hogy a pedagógusok is részt vegyenek, és közösen alkossanak a diákokkal, ugyanakkor azt az alaptézist, miszerint a tervezési folyamatban mindenki egyenrangú félként vesz részt, nincsenek alá-fölérendeltségi viszonyok, a résztvevők összetétele nem befolyásolja. Ez azt jelenti, hogy eltérő korú gyerekek és tanárok együtt is részt vehetnek a folyamatban, de hierarchikus megkülönböztetés ez esetben sem áll fenn. Látható tényezőként definiálhatók azok az oktatást segítő eszközök, amiről mindenki tudja, hogy pozitív hatással volt a tanulásra, közvetlen eredménye realizálódott. Itt valójában olyan nyilvánvaló tanítás történik, melynek során a diák képes a saját maga tanárává válni egy tervezői folyamatban (V. Juhász, 2018).

\subsubsection{A megvalósitás menete}

A workshop egy osztályteremben zajlott, papír és toll kivételével gyakorlatilag nincs eszközigénye a projektmunkának. A következőkben egy ábrával illusztrálom azt a folyamatot, ami a kreatív oktatásmódszertani workshop tartalmát adja. A hozzávetőlegesen 2-3 óra időintervallumban zajló projekt több részből állt.

5. ábra: A tréning folyamatának bemutatása a résztvevői szerepek dimenziójából

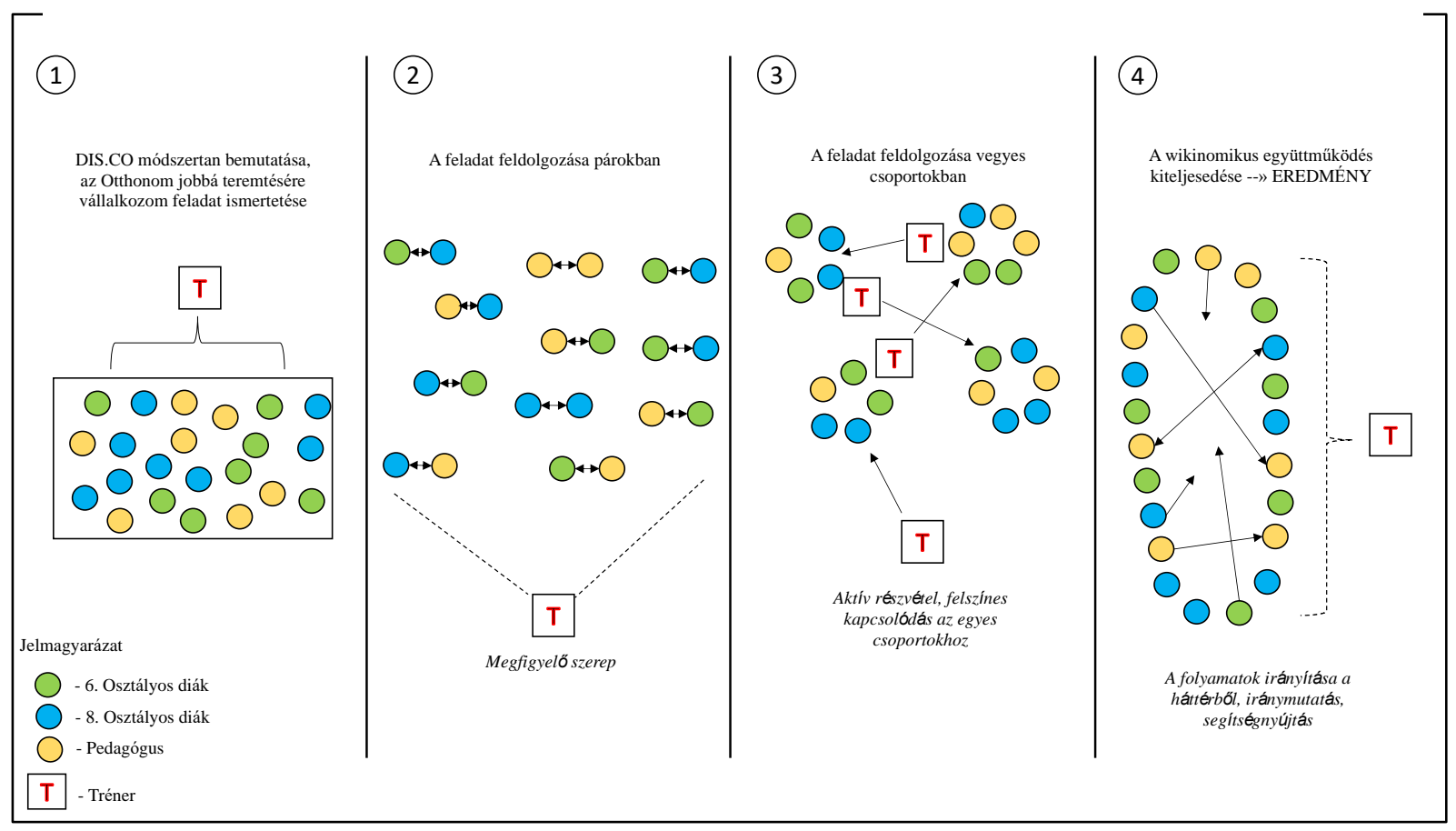

Forrás: Saját szerkesztés a megvalósult teszt workshop eredményei és folyamata alapján 
Az ábrán a tematika és a feladatok mellett a workshopot levezető tréner szerepvállalása is megjelenik. Bevonódása, feladata és felelőssége az egyes állomásokon eltérő.

1. A kiindulási pont egy prezentáció, amit a mindenkori tréner tart, amiben ismerteti az alkalmazott designkommunikáció módszertan sajátosságait, ami a workshop ideje alatt a résztvevők gondolatát meg kell, hogy határozza. A tervezői megközelítés, az egyenrangú félként való együttmüködés, a gondolat és cselekvés szabadsága a kiindulási pont, amit ez a prezentáció alapoz meg. Ekkor a trénernek van a meghatározó szerepe, az ő előadása nagyban befolyásolja a workshop kimenetelét. A hangsúly azon van, hogy ez egy, a megszokottól eltérő szituáció, ami akkor lesz sikeres, ha a szereplők képesek alkalmazkodni az egyedi helyzethez.

2. A prezentáció végén kerül elő először a konkrét tervezési feladat, miszerint kezdjenek el azon gondolkozni a résztvevők, hogy mi az, amivel ők maguk itt és most jobbá tudnák tenni a környezetüket. Elöször párban dolgoztak, és vitatták meg a feladatot néhány percben.

3. Ezt követően a véletlenszerüen beosztott csoportjaikba kerültek, ami a pilot projektben 5-6 fö együtt gondolkozását jelentette. 1-1 csoportban minden korosztály képviseltette magát. A tréner aktívan részt vesz a csoportok munkájában, de hagyja kibontakozni a csoportot, és teret ad a saját döntésnek.

4. A kis csoportokban kialakult véleményt közösen megvitatják, és az egyik csoport véleményét, vagy a közösen, az egész csoport által tovább gondolt ötletet valósággá transzformálják. A lényeg, hogy a wikinomikus együttmüködés alapján ez ne egyéni döntés, hanem egy csoportos határozat legyen. Ennél a szakasznál van az egyik legmeghatározóbb szerepe a trénernek, hogy felismerje, hogy a csoport mennyire igényli az aktív jelenlétét. Az ő felelőssége, hogy a csoportegység fennmaradjon, valamint, hogy az értékes ötletek ne szoruljanak háttérbe.

\subsubsection{A „Boldog Város” projekt}

A konkrét eredmények alapján az első teszt workshop sikeresnek tekinthető. Az 5-6 fös csoportokban létrehozott ötletek egy irányba mutattak, így a választás, és a közös gondolkodás viszonylag gördülékenyen valósult meg. A workshop eredményeként létrejött a „Boldog város” projekt, melynek alakuló ülését megtartotta a csoport. Cél, hogy életet hozzanak a városba saját, 
a város lakói által kezdeményezett ötleteken és eseményeken keresztül. Hosszú távú projektként pedig az infrastruktúra, vásárlási és szórakozási lehetőségek kiszélesítését tüzték ki célul, pontosan megtervezett lépések sorozataként. Az otthon jobbá tételét város szintjén értelmezték, és egy korábbi kutatásunk eredményét alátámasztotta az, hogy minden csapatötlet, és a végső projekt is egy vállalkozói kedvet/attitüdöt feltételez (D. D. Horváth és mtsai., 2018). Annak bizonyítása, hogy a vállalkozói kedv előtérbe kerülése, a bátor hozzáállás is a workshop eredményeként határozható meg még további kutatásokat követel, de mindenképpen foglalkozni fogok a kérdéssel a későbbiekben is. A város szintű értelmezéshez az hozzá tartozik, hogy a kezdeményezéseket, és az alapító csapatot a saját iskolájukhoz kapcsolták, ami a közvetlen környezetükhöz egy erős kötődést és lojalitást feltételez.

A projekt eredményének mérése a kutatási koncepció során ismertetett három szinten történt. Egyrészt a résztvevői megfigyelés a workshop során, másrészt az ennek egy hozadékaként megvalósult output, valamint a hallgatói és tanári vélemények, amit két módon mértem. Egyrészt reflexiók megírását kértem a résztvevőktől, másrészt a pedagógusokkal készítettem mélyinterjút. Az eredmények, valamint a visszajelzések rendkívül tanulságosak egy termékfejlesztési folyamatban.

\subsubsection{A reflexiók és a mélyinterjúk elemzésének összefoglalása}

A reflexiók elemzése, a tartalomelemzés egy fontos tanulság megfogalmazásával kezdődik. A korábbi designkommunikációt vizsgáló kutatások során az egyetemi hallgatók a tantárgy teljesítésének részeként, a projektet egy két oldalas reflexióban értékelték, és adtak visszajelzést a saját, csoportban betöltött szerepükröl, véleményükröl a kurzussal kapcsolatban, relációba helyezve a megszokott kurzusaikkal, az átélt/át nem élt flow élményröl, a tanulságokról, és elégedettségükről, a módszertan vélt/valós hatékonyságáról (A. R. Cosovan és mtsai., 2018). Az egyetemi hallgatók az évek során alkalmazkodtak a számonkérés egyes formáihoz, az önálló tudásuk prezentálásának teret adó online platformokhoz. A vizsgált általános iskolában bár informatika óra van, a gyerekek gördülékenyen kezelik az okostelefonjukat, mégis az e-mail, mint kommunikációs forma, egyáltalán nem kézenfekvő a számukra. A projekt végén kért reflexiók hiányosan érkeztek meg, és csak néhány tanulótól. A Z generáció kapcsán ez a fajta önállóság, a feladat következmény nélküli nem teljesítése nem támogatta a vélemények megérkezését. A szabadság fontos nekik, de a szabályok betartása nem minden esetben élvez számukra prioritást, amiről a kutatás kapcsán én is bizonyosságot szereztem (Lukovics, Udvari, \& Nádas, 2017). Hiába többszöri kérés mind a tréner, később 
pedig a pedagógusok nyomása, a beadandók retorzió híján elmaradtak. Ez egy fontos tapasztalat volt, így a tréning következő teszt állomásai során a workshop negyedik, záró szakaszába beépítettem 15-20 percet, amikor a friss élményiket a résztvevők a helyszínen, befolyásoltság nélkül le tudják írni, megkönnyítve és teljesebbé téve ezzel a visszajelzések, önreflexiók elemzését, és eredményeinek a termékfejlesztésbe történő beépítését, a módszer validálhatóságának biztosítását a trianguláció eszközével.

A hiányosan beérkezett reflexiók eredményei ennek ellenére egy irányba mutattak, a közösség véleménye egy határozott kép kirajzolódását tárta fel a kutató felé. A pilot projekt eredményeit a reflexiók tekintetében a pedagógusok nézőpontjából ismertetem, a tőlük kapott összegzések elemzése valósult meg. Ennek oka, hogy nagyon fontos szerepük volt a pedagógus reflexiókon keresztül feltárt eredményeknek a termékfejlesztési folyamatban.

A reflexiók elemzése meghatározott dimenziók mentén történt. A dimenziók a reflexiók elemzése során azonosított kulcsszavak csoportosítása mentén jöttek létre. A kialakított dimenziók: (1) csoportkohéziós erő, (2) heterogén csoportösszetétel, (3) érzelmi bevonódás a projektbe, (4) a módszertan megértése, valamint (5) a kreativitás felszínre kerülése. Ez összhangban van azokkal a dimenziókkal, amit a workshop kialakítása során szem előtt tartottam.

A csoportalakítási stratégiát a pedagógusok pozitívan értékelték, csoportkohéziós erőt (1) tulajdonítottak neki, úgy vélték a véletlenszerüség és a heterogenitás segítette elö, hogy „gyorsan, oldott, jó hangulatú kommunikációba fogtak a csoporttagok. A csoportok jól meghatározott cél érdekében hatékonyan terveztek, beszélgettek.” (pedagógus, 1)

Szintén egyetértés volt abban, hogy jó hangulatú, aktív csoportok születtek, a csoporttagok (a csoport méretétől függetlenül) motiválták egymást. A heterogén csoportösszetétel (2) kapcsán is egy irányba mutattak a vélemények: „Nagyon jó ötlet volt az egyenrangúak vagyunk "mozgalom" meghirdetése. A gyerekek nagyon élvezték, hogy az iskolában tanitó felnöttekkel partneri kapcsolatban lehettek. Ha csak kis idöre is. " (pedagógus, 2)

A designkommunikáció szemléletének átadása kulcsjelentőségü, hiszen a projektmunka alapját a módszer esszenciájának megértése (4) és alkalmazása jelenti. Ezt alátámasztotta a tréningen tapasztalt résztvevői visszajelzéseken túl a pedagógusok oldaláról érkező reflexiók is: „Remek minőségü, oldott hangulatú, érthetö elöadás során ismerhettük meg a design kommunikáció projekt lényegét. Részletes ismertetöt kaptunk a fejlesztésbe integrált kommunikáció fogalmáról. ” (pedagógus, 1) 
Az érzelmi bevonódást (3) mi sem bizonyítja jobban, hogy a résztvevők az idő lejárta után is a helyszínen maradtak, és folytatták a beszélgetést, tervezést. Gondolatokat indított el bennük, „a gyerekek egyszerü, tiszta látásmódja igy teret kapott, különleges megérzéseik kibontakozhattak” (pedagógus, 1), de az is az erős érzelmi bevonódást (3) igazolja, hogy „,nem féltek, öszintén kifejezni félelmeiket sem” (pedagógus, 3). Egy másik résztvevő pedagógus reflexiójában az érzelmi bevonódás pedig a következőképpen érhető tetten: ,a diákok és a tanárok közösen lelkesedtek be a "Boldog város" projekt megvalósitásának ötletén." (pedagógus, 2)

A kreativitás felszínre kerülése sem megkérdőjelezhető (5), aminek kapcsán az „ösztönös kreativitás" többször is megfogalmazódott a véleményekben, ami arra utal, hogy a módszer segítségével a résztvevők nem tudatos döntésének eredményeként realizálódnak kreatív ötletek, hanem ösztönösen érhetők tetten. Ezt a válaszadó pedagógusok hiányként definiálják a fennálló iskolai keretrendszerben. A hiány ellenére egy kiemelten fontos tényezőként tartják számon a „, sikeres önmegvalósitás” (pedagógus, 2) és a „pozitív énkép” (pedagógus, 3) kialakulásában.

\subsubsection{Tanári/pedagógus szerepek értelmezése - tanári mélyinterjúk}

A reflexiók mellett fontos visszajelzési pont volt a pedagógusokkal készített mélyinterjú. A pilot projekt során a mélyinterjúk a workshopot követően valósultak meg. A kutatásom során már a sorrendet megcseréltem, hiszen megváltozott a vizsgált csoport összetétele, amihez igazodni kellett az adatfelvételi módszerek kapcsán is. Ennek oka, hogy a megváltozott összetétel már más fókuszt kívánt a mélyinterjúk során annak érdekében, hogy a kutatási kérdésre minél pontosabb választ kaphassak majd. Kiemelt jelentőséget tulajdonítottam a saját szerepnek. A tanárok egyértelműen a segítést, bátorítást, a gyerekek aktivizációját tartották a szemük előtt, és ezt fogalmazták meg, mint saját szerepük. Ez arra utal, hogy a tanár-diák viszony teljes megszüntetése nem valósult meg, a felnőttek érezték, hogy mi a cél, és elérését szerepük tudatos formálásával segítették: „a saját szerepemet úgy próbáltam ott elhelyezni, hogy a gyerekek meg tudják mutatni, és kibontakoztatni a kreativitásukat, és legyen elég bátorságuk ahhoz, hogy ugyanolyan szerepet vállaljanak ebben a kommunikációban, mint a felnöttek." (pedagógus, 1)

A konkrétumok szintjén a pedagógusokat arra kértem, hogy fogalmazzák meg a workshop kapcsán a legfontosabb 3 pozitív és 3 negatív tényezőt. A pozitívumok között szerepelt a folyamat véletlenszerü jellege (csoportalakítás-csoportkohéziós erő), valamint az általánosságból a konkrétumig vezető út, az impulzív hozzáállás, az együtt gondolkozás. 
A workshop és a mélyinterjúk között eltelt néhány hét, így a pozitívumok között egy tapasztalt eredmény is helyet kapott, miszerint azok a diákok, akik részt vettek a tréningen másképp kezdtek el viselkedni a szintén résztvevő tanárokkal. Nyíltabb, közvetlenebb, ám a tiszteletet megtartó kapcsolattá alakult a korábbi viszony. Egy olyan kapcsolattá, ami engedi a hibázást, ami bizalmat nyújt, és ami együttmüködést tesz lehetővé, melyek mind a kreativitást támogató tényezök között kaptak helyet a szakirodalomban is (Sahlberg, 2009).

Egy dolgot tudtak a válaszadók negatívumként megfogalmazni, az a hiányérzet. A megvalósítás következő szintjének hiánya. Akarták a megvalósulást, bennük volt a tettvágy. A workshop tervezési eredményének utókövetése az ő feladatuk és felelősségük, ahogy az is, hogy a workshopon létrehozott ötlet utóélete miképpen folytatódik vagy éppen felejtődik el a mindennapi rutin részeként, elveszítve rítus jellegét.

Nagyon fontos szempont az elemzés kapcsán a kreativitás, valamint a workshop hatása a kreativitásra. Az interjú során fókuszba került a kreativitás, fogalma, jelentése a pedagógusok saját definíciója alapján a következőképpen értelmezhető: „Szabad, alkotó gondolkodás”, (pedagógus, 1), „Alkotás”, (pedagógus, 4), „A kreativitás alatt én azt értem, hogy az ember képes legyen néha a saját korlátait is átlépve olyan megoldásokban gondolkodni, ami újszerüségébe, más megközelitésbe helyezve a dolgokat, valahogy az adott területen valamifajta áttörést okozhat, vagy egy új szint képviselhet, vagy egy új színt jelenit meg. ” (pedagógus, 5) A designkommunikáció, mint fejlesztésbe, fejlődésbe integrált kommunikáció központi tézise alapján mindenki tervező (Papanek, 1971), a képesség az alkotásra minden emberben adott. A mélyinterjú során kapott válaszok is alátámasztják ezt, a válaszadó pedagógusok az alkotást a kreativitással állították párhuzamba. A létrehozott workshop is az alkotásra épít, így a válaszok arra engednek következtetni, hogy a tervezői folyamat, az általuk létrehozott produktum megalkotása hatással lehet a kreativitásra.

Az interjúk során a válaszadóktól a designkommunikáció workshop megszemélyesítését is kértem, mint a mélyinterjú részeként alkalmazott projektív technika. A feladatuk egy részletes leírás elkészítése volt, miszerint, ha a designkommunikáció workshop ember lenne, akkor milyen külső és belső személyiségjegyekkel rendelkezne. Az eredmény alapján - mely eredmény a válaszok alapján konzekvensen azonos irányba mutat -, egy igen különleges, kreatív, bölcs, lendületes személyként jelenik meg, aki kiegyensúlyozott és laza, a probléma megoldásához határozottan közelít. Mindez alátámasztja, hogy a designkommunikáció módszertan az általam kijelölt értékeket ébreszti a pedagógusokban. Megértették, a designkommunikáció módszertani kereteit, ami a megszemélyesítés, mint projektív technika alkalmazása során is felszínre került. 


\subsection{A második pilot workshop}

„Az otthonom jobbá tételére vállalkozom” workshop második pilot kutatása már az első kutatás tapasztalataira, eredményeire alapozott, annak tanulságait integráltam a folyamatba, így most a különbségekre, és az eredmények ismertetésére helyezem a hangsúlyt a dolgozatban. A második pilot workshop összetétele a kor szempontjából homogénnek tekinthető, így itt ilyen tekintetben kétség vagy bizonytalanság, az eltérő szerepekből adódó kommunikációs nehézségek nem álltak fent. A helyszínen nem módosítottam.

A workshop 2019. január 24-én került megrendezésre, közel két hónappal az első pilot workshopot követően, így volt lehetőség a tanulságok beépítésére. A workshop egy csütörtöki napon zajlott, integrálva a délelőtti oktatási időszakba, három iskolai óra, és a hozzá kapcsolódó szünetek összevonásával, ami hozzávetőlegesen 2,5 óra időintervallumot jelentett. Ez ideális hossz egy workshop számára, ennél tovább már nehezen képesek figyelni a diákok. Ezt bizonyítja az is, hogy a figyelem tartóssága (az aktív figyelem időtartama) életkoronként változik, de a 30 percet még 14 éves kor fölött sem haladja meg. A számunkra kiemelt korosztály esetében (10-12 éves kor) ez 25 perc körüli időintervallumra tehető (Torda, 2000). Egy hatodik osztályos csoport, 16 fö jelentette a kutatás alanyait, akik mind egy osztályba járnak. Az osztályfőnökkel történt mélyinterjú során kiderült, hogy egy tehetséges, értelmes, sok esetben nehezen kezelhető közösségről van szó. A közösség szó alapvetően megkérdőjelezhető, hiszen a legnagyobb problémát pont az jelenti, hogy nem tudnak a diákok együttmüködni a hétköznapi feladatokban, így ez a helyzet a workshop nézőpontjából is kihívást jelentett. A diákok nem tudtak a tréningröl, az osztályfőnök annyit jelzett nekik előtte egy nappal, hogy ezen a napon lesz valami meglepetés, így a gyerekek nem tudtak rá készülni, váratlanul érintette őket az új helyzet, amibe kerültek, de ehhez nagyon könnyen és gyorsan alkalmazkodtak.

A tréning szerkezetileg 5 jól elkülöníthető részből állt össze, mely fázisokban változik a bevonódási szint, a nyíltság, és a tréner szerepe is differenciálódik. Az 1. pilot workshophoz képes két eltérés figyelhető meg. A designkommunikációt bemutató prezentációt követően itt a környezetükben fellelhető problémát önállóan, nem párban azonosították. Ez a módosítás azért történt, hogy mindenkinek már az első lépésben legyen önálló ötlete, amit meg kell formálnia, amit végig kell gondolnia, ezzel is aktivizálva az egyént a részvételre. A másik eltérés a tréning záró akkordjában valósult meg. Tanulva a hibából a diákok a reflexiót a tréning záró szakaszában írták meg a helyszínen, így biztosítva a kutatáshoz a megfelelő számú és 
minőségü visszajelzést. A következő ábrán szemléltetem a kor tekintetében homogén közegben megvalósult workshop lépéseit, majd az eredmények ismertetésére térek rá.

6. ábra: A tréning 5 lépéses folyamata a tréner és a résztvevők relációjában

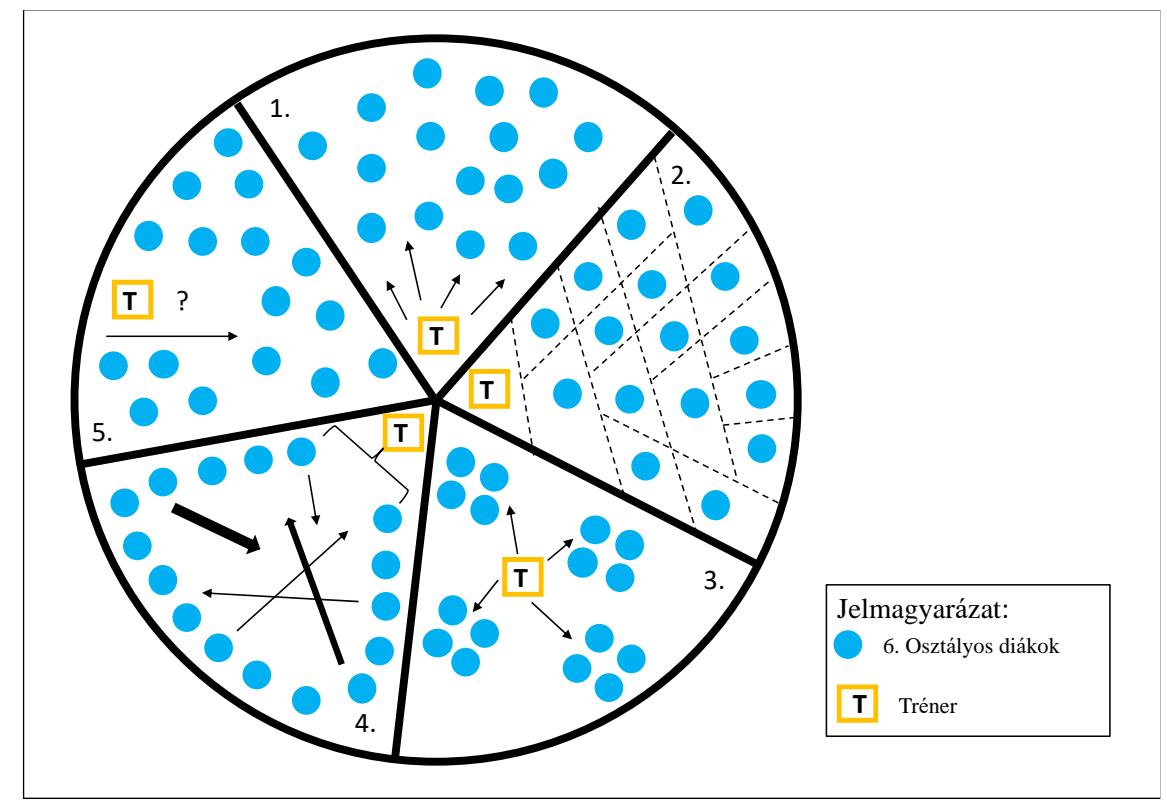

Forrás: Saját szerkesztés a megvalósitott workshop folyamata alapján

\subsubsection{A.R.T.: Aktív Rendezvény Tapolcáért}

A workshop sikerét és eredményességét a diákok, és az általuk létrehozott produktum nagyban meghatározza. A kutatásban részt vevő gyerekek egy nyári, városi fesztivál jellegü esemény koncepciójának kidolgozása mellett döntöttek. Az esemény célkitűzése, hogy minden évben egy -a leginkább fontos és sürgető-, a várost érintő probléma kerüljön megoldásra a rendezvény bevételéből. A családi rendezvény központi elemét egy vásár adja, melynek bevétele szintén hátrányos helyzetủ tapolcai lakosok segítésére, életminőségük elfogadhatóvá tételére törekszik. A vásár mellett helyet kapnak főző-és sportversenyek, kézmüves foglalkozások előadások, közösségi programok egyaránt. Az eseménynek a segítésen és a város fejlesztésén túl közösségépítő szerepet tulajdonítottak a diákok, mert úgy vélik erre minimális a lehetőség a városban. A város jobbá tételét sokkal inkább közelítették meg a diákok a társadalmi oldalról, a ,jobbá tételt” a segítésben definiálták, nem egy profitorientált termék 
tervezésében, a vállalkozói attitűd megjelenése a korosztály tekintetében homogén környezetben már egyáltalán nem volt szembetünő.

\subsubsection{Gyerekszáj - a workshop záró akkordjaként elkészült reflexiók elemzése}

A kutatás záró szakaszában, a workshop végén minden résztvevő diák kapott egy fehér papírt. A tréner kérése az volt, hogy egy emlékkönyv jelleggel mindenki írja le, hogy hogyan érezte magát, és hogyan definiálná a saját szerepét, mi az, ami tetszett neki a workshop során és mi az, ami nem. Egyéb megkötés időben, terjedelemben nem volt, szabadon írhatták le gondolataikat. 16 résztvevő, összesen 16 reflexiója került elemzésre a kutatás során. A reflexiók tanulmányozásakor Strauss és Corbin hármas kódolási logikáját alkalmaztam (Strauss \& Corbin, 1994), a kódok kialakítása során az első pilot workshop eredményei inspirációként szolgáltak.

1. A nyílt kódolási szakaszban a kategóriák létrehozásának folyamata zajlott, a reflexiók elfogulatlan olvasása, minden észrevételezett kategória rögzítése. Itt még nem strukturáltam, lényegesnek tekintettem, hogy kapjak egy átfogó képet. A kategóriákat elneveztem, a legfontosabbnak vélt elemeket kiemeltem. A kezdeti szakaszban a reflexiók átolvasása következett, és azonosításra került 8 kategória. Fontos megjegyezni, hogy itt egyrészt a gyerekek életkorából adódóan, másrészt az idő rövidsége okán nem születtek nagyon hosszú reflexiók, egy A4-es méretü írólap felét töltötték ki a diákok kézírással. A 8 kulcskategória a következőket jelentette: (1) első reakció, (2) hogyan érezte magát a workshopon, (3) designkommunikáció prezentáció jellemzése, (4) saját szerepének definiálása, (5) a feladat jellemzése, (6) a kialakult eredmény, (7) csoportmunka, (8) tréner jellemzése, (9) a sikert nehezítő tényezők.

2. Az axiális kódolás szakaszában meghatároztam az előzőekben definiált kulcskategóriák közötti kapcsolatot, feltártam a köztük lévő szinergiákat, a bennük rejlő lehetőséget. A kapcsolatok feltárását követően a szorosan egymáshoz tartozó kategóriákat összekapcsoltam. A saját szerepdefiníciót és azt, hogy hogyan érezték magukat a workshop során egy dimenzióként értelmeztem. A designkommunikáció prezentáció jellemzése és a tréner szerepe szorosan összekapcsolódik, hiszen az egyik legerősebb tréneri jelenlét a prezentáció ismertetésénél van, így ezt a két kategóriát is összevontam az axiális kódolás során. A legszorosabb kapcsolatot a kialakult eredmény, a csoportmunka és a csoportmunkát nehezítő tényezők között azonosítottam, így egyként 
kezeltem ezt a három dimenziót. Összesen három fő dimenziót határoztam meg, ami disszertációmban idézetekkel alátámasztva bemutatásra kerül.

3. A szelektív kódolás jelenti a záró szakaszt, melynek során kiválasztottam a központi jelenséget, és létrehoztam a központi elem történetét, a kulcsmotívum fókuszba helyezésével (D. Horváth \& Mitev, 2015). A szelektív kódolás folyamatában a csoportmunka és eredménye került meghatározásra, mint kulcsmotívum.

\subsubsection{Szerepdefiníció és élményfaktor}

A gyerekek saját szerepük meghatározását a workshop folyamatában, és azt, hogy hogyan érezték magukat konkrét kérdésként kapták. A reflexiók elemzése alapján egyértelműen megfigyelhető volt, hogy a két dimenzió összekapcsolódik, hiszen a workshop élmény jellegét nagyban befolyásolta saját szerepük. Szinte kivétel nélkül azt válaszolták, hogy nagyon jól/jól/nagyobb részben jól érezték magukat, ám a legtöbb esetben ehhez saját szerepüket, is társították. ,ezek voltak a legjobb órák”, , az én alapötletemre épült ez az egész, és jó érzés volt, hogy mindenkinek tetszett”, ,jól éreztem magam, csak az én véleményem nem került bele az ötletbe.”, „Minden tetszett, csak én nem nagyon tudtam benne részt venni”, „,Mondtam ötleteket, amik jók is voltak...ezek voltak a legjobb órák”.

\subsubsection{A designkommmunikáció módszerét ismertető prezentáció és a tréner szerepe}

A módszertan bemutatása prezentáció formában valósult meg, közvetlenül a workshop kezdeti szakaszában, így ez az első intenzív kapcsolat a tréner és a diákok között. A tréner a workshop folyamán végig jelen van, a módszertani bemutatást követően a háttérbe húzódik, és a koordinálásban vesz részt, valamint segíti megteremteni azokat a kereteket, melyben a csoport képes együtt dolgozni, és haladni az eredménnyel. A fentiek okán vontam össze a két dimenziót és kezeltem együtt. A diákok a workshopot tanóraként definiálták: ,, sok mindent megtanultam ezen a három órán”, de a trénert nem azonosították a tanárral, a türelmes és a kedves jelzőkkel illették: „A tréner nagyon kedves és türelmes”, ,, le a kalappal hogy ilyen nyugodt maradt” A prezentáció kontextusában megjelent az érdekes fogalma, a szerzett tudás, amivel gazdagodtak, és a tréner szerepe, aki türelemmel felvezette az előadást, majd megteremtette azt a közeget, amiben ők alkotni képesek: ,jó volt az elöadás”, „Amit a tréner mondott elöször az a beszámoló, amivel foglalkozik, azt nagyon érdekesnek találtam”, „örültem, hogy jött a tréner, 
mert legalább 3 óra alatt olyan dolgokról beszélt, amit szerintem az osztály nagy része nem is tudott”, „olyan jó dolgokkal állt nekünk elö, ami vagy amivel mi is tudunk segíteni másokon vagy a környezetünkön.”, ,nagyon megtetszett ez a dolog”. Látható, hogy a szokatlan helyzet, az újdonság pozitív irányba mozdítja el a diákok hozzáállását. A hierarchiamentes kapcsolat természetesen jobban kialakítható egy olyan személlyel szemben, akit a diákok nem a pedagógus közösség tagjaként ismernek, nincsenek berögzült szerepdefiníciók, ami fordítva is egy lehetőséget jelenthet. Amennyiben egy pedagógus tart egy ilyen jellegü workshopot a gyerekeknek ismétlődő jelleggel, úgy az befolyásolhatja a tanár és diák kapcsolatát, melynek jelentőségére a szakirodalmi elemzés során is kitértem, így ez egy nagyon fontos eredményeként értelmezhető a pilot projekt kapcsán, amit mindenképpen vizsgálni szükséges az empirikus kutatás során.

6.2.5 A csoportmunka, a közösségi alkotás nehézségei, és az eredmény, mint központi motivum

A beszámolók terjedelmének legnagyobb részét tette ki, amikor a csoportról és a közösen létrehozott eredményről nyilatkoztak a diákok, emellett nagy hangsúly került azokra a nehézségekre, próbatételekre, melyek hátráltatták az eredmény megszületését. A negatívumok összecsengtek azzal, amit az osztályfönök felvázolt az osztályról. Egy nagyon heterogén csoport, akik rendkívül nehezen müködnek közösségként. Ezt alátámasztották a reflexióban általuk definiált problémák is, miszerint: „mindig egymás szavába vágtunk”, „,mindenki egyszerre beszélt”, „,nem voltunk elég egyhangúak a döntésben”, „az osztály nagyobb része nem tudott együttmüködni”, , legkönnyebb ötleteket kitalálni volt, legnehezebb, amikor együtt kellett dolgozni”. Az eredmény, és az eredmény elérését segítő csoportmunka feloldotta, és felülírta a gyerekek által is felismert nehézségeket. Előtérbe került az, hogy ők ezt egy csapatként képesek voltak megoldani, teljesíteni, nem is akármilyen minőségben, amit ők is értékeltek, ami nekik is tetszett: „tök fura volt, hogy ezt így 16-an össze tudtuk hozni”, „,képesek vagyunk összedolgozni, csak figyelni kéne egymásra”, ,sikerült összehozni mégis valamit”, ,, egy picit megtanultunk összedolgozni”, ,jó volt, hogy csapatban kellett dolgozni”, „, közösen találtuk ki az ötleteket, mindenki beleszólhatott a dolgokba” Az eredményre büszkék voltak, sikerélményként könyvelték el, de ez a sikerélmény nem csak az eredménynek, hanem a közös, együtt alkotásnak is szólt: , létre tudtunk hozni egy rendezvényt az osztállyal és közben jól is éreztük magunkat”, ,,nagyon jó lett szerintem a végeredmény, és nem azért mert mi csináltuk, hanem tényleg”, „2 óra alatt sikerült megtervezni a mi kis rendezvényünket”. 
Kifejezetten fontos eredmény, hogy tudatosult a gyerekekben az a gondolat, hogy az eredmény nem áll meg a tervezésnél, a megvalósítás még hátra van, ennek felismerése ugyancsak az eredmény dimenziójához kapcsolódik, ami a gyerekek reflexiójában a csoportmunkával együtt jelent meg, a tervezés következő lépéseként tartják számon, amit ugyancsak együtt kell, hogy teljesítsenek: „a vásárról az a véleményem, hogy irtó jó lett, és szívesen megvalósitanám”, „,meg tudjuk valósítani, csak akarnunk kell”.

A kialakított központi jelenség négyes egysége a legmeghatározóbb idézetekkel az alábbi ábrán kerül szemléltetésre. Jól láthatóak az ábrán a kapcsolatok a dimenziók között. A felismert nehézségek ellenére a csoport képes volt csoportként müködni, és létrehozni az eredményt, amit az esemény megtervezésében rögzítettek. Valamint az eredmény indikálja a jövőbeni megvalósítás lehetőségét. Az ábrán is szemléltetésre került, amire a diákok is utaltak, miszerint, ha a nehézségeket kiküszöbölik, akkor még jobb eredmény születik, valamint a megvalósítás is reálissá válhat, ha a csoport igazán akarja. A csoportban rejlő erő, és a megvalósítás kapcsolata pedig ott jelenik meg, hogy úgy lennének képesek az esemény létrehozására, hogy közben csapatként tudnának müködni, és jól is éreznék magukat, ezzel felismerésre került a csoportban rejlő érték, és erő.

7. ábra: A központi dimenzió négyes egysége

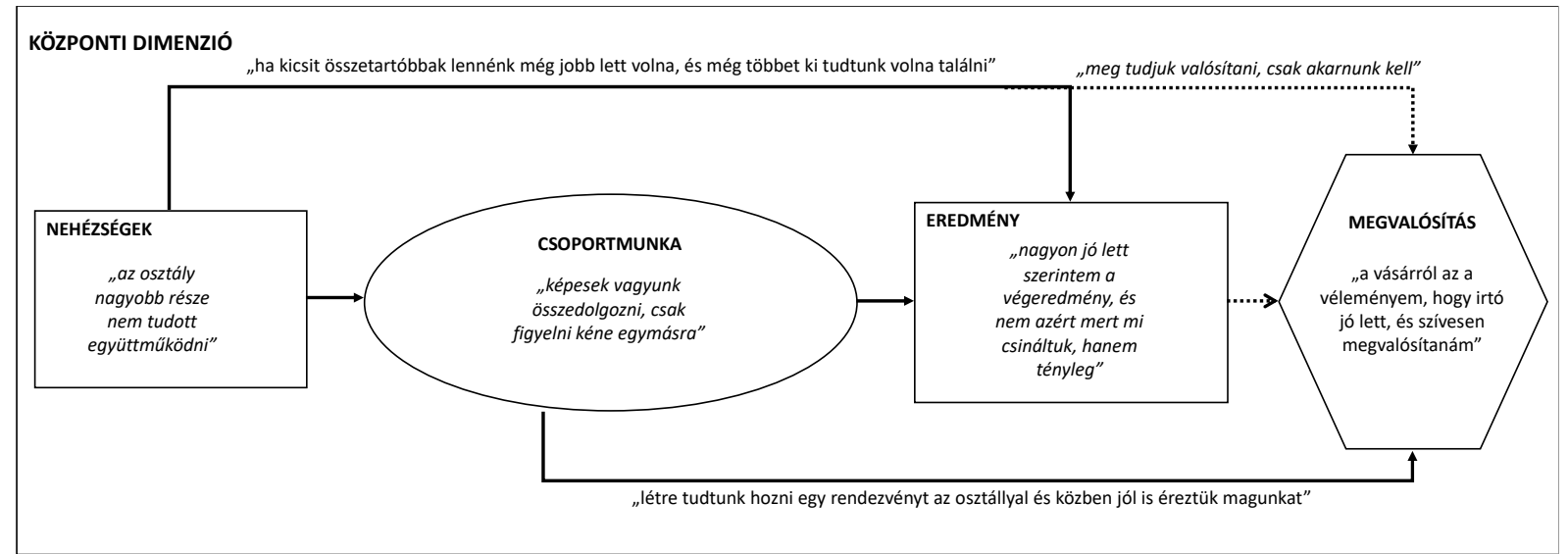

Forrás: Saját szerkesztés a workshopban részt vevö diákok reflexiói alapján 


\section{AZ ELMÉLETI MEGALAPOZÁS ÉS A KUTATÁSI TERV ÖSSZEGZÉSE}

A disszertáció szakirodalmi elemzését és a primer kutatást megalapozó fejezeteit egy strukturált, összefoglaló ábrával vizualizálom az olvasónak.

8. ábra: A dolgozat elméleti háttere és a kapcsolódó kutatási terv strukturált összefoglalója

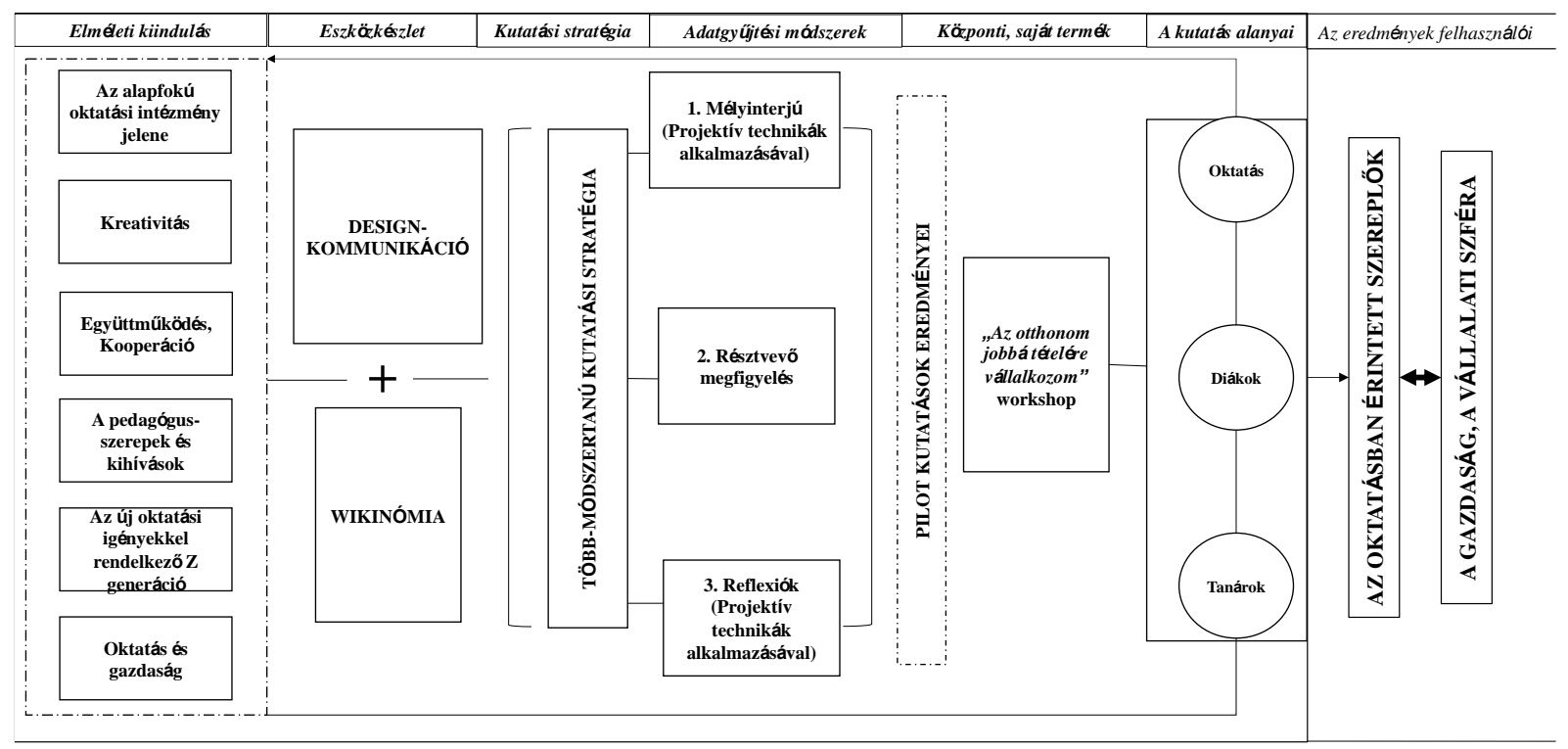

Forrás: Saját szerkesztés a disszertációban vizsgált szakirodalom és az elkészitett kutatási

terv alapján

Ahogy az ábra elméleti kiindulása is szemlélteti kezdetben részletes betekintést adtam, hogy a tudományterületeken átívelő szakirodalmi feldolgozás, a designkommunikáció módszertana és a wikinómia eszközkészlete hogyan járult hozzá egy akadémiai és társadalmi nézőpontból is aktuális probléma meghatározásához, a kutatási koncepció megtervezéséhez, a kutatási stratégiához, az adatgyüjtési módszerek kiválasztásához és a kutatási kérdés megfogalmazásához. Az ábrán csoportosítva szemléltettem azt a részletesen tanulmányozott elméleti keretet, ami a kiindulást jelentette, ami inspirációt nyújtott a témában, és rávilágított annak jelentőségére. Az „otthonom jobbá tételére vállalkozom” workshop szintén az eddigi kutatómunka és termékfejlesztés eredményeként értelmezhető, a kutatás folyamatával párhuzamosan alakult a célcsoport igényeit maximálisan szem előtt tartva.

Az oktatás és neveléstudomány, valamint annak gazdasági vonatkozása és feltételezett lenyomata, a tudományterületeken átívelő megközelítés lehetőséget teremt arra, hogy egy olyan 
témában mélyíthessem el a tudásom, mely esetében a társadalmi jelentőség, a társadalmi hasznosság, a kutatásban résztvevőknek nyújtani kívánt egyéni hozzáadott érték és/vagy tanulás valóban realizálódhat, és így értelmezhető a kutatási célok között. A kutatási terv végső fázisának megalkotásában - az irodalomfeldolgozásból merített ismeretek mellett - nagyon sokat segített a két pilot kutatás megvalósítása. A kutatások eredményei, az itt tapasztaltak beépítésre kerültek, és hozzájárultak a fejlesztéshez, akár termékfejlesztésről, akár a módszertan megfelelőségéről beszélünk. Kifejezetten sokat jelent és előremutató, hogy már az „élesben zajló” primer kutatás megkezdése előtt megtapasztaltam a vizsgált korosztály sajátosságait és a közeget, amit alkotnak, így a következő kutatási állomásokon már ezzel a tapasztalattal indultam, ami formálta a kutatói szerepfelfogást. A kvalitatív kutatás mindvégig magában hordozza a változás, a javítás, a tökéletesítés lehetőségét, ami az általam megfogalmazott kutatási kérdés megválaszolásához nagyban hozzájárult. 


\section{EMPIRIKUS KUTATÁS ÉS EREDMÉNYEI}

\subsection{A központi termék- a designkommunikáció workshop}

\subsubsection{A termék létrejöttének háttere}

A designkommunikáció elméleti alapjait bemutató fejezetben részletesen taglaltam a módszertan tervezői szemléletre építő aspektusát. A módszertan alkalmazása két szinten jelenik meg a disszertációmban. Az első szint az maga a disszertáció tervezésének a folyamata: a társadalmi hozzáadott érték, a fenntarthatóság, az interdiszciplináris szemlélet megjelenése, integrálása a dolgozatba. Mindezeken túlmenően ide tartozik, designkommunikációs módszertani sajátosságként még az a jelenség is, hogy a doktori munka eredménye nem csupán önmagában a doktori disszertáció megszületése, hanem ezzel párhuzamosan (akár a folyamaton időben és térben átívelve) egy termékfejlesztési folyamat is zajlik. A doktori munka egyik kézzelfogható eredménye tehát az „Otthonom jobbá tételére vállalkozom” designkommunikáció workshop, mint szellemi termék létrejötte.

A designkommunikáció második szintje pedig ott jelenik meg, hogy a létrehozott workshop módszertanaként alkalmazom és a kutatási kérdések fókuszába helyezem. A létrehozott terméken keresztül vizsgálom tehát a designkommunikáció módszertani sajátosságait, hozzáadott értékét a soft skillek fejlesztésében. A pilot kutatások nagy mértékben hozzájárultak a termék kialakításához, az alapok, a kiindulópontok rögzítéséhez, majd a több módszertanú kvalitatív kutatásmódszertan egyik adatfelvételi eszköze, a résztvevő megfigyelés során megtartott foglalkozások további fejlődéshez segítették a terméket, ami így kikristályosodott. Elért egy olyan szintet, mely készültségi fokon már termékként bemutatható és átadható az oktatásban leginkább érintett szereplőknek, a pedagógusoknak a mindennapi alkalmazásra. Jelen fejezet célja az empirikus kutatás bemutatásán túl, hogy pontos leírást adjon a disszertáció eredményeként megszületett termékről, annak sajátosságairól, részleteiről.

\subsubsection{A termék küldetése, víziója}

Az oktatásmódszertani termék legfontosabb missziója, létrejöttének indoka, hosszú távú törekvése az általános iskolás diákok soft készségeinek tudatos, legalább iskolai szinten összehangolt fejlesztése. A tervezői módszertanra építő foglalkozás elsősorban a kreatív, kritikai gondolkozás, az együttműködési és kommunikációs készség fejlesztésére 
törekszik az osztályszintü wikinomikus együttmüködés alkalmazásán keresztül. A létrejött termék víziója a minél szélesebb körü megismertetése a pedagógusokkal tréningeken keresztül, valamint a termék tantervbe történő integrálásának megkísérlése. Ezen túlmenően a termék víziójaként kerül meghatározásra egy kapcsolati funkció is, melyet a produktum a vállalati szféra és az oktatás között lesz képes kialakítani, fenntartani és elmélyíteni.

\subsubsection{Elsödleges és másodlagos célcsoport}

Az otthonom jobbá tételére vállalkozom designkommunikáció workshop elsődleges célcsoportjaként definiáltam az általános iskolás diákokat és öket közvetlenül tanító pedagógusaikat, különös tekintettel az iskola szervezetében az új módszerekre nyitott, kreatív szemléletű oktatókat. Az elsődleges célcsoport részeként definiálom továbbá az új módszertani eszközök alkalmazásról döntő, azt jóváhagyó iskolaigazgatókat. Másodlagos célcsoportként került meghatározásra minden oktatásban érintett szereplö, kiemelt figyelmet fordítva a munkáltatói oldalon az új munkavállalóik szükséges és elvárt készségkészletéröl döntést hozó szakértők megszólítására.

\subsubsection{Az egyedi termékígéret}

A foglalkozás egyedi termékígérete a rugalmasságán túl a sokrétü alkalmazhatóságában, személyre szabásában rejlik. A tervezői szemlélet már önmagában előfeltételezi a formálhatóságot. A kijelölt irányok adottak, azonban nincsenek szigorú keretek. A legfontosabb, hogy a workshopot alkalmazó trénerek a foglalkozás eszenciáját, a designkommunikáció workshop sajátosságait, értékrendjét megismerjék. Ez támogatja majd a felismerés megszületését, hogy az elsajátított eszközkészlet miként alakítható az adott közösségre. Kész modulválaszok helyett a probléma megoldásához vezető út megismerését kínálja a workshop.

\subsubsection{A termékleirás}

A létrehozott workshop hossza hozzávetőlegesen 3 db 45 perces tanóra óraközi szünetekkel együtt, mely időtartam lerövidíthető $2 \mathrm{db} 45$ perces tanórára. A rövidítésre abban az esetben van lehetőség, ha ugyanaz a tréner, ugyanazzal a közösséggel már legalább egy alkalommal megvalósította a foglalkozást. Fontos, hogy a workshop egyes részeinek ütemezése 
ne a megszokott tanórai időzítés mentén történjen, ezzel is kimozdítva a diákokat a berögzött rutinokból. A foglalkozás során maximum egy kifejezett szünetet érdemes tartani, de akkor is fontos egy térben tartani a diákokat, hogy a kialakuló folyamatot ne törjük meg. Természetesen, ha a gyerekeknek mosdóba kell kimenniük, akkor ezt a foglalkozás bármely időpillanatában egy jelzést követően megtehetik.

A workshopnak eszközigénye nincs, ami ugyancsak egyszerüsíti az alkalmazhatóságát. Érdemes azonban olyan teremben tartani, ahol elérhetők a diákok számára az alkotáshoz szükséges eszközök, mint például papír, íróeszköz, tábla, színes filcek, anyagok. Ezen eszközök használata nem kötelező, nem is szabad a résztvevőket ösztönözni a használatukra, de az alkotási folyamat során a vizualizációhoz segítheti a gyerekek munkáját.

A terem elrendezése kulcskérdés a workshop menetében. Olyan tér kialakítására van szükség, ahol a gyerekek tudnak könnyedén mozogni a székükkel. Biztosítani kell, hogy térben is egymás felé tudjanak fordulni, könnyen és zökkenőmentesen tudjanak a csoportok méretéhez igazodni, ne álljanak fent közöttük olyan fizikai elemek, melyek elhatárolják őket egymástól a térben.

Az otthonom jobbá tételére vállalkozom workshop az otthon, mint közös, minden résztvevő által érthető fogalom középpontba állításán keresztül zajlik. Az első workshopot mindenképpen érdemes az otthon tematika köré szervezni, ez a kiindulási pont. A foglalkozás rendszeres alkalmazása azonban lehetővé teszi más témák feldolgozását is. A workshop témája abban a tekintetben fontos, hogy mindenképpen úgy kell szerveződnie, hogy az a résztvevők számára közel egyformán ismert vagy egyformán nem ismert kell, hogy legyen. Ezt Amabile kutatási eredményeire is alapozom, aki arra világít rá, hogy kreatív megoldások nagyobb valószínüséggel születnek, ha az egyének olyan terület kapcsán alkotnak valami újat, melyet ismernek, amivel sokat foglalkoznak (Amabile, 1996). A foglalkozás során azonban nem a téma, sokkal inkább a lezajló folyamatok a meghatározóak. A tematika csupán a felszínt jelenti, a mögöttes folyamatok feltárásának mozgatórugójaként. A téma meghatározása esetén ugyancsak fontos kritériumpontként jelentkezik a nyílt kérdésfelvetés. Olyan problémára, kérdésre kell, hogy a diákok keressék a választ, amire nincs pontosan, jól körülhatárolható megoldás, így összhangban a fentiekkel a megoldás és a hozzá vezető út egyaránt fontos, legtöbbször az eredmény az maga az odavezető út lesz. A fejlődési faktorok tekintetében mindenképpen.

A workshop felépítése a következők szerint valósul meg. A program bemutatkozással indul, mind a foglalkozást tartó tréner, mind a diákok oldaláról. A bemelegítő, játékos feladat részeként megtörténhet a terem fentiekben ismertetett elrendezésének megvalósítása is. A 
workshopokhoz, tréningekhez hasonlóan klasszikusan olyan feladatokkal szükséges kezdeni, ami egy oldott hangulatot eredményez, segíti a ráhangolódást, megteremti a későbbiekben szükséges fókuszált figyelmet. Ezt követően a designkommunikáció módszertanának bemutatása következik egy interaktív előadás formájában, ami rávezeti a diákokat a kreatív, tervezői attitüd átélésére. Itt egy tudományos, akadémiai keretek szerint rögzített módszertanról van szó, így kulcsfontosságú, hogy a célcsoporthoz igazodó hangnemben és értelmezésben kerüljön megtartásra az előadás, hogy valóban alkalmazni tudják a diákok a feladat során az itt elhangzottakat. Szükséges ez ahhoz, hogy ne csak megismerés, hanem felismerés, valódi tudás elsajátítása történjen meg. Csak a prezentáció végén kerül elő a workshop konkrét, központi témája. Fontos, hogy a témáról a tréner és a diákok között nem kezdődhet el beszélgetés, itt ügyelni kell arra, hogy befolyásolás nélkül kezdhessenek gondolkozni a gyerekek. Itt kezdődik el a foglalkozás második szakasza. (1) Első lépésként a téma és a hozzá kapcsolódó kérdés (Jelen workshopsorozat esetében: Az otthonotok, környezetetek jobbá tételére vállalkoztok!) hangzik el, amit önállóan végiggondolnak a diákok. Itt mindenkinek kell, hogy egy kialakult ötlete, véleménye legyen. Az egyéni eredményeket nem osztják meg a csoporttal, hanem ha mindenki rendelkezik kialakult ötletekkel, akkor véletlenszerüen 4-5 fös csoportba kerülnek és elkezdődik a workshop második szakaszának második eleme. A fizikai tér is ehhez igazodik, az egy nagy körből több kisebb egymás felé forduló csoport kialakítása történik. (2) A kis csoportok feladata, hogy az egyéni ötletekből egy közös megoldást generáljanak. Vitassák meg, és minden csoportnak legyen egy válasza, kigondolt koncepciója arra vonatkozóan, hogy hogyan tenné jobbá otthonát, környezetét. A tréner ezalatt az idő alatt körbejár, támogatja facilitátorként a csoportok munkáját, azonban nem minősít, értékítélettől mentesen ösztönöz, de nem formálja a véleményt. Nincs jó vagy rossz és a tréner nem bírálhat. Átlendíthet a holtpontokon, de sokkal inkább kérdez, mint kijelent. Az idő beosztásáért a tréner felel, nem szabad megtörnie az adott esetben kialakult áramlatot azzal, hogy időkorlátba szorítja a diákokat. A harmadik szakasz jelenti a (3) wikinomikus együttmüködést, amikor kis csoportok egy nagy közösséggé formálódnak és feladatuk egy osztály/egész csoport szintű döntés és produktum megvalósítása, vizualizációval együtt. Ennek minőségéről, típusáról a diákok döntenek. A produktum lehet egy kiáltvány, egy rajz, egy alakuló ülés, egy vers, de az első alkalmak során sok esetben a produktum maga a közös, előremutató beszélgetés és vita lesz. Itt van a legnehezebb feladata a foglalkozást vezető trénernek, hiszen nem szabad beleszólnia a csoport munkájába. Az osztályszintü együttmüködés a leginkább idegen és szokatlan, újszerü élmény a diákoknak, gyakorlatilag az egész workshop során erre készítjük fel őket. Ez az első alkalommal idegen számukra, lehet, hogy hosszabb idő, amíg eredményre jutnak, de 
mindenképpen hagyni kell öket kibontakozni, hiszen ezek azok a legfontosabb pillérek, melyek a fejlődést hozhatják, ami alkalomról alkalomra mutathatja az előremutató változásokat. A második szakasz harmadik pillére esetén fontos, hogy az eredményüket a végén valamilyen formában be kell mutatniuk, hogy milyen konszenzusra jutottak/nem jutottak. A foglalkozás záró szakaszában történik az igazi eredmény, olyan ez picit, mint a jóga óra végén a savasana, amikor a tested összegezi és beépíti az azt megelőző 60/90 perc jótékony hatásait. Itt a diákok leírják, hogy hogy érezték magukat, mi az, ami tetszett nekik mi az, ami nem. Egy üres fehér papírt kapnak, melyet emlékkönyv jelleggel önállóan megtöltenek az élményeikkel, érzéseikkel. Ennek közvetlenül a workshop után, annak utolsó akkordjaként kell megtörténnie, ugyanabban a helyszíni környezetben. Ez az egyik legfontosabb outputja a pedagógusnak, mely megfelelő elemzése esetén egy tükröt nyújt az oktatónak, amire építve kialakítható a következő workshop.

\subsubsection{A termék elérhetösége, bevezetése az iskolai környezetbe}

A tréning elérhető és alkalmazható minden pedagógus számára, azonban annak érdekében, hogy helyesen, a céloknak megfelelően történjen a megvalósítás egy erre kijelölt folyamaton és képzésen kell részt vennie az oktatónak, mielőtt önállóan is alkalmazza a designkommunikáció módszertanára építő kreatív oktatásmódszertani eszközt. Az oktatást a Budapesti Corvinus Egyetem, Marketing-, Média- és Designkommunikáció Tanszékének erre kijelölt oktatói végzik. Az elméleti tudásátadást követően a pedagógusnak megfigyelőként részt kell vennie egy, a fentiekben részletesen ismertetett designkommunikáció workshopon. Ez történhet a saját, érintett iskolaközösségében, de vendégiskolában egyaránt. Második lépésként szerepcsere történik, a pedagógus tartja a workshopot, amit a designkommunikáció módszertan szakértői csoportja ellenőriz, felügyel. Az itt történtek alapján megvalósul egy értékelő beszélgetés és ezt követően kap jogosultságot a pedagógus a workshopok önálló tartására. Fontos, hogy innentől kezdve a designkommunikáció módszertan oktatói hálózatának részévé válik, ami folyamatos támogatást, nyomon követést és az akadémiai kutatásokba történő bevonódást is jelenti, így biztosítva az oktatásmódszertani eszköz folyamatos fejlesztését a beérkező eredmények tükrében. Így, -a tudás folyamatos megosztásával, a wikinomikus együttműködés rendszereként- biztosítom a minőségi stabilitást egy dinamikus termék állandóváltozó viszonyrendszerben. 


\subsection{A kutatás előkészítési folyamata, a gyakorlati megvalósítás}

A kutatás előkészítési szakasza a pilot workshopok eredményeinek feldolgozását és a doktori tanulmányok mérföldkövét jelentő komplex vizsga abszolválását követően kezdődött meg 2019 nyarán. Az időzítés azért is volt fontos, hogy lehetőség legyen beépíteni a komplex vizsgán kapott bírálói visszajelzéseket. A módszertani fejezetben ismertetett hólabda mintavételi mód alkalmazásának segítségével, a közösségi média szakmai-pedagógus csoportjainak bevonásával történt a kapcsolatfelvétel az érdeklödő általános iskolai intézményekkel. A minta létrejöttét támogatta, hogy több esetben a pedagógusok a felhívást látva/ a workshopról kollégától értesülve proaktív módon jelentkeztek, így a visszautasítás lelki és technikai nehézségeivel nem kellett kutatóként szembesülni és megküzdeni. A pedagógusok nyitottsága és érdeklődése a kutatás iránt már önmagában egy meghatározó pozitív visszajelzést jelentett a kutatás és a téma kapcsán, ami igencsak ösztönzőleg hatott rám.

Voltak olyan iskolák, ahol az első egyeztetés a pedagógussal történt, majd ő egyeztette házon belül saját intézménye vezetőivel, de előfordult olyan is, ahol az intézmény igazgatója volt az elsődleges kapcsolattartó és ő irányított tovább a kutatásba bevonni kívánt iskolai osztály osztályfőnökéhez. Tekintettel arra, hogy az általános iskolákban a munka augusztus második felében kezdődik a pedagógusok számára, és az órarendet, valamint a tanév pontos időbeosztását is csak ekkor ismerik meg és alakítják ki, így a nyár első felében csak az első érdeklődések, egyeztetések zajlottak, a konkrét időpontok rögzítésére 2019 augusztus második felében és 2019 szeptember elején került sor. Minden egyes érintett intézmény számára kiküldésre került egy szakmai bemutatkozó levél, melyben rögzítésre került a kutatás célja, a kutatás és kutató bemutatása, a várható feladatok, majd megkezdődött a konkrét időpont lefixálása. Ez utóbbi minden esetben telefonos egyeztetést, szóbeli beszélgetést is jelentett, melynek során egy informális ismerkedés is megtörtént a kutató és a vizsgálatban érintett pedagógus között. Fontos kapcsolatfelvételi pontot jelentett a workshopot megelőző hetekben az osztályfőnök és a résztvevő diákok szülei számára eljuttatott hozzájárulási nyilatkozat, amit aztán a helyszínen kaptam vissza aláírva, így biztosítva a módszertani fejezetben már részletesen kifejtett kutatásetikai alapokat és a kutatás igazodását a fennálló adatvédelmi szabályokhoz.

A távolságok miatt ezek többnyire egész napos elfoglaltságot jelentettek, sok esetben a nyolc órakor kezdődő tanórán már indult is a workshop. Az egyetemi oktatói elfoglaltságaimmal, a társkutatók időbeosztásával és a diákok, valamint a pedagógusok számára megfelelő időpontok - sokszor nem egyszerü - összehangolásával többnyire keddi és pénteki 
napokon valósult meg a foglalkozás, heti egy, olykor heti két alkalommal 2019 szeptember és 2020 február között. A helyszínekre autóval utaztunk, rajtam kívül minden esetben részt vett a kutatásokban egy, esetenként két társkutató is, akik a helyszíni dokumentáción túl saját reflexióval is támogatták a résztvevő megfigyelést.

A pilot kutatásokon kívül 24 alkalommal valósult meg a foglalkozáson keresztül az adatfelvétel. Ez jelentette a 19 magyarországi megyét, Budapestet és egy határon túli magyar települést. A további 3 alkalom pedig úgy alakult, hogy Bács-Kiskun megyében ragaszkodott az intézmény vezetője ahhoz, hogy mindkét osztály részese lehessen a foglalkozásnak. Veszprém megyében, Tapolcán ugyancsak két foglalkozás zajlott, egyik esetben kísérleti jelleggel, a kutatás elsődleges korosztályos fókuszától nagymértékben eltérő második osztályos csoporttal. Továbbá Borsod-Abaúj-Zemplén megyében is két workshop került megtartásra. Itt az okot az jelentette, hogy hozzávetőlegesen egy időben történt meg a kapcsolatfelvétel két oktatási intézménnyel is, és mindketten nagyon szerették volna, ha a kutatás náluk zajlik, így kiterjesztve a mintavételt mindkét helyszínre ellátogattam előtérbe helyezve a kutatás társadalmi jellegét. Érdekesség, hogy a kutatás során 7300 megtett kilómétert jelentett az, hogy minden érintett helyszínre eljussunk és több, mint 500 diák, valamint 24 pedagógus részvétele tette teljessé a több módszertanú kvalitatív kutatásom. A workshopok pontos helyszínét jelentő városokat, a résztvevő iskolákat és a megvalósítás időpontját az alábbi táblázatban foglaltam össze az olvasónak. 
3. táblázat: A megvalósult iskolai foglalkozások összegzése időpont és helyszín szerint rendezve

\begin{tabular}{|c|c|c|c|c|c|c|}
\hline & Megye & Időpont & Város & Iskola & $\begin{array}{c}\text { Diákok } \\
\text { száma }\end{array}$ & $\begin{array}{c}\text { Megtett } \\
\text { km }\end{array}$ \\
\hline 1. & Bács-Kiskun megye & 2019. szeptember 6., péntek & Kalocsa & Kalocsai Eperföldi Sportiskolai Általános Iskola & 49 & 270 \\
\hline 2. & Veszprém megye & 2019. szeptember 17., kedd & Tapolca & $\begin{array}{c}\text { Tapolcai Bárdos Lajos Általános Iskola Kazinczy Ferenc } \\
\text { Tagintézmény }\end{array}$ & 35 & 640 \\
\hline 3. & Pest megye & 2019. szeptember 20., péntek & Nagykőrös & Nagykőrösi II. Rákóczi Ferenc Általános Iskola & 15 & 180 \\
\hline 4. & Budapest & 2019. szeptember 23., hétfö & Újpest & Újpesti Bene Ferenc Általános Iskola & 16 & 0 \\
\hline 5. & Heves megye & 2019. szeptember 24., kedd & Eger & Egri Kemény Ferenc Sportiskolai Általános Iskola & 25 & 284 \\
\hline 6. & Borsod-Abaúj-Zemplén megye & 2019. október 1., kedd & Bodrogkeresztúr & Bodrogkeresztúri Eötvös József Általános Iskola & 19 & 450 \\
\hline 7. & Csongrád megye & 2019. október 8., kedd & Hódmezővásárhely & Hódmezővásárhelyi Varga Tamás Általános Iskola & 32 & 382 \\
\hline 8. & Borsod-Abaúj-Zemplén megye & 2019. október 15., kedd & Sajószentpéter & Sajószentpéteri Kossuth Lajos Általános Iskola & 23 & 400 \\
\hline 9. & Tolna megye & 2019. október 22., kedd & Tamási & Würtz Ádám Általános Iskola és Alapfokú Művészeti iskola & 20 & 285 \\
\hline 10. & Szabolcs-Szatmár-Bereg megye & 2019. november 5., kedd & Baktalórántháza & Baktalórántházi Reguly Antal Általános Iskola & 15 & 540 \\
\hline 11. & Jász-Nagykun-Szolnok megye & 2019. november 8., péntek & Besenyeszög & $\begin{array}{c}\text { Chiovini Ferenc Kolping Katolikus Általános Iskola, Alapfokú } \\
\text { Művészeti Iskola }\end{array}$ & 15 & 260 \\
\hline 12. & Békés megye & 2019. november $12 .$, kedd & Mezőberény & $\begin{array}{c}\text { Mezőberényi Általános Iskola Alapfokú Müvészeti Iskola és } \\
\text { Kollégium }\end{array}$ & 23 & 414 \\
\hline 13. & Fejér megye & 2019. november 19., kedd & Baracs & \begin{tabular}{|c|}
$\begin{array}{c}\text { Széchenyi Zsigmond Általános Iskola és Alapfokú Művészeti } \\
\text { Iskola }\end{array}$ \\
\end{tabular} & 25 & 180 \\
\hline 14. & Komárom-Esztergom megye & 2019. november 22., péntek & Dorog & $\begin{array}{c}\text { Dorogi Magyar-Angol Két Tanítási Nyelvủ és Sportiskolai } \\
\text { Általános Iskola , Zrínyi Ilona Tagintézmény }\end{array}$ & 15 & 116 \\
\hline 15. & Hajdú-Bihar megye & 2019. november 26., kedd & Debrecen & Debreceni Gönczy Pál Általános Iskola & 25 & 468 \\
\hline 16. & Györ-Moson-Sopron megye & 2019. december 3., kedd & Tápszentmiklós & Tápszentmiklósi Csokonai Vitéz Mihály Általános Iskola & 12 & 250 \\
\hline 17. & Somogy megye & 2019. december 6., péntek & Kaposvár & $\begin{array}{l}\text { Zrínyi Ilona Magyar-Angol Két Tanítási Nyelvủ Általános } \\
\text { Iskola }\end{array}$ & 22 & 380 \\
\hline 18. & Zala megye & 2019. december 13., péntek & Alsópáhok & Dr. Szántó Imre Általános Iskola és Óvoda & 24 & 380 \\
\hline 19. & Veszprém megye & 2020. január 17., péntek & Tapolca & $\begin{array}{c}\text { Tapolcai Bárdos Lajos Általános Iskola Kazinczy Ferenc } \\
\text { Tagintézmény } \\
\end{array}$ & 14 & 640 \\
\hline 20. & Baranya megye & 2020. január 21., kedd & Pécs & Pécsi Bánki Donát Utcai Általános Iskola & 20 & 414 \\
\hline 21. & Vas megye & 2020. január 23., csütörtök & Szombathely & Paragvári Utcai Általános Iskola & 23 & 440 \\
\hline 22. & Nógrád megye & 2020. február 4., kedd & Dejtár & Dejtári Mikszáth Kálmán Általános Iskola & 10 & 180 \\
\hline 23. & Szlovákia & 2020. február 7., péntek & Pelsőc & Dénes György Alapiskola Československej armády & 19 & 410 \\
\hline
\end{tabular}




\subsection{A kutatási eredmények bemutatásának menete és keretrendszere}

A kutatás összetettsége, a nagy számú minta és a diverz adatfelvételi módszerek okán a kutatás eredményei egy elöre meghatározott, helyszínenként azonos keretrendszer mentén kerülnek bemutatásra, mindvégig fókuszba helyezve a disszertáció során megválaszolni kívánt kutatási kérdést és alkérdéseket. Az elemzés első szakaszában iskolánként ismertetem az eredményeket az egyes adatfelvételi módszerek mentén szegmentálva, így külön bemutatva a pedagógus mélyinterjút, a résztvevő megfigyelést és a diákok által írt reflexiókat, és az egyes adatfelvételi módszerek összecsengő, egymásra építő eredményeire is kitérek. Azért kiemelten fontos, hogy a kódolás, az elemzés és a legfontosabb részeredmények ismertetése helyszínenként is megvalósuljon, hogy lehetővé tegye az egyes megyék közötti összehasonlíthatóságot. Ez nem elsődleges célja jelen disszertációnak, azonban, ha a termék széleskörü alkalmazását szeretnénk országszinten biztosítani a pedagógusoknak, akkor nagyon fontos visszajelzésként szolgálhat az egyes megyék, valamint régiók önálló eredménye is. Továbbá a teljes kép megismerése, a folyamatok, problémák alapos feltárása, az összefüggések meghatározása és az ebből eredeztethető tudományos hozzájárulás nem tekinthető megalapozottnak az egyes helyszínek eredményeinek ismertetése hiányában. Ezen túlmenően a helyszínenként rögzített elemzés feltárja a termék fejlődésének lépcsőit, mely a kutatási folyamat során végbement, valamint jól szemlélteti a kutatói szerep és viselkedés folyamatos alakulását, a kvalitatív kutatásmódszertan sajátosságaként.

A lokációnkénti kutatási eredmények ismertetését követően kerül sor a 24 foglalkozás együttes elemzésére, a legfontosabb kulcskategóriák rögzítésére, így az egyértelmü és átlátható struktúra támogatja majd a kutatási kérdés konzekvens megválaszolását, hozzájárul a validitáshoz. Az együttes eredmény bemutatása során kerülnek elemzésre a projektív technikák, valamint a foglalkozások során megvalósult produktumok jellegének ismertetése és az ebből levonható következtetések is helyet kapnak.

\subsubsection{A kódolás technikai folyamata}

A kódolás elméleti hátterét a módszertani fejezetben részletesen taglalt Strauss és Corbin három lépcsős kódolási struktúrája biztosította (Strauss \& Corbin, 1994). A kódolás egy összetett Excel táblázatban valósult meg, melynek első munkalapján történt a mélyinterjúk, második munkalapján pedig a diák reflexiók kódolása. Az egyes helyszínek egyedi elemzését 
az eltérő színek használata könnyítette meg. Minden helyszínen megvalósított workshop kapott egy indexet, ami egy és huszonhárom között jelentett egy számot. Összesen huszonnégy workshop valósult meg, azonban Kalocsán két foglalkozás is történt. Itt a megvalósítás dátuma, a körülmények, a lokáció és a korosztály is azonos, ezért az elemzésben egyben kezelem. Veszprém megyében, Tapolcán is két workshop zajlott, ugyanakkor eltérő időben és szignifikánsan eltérő korosztállyal (6. és 2. osztályos diákok), így ebben az esetben külön került elemzésre, ezt a kódolás egyértelmüsége miatt fontos megjegyezni. A helyszín indexe jelentette a pedagógussal készített mélyinterjú indexét is. A könnyebb összehasonlíthatósághoz és beazonosíthatósághoz járult hozzá, hogy ezekhez az indexekhez igazodott a diákok reflexióinak az indexálása is. Az első helyszínen részt vevő diákokat 1.1, 1.2, 1.3 stb., a második helyszínen részt vevő diákokat 2.1, 2.2, 2.3, stb. kódokkal láttam el, majd logikusan számoztam tovább minden helyszínt, egészen 23-ig. Ez az indexálás biztosította, hogy az anonim módon elkészített reflexiók helyszínhez kapcsolhatók legyenek, de egyedi azonosítóként is szolgáljanak, megadva a lehetőséget egy későbbi kutatásban is feldolgozható adatbázis létrejöttének.

\subsection{Helyszíni eredmények strukturált prezentálása}

\subsubsection{Bács-Kiskun megye, Kalocsa}

Mélyinterjú

A kvalitatív kutatás adatfelvételi folyamata a mélyinterjúval indult minden egyes helyszínen, melynek elsődleges célja a módszertani fejezetben megfogalmazottak szerint egy feltárás, a kapcsolatok, a fennálló problémák, valamint a kreativitáson keresztül a soft készségek jelenlétének vizsgálata. Kalocsán két pedagógussal is megtörtént a beszélgetés, az elemzés során saját szavaikat is gyakran idézem. Mindkettőjüket intenzív kapcsolat köti a vizsgált osztályhoz, Ezt a kapcsolatot a nyitottság, az „, együtt nevetünk, együtt sírunk” jelenség mozgatja. Az alapvetően optimális reláció a szülőkkel is adott: „,sikerült is jó kapcsolatot kiépíteni mind a gyerekekkel, mind a szülőkkel”. Az osztályközösséget, ha egy szóval kell meghatározni, akkor arra a „csiszolódunk” kifejezést alkalmazták. Elmondásuk szerint egy nagyon aktív közösség, akiknek a magatartásával akadnak problémák, azonban, ha „,baj van, akkor képesek az összefogásra”, mindemellett egyéni véleményüknek is teret adnak, de ez elsősorban akkor történik csak meg, ha a pedagógus kérdezi őket. A városi elitiskolákkal nem tudják felvenni a versenyt az infrastrukturális elmaradások okán, de a módszertanban próbálnak 
kompenzálni. Jellemző a csoportmunka, azonban föként strukturált, irányított keretek között, meghatározott feladatok kiosztása mellett zajlik. A kreativitás többszintü megélhetését nélkülözhetetlennek tartják, több olyan lehetőség megteremtését szorgalmazzák, melyben az egyéni ötletek meg tudnak jelenni az oktatásban, de elmondásuk szerint ehhez a pedagógusnak „,borzasztó sokat kell dolgozni”. Az interjúleirat elemzése Strauss és Corbin kódolási logikája mentén zajlott 3 szinten (D. Horváth \& Mitev, 2015), melynek eredményeként az egyéni ötlet térnyerésének fontossága került kulcskategóriaként definiálva. A jövőkép negatív, az iskolarendszer hatására az egyéni kreativitás megszünését jósolják, ugyanakkor szorgalmazzák azt a fajta kreatív látásmód integrálását a hétköznapokba, mely ezt a folyamatot megfordíthatja. A kódolás részleteit egy-egy ábrában foglaltam össze minden helyszínre vonatkozóan, majd a kutatás eredményeinek összegzése során kerül sor a 24 helyszíni kódrendszer egységesítésére, ami alapján megalapozottan megtörténhet a kutatási kérdések megválaszolása.

\section{9. ábra: Pedagógus mélyinterjú kódjegyzék - Kalocsa}

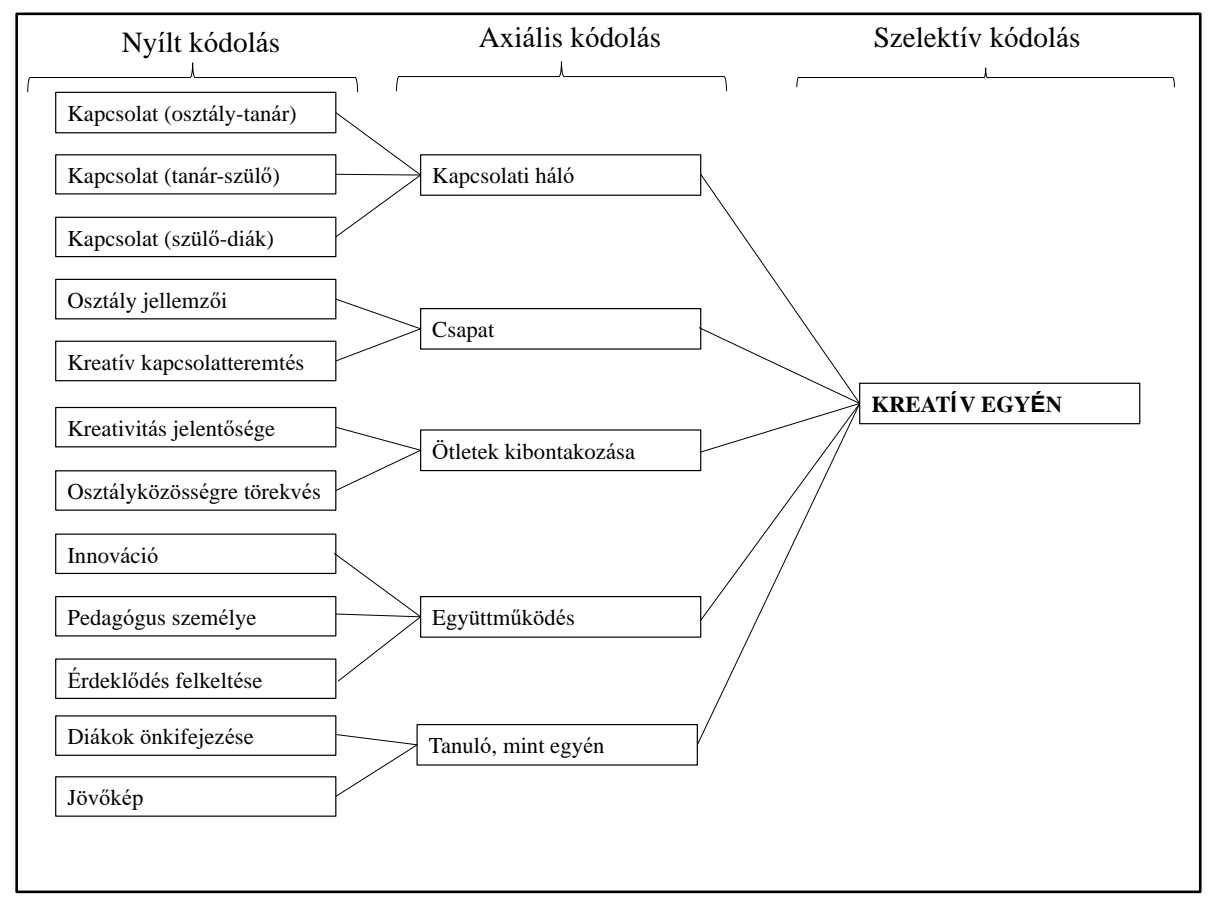

Forrás: A mélyinterjú leiratának elemzése alapján saját szerkesztés

Az interjúszövegek olvasása közben megtörtént a címkézés, majd az összefüggő elemekből létrejöttek a kategóriák a nyílt kódolás során. Az axiális kódolási szakaszban meghatároztam azt az 5 összefüggő fogalmi rendszert, mely megragadja az interjú mondanivalóját. A kulcskategória tehát a kreatív egyén fogalma, akit egyik oldalról a fennálló 
oktatási rendszer elnyom, ugyanakkor a pedagógus, ha időt és energiát fektet kihasználva az osztályközösségben rejlö egységet, akkor az együttmüködésre építő csoportmunkákon keresztül fenntarthatja és fejlesztheti az egyénben lakozó egyediséget és kreativitást.

Résztvevő megfigyelés

A résztvevő megfigyelés a módszertani fejezetben rögzített szempontok mentén valósult meg. Minden helyszínen két kutató önreflexiójából kerül feltárásra az olvasók felé a megfigyelés során tapasztalt eredmény. Az egyik reflexió az én tollamból íródott, mint a kutatást vezető és koordináló, annak aktív és passzív szereplőjeként is megjelenő mentori nézőpontból, a másik reflexió pedig egy megfigyelői szerepben jelen lévő második kutató gondolataival gazdagítja az elemzést, aki minden helyszínre elkísért. Emlékeztetőül, a megfigyelési szempontok tehát a következők: (1): prezentációhoz kapcsolódó figyelem, (2): az elhangzott kérdések mennyisége és jellege, (3): önálló feladatmegoldási folyamat, (4): magatartás, (5): önállóság, (6): konfliktushelyzetek, (7): pozitív megoldások, (8): a diákok eredményhez füződő kapcsolata, (9): A létrehozott eredmény/produktum.

Az osztály kedvesen, érdeklődően fogadott. A prezentációt figyelmesen végighallgatták (1), a kérdésekre válaszoltak, de ők maguk nem kérdeztek (2). Tátott szájjal, csendben követték az eseményeket, de a prezentáció második felében már elkezdtek kicsit zsizsegni. Ez volt az első arra utaló jel, hogy a következőkben érdemes egy kicsit lerövidíteni, kompaktabbá tenni az elméleti előadást, valamint a foglalkozás bemelegítő feladatai közé egy játékot kell illeszteni annak érdekében, hogy az oldottabb hangulat hamarabb létrejöjjön. Ugyancsak ennek a hangulatnak a kialakításához egy sokkal közelebbi kutató-diák távolság elérése a cél, hogy minél távolabb kerüljünk a megszokott tanár-diák hierarchikus viszonytól.

Az első körben, amikor egyedül végig kellett gondolniuk azokat a problémákat, melyek az otthonuk környezetében fellelhetök, látszólag gondolkoztak, de aztán kiderült, hogy a legtöbbjüknek nincs konkrét ötlete. Ez összecseng a pedagógusaik által feltárt jelenséggel is. A kiscsoportban megvalósuló munka viszonylag jól haladt, bár magatartás-béli problémák azért akadtak (4). Mindent, de tényleg mindent megkérdeztek (megfordíthatják-e a lapot, írhatnak-e tollal) és minden hozzászólás előtt jelentkeztek, az önállóság nem volt jellemző (5). Végig hozzám beszéltek és nem a társaikhoz. Az osztályközösségük valóban nem egészen ideális, bántották és csúfolták egymást több esetben. A szerveződésre, a feladatok megvalósítására képtelenek (3). 2-3 kisgyerek volt, aki végül felvállalta a vezető szerepet, és ők voltak azok, akik a legtöbbet tettek hozzá az eredményhez. A többiek elfogadták, vita nem alakult ki (6). 
Érezhető volt, hogy a workshop második felére nagyon elfáradtak. Aktívan jelen kellett lennem, ha nem mentoráltam a folyamatot, akkor elakadtunk (5). A tervezés jelentőségét, azt, hogy létrehoztak valamit, azt megértették (8). Amit végül megalkottak az egy esővíz-gyüjtő az iskolában (9), majd ebből az esővízből öntöznék az újonnan ültetett fákat. A projekt irányítói az osztályközösség tagjai, ki-ki a saját lakóterülete környezetében. Ültess! Gyüjtsd! Csináld! A workshop vége felé közeledve a magatartásuk rohamosan romlott, ahogy a figyelmük már nem volt olyan aktív, ugyanakkor egy pillanatra talán fellelhető volt a lelkesedés, egy halvány flow, hogy ezt a projektet valóban véghez vihetik. A reflexiók írása kétségkívül újra feltöltötte őket, ott mintha megint kicsit lelkesebbek lettek volna, irányítva voltak, kaptak pontosabb feladatot, ez már egy kevésbé ismeretlen terep volt számukra, még a feladatok kétes, bizonytalan megfogalmazása ellenére is.

Reflexiók elemzése

10. ábra: Diák reflexiók kódjegyzék - Kalocsa

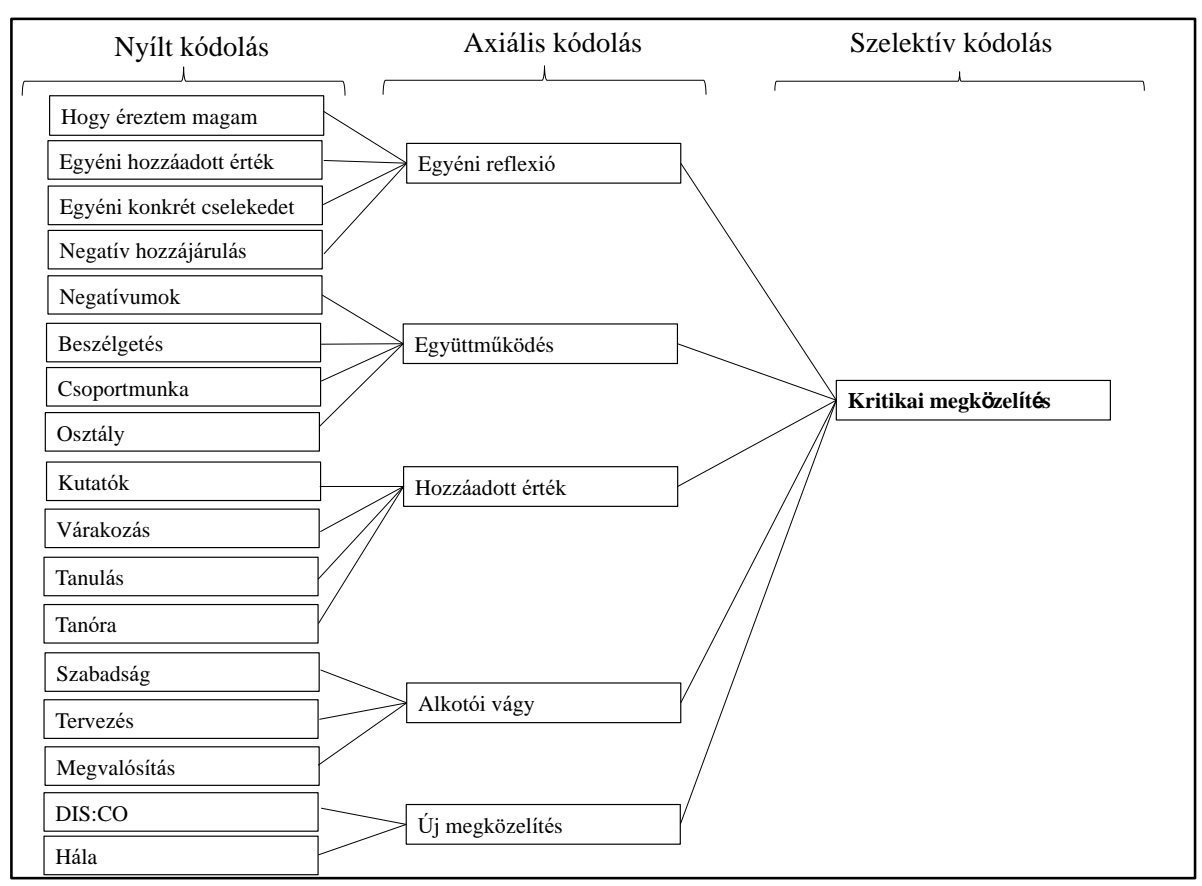

Forrás: A diák reflexiók elemzése alapján saját szerkesztés

A diák reflexiók elemzése ugyancsak a nyílt kódolási logikával indult, melynek során azonosításra kerültek a legfontosabb kategóriák. Az összefoglaló ábrán egyértelműen láthatóak 
a kódok, azonban arra érdemes rávilágítani, hogy a résztvevő diákok kritikai látásmódja nemcsak társaikkal, de magukkal szemben is jelen van. Ezt megerősítették a pedagógusok is a mélyinterjú során elmondottak által. Felismerik az együttműködést gátló tényezőket, azonban a készség, hogy ezt a felmerülő problémát feloldják maguk között, az nincs meg. A probléma felismerése tehát megtörténik, de a megoldására már nem képesek. A csoportmunkát igénylik (,kedvencem a csoportmunka volt”), ugyanígy az osztályszintü beszélgetést (,,az tetszett, hogy lehetett beszélgetni”) is, de az együttmüködéshez szükséges skillek nem teszik ezt gördülékennyé (,kár, hogy az osztály nem tud egy koponyaként gondolkozni”). A reflexiók során kiemelt helyet kapott a kutatók pozitív minősítése („A kutatók nagyon kedvesek voltak, többször is jöhetnének és többet tanulhatnánk tölük”), ami arra enged következtetni, hogy a pedagógus/mentor személye kiemelten erős befolyással bír, ami ugyancsak a tanári mélyinterjúban elhangzottakat igazolja, miszerint a pedagógus befektetett energiája nélkülözhetetlen. Az alkotói vágy fogalma is helyet kapott az axiális kódolás során, magába integrálva a korábban szabadság, tervezés és megvalósítás címkeként létrehozott elemeket. Itt arra következtethettünk a reflexiók elemzése során, hogy a diákok vágynak az alkotói szabadságra („tetszett, hogy majdnem azt tehettük, amit szeretnénk”), az önálló ötleteik megvalósítására („remélem később, ha nagyobbak leszünk, akkor megvalósithatjuk ezt a szervezetet”), arra, hogy teret kapjanak a tervezésre (,gondolkoztunk, hogy milyen legyen és végül sikerült”). A megvalósult workshopon történő részvételért hálásak, hiszen itt lehetőség nyílt a kreativitás kibontakozására, egy új és innovatív alkotói munkára és tehették ezt tanórai keretek között (,nagyon köszönöm, hogy itt lehettem”, „,nagyon jó lenne, ha lenne még több ilyen”). Kulcskategóriaként a diák, mint egyén került a fókuszba, és az a kritikai megközelítés, melyen keresztül reflektált magára, a társaira. Felismerte azt, hogy mivel hátráltatta a közös munkát ugyanakkor azt is, hogy milyen hozzáadott értékekkel gazdagodott a foglalkozás alatt. A saját, valamint az osztályközösség együttműködése során tapasztalt korlát felismerése már önmagában egy nagy lépés ahhoz, hogy a fejlődésre történő igény megszületése mellett a megoldásra is sor kerülhessen.

\subsubsection{Veszprém megye, Tapolca}

Mélyinterjú

A második helyszínt a Tapolcai Bárdos Lajos Általános Iskola Kazinczy Ferenc tagintézménye biztosította számomra. A mélyinterjú nyílt kódolása során ismét rögzítésre 
került az a kapcsolati mátrix, amiben jelen helyzetben megjelent a tanár-diák, a diák-szülő mellett az osztályfőnök és a többi kolléga között fellépő rendszer is. A pedagógus törekszik a jó kapcsolat kiépítésére, számára is fontos, hogy a közösség részének érezze magát, ugyanakkor a megszokottnak vélt hierarchikus tanár-diák kapcsolat megtartására törekszik: „úgy érzem, hogy nagyon jó valamilyen közösséghez tartozni, és nagyon jó valamilyen közösséget irtó kicsit irányítani, támogatni őket ezen az úton, iskolai tanulmányaik során”. Az osztálya irányában a kapcsolat elmélyítése érdekében igyekszik nyitni a többi pedagógus felé, így egy komplexebb színtéren keresztül kap információt a diákjairól (,Meg hát az a tapasztalat, hogy meghallgatom a kollégákat, kérem a kolléga véleményét, és próbálom őket így megismerni igazából.") A pedagógus személyiségéből adódóan fontos a bizalom („legyek az idézőjelbe tett „,társuk”, akihez bármivel fordulhatnak, bármilyen problémával jöhessenek”), a diákok pozitív visszajelzése, hogy tisztában legyen azzal, hogy személyisége a megfelelően illeszkedik a tanulók elvárásaihoz. Az osztály, mint közösség értelmezése egyelöre még nem releváns, vannak széthúzások, a lányok valamivel összetartóbbak, de osztályegységről még nem lehet beszélni.

A szabadságot a korábbi pedagógusokhoz képest másként értelmezi (,De az se jó, ha teljesen szabadra engedjük őket. Tehát a kötöttség és a szabadság közötti megfelelö arányt kellene mindenkinek megtalálni”), itt a keretek rögzítését fontosnak tartja. Egyrészt a felfokozott sebességben zajló élet követeli ezt meg („Annyira gyorsan pörög a világ itt körülöttünk, és a gyerek is annyira gyorsan pörög, mindenhez hozzá akar nyúlni, mindent el akar sajátítani, és a sok mindenből semmi sem marad meg”), másrészt az újító módszerek ismeret-átadásában sem bízik.

A megváltozott/vagy a változás szükségességét megkövetelő elvárások a pedagógusok felé kiemelt jelentőséget kapnak, mind az újítás, mind a közösség érdekében tett extra erőforrások („Tehát sokkal több programot kell szervezni ahhoz, hogy én is jobban megismerjem öket, a köztünk lévő kommunikáció, kapcsolat még jobb legyen. Ez nehézkes most. Nehezebb nekem, De ez az én dolgom"), valamint a sajátos nevelési igényű gyermekek kapcsán is. Ez utóbbinál felhívja a figyelmet a jövő pedagógusai felé támasztott követelmények újra definiálására egyaránt („Ebbe biztos, hogy az egész rendszernek hiányossága van, vagy az egész rendszer rosszul van feltöltve"). Az elmondások alapján ez az a központi kulcsmotívum, amire 
minden visszavezethető. Az interjú elemzéséhez kialakított összefoglaló kódrendszer a következő ábrában kerül bemutatásra.

11. ábra: Pedagógus mélyinterjú kódjegyzék - Tapolca

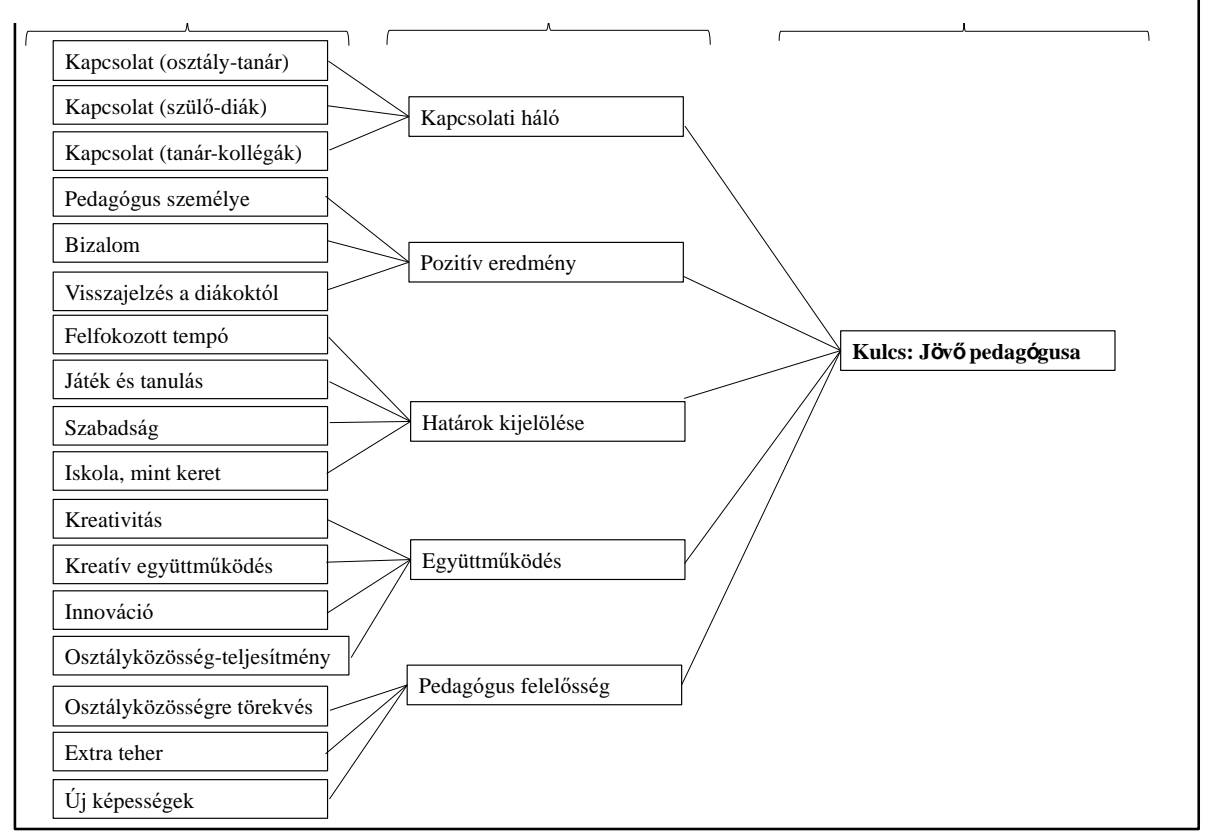

Forrás: A mélyinterjú leiratának elemzése alapján saját szerkesztés

Résztvevő megfigyelés

A Kalocsán megvalósuló foglalkozások tanulságai a tapolcai helyszínen már beépítésre is kerültek. A kedves és pozitív fogadtatást követően most először egymás felé fordulva, körbe ültünk a gyerekekkel, melynek együttmüködésre ösztönző hatása a szakirodalom által is igazolt (M. Galton \& Williamson, 2003).

A rövid bemutatkozásomat követően egy labdás játékkal kezdtünk. Az otthon fogalomra kellett asszociálni, és mindig az mondta a választ, akinek dobták a labdát. Ezt követte a prezentáció, a fogalmak tudatosabb magyarázatával. Az elején nagyon aktív volt a figyelem (1), nagyon jó, tudatos hozzászólások érkeztek (2), azonban az előadás második felére éreztem a lelkesedés csökkenését (4), a tapasztalatom alapján itt a megértés is csökken, nehezebb fogalmak kerülnek előtérbe, ami rávilágított a prezentáció kis mértékü átstrukturálásának szükségességére, több interaktivitás beépítésének jelentőségére.

Ezt követően megalakítottam véletlenszerűen a kis csoportokat, ahol az alkotás nagyon hatékonyan müködött (5), érezhető volt, hogy hasonló kiscsoportos munkákban már volt 
részük, ahogy ezt a mélyinterjú is megerősítette („Erzsi néni próbálja egy kicsi irányítással kialakitani ezeket a csoportokat, a kialakitott csoportok ma már jól müködnek.”)

A négy önálló projekt a következő volt: 1. Önellátó farm (megújuló energiaforrással), 2. Kutyamenhely (ahol a gyerekek vinnék sétáltatni a kutyát, játszanának velük) lenne orvos, nem lehetne elaltatni az állatokat, 3. Környezet szebbé tétele (kidíszíteni azt), valamint 4. Tóparton pogácsát és meleg teát osztogatnának a hajléktalanoknak. Meglepö, hogy a hatodikos gyerekek olyan kérdéseket hoznak fel, mint a hajléktalanság, a szegények megsegítése vagy az állatvédelem intézményesített rendszere. Itt tértünk át a wikinomikus együttmüködésre. Körbe ültünk (a kutató is bent ült a körben) és elkezdtek együtt ők beszélgetni. Kezdetben mindenki inkább felém beszélt, de aztán elkezdtek nyitni egymás felé (7). Csitítgatták egymást (6), majd szavaztak, végül az a döntés született, hogy a 4 projektből közösen hozzanak létre egyet. Én kutatóként ezzel párhuzamosan kiléptem a körből fizikálisan is, de továbbra is jelentkeztek a gyerekek, ha mondandójuk volt. Miután meghozták a döntést, miszerint a 4 projektből megalakul egy közös ötlet utána visszavonulót fújtak $(8,9)$. Elkezdtek nyügösködni, dekoncentráltság kezdett eluralkodni. Még nagy nehezen elneveztük az ötletet „Farm projektnek" (9), de aztán már nem nagyon lehetett őket terhelni, ami 2,5 óra után alapvetően érthető. Ennek ellenére érdekes tapasztalás, hogy míg kis csoportokban kifejezetten jól müködtek, amint nagy egészként kellett volna felelős döntéseket hozniuk, bizonytalanná váltak, a „felnőttől” várták a megoldást a legtöbb esetben. Ez is rávilágít, hogy a gyerekeket többször kellene kibillenteni a megszokott iskolai szituációkból, és hasonló feladatok, gondolatkísérletek elé állítani őket. Érdekesség, hogy az osztályfőnökük által képviselt hagyományosabb tanár-diák kapcsolati szemlélet ellenére a tegeződés felém gördülékenyen müködött, ami az újszerü, kötetlen szituációval magyarázható.

Az emlékkönyvembe (mint diák reflexió), szívesen írtak, és ez a feladat már kicsit könnyebben is ment nekik, egy sokkal inkább ismerős helyzetet jelentett, ahogy azt Kalocsán is tapasztaltam. 
Reflexiók elemzése

12. ábra: Diák reflexiók kódjegyzék - Tapolca

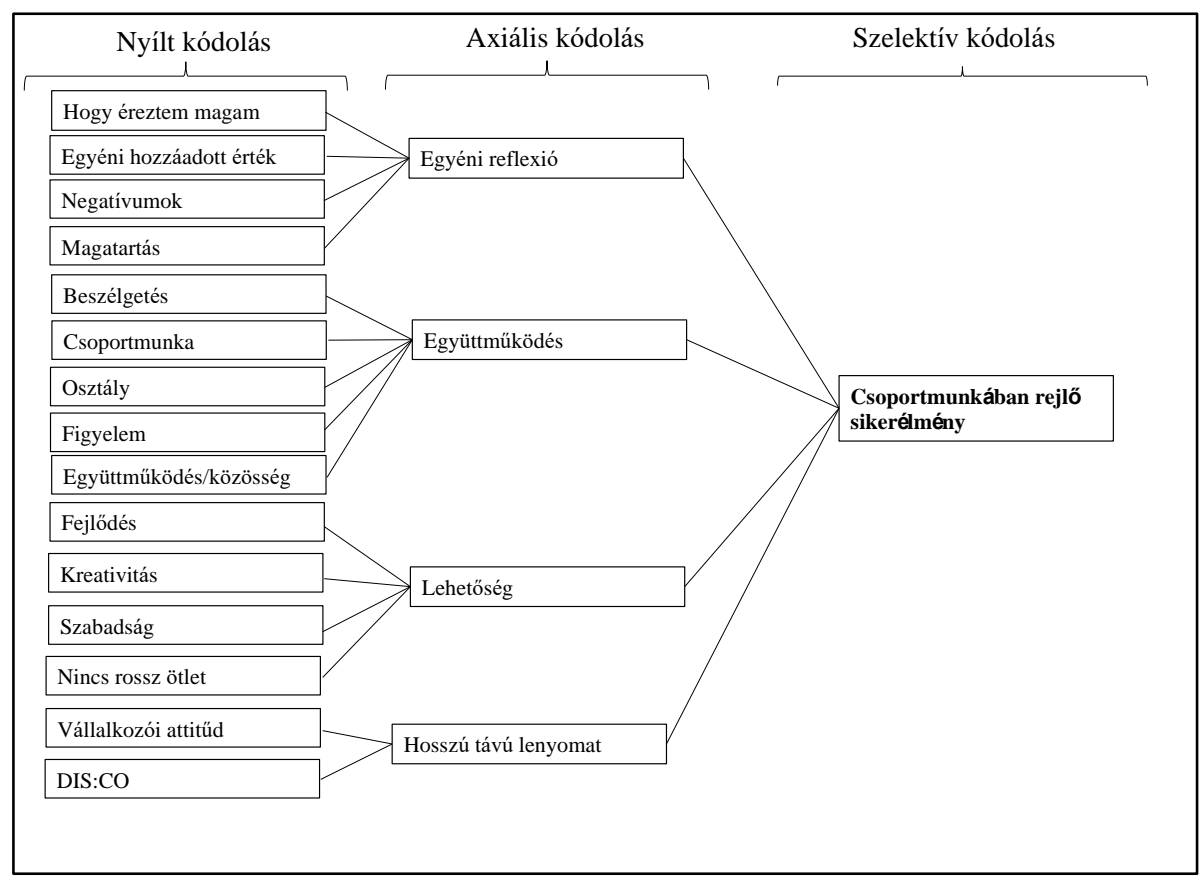

Forrás: A diák reflexiók elemzése alapján saját szerkesztés

A reflexiók kódolása majd elemzése során a leginkább szembetűnő eredmény, amit az ábrában látható összefoglaló kódjegyzékből kiemelnék, az a csoport, csoportmunka, mint egység és többé-kevésbé siker megragadása volt, történt ez azonban azzal a kritikai hozzáállással („egy kicsit rosszul, de müködtünk”), hogy a fejlődés szükségességét és lehetőségét felismerték („Az osztály egy csoportként tudott együtt dolgozni, igaz, néha hülyeségek is felmerültek”, „Nagyrészt sikerült együtt dolgoznunk, de idővel majd mehet még jobban is”). A csoportmunka kétségkívül közel áll hozzájuk (,a legjobban az tetszett amikor csoportokban kellett dolgozni”), ennek során lehetőséget kapnak a beszélgetésre, a társas interakció megteremtésére (,az tetszett amikor beszélgettünk”), ami a közösség erősödéséhez („egész jól összemüködtünk”) is vezethet hosszabb távon. Az így kiscsoportban létrehozott eredmény sikere a diákok fejében felülírta a wikinomikus együttmüködés során nyújtott kevésbé produktív kimenetet („,nagyon jól dolgoztunk együtt, mert megoldottuk a feladatot”, ,a feladatban az osztály jól müködött együtt, azért, mert sok jó ötlet és gondolat jött így létre").

A kódolás során kifejezetten érdekes információt jelentett még a workshop eredményeként a vállalkozói attitüd megjelenése, melynek során a létrehozott produktum üzleti aspektusai is visszaköszöntek a reflexiókban (,legjobban a cégalapitás tetszett”, „Az osztály 
nagy része sokat dolgozott, hogy egy jó ötletből nagyon-nagyon jó vállalkozás legyen”). A diákok gondolatai egy felismert felelősségvállalásra világítanak rá, aminek eredményeként a feladat komolysága és értéke is emelkedik a szemükben, valamint a képzelet, így a kreativitás és a flow élmény is nagyobb szerepet kaphat („Próbáltuk a szabadjára engedni képzeletünket”, „,nagyon tetszett az a sok jó ötlet, amiket a többiek mondtak és a sok öröm, amit az arcokon láttam").

\subsubsection{Pest megye, Nagykörös}

Mélyinterjú

Nagykőrösön a mélyinterjú egy kifejezetten nyitott, lelkes pedagógussal készült, aki ambiciózus és a vizsgált osztály az első, ahol osztályfönöki szerepet is ellát. Az osztály részének érzi magát, sokkal inkább valódi csapattag, mintsem vezetői szerep determinálja a közösséghez való viszonyát (,Köztük érzem jól magam, szerintem ők is ezt mondanák, közvetlen vagyok velük nagyon.”). Minden lehetőséget megragad az innovatív módszerek bevonására, ebben látja a jövőt. Az elmaradott intézményi infrastruktúra felzárkóztatása ugyan hozzájárulhat az ideális oktatási modellhez (,itt nálunk talán az iskolának az infrastruktúráján van bőven mit javitani, de a tanitás színvonala nem függ töle, Lehetne több, jobb, de mindig abból kell élni, ami van."), azonban, ha a kreatív hozzáállás adott a pedagógus oldaláról, akkor az már akár elegendő is lehet egy elöremutató oktatási rendszerhez (,Nagyon fontos, szinte az egyik legfontosabb a tanitásban. Az új igényeknek megfelelni. Talán azért fontos, mert évröl évre más igénnyel jönnek ide a diákok, és erre kreatívnak kell lenni, hogy új módszereket tudjunk bevetni és alkalmazni”.). A kulcskategóriát a fiatal pedagógusok újító, kreatív hozzáállásának („De, ha csak a meglévö módszereket akarjuk használni, ahhoz is nagyon jó a kreativitás, hogy esetleg egy új perspektivával ruházzuk fel. Mindenképpen fontos és kell használni a kreativitást.") és a hosszú évtizedek óta pályán lévő szakmailag kifogástalan tanárok tapasztalatának egységesítésében látja („De szerintem tölünk, fiataloktól is kell nekünk az a nyitottság feléjük, hogy viszont nekik tapasztalatuk rengeteg").

A kapcsolati mátrix hasonlóan írható fel itt is, általános jelenségnek tünik, hogy maga az osztályfőnök kevés időt tölt az osztályával, amit szabadidős programok szervezésével az osztályközösség erősítése érdekében próbál kompenzálni. Megjelenik egy új dimenzió és kódkategória, az egymásra figyelés a diákok között (,úgy veszem észre, hogy egy osztályfőnöki órán nagyon nehéz, hogy egymásra figyeljenek. Harc. így felsőben nem igazán érdekli öket, 
hogy mi volt a másikkal."). Az osztályközösségen a pedagógus elmondása alapján van még mit kovácsolni, és ez főleg az egymásra figyelés fejlesztésére értendő („Van még a közösségen fejleszteni való az egymással való kapcsolatokban."). Ide kapcsolódik, hogy annak ellenére, hogy igen gyakori a csoportmunka a diákok hétköznapjaiban (,Az osztályban a legtöbb kolléga csoport munkában dolgoztatta öket már alsóban is, tehát nem ismeretlen nekik.”), a véleményük kifejezése, az önkifejezés nem jellemző, ebben még sok a fejlődési potenciál (,Nem jellemző. Ez az önálló véleményalkotás... nehezen fejezik ki magukat. Az érzelmi intelligencia nehéz.”). A mélyinterjú kódrendszere a következő ábrán látható módon foglalható össze.

13. ábra: Pedagógus mélyinterjú kódjegyzék - Nagykőrös

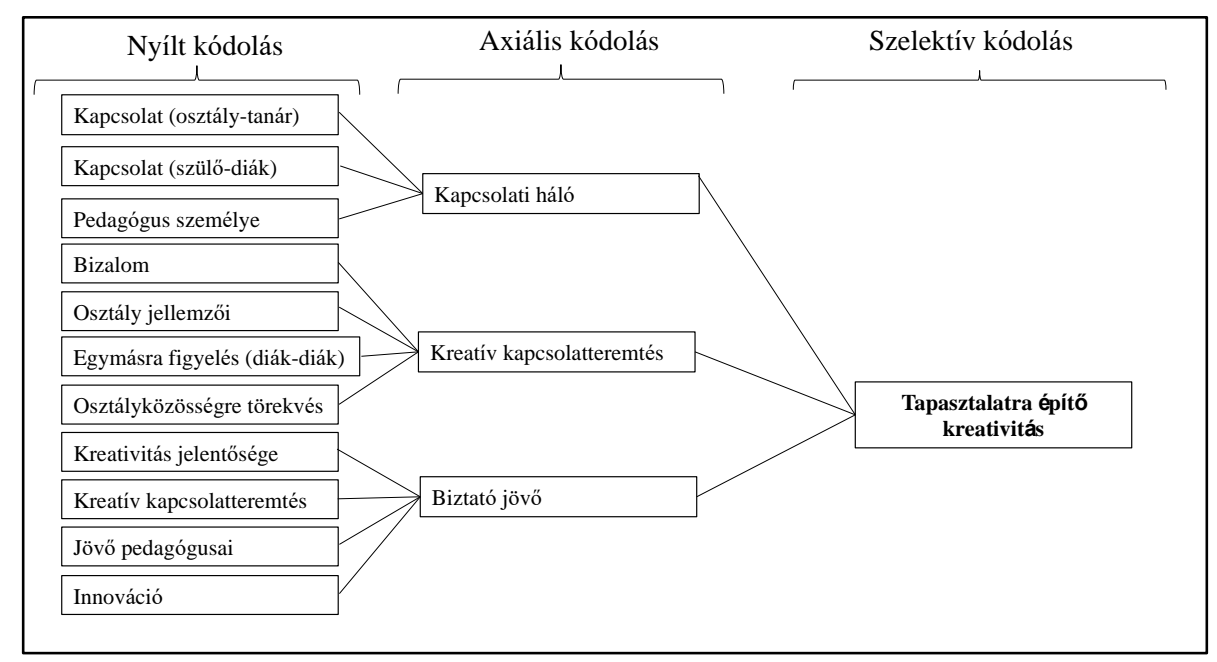

Forrás: A mélyinterjú leiratának elemzése alapján saját szerkesztés

Résztvevő megfigyelés

A nagykőrösi workshop helyszíne egy teljesen átlagos iskola, kívülről picit „lerobbant”, a pedagógus által említett felújítás valóban aktuális lenne, de egyébként tágas, világos, nagy udvar található az iskola közepén. Ez egy kevésbé jó iskolának számít Nagykőrösön belül, nem az „elitiskola”, továbbá ebben a körzetben van az állami gondozottak intézménye, így sok hátrányos helyzetü és állami gondozott kisgyerek is jár ide, az osztályon belül is vannak diákok, akikre oda kell figyelni, mert napról napra élnek.

A workshopot pontosan kezdtük, a gyerekek kedvesek voltak és befogadók. Mónika az osztályfőnök érdeklődő volt, ő végig részt vett a workshopon megfigyelőként, ami bizonyította 
innovatív szellemiségét, nyitottságát az új módszerek iránt. Már rögtön az egy üzenetet jelzett, mikor a labdás feladatnál a gyerekek neki is kidobták a körből a labdát, mindenképpen a Mónika által is elmondottakat erősítette meg, hogy szeretik, elfogadják, befogadták őt, tényleg a közösség része.

A prezentáció alatt figyeltek (1), a többi osztályhoz képest aktívak voltak, hozzászóltak (2). A kiscsoportokban történő dolgozás során születtek ötletek, de viszonylag nehezen. A gyerekek jól elvoltak, csendben beszélgettek egymással, de jellemző volt, hogy eltértek a feladattól (4), kevésbé jelent meg az említett gyakorlat és rutin a csoportmunkák kapcsán.

A közös feladat elött a korábbi foglalkozások példájából tanulva tartottam egy nagyon rövid szünetet, majd ezt követően ültünk egy nagy körbe, hogy ök közösen megoldják a feladatot, elkezdődött a wikinomikus együttmüködés. Ahogy kiléptem a körből a gyerekek összezártak. Most először határozottan elmondható, hogy kialakultak a csoportszerepek. Volt egy moderátor, aki mindent megtett annak érdekében, hogy dülőre jussanak. Nem volt akadályozó ember, mindenki együttmüködött. Egyszer sem voltak tiszteletlenek a másikkal, nem nevették ki egymást és a legtöbb alkalommal meg is hallgatták egymás ötletét. A feladatot teljesen önállóan sikerült teljesíteniük (3), amely során mindig volt egy-egy személy, aki magára vállalta a vezető, irányító szerepét. Az összhang végig kísérte a munkájukat és egyszer sem kértek segítséget. Mikor megszólalt egy kislány, és nem volt elég csend, akkor a fiúk elcsitították a többieket. Fegyelmezték egymást (6): , Egyszerre csak egy ember beszél”, ,, most is hány ember beszél? ”, , Hagyjuk a Dórit beszélni”, ,, Mindenki csendbe marad”. Felmerült a moderátor részéröl a kérdés: „,kinek van ötlete?” Megbeszélték, hogy több ötlet esetén egyet mondanak el, ami a legjobban tetszik nekik (7). (ez aztán csak részben valósult meg, jellemző volt, hogy végül minden ötletet elmondtak) Megjelent az igazságosság: „meghallgatunk mindenkit és a végén lesz szavazás”, „Legyen egy szabály: 1 ember maximum 2 emberre szavazhat!'. Ha valaki butaságot mondott, akkor sem nevették ki egymást. Volt egy kisfiú, aki nagyon izgult, nehezen szólalt meg és nevetés helyett azt mondták a társai: , Vegyél egy nagy levegöt”. Ez ellentmond az interjú során elhangzottakkal, az egymásra figyelés az érdektelenség kapcsán. Jelen feladat hozzájárult az egymás felé irányuló figyelem létrejöttéhez. A foglalkozás végén megtapsolták, éljenezték egymást, az eredményt értékesnek ítélték, sikerélmény, flow élmény valósult meg (8). A létrehozott ötletek a következők voltak:

1. Gyárakban kézzel dolgozzanak ne gépekkel, csökkenteni ezzel az energiafelhasználást, és a hajléktalanokat is fogják be munkára, legyen több elektromos autó

2. Afrikába vigyenek élelmet (,gazdagabb országok ellátmányos csomagokat küldenének, ruhákat, orvosi cuccokat") 
3. Öntözőrendszer a városba esővízből, patakból

Amikor készen voltak, akkor felém fordultak, mondták, hogy készen vagyunk és bemutatták az ötletet (9). A projektnek a Világ szebbé tétele nevet adták, amit ugyancsak szavazás útján választották meg.

Reflexiók elemzése

A reflexiók elemzése arra engedett következtetni, hogy a vizsgált diákok vagy nagyon szükszavúak az írásos kommunikációban, vagy kimerültek a foglalkozásban, de nagyon lényegre törő, tömör reflexiók születtek, meglepően egyértelmü kódrendszerrel.

\section{4. ábra: Diák reflexiók kódjegyzék - Nagykörös}

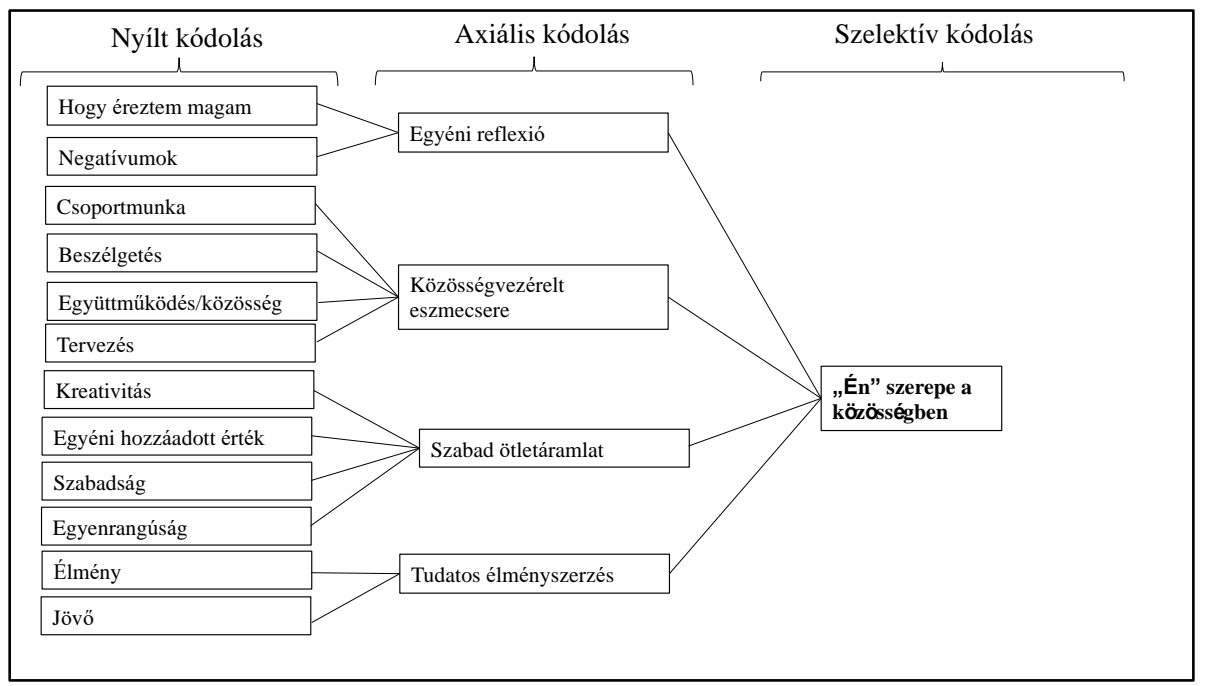

Forrás: A diák reflexiók elemzése alapján saját szerkesztés

Kivétel nélkül pozitív visszajelzést adtak arra vonatkozóan, hogy hogyan élték meg a foglalkozás időtartamát. A közösség együttmüködése, a csoportmunka és a közösségben történő, szabad áramlatú, nyílt beszélgetés meghatározó jelentőséggel bírt számukra (,,az tetszett, hogy az emberiség nagy problémáiról lehetett beszélgetni”, „nagyon tetszett, mikor csoportban beszélgettünk”, „Azért voltak jók ezek az órák, mert mindenki beleszólhatott mindenki beszédébe”) Fontos, hogy mindezt egyenrangú félként képzelik el („Tetszett amikor megszavaztuk, kinek a legjobb a terve"), ami igazolja a résztvevői megfigyelés során a foglalkozáson tapasztaltakat. Az egyenrangú együttmüködés mellett (,meg kellett egyezni a döntéseinkről”), olykor azt kiegészítve erőteljesen megjelenik az „én” hozzáadott értéke, 
vagyis, hogy az egyén miként járult hozzá a közösen létrehozott produktumhoz, igazolva ezzel a csoportban betöltött szerepét (,gondolkoztam és jó ötleteket adtam”, ,segitettem megoldani a problémát"). Ez túlnyomórészt minden reflexióban visszaköszönt így nem véletlen, hogy az elemzés eredménye során ez az, ami a kulcskategóriát a legintenzívebben formálta.

A tudás megszerzését a szórakozással összekötött tanulásban látják, amit a designkommunikáció workshop során a gyakorlatban is tapasztaltak és élményként megéltek (,jól éreztem magam, mert jól szórakoztam a barátaimmal és az osztálytársaimmal”, „Tetszett, amikor a jövö érdekében szórakozva gondolkoztunk").

\subsubsection{Budapest, Újpest}

A budapesti foglalkozás során, a kutatásban részt vett osztályfőnök rendkívül innovatív szemléletü és cselekedeteivel is aktívan hozzájárul, hogy a diákjai minél több új módszertannal és tanulási formával megismerkedjenek, minél több program részesei lehessenek (,számtalan programunk volt tavaly, amiért a gyerekek is meg a szülök is hálásak voltak. A nagy részük ilyen jellegü volt, mint ez, hogy kicsit figyeltem, és amit ingyen lehet kapni, abba belementünk”). Ez a fajta proaktív megközelítése a designkommunikáció egyik alappillérére épít, a kreatív alkotói kapcsolatteremtés (A. Cosovan \& Horváth, 2016) jelenségét tárja fel a gyakorlatban. A hagyományos iskolai keretrendszert, a megszokott feladatokat újra értelmezi, a diákönkormányzatot segítő pedagógusként nemcsak a tanórákat színesíti, osztályközösséget kovácsoló programokat is szervez, de az osztály dekorálása is egy közösségi tervezői munka és csapatépítés eredményeként készül. Alapvetően irányít (,aztán összeraktunk dolgokat, én mondtam, ők ráírták, lamináltuk”.), vezetőként („Ök húztak egy kalapból, hogy ki kerül majd a csoportjukba. Egyelöre figyelem. Nyilvánvaló, hogy van köztük, aki népszerü, meg szeretnek, de alkalmatlan a csoportvezetésre. Ezen kell majd finomítanom.") vesz részt a folyamatokban, de próbál a gyerekeknek is alkotói szabadságot hagyni (,Én nagyon a gyerekekre bízom, hogy tessék, üljetek össze, csináljátok meg”).

Azonban az innovatív hozzáállás nem elég, szükséges hozzá egy támogatói közeg (Sahlberg, 2009). Ez a támogatás a kollégák részéről adott („Viszont a kollégák nagyszerüek, ez az, ami nagyon fontos, hogy együtt tudjunk müködni."). Az infrastruktúra hiánya azonban gátló tényezőként jelentkezik („Jó lenne, ha a tárgyi feltételek meglennének, tehát alkalmazkodnánk ehhez a digitális világhoz.”, „De, ha ebben a teremben lenne egy interaktív tábla, akkora minöségi ugrás lenne, mert hát nekünk rengeteg anyag van interaktív, tudnám is használni."). Emellett azonban további két nehezítő körülmény is érintésre és új 
kódkategóriaként rögzítésre került, a közvetlen vezetőség (,A másik, hát egy demokratikus vezetöre lenne szükség. Nálunk nem demokratikus. Eléggé autokrata.”) és az oktatáspolitikai helyzet kapcsán (,A „MI” ellenébe megyünk most folyamatosan. Legalábbis az oktatáspolitikának azt hiszem ez a fö célja, hogy robotokat, mindent végre hajtó emberkéket neveljenek, akiknek önálló gondolkodásuk nulla”). Többek között a fenti tényezök is a kreativitás gátjaként jelentkeznek (,Rengeteg energia van bennük, és fantasztikus embereket lehetne nevelni belölük, de olyan szinten elnyomjuk ezt bennük.”), ahelyett, hogy a kreativitás motorját biztosítanák, amire többek között azért is van szükség, hogy: „,gondolkodó embereket neveljünk, akik majd egy kicsit okosabban tudják irányitani az országot, és az oktatáspolitikát." Ezzel párhuzamosan a pedagógus kollégákat egy végtelen adminisztrációs teher is nyomja, amiben olykor a hétköznapok feladata is kihívás, nem beszélve az ezen bőven túlmutató újító törekvésekről (,Ez az első három hét egyszerüen beszippantott minket, és olyan igazi érdembeli dolgot nem csináltunk. Mert annyi adminisztráció van. Most is még az órarendünk alakulóban van. Nagyon nehéz.").

A kapcsolati háló kontextusában jelen kutatási helyszín esetében nagy hangsúly helyeződött a szülőkre. Értendő ez a szülő-gyerek, továbbá a szülők közötti kapcsolatra is (,,itt nagyon sok megmondós szülő volt, akik a szülőket is nagyon befolyásolta. ”). Ez szintén egy új kódkategóriaként jelent meg, hiszen itt olyan közvetett szereplők befolyásáról van szó, akik a gyerekeken keresztül próbálnak adott esetben a pedagógus véleményével szembemenő döntést és határozatot hozni („A tavalyi évet nagyon megküzdöttem. A gyerekekkel nem volt probléma, inkább a szülői háttérrel. Ök máshogy gondoltak dolgokat, és hátulról ezt sugallták a gyerekeknek. Nekem nagyon sok gátat és akadályt kellett áttörnöm.”). Az itt felismert szituáció kapcsán a legnagyobb probléma, hogy ez ugyancsak egy gátló tényezőként jelenik meg az oktatás során, ami hosszú távon a gyerekek fejlődésének árt(hat).

A fentiekben kiemelt kódkategóriákat is összegző kódfa a következőképpen került ábrázolásra. 


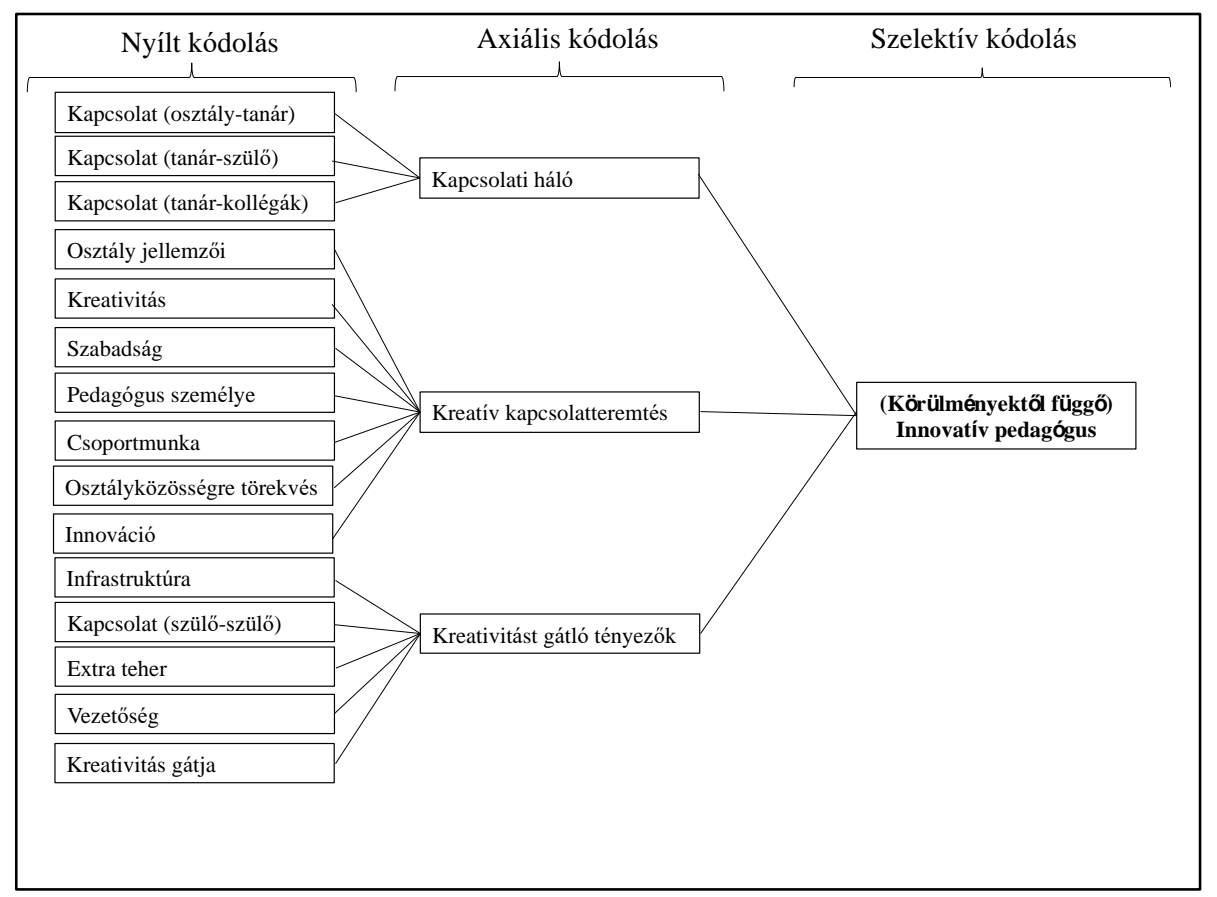

Forrás: A mélyinterjú leiratának elemzése alapján saját szerkesztés

Résztvevő megfigyelés

A mélyinterjú során vélt észrevételeim az osztályfönökkel kapcsolatban, a workshop során is beigazolódtak. Az összességében kedves, lelkes, újító, modern, nagyon aktív szív-lélek pedagógus a sok jó tulajdonsága mellett több esetben is próbálja irányítani a diákokat. Szakmai tudása és innovatív elképzelései és megvalósítása figyelemre méltó, azonban kissé ellentmondást keltő volt az, amit az interjún mondott és ahogyan a gyerekekkel viselkedett. Az interjú során kiemelte, hogy elengedhetetlennek tartja, hogy a gyerekek megtanuljanak önállóan gondolkozni és munkája során ő erre törekszik. Ezzel ellentétben a workshop alatt nem várta meg, hogy a gyerekek maguktól elrendeződjenek egy fiú egy lány sorrendbe, hanem úgy gondolta, hogy az a megoldás, ha mond egy nevet, akit „rákényszerít” a feladat végrehajtására. Ez a szemléletmód az egész munkáját jellemzi. Látszik a hozzáállásán, hogy ha valamit elgondol, akkor azt szeretné, hogy a gyerekek is úgy jussanak el a feladat végéig, ahogyan azt ö elgondolta. Lehet, hogy közben ad lehetőséget arra, hogy gondolkozzanak, de nem önállóan! Terelgeti a gondolatukat, azon az úton, amit ő elképzelt, és ez visszatükröződött a feladat megoldásán is. Majdnem végig bent volt a workshopon, kérnem is kellett, hogy ne 
vezérelje a gyerekeket annak érdekében, hogy az eredmény ne torzuljon. Ez egy fontos tanulság volt a későbbi foglalkozásokra nézve, hogy a pedagógusokat csak azzal a feltétellel engedtem bent maradni a workshopon, ha biztosított róla, hogy valóban csak megfigyelő lesz és nem szól bele a folyamatokba, hiszen az sérti a kutatás eredményeit.

A diákok a prezentációt végig hallgatták (1), hozzászóltak, ha kérdeztem, akkor aktívan válaszoltak (2). A gyerekek foglalkozásába beleesett a reggeli szünet, ami ugyan az osztályteremben zajlott, de kicsit kizökkentette őket, így ez is egy olyan elem volt, amire már a későbbiekben tudatosan figyeltem. A kiscsoportokban nagyon jó témák kerültek előtérbe. Nehezen de megindult a beszélgetés, viszonylag jól haladt, szépen épültek a projektek (3), volt két csoport, akik kifejezetten sokat beszéltek a témáról, melyek a következők voltak: Több minőségi családdal töltött idő a kütyük rovására, Energiatakarékosság és Jó kapcsolat a szomszédokkal, segítségnyújtás, ha szükség van rá.

A probléma valójában akkor kezdődött, mikor egy nagy csoportban kellett dolgozni. Mikor arra került a sor, hogy közösen döntsék el, hogy mi az, amivel az otthonuk jobbá tételére vállalkoznak, teljes fejetlenség és káosz uralta el az osztályt. Megindultak a mikrobeszélgetések, amiknek soha nem lett vége. Egyéni próbálkozások mindig voltak, de a sikertelenség (nem figyelt senki a másikra) miatt a ,játék” végére mindenki inkább beletörődött és elfogadta az első megoldást, amit hallott, csak legyen már vége. A krízishelyzetet igazolja, hogy többször is kifordultak a körből és segítséget kérő tekintettel néztek rám (5). A fiúk nem voltak hajlandóak a lányok mellé ülni, ahogy ezt a fennálló konfliktust az osztályfőnök az interjúban említette. Az ötletek átadása nem valósult meg, az 1-1 kósza információ is elveszett a csoportban. Közbe kellett szólni, fegyelmezni és irányítani kellett. Két kislány aztán nagy nehezen kezébe vette az irányítást. („Csoportok álljanak fel és úgy mondják el az ötleteiket”,,Maradjatok csendben”)

Érezték ők, hogy nem figyelnek egymásra (6), nem haladnak, ez többeket felbosszantott. Egy kisfiú mérges is lett, mert nem hallotta a kommunikációt. Mindenki zsizsegett. Kinevették egymást. „,ne szenvedjünk”, „csitt már”. Kezdett fogyni a türelem, érezték, hogy kellene valamit alkotni, de semennyire nem tudták ezt közösen megvalósítani (6). „Döntsük már el légyszíves”, „ezzel nem fogsz sokat érni, ha kiabálsz” Végül aztán néhány kislány kiscsoportban összevont két ötletet, közös szemétszedés és faültetés a szomszédokkal. Közös környezetvédelem nevet kapta a projekt (9), melynek elemei a minden szombaton megvalósuló szemétszedés, szerdánként növényültetés, aki szemetel az pedig bírságot kap. 
Összességében a lányok sokkal kreatívabbak voltak, holott kis csoportokban a fiúk is nagyon aktívnak bizonyultak. Nagy nehezen tehát megszületett az ötlet, de sokkal inkább volt ez kiscsoportos feladatmegoldás, mint wikinomikus, osztályszintű együttmüködés.

Itt is egyértelműen látszódott tehát, hogy a kiscsoportos feladat jól megy nekik, hiszen ebben van már tapasztalatuk, azonban érezhető volt, hogy irányítás nélkül elvesznek. Az önálló problémamegoldás nem volt jellemző, a kreativitásuk nem tud kibontakozni, mert a köztük fennálló kommunikációs probléma és az, hogy a gondolatuk szabad áramlására nem kapnak teret a hétköznapokban, meggátolja a folyamatot.

\section{Reflexiók elemzése}

A mélyinterjú és a résztvevő megfigyelés eredményének tükrében meglepő volt a diákok reflexióinak elemzése során kapott információ. A diákreflexiók a megszokott lényegre törő kifejezésmód helyett viszonylag hosszan taglalták a workshop során tapasztalt élményeiket. Egyáltalán nem élték meg kudarcként a wikinomikus együttmüködés hiányát, ugyanakkor felismerték, hogy az osztályszintű együttmüködésben voltak problémák (,Amikor az egész osztály kezdte megbeszélni, hogy melyik lehet a legjobb, ott volt egy kis vita.”). A probléma felismerése azonban nem a javításra irányult, sokkal inkább jelent meg az a visszajelzés, hogy a kevésbé sikeres együttműködési folyamat, pontosan ennek okán nem volt a kedvükre való (,Ami annyira nem tetszett az osztály megbeszélés, mert mindenki beszélgetett és nem lehetett jól koncentrálni.”, „ami nem annyira tetszett az az volt, amikor körben ültünk és meg kellett beszélni a környezetvédelmet"). Nagy hangsúlyt kapott az egyéni hozzáadott érték bizonyítása (,Sok ötletem volt, van és mindet el is mondtam.”, „Ebbe a munkába próbáltam mindent bele tenni és szerintem aktív voltam.”, „Nekem mindenben volt egy kicsi szerepem, mert mindenhez hozzászóltam”). Fontos volt ez azért is, mert az eredményre büszkék voltak és érezni akarták, hogy annak létrehozásában részük van, az övék is az érdem (,Nekem az is tetszett, hogy része voltam a végeredménynek és segithettem, és az én ötletemböl is sikerült összerakni ezt a projektet.").

Minden kétséget kizáróan a kiscsoportos munka tetszett nekik a legjobban, ott már otthonosabban mozogtak, ebben volt tapasztalatuk, rutinosabban kezelték a helyzetet. Ez is rávilágít, hogy az ismert helyzetek támogatják az együttmüködési folyamatokat (,A négy fös csoport megbeszélés jobb volt, mert jobban meg tudtuk egymást hallgatni”, „Jó volt az, amikor kisebb csoportokban megbeszéltük, hogy mit lehetne tenni az otthon érdekében."). Pozitívumként emelték ki, hogy az itt létrejött csoportmunka szabadságot és irányításmentes 
gondolkodást biztosított nekik, amit élveztek („Jó volt, hogy mindenki belerakta a saját ötletét”, „Úgymondva együtt terveztünk és kitaláltunk dolgokat”, „Nagyon jól éreztem magam, mivel magunktól kellett csoportba lenni és ötleteket kitalálni, megbeszélni.")

16. ábra: Diák reflexiók kódjegyzék - Budapest

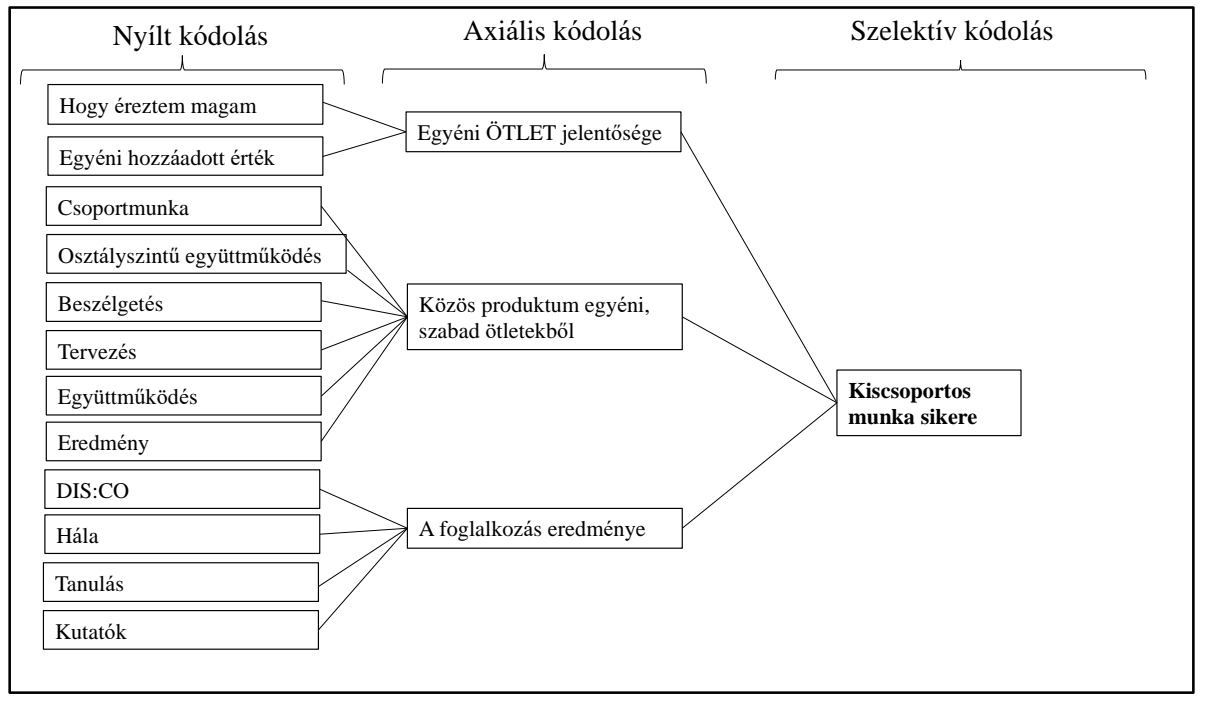

Forrás: A diák reflexiók elemzése alapján saját szerkesztés

\subsubsection{Heves megye, Eger}

Mélyinterjú

Egerben volt az első olyan osztály, akit vizsgáltam és akinek az osztályfőnöke férfi volt. A mélyinterjú legfontosabb eredményeként két dologra világított rá. Az egyik a pedagógus tapasztalatának szükségessége és jelentősége. Az a fajta tapasztalat, amit nem években, hanem nyitottságban és a gyerekekkel eltöltött időben mérnek („,Fontos az oktatást minél több oldalról megközelíteni. Ez állhat közel a megoldáshoz. Próbálkozni erröl, arról. Ehhez tapasztalat kell. A tapasztalat nem feltétlenül a korral jár. Van, aki egy év alatt annyit tapasztal, mint más öt év alatt. Ha valaki sokat van a gyerekek között, akkor sokat tapasztal.”). A másik kulcstényező az a verseny. A verseny a gyerekek figyelméért a digitális világ impulzusaival szemben. Ebben a versenyben egyetlen esély létezik: a kreativitás (,Nekünk most jelenleg a videójátékokkal, az okostelefonokkal kell versenyezni, hogy felkeltsük a gyerek figyelmét arra, hogy hahó mi is itt vagyunk és szeretnénk neked mondani valamit. És ez nehéz. Ha nem próbálunk meg kreatívak lenni, a gyerek nem fog ránk figyelni. Soha. Mert azon jár az esze. És ezt semmi mással nem lehet a jelenlegi állapotában az oktatásban elérni, csak kreativitással.") 
Az osztályfőnökre jellemző a kreatív hozzáállás, biztosítja a diákoknak az alkotói szabadságot, azonban igyekszik megtartani az egységet az újhullámos és a hagyományos, hierarchikus oktatási módszer között (,Szeretem őket szabadjára engedni, a gondolatokat. Nem tartom jónak a régi vaskalapos óratartásokat. Igyekszek újfajta módszert is bevezetni, de a frontális osztálymunkát is szeretem. Mindenre vevö vagyok, ami a gyerekeknek egy kicsi pluszt adhat. Szeretek mindent, ami más, ami új.”)

Érdekességképpen fontos még megemlíteni a fiúk és a lányok között fennálló ellentétet, ami az amúgy is labilis és nem kiforrott osztályközösség erősítésében nem segít, viszont életkori sajátosság, aminek kezelése a hétköznapokban a közösség szintjén ugyancsak a pedagógusra hárul (,A fiúk és a lányok: teljes egységtelenség jellemzi. Teljesen külön vannak. Nem nyitnak egymás felé.”). Ennek kapcsán nem elhanyagolható azonban a közösség erősítése, az együttmüködés fejlesztése, hiszen ez nagyban hozzájárul a jó teljesítményhez (,Ha jó az osztályközösség, az órán jobb a hangulat, több minden megmarad nekik. Közösen jobban tudnak odafigyelni, jobban el tudják sajátítani a különbözö feladatokat.”).

17. ábra: Pedagógus mélyinterjú kódjegyzék - Eger

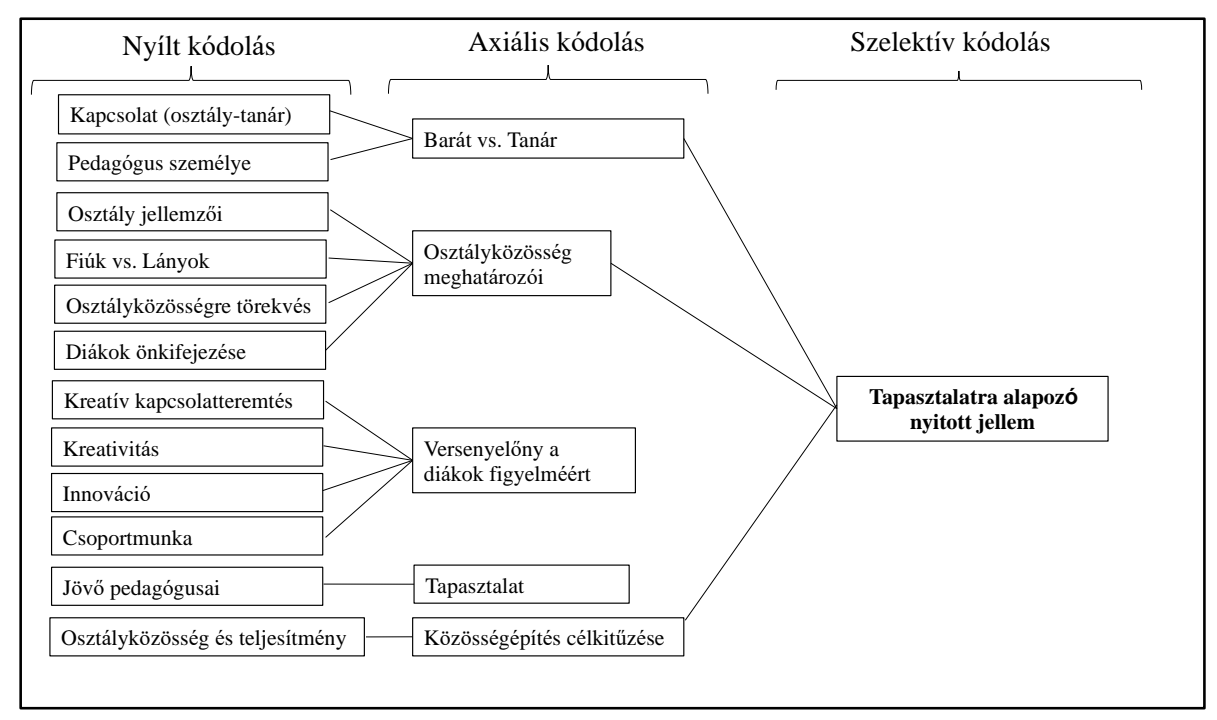

Forrás: A mélyinterjú leiratának elemzése alapján saját szerkesztés

Résztvevő megfigyelés

Az iskola egy szimpatikus, kertvárosi intézmény, rendezett körülmények fogadtak bennünket. Látszott, hogy a diákok nagyon kedvelik az osztályfőnököt, vicceskedtek egymással, jó hangulatúan, vidáman közeledett a gyerekek felé. Abszolút pozitív volt a fogadtatás, a gyerekek kíváncsiak voltak, és készségesek. Látszott rajtuk, hogy nyitottak az 
újdonságra és örültek is nekünk. A kedves és közvetlen nyitást a legtöbben jól kezelték, talán egy-két diáknak esett nehezére a tegeződés, de mindannyian nagyon udvariasak, figyelmesek voltak. Úgy éreztem nagyon fontos számukra, hogy az, akivel beszélnek/aki beszél hozzájuk, milyen hangulatban van, mert könnyen átragadt rájuk.

A DIS:CO bemutatása során az tünt ki a leginkább, hogy mennyire felnéznek a képen szereplő 8 éves Izára, aki már tervezett egy logót. Megmosolyogtató volt látni az arcukat, a leeső állakat és hallani a velük együtt járó „woooow” -okat. Ezzel kapcsolatosan még megemlíteném azt is, hogy erősen azt éreztem, hogy vágynak az elismerésre, hogy számít nekik a mások véleménye (1).

A prezentációt alapvetően figyelmesen hallgatták végig (1), most többször bevontam öket kérdésekkel, mint a korábbi alkalmakkor, törekedtem a nagyobb fokú interaktivitásra. A kiscsoportos foglalkozások előtt hagytam időt a tízóraira, kell nekik néha egy minimális szünet a feltöltődéshez. A kis csoportokban a munka nehezen indult meg, aztán amikor belejöttek, akkor egészen jó ötletek születtek és célzottan a témáról beszéltek (3). A szokásosnál nagyobb zsivaj volt a teremben (4), ez talán annak is betudható, hogy szinte kétszer annyian voltak, mint a korábbi osztályok. A témák, amik a kis csoportokban előkerültek: Környezetszennyezés, mit tehetünk? Állatfajok védelme, Cigaretta, Telefon helyett körülöttünk lévő világra koncentráljunk mozgalom, Müanyag(zacskó)mentes világ

A kiscsoportos munka után is volt 2-3 perc szünet, aztán jött az együtt dolgozás, a wikinomikus együttműködés szintjén. Én elmondtam a feladatot, majd kiléptem a körből, fizikailag is, hogy érezzék, hogy ez most az ő terepük, egymásra számíthatnak csak. Először azt gondoltam, hogy ez nehezen fog menni, mert a kisebb csoportok is döcögősen indultak be. De aztán volt egy fiú, aki felvállalta azonnal a moderátor szerepet, és egy pillanat alatt körvonalazódtak a csoportszerepek (5): „én beszélek ti csöndbe lesztek”, „Nekünk az volt az ötletünk, hogy...”, „,mindenki mondja el az ötletét...” Amikor a csapatok elmondták, akkor a moderátor szerepet felvállaló fiú megkérdezte, hogy van-e még valaki, akinek van önálló, saját ötlete a csoportokban átbeszélteken túl (,,lehet új ötlet is ”)?!

Megfigyelhető volt, hogy itt nagyon pontosan értelmezték a feladatot, nem igazán kérdeztek vissza, de biztos, hogy sokkal kisebb mértékben, mint a korábbi workshopok alkalmával. Volt egy kislány, aki külön is elmondta az ötletét részletesen. Volt alkalom, hogy picit kuncogtak egymás ötletén, de gonoszság nem volt tapasztalható. Egymás fegyelmezése jellemző volt, a prezentáció alatt is, és ez később sem szünt meg.

Belekötöttek, vitatkoztak egymással (6). Valóban egy értelmes vita-párbeszéd alakult ki közöttük, érezhető volt, amit az osztályfőnök elmondott az interjú során, hogy magyar órán 
tanulnak vitakultúrát. Megkérdőjelezték az ötleteket. Ök voltak az elsők, akik felismerték, hogy itt egy olyan ötlet kell, amiért ők is tudnak tenni! És ezt a középpontban tartották: , legyen valamilyen gondolat, amin mi tudunk segiteni”, „csönd már, Miki beszél” Több rendőr szerep is előkerült: „egyszerre csak egy beszéljen”, „hölgyeménynek egy kis türelmet szeretnék” meghallgatásra intették egymást

A moderátorra alapvetően hallgattak, de azért volt olyan, aki szerette volna tompítani a szerepét: „engem az is érdekel, hogy más mit gondol”. Volt a vége felé egy mélypont, annyi hozzászólás, észrevétel, kétkedés volt az egyes ötletekben, hogy úgy érezték, hogy valami mellett leteszik a voksukat, aztán meggyőzik egymást arról, hogy az talán mégse jó. Érezhető volt, hogy a végéhez közeledve egyre többen bevonódnak, ugyanakkor kezdték elveszíteni a türelmüket, egy minimális közbeszólásra, óvatos terelésre, fókuszálásra gyorsításra szükség volt a részemről, ami megindította a „,véghajrát”: , mindenkinek engednie kell”, ,, kell egy közös nézőpont”, „,megpróbáljuk az összeset egybepréselni, és akkor mindenkinek jó”, „az a baj, hogy már eldöntöttük, de még mindig veszekszünk”.

A projekt végül körvonalazódott, elöadták az eredményt (9), amire jutottak, ami a műanyagmentességre irányult, a műanyag zacskók betiltásával kezdenék, és így haladnának majd lépésről lépésre a környezet megóvása érdekében. Záró gondolatként szeretnék kitérni egy jelenségre (8), ami ugyan csak érintőlegesen része a kutatásnak mégis olyan témát érint, ami egy jövőbeni kutatásnak fontos részét képezheti. Mindkét nagyobb feladat megoldásaként globális problémákra próbálták megkeresni a megoldást, és néhány elejtett mondatból és arckifejezésből azt éreztem, hogy valamilyen szinten klímaszorongásuk van. Nyilván fontos, hogy tudnak a világunkat érintő problémákról, de lehet, hogy néhányukat már inkább nyomasztja. Nagyon vegyesen állnak a dolgokhoz, néhányan szinte teljesen lemondóan, mondván, „aki függő, annak hiába mondod”, a másik oldal pedig így „,ha nem mi állunk össze, akkor ki fog?’. Ennek ellenére a pozitív irányba sikerült elvinniük az eredményt. 
Reflexiók elemzése

18. ábra: Diák reflexiók kódjegyzék - Eger

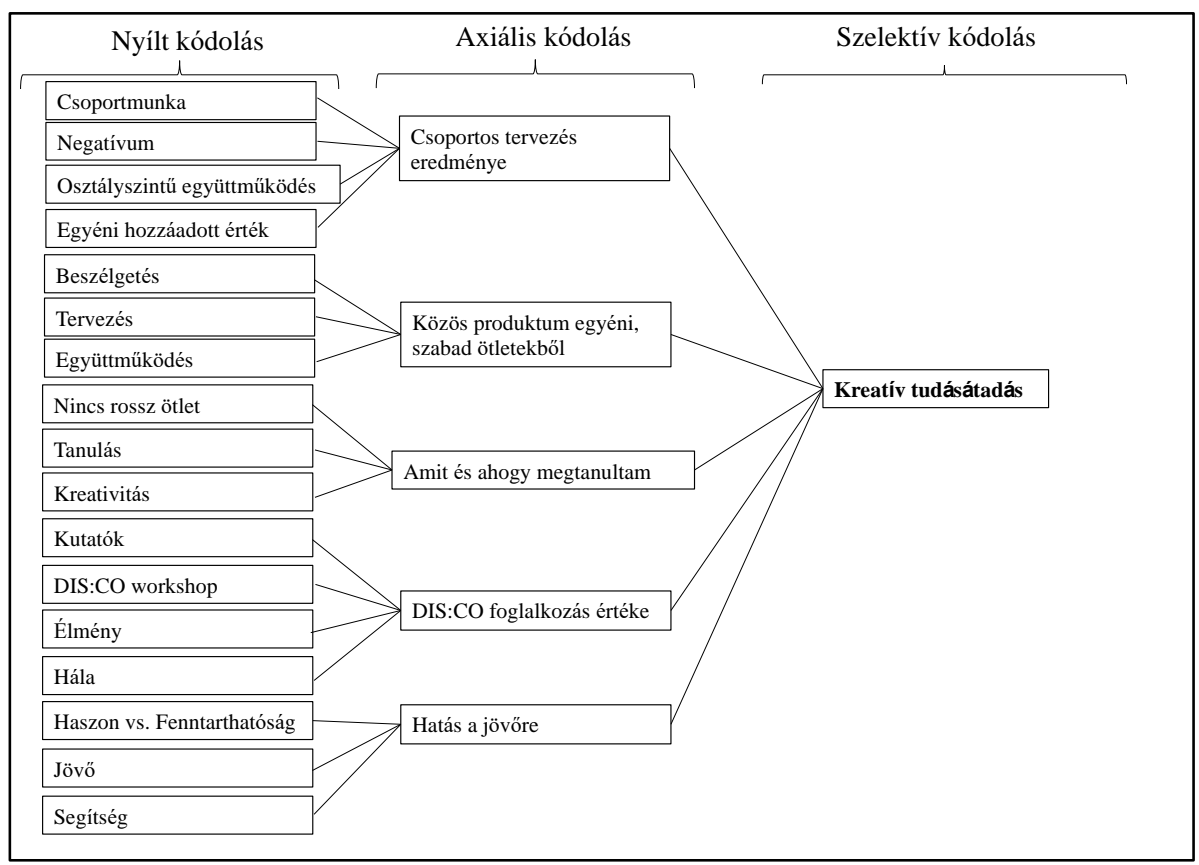

Forrás: A diák reflexiók elemzése alapján saját szerkesztés

Egerben a diákok reflexiói egyértelmủen igazolták a workshop során tapasztaltakat, egy igen értelmes, rendkívül müvelt, széles szókinccsel rendelkező osztályközösség. Választékos szóhasználat, összetett mondatok jellemezték az írásukat. A kódjegyzéket bemutató ábrán túl néhány fontos és új dimenziót szeretnék kiemelni. Az egyik nagyon fontos aspektus a tanulás, a tudás megszerzésének elismerése és felismerése, amit a workshop során kaptak (,Sok új fogalommal ismerkedtem meg”, „Ezen az órán olyan dolgokat tanultam, ami nem most, hanem sokkal később kamatozik majd”, „,nagyon sok újat tudtam meg, ami nagyon érdekes volt”). Ezzel párhuzamosan pozitív értékelésre került maga a designkommunikáció workshop is, a prezentáció (,Az interaktív táblán, amik fel voltak vetítve nagyon tetszettek, hisz onnan is sok újat tudtam meg”) és a foglalkozás részét képező feladatok („Nagyon tetszettek az érdekes, izgalmas feladatok”), valamint a módszertant mozgató kreativitás („Jól éreztem magamat, mert még sohasem hallottam erröl a módszerröl, de tetszett, mert a kreativitásra épül.”). Külön kiemelték pozitívumkét azt, hogy nincs rossz válasz, nincs szorongás, csak a szabad alkotás („Nem lehetett hibázni és interaktivvak voltak a feladatok.”, „az volt a legjobb, hogy nem lehetett hibázni”). A fentiekhez szorosan kapcsolódó elem pedig nem más, mint az az élmény, amit szavakba öntöttek, amivel gazdagodtak ebben a három órában („Én egy jó időtöltésnek fogtam fel, azért, mert rengeteg mindent lehet tanulni és jól is éreztem magam és a környezetet is lehet 
védeni.”, „Remélem még lesz részem ilyen élményben”, „Az egész müsor nagyon precíz és élvezetes volt, látszott mennyi munka volt benne, köszönöm ezt az élményt").

A jövő dimenziója 3 szinten is megjelent a diákok reflexióiban. Tisztában voltak azzal, hogy ez az én doktori kutatásomnak egy része, és jó érzéssel töltötte el őket, hogy ők ennek eredményéhez majd hozzájárulhatnak: „Örülünk, hogy tudtunk segiteni Daniella munkájában”, „Tudtunk segíteni Daniellának a doktorijában”. A második szint az a fenntarthatósághoz való aktív, tettleges hozzájárulás lehetősége és a növekvő érdeklődés megjelenése a foglalkozáson keresztül: „Sokkal jobban elkezdtek ezek a dolgok érdekelni, mint eddig”, „Az különösen tetszett, amikor kis csoportokba ültünk és a környezetvédelemhez járuló folyamatokat kellett kitalálni”. A harmadik pedig az eredmény, a téma megkérdőjelezése, hogy van-e ennek értelme, filozófiai megközelítés az emberiség attitüdje kapcsán (haszon vs. fenntarthatóság), ami rávilágít, hogy milyen mély gondolatokat tárt fel a foglalkozás a diákokban: „A müanyag zacskót nem lehet megszüntetni, mert az embernek rengeteg haszna van belöle. Tudom, hogy szennyezi a környezetet, de szerintem ez akkor sem megvalósitható”, „én nem tartom ezt a témát fontosnak, mert 7,5 milliárd emberböl ezt a fele nem gondolná fontosnak, nem érdekelné, ha nincs haszna belöle".

\subsubsection{Borsod-Abaúj-Zemplén megye, Bodrogkeresztúr}

Mélyinterjú

A bodrogkeresztúri pedagógus egy karakán, alapvetően szabálykövető, ám kifejezetten újító és innovatív szemléletmódot képviselt. Az oktatás több számára, mint egy puszta foglalkozás (,Azt csinálom, ami a szenvedélyem. Ez hivatás.”). A játék és a tanulás összekapcsolását támogató módszertanokat alkalmazza a hétköznapokban (,Az ember igyekszik mindenféle módszert bevetni, meg játékositást. Szünetekben igénylik, játszanak, és észre sem veszik, hogy a szabályokat együtt értelmezik, olvasnak, stratégiai játékokat tanulunk.") Az oktatás hatékonyságának növelését a probléma-központú tanításban látja („Vagy van egy probléma, és eköré vonjuk a matematikát. Épitsünk egy nagyobb házat. És belegondolunk: ebben van töri is, ének is, matek is, fizika is, kémia is."), a diákok számára a legértékesebb tudást a készségek elsajátításában feltételezi (,Hangsúlyozzák, hogy a mai gyerekek olyan szakmát fognak végezni, ami ma még nem is létezik. Mi pedagógusok úgy tudjuk öket szakmákra tanítani, hogy képességeket fejlesszünk.”) Ez pontosan alátámasztja disszertációm célkitűzéseit, valamint a designkommunikáció módszertani alapjait is megerősíti. 
Az oktatási keretrendszert nem tartja alkalmasnak a fejlesztésre, gátat szab a tehetséggondozásnak („Tehetséggondozás és fejlesztés. Ez ma Magyarországon nincs megoldva, csak annál a családnál, ahol pénz van, és hordja a gyerekét."). A hierarchikus oktatási modellt is elveti (,az a fajta tanitás és oktatás, hogy gyere, üljünk szembe és elöadok és magyarázok, az csőd! Azt nem szabad csinálni."). A másik problémát a pedagógusképzésben rögzíti. A jövő pedagógusainak felkészítését vonja kérdőre („,Van kezdő fiatal generáció. Eljön, meglátja, hogy mi a helyzet, itt hagyja két három év után. Egyrészt a fizetés, másrészt nincs felkészitve kellöképpen hatékony módszerekkel. Pedig a tanárképzöknek ez dolga lenne. Nem kapnak mostani használható aktív módszereket.") egy olyan célcsoporttal szemben, aki nem szabálykövető („Nehezen viseli a mai gyerek a szabálykövetést.”), egyre nehezebben motiválható („Nem tudják, hogy miért kell tanulni. Nehéz őket motiválni.”), kommunikációs készségeik minősége lehangoló („,Szókincsük egyre csak gyérül., Kimentünk, tessék kapcsolatot teremteni, kérdezni. Hát, siralmas volt.”) ezzel szemben, az egymás és a pedagógus felé megvalósuló kritika éles (,A kemény kritika megy a másik felé.”).

A megoldást az új, tervezői módszerek integrálásában, a diákok aktív bevonásában látja (,Mindenféleképpen az oktatás interaktívvá kell tenni. Legyen részese a gyerek. Bevonom öket az alkotó tevékenységbe.").

19. ábra: Pedagógus mélyinterjú kódjegyzék-Bodrogkeresztúr

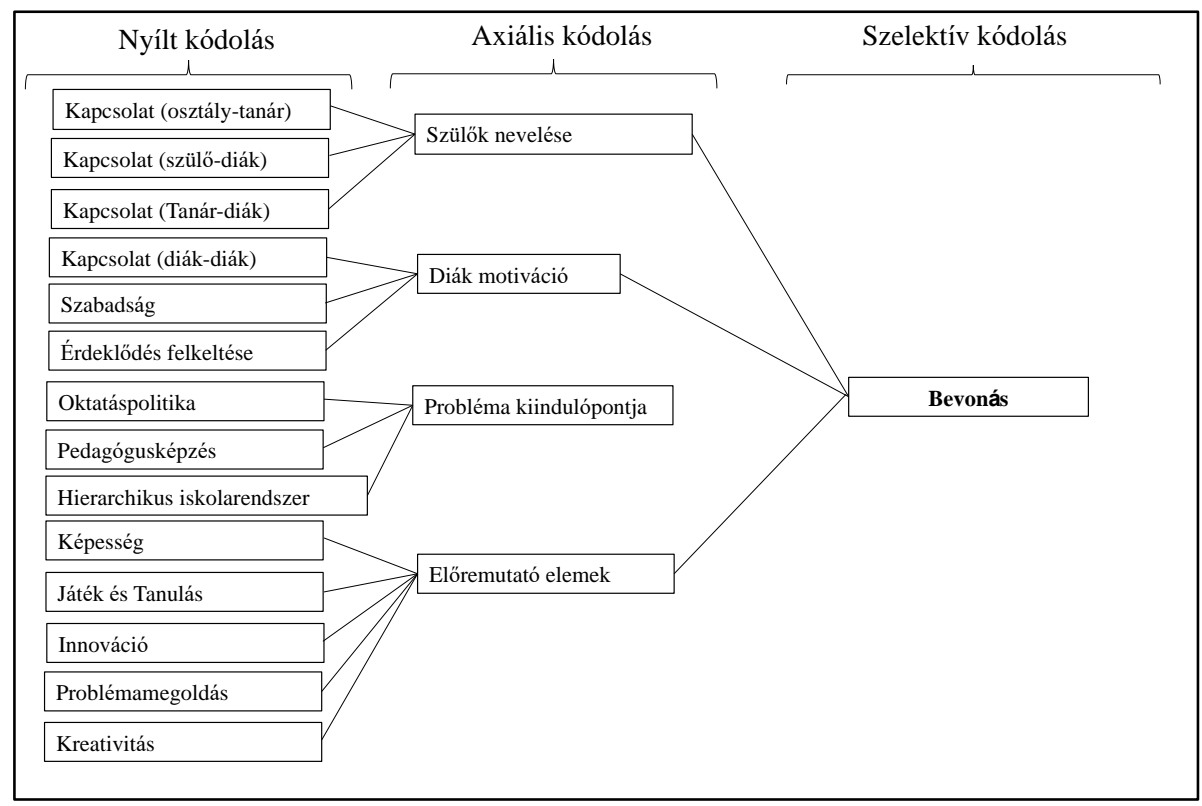

Forrás: A mélyinterjú leiratának elemzése alapján saját szerkesztés 
Résztvevő megfigyelés

A mélyinterjút követően valósult meg a workshop, ahol az első bemelegítő feladatban már érezhető volt az a heterogenitás, amiről az osztályfőnök is beszélt a gyerekek családi háttere kapcsán. A prezentáció talán a szokásosnál hosszabbra sikeredett (1), a megnövekedett interaktivitás miatt, a gyerekek jobban hozzászóltak, válaszoltak a kérdésekre (2). Nehezen azonosították magukat tervezőként, de aztán amikor rákérdeztem, hogy ez biztos-e, akkor aztán elkezdtek sziporkázni az ötletek, hogy mikor válnak ők tervezőkké a mindennapjaik során: „kigondolt dolgot megvalósítunk” // „elültetem a hagymát” // „tervezők vagyunk, amikor legózunk” // „amikor képes vagyok arra, hogy olyan dolgot csinálok, amit még senki nem valósitott meg".

Csendes, érdekes társaságként definiálnám, a magatartásuk rendben volt (4), aktív figyelem jellemezte őket. Kis csoportokban otthonuk jobbá tétele kapcsán előkerült az iskolabüfé, a falun belüli környezettisztítás, a környezetvédelem. Jellemző volt két csoportra is a bomlasztás (6), ami összecseng a pedagógus által elmondottakkal: „,azt látom, hogy azok vállalják a véleményüket, akik nem pozitiv irányba vinnék a közösséget, inkább a negatív hangadók. A lázitók.". A közös kommunikáció nagyon nehezen kezdődött el, talán nekik kellett sok idő, hogy megnyíljanak. Amikor nagy csoportban, osztályszinten kezdtek el együtt dolgozni, akkor egy kislány szólalt meg, és vette fel az irányító csoportszerepet (7). „Szerintem úgy kéne, hogy minden csapat megosztja az ötletét.”, , Kezdje az egyes csapat”. Elöször nagyon együttmüködők voltak, de aztán picit felborult a rend. Ügyesen kezdték, majd elveszítették a fókuszt, de összességében elmondható, hogy mikor magukra hagytuk őket az elejétől a végéig kis megtorpanásokkal ugyan, de a cél felé haladtak.

Végül közös produktumként egy iskolabüfét hoztak létre (nincs iskolabüfé, szemben a kisboltban korlátozottan tudnak vásárolni, ahova át kell őket kísérni az úton), ami értékeli a szemétszedést, és kedvezményt ad a környezettudatosságért cserébe, így összekapcsolva a kiscsoportos ötleteket (9). Pozitív volt azt látni, hogy az alkotói folyamatot a lehető legprecízebben és legrészletesebb tervvel valósították meg. Jellemző, hogy összefésülik az ötleteiket a diákok, vagy többet választanak, de az értékelhető ötleteket nem nyomják el, inkább csinálnak belőle valamilyen módon egyet, ami egyfajta kompromisszumra, az alkotói tiszteletre is utalhat (8). Talán a legpozitívabb élmény az volt, hogy ebben az osztályban nem csak felmerült az ötletek összegyúrásának a lehetősége, hanem meg is valósították azt. Természetesen náluk is voltak mélypontok, amikor egy-egy gyerek kifakadt és közölte, hogy: 
„Tesztek hozzá, tesztek hozzá, de nem jutunk elörébb.” A végére ennek ellenére egy komplex tervet készítettek, amelynek ők maguk is részesei voltak (8).

Reflexiók elemzése

20. ábra: Diák reflexiók kódjegyzék - Bodrogkeresztúr

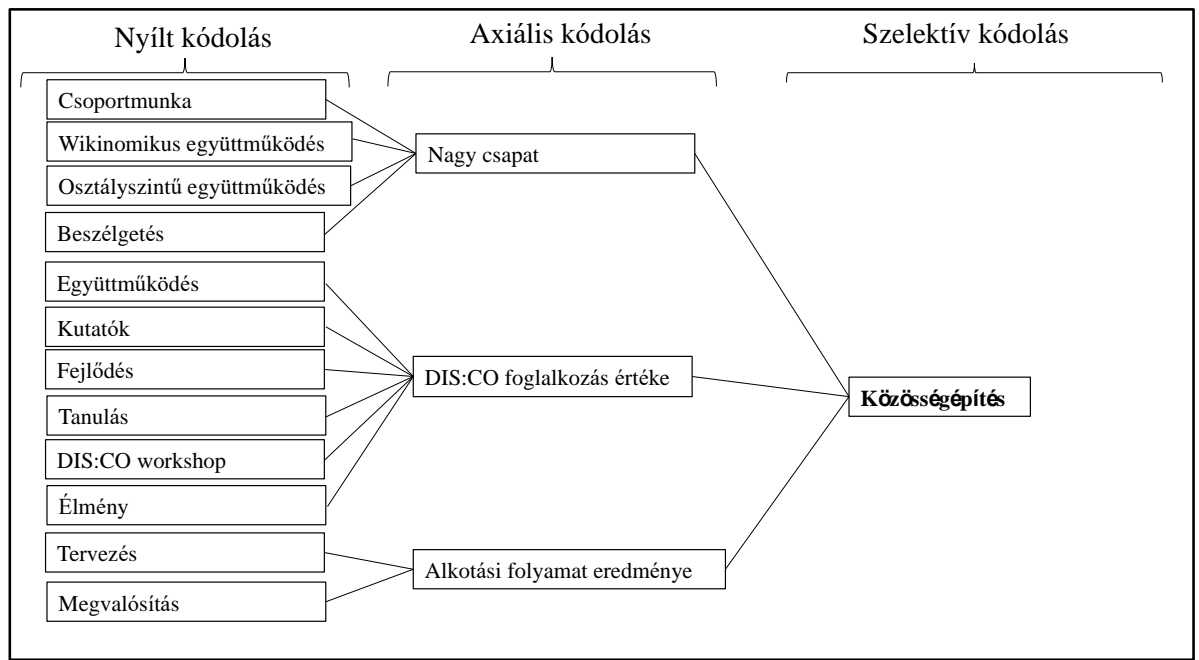

Forrás: A diák reflexiók elemzése alapján saját szerkesztés

A reflexiók elemzése alapján két fontos jelenséget érdemes kiemelni. Az egyik a megvalósítás fogalomköre, melynek során a célkitüzésen (,Az tetszett, hogy csoportba meg kellett beszélni, hogy mit akarunk elérni”), a tervezői feladaton túl, annak megvalósítása, a produktum is elötérbe kerül (,amit tervezek, azt szeretem, hogy meg is valósithatom”). A folyamat kiteljesedését a folyamaton túl a megvalósításban vélik felfedezni, amire képesnek tartják a közösséget: „,ha összefogunk még meg is tudjuk valósítani”.

Amit szintén ki kell emelni a foglalkozás eredménye kapcsán az az osztályközösség erősödése. Mivel Bodrogkeresztúrra a környező falvak diákjai járnak iskolába, a gyerekeknek iskola után nincs lehetőségük együtt tölteni időt, amire azonban szükségük lenne. Ennek okán kifejezetten nagy értéket tulajdonítottak annak, hogy a foglalkozás ezt megadta számukra. „,̈sszehozta az osztályunkat”, ,jól éreztem magam, mert egy csapat voltunk”, , tetszett, hogy az osztály összeült”, ,jó kis együttlét volt”, , ezzel az egész programmal összébb kovácsoltuk az osztályt”. 


\subsubsection{Csongrád megye, Hódmezövásárhely}

Mélyinterjú

21. ábra: Pedagógus mélyinterjú kódjegyzék-Hódmezővásárhely

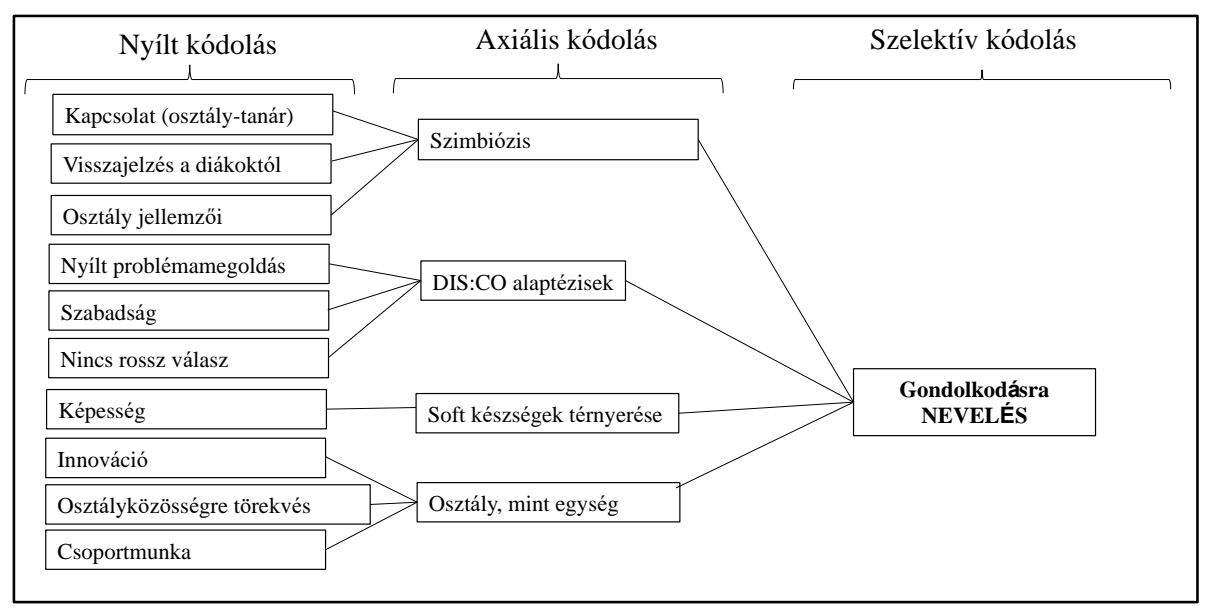

Forrás: A mélyinterjú leiratának elemzése alapján saját szerkesztés

A hódmezővásárhelyi pedagógus egy kifejezetten fiatal, lelkes, az újdonságokra nyitott, hivatása felé elkötelezett tanár. Innovatív megközelítése elsősorban a digitális módszerek alkalmazásában realizálódik. A LEGO oktatási programját használja, ami alapvetően a designkommunikációhoz szorosan kapcsolódó design gondolkodás módszeréhez kapcsolható. Talán erre vezethető vissza, hogy sok olyan fogalom megjelent (ahogy a kódjegyzékben is látható) az oktatási-nevelési metódusához kapcsolódóan, amit a designkommunikáció is a sajátjának feltételez. Ide kapcsolható a nyílt problémamegoldás szükségességére utalás („Tök jó feladat, de csak egy jó megoldás van, vagy egy úton jut oda, akkor az mennyiben fejleszt?’), a nincs rossz válasz elv („Ha magamra gondolok, én erre próbálom tanitani őket: Nincs rossz válasz”), de a szabadság-kreativitás kapcsolatrendszeréhez füződő megközelítése is (,Ha a kreativitásra gondolok, akkor nálam mindig valami szabad, valami más, valami máshogy megközelítés a jellemzö. ”).

$\mathrm{Az}$ interjúból fontos még kiemelni, hogy itt is megjelenik a képességek, készségek szerepe az értékteremtésben, ami a kritikai gondolkozás fókuszba helyezésén keresztül rávilágít a kommunikáció és a kreativitás megkerülhetetlenségére is (,meg kell tanitanunk őket gondolkodni, kifejezni magukat. Ahhoz, hogy értékteremtö felnöttek legyenek, ahhoz elengedhetetlen, hogy kreatívak legyenek, és tudják is használni a kreativitásukat.”). 
Résztvevő megfigyelés

A foglalkozás alapvetően jól indult. Egy befogadó közösséget feltételez, hogy van egy sérült osztálytársuk, akinek nincs meg az alkarja, és a kislányt végig segítették, támogatták, a közösség teljes értékü tagjaként tekintik, amit az osztályfőnök is megerösített, hogy a hétköznapokban is ez a jellemző. Minimális nevetgélés volt az elején, ez jellemző, hogy a kezdeti zavarukat így kompenzálják. A prezentáció során interaktívak voltak (1), majd a kis csoportokba való szegmentáció is gördülékenyen ment (3). Beszélgettek, de nem fókuszáltan, jellemző volt, hogy eltértek a témától (4).

Az osztályszintü együttműködéstől sem ijedtek meg. Volt két akaratos kislány, az ő szavuk érvényesült. „Na, akkor mindenki mondja el a problémáját” Érdekes volt, hogy itt nem a csoportproblémákból indultak ki, hanem egyesével mondtak valamit, de azokat valójában a csoportproblémákra lehetett visszavezetni (3). Túl sok volt a lehetőség és ők maguk sem voltak tisztában azzal, hogy ki mit mondott. Végezetül azok ötlete került fel a lapra, akik vállalták azt és akiknek a legnagyobb hangjuk volt (6). Maga a csapatfeladat ment, a szerepek, a koordináció, de az ötletek gyengék voltak. Nem annyira értették a feladat lényegét, de kis segítséggel elindultak a megoldás irányába (5). Egyikük felhívta a figyelmet a designkommunikáció alaptézisének szempontrendszerére is, megpróbáltak megfelelni. Végül a környezetszennyezés, a müanyag szívószálak beszüntetése, szebb kert és egy „otthonosabb otthon" került a figyelem fókuszába.

Kommunikációjukban visszatükröződött a pedagógus összefoglalása az osztályról, miszerint: „Van egy-egy gyerek, aki nagyon szívesen kifejezi a véleményét, de ö a kákán is csomót keres. De sokszor csak ilyen sült halak. Nem mondanak semmit." Nagyon sok kisgyerek nem tudta kifejezni magát, ami egy szembetünő problémaként realizálódott, ahogy az is, hogy egy hangosabb szó, akár egy durva beszólás nagyobb hatást keltett, mint egy észérv (6).

Ez volt az első csoport, ahol nem csak szóban prezentálták az eredményt, hanem közösen vizualizálniuk kellett azt, amit létrehoztak (8). Ennek az elemnek a beépítésére azért volt szükség, hogy a korábban már taglalt megvalósításnak fizikai formában is teret engedjek, növelve a sikerélmény lehetőségét. A folyamat során kialakult szerepek csak alátámasztották a fentieket: Két kislány irányított, és sok kisgyerek volt jellemezhető a málé kifejezéssel, akik csak úgy vannak, és fogalmuk nincs az érzelmeikről, hogy tetszik-e neki, avagy sem. Az önkifejezés, a kommunikációs készség, de legfőképpen annak hiánya az, ami a legnagyobb gátat szabta a folyamat kiteljesedésének. Itt emelném ki azt is, ami ugyancsak megerősíti az 
osztályfőnök által elmondottakat. A kreativitást igénylö feladat önmagában csak szükséges, de nem elégséges feltétel, kell hozzá még az, hogy a diákok alkalmazni is tudják a kreativitást.

Reflexiók elemzése

A diákok reflexióiból kitünik, hogy nagyon jól érezték magukat, hálásak, amiért ez a foglalkozás velük valósult meg („Nagyon köszönjük, hogy ennyire jó előadást hoztatok”, „Olyan sok hatodikos van a mi osztályunkon kivül is és nagyon örülök, hogy pont hozzánk jöttetek.”). Érdekes, hogy nagyon sok visszajelzés érkezett a kutató személyére (,nagyon kedvesek vagytok”, ,jó idegzetüek”), valamint a közvetlen, szabad (,nem szidott le senki, ha nevettem”), hierarchiamentes (,Nagyon tetszett az, hogy nem kellett magázni egymást”) szituáció megteremtésére. A kutatóra érkezett pozitív visszajelzésből is látszik, hogy változó magatartásukkal tisztában vannak, önkritikusak, és társaik felé is megfogalmazták, mint a foglalkozás kapcsán tapasztalt negatív attribútum („nem tetszett a nagyobb hangzavar”, „,nem tetszett amikor a többiek zajongtak").

A folyamatot tisztán látják, annak ellenére, hogy a megvalósításban akadályba ütköztek. Rávilágítanak a reflexióban, hogy megtörténik a probléma felismerése (,A földet az emberiségtöl kéne megóvni, hogy ne szennyezzék szegény földet”), majd annak osztályszintü megbeszélése (,Az tetszett, amikor csapatot alkottunk és meg kellett beszélni azt a bizonyos problémát”), ezt követően pedig a megoldás megteremtése (,A környezetet meg lehet menteni a hozzájárulásunkkal") a hozzájárulásukkal együtt valósul meg. Felmerül a kérdés, hogy ha ennyire átlátják, akkor miért nem tudják alkalmazni ezt az ismeretet megfelelően a gyakorlatban. A szóbeli kommunikáció, az önkifejezés hiánya magyarázatként szolgálhat a problémára. A reflexiók elemzése során kiemelt jelenségeket is magába foglaló kódrendszert az alábbi ábra összegzi. 
22. ábra: Diák reflexiók kódjegyzék - Hódmezövásárhely

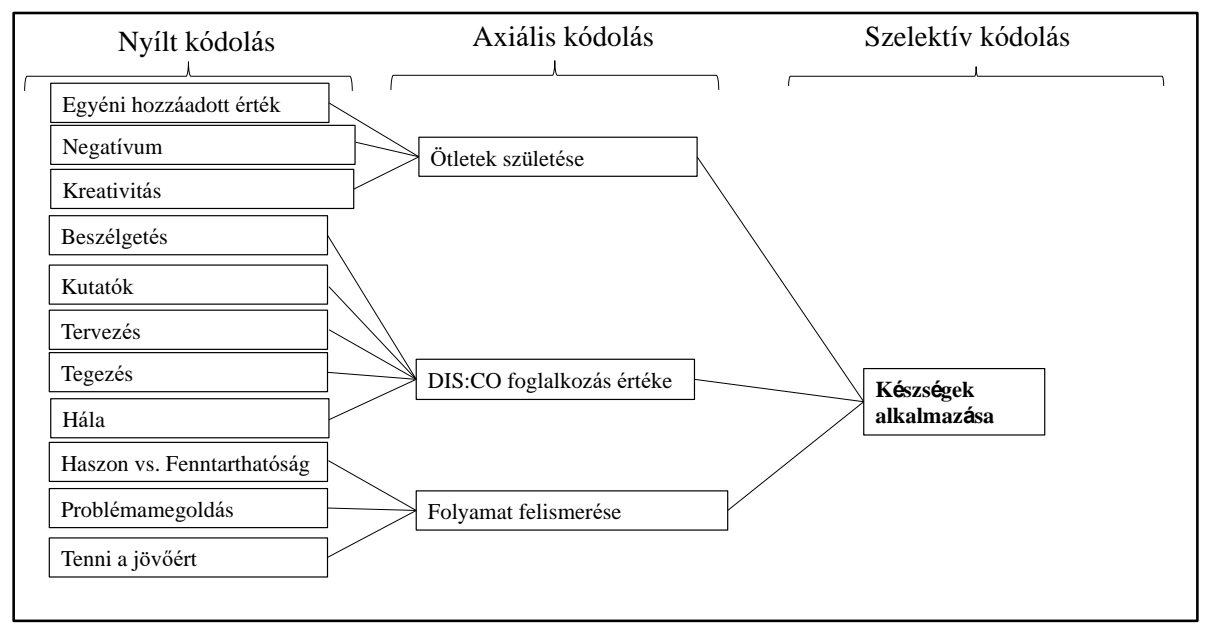

Forrás: A diák reflexiók elemzése alapján saját szerkesztés

\subsubsection{Borsod-Abaúj-Zemplén megye, Sajószentpéter}

Mélyinterjú

23. ábra: Pedagógus mélyinterjú kódjegyzék - Sajószentpéter

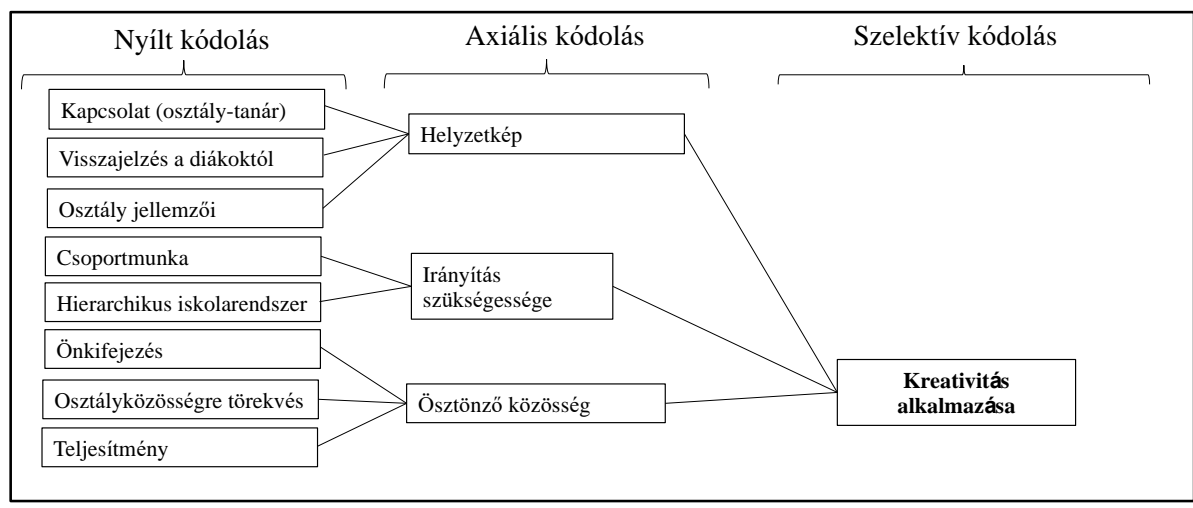

Forrás: A mélyinterjú leiratának elemzése alapján saját szerkesztés

A pedagógus mélyinterjú elemzése és kódolása során, ami a kutatási fókuszom szempontjából a leginkább érdekes eredmény az a kreativitás kapcsán a pedagógus tollából megjelenő fogalmi definíció (,Kreativitás az, hogy valaki fölfog valamit, a magáévá teszi, és be tudja azt építeni valamilyen módon, és tovább tudja azt használni valamilyen módon.”). Hódmezővásárhelyen is előkerült már, hogy a kreativitás minden kisgyerekben fellelhető, ugyanakkor az alkalmazás, a tudatos beépítése a folyamatba már kevéssé hatékony. Ehhez kapcsolódóan a pedagógus feladatát abban látja, hogy erre alkalmas módszerek bevonásával tudatosan támogatja a kreativitás ösztönös megjelenésével párhuzamosan, annak célzott alkalmazását (,,arra kellene törekedni, hogy vagy elültetni, vagy elöszedni, és hasznos dologra 
forditani."). A designkommunikáció workshop sajátossága, hogy nem keretezi a kreativitást, tartományokon átívelő kreativitás megközelítése alkalmas módszerként szolgál a probléma kiküszöbölésére.

A fentieket vélhetően nem segíti a hierarchikus iskolarendszer, ami folyamatos instrukciókkal látja el a diákokat, akik ehhez a helyzethez hozzászoktak és nem várható el tőlük, hogy parancsszóra képesek legyenek az önállóságra, a gondolatok szabad áramlására. Érthető tehát, hogy igényük van a pedagógus irányítására (,Szokatlan volt nekik, hogy nem voltak irányítva. Ez a csoport, ök nagyon szeretik, ha öket irányitják.”).

\section{Résztvevő megfigyelés}

A terem átrendezését követően kezdődött meg a workshop. Ez az iskola egy tehetségpont, így a gyerekek a főbb tantárgyakat csoportbontásban tanulják, ami azt jelenti, hogy az osztály nincs mindig együtt, egy másik hatodik osztállyal alkotnak csoportokat képesség alapján. Az osztálynál osztályfőnök csere volt, így a mostani osztályfőnök egy éve van velük. A valódi osztályközösség megléte tehát bizonytalan lábakon áll. Az osztályfönök és a magyar tanár szinte végig bent voltak, és több esetben beleszóltak, hangosan beszéltek, ami egyértelmüen zavaró volt, nem volt jó hatással a gyerekekre, akik így nehezen tudtak elszakadni a hagyományos, szigorú hierarchikus keretrendszertől.

A prezentáció során aktívak voltak (1), rengeteget hozzászóltak, kérdeztek (2), egyértelmüen nagyon okos gyerekekröl beszélünk. Végig figyelemmel kísérték az előadást (1), annak második felében a kérdés már nem volt jellemző (2), de ha én kérdeztem, akkor arra mindig sok hozzászólás érkezett. Kis csoportokban jól müködtek, csendesen beszélgettek végig, nem nagyon volt olyan, aki elhülyéskedte (4). A gyerekek önkifejezése valóban összecseng a pedagógus által elmondottakkal, nagyon szépen, választékosan fejezték ki magukat.

A nagy csoport először jól indult: „na valaki mondjon egy ötletet”, úgy tünt, hogy kialakulnak viszonylag gyorsan a csoportszerepek, de aztán sokkal inkább a káosz, a nyüzsi, a klikkesedés vált jellemzővé (5). Egymásra már kevésbé figyeltek, nem is hallották egymást (6). Csoportszerepek nem alakultak ki. Néha volt, hogy valaki hangosabban beszélt, akkor néhány másodpercre elnyerte a figyelmet, de aztán újra nyüzsi és zsivaj és külön csoportok kaptak helyet (6). Érezték, hogy nehezen megy ez nekik, ami még inkább hátráltatta a munkát. A végén mindennek ellenére ők úgy érezték, hogy a döntés, a produktum együtt született, hogy ők ezt közösen döntötték el, és hogy mindenki egyet értett a végeredménnyel $(8,9)$. 
Az, hogy miért nem tudtak együtt dolgozni vélhetően annak tudható be, hogy keveset vannak együtt, mint osztály, valamint a pedagógus által is említett szabályok és az iránymutatás szükségessége hiányzott a gyerekeknek. Hiába a sok csoportmunka, csak olyan módszert alkalmaznak, melynek során a csoportszerepek és a feladatok rögzítettek, így a valódi nyílt problémamegoldási helyzettel nem szembesülnek. Magas érzelmi intelligenciájú, okos diákok, kiemelt volt a szóhasználatuk, mégis nem tudták elérni azt, hogy a csoportot terelgessék, és valóban csoportként müködve hozzanak létre egy mindenki számára elfogadható döntést (8) (még akkor sem, ha ök ezt közös döntésként élték meg). Hiányzott a közös gondolkodás, megalkuvás, a kompromisszum, elfogadás és egymás motiválása, melyek mind a soft készségek fejlesztését kívánnák meg a hierarchikus vasszigor és fegyelem helyett.

\section{Reflexiók elemzése}

A reflexiók eredménye is abszolút összecseng a fentiekkel. A diákok a feladatot nem érezték kudarcnak, azonban a produktumhoz való hozzáállásukat meg sem említették. Ezzel párhuzamosan viszont szinte kivétel nélkül rögzítették azokat a jelenségeket, ami miatt nem sikerült gördülékenyen az együttmüködés („Nem jutott mindenki szóhoz, mert folyton kiabáltak”, „Nem hallgattuk meg egymást”, „,Nem mindenki vette komolyan, bolondságokat beszéltek.”). A foglalkozás egyediségét a tanulás („Tetszett az, hogy új információkat tudhattam meg és elmondhatta mindenki a véleményét”, „, Sokat játszottunk és tanultam új dolgokat”), az alternatív szabályok („Jó volt a program és, hogy nem voltunk szigorú szabályokhoz kötve”), a szabadság (,Az tetszett benne, hogy nevethettünk, meg sokat beszélgettünk”, ,,Tetszett az órában az, hogy ez egy ilyen laza óra volt, de tanultunk is valamennyit") és a kreativitás (,Nagyon tetszett az, hogy kreativnak kellett lenni mindenben”, „, Nagy kreativitás kellett ahhoz, hogy ez létrejöjjön”) fogalmaihoz kapcsolták.

A designkommunikáció foglalkozást az élmény (,, Nagyon bele lehetett élni magadat” „Nem tetszett, hogy véget ért ez az egész, mivel nagyon jól éreztem magam”), a hála („Remélem, hogy máskor is eljöttök ide a 6. a osztályhoz”) és az ajánlás (,Szerintem nagyon sok embernek részt kellene vennie egy ilyen órán, mert sokkal átláthatóbbá tette nekem ezt a témát") nézőpontjából értékelték.

A téma, hogy tehetnek valamit a jövőért nagy hatással volt rájuk (,Az tetszett, hogy próbáltuk a környezetünket védeni, megbeszélni ezeket a dolgokat"), a vállalkozói attitűd is megjelent (,Szerintem mi most nem diákok voltunk, hanem kis emberek, akik, mint egy megbeszélésen megterveztük a jövőt."). 
24. ábra: Diák reflexiók kódjegyzék-Sajószentpéter

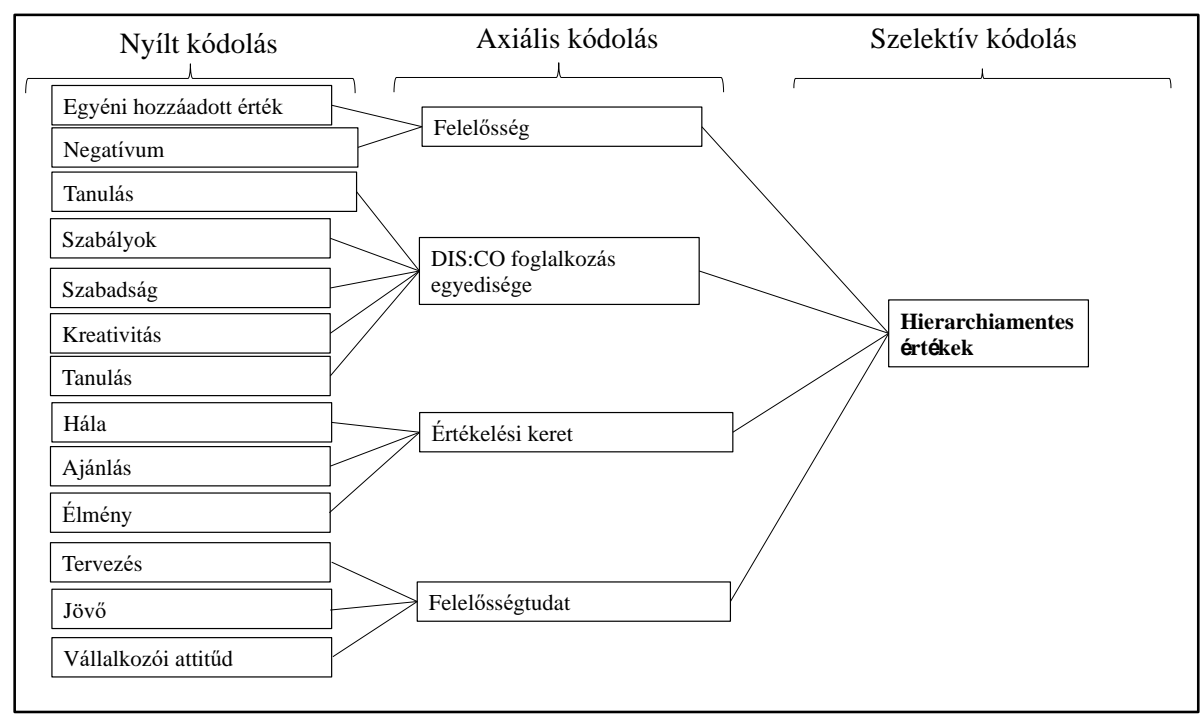

Forrás: A diák reflexiók elemzése alapján saját szerkesztés

\subsubsection{Tolna megye, Tamási}

Mélyinterjú

A Tamásiban készült interjú egy olyan pedagógus személyiséget tárt fel elém, ahol a kreatív kapcsolatteremtés nem újszerü módszerek által, hanem a pedagógus személyiségén keresztül valósul meg, ő maga is ebben látja a pedagógus legnagyobb erősségét (,sokkal fontosabb a tanár személyisége, mint az, amit megtanít. Úgy éreztem, hogy ez annyira rólam szól."). Pótanyaként szereti a diákjait, és a példamutatás az, ami meghatározza véleménye szerint a diákok viselkedését (,Én azt gondolom, hogy tükröt tartanak ők. Pontosan azt adják vissza, amit adunk.”). Szabadságot, teret ad a gyerekeknek, meghallgatja őket, ami a tanórán (,nekem hitvallásom az, hogy nálam nem szabad félni, ne úgy üljön be, hogy görcsöl”) és a kommunikáció során egyaránt megjelenik (,Ezeknek a gyerekeknek szükségük van arra, hogy valaki meghallgassa öket, az ö kis életüket, meg a problémáikat, meg a lelki válságaikat.”). A tanórán kívül is megteremti az interaktivitást, ami már korábbi interjúkban is előkerült. A közösség építésének legfontosabb elemét az elfogadásban rögzíti („Mindenképpen az elfogadás. Az egyetlen dolog, amire harapok mind a magánéletben, mind az osztályközösségben, ha valaki a másikat bántja.").

Ez a hozzáállás azonban ellentétes azzal, amit a pedagógus társadalom (,De úgy érzem, hogy kilógok itt a sorból, és sokszor azt is érzem, hogy a pedagógus társadalom kivet magából, 
mert nem tudok azonosulni a pedagógus konvenciókkal, a tekintélyelvüséggel’), az oktatáspolitika (,megnyomoritjuk a gyerekeket, mert sajnos a magyar állami iskolákra az a jellemzö’) és a rögzült hierarchikus iskolarendszer (,Sok kolléga nem toleráns, a gyerek egy robot, akinek minden órára fel kell készülnie, ö nem hibázhat, nem hagyhat otthon semmit, nem lehet beteg.”) kínálni tud. Ez a keretrendszer a diákok nézőpontjából téves motivációt („Ő csak azért tanul, a jó jegyért. nem azért, mert neki ez a tudásvágya.”), vagy motiválatlanságot („Az én gyerekem, aki mellette sportol, utál iskolába járni, mert utálja azokat a haszontalan dolgokat, amiket meg kell tanulni, betanulja, aztán elfelejti. Ugyan kitünö tanuló, de tudja, hogy nem sok hasznát veszi ezeknek a dolgoknak az életben.") eredményez, nem teszi lehetővé, hogy a diák felszabadult legyen, az a fajta szabadság marad el, ami a kreativitást ösztönözhetné.

25. ábra: Pedagógus mélyinterjú kódjegyzék - Tamási

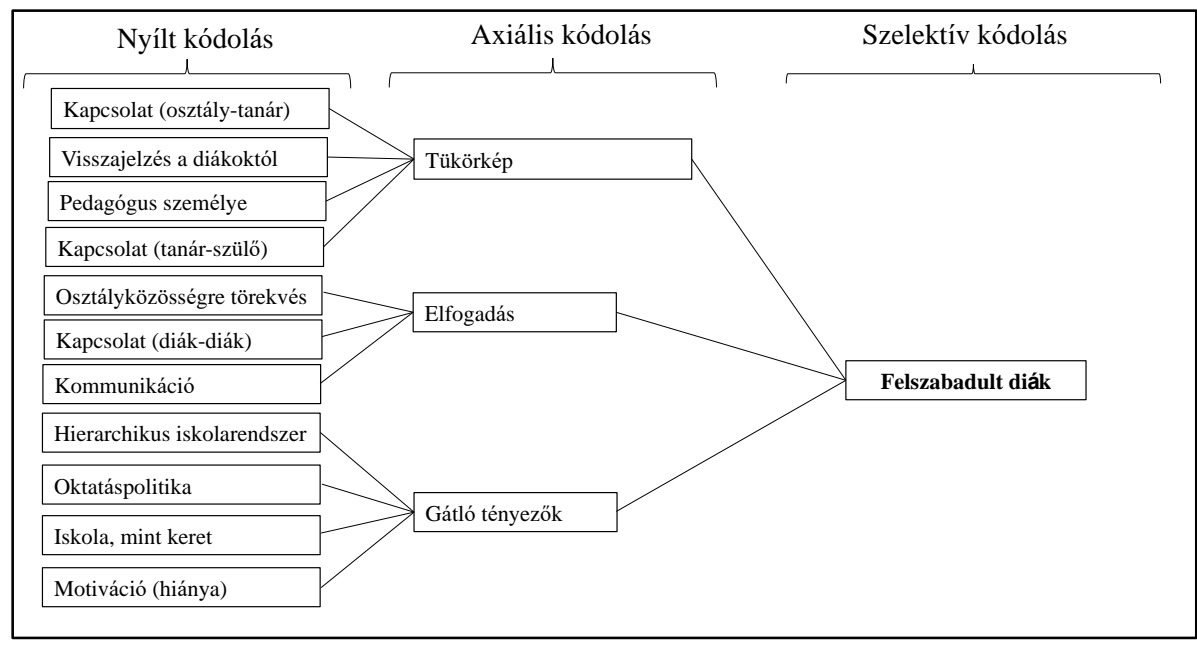

Forrás: A mélyinterjú leiratának elemzése alapján saját szerkesztés

Résztvevő megfigyelés

Az osztályfőnök meglátása az osztályról beigazolódott, egy rendkívül jó képességü, értelmes és okos osztállyal dolgozhattunk. Volt egy kisgyerek, akire az igazgatóhelyettes rögtön felhívta a figyelmünket (az osztály elött), hogy rá különösen figyeljünk (4). Nyilvánvalóan erre a kisgyerek és az osztály is rájátszott és az amúgy véleményem szerint teljesen kezelhető kisfiút egy igen sajátos polcra tették, a kezelhetetlen/hiperaktív fiókba. A gyerekek a bemutatkozás alatt figyeltek, majd a labdás bemutatkozás során a következő fogalmakkal azonosították az otthonukat: „otthon, család, szeretet, összetartozás, boldogság, szórakozás, macska, öröm, nyugalom, humor, biztonság”. Természetesen itt is jellemző volt, 
hogy az első hozzászóló befolyásolta a többiek véleményét, de ez tendenciaként figyelhető meg mindegyik iskolában.

Ezt követően került sor a megszokott menetrend szerint az előadásra (1), ami meglehetősen interaktív volt. Nagyon sok hozzászólás érkezett a gyerekektől, az előadást aktív figyelem (2) jellemezte, a vége felé kezdték elveszíteni picit a figyelmüket, ami teljesen érthető volt. A kapcsolatteremtést a barátsággal, a nyitottsággal a párbeszéddel azonosították külön kiemelték az arckifejezést, a testbeszédet.

A kiscsoportokban kifejezetten jól ment a munka (3), nagyon aktívak voltak, folyamatosan beszélgettek, akartak együtt dolgozni. Előtte az egyéni problémát is hamar azonosították, felmerült kérdésként, hogy otthon azonosítható-e a tágabb környezetükkel (környezet/iskola).

Kis csoportokban a következő témákat érintették (3):

1. Szemétszedés- volt egy csoport, aki ennek kapcsán végigvette az összes designkommunikáció sorvezetőt, hogy az állandó/változó szerint fontos, hogy ki melyik napon szedi, fix vagy változó napokon történik-e az esemény. A kockázatot abban értelmezték, hogy kockázatos lehet, ha kesztyü nélkül szedik, ha összeszedik, de egy helyen hagyják és az is, ha nem szedik össze! Erre próbáltak azonnal megoldást is találni.

2. Egy másik csapat arra fókuszált, hogy ők a tanulmányi eredményeiket javítanák (TEJ) projekt. Jobbak lesznek a jegyeik, motiválják egymást, kikapcsolják a telefonjaikat és többet foglalkoznak a tanulással.

3. Kajaautomata: Mely arra szolgálna, hogy bele lehet tenni az ételt és a hajléktalanok kivehetik belőle. Kockázat lehet itt az étel romlandósága (hütő) és esetleg az, hogy illetéktelen veszi ki az ételt.

4. Környezetvédelmi csapat, aki megtervezte már a plakátot is (háttérben vízesés, felülre a név, hogy miért alapították) minden hétvégén mennek körbe szemetet szedni és ezt összekötnék egy kis „mulatozással” hiszen mindenki vidám és énekel.

Megkezdődik a nagy csapat munkája. Van egy kislány (az osztályfőnök lánya), aki megkezdi és kézbe veszi az irányítást. Miután kiderült, hogy két csapat is a szemétszedésre adta a voksát, a többi ötlet kicsit háttérbe szorult. Egész ügyesen zajlott az osztályszintű együttmüködés. Mindenképpen figyelemre méltó, hogy a módszertani sorvezetőket szem előtt tartják és végigveszik a projekt kapcsán. Érzik is, hogy nem mindenki vett részt egyenlő arányban, hiszen mikor megkérdeztem, hogy osztályszinten született-e a döntés, akkor az volt a vélemény az egyik kisfiúnak címezve, hogy „,nem osztályszinten, mert te nem figyeltél oda”, „,aki idefigyelt annak az ötlete" Eredményként a „Szedd magad akciót" határozták meg. A produktum 
vizualizálása nagyon tetszett nekik (9), összekuporodtak együtt a földön és úgy rajzoltak. A kezdeti nagy lelkesedés a vége felé picit csökken (4), elszállingóznak, de az erős mag megmarad és nagyon informatív plakát születik (8). Láthatóan nagyon jól érezték magukat, és ezt az elismerésüket ki is fejezték a kutatók felé.

Reflexiók elemzése

A gyerekek reflexiója határozottan az élmény köré összpontosult (,Köszönöm az élményt, örülök, hogy ellátogattatok hozzánk”). Kifejezetten jól érezték magukat, ami jól definiálható elemek meghatározására épített. Nagyon fontos volt számukra a pozitív kutatói attitűd (,Ez $a z$ óra nagyon fantasztikus volt és méghozzá azért, mert bármit mondtunk, te mindig pozitívan álltál hozzá.”), hogy nincs rossz válasz (,Érdekes volt és tetszett az is ebben a foglalkozásban, hogy nem volt rossz válasz és sok jót tudtam mondani”), valamint az is, hogy hierarchiamentes keretek között dolgozhattak („Tetszett, hogy mindenkit meghallgattak és mindenkinek számított a véleménye”, „Tetszett, hogy mindenki ugyanannyit ért, és mindenkivel ugyanannyit foglalkoztál"), ami összecseng a pedagógus által elmondott szigorú oktatási korlátok, mint problémaforrás jelenlétével. Ugyancsak hozzáadott értékként jelent meg, hogy tanulhattak (,sok mindent tanultam ebben a pár órában”) a foglalkozás során, és tehették ezt játékos módon (,A mai napon 3 nagyon szuper játékos órát tölthettünk veled”, ,Szerettem, hogy nem egy komoly rideg, hanem egy játékos óra volt”).

A hála és a visszatérés lehetősége is fokozottan jelen volt, a gyerekek meghatározó hányada szerette volna, hogy újra megvalósuljon a workshop (,Remélem még látlak, és tartasz még ilyen órát”, „Nagyon szépen köszönjük, amit értünk tettél, szebbé és érdekesebbé varázsoltad a napunkat").

A közös munkát szerették, de a stabil osztályközösségük okán kivételesen nem ez volt a fő fókuszban, sokkal inkább vonták ezt össze a téma komolyságával, értékelve azt, hogy egy jelentőségteljes probléma megoldásán dolgozhattak és tehették ezt együtt („Tetszett az a rész, amikor ki kellett találni, hogy hogyan tudunk mi segíteni a világnak”, „Együtt nagyon szuperul és értelmesen tudtuk megoldani a problémát"). 
26. ábra: Diák reflexiók kódjegyzék - Tamási

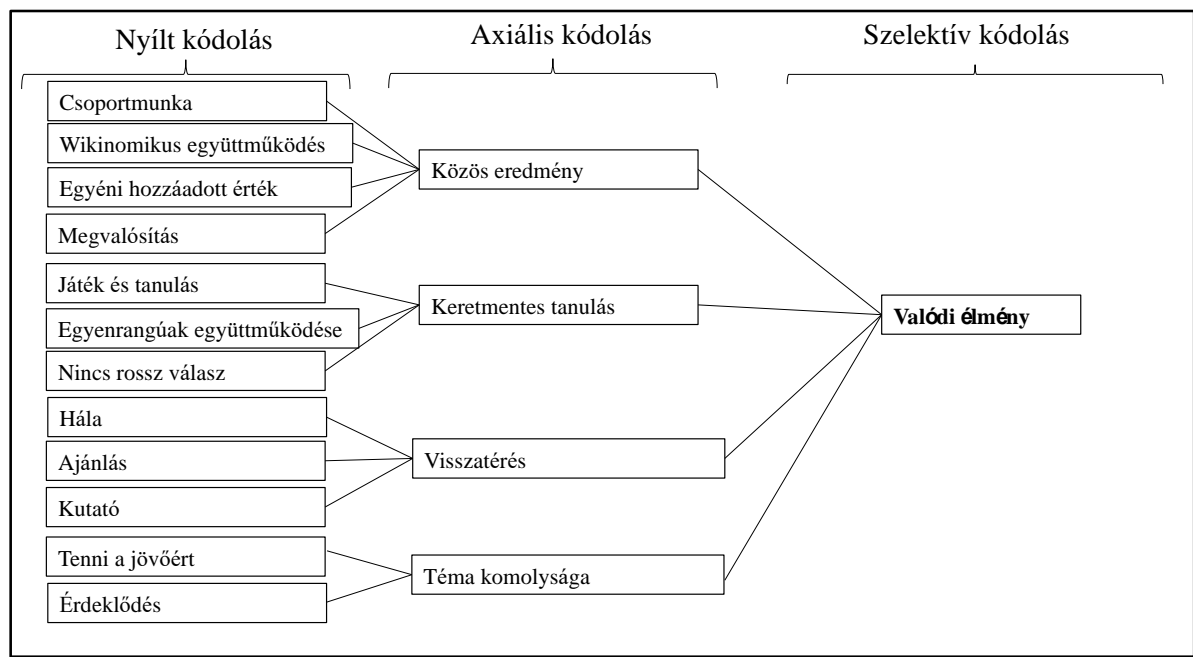

Forrás: A diák reflexiók elemzése alapján saját szerkesztés

\subsubsection{Szabolcs-Szatmár-Bereg megye, Baktalórántháza}

Mélyinterjú

Fontos rögzíteni a helyzetet, hiszen itt egy szegényebb iskolai környezetben zajlott a foglalkozás, sok a hátrányos helyzetű kisgyerek, ami már önmagában meghatározza a pedagógus kereteit és lehetőségeit. Az osztályban 15 tanulóból, 12 hátrányos helyzetű, közülük is a legtöbben halmozottan hátrányos helyzetüek. Van olyan kisgyerek, aki nevelőotthonban nevelkedik és olyan is, akinek az apukája börtönben van. Nem véletlen, hogy munkájának nagy részét az oktatás mellett a nevelés jelenti („Ha azt nézzük, a pedagógus munkája két fö részböl áll, az oktatás és a nevelés.”). A közösség építésére az agilis igazgató törekvéseinek eredményeként van lehetőség („mindenféle pályázati lehetőségbe részt veszünk, és az igazgatónk is ebben nagyon aktív, meg partner, meg kezdeményezö. Ennek kapcsán eljutunk több helyre.”), a pályázatok, és az általuk biztosított jutalmak motivációként is szolgálnak a diákoknak. Az iskola minden pályázatot megpróbál, ugyanakkor kicsit „habzsolja” a pályázat nyújtotta anyagi és eszköz előnyöket, de a programok valódi tartalma (ha van persze), már kevésbé kedvező, hiszen azzal sok a munka, ami plusz terhet jelent a pedagógusoknak.

Fontos még kiemelni a kreativitáshoz füződő viszonyt. Ami inkább a gátló szervezeti tényezőkben jelenik meg (,Mindenkinek megvan a maga programja, itt megvannak a sémák, hogy mi szerint kell csinálni, én nem látok benne kreativitást.") és az egyéni kreativitás támogatása is bizonytalan lábakon áll (,A 8. osztályban van egy kislány, aki nagyon kreatív, és nem tudunk neki segíteni, ahogy kellene.”). Ehhez társul még a pályázatok kötött jellege, ami 
az egyéni hozzáadott értéket nem, vagy nem igazán teremti meg a pedagógusnak („Igazából azért nem találok semmi olyan kreatívat, mert annyi minden van, ami kötött. Valakinek az adott programja, és aszerint kell végigmennünk, van egy algoritmus szinte. Gyakorlatilag abban nincs kreativitás, és annyi mindenben, de minden téren veszünk részt. Ebbe a mi kreativitásunk eltünik.”). Ezzel párhuzamosan azonban tisztában van a tanár azzal, hogy a kreativitás kibontakozásához az ő személye is szükséges feltétel (,Mert egy kreatív pedagógus biztos, hogy tud hatni a gyerekekre. És akkor a kreativ gyerek, aki eleve kreativ, mert szerintem erre születni kell, abból elö tudja csalogatni.”). A kreativitás interjúban megjelenő dimenzióit a kódjegyzék is tartalmazza.

27. ábra: Pedagógus mélyinterjú kódjegyzék - Baktalórántháza

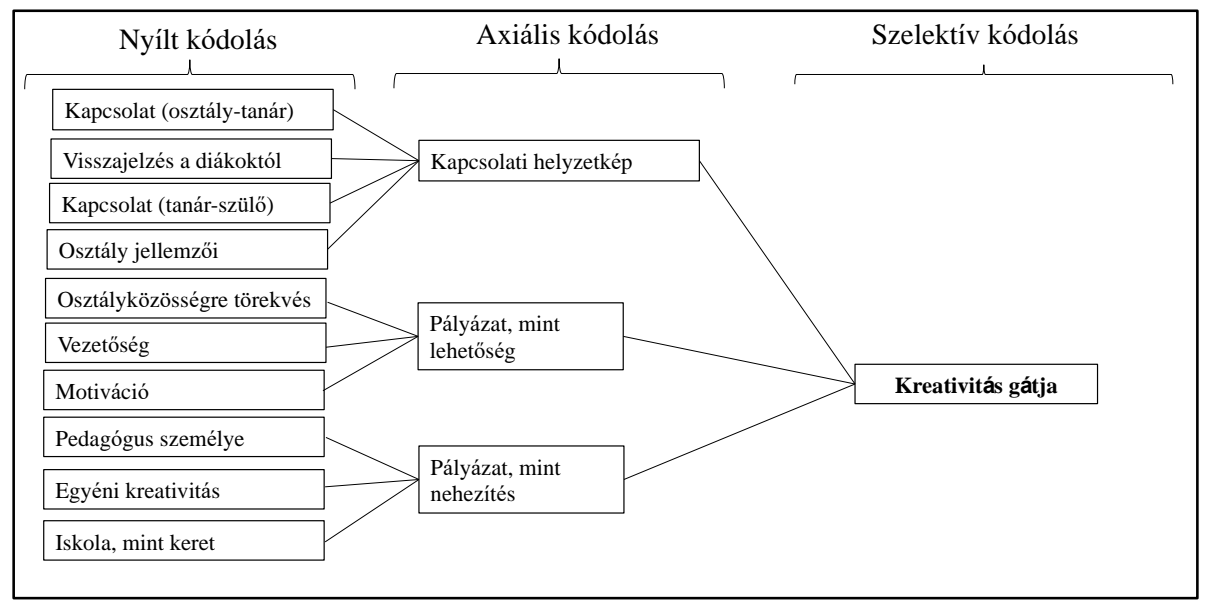

Forrás: A mélyinterjú leiratának elemzése alapján saját szerkesztés

Résztvevő megfigyelés

A workshopot csak 12:30-kor tudtam elkezdeni, ami azért azt jelentette, hogy a gyerekek már szinte egy egész iskolai délelőttön túl voltak, fáradtan kezdték a munkát (1). Kedves, aranyos diákok voltak a résztvevők, magatartásproblémák igazán nem merültek fel a foglalkozás alatt. A labdás feladatot szerették, hamar befogadtak a körbe. Az elején nagyon meg voltak illetődve, de aztán belejöttek a játékba (2). Nem véletlen, hogy az otthont fóként evéssel, tévézéssel és alvással azonosították. Egy-két alkalommal elhangzott a család szó, de a korábbi csoportoknál jellemző érzelmet kifejező asszociációk elmaradtak. A prezentáció nagyon interaktívra sikeredett (2). Voltak értékes hozzászólásaik, de többnyire inkább átlagos, vagy átlagon aluli képességekkel rendelkező gyerekek voltak. 
Kis csoportokban nagyon ügyesen dolgoztak (3). Három csoport volt. Egyikük a szemétszedés, a szelektív hulladék kérdésével foglalkozott (5). Volt egy csoport, aki pedig éhező gyermekek segítését tüzte ki célul. A harmadik csoportnál az állatok védelme volt a központi téma, de konkrétumokig nem jutottak.

Az osztályszintű közös munkának nagy lendülettel álltak neki, hamar bezárták a kört. Elkezdtek együtt beszélgetni, aztán összeesett a csapat. Elvicceskedték, elfáradtak, nem tudták értelmezni a feladatot, szétesett az egész, de ezt ők is érezték (,Ílgy csak magunkat szégyenitsük"). Jellemző volt egymás fegyelmezése (4), és a felénk való megfelelés is megjelent (,Saci néni úgy irt le minket, hogy mi okosak vagyunk, eljöttek ide és tessék”).

A közös rajz során (9) érdekes megoldás volt, hogy egy kislánynak (korábban már utalt rá az osztályfőnök, hogy ő a „kreatív” kislány, valószínüleg ez így van az ő fejükben is) adták a lapot, ő rajzolt. De a többiek nem hagyták magára, végig ott voltak a környékén, és mondták, hogy mit rajzoljon (8). Kiscsoportban jól müködtek, nagyobb csoportban határozottan szétcsúsztak, nem is született igazi produktum, ennek ellenére a gyerekek láthatóan jól érezték magukat.

Reflexiók elemzése

A reflexiók is rávilágítottak arra, hogy a diákok jól érezték magukat. Azokat a helyzeteket emelték ki, amikor hatékonyabban tudtak együtt dolgozni és amit komolyan tudtak venni (,Nekem legjobban a kiscsoportos munka tetszett, mert azt komolyan vettük”). Zavarta őket, hogy a feladatok egy részét nem tudták megoldani, önkritikájuk erös, felmérték, hogy ez a nevetgélésnek volt a következménye („Elhülyéskedtük, az osztály kacarászott, nem tudtunk választ adni a kérdésre”, „Több, mint a felét elkacagtuk a nagycsoportos munkának és nem is jól oldottuk meg a feladatot”.). A foglalkozáshoz kapcsolódó feladatokat (,Az előadás minden részét élveztem”, „Jók voltak a feladatok”, „Érdekes volt ez a DISCO munka”) és a kutató személyét is kiemelték („Kedves és megértő voltál, ezen kívül türelmes és vicces”). Felismerték, hogy a foglalkozáson tudást is elsajátítottak („Jó volt megtudni új dolgokat”) és felmerült az igényük a folytatásra is („Jó feladatok voltak és nem voltak unalmasak, bárcsak az órák is ilyenek lennének”. „Ebböl akár egy szakkört is lehetne csinálni”, „, Annyira szuperul éreztem magam, hogy még remélem találkozunk egyszer".)

Saját maguk hozzáadott értéket nagyon sok esetben a jó ötletekben látták, ami arra enged következtetni, hogy a kreativitás bennük van, csak nincs terük és lehetöségük annak kibontakoztatására, ami teljesen összecseng az interjúban elmondottakkal. 


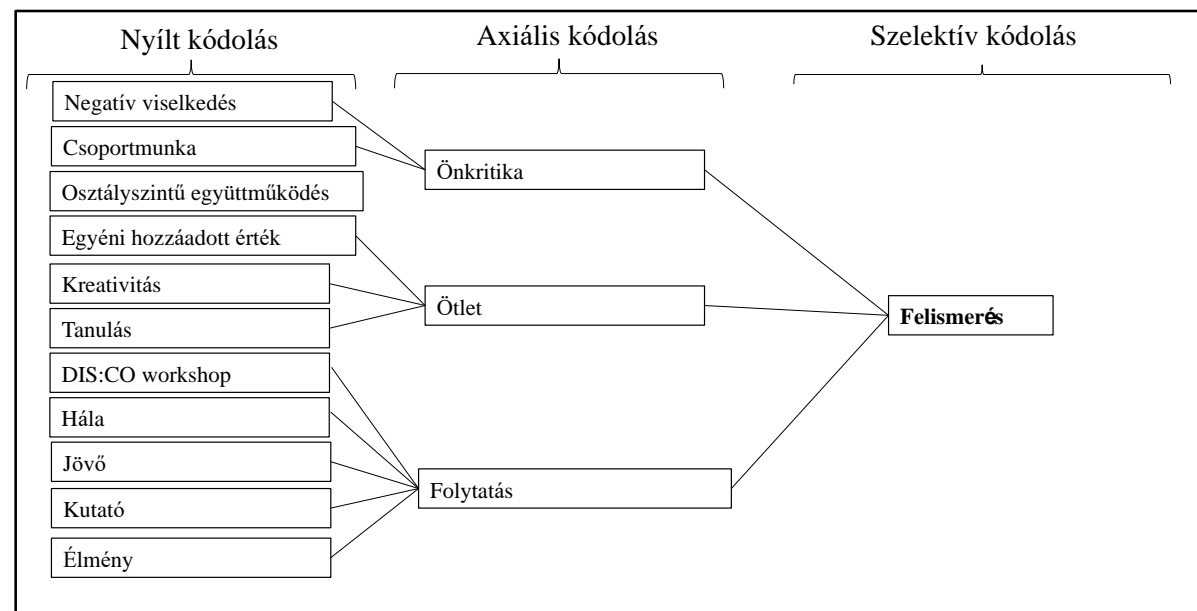

Forrás: A diák reflexiók elemzése alapján saját szerkesztés

\subsubsection{Jász-Nagykun-Szolnok megye, Besenyeszög}

Mélyinterjú

A designkommunikáció kapcsolatát és rokon viszonyát a művészet alapú kutatásokkal már egy korábbi fejezetben rögzítettem, azonban most itt a gyakorlatban újra elökerült a párhuzam. Besenyeszög településén a pedagógus, akivel a mélyinterjú készült az intézmény művészeti iskolájának az alapítója, ami meghatározza attitűdjét, a kreatív alkotói kapcsolatteremtés természetes velejárója mindennapjainak (,Az átlagos megcsinálja a dolgát, és jól megcsinálja. Régebbre visszanyúl, vesz onnan valami ötletet, de nem viszi tovább, ugyanazt csinálja. A kreatív tervezői kapcsolat, szerintem én vagyok, hogy kreatívan tudom feldolgozni a dolgaimat."). Diákjai szemében is ő maga a megtestesült kreativitás (A gyerekek nézőpontjából: nagyon kreatívnak tartanak, „,nagyon jó ötletei vannak tanár néninek”). A kreativitás iskolába történő integrálását azért is tartja kiemelten fontosnak, mert véleménye szerint nincs más út a diákok felkészítésére a folyamatosan változó környezet (,Mert az egész világunk megváltozott. Tehát változik. A kreativitás, a kreatív megoldások azok válaszok a folyamatra, a változásra.”) a készségek fejlesztését kívánja meg (,Azt se tudjuk, hogy mi kell 5 év múlva. Azért nagyon fontos, hogy ne egy adott anyagot tanuljon, hanem próbáljon rugalmasnak lenni. És akkor, ha valaki elég kreativ, az tud ebböl épitkezni, meg tud változni, újat tud hozni, tanulni.").

Ugyanakkor probléma, hogy erre a hazai oktatási keretrendszer, a hierarchikus viszonyok (,Magyarországon, mindig volt a „,nagy” tanárnő, és akkor ő mondta az igét. Ezt be kellett 
látni, hogy ez már régen nem így van.") nem engednek kellö teret, nem követi a rendszer kellő ütemben az élet és a diákok igényeinek a változásait (,Szerintem nem az életre tanitanak. Én nekem nagyon merev az iskolarendszerünk."). A pedagógus lehet valamilyen szinten a kreativitás térnyerésének a motorja, azonban pontosan a fenti problémák okán a rendszer ezt nem hagyja, hiszen az egyéb kötelezettségek óriási terhet rónak rájuk. („Tehát sok mindent lehet csinálni, csak munka kell hozzá. És nem panaszkodván, de most, ha 24 órát bent vagyunk, akkor én sem tudok annyi az ötleteimre fordítani pluszba, mert az energiámat kiveszi az, hogy a gyerekekkel vagyok annyit.")

29. ábra: Pedagógus mélyinterjú kódjegyzék - Besenyeszög

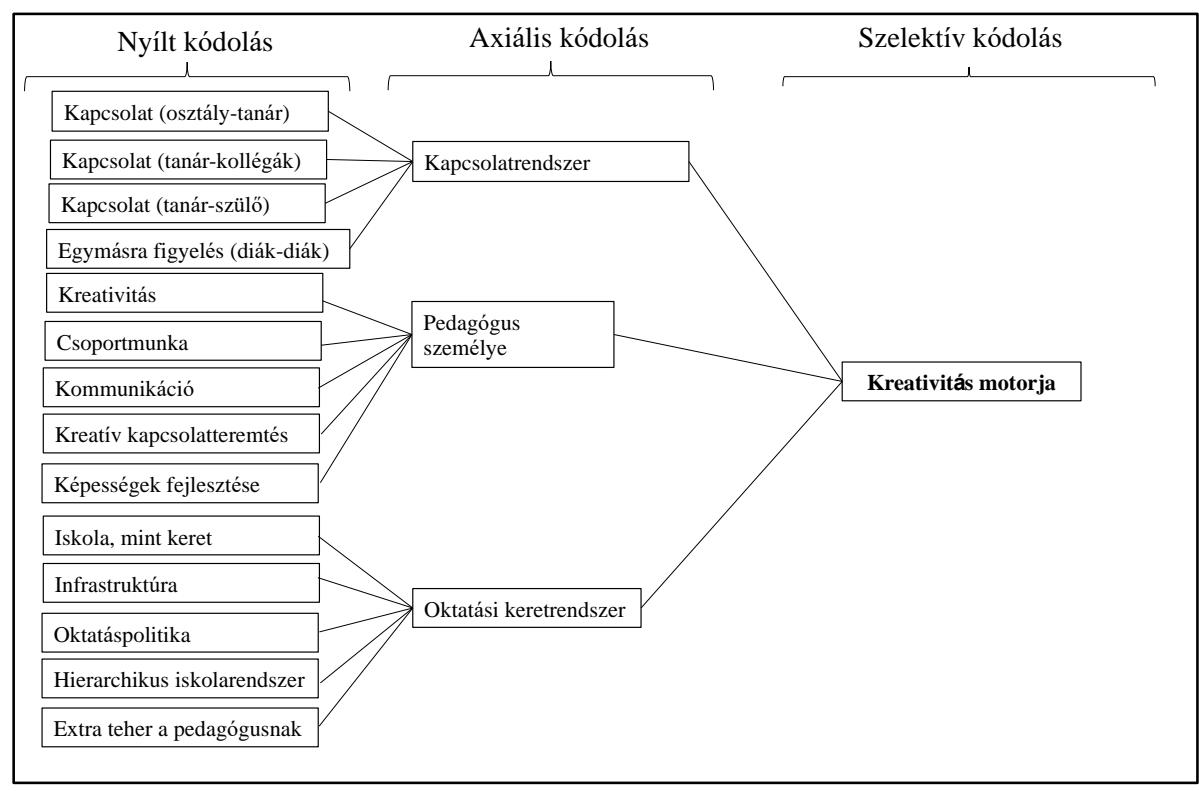

Forrás: A mélyinterjú leiratának elemzése alapján saját szerkesztés

Résztvevő megfigyelés

A workshop az iskola melletti különálló „művészeti kuckóban” kapott helyet. 10-kor kezdtük a gyerekekkel a foglalkozást, ez az ideális időpont. Ekkorra felébrednek, aktívak, de még éppen bírják ebédig. Teljesen más volt a workshop egy olyan helyszínen, ahol nincsenek tanteremre emlékeztető szabályos formák, rendszer, asztalok, székek. Egy olyan helyre érkeztünk, ahol mindenki megnyílhatott, ahol nem volt az az érzésünk, hogy egy iskolában vagyunk, ahol mindenki felszabadult, játékos és kreatív tudott lenni, hiszen akkor járnak erre a helyre, amikor ez a feladatuk. Munkájuk során érződött mindez. 
A gyerekek magaviselete is rendben volt, maximálisan, szót fogadtak nekem (4). 16 kisgyerek jár az osztályba, közülük egy ikerpár hallássérült, de ez a gyerekeket cseppet sem zavarta, befogadták őket. Az osztályközösség tehát erős és szoros volt. Nem nevették ki egymást, nem gúnyolódtak. Nagyon jól müködtek együtt mind kis és mind nagycsoportban (3).

Az otthont itt már sokkal inkább társították érzelemhez és a családhoz: „család, barátok, jól érzem magam, háziállat, jó otthon, kockulni, ott a legjobb lenni, biztonságban érzem magam" kifejezések kerültek elö. A prezentáció itt is nagyon interaktív volt (1), ők egy nagyon értelmes, okos társaság, hihetetlenül jókat mondtak (2), látszik, hogy van mögöttük családi háttér, hogy foglalkoznak velük. Az egyéni feladatot csendben oldották meg (3), majd négy darab négy fös csoportba osztottam őket. Nagyon ügyesen dolgozott a legtöbb csoport (5), valóban a témáról beszélgettek, és mindenkit bevontak. A következő ötletek születtek (9):

1. Nyugiszoba, ahova el tudsz vonulni és le tudod vezetni a stresszt

2. Újrahasznosított anyagokból készített robot, aki megcsinál mindent

3. OBJEKTÍV MEGOLDÁS -rendrakás (minden nap rakjunk rendet, hogy ne gyüljön össze a rendetlenség)

4. Egy felhívás, hogy ne a számítógép előtt üljön mindenki, hanem menjünk ki a szabadba játszani

A nagy csoportban sem okozott problémát nekik a feladat. Munkájuk (hatodikosokhoz mérten) olyan szépen fel volt építve, mint egy komoly probléma megoldása egy szervezetben (3). A kiscsoportokban megfogalmazott javaslatokat mindenki számára befogadható és érthető módon közvetítették, ezt követően gondolkodás nélkül jött a kijelentés, hogy a megoldás nem más, mint a problémák összegyúrása. Érdekes volt, hogy nem alakultak ki kifejezetten csoportszerepek, volt 10 tanuló, akik az erős magot képezték és ők beszéltek, egymást meghallgatva. Kitalálták, hogy csinálnak egy olyan hotelt (9), amiben takarítórobotok vannak, egy stresszlevezető hotel, nincs elektronika, természetes anyagokból van a robot, reggeldélben-este meditáció várja a vendégeket. BIOHOTEL lenne a neve, minden egészséges és környezettudatos összetevőkből állna. A hotel finanszírozását állami pályázatból fedeznék. Kockázatként definiálják, hogy instabil és esetleg nem lesz rá pénz. Mivel napenergiát használnak ezért ez mindenkinek jó, társítják az objektív jó megismert fogalmához (8). Egyenrangú felekként müködnek (6), az építő gondolatot elvárják egymástól („,majd, ha lesz tudsz érvelni a saját ötleted mellett, akkor felszólalhatsz")

Az osztályszintü együttmüködést követően jelezték felém, hogy készen vannak (3). A közös rajznál szétestek picit (4), ott valóban az az 5-10 ember rajzolt és vonódott be instruálva 
a többieket, és volt két kisebb csoport, akik kimaradtak. Utólag kiderült, hogy ök szerettek volna részt venni csak valahogy kirekesztve érezték magukat.

Reflexiók elemzése

A diákok pozitívan értékelték a designkommunikáció workshop elemeit („,Tetszett az elöadás és a csoportmunka is”, „Általában az elöadásokat unalmasnak tartom, de ez nagyon érdekelt”). Megemlítették a közösségépítő jellegét is („Az én szerepem az volt, hogy a barátaimhoz közelebb kerültem"), de sokkal hangsúlyosabban került elő maga a tanulási folyamat („Nagyon jól éreztem magam sok új dolgot megtanulhattam”, „Sok hasznos információt tanulhattunk a jövöre tekintve, új fogalmakkal is megismerkedhettünk"), mint hozzáadott érték. Szintén teret kapott a folyamat beteljesítéseként a tervezett produktumok létrehozására irányuló igény és elhatározás (,Biztos meg fogom csinálni ezt a 30 napos rendrakás kihívást, mert ezzel egy csomó időt lehet megspórolni.”, „, A BioHotelt egy nap még meg fogjuk valósitani”, „Nekem nagyon tetszett, de öszintén az nem volt jó, hogy nem készitettünk tervrajzot”) A foglalkozás élmény jellege („Nagyon jól szórakoztam”, „Nem gondoltam, hogy ennyire jó lesz”), a játszva tanulás (,Nekem tetszett, mert interaktív, bevonós kis játékos feladatokkal egybevegyitett tervezés volt ez") támogatta a kreativitás kibontakozását. A folyamatot nyitva hagyva a diákok a további közös munkát szívesen fogadnák (,Máskor is gyere el és majd több dolgot is kipróbálhatnánk”, „,̈rülnék neki, ha máskor is lenne hasonló foglalkozás.")

30. ábra: Diák reflexiók kódjegyzék - Besenyeszög

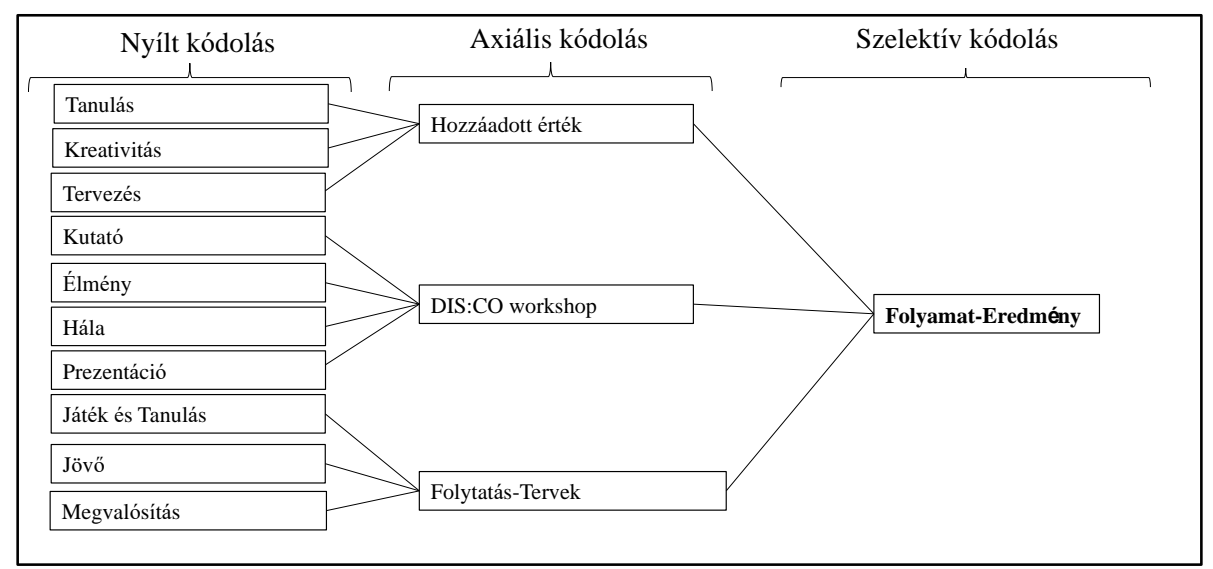

Forrás: A diák reflexiók elemzése alapján saját szerkesztés 


\subsubsection{Békés megye, Mezöberény}

Mélyinterjú

A legtöbb helyszínen megerősítést nyert az, hogy a felhívásomra, amikor az iskolákat kerestem a kutatáshoz valóban olyan pedagógusok jelentkeztek, akik nyitottak, innovatív szemléletủek és befogadók az új módszerek felé. Az a pedagógus, aki ilyen attitüddel rendelkezik erősen meghatározza a vizsgált közösséget is, nem egyszer volt tapasztalható, hogy az osztályfőnök tükröt tart a diákokról. Ez a felismerés nagyon erősen összecseng a szakirodalmi elemzés során tárgyalt előremutató pedagógusszerepekkel (Beghetto, 2006). Mezőberényben az egész iskolai környezet támogatja az újítást („Innovatív iskola a miénk, igy pedagógusként is innovativnak kell lenni.”), ahogy az iskola vezetősége az egyéni fejlődésnek is teret enged (,folyamatosan, rengeteg továbbképzésen vettem részt az évek során, de az igazgató is ösztönzött erre mindig."). Hiába támogató azonban a közvetlen környezet, ha olyan oktatáspolitikai irányokat kell betartani a pedagógusoknak, ami gátat szab a kreativitásuknak és a szabadságuknak (,Ami meg jó tankönyv, azt meg nem engedik, hogy bekerüljön az oktatásba. Nem rendelhetem meg. Miért is? Hol van az én szabadságom? Hol van az, hogy olyan eszköz legyen az én kezembe, ami az én munkámat 100 százalékosan segíti?”) A növekvő adminisztrációs teher sem támogatja azt, hogy az időt a kreatív módszerek iskolába történő integrálására fordítsák (,Aki nem annyira nyitott a dolgok felé, az azt szüri le, hogy mennyi munka, mennyi pluszt hoz neki. Pedig már így is kimerült. Hogy mennyi adminisztrációt löcsölnek rá.").

Az interjú során kiemelt jelentőséget kapott a kreativitáson keresztül a készségalapú oktatás fejlesztése. A pedagógus feladataként rögzíti, hogy rávilágítson a nyitott gondolkodásra arra, hogy nem csak egy jó megoldás van (,A gyerek azt lássa, hogy neki nem csak egy útja van. Hanem hogy több irányba el tud menni, mert vannak lehetöségei.”) és, hogy mindig kritikusan, ne nyomás és befolyás okán hozzanak döntéseket (,Ha a kreativitását fejlesztjük, ez által ö sokkal tágabb dolgokból tud válogatni. Azt szoktam nekik mondani, hogy ne engedjétek magatokat befolyásolni.”) A soft készségek fejlesztésén keresztül megvalósuló személyiségfejlődést sokszor fontosabbnak tartja, mint a tárgyi tudást (,,Kell a tantárgyi tudás is, az alapokat nyilván, de azt mondom, hogy fele-fele arányban a személyiségfejlesztés - kreativitásfejlesztés - meg a tananyag.").

A csoportmunka rendszeresen jelen van oktatási tevékenységében, felismerte és a gyerekek felé is ismertté teszi, hogy miért van jelentősége az együttmüködés, mint soft készség 
elsajátításának (,Elmeséltem nekik, hogy az életben, ha elkerülsz egy pályára, akkor ott csoport, team-munkában kell majd dolgoznotok. Persze, meglesznek az egyéni feladatok, de nektek együtt kell nektek valamit a cég érdekében tennetek, ahhoz együtt kell müködni”).

31. ábra: Pedagógus mélyinterjú kódjegyzék-Mezöberény

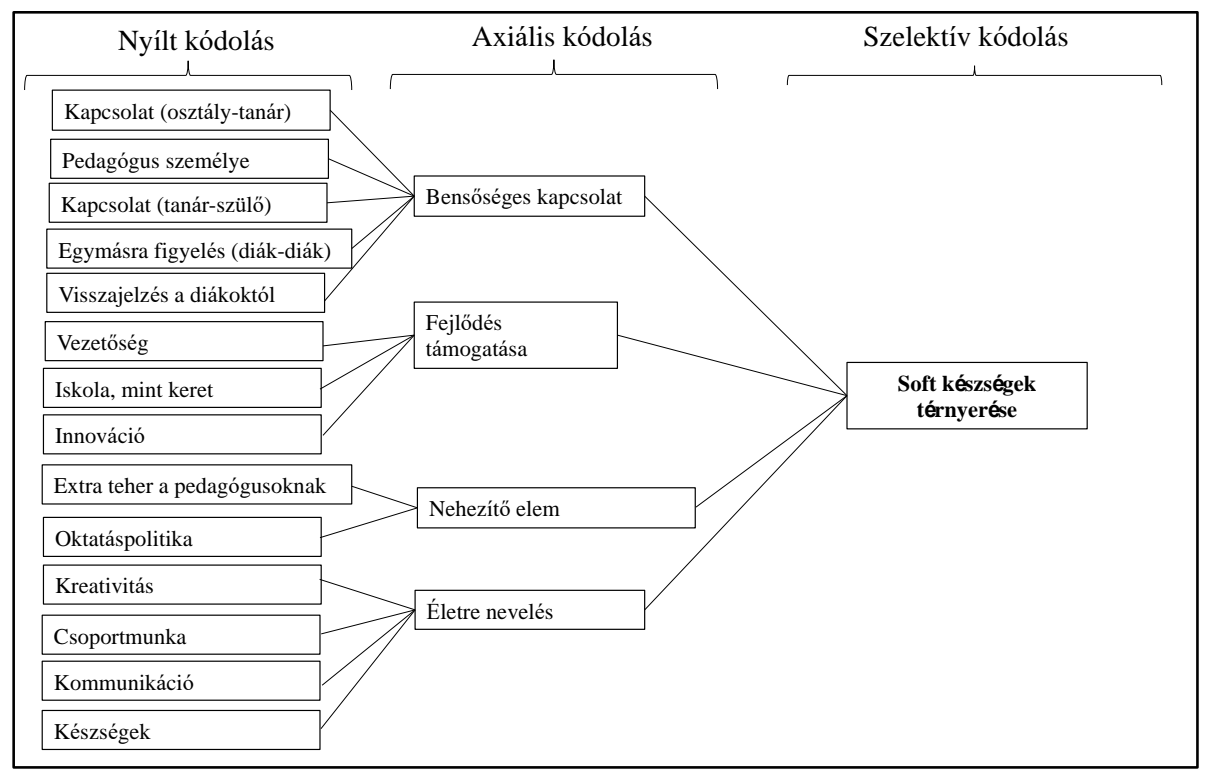

Forrás: A mélyinterjú leiratának elemzése alapján saját szerkesztés

Résztvevő megfigyelés

Az osztálynak meglepetés voltunk, még egy matematika dolgozat is elmaradt, így külön örültek nekünk. 23 fö, az osztályban nem volt hátrányos helyzetü diák. 1 hiányzó volt, összesen 24 fö jár az osztályba. A tanárnő végig bent volt a workshopon, de nem volt zavaró, tényleg nem szólt bele, csendes megfigyelőként volt jelen. A gyerekek biztos, hogy nagyon szeretik, hiszen a labdás bemutatkozó feladatnál kidobták neki is a labdát (utoljára ilyen Nagykőrösön volt). A végén az osztályfőnök mondta, hogy micsoda felismerés volt ez neki a gyerekekröl, mennyire tetszett neki, új arcát mutatta a gyerekeknek.

A workshop végig jó hangulatban telt, magatartásproblémák egyáltalán nem voltak az osztályban (4). A workshop legerösebb pontja a prezentáció volt (1), nagyon interaktív beszélgetés valósult meg (2). Egyénileg hamar kigondolták a problémákat, majd 5 kis csoportban dolgoztak (3). Itt nagyon jól müködtek (gyakori náluk az irányított csoportmunka) A következő témákban születtek ötletek: szemétszedés, egy vállalkozás, aminek keretében felhívják a figyelmet arra, hogy mennyire káros szennyezni a környezetet. Csinálnak 
prezentációt, amit előadnak iskolákban és müvelödési házakban, plakátokat és tábort, ahol oktatnak erről. Előkerült az ,újféle” energiák használata is (9).

Beültek a nagy csoportba. Ez volt a leggyengébb része a munkának, tisztán látszik, hogy ez a tömeges kapcsolatteremtés nagyon ritkán megy az osztályoknak, ezt fontos lenne fejleszteni. Végül egy kisfiú és egy kislány felvállalta a csoportvezető szerepet. Felismerték az ötletek közötti kapcsolódási pontokat, majd arra a döntésre jutottak, hogy összehangolják és ez alapján születik majd meg a közös produktum, de ezen a ponton elengedett a csoport és elkezdtek klikkesedni, dekoncentrálttá válni, és csak a két csoportvezető és a körülöttük lévő diákok dolgoztak. Zür keletkezett, melyben egymástól várták a megoldási javaslatot.

Végül a kiscsoportban a döntéshozók határozottan döntést hoztak, de figyeltek arra, hogy mindenkinek az ötletét integrálják a közös produktumba. A projekt a Világmegváltók nevet kapta (9) (Az osztályt 4 fős csoportokba rendezték és mindenkinek a környezettudatos magatartás megvalósítása és népszerüsítése lenne a feladata, kinek-kinek a csoportjához meghatározott célkitüzésekhez igazodva) és a végén még a designkommunikáció alapelvei mentén is elemezték azt. A közös rajz nagyon jól sikerült, mikor elkészültek bemutatták, megalkották a saját újrahasznosított jelüket (8).

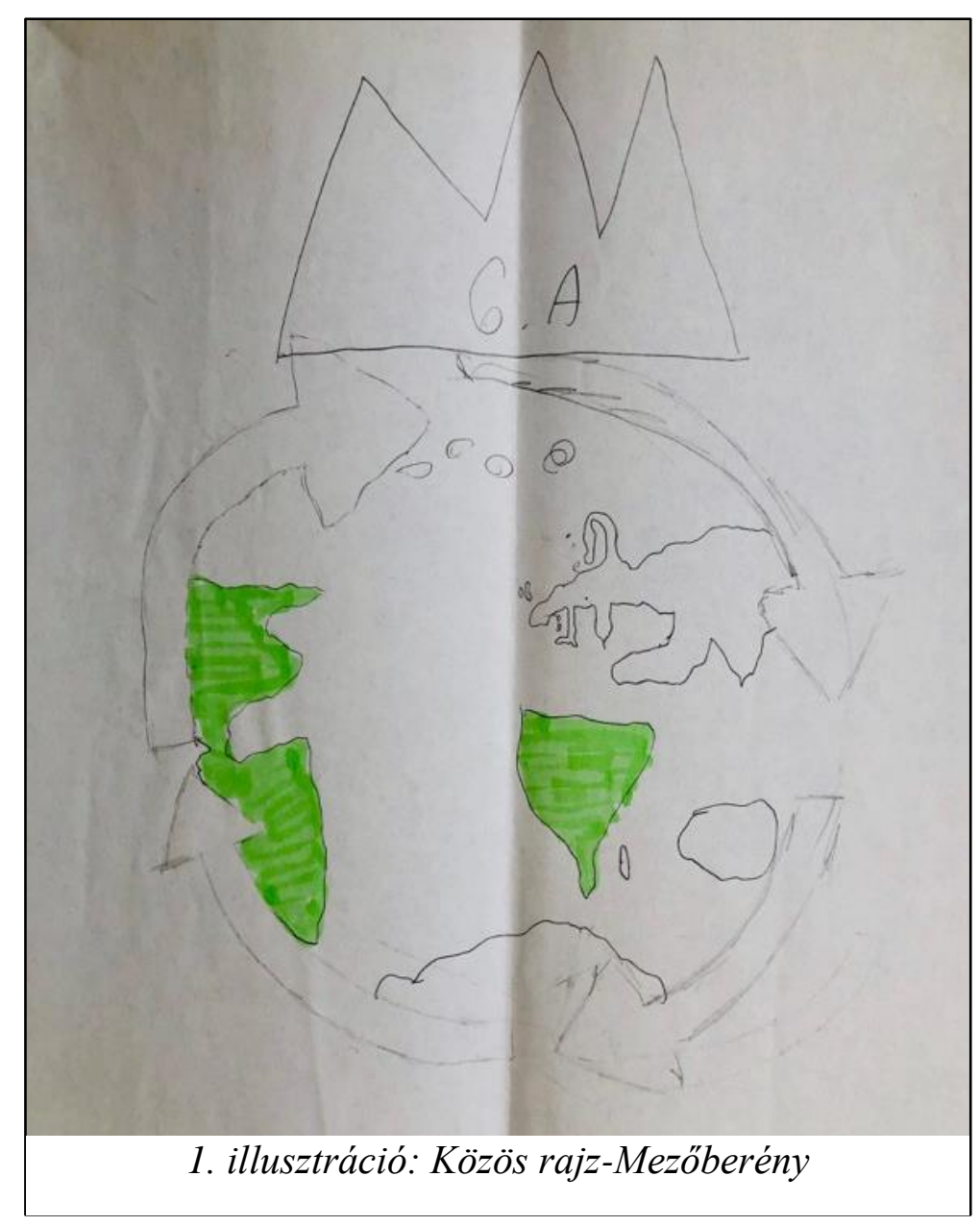


Az ötletükkel kapcsolatban kiemelném, hogy ez volt az első olyan osztály, ahol osztályszinten úgy gondolták, hogy ők képesek megváltani a világot (8) és nem számít, hogy milyen kicsik ehhez (5). A hangsúly az akaraton volt, ami nagy érték ilyen kicsi gyerekek gondolkodásában.

\section{Reflexiók elemzése}

A diák reflexiók kapcsán két jelentőségteljesebb pont volt, ami a korábbiakat kiegészíti és még nem került elő. Esetükben nagyon gyakori a csoportmunka a hétköznapi oktatásban, azonban nagyon jól körülhatárolt feladatokkal, célkitüzésekkel, iránymutatással. A legtöbb esetben a csoportszerepek is adottak a pedagógus mélyinterjú alapján. A designkommunikáció során azonban pont ez a külső irányítás veszik el, ami kis csoportban még megoldható számukra, azt képesek a helyén kezelni azonban a nagycsoportos együttmüködés során nem tudnak élni a szabadság lehetőségével ezért fordul át káoszba. Ezt közvetve meg is fogalmazzák a reflexiókban, ahol a kis csoportos együttmüködést pozitívan értékelik (,Nagyon tetszettek a beszélgetések meg a kis csoportmunkák”), azonban az osztályszintü együttmüködés során zavarja őket a kialakult rendetlenség és az ebből fakadó „sikertelenség” (,Amikor az egész osztálynak együtt kellett dolgoznia, az annyira nem tetszett, ott nagy volt a hangzavar")

A másik fontos jelenség, amit itt kiemelnék az a megvalósítás iránti igény. A terv cselekvéssé formálása megjelent, mint vágy, mint célkitűzés a jövőre nézve („,Jó lett volna, ha megvalósitjuk azt, amiröl szó volt”, „Nagyon jó program volt, lehet, hogy meg is tudnánk valósitani”). De olyan is előfordult, aki nem a közösség, de a saját, egyéni szintjén döntött a cselekvése megváltoztatásáról a foglalkozás eredményének hatására. („Védeni fogom a környezetemet")

A tanulás (,Tetszett, mert egy csomó dolgot tanultunk, ami nagyon hasznos”), a játszva tanulás („Tetszett, hogy az egész játékos volt”), az interaktivitás („Tetszett, hogy interaktív volt az óra”) és kreativitás („Tetszettek a feladatok és, hogy használhattuk a kreativitásunkat”) is a pozitív értékekhez és élményekhez (,Szuperul éreztem magamat”, „Vicces és jó hangulatú volt”) adódtak a diákok által a designkommunikáció foglalkozásra vonatkoztatva. 
32. ábra: Diák reflexiók kódjegyzék - Mezőberény

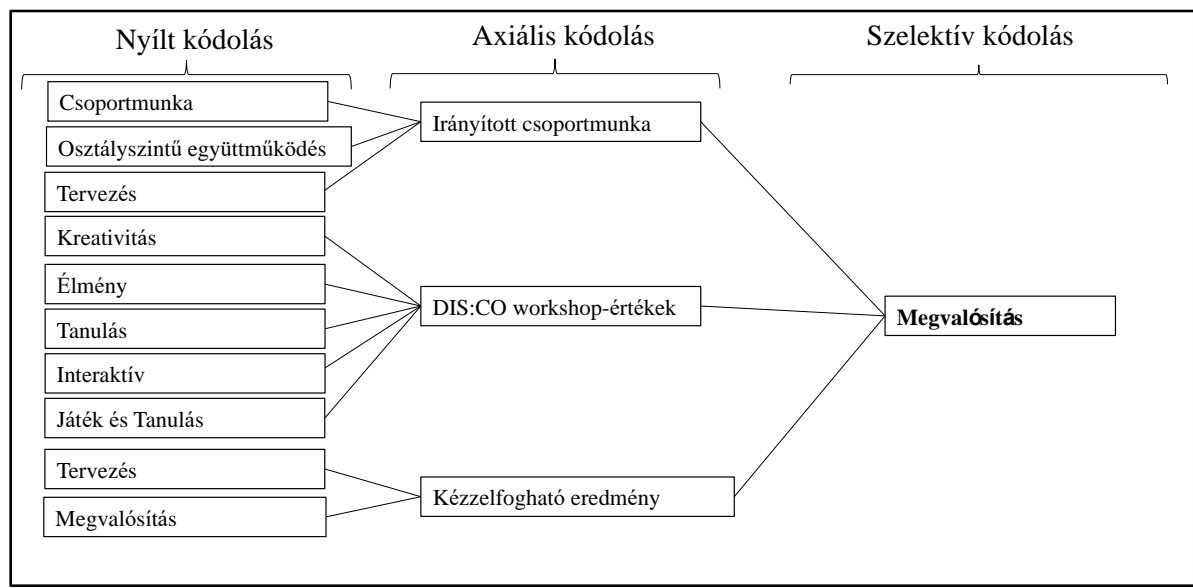

Forrás: A diák reflexiók elemzése alapján saját szerkesztés

\subsubsection{Fejér megye, Baracs}

Mélyinterjú

Baracson a pedagógus magát egyértelműen konzervatív pedagógusnak állítja be (,A koromnál fogva én konzervatív vagyok."), aki az osztályát alsó tagozattól ismeri, alapvetően jó kapcsolatot ápol diákjaival („,A többség szeretettel fordul felém, mert én is szeretem őket. Tudják azt, hogy vannak nálam szabályok, amiket be kell tartani.”) és a szülőkkel egyaránt („Jó kapcsolatom van a szülökkel is, a zömével.”). Osztályát egy átlagos falusi iskolai közösségként jellemzi, fontos megjegyezni, hogy a gyerekek önállóságát hiányolja („Nem elég önállóak.”).

A kreativitást fontosnak tartja (,Nagyfokú kreativitás kell hozzá. Módszertan. A tanitási módszerekben is kell, hogy kreatív legyen az ember.”), a mai generáció megközelítése kapcsán pedig kifejezetten érvényben van, hogy más módszerekkel kell őket megközelíteni („A mai gyerekek egészen mások, 35 éve vagyok a pályán, látom. Ök nem fogadják el úgy, hogy elmondom, és ez a szentírás. Úgy nem is érdekli öket. Sok mindent ki kell ahhoz találni, nagyon sok mindent másképp kell, hogy érdekelje öket.”). Ezzel párhuzamosan azt is elismeri, hogy jelenleg ennek nem jut megfelelő tér a hétköznapokban (,a gyereknek a kreativitását és az önállóságát sokkal jobban ki lehetne használni.”).

A gátló tényezők, amivel ezt indokolja az az idő hiánya és a pedagógusra háruló extra teher (,Lehetne kreativ is, de erre sajnos nekem nincs idöm. Rengeteg plusz programot kellene ehhez végezni. Ebböl, az időböl mindig kevés van.”), valamint az oktatáspolitikai keretrendszer által emelt falak, melyek sok esetben ellehetetlenítik a nyitottságot és a rugalmasságot (,Nagyon be vagyunk korlátozva most a tananyag mennyisége által elsősorban. Nyilván azt 
nem lehet, hogy nincs elöírás, hogy mit kell tanulni, vagy mit kell megtanitani, de egész más úton is el lehet jutni ugyanoda, amire nekünk nincs lehetöségünk”.).

33. ábra: Pedagógus mélyinterjú kódjegyzék - Baracs

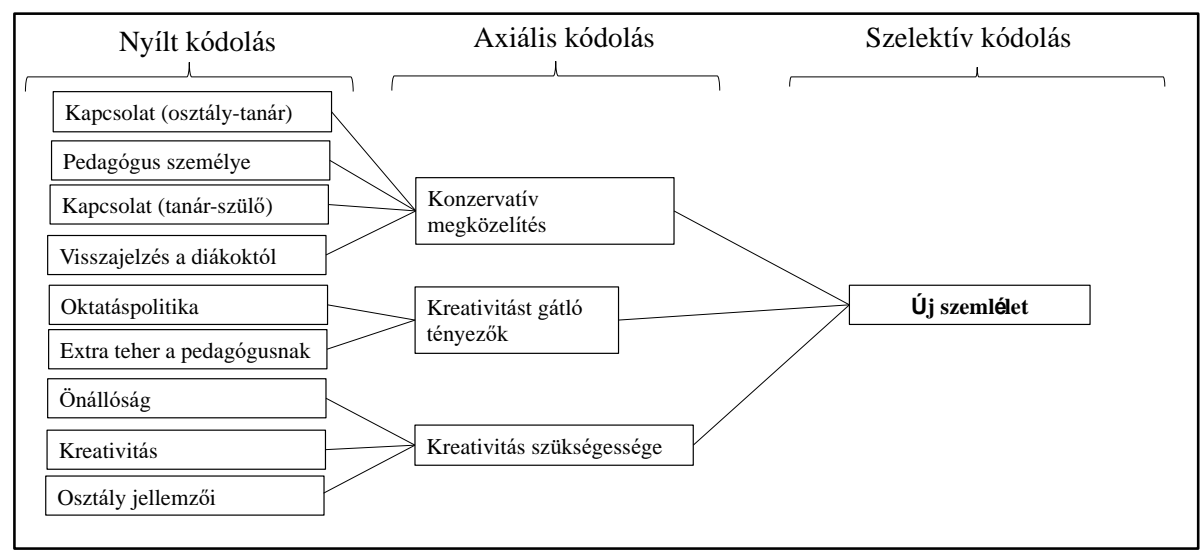

Forrás: A mélyinterjú leiratának elemzése alapján saját szerkesztés

Résztvevő megfigyelés

Az osztály már a bevezető feladatot elnevetgélte, a kezdetektől látható volt, hogy a csoportban magatartásproblémák is lesznek (4), sok a kihúzó, közösségromboló kisgyerek. A workshopon egyébként a pedagógus végig bent volt, de ígéretéhez hűen nem szólt a gyerekekre. A fiúk és a lányok a korosztály sajátosságait alátámasztva teljesen külön ültek egymástól, minimálisan sem közeledtek a foglalkozás folyamata során. A gyerekek önállóságának hiánya végig tapasztalható volt (5).

A prezentáció alatt valósult meg a workshopnak a legértékelhetőbb pontja, ugyanakkor itt is fegyelmezni kellett őket, mert belevágtak egymás szavába (6) és a szép szóra nem nagyon hallgattak.

Kiscsoportokban elfogadhatóan dolgoztak (3), de itt is voltak gyerekek, akik kivonták magukat a csoportból (4), nem voltak összeszedettek, 1-2 csoportot leszámítva nem a témáról beszéltek, az osztályközösség hiánya nagyon szembeötlő. Nagy volt a hangzavar és erős a dekoncentráltság. Egyértelmüen tapasztalható volt, hogy a csoportmunka minimális az iskolai közösségükben. A kiscsoportos ötletek a következő témák köré csoportosultak: Óvjuk az erdőket, új fák ültetése, állatoknak otthon biztosítása, sérült állatok gondozása, Törődni egymással, Újrahasznosítás (9).

Átlagos képességű gyerekek alkották az osztályt, de azért elvétve voltak jó hozzászólások, vagyis a potenciál, hogy valami jót alkotnak benne volt a levegőben. Tekintve, 
hogy nem hallgatták meg egymást, nem indult el a tervezői élmény, így hamar feladták, és nem volt, ami hajtotta őket. Zajongtak végig, nem tudtak fókuszálni (4). Az osztályszintü együttmüködés nagyon gyenge volt. Végül a lányok alakítottak egy külön csoportot, amin a fiúk megsértődtek, hogy őket kihagyják. A létrehozott produktum egy karácsonyi vásár ötlete lett, amit kombináltak egy szemétszedési akcióval (9). A közös rajzolás a workshop végén összehozta az osztályt (3), az előző folyamatokhoz képest itt fejlődés volt megfigyelhető a közös munka tekintetében (8).

Reflexiók elemzése

A reflexiók során nagyon röviden írtak a diákok, egyértelműen látszik, hogy nem igazán tudják kifejezni véleményüket, de erre a mélyinterjú alapján nem is kapnak támogatást, sőt. (,Egyébként elég szabadon nyilvánitanak véleményt, valószinüleg azért, mert ehhez voltak szokva kiskoruktól kezdve. Néha el kell mondani, hogy nem biztos, hogy ez a helyes.")

A foglalkozás során jól érezték magukat, tetszett nekik, ugyanakkor szembetünő volt, hogy zavarta őket a fiúk-lányok közötti konfliktus (,nem tetszett, hogy a lányok minket kiszoritottak”, , az volt a baj, hogy a fiúk bohóckodtak”) és a magatartásproblémák (,Nekem az nem tetszett, hogy néhányan végig röhögték és dumálták az egészet”, „Nem volt jó, hogy a fele osztály nem dolgozott”, „Hangosak voltak a társaink, ezért nem lehetett odafigyelni”). Vélhetően a produktum és a vele járó siker, valamint a tervezői flow élmény elmaradása bennük is hiányérzetet keltett. Objektív módon felismerték és megfogalmazták azt a két dimenziót, ami a probléma forrását jelentette. Egy ilyen foglalkozás során az első lépés mindig a probléma feltárása, ami már önmagában egy eredmény, hiszen ezek azok az információk, amire a következő workshopokon már építeni lehet. Ha pedig ezt a problémát a diákok fogalmazzák meg, akkor még egy lépéssel közelebb vagyunk a megoldáshoz vezető úton.

34. ábra: Diák reflexiók kódjegyzék - Baracs

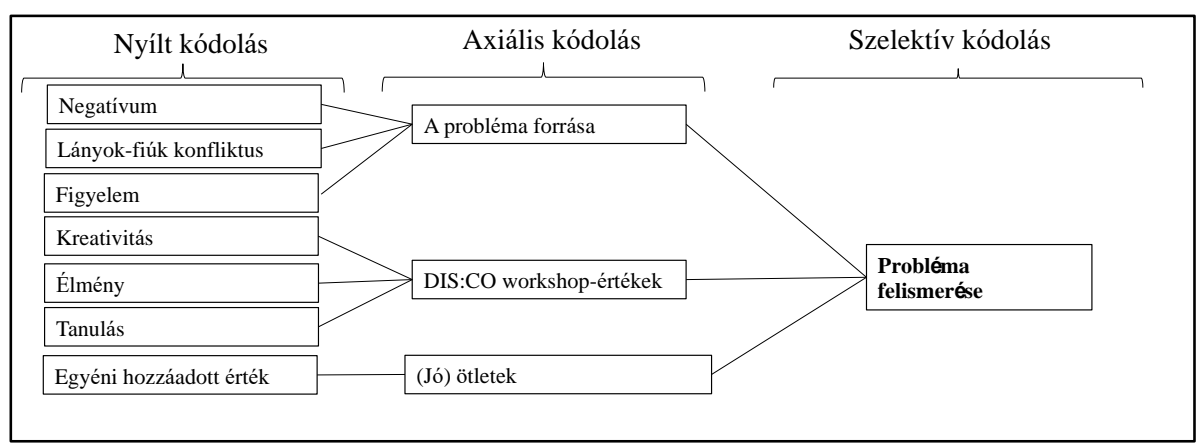

Forrás: A diák reflexiók elemzése alapján saját szerkesztés 
Mélyinterjú

Egy fiatal, lendületes osztályfönökkel valósult meg a kutatás Dorogon, aki a pedagógus pályát hivatásának tekinti (,,abszolút úgy érzem, hogy tanár vér folyik az ereimben, édesanyám is tanár.”). A diákok kapcsán a legnagyobb problémát az otthonról hozott hiányosságokban látja (,A legnagyobb problémám az otthonról meg nem kapott nevelés.”), ennek ellenére a szülőkkel nagyon jó kapcsolatot ápol („Szülőkkel is elég jó a kapcsolat. Segítőkészek.”).

Véleménye szerint a feladatait, a kreativitás kibontakozását gátolják az infrastrukturális hiányosságok (,Nekem, ami nagyon hiányzik az iskolából, az a technikai felszereltség”) és az oktatáspolitikai irányelvek (,,a mai magyar oktatás gyártósorra képzi a gyerekeket, ezt tanuld meg és készen van.”) egyaránt. Ezzel szemben, aminek igazán szükségét látja, az a problémamegoldáshoz kapcsolódó készségek fejlesztése (,Muszáj lenne az, hogy a gyerekek újat találjanak ki, és egy-egy problémát meg tudjanak oldani a saját elképzeléseik szerint."). A kreativitás térnyerését is a használható tudás átadásán keresztül lehet véleménye szerint megvalósítani (,Az oktatásnak arra kellene fókuszálni, hogy tényleg használható tudást adjon át, amiböl fog tudni kreatívan, vagy ha nem is kreativan, de meg tudja oldani a feladatot.")

A gyakorlatban azonban ettől még messze vagyunk. Az iskolában a csoportmunka nemigen valósul meg, ami egyrészt adódik a pedagógus hozzáállásából és hozzá nem értéséből (,Általában azért csináljuk, mert, hogy kéne, de őszintén szólva, még én sem éreztem azt, hogy egy annyira jól müködne, hogy egy tananyagot megtanulnának csoportmunkába. Én se vagyok benne profi.”), de nehezítő körülményt jelent a diákok önállóságának a hiánya is (,nincsenek azon a szinten, hogy öket magukra hagyjam - persze, hátulról irányít az ember. De nagyon sok segitséget igényelnek.”). A megoldást abban látja, hogy már a lehető legkisebb korban el kell kezdeni az újító módszerek használatát az oktatásban („De ha nem hozzák már alsóból magukkal, akkor felsöben már rettenetesen nehéz. Nem tudtak együtt dolgozni.”). 


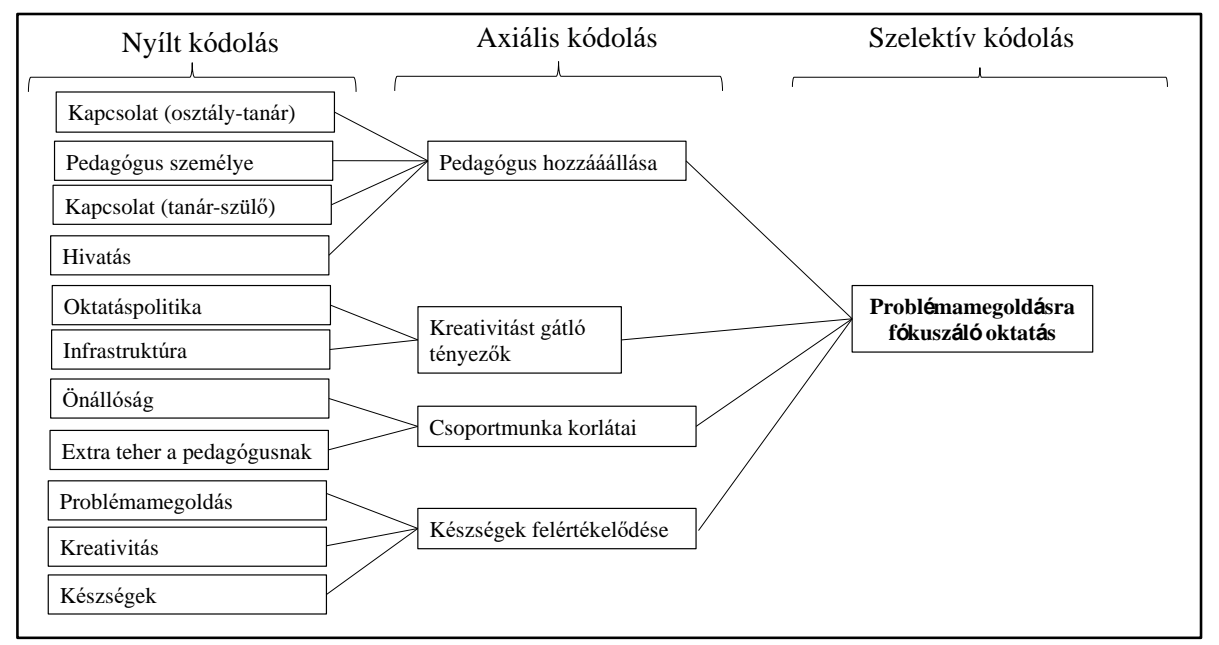

Forrás: A mélyinterjú leiratának elemzése alapján saját szerkesztés

Résztvevő megfigyelés

Jó képességü gyerekek alkották az osztályt, itt a fiúk-lányok szeparációját kevésbé lehetett észrevenni. Kis csoportokban kezdtek el dolgozni, valóban a témáról beszélgettek, komolyan vették a feladatot, voltak csoportok, akik jegyzetet is írtak (7). A következő eredmények születtek a kiscsoportos feladatrész alatt.

1. Tegyük színesebbé otthonunkat, ne bántsuk egymást, környezetünkben lévő embereket ösztönözzük, ehhez mi is hozzá tudunk járulni.

2. Fekete füst eltüntetése (gyárak), több elektromos autó, még több fa, bírság a szemetelésért.

3. városokban szemetet szedni, csoportonként, mindig adott egy csoport, aki felelős.

4. Az osztályelnök megválasztását szorgalmazták, aki döntéseket hoz az osztály nevében.

Ezt követően tértünk át a wikinomikus együttmüködésre. Nagyon ügyesen dolgoztak együtt, kiemelkedően jó párbeszéd és beszélgetés alakult ki közöttük (3). Felszólították egymást, csak egy ember beszélhetett (4). Felnőtt közösségeket meghazudtoló vita és kooperáció alakult ki. Ök voltak az első olyan csoport, akik valóban valami olyat hoztak létre, ami a saját közösségük fejlesztésére szolgál (,kinek vannak jó ötletei, az rakja fel a kezét”, „,szerintem olyan dologban gondolkodjunk, amit mi tudunk megvalósitani”, „, tervezzünk szemétszedö programokat")

Volt egy kislány, aki abszolút felvállalta a rendező, csendre intő, főnök szerepet, mindig ő adott szót (,légyszives mindenki maradjon csendbe és csak az beszéljen, akit felszólítunk”.), 
amit a többiek alapvetően elfogadtak. Felismertek olyan jelenségeket, amit az emberek nagy része nem, vagy csak nehezen és érettebb korban (,ha mi megcsináljuk, azzal már teszünk”) Folyamatosan jellemző volt, hogy fegyelmezték egymást a gyerekek (4). Sokat ötleteltek, mindig jöttek újabb és újabb gondolatok, érveltek, példákat hoztak. Ha elakadtak, akkor közösen, a csoport közös véleményét elötérbe helyezve, demokratikus úton folytatták a munkát (,gyorsan menjünk egy kört és mindenki mondjon igent, ha tetszik neki, mint az x faktorban.”, „lehetne olyan, ahogy a Pál utcai fiúkban szavazták meg a grundon”). A krízishelyzeteket (6) érvekkel igyekeztek megoldani (,erőszakkal nem lehet megoldani semmit”, ,emberek van két percünk és még mindig nem történt semmi”), a közösség többi tagjára nézve is felismerték felelösségüket („ha mi jók vagyunk, akkor tudunk befolyásolni embereket”).

A közös produktum az osztályelnök választás koncepciójában és a szavazási rendszer megalkotásában teljesedett ki, amit vizualizáltak és szóban prezentáltak (9). Ők voltak az első olyan csoport, akik az otthon jobbá tételét saját közösségük formálásában valósították meg. Eddig győzött az asszociáció, miszerint a környezet az osztályterem falain kívül van. Ez az osztály viszont nem nyitotta ki az ajtót és nem hagyta el az osztálytermet. A saját közösségük fejlesztésére és javítására vállalkoztak (8). Az osztályelnök választása ezen segítene, mindenki jobban viselkedne ösztönöznék egymást. Az osztályelnök tervezné az osztály közös jövőjét, akinek feladatait és felelősségi körét a következőképpen rögzítették: „osztályközösségen segítene talán”, „értelmes döntéseket hoz”, „Anita néni válláról levennénk a terhet”, „ő a felelös, ő hozza a kisebb döntéseket”. A környezet védelmére irányuló tevékenységhez ragaszkodtak, így az ,az osztályelnök vezetésével mehetnénk szemetet szedni”.

A workshop hosszabb is volt a korábbiakhoz képest, mert a diákok úgy benne voltak az alkotói, tervezői folyamatban, hogy nem lehetett őket megszakítani (3). Látható tehát, hogy egy valós probléma köré összpontosuló, a készségek fejlesztését középpontba helyező feladat milyen eredményeket hozhat ki egy osztályközösségből.

\section{Reflexiók elemzése}

A diákok reflexiói a kapott értékek kiemelése mentén épültek fel, más-más aspektusból, de az osztály egységét, a közösség elöremutató fejlődését helyezték a középpontba. Az egyetlen megfogalmazott negatívum az olykor előforduló hangoskodásra, a magatartásban általuk feltételezett hibákra összpontosult. Ez többször megjelent már a foglalkozások során, hiszen a hierarchiát támogató iskolai rendszer a jó és példamutató magatartást többnyire a csend és fegyelem köré építi, így a diákok mindent, ami ettől eltér azt hibának vélnek, hiszen ebben 
szocializálódnak az iskolai rendszerben. A designkommunikáció workshop azonban szabadságot ad, így a beszélgetés, vita, hevesebb kommunikáció -mindaddig amíg az a megoldás felé visz- része lehet az alkotói folyamatnak.

A legnagyobb értékként az osztályszintü együttműködés sikerét (,tetszett, hogy az osztály ilyen harmóniába dolgozott”, ,, Tetszett nekem, hogy tudtunk normális, egy osztályként dolgozni és gondolkodni”, „, A közös munka szuper volt, föleg amikor az egész osztály együtt dolgozott”) és ehhez kapcsolódóan az osztályközösség erősödését fogalmazták meg (,Nagyon jó volt, végre lett egy kicsit osztályközösség”, „Nagyon jó volt ez a program és szerintem egy kicsit nagyobb lett az osztályközösség is”). Kiemelésre kerültek az elöremutató beszélgetések, de itt is a közösség motívumának megjelenése mellett („Jó volt, hogy az osztály tudott végre normálisan beszélgetni”, „Szerintem ez volt ebben az évben a legnormálisabban töltött beszélgetés”). Az együttmüködés („Jó volt látni, hogy az osztály együtt dolgozott”, , Együttmüködtünk és meg tudtunk beszélni tök jó dolgokat”) és a megértés („Jobban bele láttam az osztálytársaim gondolkozásába") szintjén is sikerült közelebb kerülniük egymáshoz. Az eredményt a saját belső közösségük fejlődésén túl a külvilág róluk alkotott kép megváltozásában is remélték (,Rájöttem, hogy a 6.b. osztály, ha elhangzik, nem csak arra kell gondolni, hogy a legrosszabb osztály az iskolában"). A kiemelt összefüggéseken túl a reflexiók elemzése a következő kódjegyzékkel szemléltethető.

36. ábra: Diák reflexiók kódjegyzék - Dorog

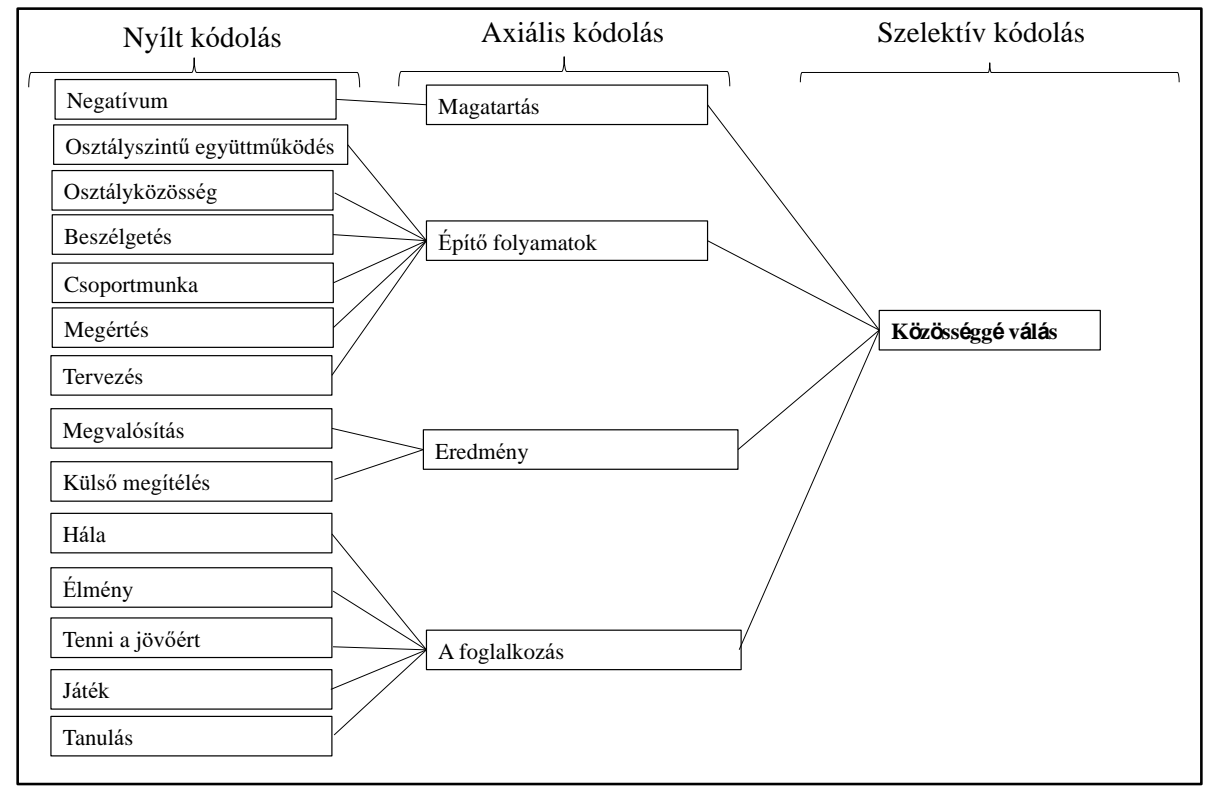

Forrás: A diák reflexiók elemzése alapján saját szerkesztés 


\subsubsection{Hajdú-Bihar megye, Debrecen}

Mélyinterjú

$\mathrm{Az}$ interjút erősen meghatározta, hogy a vizsgált osztályban most olyan problémák zajlanak, ami kihívások elé állítja úgy a pedagógust, mint az osztályközösséget. Az osztály családi háttere rendezetlen („Nagyon nehéz összetételü osztály szociális hátteret tekintve. 30an vannak. 21 gyereknek elváltak, vagy válófélben él, vagy mozaik családban él, és mozaik családban nincsen béke.”), az otthontól nem kapják azt a fajta kiegyensúlyozott biztonságot, amire szükségük lenne a jó teljesítményhez (,Nem hozzák a biztonságot. Nem hozzák azt a fajta biztos tudatot, hogy ha én hazalépek, akkor én ott biztonságban, teljes elfogadásban vagyok.”). Pontosan ennek okán az amúgy is igen nyitott és innovatív pedagógus felelősséget érez, így a fentiekben leírt problémákat irányított beszélgetéseken keresztül próbálja orvosolni, ha kell akkor a tanmenettől eltérve is időt szán erre (,Az etika órának megvan a tananyaga, de mi mindig körbe ülünk, az adott fogalomról beszélgetünk, érzékenyitő filmet nézünk, drámajátékot játszunk. Van visszatérő téma: család, kommunikáció, milyen a jó közösség, milyen a jó vezetö.").

Érdekes, hogy az osztályra jellemző, hogy nem segítik egymást (,Nem müködik az a segítő szándék, hogy valaki lemarad a tanulásban, akkor egyértelmü legyen, hogy azonnal elmondják, hogy mi a lecke.”), ugyanakkor, ha egy cél érdekében kell fókuszáltan dolgozni, akkor magas szintű teljesítményre képesek (,ha össze kell dolgozni, akkor olyan kimagasló tevékenységet tudnak megvalósitani, és annak a végterméke is olyan, hogy megállja a helyét bárhol, bármikor meg lehet mutatni.").

Saját és az iskola feladatának tekinti, hogy a diákokat az életre és a munkára is nevelje, így a készség alapú oktatást helyezi középpontba (,Az iskolában a nevelésünknek egy elfogadott közös alapelve, hogy arra kell felkésziteni a gyerekeket, hogy úgy tudjanak majd dolgozni együtt, hogy a munkavégzésre készitjük fel öket, hogy ismeretekkel, leginkább a jártasságokkal rendelkezzenek, amelyekkel képesek lesznek majd dolgozni."). Erre a csoportmunka ideális lehetőséget biztosít („Ez a csoportban való munka szerintem nem fog kimenni a divatból. Ez most igény arra, hogy ök tudjanak együtt dolgozni, meg tudjanak nyilni és a kreativitásukat is fejleszti."). Egyéni sikerét pedagógusként és nevelőként az osztály közösségének fejlődésében látja (,Én akkor tartom sikeresnek az osztályfönöki tevékenységet, ha a végén értékeljük magunkat, meg a közösséget, akkor visszajelzés az az, hogy innen, valahonnan valahova eljutottunk."). 
37. ábra: Pedagógus mélyinterjú kódjegyzék-Debrecen

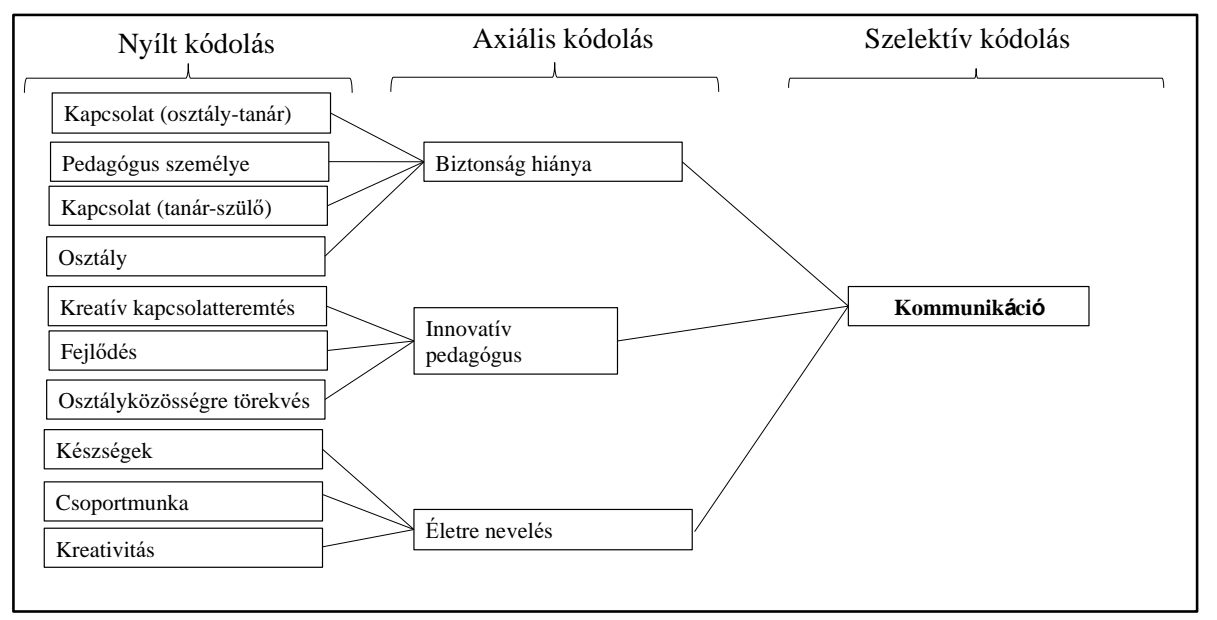

Forrás: A mélyinterjú leiratának elemzése alapján saját szerkesztés

Résztvevő megfigyelés

A gyerekek érdeklődve fogadtak, nagyon szimpatikusak voltak és kiemelten jó magaviseletűek (4). Érezhető volt, amit az osztályfőnök is elmondott, hogy egy kijelölt célra nagyon összeszedetten képesek fókuszálni. A bevezető feladat során olyan fogalmakkal azonosították az otthont („Család, családon belüli szeretet, kikapcsolódás, ott töltött idő, kockulni lehet, testvéri szeretet, mindig van, akire számithatok, végre szabad vagyok, intim szféra, családdal együtt töltött idő, védelem, elfogadás, biztonság, kutyus, családi szeretet, sok együttlét, mindig megértenek, bizalom, bonyolult, természet, boldogság, testvérek, számíthatok mindenkire összetartás”), ami alapján arra lehetne következtetni, hogy stabil a családi háttér, azonban ismerve a körülményeket, ezek sokkal inkább a vágyott értékekre utalnak.

A prezentációt aktív figyelem jellemezte (1), végig jelentkeztek, nem beszéltek bele (2). A rövid szünetben első dolguk volt az osztályfönöküknek elmondani, hogy mi újat tanultak. Kis csoportokban is ügyesen dolgoztak (3), de az igazi áttörés az osztályszintű együttműködés folyamata alatt valósult meg. Egy kislány érezte, hogy át kell venni az irányítást, így már az elején egy nagyon jó irányba billentette a munkát, felvette a csoportvezető szerepet (, kézfeltartással jelezzük, hogy ki mire gondol?” Vagy menjünk sorba?). Végül arra jutottak, hogy mindenki ismerteti a véleményét (5), az ötletét. Először mindig a csoporttag, a csoport ötletét, aztán kiegészítették egymást, bekerültek új ötletek. Nagyon ügyesen hozzákapcsolódtak egymás gondolatához, fel is merült, hogy mindenkinek az ötletét integrálják a projektbe (3). A produktum „Banános Joe” néven született meg, ami egy applikáció, melynek célja a gyerekek 
környezettudatosságra nevelése, de ez egy olyan alkalmazás, ami a ,gyerekeken keresztül neveli a szülöket is”. Felmerült, hogy a fejlödés érdekében a „A többiek ötletét is bele kellene integrálni, hogy a Banános Joe még jobb legyen.” (9)

Megszületett tehát egy termék (9), aminek ha öntudatlanul is, de kitalálták a marketingkommunikációs kampányának alapjait: Logó: „csinálhatnánk neki egy figurát” Promóció: „Reklámokat is csinálhatnánk”, „Viberen lehetne Banán Joe matricacsomag, amit ha megvásárolsz támogatod a kezdeményezést”, „Legyen oktatófilm kicsiknek, melyben Banán Joe elmondja, hogy szelektíven gyüjtsd a hulladékot” Kutatás: „bocsánat, hogy közbeszólok: egy felmérés kéne, hogy az emberek hogy fogadják el”, Merchandising: „3-6 éves gyerekeknek plüss Banán Joe játékot is gyárthatnánk újrahasznositott anyagokból”, PR esemény: "Legyen Banán Joe nap, amikor virággyüjtés és szemétszedés rendezvény van” Felismerik azt is, hogy a megvalósításhoz tőkére van szükség, így a vállalkozói attitüd is előtérbe kerül. (,gondolkoznunk kell azon, hogy valósitsuk meg”)

A vizualizációhoz behoznak egy asztalt az osztályon kívülről, hogy körbe tudják állni (5) és a folyamat záró szakaszát is együtt alkothassák meg (3). A rajz elkészülte után megtapsolták egymást és magukat, valódi flow élmény volt tapasztalható. A produktumhoz füződő viszonyuk büszkeséggel írható le (8), a csoportképen is helyet kap, és az osztályfönök felé is jelzik, hogy cselekvéssé formálnák a tervezést. („Jutka néni, ebbe már mindenki beleélte magát”)

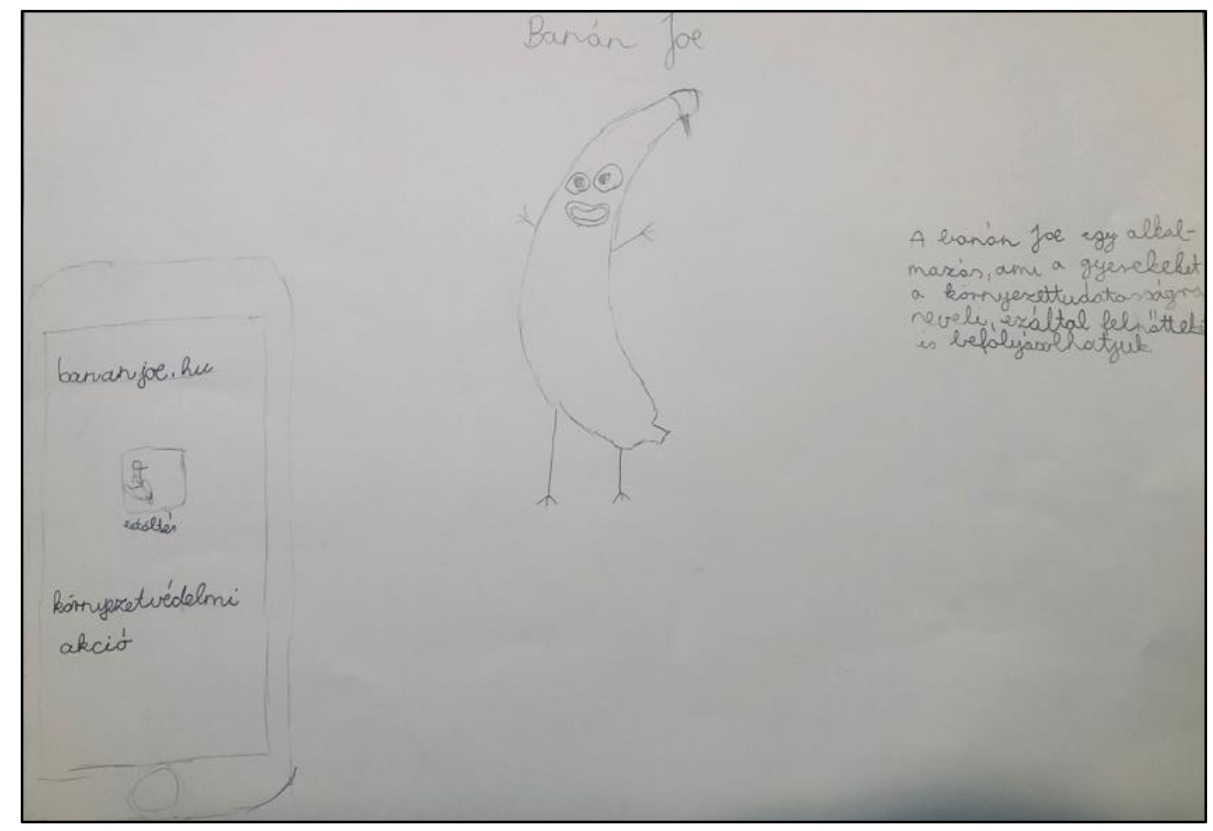

2. illusztráció: Közös rajz-Debrecen 
Reflexiók elemzése

38. ábra: Diák reflexiók kódjegyzék-Debrecen

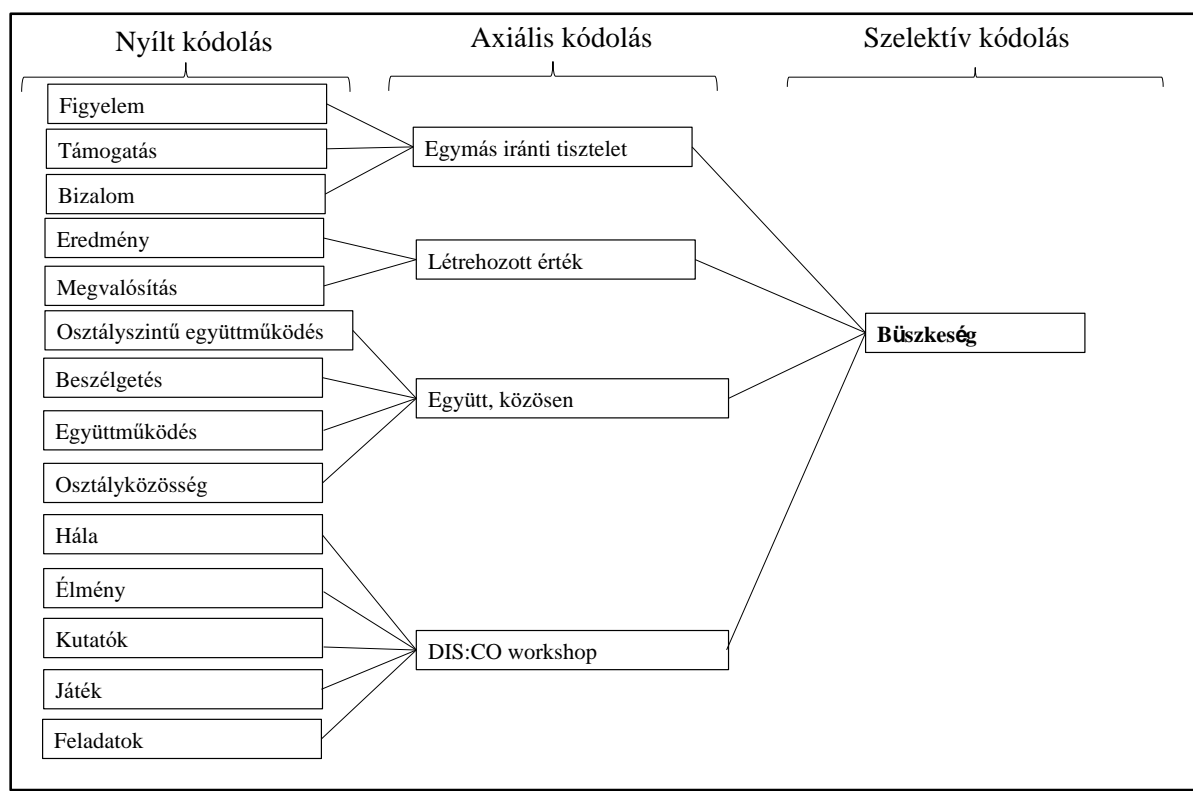

Forrás: A diák reflexiók elemzése alapján saját szerkesztés

Ahogy a kódjegyzékben is láthatjuk alapvetően négy fő kódkategória köré építhető fel a diákok visszajelzése a reflexiókon keresztül. A feladat, a környezet, az empátiára építő szemlélet kihozta belölük az egymás iránti tiszteletet. Támogatták egymás ötletét („Összedolgoztunk és támogattuk a másik ötletét”), meghallgatták egymást („Nekem a többiek véleménye is fontos volt, ezért mindenkit meghallgattuk és ezt mindenki élvezte szerintem") és érezték az egymás felé tanúsított bizalmat is (,Nekem az volt a legjobb, mikor megbíztak bennem az osztálytársaim").

Értéket hoztak létre, egyéni és közösségi eredményükkel tisztában vannak („,Boldogan részt vettem ezen a programon és én jó értékelést adok magamnak, de a program 5 csillagot is kap, de az is biztos, hogy 10 csillagot is megérdemel'), büszkék rá és nagyra értékelik, ehhez társítható, hogy a megvalósításban is örömmel részt vennének („Ha viszont mégis valóra válna akkor szívesen segitenék benne, mert egy ilyen dolog globális méretüvé is válhatna").

Az tetszett számukra a legjobban, hogy ezt a sikert együtt érték el, mint csapat (,Most éreztem elöször, hogy egy csapat vagyunk”), mint osztályközösség („Olyan jó látni, hogy együttmüködik az egész osztály”), aminek szerves részét alkotta a csoportmunkán túl a közös élményszintü beszélgetés („A program megvalósitásáról szóló beszélgetés volt a legjobb szerintem"). 
A reflexiókban ezt a lehetőséget, a foglalkozást, amiben részük volt megköszönték, az osztály nevében is kifejezték a hálát („Köszönöm Daniella néni, hogy egy ilyen szuper foglalkozáson vehettem ma részt”, ,,nagyon köszönjük az osztály nevében”, , Köszönöm, hogy elutaztál ilyen messzire").

\subsubsection{Györ-Moson-Sopron megye, Tápszentmiklós}

Mélyinterjú

39. ábra: Pedagógus mélyinterjú kódjegyzék - Tápszentmiklós

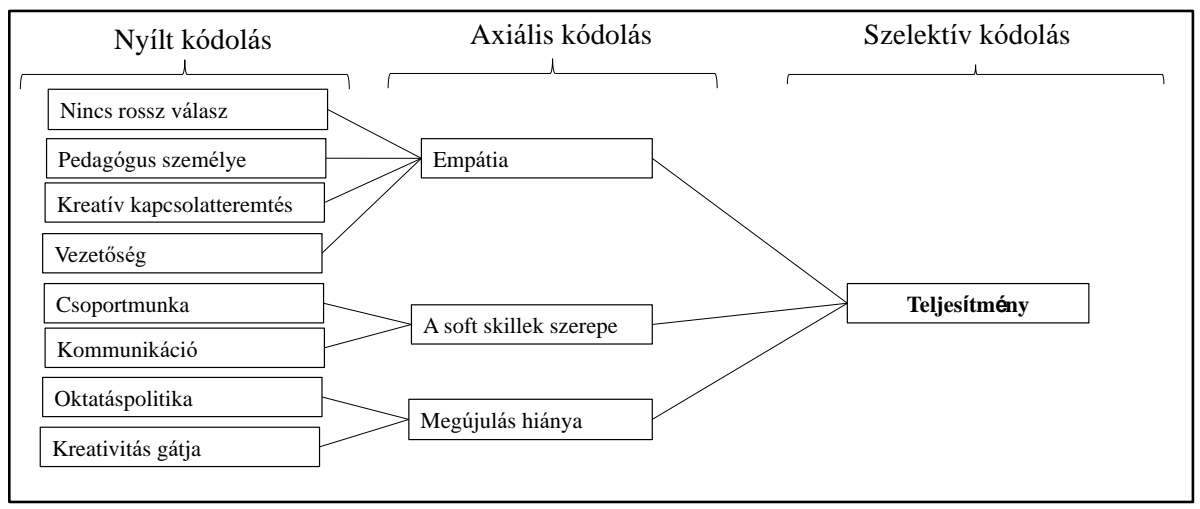

Forrás: A mélyinterjú leiratának elemzése alapján saját szerkesztés

Ahogy a kódjegyzékból is látható a mélyinterjú vezérfonalát a teljesítmény és annak értékelése határozza meg. Felmerült ugyanis a kérdés, hogy ha a pedagógus újszerü, nyitott, innovatív és figyelmet fordít a képességek fejlesztésére is, akkor a rigid oktatási rendszeren belül hogyan történhet a teljesítménymérés és a számon kérhetőség. Ehhez kapcsolódva szeretnék visszautalni az ezzel összecsengő szakirodalmi elemzésre is. Sahlberg (2009) rávilágít, hogy a tesztalapú, könnyen mérhető számonkérés gátja a kreativitásnak. Vagyis a kreativitás megteremtéséhez és kibontakozásához a teljesítmény mérését is egy innovatív megközelítésben érdemes újra gondolni (Sahlberg, 2009).

A kérdezett pedagógus újító szemléletü, nagyfokú empátiával közelít a gyerekek felé. Közvetlen felettese és az oktatási környezete ennek teret ad („Nekünk megengedö fönökünk van, és jó légkör van. Mindenkire rábízza, hogy mennyit dolgozik. Ha valaki lelkes, akkor örül, de arra nem erőszakolja rá, akik meg nem."), annak ellenére, hogy kollégáira nem ez a hozzáállás jellemző. A kreatív kapcsolatteremtésre időt szán, azt vallja, hogy az csak akkor megy, amennyiben „azt a pedagógus gondosan müködteti, és abba energiát fektet”. A hibázást elfogadja (,A másik, hogy lehet hibázni, nem gúnyoljuk ki, nem nevetjük ki.”), a diákok véleményének pedagógustársaival ellentétben (,A mai oktatási rendszerben 10 tanárból 9 nem 
fogadja el a gyerek véleményét.") teret enged. Nehéz ideális pedagógusként jelen lenni a hétköznapokban, hiszen minden gyerek más és más oktatási-nevelési célokat kíván meg. A kreativitás lényegét pontosan ebben a változáshoz történő alkalmazkodásban, a nagyfokú rugalmasságban látja (,minden gyerek más, meg minden év más, meg változik a világ, hihetetlen gyorsan, aki nem kreativ, annak nem is tudom, hogy szabadna-e tanitani"). Sok esetben ennek gátat szabnak a fennálló oktatáspolitikai keretek (,Egy ideális iskolába nem lenne tananyag, pláne nem ilyen, mint ami most van. Ez az idejétmúlt, korszerütlen... Én ettöl nagyon szenvedek.").

A mai diákok számára hasznosítható tudás átadására törekszik („Fontos, hogy tudja magát kifejezni, tudjon kommunikálni, akarjon megszólalni, merjen kiállni, a testbeszédét tudja uralni.”), így a készségek fejlesztésére is figyelmet fordít, (,Szövegértést is sokat iratok. Ez olyan kompetencia, ami a valós életben is hasznos. Mert a József Attila önéletrajza kevésbé...”). A csoportmunka alkalmazását a kooperáció erősítése céljából integrálta a hétköznapi oktatási módszerébe, ahol a folyamat mellett az előállított produktumnak is jelentősége van (, Én, ha csoportmunkát csinálok, akkor az kooperatív munka. Amikor elöállítunk valamit.").

Résztvevő megfigyelés

A diákok magatartása kivételesen jó volt (4), fegyelmezetten viselkedtek. Egyszer sem kellett rájuk szólni, meghallgatták egymást, nem vágtak egymás szavába, megvárták míg a társuk elmondja a véleményét (4). 14 fö volt jelen. A csoportmunka sem volt ismeretlen számukra, a kiscsoportos egyeztetés kiválóan ment (3), látszott, hogy ebben van valamennyi gyakorlatuk, azonban nagyobb csoportban nehezebb volt a kooperáció. A kiscsoportos ötletek a környezetvédelem és a társadalom szegényebb rétegeinek a megsegítésére irányultak (9). Az osztályszintü együttmüködés során tényleg kizártak bennünket (5) a kör összezárt és elég halkan kezdtek el beszélgetni. Nehéz volt őket hallani, és aztán az egyik legnagyobb baj az volt, hogy ők maguk sem hallották egymást. A közösség egyik tagjának javaslatára végigmentek a csoportötleteken (3). Meghallgatták egymást, beszélgettek. Nem alakulnak ki jól definiálható csoportszerepek, a közösség egyenrangú tagjaiként müködnek. Nem találták a megoldást, ami átmeneti mélypontot, kilátástalanságot hozott. Mindenáron a három kiscsoportos ötletből akartak egyet csinálni, ettől nem tudtak elrugaszkodni. Egy darabig próbálkoznak, aztán feladták, itt picit megtörik a csoport (,az úgy nem jó, hogy csak ti beszéltek, nekünk is mondjátok”, „hallgassuk meg egymást, mert most külön csoportokba szegődtünk”) Az ötlet 
végül főleg négy-öt aktív kisfiúhoz kapcsolódik, próbálták beintegrálni a többiek ötletét, de ez csak részben sikerült.

A megvalósult produktum a Rászorulókat Segítő Elektromos furgon nevet kapta, amit annyira nem sikerült kidolgozni, és közös ötletté formálni (9). A furgon tetején napelem lenne, ami működteti a hűtőt, amiben étel van. Buszmegálló szerűen mennek faluról falura, és ahol szükség van rá, ott megállnak, gyüjtenek és adják tovább a rászorulóknak. A megoldás értékeként definiálják azt, hogy nem szennyezik a környezetet és segítik a hajléktalanokat, nélkülözöket (8). A kockázatok között felmerült, hogy valóban ahhoz jutnak-e el, aki tényleg rászoruló. Az objektív jó megvalósítására törekedtek, ugyanakkor megfogalmazták, hogy ez nem csak rajtuk múlik (,tuti mindig lesz olyan, akinek nem jó. Az a lényeg, hogy akit céloz, annak jó legyen") A foglalkozás záró akkordjaként pedig megszületett a produktum vizuális lenyomata egy közös rajz formájában (9).

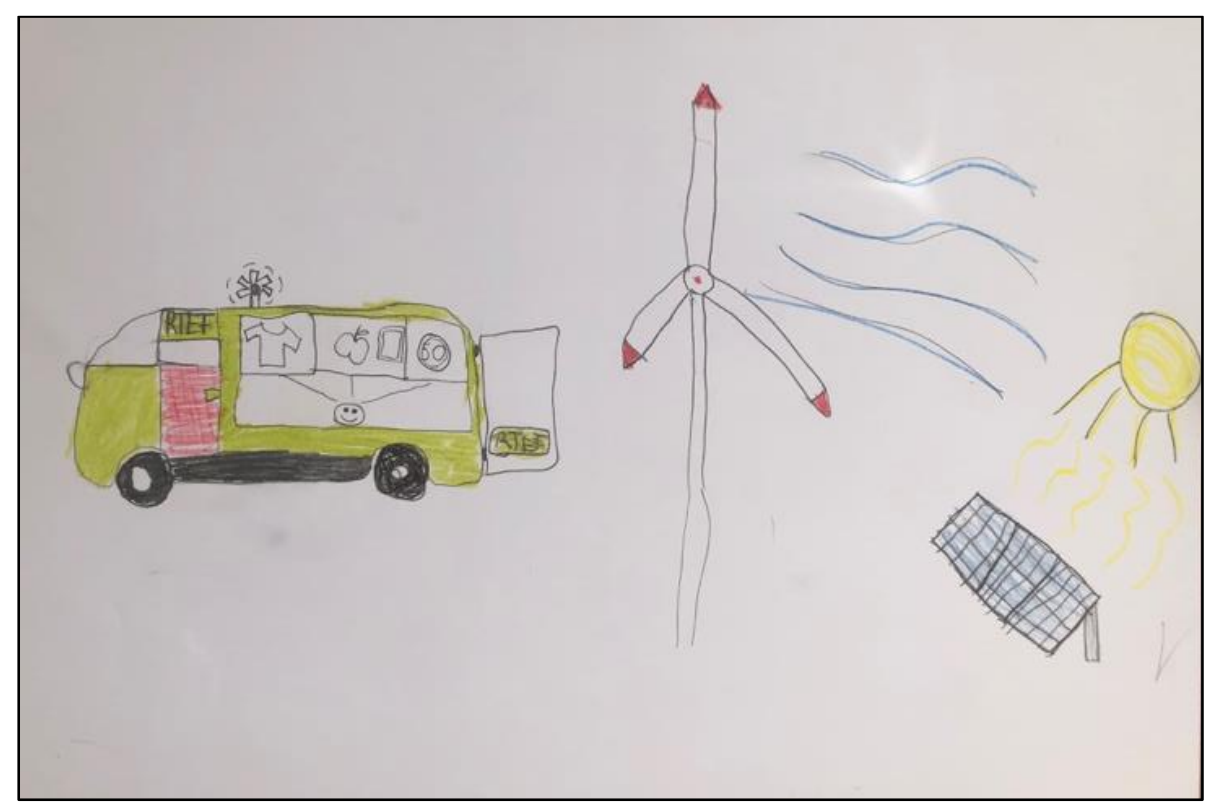

3. illusztráció: Közös rajz-Tápszentmiklós

Reflexiók elemzése

A diákok reflexióin érezhető volt, hogy sok fogalmazási feladatot kapnak (ahogy a mélyinterjúban a pedagógus említette), mert nagyon összeszedetten írtak, hosszú és tartalmas reflexiók születtek. A sok jó ötletből egy közös eredmény jött létre, amiben saját (,Ez az ötlet sok-sok jó ötletből jött össze, köztük az enyéimböl is") és a közösség együttes hozzájárulását is rögzítették (,Együtt dolgozhattunk, összeraktuk mindenkinek az ötletét”). A megoldáshoz 
vezető utat folyamatként értelmezték (,Nekem a közös ötletelés volt a kedvencem”), amiben a közösség tagjai meghallgatták egymást és kifejezhették véleményüket (,Nagyon tetszett, hogy elmondhattam a véleményemet, és másokat is meghallgathattam"). A kutatók hozzáállása (,Kedvesek voltak és szeretettel, türelemmel bántak velünk”), a hibázás lehetősége (,Az tetszett, hogy ha valaki rosszat mondott akkor Daniella néni nem szidott le senkit”), a szabadság („,ól éreztem magam, mert ez egy nem mindennapi óra és ez olyan laza óra volt”) és az egyenrangú helyzet biztosítása („Jó volt, hogy mindenki egyenlö, tehát jól éreztem magam”) ösztönzőleg hatott a diákokra, amit ki is fejeztek a reflexiókban. A tér szokatlan elrendezése támogatta a közösség együttműködését, amit szintén felismertek és pozitívumként értékeltek a diákok (,„Az is tetszett, hogy középen egy körben ültünk és nem a padban, mint matek órán").

Erőteljes volt a létrehozott produktum felé irányuló kapcsolat, a segítő szándék, de megjelent az ehhez kapcsolódó objektív jó egy értelmezési lehetősége is, vagyis a számunkra okozott jó érzés azáltal, hogy másoknak jót teszünk (,Ha támogatjuk a szegény embereket az nekem egy jó érzés egy jó cselekedet").

40. ábra: Diák reflexiók kódjegyzék - Tápszentmiklós

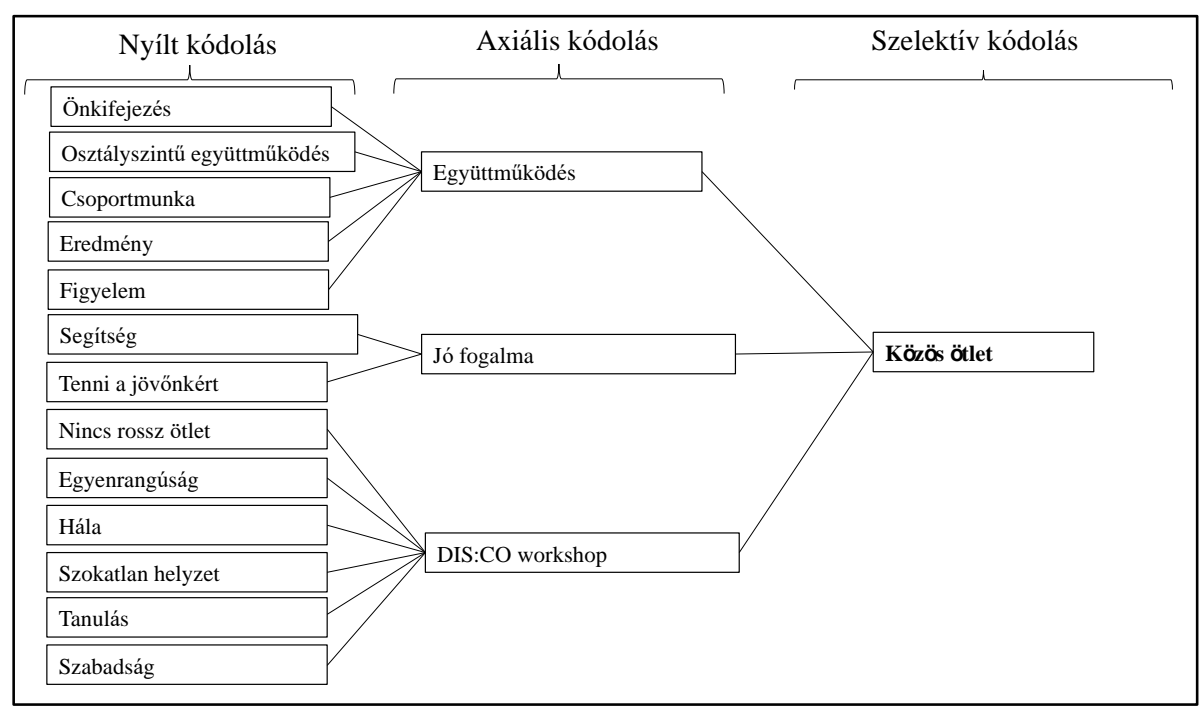

Forrás: A diák reflexiók elemzése alapján saját szerkesztés

\subsubsection{Somogy megye, Kaposvár}

Mélyinterjú

A kaposvári vizsgálat során interjúalanyom egy angol-testnevelés szakos férfi pedagógus volt, aki magát kevésbé tartja nyitott személyiségnek. Osztályával jó a kapcsolata, de többnyire az iskola falain belülre korlátozódik. Ennek ellenére meglátása szerint erős osztályközösség 
jellemzi a csoportot. Az infrastrukturális hiányosságokat az iskolában látja, ugyanakkor az oktatás színvonalát sokkal inkább a pedagógusok- szülők-diákok kapcsolatrendszere határozza meg véleménye szerint (,egy iskola attól erös, akik benne vannak. Lehet jó az infrastruktúra, ha a gyerekek, szülők, pedagógusok viszonya nem megfelelö, akkor nem fog jól müködni."). A katalizátor, az újító törekvések alapvetése a gyerekek ösztönzése a fejlődésre, a belső motiváció kialakítása, („Ki kell alakitani saját magunkban, illetve nekünk, pedagógusoknak a gyerekekben egy belsö igényt arra, hogy ők magukat tovább fejlesszék") és ezzel párhuzamosan a pedagógusban az igény a folyamatos fejlődésre, hogy jobb és jobb legyen (,Ha nem érzi annak a szükségét, hogy ő képezze magát, hogy új dolgokat találjon ki, amik müködnek is, akkor pillanatok alatt kiég").

A kreativitás és a spontaneitás fogalmát összekapcsolja (,Nagyon fontos része a pedagógusi munkának, és össze is kapcsolódik a kreativitással a spontaneitás”), a kreativitást a tudásanyag megfelelő felhasználásában rögzíti. A kreatív kapcsolatteremtés megvalósítását csak akkor tartja életszerünek, ha megismeri a diákot, ha tudja, hogy hogyan kell öt megszólítani. A játék kiváló rálátást ad a pedagógusnak a gyerek személyiségéről (,játék közben senki nem tudja megjátszani magát, akkor a legöszintébb, amikor önfeledten játszik. Ott kijönnek azok a tulajdonságok, hogy mennyire csapatjátékos valaki, mennyire ad a másiknak, mennyire önző.").

A csoportmunkát, a kapcsolódó újító módszereket alkalmazza (,kollégáim is és én is igyekszünk, amikor csak lehet, megbontani, és nem a frontális osztálymunkát eröltetni."), ám a gyerekek nem mindig elég önállóak hozzá, gyakran terelgetésre szorulnak (,Néha azért kell őket noszogatni. A tanári közbeavatkozás néha szükséges.”), így jellemzően a szabályozott, koordinált, célokhoz, csoportszerepekhez és időhöz rendelt feladatokat részesíti előnyben.

41. ábra: Pedagógus mélyinterjú kódjegyzék-Kaposvár

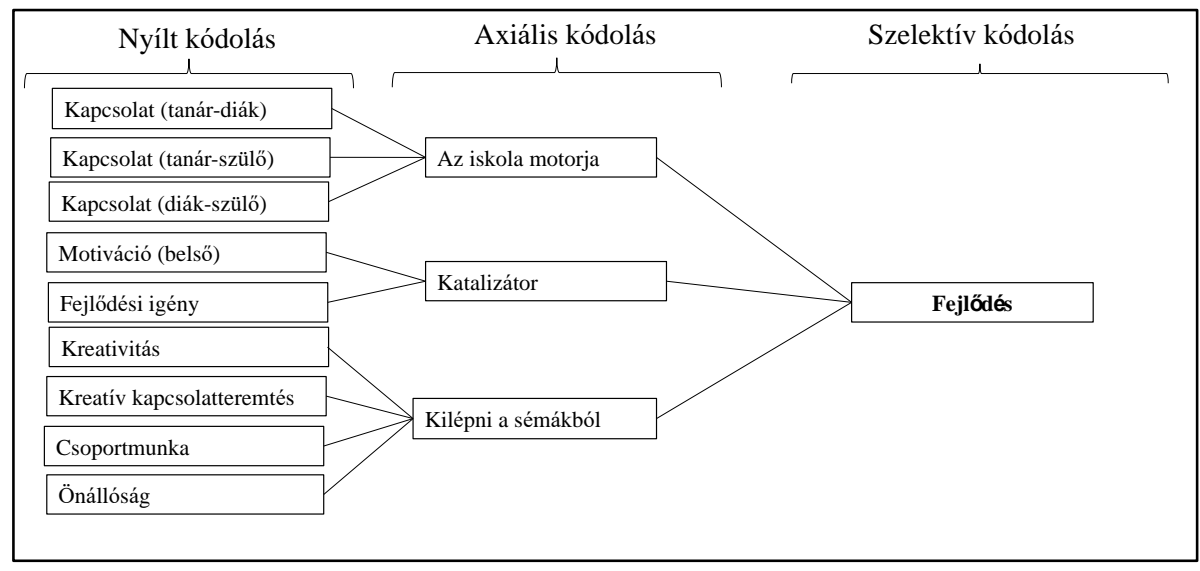

Forrás: A mélyinterjú leiratának elemzése alapján saját szerkesztés 
Résztvevő megfigyelés

A 24 fős osztály magatartása rendben volt (4). Viszonylag nagy volt a hangzavar, de ha kellett rendre intették egymást (5). Figyeltek, érdeklődők voltak, sokat jelentkeztek (1). A prezentáció során sok értékes hozzászólás érkezett, aktív bevonódás jellemezte az osztályt (2). Kis csoportokban kicsit zsibongva, de ettől függetlenül koncentráltan dolgoztak (3). 5 csoportra oszlottak, ahol az otthon jobbá tételét a szemétszedésben, az esővíz-gyüjtésben és a nyilvános mosdók felújításában látták.

A nagy csoportban zajló munka során megérezték a felelősséget, hamar kialakultak a csoportszerepek, hallgattak egymásra (5). A kiinduló kiscsoportötleteket szavazásra bocsátották (,várjatok, várjatok: mondja el minden csapat a saját ötletét”, „A végén szavazunk, ha szavazat-egyenlöség van, akkor összevonjuk az ötleteket”). A csoportok elmondták az ötleteiket (9), és utána mindegyikröl beszélgettek kicsit, kérdezték egymást, de nem ragadtak le egy ötletnél, hanem tovább mentek. Jelentkeztek, kérdeztek, és minden ötlet kapcsán hagytak időt a megbeszélésre. („Következő csoport, vagy van még kérdés?”) Sok idejük elment azzal, hogy meghallgattak mindenkit (7), és megvitatták, így a közös tervezésre kevesebb idejük maradt, de valójában ez is egy alkotói folyamat, amin végigmentek. Végül szavaztak, de valójában nem akarták, hogy bármelyik is nyerjen, hanem inkább megpróbálták kitalálni, hogy hogy lehet mindenkinek az ötlete nyertes (8). A „Jobb Föld érdekében” vállalkozás megalakult, aminek logót is terveztek és pontos folyamatban rögzítették a tevékenységet, a kitalált innovatív gyógyszer, mint termék eladásából befolyt bevételt olyan jótékony célokra fordítják, mint szemétszedés, esővízgyüjtő - rendszer és a nyilvános mosdók felújítása.

\section{Reflexiók elemzése}

A reflexiókat, az osztály egysége, mint a foglalkozás legnagyobb értéke határozta meg. Ez említésre került az osztályszintủ együttműködés dimenziójából (,Legjobban a közös munka tetszett, amikor az egész osztály benne volt a munkában”), de az osztály együtt alkotására is nagyon sok diák reflektált pozitívan. Megjelent az értékes, minőségi idő és a hozzá társított élmény és boldogság, amit a közösség adott számukra (,Nagyon tetszett, hogy mindannyian részt vettünk”, „Még sosem voltam ilyen boldog úgy, hogy az osztálytársaimmal voltam”, „Végre egy rendes osztályként tudtunk együtt dolgozni”, „Jó volt az együtt töltött idö az osztállyal”). A folyamat részének tekintették a közösség erősödését („Osztályépitő volt a program”, „Összehangolódott az osztály”). 
A reflexiók kapcsán fontos még kiemelni, hogy a tervezés és az eredmény a gondolatukban összefonódott (,Átéreztük, hogy milyen nehézségekkel jár valami újat létrehozni, mire kell figyelni, hogyan kell átgondolni”, „Jó volt, mikor együtt az osztállyal összekreáltuk az összegyüjtött projektekböl az egész lényegét"), ami a designkommunikáció alappillérét helyezi fókuszba, miszerint a megoldás és a megoldáshoz vezető út sokszor egyszerre, egy időben alakul és formálódik. A foglalkozás során kapott szabadságot (térben és időben) élvezték és kihasználták („Jó volt, hogy kaptunk időt arra, hogy megbeszéljük az ötleteinket").

42. ábra: Diák reflexiók kódjegyzék - Kaposvár

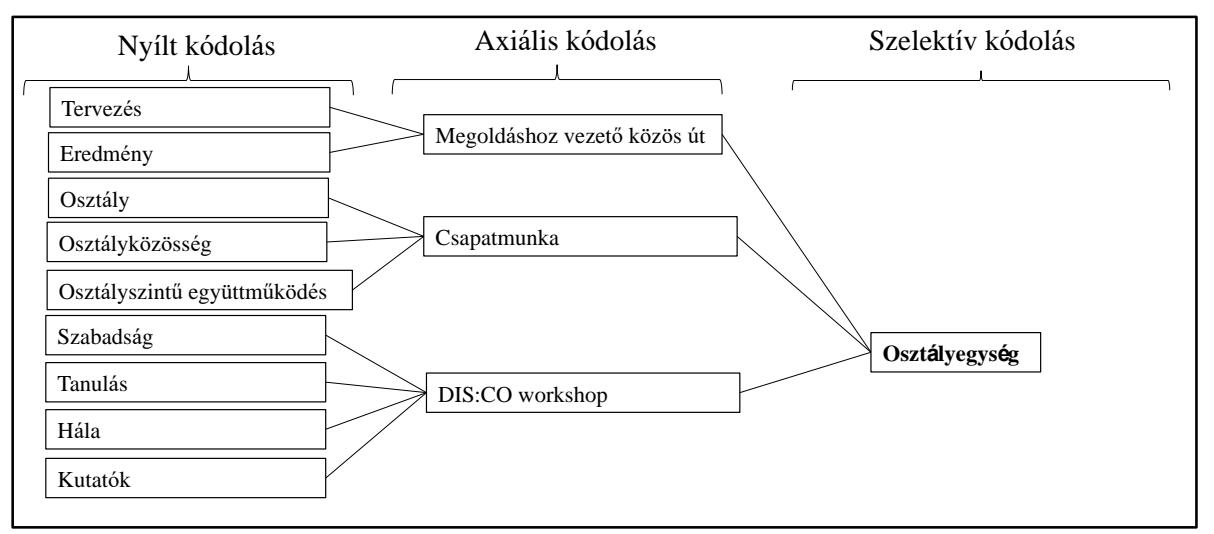

Forrás: A diák reflexiók elemzése alapján saját szerkesztés

\subsubsection{Zala megye, Alsópáhok}

Mélyinterjú

Alsópáhokon egy családias iskolában volt lehetőségem megtartani a kutatást, ahol az interjú alanya egy 40 éve a pályáján lévő pedagógus volt („Családias iskola vagyunk, már tanitottuk a szülők nagy részét.”). A vizsgált osztály tanulmányi eredménye elmondása alapján kiemelkedő, a szociometriai felmérés alapján azonban az osztályközösség még javításra szorul (,,nem igazi. Klikkek vannak. De ha kell, akkor bizonyos dolgok miatt össze tudnak fogni. $70 \%$ körüli. Van még mit alakitani.”).

A pedagógusok fő feladatát az oktatás helyett inkább a nevelésben feltételezi (,a legkevésbé feladatunk manapság már az oktatás, hanem a nevelés."), tapasztalata alapján ezt egyre kevésbé kapják meg otthonról a diákok (,a szülők odahaza nagyrészt nem azt a szerepet töltik be”). 
A soft készségek fejlesztése itt is központi kérdésként kerül elő, az iskola feladata kellene, hogy legyen többek között, hogy a probléma megoldására készítse fel a diákot („Biztos, hogy vannak fölöslegesen tanítandó dolgok, a nagy lexikális tudás a mai világban már idejét múlt. Én egy olyan iskolát szeretnék, ahol problémákat tud megoldani a gyerek, hogy egy problémát hogyan lehet megoldani, ahhoz kulcsokat kapni. Nyitottnak lenni.”). A problémamegoldás igénye mellett a nagyobb önállóság („A gyerekeknek sokkal nagyobb önállóságot kellene elérni.”), a tudás átadásának képessége (,A tudását, nem csak a szellemi tudását, hanem amit ő alkotott, át tudná adni a többinek.”) és a kudarc kezelése (,a kudarctürő képességük az gyakorlatilag nulla. Ez egészen biztos, hogy hosszú távon nem vezet jóra.") is megoldásra váró feladat.

A hagyományos csoportmunka hatékonyságát megkérdőjelezi, ugyanakkor a kooperatív tanulásszervezésben (Johnson \& Johnson, 1987) feltételezi a potenciált. Ennek sokszor gátat szab az idő és a pedagógusra háruló extra feladatok (,Ez a kooperatív, ami a mai trend...Én azt valahogy sokkal jobb hozadéknak látom. Csak az nagyon sokrétü, és sok felkészülést igénylö. Amikor az ember 26 órában fut ide, fut oda, nem könnyü azt megcsinálni. ”).

43. ábra: Pedagógus mélyinterjú kódjegyzék-Alsópáhok

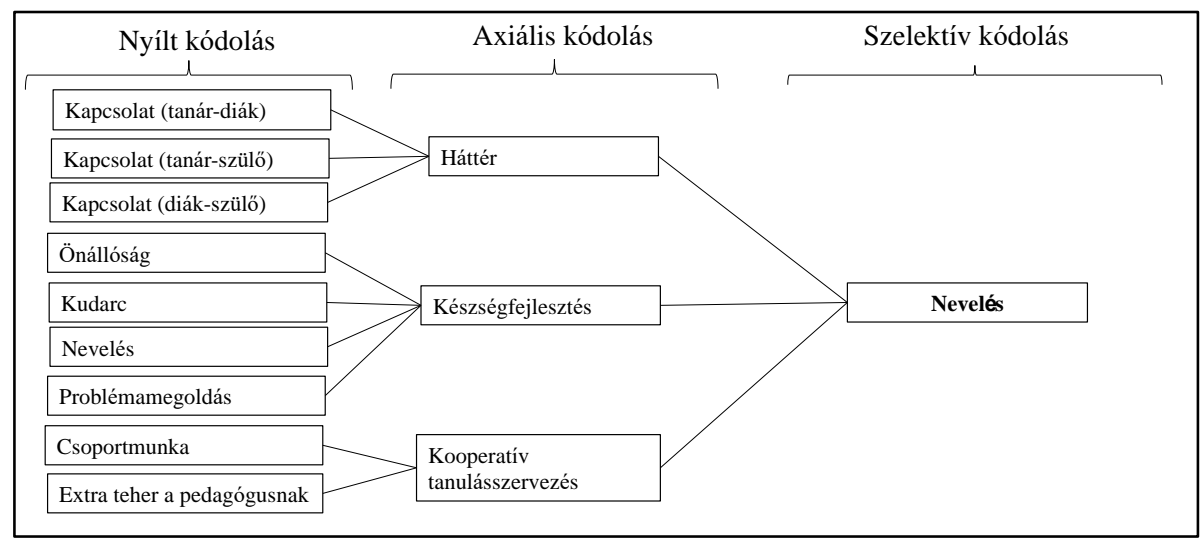

Forrás: A mélyinterjú leiratának elemzése alapján saját szerkesztés

Résztvevő megfigyelés

Nagyon értelmes, aktív, eleven társaság (4), folyamatosan jelentkeztek a prezentáció alatt (2), nagyon aranyosak, közvetlenek voltak, őszinte és bátor véleményalkotás jellemezte a közösséget (1). Az osztályban hátrányos helyzetü tanuló nincs, jómódú, rendezett körülmények között élő gyerekek. Aki esetleg nem szólt, de ha néha kérdeztem egyből tudta a választ, hozzá tudott szólni (2). A prezentáció alatt volt a tízórai szünetük, amikor ki kellett menniük az ételért, 
és az egy kicsit megtörte a folyamatot, utána idő volt, mire visszarendeződtek (4). A gyerekek elmesélték, hogy egyáltalán nem jellemző a mindennapjaikra a csoportmunka, hiszen akkor addig nem haladnak a tananyaggal, ezért a tanárok nem alkalmazzák, ritkán a páros munka előfordul.

Kiscsoportban bár a témáról beszélgettek, mégsem éreztem azt, hogy igazán ütős ötletek születtek volna (3). Ez a csoport volt az egyik olyan kivétel, akik nem a környezetvédelemmel foglalkoztak (9).

Mikor nagycsoportban elkezdtek dolgozni érdekes volt, hogy egyik pillanatról a másikra fogták magukat beültek a földre a kör közepére, összekucorodtak és elkezdték a beszélgetést (5). Nem mondom, hogy nem vágtak egymás szavába (6), de közben konstruktívan egyezkedtek. Volt egy kisfiú, aki egyértelmüen átvette az irányító szerepét, és kimondta, hogy legyen a produktum egy „osztályház”, így a csoportok külön ötletei nem kerültek megvitatásra, a megvalósítás során azonban már hozzárakták az ötletüket (,Legyen két emelet, egyiken a fiúk, másikon a lányok”, „lenne egy közös mozi”). (8) Egy ideig elrugaszkodnak a valóságtól (8), aztán elkezdték a megvalósítás irányába formálni ötleteiket, hogy ők maguk is meg tudják teremteni („olyat csináljunk, amit meg is tudunk valósítani”, „valóságbeli házat tervezzünk”) Érdekes tendencia, ahogy a „mindenkinek külön emelete van” kiindulásból odáig jutnak, hogy mindenki egy szobában van, hiszen az egész a közösségük építéséről szól (,együtt tanulunk, együtt szórakozunk”)

Amikor végeztek, akkor utána egy pillanat alatt mindenki visszaült a helyére. Aztán a rajzhoz visszaültek, itt kevesebben vonódtak már be, de összességében elmondható, hogy közös munka volt, amit láthatóan nagyon élveztek. A projekt összefoglalását egy kislány vállalta fel (8), és kimondták, hogy a cél az volt, hogy „,csapatot épitsenek és egy jobb közösséggé váljanak".

Reflexiók elemzése

A diák reflexiók egyértelműen a tervezés kulcskategóriája köré épültek. Más-más aspektusokból közelítették, de a legnagyobb hatást a közös ház megtervezése jelentette számukra. Túl azon, hogy jól érezték magukat a tervezés során (,Nagyon jó volt az egész, a legjobban a közös ház megalkotása tetszett”), csapatmunkaként élték meg a pillanatokat („Nagyon szórakoztató volt a közös lakás tervezése, a csapatmunka”). Elhelyezték magukat a valós tervezői szerepben (,Jó volt, hogy tervezők lehettünk”, „,Tervezöként gondolkodtam és a társaimmal közösen alkottam”) és elégedettek voltak a saját elképzeléseik mentén megalkotott 
produktummal (,Szerintem jó lett a közös házunk is, amit együtt alkottunk, a saját képzeletünk szerint.”) A tervezés folyamata lehetővé tette számukra egymás jobb megismerését („Nagyon sokat megtudtam a barátaimról”, „Nagyon jól éreztem magam, mert kicsit közelebb kerültünk az osztállyal’) és nem utolsó sorban a közösség erősödéséhez is hozzá járult (,Most éreztem úgy, hogy az osztály igazán összetart”, „, A közös háztervezés az jó ilyen osztályközösség jobbá tételére").

Az átélt élmény leírására erős szavakat használtak (,,Nagyon emlékezetes lesz ez a nap”, „Imádtam az egészet”, „Rettenetesen jól éreztem magam”, „Eszméletlenül jól éreztem magamat”), és negatívumként azt idő gyors múlását fogalmazták meg (,Az idő nagyon gyorsan eltelt sajnos").

44. ábra: Diák reflexiók kódjegyzék - Alsópáhok

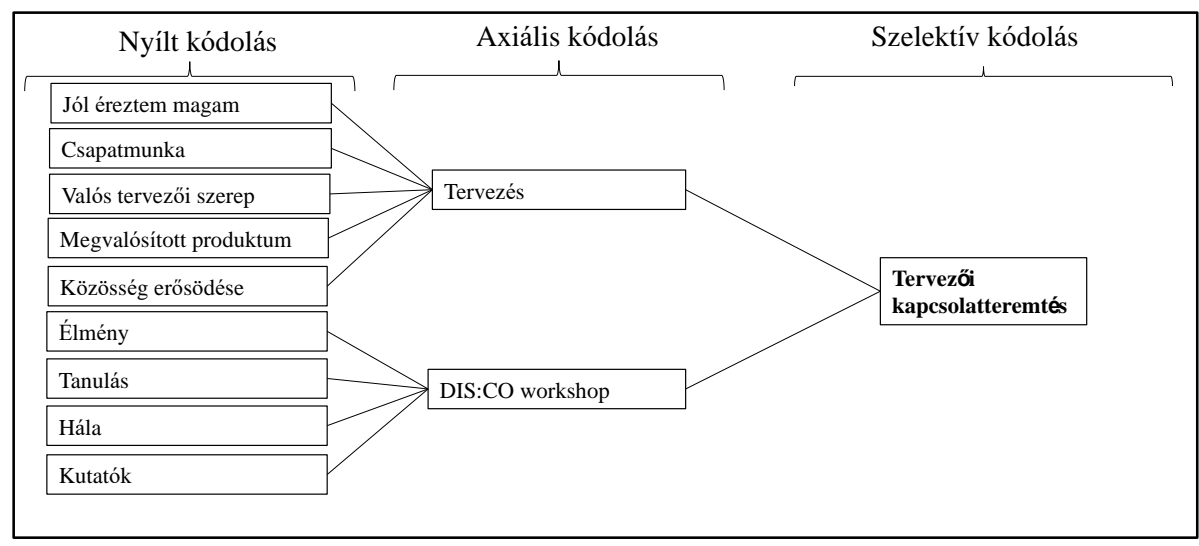

Forrás: A diák reflexiók elemzése alapján saját szerkesztés

\subsubsection{Veszprém megye, Tapolca (2. osztályos diákok)}

A Tapolcán megvalósuló kutatás egyfajta kitekintésként is értelmezhető, hiszen a megszokott hatodik osztályos tanulók helyett, itt a második osztályos diákok kerültek a vizsgálat középpontjába. Fontos látni, hogy korosztálytól függetlenül is tud-e müködni a designkommunikáció, (mint oktatásmódszertan) elemeire támaszkodó saját fejlesztésü workshop. A cél, hogy feltérképezzem, hogy vannak-e, és ha igen, akkor melyek lehetnek azok az elemek, amin adott esetben változtatni kell ahhoz, hogy egy fiatalabb, kreativitásra fogékonyabb (Kaszás, 2011) korosztályban is teret engedjünk a foglalkozáson keresztül a soft készségek fejlesztésére.

Mélyinterjú 
A második osztályos diákok osztályfönöke egy igazi tanító néni, aki szeretettel fordul a gyerekekhez és hivatásának tekinti a szakmát (,A gyerekeket imádom, a hobbim is egyben a munkám.”). A csoportmunka nem jellemző, inkább párokban dolgoznak, amit a diákok kifejezetten igényelnek, sokszor ők kérik a feladat megoldását megelőzően („Ők igénylik, akarják. Párban szoktunk dolgozni. söt, ök kérdezik, hogy megoldhatják-e párban a feladatot."). Újító szemléletét azonban egyéb módszerekkel integrálja a hétköznapokba, nagy figyelmet fordít a beszélgetésre (,hétfön reggel nem egyböl nekiállunk tanulni, hanem körbe ülünk, és van egy beszélgetés. Ezzel indul a hét. Maguktól is kialakitják a kis kört, és úgy várnak, hogy bent ülnek. Igényük van rá"), kihasználva annak a kommunikációra és a közösség építésére gyakorolt hatását, de fontos szempontrendszer számára a tanulás játékos formájának megvalósítása is (,játszol velük, úgy tanitasz, hogy észre sem veszik”).

Úgy véli, hogy a pedagógusok és az iskolai keretrendszer az, akiknek és aminek felelőssége van a gyerekek fejlődésében, hiszen alapvetően minden diák „,ideális” diákként lép be az iskola kapuján, így az ő felelősségük is az, hogy kivé válik (,Mindegyik úgy jön be, hogy ideális diák, aztán vagy meg tudjuk tartani ideális diáknak, vagy mi rontjuk el.”).

A fejlődést, a megújulást a jó pedagógus egyik legfontosabb ismérvének tartja, amit ő két pillérre épít. Az egyik a belső motiváció, a belső igény a fejlődésre („Csomó mindent kitalálok, ezt a pálya hozta, hogy állandóan meg kell újulni, meg valamit kitalálni, hogy érdekesebb legyen”), a másik pedig az őt körülvevő, inspiráló kollégák, az egymástól történő tanulás, a tudás megosztása (,Egymástól is, fiatalabb kollégáktól, bemutatókon látja, hallja, alkalmazza, tovább fejleszted a saját órádon.”).

45. ábra: Pedagógus mélyinterjú kódjegyzék-Tapolca (2. osztályos diákok)

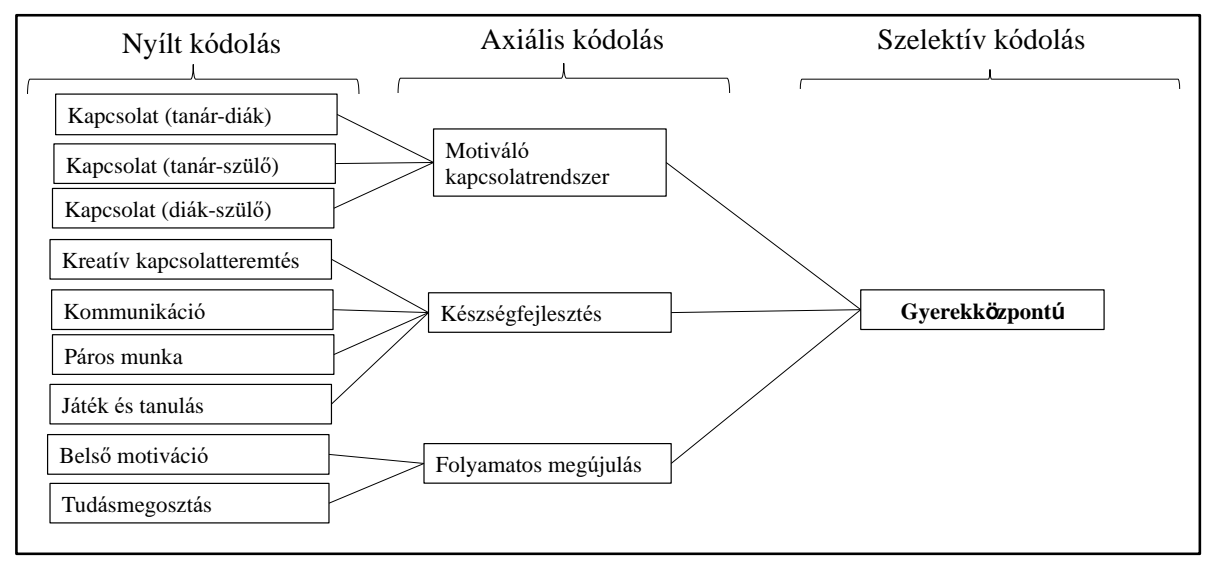

Forrás: A mélyinterjú leiratának elemzése alapján saját szerkesztés 
Résztvevő megfigyelés

Az a szerencsés helyzet állt elő, hogy a korábbi, ugyancsak Tapolcán megvalósuló workshopok miatt a diákok már ismertek engem, így rövidebb volt az oldódási folyamat, gördülékenyebb a kapcsolatteremtés. Az első eszközölt változtatás a prezentációban valósult meg, leegyszerüsítettem és a leglényegesebb fogalmak bevezetésére koncentráltam (1). Definíciók tekintetében nem mentünk bele a részletekbe, idegen szavakat nem használtam nekik, mindent közérthetően magyaráztam, példákkal illusztrálva a könnyebb megértés érdekében. Meglepően jól nyilatkoztak (1), és összességében nem volt érezhető az a négy év, ami a második és hatodik osztály között van. Bizonyos helyzetekben jobban müködött a csoport, mint egy hatodikos (vagy akár egy felnőtt) közösség. A kérdéseik, a válaszaik, a megoldásaik a prezentáció során egy-egy felmerülő szituációra rendkívül értelmesek, kreatívok, olykor megdöbbentően érettek voltak (2). Két órán keresztül aktív figyelem jellemezte az osztályt (4). Egy olyan korosztályt, akik számára a negyvenöt perces tanórák is kihívást jelentenek.

A csoportos munka előtt tartottunk egy rövid szünetet. A három darab, véletlenszerüen kialakított négy-öt fös csoportokban egészen ügyesen beszélgettek, alapvetően a környezetszennyezés került a középpontba (3).

Az osztályszintü együttműködés során nagyon helyesek voltak, ahogy kiálltam a körből közelebb húzódtak egymáshoz. Nonverbális kommunikációval is jelezve, hogy ők egy csapat, akik együtt fognak dolgozni (5). Egy kisfiú és egy kislány irányították a beszélgetést. Nem voltak egyértelmü csoportszerepek, de meghallgatták egymást (4), mindenki elmondta a véleményét, majd szavazást kezdeményezett egy másik kislány. Egészen hihetetlen módon szervezték meg maguk között a diskurzust (7). (,,hadd mondják el”, ,jó, akkor kezdjünk neki”, „,hadd mondjam végig”, „ki szavaz”) A produktum, amit létrehoztak az a „Tengeri megmentők" szervezete, akik a tengerben élő állatokat védik azáltal, hogy megtisztítják a tengert a szeméttöl (9). 
A részletek megfogalmazása és az eredmény lerajzolása már ennyire nem volt zökkenőmentes, a fiúk (miután nem az ő ötletük került kiválasztásra) kivonultak a munkából, azonban a lányok továbbra is együtt dolgoztak (8). Még logót is rajzoltak, ahogy egy polip beszorul a kerékbe (9). Eredményükre büszkék voltak (8), azonban csak részben gondolták úgy, hogy ez közös produktum, amit a lányok-fiúk elszeparálódásához lehet kötni.

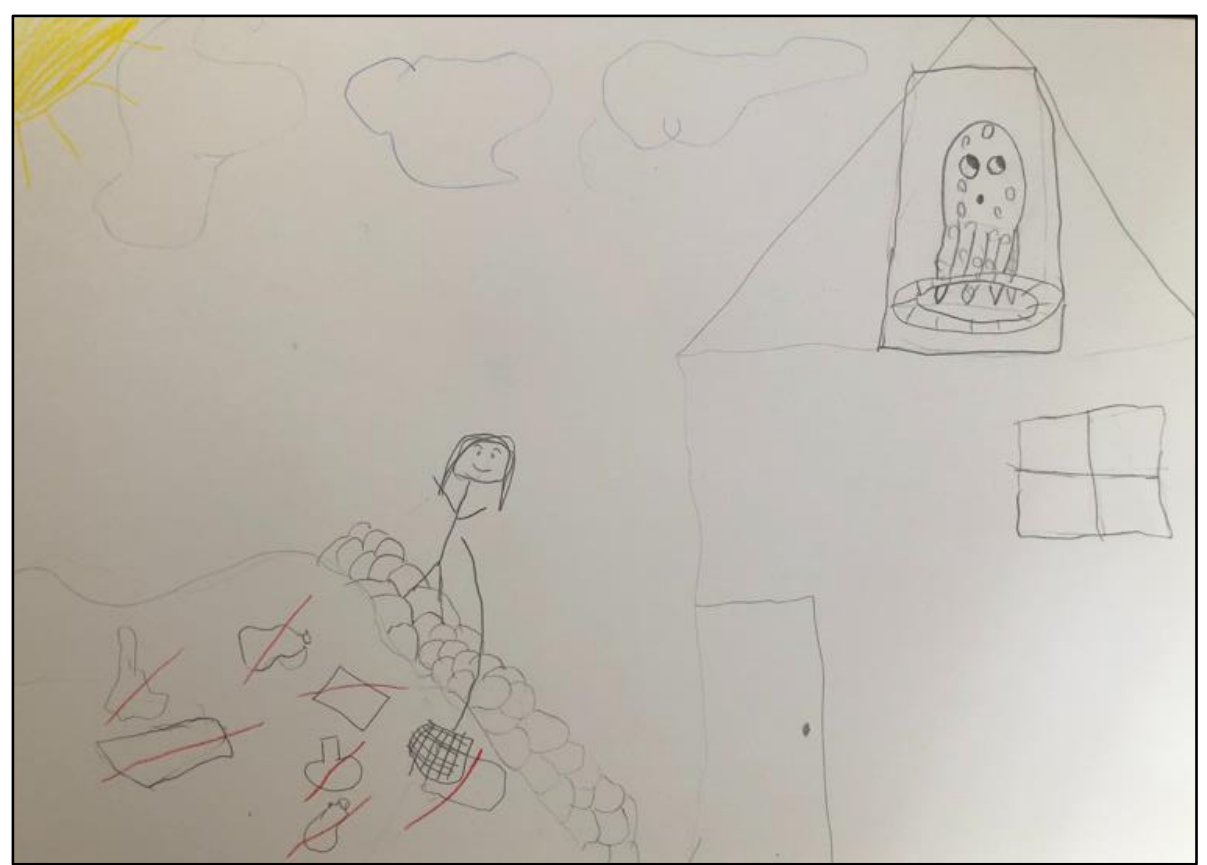

4. illusztráció: Közös rajz-Tapolca

Reflexiók elemzése

A diákok fogalmazását, szóhasználatát, kifejezésmódját és helyesírását tekintve sok hatodikos osztálynál magasabb színvonalú reflexiók születtek. Természetesen más kontextusban értelmezték a foglalkozást, de összességében sok hasonló meglátás született, csak egy egyszerübb logikai vonal mentén építették fel írásaikat.

Kivétel nélkül jól érezték magukat, saját hozzáadott értéküket a produktumhoz felismerték és pontosan meg tudták fogalmazni (,Jó ötleteim voltak”, ,én is mondtam dolgokat, meg a játékban is mondtam okosakat."). A workshop leginkább kedvelt része számukra a rajzolás volt („Jó volt a rajzolás”, „Nagyon tetszett, ahogy rajzoltunk”), a játszva tanulás szerepe jelentős még az életükben, ezt (ahogy a pedagógus az interjúban el is mondta) ilyen kis korban alkalmazni kell a pedagógusnak.

A tervezés folyamatában a közösség, az együttmüködés, mint faktor ugyancsak megjelent (,Az tetszett, hogy a közös munkánál együtt gondolkodtunk”, „tetszett, amikor kis körben 
ültünk’). Az eredményre is reflektáltak, büszkék voltak a teljesítményükre, amit a reflexiók is alátámasztottak (,És szerintem tök jó volt az az ötlet, amit mi alkottunk”).

Érdekes, hogy a hála („Köszönjük a programot”, „Nagyon jó volt a mai nap, örültem, hogy itt lehettem") is elötérbe került, ami arra enged következtetni, hogy értékként és élményként (,Izgalmas volt”) rögzült bennük a foglalkozás.

46. ábra: Diák reflexiók kódjegyzék - Tapolca (2. osztályos diákok)

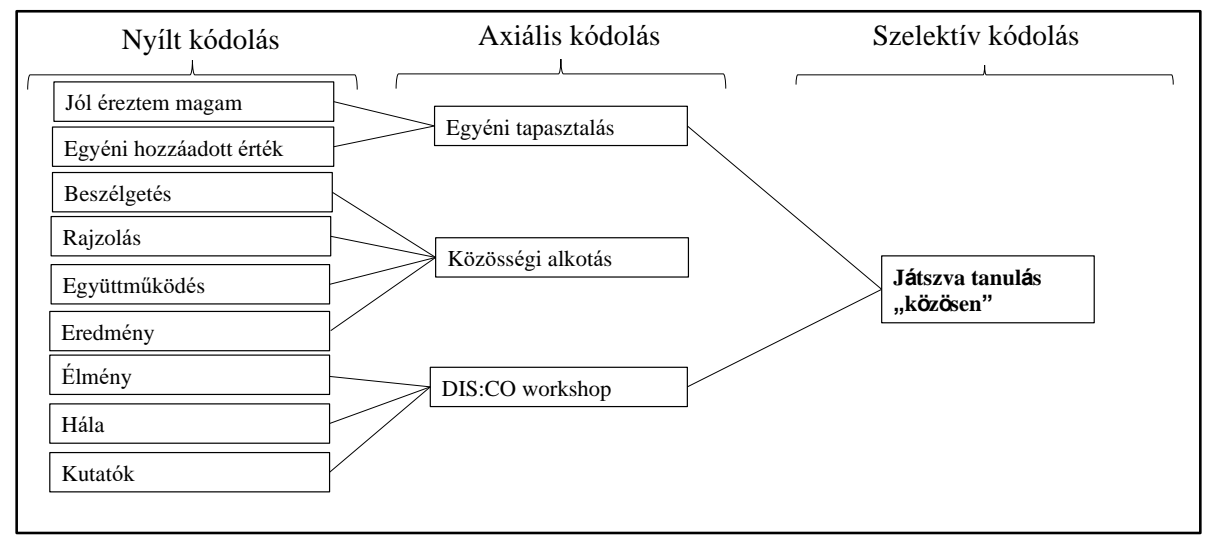

Forrás: A diák reflexiók elemzése alapján saját szerkesztés

\subsubsection{Baranya megye, Pécs}

Mélyinterjú

Pécsett egy nyitott, a lehetőségeket kereső pedagógussal valósult meg a mélyinterjú. Az osztályával a kapcsolata nem a legszerencsésebb, aminek oka a kevés együtt töltött idő (,Ezt hiányolom, ezt a folyamatos jelenlétet az ö életükben, és ezt ők is érzik, hogy nem vagyok mindig ott."). Ennek ellenére iskolán kívüli szabadidős tevékenységekkel próbálja ezt kompenzálni (,Akkor is próbálunk olyan dolgokkal foglalkozni, amikor tényleg együtt tudnak müködni, és együtt kell müködniük."). Az osztályban az elfogadás, az egymás megértése kevésbé müködik, ugyanakkor, ha van egy jól definiálható cél, akkor képesek az összefogásra (,,ha valami cél van, össze tudjuk kapni magunkat").

A pedagógusok közötti tudásmegosztás nem, vagy csak nagyon ritkán müködik (,,az, hogy én belelássak, vagy belekérdezzek más munkájába, nem jellemzö. Lehet, hogy igény lenne rá, de az idősebb kollégák nem szívesen beszélnek arról, hogy ők milyen módszerrel meg hogyan tanitanak”), pedig ez egy olyan fejlődésre vágyó személyiségnek, mint ő sokat jelentene (,Én nagyon szivesen veszek minden ötletet, amit kapok, meg ha 
másnál látok valamit.”). Bízik abban, hogy a fiatalabb kollégák már sokkal inkább ezt az irányt fogják képviselni (,ahogy fiatalodik ez a tanári kar, gondolom lesz erre igény”)

A képességek felértékelődése megjelenik az interjú során. Úgy a kreativitást (,a munkahelyek sem abba az irányba mennek, hogy csak ülünk és nézünk. Szükség van fantáziára és kreativitásra, hogy a későbbiekben kiigazodjanak és megtalálják a helyüket a világban"), mind az együttmüködést (,Majd, ha bekerültök egy munkahelyre, akkor ott majd olyan emberrel is együtt kell müködnöd, akivel nem szeretnél, ezt most tanuld meg, hogy hogyan tudod véghezvinni. Ezt próbálom nekik itt átadni.”) olyan képességként definiálja, ami elengedhetetlen a munkavállalói létben, ebből kifolyólag a pedagógus felelőssége is, hogy erre felkészítse a diákot.

47. ábra: Pedagógus mélyinterjú kódjegyzék-Pécs

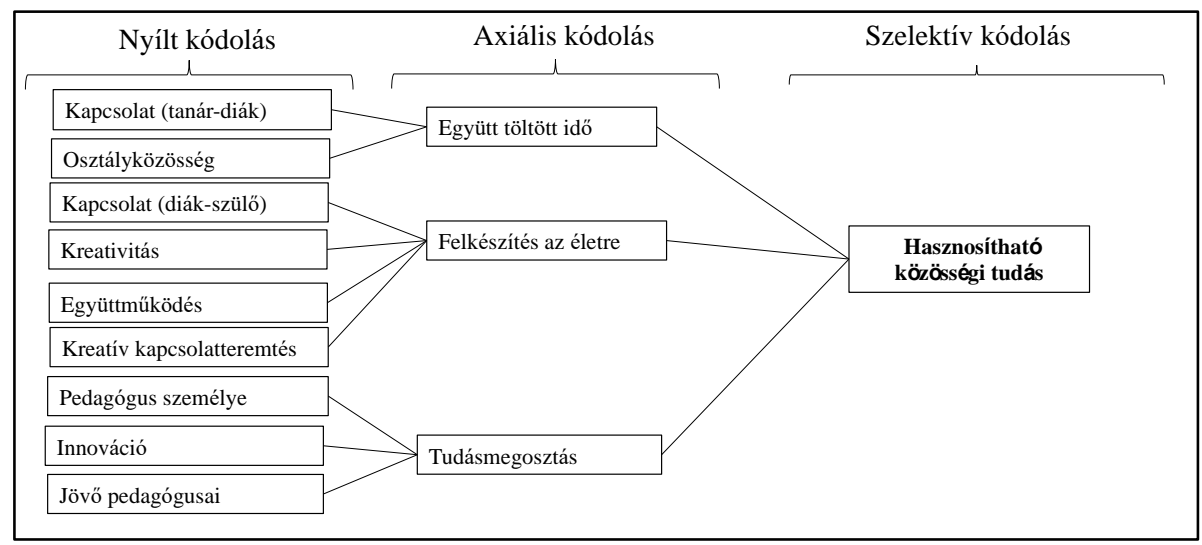

Forrás: A mélyinterjú leiratának elemzése alapján saját szerkesztés

Résztvevő megfigyelés

Egy kedves szimpatikus osztály volt, 20 fővel. Átlagos hátterü gyerekek, nem volt köztük kimondottan hátrányos helyzetü. A helyszínt Pécs egy külvárosi általános iskolája biztosította. Kommunikatívak voltak, jelentkeztek (2), és amit az elején kértem, hogy hallgassuk meg egymást amikor valaki beszél az müködött, a magatartásukkal nem volt probléma. Az elöadás vége felé kezdtem érezni, hogy nehezebben bírják (1), de összességében ezzel sem volt baj. Ennél a csoportnál jellemzően több szünetet kellett tartani.

A csoportmunkában tudtak a gyerekek kiteljesedni (3). Kis csoportokban végig a témáról beszélgettek, valóban jó beszélgetések történtek meg. Az otthon jobbá tételét ők is a környezetszennyezés/környezetvédelem oldaláról közelítették meg (8). 
Az igazi lényeg és meghökkenés a nagycsoportos munkában realizálódott (5). Kezdetben az volt a terv, hogy a négy ötlet közül megszavazzák a legjobbat, de aztán elkezdtek róluk beszélgetni és egy konstruktív beszélgetés alakult ki (7). A csoportok megtapsolták egymást, elismerték egymás munkáját (8). Nem egy központi probléma köré építették a projektet, hanem sok fontos kapcsolódó problémára hívták fel a figyelmet a környezet védelme, a hátrányos helyzetüek segítése kapcsán (9). Kiindultak a csoportötletekből, de aztán a továbbgondolták és elkezdett egy önálló ötlet életre kelni (3). Itt tipikusan az az eset állt fent, hogy maga a folyamat sokkal fontosabb volt, mint az eredmény. A projektnek a Természetvédelmi egység nevet adták és egy logót is készítettek, ami a Földet ábrázolja középen egy felkiáltójellel. (8)

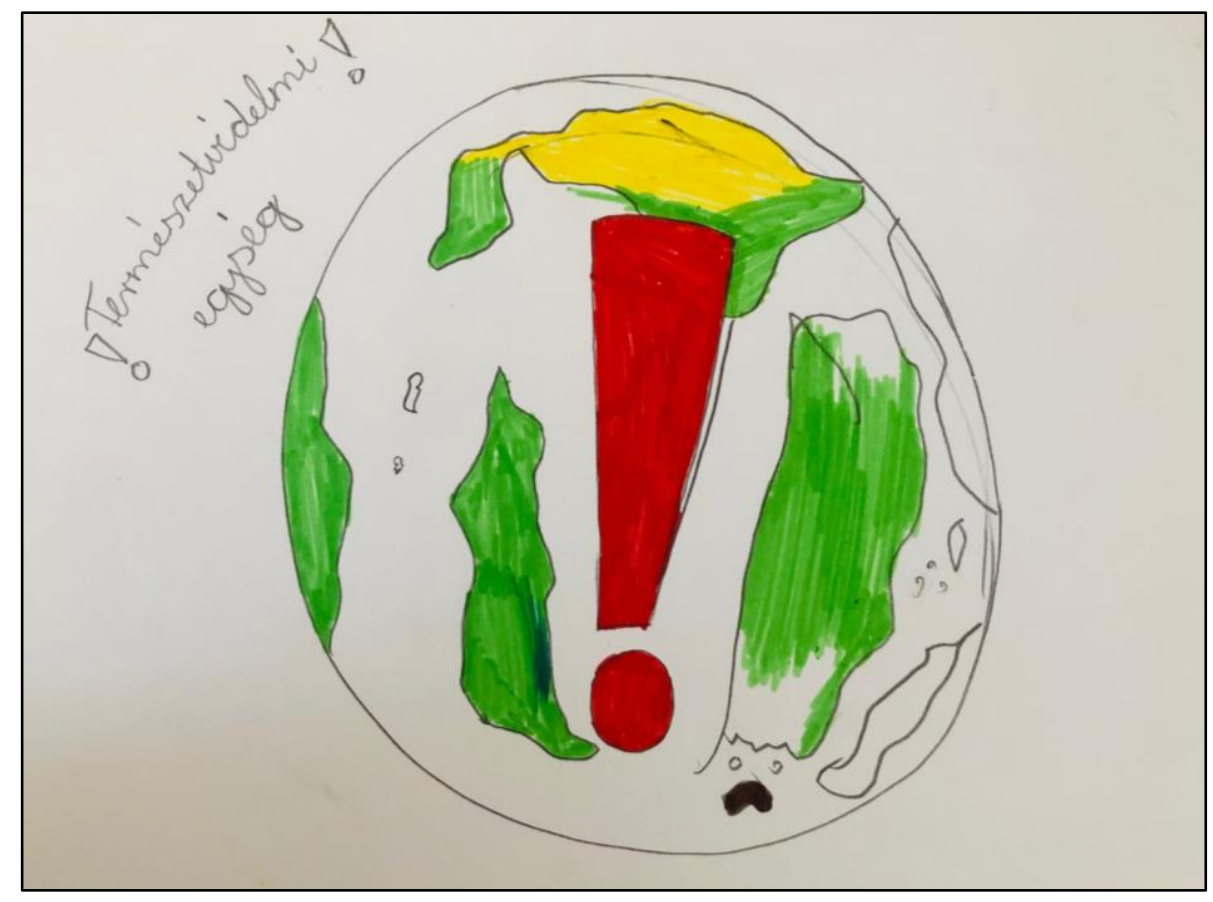

5. illusztráció: Közös rajz-Pécs

A folyamatot tekintve mindenkit meghallgattak, teret adtak egymásnak (,Tegye fel a kezét, akinek ezen kivül van ötlete?”), a közös megoldásra törekedtek (,Az az egyik legfontosabb, hogy olyat kell találni, ami mindenkinek tetszik.”, „Nem, nem egy ember rajzolja, rajzoljunk közösen”) Végül annyira jól elbeszélgettek, hogy minimális nyomást is kellett rájuk gyakorolni az idővel.

Az eredményükre büszkék (8), az osztályfőnökük felé is megfogalmazzák szóban, hogy mennyire jól együtt tudtak dolgozni, erre nem volt korábban példa és azzal búcsúzott az osztály, hogy ezt szeretné a hétköznapokba beépíteni. 
Reflexiók elemzése

48. ábra: Diák reflexiók kódjegyzék-Pécs

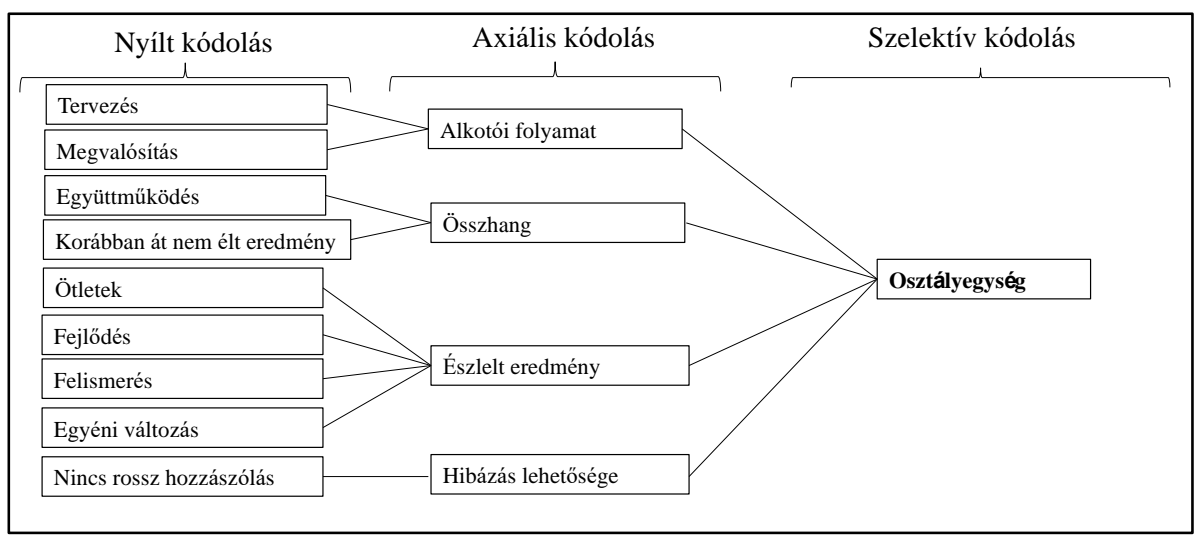

Forrás: A diák reflexiók elemzése alapján saját szerkesztés

A diákok a tervezés (,Az ötletelések nekem nagyon tetszettek, mivel az osztály nagy része nagyon jó dolgokat mondott”) és a megvalósítás („Maga a megvalósitás az nagyon jó”) folyamatát emelték ki írásaikban, de ami a legnagyobb arányban megjelent az az osztály közös, eredményes együttmüködése. Ehhez kapcsolódóan megjelent az összhang és az egyetértés ( „,ól éreztem magam, mivel végre összhang volt az osztály között”, „Jó volt látni, hogy az osztály egyet értett'). Ami ezt is fokozta, az olyan tapasztalás, amit eddig osztály szinten nem éltek még át, ez a foglalkozás jelentette az áttörést számukra a közösség szintjén (,Szerintem ez volt az osztály eddigi legjobb csoportmunkája”, „, Nagyon jól éreztem magam, a mi osztályunk még soha nem tudott ennyire jól kibontakozni").

Eredményként rögzítették a jó ötletek megszületését („Nagyon jó kis ötletek születtek”), de azt is, hogy a workshopon keresztül társaikhoz közelebb kerültek, jobban megismerték egymást („Sok mindent megtudtam a társaimról, amit eddig még nem tudtam”). A mühelymunka változást, fejlődést és felismerést is hozott számukra, ami tetten érhető volt az osztály megítélésében (,Az osztály magatartása nagyot nőtt a szememben”, „A csapatmunka se volt régen a legjobb, de ez most másképp lett”) és saját viselkedésükben egyaránt („Én nem szoktam ilyen programokon nagyon beszélni, de most volt pár ötletem, amit le is irtunk").

Zárásként felhívnám a figyelmet az iskola hierarchikus viszonyrendszerére, a hibázás nem megengedésére melynek ideiglenes lebontása ugyancsak értékképző elemként maradt meg a gyerekekben („Tetszett, hogy azt mondtad, hogy nincs rossz hozzászólás, ötlet, mert ez a tanórákon nem így van"). 


\subsubsection{Vas megye, Szombathely}

Mélyinterjú

A szombathelyi pedagógus egy közvetlen, fiatal, újító gondolkodású, pozitív szemléletü nyelvi szakos tanár, aki ugyancsak hivatásként tekint szakmájára (,A nehéz viszonyok között is hü maradok, csak ezt tudom elképzelni. Gyerekkorom óta ez akartam lenni.”). Osztályával és a szülökkel is közvetlen, jó kapcsolatot ápol („,ól ismerem a szülőket. Úgy indítom a szülői értekezletet, hogy az nem tabu, hogy az én telefonszámom mi, és fel lehet hívni.”). Osztályában nincsenek hátrányos helyzetü gyerekek, rendezett, normális, családi háttér a jellemző, válogatott diákok, 4,7-es tanulmányi átlaggal. Problémaként a gyerekek maximalizmusát említi (,Ha azt mondanám, hogy ahol fejlödniük kellene, az az örült maximalizmus, amit otthonról is hoznak"), ami örökös versenyhelyzethez vezet. Ez a versenyhelyzetet sokszor a szülők is generálják, pedig nem hat pozitívan az osztályközösségre (,Nem mindig tolerálják jól azt, aki gyengébb teljesitményü.").

Az iskolában minden adott, a pedagógusok segítik egymást a fejlődésben („Összetartunk, több ember több agy, sokkal modernebbül tudja.”) és a megfelelő infrastrukturális keretek („Én nagyon meg vagyok elégedve a mi iskolánk felszereltségével. A táblák, gyönyörü szép bútorokat kaptunk, festhetjük a termünket. 30 db tabletünk is van, amit használhatunk”) is teret adnak a pedagógusoknak és diákoknak a kiteljesedésre, az új módszerek alkalmazására.

Az életre nevelésben, a helytállásban a kreativitásnak fontos szerepet tulajdonít (, $A z$ életbe való beválás, beilleszkedés, helytállás miatt is fontos. Azt gondolom, hogy a kreatív ember mindenben meg tudja találni az örömét, a kiteljesedését, a munkájában, a tanulmányaiban.”), ugyanakkor osztálya kapcsán pontosan a maximalizmus, és a csak tól-ig, érdemjegyekben történő gondolkodás sok esetben ezt hátráltatja (,A b osztályok nem mindig kreatívok. Mert nagyon abban gondolkodnak, hogy jegy, tól-ig, nehogy belevigyek valami fantáziát, mert akkor hátha kicsúszok abból az ötösböl."), ez mindenképpen fejlesztést kíván a pedagógustól. 
49. ábra: Pedagógus mélyinterjú kódjegyzék-Szombathely

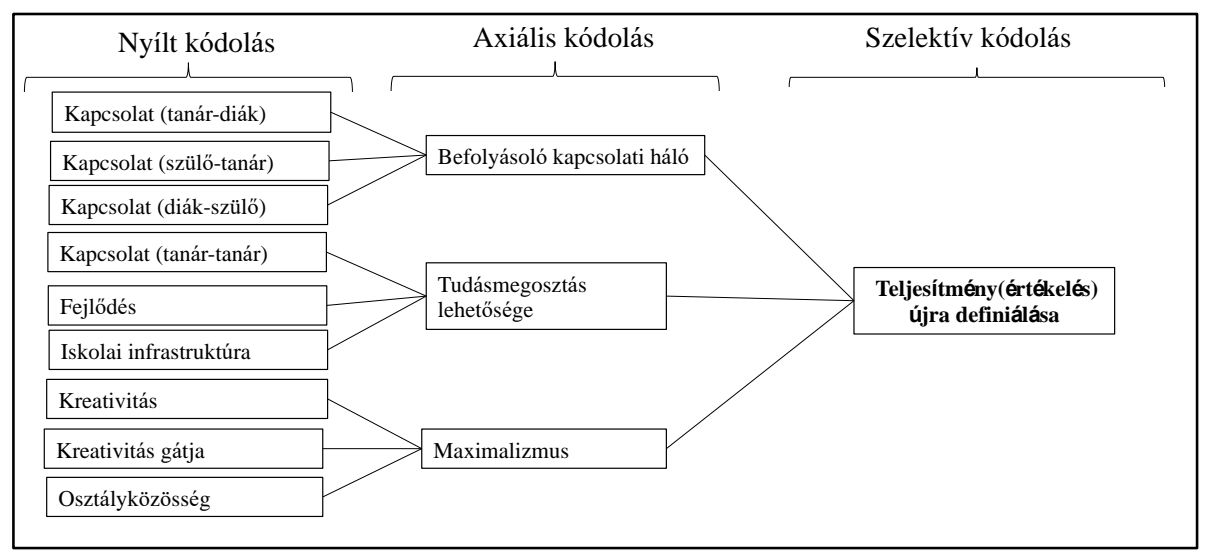

Forrás: A mélyinterjú leiratának elemzése alapján saját szerkesztés

Résztvevő megfigyelés

Egy nagyon jól szituált osztály volt a kutatás alanya Szombathelyen. Hátrányos helyzetü gyermek nincs, mint megtudtuk a pedagógustól ők harmadik osztálytól kerülnek egy osztályba, mint a legjobb gyerekek, a kiválasztottak, a nyelvi tagozatos osztály. Ennek ellenére a workshop elején nagyon visszafogottak, nem annyira interaktívak (2), de aztán lassan belelendülnek. A foglalkozás elején a pedagógus intézkedett, rendezte, csitította őket, de aztán kértem, hogy ne fegyelmezzen és akkor már sokkal visszafogottabb volt.

A magatartásuk alapvetően rendben volt (4). Az előadás után tartottunk egy szünetet, amikor ettek. Aztán egyedül végig gondolták a feladatot. Csoportban és nagyobb csoportban már zajosan dolgoztak. Öt kis csoport alakult meg első körben. Beszélgettek, de olyan igazán nagy átütő ötleteket, gondolatokat nem hallottam (3). Azon viszont annál jobban meglepődtem, hogy a csoportmunkát követően a wikinomikus együttműködés során egészen összeszedett output született meg (9), de az odavezető út nem volt inspiráló. Beszéltek kutyasétáltatásról, szemétszedésről, komposztálásról és olyan boltról, ami azonnal újra hasznosítja a szemetet. Alapvetően itt is a környezetvédelemre fókuszáltak, de inkább vállalkozás oldalról közelítették meg (8).

Ahogy kiléptem a körből úgy közelebb mentek egymáshoz, ez a kedvenc részem, amikor a közös „együtt dolgozás” fizikailag is megteremtődik általuk, iránymutatás nélkül (7). Jól definiálható csoportszerepek nem alakultak ki, több vezető szerep volt, elég határozott személyiség mindegyik diák, ahogy azt már az osztályfőnök interjújából is megtudtuk, itt beigazolódott, ahogy az is, hogy sokkal inkább a teljesítmény, mint a kreatív gondolat és fantázia mozgatja őket. 
A vége felé közeledve elveszítették a fókuszt, a feladat lényegét nem érezték, olyan igazi vita, beszélgetés, konstruktív ötletelés nem alakult ki (5). Érdekes, mert alapvetően közösen dolgoztak, minden csapat elmondta a véleményét, hogy mit hozott létre (7). A rajz minimális áttörést hozott náluk, abba jobban érdekeltebbé válnak (8), még közelebb húzódnak egymáshoz, páran lemorzsolódnak, de kialakul egy kemény mag. Amit létrehoztak, azt végül egy kislány ismerteti nagyon összeszedetten: Létrehoztak egy „Save the World” nevü céget, ami az embereket arra motiválja, hogy a szemetet hozzák be és azt a cég felhasználja. Különböző boltokba megy tovább az az előállított termék, amit készítenek. A produktummal az osztály alapvetően elégedett, közös eredményként értékelik (8).

Reflexiók elemzése

A diákok jellemzően a csoportmunka, az együttmüködés, az osztályközösség és az eredmény köré építve formálták véleményüket. Kifejezetten meglepő az a pozitív hozadék, amit a foglalkozáshoz társítottak. A csoportmunkát egyértelműen szeretik, igényük van rá (,A legjobban a csapatos feladatok tetszettek”, „A csoportos feladat nagyon jó volt, nekem az tetszett a legjobban”). Az együttmüködés kapcsán a közös munkát emelték ki („Szerintem mindenki hozzátett valamit az egészhez, hogy ez az eredmény jöjjön létre”, „, Szinte minden tetszett, de föleg a közös projekt megalkotása”), melynek végkifejlete az az értékes eredmény, amire büszkék, és aminek mind együtt a részesei $(, A$ csoporttal közösen kitalált környezetvédelmi tervvel és a többi csoport tervével szerintem egy nagyon jó projektet hoztunk létre”, „A végeredmény közös megegyezés alapján jött létre”) A foglalkozás eredményeként tartották számon azt is, hogy a közösségük erösödött, a kapcsolataik szorosabbá váltak (,Jobban összehozta az osztályt”, „Nagyon tetszett, hogy kicsit játékos is volt, de egyben érdekes is és, hogy az osztály jobban közelebb került egymáshoz”, „Jó volt, hogy az osztálytársaim, akikkel nem szoktam beszélni a csoportmunkában jó fejek voltak”).

A foglalkozás szabadságot adott nekik, nem érezték az iskolai nyomást („Összeszedett elöadás volt, látszott rajta a sok készülés, de mégsem éreztem azt a nyomást, amit egy tanári órán érezni szoktam”), az előadásokat érdekesnek tartották, a kreativitásuknak teret engedett (,Kreativan alkothattam, elengedhettem a fantáziámat”). Motiválta őket, hogy játékos formában (,Nagyon jól éreztem magam, tetszettek a "játékok"'’) tehetnek a jövőért (,Rendkívül tetszett, hogy a környezetünket kellett jobbá, környezetbarátabbá tenni”), a workshop tapasztalatot és élményt nyújtott a számukra, amit ismételten erős jelzőkkel illettek (,Kezdetben azt hittem, hogy ez is egy szokásos unalmas program lesz, de szerencsére ezt a gondolatomat 
hamar el kellett felejtenem”, „Én személy szerint nagyon jól, felszabadultnak éreztem magam").

50. ábra: Diák reflexiók kódjegyzék - Szombathely

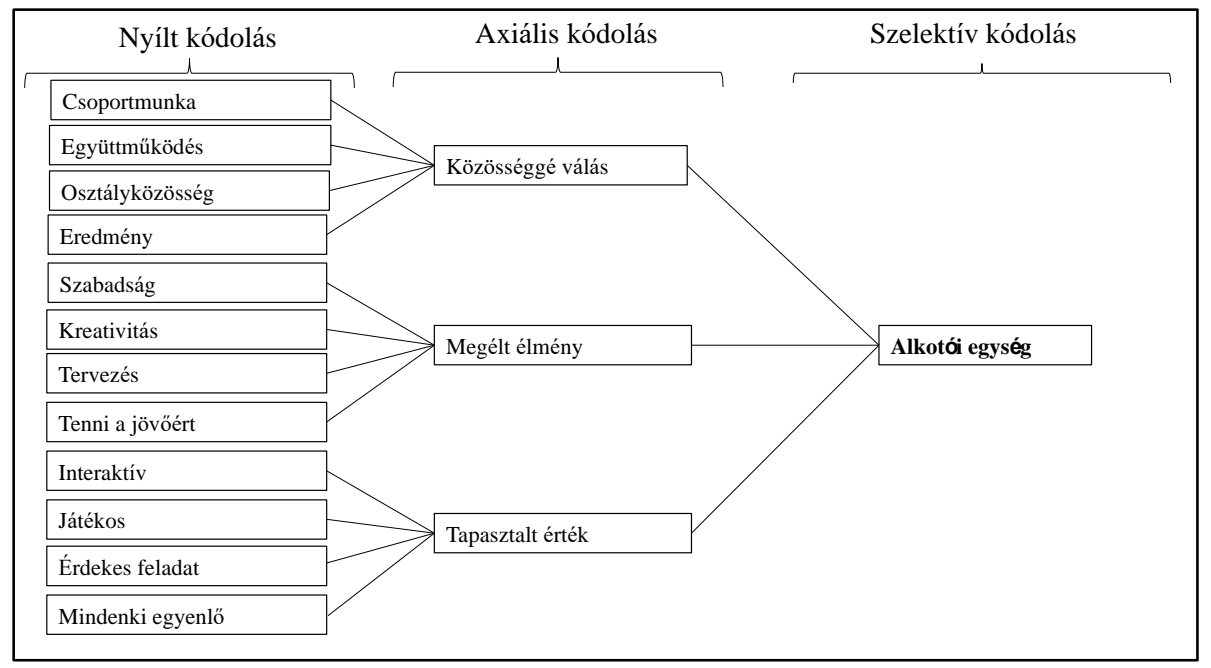

Forrás: A diák reflexiók elemzése alapján saját szerkesztés

\subsubsection{Nógrád megye, Dejtár}

Mélyinterjú

A rendkívül kedves és közvetlen dejtári pedagógusnak nincs könnyü dolga az osztályával. Két gyermeket kivéve mindegyikük hátrányos helyzetü és öt olyan hallgató is van, aki beilleszkedési tanulási és magatartási zavarral küzd. A legtöbb tanuló esetén elmondható, hogy a család nincs jelen az életükben, de ha igen, akkor abban sincs sok köszönet (,a roma családok felépitése: anyukája a gyerek. Apuka nincsen jelen, csak ritkán, legföljebb, amikor megcsapja öket. Vagy meg kell szidni. Alapvetöen otthon sincs.").

A közösség nem összetartó, nem segítik egymást (,Ötödször kérdezi valaki, hogy mi a házi, és senki sem válaszol, pedig 12-en látták a Messengeren.”), pedig a pedagógus iskolán kívüli programokkal is sok energiát fektet abba, hogy közösséggé formálja őket. Az otthoni lemaradással azonban nehéz versenyeznie.

Az iskola infrastrukturális háttere sem segíti az új módszerek alkalmazását (,Az internet elérhetöség lassan a Jóisten ajándéka, ha használni is tudjuk, nem mindig van.”), de a tanári közösség támogató és összetart, ami ezt némileg kompenzálja (,nagyon jó kollégáim vannak. Sok mindenben tudnak segiteni.”). 
Csoportmunka egyre gyakrabban van jelen általa az osztály életében. Igyekszik az iskola által támasztott hierarchikus falakat legalább az iskolán kívül lebontani (,Sokat megyünk moziba. Ott én is gyerekké válok, és rendelek pizzát, jókat röhögünk egymáson. Nem lealacsonyodás vagy megaláztatás, ha egy pár percre vagy órára én is gyerekké válok. Akkor meg elkezdenek véletlenül tegezni”.) és ezeket a helyzeteket kihasználni a kommunikációra (,Ezért jó, amikor moziba megyünk, mert a kacagáson viccen keresztül beszélgetünk.”).

A kreatív kapcsolatteremtést két pilléren keresztül alkalmazza a hétköznapokban a közösség, a hovatartozás erősítése céljából. Az egyik a haza szeretete (,a hagyományok tiszteletére próbálom a gyerekeket tanítani. Ami nem csak a szigorúság meg nem csak a vakfegyelem, hanem a családunkhoz, szülökhöz köthetö dolgok. És a közösség.”), a másik pedig a kapcsolatteremtő felek között fennálló kapcsolat érzelmi mélysége és annak biztosítása (,,kell egy szerelmi kapcsolat, egy müvészeteket közvetitö szereplö és egy rendezö között. Kell az, hogy a diák felnézzen a tanárára, a tanár pedig imádja benne azt, hogy olyan ügyes").

\section{1. ábra: Pedagógus mélyinterjú kódjegyzék-Dejtár}

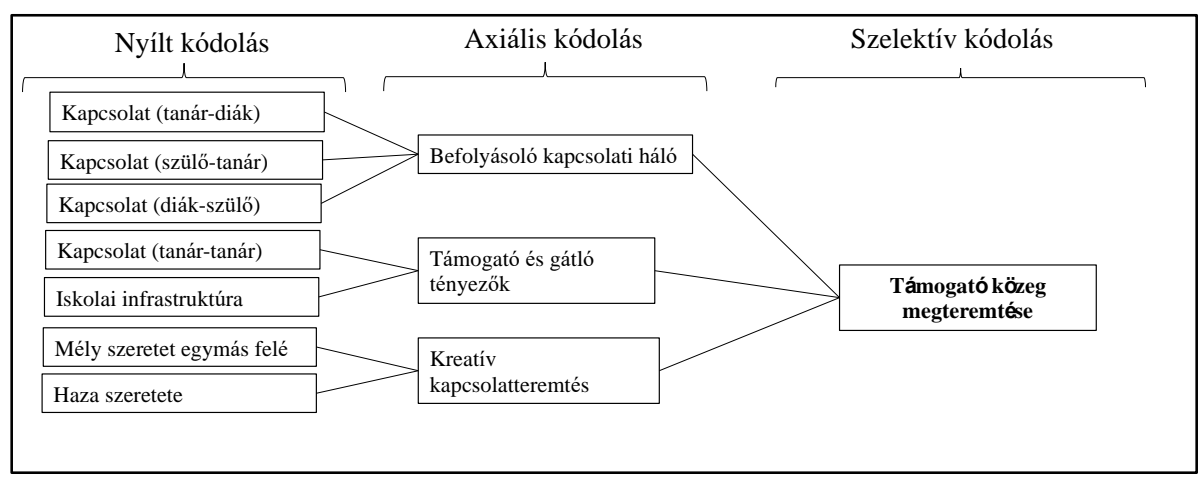

Forrás: A mélyinterjú leiratának elemzése alapján saját szerkesztés

Résztvevő megfigyelés

A workshop a többi foglalkozáshoz képest hamar lezajlott. A gyerekeken sajnos érződött, hogy nem foglalkoznak velük otthon, nincs gyerekszobájuk. Nincs szókincsük, nagyon nehezen fejezték ki magukat (2). Mindent sokszor kellett megkérdezni tölük, az interakció nehezen történt meg (2), és sokkal jobban kellett figyelni arra, hogy hogyan fogalmazok, milyen szavakat használok.

Az elején nagyon visszafogottak és megilletődöttek voltak (4). A magatartásukkal nem volt gond, amennyire tölük telt figyeltek (1). A probléma abban manifesztálódott, hogy nem 
volt mit mondaniuk, többnyire nem volt véleményük. Alig adtak visszajelzést, nehéz volt meghatározni, hogy azért, mert nem tudják, vagy mert ennyire új nekik a helyzet.

Kiscsoportban szinte nem is dolgoztak. Beszélgettek, próbáltak valami megoldást kihozni, de nem volt kapcsolatteremtés (3). Kiscsoportban annyi ötlet valósult meg, hogy szedjenek szemetet (9). Látható volt, hogy nem a nem akarás, hanem sokkal inkább a nem tudás jelent meg. Egy nagy csoportban dolgozva sem tudtak egymással kommunikálni, beszélgetni. Ezzel párhuzamosan érezték, hogy itt valamit létre kellene hozni. A rajzolás ügyesen ment nekik, ott tényleg közösen dolgoztak (9).

Egy ilyen szituációban még inkább felmerül az igény a készségek, a kommunikáció, a közösség fejlesztésére, ami itt valóban a mindennapi életükben szükséges boldoguláshoz segítené őket. Helyzetükben fokozottan igaz, hogy ha az iskola ezt nem adja meg nekik, akkor otthonról ők ezt minimális mértékben sem fogják megkapni.

\section{Reflexiók elemzése}

A résztvevői megfigyelés során tapasztaltak a reflexiókban is visszatükröződtek. Szükszavúan és sok helyesírási hibával próbálták kifejezni az egyébként pozitív véleményüket. Jól érezték magukat, örültek annak, hogy sikerült új dolgokat megtanulniuk (,Nagyon tetszett, hogy ilyen remek ötleteket hoztak és megtanultam új dolgokat maguktól"). Tetszett nekik, hogy ezt játékos formában tehették (,Nem volt unalmas, jó játékos volt”) és az élményhez („,ól éreztem magam, mert jó volt a hangulat”) hozzákapcsolták a kutatók személyét is (,Akik tartották az elöadást azok nagyon kedvesek voltak”).

Ha nem is olyan sokrétủen, mint egy-egy korábbi helyszínen, de megjelent értékként a közösség fogalma, a folyamatból azokat az elemeket emelték ki, amikor együtt, közösen dolgoztak. Ez a csoportmunka („Jól éreztem magam, mert sok volt a csapatmunka, a csapatprogram is jó volt”) és a rajzolás volt („,Tetszett, hogy rajzoltunk közösen, A rajzolás tetszett a legjobban, tetszett mikor mindenki rajzolt, és mindenki tudott valami jót is mondani”). 
52. ábra: Diák reflexiók kódjegyzék - Dejtár

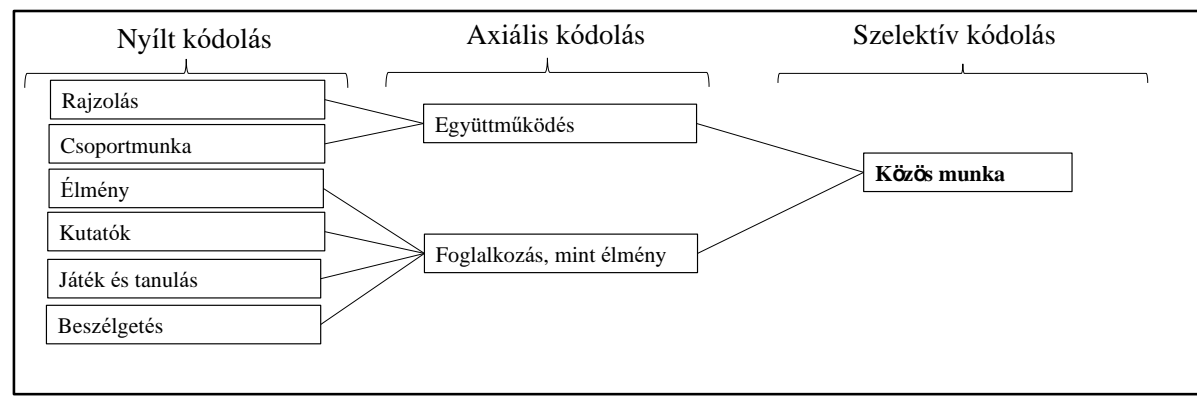

Forrás: A diák reflexiók elemzése alapján saját szerkesztés

\subsubsection{Szlovákia, Pelsöc}

Mélyinterjú

A magyarországi megyék mellett a kutatás mintájába bele tartozott egy határon túli magyar település vizsgálata is. Pelsőcön a pedagógus egy igen kedves, szeretetteljes tanár, akinek célja a fejlődés, gondolatai középpontjában a gyerekek állnak („,Nagyon szeretnék nyitni a világra, mindig frissen tartani magamat arra, hogy mi történik a nagyvilágban, és ahhoz képest mivel és hogy foglalkozzunk a gyerekekkel"). Ezt a törekvését támogatja az a pedagógus közösség, aki körülötte van, hiszen bennük is adott az igény a fejlődésre (,De a tanárok közül mindenki törekszik rá, hogy folyamatosan fejlödésben legyen, hogy keresse, és közösen is keressük ezeket”). Az iskola egy kicsi, családias közösséget biztosít, ahol a személyes kapcsolatok meghatározók („Ez nem egy ilyen futószalag iskola. Tényleg mindenkinek személyes kapcsolata van a diákjaival.").

Az oktatáson túl, a nevelésre is hangsúlyt fektet, az iskola igazi feladatát a lexikális tudáson túlmenően a munkára, életre való felkészítésben látja (,Az iskola szerepe és a tanár szerepe az, hogy segítsünk nekik túllátni az orrukon, vagy a következö nagyvároson túlra is. Nyitogassuk öket, mutassunk nekik új világokat, új lehetöségeket.”). Ehhez kapcsolódnak azok a készségek, melyek kapcsán a pedagógus felismerte, hogy fejlesztésre szorulnak. Ide tartozik a sokszor rosszul, vagy egyáltalán nem müködö közös kommunikáció és ennek hozományaként az együttmüködésben rejlő fennakadások (,nem tudnak együtt kommunikálni, és a következö gondolatom az, hogy hogyan lehet ezt fejleszteni. Mivel tudom öket ezen fejleszteni."), valamint a közösségben a saját szerep felfedezése (,De sokkal izgalmasabb az, amikor a gyerek megtalálja a közösségben az ö saját szerepét"). Itt került említésre az önállóság hiánya is, hiszen minden esetben megkapják kívülröl a támogatást, az iránymutatást, ezért érdemes lenne 
olyan helyzetekbe állítani öket, ahol ez a támasz elmarad („A kolleganövel beszélgettünk róla, hogy mindig megkapják kívülröl az impulzust, és nagyon jó, hogy ezen a foglalkozáson meg nem fogják ezt megkapni.").

A kreativitás fejlesztésére irányuló feladatok a pedagógusnak több terhet jelentenek, ugyanakkor nagyon fontosnak tartja. Meglátásai szerint ennek a kulcsa a személyre szabott, (kreatív, tervezői) kapcsolatteremtés a diákokkal („,nem mindegy, hogy melyik osztálynak hogyan tálalja ugyanazt a tananyagot. Kell hozzá ismerni az osztályt, és meg kell találni azt az utat, ahogy az nekik befogadható").

53. ábra: Pedagógus mélyinterjú kódjegyzék-Pelsőc

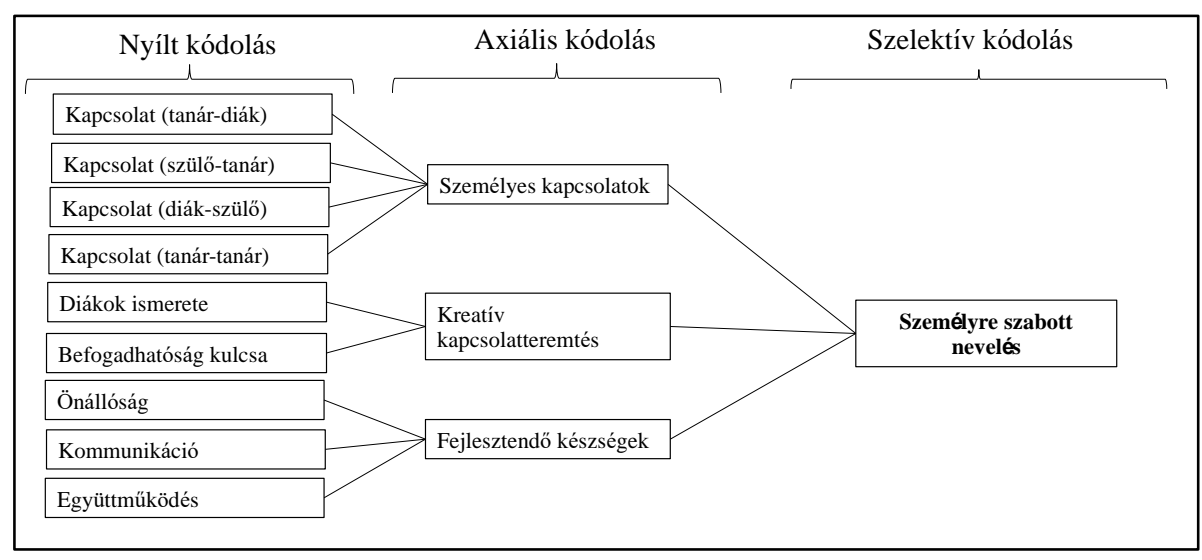

Forrás: A mélyinterjú leiratának elemzése alapján saját szerkesztés

Résztvevő megfigyelés

A foglalkozás során a két pedagógus végig bent volt, ami részben jó, hiszen érdekelte őket és fejlődni szerettek volna, ahogy az a mélyinterjúban írtakat is alátámasztja, azonban az egyik pedagógus folyamatosan rendezte és irányította a gyerekeket, amit kezelni kellett. A gyerekek tanítónéninek hívták a pedagógusokat, eddig sosem tapasztaltam ezt, mindig a nevükön szólították a diákok a tanárokat, ez egy kicsi távolságtartást feltételezett.

Az elején meg voltak illetődve, de ez gyakori, a korábbi foglalkozások alapján már tendenciának tekinthető. Úgy éreztem most a prezentáció jól sikerült, a gyerekek értékes hozzászólásaikkal, kérdéseikkel támogatták is ezt az érzetet (2).

Az előadást egy rövid szünet követte, majd elkezdődtek a feladatok. Itt mintha egy másik csoporttá váltak volna. Elöször egyedül gondolkoztak, aztán kiscsoportban még közepesen mentek a dolgok, de nagy ötletek nem születtek (9). Főként a fák ültetésére fókuszáltak, hogy ha kivágunk egy fát, akkor ültessünk helyette újat, de felmerült még a környezetszennyezés és 
az autó, mint közlekedési eszköz biciklire cserélése (9). Ötletek voltak, de a megvalósításig, a konkrétumokig már nem jutottak el (3). Ahogy kiléptem a körből közelebb mentek egymáshoz, de nem volt látványos. Nem vállalta fel senki a csoportszerepet, volt több erősebb hangú gyermek, de nem álltak ki magukért, csak gyenge próbálkozások voltak. Addig eljutottak, hogy a kis csapatok egyesével elmondták az ötleteiket, de közös eredmény nem született (8). Egyértelműen látszott, hogy a csoportmunka nincs jelen a hétköznapjaikban (5), és a pedagógus által is kiemelt, kommunikációra irányuló fejlesztések valóban szükségesek. Voltak, akik ki is mondták, hogy ők inkább hátravonulnak és kilépnek a körből. Látszott, hogy zavarja őket ez a passzivitás, de mégsem sikerült ezen változtatniuk. A magatartásukkal nagy baj nincs, fegyelmezik egymást (4), de a csoportos kommunikáció a kapcsolatteremtési képesség az kritikán aluli, amit ők is éreztek („egyszerrre beszélnek százan, és nem értjük egymást”). Az önállóság teljes hiánya volt tapasztalható.

A foglalkozás végén rendhagyó módon kérdezgettem őket, hogy ezzel elégedettek-e, hogy miért nem sikerült ezt jobban megoldani. Ök maguk sem voltak elégedettek (9), érezték, hogy nem tudnak együttmüködni, egymásra mutogattak. Ennek ellenére szóban is jelezték, hogy „imádták” a napot, és azért lenne szükség ismétlésre, hogy „legközelebb az együttmüködés is jobban menjen".

Reflexiók elemzése

A diákok kommunikációs nehézségei írásban is kiütköztek, szűkszavúan fogalmaztak, és nagyon nehezen volt olvasható az írásuk, de ennek okaként lehet rögzíteni a kétnyelvüséget is. Ennek ellenére írásaikkal igazolták a résztvevői megfigyelés során tapasztaltakat és a mélyinterjú során feltárt problémákat.

A csoportmunkát értékelték, szeretik, a foglalkozás legjobb részeként tartották számon (,nagyon tetszett még az, hogy csapatmunka volt az egész”, „nekem az tetszett, amikor ötös csoportokban dolgoztunk, az nagyon, de nagyon jó volt, mert szeretek csoportban dolgozni”). Hiányérzetet keltett bennük az elmaradt siker, a közös eredmény, amit a negatívumok között emlegettek. Ennek okát sok esetben a veszekedésre, a megegyezés hiányára vezették vissza, felismerték, hogy nem tudnak együttmüködni (,,nem tetszett, hogy veszekedtük”, „az nem tetszett, hogy nem tudtunk együtt dolgozni”, ,, az nem tetszett, hogy nem lehetett egyet érteni, mert minden mindenkinek rossz volt”). Ezzel párhuzamosan pedig értékelték azt, hogy volt lehetőségük közös időre, ami rávilágít arra is, hogy ez mennyire hiányzik nekik, erre mennyire 
nincs tér a hétköznapokban (,Jó volt, hogy két órát együtt voltunk”, ,jól éreztem magam, voltam sokat az osztálytársaimmal").

A téma felkeltette a figyelmüket, a jó ügyért cselekvés hozzáadott ahhoz, hogy jól érezték magukat a foglalkozáson (,természeten járt az eszünk, és védeni akarjuk a környezetet”, „Jó dolgokról beszélgettünk, és én is szeretném, hogy védjük a környezetet”). A kutató gyerekekre történő hatása a korábbi foglalkozásokon is megfigyelhető volt, itt azonban ez még intenzívebben jelen volt (,,az tetszett, hogy nagyon kedvesen bántak velünk és bármi bajunk volt, akkor segitettek"), rávilágítva arra a szabadságérzetre is, hogy a kérdés, és a rossz válasz is megengedett volt („Ezek a nénik nagyon kedvesek voltak, hogy megengedték, hogy kérdezzünk és nem volt rossz válasz").

54. ábra: Diák reflexiók kódjegyzék - Pelsőc

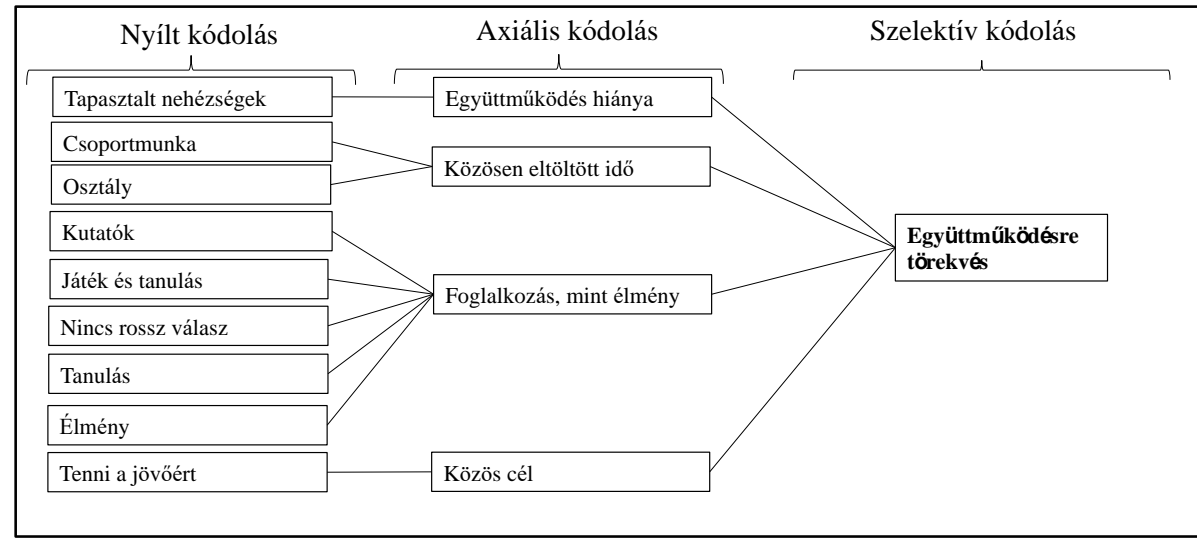

Forrás: A diák reflexiók elemzése alapján saját szerkesztés

\subsection{Az eredmények összegzése}

A lokációnként ismertetett elemzések alapján is egyértelmüen látható, hogy a feltáró jellegü kvalitatív kutatás eredményeként a kutatási kérdéseim relációjában is fontos folyamatokat sikerült azonosítanom. A helyszínenként feltárt központi kódokat összegezve, az ismétléseket kiszürve, a metszeteket kiemelve a következő kulcskategóriák kerültek a fókuszpontba: (1) A keretrendszer és az azt mozgató kapcsolati háló, (2) Osztály, mint közösség, (3) Életre nevelés: készségek fejlesztése, (4) A fejlődés dimenziói, (5) Hivatásom: pedagógus, (6) A produktum. Az összegzés, a folyamat során létrehozott kulcskategóriák mentén történik. 


\subsubsection{Keretrendszer- Kapcsolati háló (1)}

A kutatás eredményeként egyértelműen kirajzolódik az a fizikai keretrendszer és személyes kapcsolati háló, ami azt a kiindulási helyzetet biztosítja, amihez a folyamat szereplőinek vagy alkalmazkodni kell, vagy törekedni annak pozitív irányú elmozdítására. Itt megjelentek bizonyos oktatáspolitikai irányelvek, melyek felé a pedagógusok kritikusan állnak, ám saját, egyéni befolyásukat nem tudják érvényesíteni. Ezt alátámasztja a szakirodalmi elemzés is, mely ugyancsak ráerősít a minimális szabad mozgástérre, és az amúgy is redukált lehetőségek keretek közé szorítása sem kedvez a pedagógusok törekvéseinek (Z. Fodor, 2018). A meglévő irányelvek nagy többségét az innovatív, előremutató folyamatok gátjaként rögzítik, a változást csak a közösség összefogásában látják (,Nagyon be vagyunk korlátozva. Nyilván azt nem lehet, hogy nincs elöirás, hogy mit kell tanulni, vagy mit kell megtanitani, de egész más úton is el lehet jutni ugyanoda, amire nekünk nincs lehetöségünk.”). Arra is fontos felhívni a figyelmet, hogy ezeknek a rögzített kereteknek hosszú távon is hatása van a gyerekek fejlődésében, és vissza nem fordítható folyamatok mehetnek végbe (,az egységesítés a cél: $a$ gyermek bemegy az osztályba, és örömmel indul a rajzolásnak, de rájön, hogy nekik egységesen kell rajzolni, Így jár a gyurmázással is. Utána átkerül egy olyan alternatív iskolába, ahol a gyerekek egyéni képességeire kíváncsiak, de addigra szegényböl kiölték ezt az egyéniséget.”) A keretrendszer fizikai tényezőjeként, legtöbbször egy igen jelentős akadályként került rögzítésre az iskola infrastrukturális háttere, legyen szó az intézmény épületéről vagy éppen a digitális felszereltségröl (,Az internet elérhetőség lassan a Jóisten ajándéka, ha használni is tudjuk, nem mindig van.”), a közösségi terek hiányáról. Az egyes helyszínek között óriási differenciák vannak, általánosságban azonban elmondható, hogy a pedagógus munkáját, elöremutató oktatási törekvéseit nem segítik, sokkal inkább hátráltatják, extra terhet helyezve így (is) a tanárokra.

A személyes kapcsolati háló a vártnál nagyobb jelentőséget kapott. Az osztályfőnök, mint központi, meghatározó egység szerepel a rendszerben, a kapcsolatok mozgatójaként van jelen. Az általa müködtetett emberi kapcsolatok hatással vannak az egész közösségre, de leginkább a kutatásom fókuszát jelentő diákokra. Az osztályfőnök és az osztály relációja jelent meg a legintenzívebben. Ennek a kutatási kérdés kapcsán fontos jelentősége van és a korábbiakban taglalt szakirodalmi elemzések is alátámasztják, miszerint a kreativitást támogató tényezők mellett az innováció térnyeréséhez szükséges a megfelelő tanár-diák kapcsolat (Ferrari és mtsai., 2009). Meglepően nagy hangsúly került a szülőkre is, úgy a tanárral ápolt viszony, mint a diák-szülő vonatkozásában. Az otthonról (nem) hozott értékek, a szülőktől kapott nevelési 
irányelvek („A szülök ugyanígy pörögnek, dolgoznak, mindent csinálnak, és a gyereknevelés, én úgy látom, hogy egy kicsit háttérbe szorul.") jelentősen befolyásolják, sok esetben korlátozzák a pedagógus lehetőségeit, de legfőképpen determinálják azt a szintet, ahonnan a fejlődési folyamatok elindulhatnak (,Mi itt sok mindent tudunk hozzáadni, de az alap beállítottságán nem nagyon tudunk változtatni. Nevelni azért otthon is kellene”). Kifejezetten erős elemként volt jelent a pedagógus kapcsolata kollégáival és elfoglalt pozíciója a pedagógus közösségben. Rávilágított, hogy ez milyen erős mozgatója a később részletesen tárgyalni kívánt fejlődésnek és a tudás megosztásának („Nyilván a nevelőtestület is összetartó, és egy felé húzza a szekeret."), valamint a pozitív munkakörnyezetnek, aminek szintén jelentős hozadéka lehet a rendszerben. A kapcsolati háló szerves elemének tekinthető a vezetőség, aki iskolai szinten irányítja a folyamatokat, meghozza a döntéseket. Ő az, aki közvetlenül a motorja (,,mindenféle pályázati lehetőségbe részt veszünk, és az igazgatónk is ebben nagyon aktív, meg partner, meg kezdeményezö”) vagy gátja lehet egy olyan újító módszertan alkalmazásának is, mint amilyen az általam létrehozott foglalkozás (,A másik, hát egy demokratikus vezetöre lenne szükség. Nálunk nem demokratikus. Eléggé autokrata. Habár, amit kedvelek, hogy ha megyek hozzá, egy ilyennel, mint a mai napi, akkor persze, jó ez nekünk meg a gyerekeknek, tehát csináljuk.").

\subsubsection{Osztály, mint közösség (2)}

A személyes kapcsolati háló egyik igen lényeges eleme, a diákok között húzódó kapcsolatrendszer. Jelentősége okán külön kódkategóriaként került elemzésre. Az osztály, mint közösség fogalma más-más dimenzióiban, de végiggyürüzött az egész kutatási folyamaton és minden adatfelvételi módszer, minden egyes lokációjában szerepet kapott, nem véletlen, hogy kutatási kérdésem fókuszába is került.

Megjelent egyrészt a pedagógusok nézőpontjából, akik rögzítették a jelenleg fennálló osztályközösség erösségeit („,ó az osztályközösség, büszkék arra, hogy a tanárok elmondják a szülőknek, hogy milyen jó ott órát tartani”) és gyengeségeit („Keveset tudnak egymásról, keveset beszélgetnek, keveset vannak együtt a szabadidejükben. Eleve 5-6 faluból jönnek”), a közösség életében jellemzően megtalálható hiányosságokra is rávilágítottak („,Van még a közösségen fejleszteni való az egymással való kapcsolatokban.”). Az osztályközösségre törekvés ugyancsak előkerült a pedagógusok részéröl, mint saját feladat („,Az, hogy egy összefüggő osztály legyen, az az osztályfönöknek a feladata”), azonban ez egyértelműen iskolán kívüli tevékenységekben realizálódik csak, aminek gyakorisága a pedagógus hozzáállásán 
múlik (,Mindig keresem a lehetöségeket. Mindig élek vele, ha van valami új, amit kipróbálhatunk, például ez a workshop, akkor csináljuk. Nagyon jó, mert olyan dolgokban vesznek együtt részt, amiben mások nem. És akkor ettöl ök egy közösség, ami öket összetartja."). Itt szeretnék kicsit visszautalni az irodalomfeldolgozás ide kapcsolódó eredményére. A vizsgált Z generáció esetén az online/offline kapcsolatrendszer torzult aránya, a digitális térben megvalósuló erősebb jelenlét gátolhatja a társadalmi és személyes kapcsolatfelvételi képességeik fejlesztését (Turner, 2015), ami hosszú távon befolyásolhatja munkavállalói sikereiket is. Az osztályközösség egy ismert, biztonságos közeget nyújt, így a csoporton belüli jó kapcsolat, az erős osztályközösség teret ad a diáknak a személyes kapcsolatokban rejlő értékek felismerésére.

Megjelent az osztályközösség és a tanulmányi eredmény között feltételezett összefüggés is („nagyon fontos a személyiségfejlesztés is, és a közösségfejlesztés is. Én mind a kettőt nagyon fontosnak tartom ahhoz, hogy a tanulmányi eredményük is jó legyen"), ami új megközelítést jelentett a tanároknak, eddig ez így nem állt össze a gondolataikban.

A diákok relációjából a közösség kulcstényező, a designkommunikáció foglalkozás során számtalan aspektusból világítottak rá, a kutatás egyik legjelentősebb eredményeként értelmezhető. Megjelent az élmény faktor (,Nagyon jól éreztem magam, a mi osztályunk még soha nem tudott ennyire jól kibontakozni”), a társaival töltött minőségi időre utaló szükség. Kifejezésre juttatták azt, hogy az osztályszintű és/vagy kiscsoportos együttmüködés („Olyan jó látni, hogy együttmüködik az egész osztály”), -aminek az alkotói-tervezői folyamat szerves részét képezi- mennyire fontos számukra. Ide tartozik a közös gondolkodás (,tetszett, hogy a közös munkánál együtt gondolkodtunk”) és az egyetértés („Jó volt látni, hogy az osztály egyet értett”) is. Felismerték, ha ez sikerült és azonosították a problémákat, amikor ez nem volt zökkenőmentes, vagyis képesek voltak a workshop eredményeként az önkritikára. A foglalkozás legnagyobb hozadékaként tapasztalták a közösség fejlődését, az osztályközösség erösödését („Osztályépitő volt a program”, „Összehangolódott az osztály”, „,Nagyon jól éreztem magam, mert kicsit közelebb kerültünk az osztállyal’) a megélt alkotói folyamaton keresztül. A létrehozott produktum szintjén is megjelent a közösség, az eredményt közös sikerként értékelték („Jó volt, mikor együtt az osztállyal összekreáltuk az összegyüjtött projektekből az egész lényegét"). A közösség felértékelődése nem csak jelen kutatásban érhető tetten, a taglalt szakirodalom is alátámasztja létjogosultságát. Az iskolai, majd hosszabb távon a munkahelyi siker, a helytállás az összetett társadalmi rendszerben megköveteli azt, hogy a diákok képesek legyenek csapatban, egy csapatként működni (Igel \& Urquhart, 2012). 


\subsection{3 Életre nevelés: készségek fejlesztése (3)}

A vártnál sokkal erőteljesebben kerültek felszínre a soft készségek, és azok egyre növekvő jelentősége, amit a szakirodalom is megerősít (Hurrell, 2016; Succi \& Canovi, 2020; Zoltayné Paprika \& Nagy, 2013). Az oktatásban betöltött szerepükön túl az életben és a munka világára irányuló felkészítés kapcsán is nagy figyelmet kaptak (,nagyon fontos az együttmüködés, és mindig hangsúlyozom nekik, hogy ez a jövö. Majd, ha bekerültök egy munkahelyre, akkor ott majd olyan emberrel is együtt kell müködnöd, akivel nem szeretnél, ezt most tanuld meg, hogy hogyan tudod véghezvinni. Ezt próbálom nekik itt átadni."). A kutatás alapján a tanárok felismerték azt, hogy a soft készségek fejlesztése, azok tudatos alkalmazásának elsajátítása az életben maradáshoz, az értékteremtéshez, a sikeres munkavállalói léthez nélkülözhetetlen (,Ahhoz, hogy értékteremtő felnőttek legyenek, ahhoz elengedhetetlen, hogy kreatívok legyenek, és tudják is használni a kreativitásukat."). A pedagógusok szerint ehhez hosszú távon azonban újra kell definiálni a teljesítményértékelés kereteit, hiszen az egytől ötig terjedő skála nem lesz optimális a soft skillek értékelésére (,És nem jegyet kap rá, hanem kap egy értékelést. Vagy félévente, évvégeken lenne valami megmérettetés, de akkor sem jegyben mérem, hanem szöveges értékelés. Mert ez az öt jegy rettenetesen kevés ahhoz, és ennek a generációnak nem is jó ez az öt jegy.”). A teljesítményértékelés kereteinek újra definiálásának szükségét a szakirodalom is alátámasztja, hiszen a tesztalapú, könnyen mérhető számonkérés nemcsak, hogy nem alkalmas a soft készségek mérésére, de a kreativitást gátló tényezők között is megjelenik (Sahlberg, 2009).

Az osztályközösség kódkategóriája során már érintett együttmüködésen túl, a kreativitás, a kommunikáció és a problémamegoldás kapott hangsúlyt a kutatás elemzésének eredményeként. Érdekes összefüggést és átfedést mutat, -így az eredményt is alátámasztjaPéter-Szarka szakmai véleménye. A tanulás és innováció készségei közé tartozik a kreativitás, a kritikai gondolkodás, a kommunikáció és az együttmüködési képesség, melyek alapján eldől, hogy ki tud sikeresen helytállni a jövőben az élet és a munka egyre összetettebbé váló világában (Péter-Szarka és mtsai., 2015).

A pedagógusok felismerték, hogy a lexikális tudáson túlmutató soft készségek fejlesztésére is teret kell tehát biztosítaniuk (,,a nagy lexikális tudás a mai világban már idejét múlt. Miután egy kattintással mindent meg lehet nézni. Én egy olyan iskolát szeretnék, ahol problémákat tud megoldani a gyerek, hogy egy problémát hogyan lehet megoldani, ahhoz kulcsokat kapni. Nyitottnak lenni.”). Ennek megvalósítása kihívás elé állítja őket, keresik azokat a módszertanokat, melyek ezt támogatják. A kommunikáció fejlesztésének szüksége 
nem kérdés (,,nem tudnak együtt kommunikálni, és a következö gondolatom az, hogy hogyan lehet ezt fejleszteni. Mivel tudom őket ezen fejleszteni."). Általánosságban elmondható, hogy szóban erősebbek, azonban az érvek, a vitakultúra és az egymás meghallgatása finoman szólva sem kiforrott. Az írásbeli kifejezőképességük, véleményük korántsem összefüggő megfogalmazása, gyenge szókincsük nem mutat bíztató képet. („Nem játszanak eleget, alap dolgokkal nincsenek tisztában. Szókincsük egyre csak gyérül.”, „légy kreativ, tudd, hogy mit mondjál. Saját szókincsedböl igenis kreatívan fogalmazd meg, ez a gyerekeknek egyre nehezebb.”) Hiányosságaikat, a fejlődés szükségét a diákok is látják, ugyanakkor a foglalkozás pozitív hatását érezték (,„a kommunikáció néha akadozott, de egész jól sikerült”, „,még egy kicsit nehézkes, de egyre jobban alakulunk”)

A problémamegoldási készég fejlesztését a nyílt problémamegoldási (Dorst, 2011) helyzetekre épülő foglalkozásokban látják (,Muszáj lenne az, hogy a gyerekek újat találjanak ki, és egy-egy problémát meg tudjanak oldani a saját elképzeléseik szerint”, „A gyerek azt lássa, hogy neki nem csak egy útja van. Hanem hogy több irányba el tud menni, mert vannak lehetőségei."), amire a designkommunikáció is épít. Amennyiben csak egy jó megoldásra alapozhatnak, úgy az nem segíti őket abban, hogy a gondolataik szabadon szárnyalhassanak („Tök jó feladat, de csak egy jó megoldás van, vagy egy úton jut oda, akkor az mennyiben fejleszt?").

A kreativitás jelentősége az oktatási környezetben megkérdőjelezhetetlen úgy a pedagógusok, mind a gyerekek részéről. Egy ideális világban az oktatás fejleszti a kreativitást, amit a gyerek az életben kamatoztat (,Minél kreativabb egy gyerek, annál több mindenhez tud hozzányúlni. Tehát több mindennel lesz felvértezve az élet során.”). Ahhoz azonban, hogy a kreativitást egy pedagógus képes legyen fejleszteni a diákban a saját kreatív hozzáállására is szükség van (,Nagyon fontos, szinte az egyik legfontosabb a tanitásban. Az új igényeknek megfelelni. Talán azért fontos, mert évröl évre más igénnyel jönnek ide a diákok, és erre kreativnak kell lenni, hogy új módszereket tudjunk bevetni és alkalmazni.") Ennek szakirodalmi megerősítése többek között, hogy egy kreatív tanár jellemzően több időt fordít a tanár-diák kapcsolat formálására , ami erősebb és harmonikusabbnak tekinthető kapcsolatot eredményez a kutatás által feltárt legfontosabb kapcsolati összetevőben (Morais \& Azevedo, 2001). Ennek jelentőségét tovább fokozza, hogy a jó tanár-diák viszony visszahat a diákok közötti kapcsolatra, együttmüködésre is, így megteremtődik egy hármas, egymásra oda-vissza ható viszonyrendszer a kreatív tanár, a pozitív tanár-diák viszony és a jó kapcsolat a diákok között (Torgyik, 2004). 
A foglalkozás során a diákok felismerték, hogy az otthonom jobbá tételére vállalkozom, designkommunikáció workshop a fentiekre megoldást nyújthat. Alaptulajdonságai között tartották számon azt, hogy a módszer a kreativitásra épít („Jól éreztem magamat, mert még sohasem hallottam erröl a módszerről, de tetszett, mert a kreativitásra épül.”). Biztosítja azt, hogy a diák a feladat megoldását csak a kreativitása kibontakoztatása útján legyen képes megvalósítani (,Nagyon tetszett az, hogy kreatívnak kellett lenni mindenben”, „,Nagy kreativitás kellett ahhoz, hogy ez létrejöjjön”). A problémamegoldási készség használatára is szükségük volt a diákoknak, ráadásul egy olyan központi témára keresték a megoldást, ahol a jó lehetőségek száma végtelen ("A legjobban a problémamegoldás tetszett”, „Az tetszett, amikor csapatot alkottunk és meg kellett beszélni azt a bizonyos problémát".)

\subsubsection{Fejlödésre törekvés, a fejlödés dimenziói (4)}

A fejlödés külön kódként kerül elemzésre, ugyanakkor elemei áthallásosak, a többi kódkategóriát is érintik. Ide tartozik az osztályközösségben realizált fejlődés, továbbá az is, hogy a workshop lehetőséget adott a diákok kreativitásának a fejlődésére, ugyanakkor azt is idekapcsolhatjuk, hogy a pedagógusok a soft készségek fejlődésének szükségességét prioritásnak tekintik. A fejlődésnek azonban további fontos dimenzióiról is be kell számolni a 24 állomásos kutatás legfontosabb eredményei között.

A designkommunikáció workshop a diákok fejlődésén végbemenő pozitív eredményeken túl a pedagógusok fejlesztésére is törekszik, amire egyre nagyobb szükség van („Kollégák többsége, kétharmada 40-50 év között van. Egy nagy rész úgy van vele, hogy jó az úgy, ahogy megtanulta, és úgy viszi tovább.”). Mindenekelőtt arra a nyitottságra van szükség, hogy befogadók legyenek az új módszerekre és megfogalmazódjon bennük az igény a folyamatos fejlődésre a diákok hatékony fejlesztése érdekében. Ez azt jelenti, hogy a designkommunikáció műhelymunka során kétszintü fejlődés tapasztalható, egyrészt a diák, másrészt a pedagógus oldaláról. Ehhez teret adhat a korábban már felvázolt kapcsolati háló e tekintetben két legfontosabb tényezője: a vezetőség és a kollégák (,De a tanárok közül mindenki törekszik rá, hogy folyamatosan fejlödésbe legyen, hogy keresse, és közösen is keressük ezeket.”). Itt előkerült a tudás megosztásának kérdése is, mint a wikinomikus együttmüködés egy alaptézise (Fuchs, 2008). Felfogás béli változásra van szükség, a tanároknak is meg kell tanulni a diákokhoz hasonlóan közösségben, jó közösségben együttmüködni („Összetartunk, több ember több agy, sokkal modernebbül tudja.”), ahol a cél az egyéni fejlödésen túl a közös fejlődés a diákok érdekeit szem előtt tartva. 
A fejlődés továbbá a jövő pedagógusain keresztül is megjelent két aspektusban. Egyrészt a tanárok szükségesnek vélik a pedagógusképzés reformálását, az új, innovatív módszerek tananyagba történő integrálását (,,nincs felkészitve kellöképpen hatékony módszerekkel. Pedig a tanárképzőknek ez dolga lenne. Nem kapnak mostani használható aktív módszereket."), ugyanakkor bíznak abban, hogy a friss, pályakezdő pedagógusok lendülete, az általuk képviselt modern oktatási-nevelési szemlélet a többi kollégára is motiválóan hat majd és fejlődésre ösztökél (,Egymástól is, fiatalabb kollégáktól, bemutatókon látja, hallja, alkalmazza, tovább fejleszted a saját órádon.”). Az igazi egységet és fejlődést azonban a fiatalok új szemlélete és az idősebb kollégák tapasztalatának megosztása, majd a közös tudás új alapokra helyezése jelentené („De szerintem tölünk, fiataloktól is kell nekünk az a nyitottság feléjük, hogy viszont nekik rengeteg a tapasztalatuk").

\subsubsection{Hivatásom és felelösségem: pedagógus vagyok (5)}

A pedagógus legfontosabb kompetenciája kell, hogy legyen, hogy a pedagógiát, mint foglalkozást hivatásból válassza, így különösképpen jellemző lesz rá a felelősségtudat a helyi közösség iránt is (Hernádi és mtsai., 2008). Ahogy az irodalomfeldolgozás során is érintett szakirodalom rávilágít olyan pedagógusokra van szükség, akik hivatásként élik meg a szakmát. Kutatásom során többnyire ilyen osztályfönökökkel találkoztam, aminek oka a korábban kifejtett mintavételi sajátosságokra is visszavezethető (,,abszolút úgy érzem, hogy tanár vér folyik az ereimben, édesanyám is tanár”, „A gyerekeket imádom, a hobbim is egyben a munkám.”, „A nehéz viszonyok között is hü maradok, csak ezt tudom elképzelni. Gyerekkorom óta ez akartam lenni.”, „azt csinálom, ami szenvedélyem. Ez hivatás.”).

A kutatás eredményei között tartom számon, hogy a pedagógus mélyinterjúk során kirajzolódott személyiség alapján következtetni lehetett az osztályegységre, a diákok között fennálló kapcsolatra és a közös munka várható minőségére, ami a résztvevő megfigyelések eredményeként igazolódott. Így tehát a pedagógus egyfajta tükröt tartott az osztálynak. A kutatás jellemzően az újdonságokra nyitott, innovatív szemléletű, elhivatott pedagógusokkal valósult meg, azonban még így is sok esetben motivációs hiányok léptek fel, ami az újítás gátjaként jelentkezett (,ha 24 órát bent vagyunk, akkor én sem tudok annyit az ötleteimre fordítani pluszba, mert az energiámat kiveszi az, hogy a gyerekekkel vagyok annyit.", „Aki nem annyira nyitott a dolgok felé, az azt szüri le, hogy mennyi munka, mennyi pluszt hoz neki. Pedig már így is kimerült.”, „erre sajnos nekem nincs idöm. Rengeteg plusz programot kellene ehhez végezni. Ebböl, az időből mindig kevés van.”). Több esetben is tapasztalható volt, 
hogy az újító szándék csak a kommunikációban, nem a tettekben mérhető, amit aztán az osztály munkája igazolt. Nem elég tehát az, ha egy pedagógus elhivatott, az egyedi értékrendje (V. Wilson és mtsai., 2006) is befolyásolja személyiségét, ezen keresztül pedig a diákok felé állított mintát. A diákok számára az eszménykép funkció hangsúlyos jelenléte, az önmagukon kívüli felelősségvállalás ismeretlen jellege még inkább ráerősít a pedagógus magatartásának példamutató szerepére (Cseke, 2007). Amennyiben a pedagógus teljes személyiségével van jelen az oktatói-nevelői tevékenységében, akkor az hozzájárul ahhoz, hogy valódi példaképpé váljon diákjai számára (Lévai, 2013), ami felelősség, ugyanakkor jogosítványt jelent a diákok pozitív irányú befolyásolására, ahogy arra is, hogy motiválja őket az újdonságok befogadására.

A kutatás részeként projektív technikát is alkalmaztam, melynek során meg kellett a pedagógusoknak nevezni azt az állatot, amelyik szerintük betöltené azt a minőségü pedagógusszerepet, ami számukra követendő példa. Végignézve az átfedéseket, kiemelve a legtöbbször előforduló elemeket összeállt az ,ideálisnak vélt” pedagógus. A tanár, aki tekintélyt parancsol, véd és óv, mint az oroszlán, ahol a falkában megjelenik az összetartozás is. Képes szárnyra kelni és elrugaszkodni a földtől, akár egy madár. Bölcs, mint a mesében a bagoly és kellő rugalmassággal, valamint kreativitással rendelkezik, mint a majom, aki nem mellesleg minden problémát megold. A jó pedagógus rendelkezik a kutya tulajdonságaival is, aki jól tanítható és hüséges, példaként tekint a gazdájára. Összefoglalva „,amelyik állat védi a kölykeit, az jó pedagógus lenne. Az állatoknak a $99 \%$-a ilyen.”. Védi, azaz felelősséggel tartozik érte.

A pedagógus lét tehát több, mint hivatás. Felelősség. Ez a felelősség a pedagógusok tudatában is jelen van, ahogy a projektív technika is felszínre hozta. A kutatás -megerősítve a szakirodalomi elemzést- rávilágított, hogy a pedagógus személye milyen hatást képes gyakorolni a diákokra. Az osztálynak a tanár nem csak példaképként funkcionál, de viselkedése tükörképet jelenthet a közösségben lezajló folyamatokról.

\subsubsection{A produktum (6)}

A megszületett produktumok elemzése a résztvevő megfigyelés lokációnkénti összegzéseként valósult meg. A foglalkozás eredményeként létrejött produktumok sajátosságai informatív elemekkel bírnak a kutatási kérdésünk relációjában és azon túl egyaránt. A kutatás rávilágított, hogy a közös feladatmegoldás során a csoportdinamika, az otthon fogalmának vizsgálata nem elsődlegesen a várt családi otthon fogalmát mobilizálta a gyerekekben, egy ezen túlmutató absztrakciós szinten került értelmezésre. A közös otthon 
tematika, az otthon jobbá tétele szinte kizárólag környezeti fenntarthatósági ötleteket hívott elö a diákokból, mely eredmény kapcsán a csoportmunkának, a wikinomikus együttmüködésnek és a designkommunikáció által meghatározott ,jó" fogalmi kereteinek nagy szerepet tulajdonítok. A feladat során kerestek és találtak egy közös referenciapontot a tágabb otthonban, a környezetben. Mindemellett a létrejött produktumhoz kapcsolódóan a diákokat motiválta a jobbítás szándéka, az, hogy ők, együtt közösen tehetnek valami jót a jövőjükért, a környezetükért, közös értékteremtés valósult meg (,,Tetszett, hogy nekünk kellett úgymond jobbá tenni a világot”, „,nagyon tetszett, hogy az volt a téma, hogy hogyan vigyázzunk a földre”) Ez már önmagában rávilágít a módszertan hatékonyságára, hiszen többek között ez a designkommunikáció célkitüzése. 
4. táblázat: A designkommunikáció workshop során létrehozott produktumok sajátosságai // 1. rész

\begin{tabular}{|c|c|c|c|c|c|c|}
\hline $\begin{array}{l}\text { Akciókutatás } \\
\text { helyszíne és } \\
\text { idöpontja }\end{array}$ & (1) a megvalósított produktum & $\begin{array}{l}\text { (2) a produktumban } \\
\text { felismerhető a fenntartható } \\
\text { fejlödés fogalma }\end{array}$ & \begin{tabular}{|c|}
$\begin{array}{c}\text { (3) A fenntarthatóság } \\
\text { környezeti/technológiai/társa } \\
\text { dalmi }\end{array}$
\end{tabular} & $\begin{array}{l}\text { (4) globális vagy lokális } \\
\text { gondolkodásra vall }\end{array}$ & $\begin{array}{l}\text { (5) aktivitásra, cselekvésre } \\
\text { buzdítás megjelenése }\end{array}$ & (6) vállalkozói attitüd \\
\hline $\begin{array}{c}\text { 06/09/2019 } \\
\text { Kalocsa1 }\end{array}$ & esővíz-gyüjtő az iskolában & igen & környezeti & \begin{tabular}{|c|} 
Lokális: “A projekt irányítói az \\
osztályközösség tagjai, ki-ki a \\
saját lakóterülete környezetében”.
\end{tabular} & \begin{tabular}{|c|} 
Megjelenik: ebből az esővízbőll \\
öntöznék az újonnan ültetett fákat
\end{tabular} & Nem jelenik meg \\
\hline $\begin{array}{c}\text { 06/09/2019 } \\
\text { Kalocsa2 }\end{array}$ & $\begin{array}{l}\text { “Szekrény Kommandó:” egyéni } \\
\text { szekrények iskolába való } \\
\text { bevezetését tüzték ki célul }\end{array}$ & nem & Nem jelenik meg & lokális & $\begin{array}{l}\text { Megjelenik: "első körben az } \\
\text { osztályfőnök a szülök és a } \\
\text { diáktársak támogatására van } \\
\text { szükség"- aláírást gyüjtenek }\end{array}$ & Nem jelenik meg \\
\hline $\begin{array}{c}17 / 09 / 2019 \\
\text { Tapolcal }\end{array}$ & $\begin{array}{c}\text { Önellátó farm (megújuló } \\
\text { energiákkal) és kutyamenhellyel }\end{array}$ & igen & Környezeti, társadalmi & $\begin{array}{c}\text { Lokális, megújuló energiák okán } \\
\text { globális jelleg is megjelenik }\end{array}$ & Minimálisan jelenik meg & Megjelenik \\
\hline $\begin{array}{l}\text { 20/09/2019 } \\
\text { Nagykőrös }\end{array}$ & \begin{tabular}{|c|}
$\begin{array}{l}\text { Világ szebbé tétele: Afrikába élelem, } \\
\text { öntözőrendszer, energiafelhasználás } \\
\text { csökkentése }\end{array}$ \\
\end{tabular} & igen & $\begin{array}{l}\text { Környezeti, társadalmi, } \\
\text { technológiai }\end{array}$ & globális & Minimálisan jelenik meg & Nem jelenik meg \\
\hline $\begin{array}{c}\text { 23/09/2019 } \\
\text { Budapest }\end{array}$ & Közös környezetvédelem & igen & környezeti & $\begin{array}{l}\text { Lokális: közös helyi } \\
\text { szemétszedés és virágülttetés }\end{array}$ & $\begin{array}{l}\text { Megjelenik: Minden szombaton } \\
\text { szemétszedés, szerdánként } \\
\text { növényültetés }\end{array}$ & Nem jelenik meg \\
\hline $\begin{array}{l}\text { 24/09/2019 } \\
\text { Eger }\end{array}$ & “Védjük meg a földet a müanyagtól!" & igen & környezeti & globális & $\begin{array}{l}\text { Megjelenik: „legyen vmilyen } \\
\text { gondolat, amin mi tudunk } \\
\text { segíteni”, }\end{array}$ & Nem jelenik meg \\
\hline $\begin{array}{c}\text { 01/10/2019 } \\
\text { Bodrogkeresztúr }\end{array}$ & \begin{tabular}{|c|} 
Sulibüfé, ami értékeli a \\
szemétszedést, és kedvezményt ad a \\
környezettudatosságért cserébe
\end{tabular} & igen & környezeti & lokális & Megjelenik & Megjelenik \\
\hline $\begin{array}{c}\text { 08/10/2019 } \\
\text { Hódmezővásárhely }\end{array}$ & Szemétgyüjtő napok & igen & környezeti & lokális & Minimálisan jelenik meg & Nem jelenik meg \\
\hline $\begin{array}{c}15 / 10 / 2019 \\
\text { Sajószentpéter }\end{array}$ & „Minden müködjön napelemmel” & igen & Környezeti, technológiai & lokális & Nem jelenik meg & Nem jelenik meg \\
\hline $\begin{array}{l}\text { 22/10/2019 } \\
\text { Tamási }\end{array}$ & „Szedd magad akcióterv" & igen & $\begin{array}{c}\text { Környezeti, társadalmi: „,sok } \\
\text { ember nem gondol a jövöre, } \\
\text { nem csak magunkra kell } \\
\text { gondolni, hanem az } \\
\text { unokáinkra is” }\end{array}$ & globális & $\begin{array}{c}\text { Megjelenik: ,fejlödik a } \\
\text { környezetünk, ha tisztább, illetve } \\
\text { mi is levegön vagyunk és a } \\
\text { hajlongatással sportolunk" - heti } \\
3 \text { alkalom }\end{array}$ & Nem jelenik meg \\
\hline $\begin{array}{c}05 / 11 / 2019 \\
\text { Baktalórántháza }\end{array}$ & Éhezö gyermekek segítése & igen & társadalmi & globális & Nem jelenik meg & Nem jelenik meg \\
\hline $\begin{array}{c}08 / 11 / 2019 \\
\text { Besenyeszög }\end{array}$ & $\begin{array}{l}\text { BioHotel (takarító robotok, nincs } \\
\text { elektronika, minden természetes) }\end{array}$ & igen & technológiai & lokális & Nem jelenik meg & Megjelenik \\
\hline
\end{tabular}

Forrás: saját szerkesztés D. D. Horváth \& Horváth, 2020 alapján 
5. táblázat: A designkommunikáció workshop során létrehozott produktumok sajátosságai // 2. rész

\begin{tabular}{|c|c|c|c|c|c|c|}
\hline $\begin{array}{l}\text { Akciókutatás } \\
\text { helyszíne és } \\
\text { idöpontja }\end{array}$ & (1) a megvalósított produktum & $\begin{array}{l}\text { (2) a produktumban } \\
\text { felismerhető a fenntartható } \\
\text { fejlödés fogalma }\end{array}$ & $\begin{array}{c}\begin{array}{c}\text { (3) A fenntarthatóság } \\
\text { környezeti/technológiai/társa } \\
\text { dalmi }\end{array} \\
\end{array}$ & $\begin{array}{l}\text { (4) globális vagy lokális } \\
\text { gondolkodásra vall }\end{array}$ & $\begin{array}{l}\text { (5) aktivitásra, cselekvésre } \\
\text { buzdítás megjelenése }\end{array}$ & (6) vállalkozói attitüd \\
\hline $\begin{array}{l}\text { 12/11/2019 } \\
\text { Mezöberény }\end{array}$ & $\begin{array}{l}\text { Világmegváltók (szemétszedés, } \\
\text { újrahasznosítás, elektromos autók) }\end{array}$ & igen & környezeti & globális & $\begin{array}{c}\text { Megjelenik: „Felosztanánk az } \\
\text { osztályt, mindenki mást csinálna } \\
\text { csoportokban” }\end{array}$ & Nem jelenik meg \\
\hline $\begin{array}{l}\text { 19/11/2019 } \\
\text { Baracs }\end{array}$ & \begin{tabular}{|c|} 
Karácsonyi vásár és szemétszedés \\
(szemétmentes karácsonyi vásár, \\
bejövö pénzböl hajléktalanok \\
segítése) \\
\end{tabular} & igen & Társadalmi, környezeti & lokális & Nem jelenk meg & Nem jelenik meg \\
\hline $\begin{array}{l}\text { 22/11/2019 } \\
\text { Dorog }\end{array}$ & $\begin{array}{c}\text { Osztályelnök koncepció: „az } \\
\text { osztályelnök tervezné az osztály } \\
\text { közös jövőjét!!” }\end{array}$ & igen & társadalmi & lokális & $\begin{array}{l}\text { Megjelenik: „,szerintem olyan } \\
\text { dologban gondolkodjunk, amit } \\
\text { mi tudunk megvalósítani” }\end{array}$ & Nem jelenik meg \\
\hline $\begin{array}{l}\text { 26/11/2019 } \\
\text { Debrecen }\end{array}$ & \begin{tabular}{|c}
$\begin{array}{c}\text { Banán Joe egy applikáció, akivel a } \\
\text { gyerekeket és a felnötteket is rá } \\
\text { tudjuk venni, hogy } \\
\text { környezettudatosan éljenek. }\end{array}$ \\
\end{tabular} & igen & környezeti & globális & $\begin{array}{l}\text { Megjelenik: „Jutka néni, ebbe } \\
\text { már mindenki beleélte magát” }\end{array}$ & Megjelenik \\
\hline $\begin{array}{c}\text { 03/12/2019 } \\
\text { Tápszentmiklós }\end{array}$ & $\begin{array}{l}\text { RTEF: Rászorulókat Támogató } \\
\text { Elektromos Furgon (napelemmmel } \\
\text { müködik, okoshütő) }\end{array}$ & igen & $\begin{array}{l}\text { Társadalmi, környezeti, } \\
\text { technológiai }\end{array}$ & $\begin{array}{c}\text { Lokális: „Buszmegállószerüen } \\
\text { mennek faluról falura, és ahol } \\
\text { szükség van rá ott megállnak, } \\
\text { gyüjtenek és adják tovább” }\end{array}$ & Nem jelenik meg & Nem jelenik meg \\
\hline $\begin{array}{c}\text { 06/12/2019 } \\
\text { Kaposvár }\end{array}$ & Jobb föld érdekében & igen & Technológiai, környezeti & Lokális és globális & $\begin{array}{c}\text { Megjelenik: „Felmerül, hogy egy } \\
\text { héten egyszer legyen erröl is egy } \\
\text { tanóra” }\end{array}$ & $\begin{array}{l}\text { Megjelenik: ,gazdasági } \\
\text { körforgás” }\end{array}$ \\
\hline $\begin{array}{l}\text { 13/12/2019 } \\
\text { Alsópáhok }\end{array}$ & $\begin{array}{l}\text { Oszzályház: ,a célja az volt, hogy } \\
\text { csapatot építsenek és egy jobb } \\
\text { közösségéé váljanak” }\end{array}$ & igen & társadalmi & lokális & Nem jelenik meg & Nem jelenik meg \\
\hline $\begin{array}{l}\text { 17/01/2020 } \\
\text { Tapolca2 }\end{array}$ & $\begin{array}{c}\text { Tengeri megmentök, akik a } \\
\text { tengerben élő állatokat védik, szedik } \\
\text { ki onnan a szemetet } \\
\end{array}$ & igen & környezeti & globális & Nem jelenik meg & Nem jelenik meg \\
\hline $\begin{array}{l}\text { 21/01/2020 } \\
\text { Pécs }\end{array}$ & $\begin{array}{c}\text { „Természetvédelmi egység” } \\
\text { Környezetvédelem plusz kevesebb } \\
\text { szemét, segítünk a szegényeknek, } \\
\text { több e-autó. }\end{array}$ & igen & Környezeti, társadalmi & globális & Nem jelenik meg & Megjelenik \\
\hline $\begin{array}{l}23 / 01 / 2020 \\
\text { Szombathely }\end{array}$ & $\begin{array}{c}\text { STV cég- Save the World } \\
\text { Embereket arra motiválja, hogy a } \\
\text { szemetet hozzák be és azt a cég } \\
\text { felhasználja. Különbözö boltokba } \\
\text { megy tovább az az elöállított termék, } \\
\text { amit készítenek. }\end{array}$ & igen & Környezeti, társadalmi & globális & Nem jelenik meg & Megjelenik \\
\hline $\begin{array}{l}\text { 04/02/2020 } \\
\text { Dejtár }\end{array}$ & Szemétszedés & igen & környezeti & lokális & Nem jelenik meg & Nem jelenik meg \\
\hline
\end{tabular}

Forrás: saját szerkesztés D. D. Horváth \& Horváth, 2020 alapján 
A szemléltetés érdekében készült egy összefoglaló táblázat is (4-5. táblázat), amiben meghatározott szempontrendszer mentén jellemeztem és kategorizáltam az elkészült produktumokat ((D. D. Horváth \& Horváth, 2020). A szempontrendszer a következőkre épített: (1) maga a megvalósított produktum, (2) a produktumban felismerhető-e a fenntartható fejlődés fogalma ${ }^{10}$, (3) a fenntarthatóság környezeti/technológiai/társadalmi jellege, (4) globális vagy lokális gondolkodásra utaló elemek, (5) aktivitásra, cselekvésre buzdítás, (6) vállalkozói attitüd megjelenése. Ez utóbbi konkrét kutatási kérdésem megválaszolásához járul majd hozzá.

Szinte kivétel nélkül minden csoportban a létrehozott terv kapcsolódik a fenntartható fejlődés fogalmához (2), mely arra utal, hogy a diákokat aktívan foglalkoztatja ez a téma. A legtöbb megoldás az összefogásra, a közös értékalkotásra alapozott, ami az osztályszintü együttműködés jelentőségét erősítette. A fenntartható fejlődés 3 aspektusa (Parapatits, 2019) közül elsősorban a környezeti aspektus, a természeti tőke megőrzése került elő a közös tervezői folyamat során (3). Érintőlegesen került szóba a technológia és a társadalmi vonatkozás, ami rávilágíthat arra is, hogy a fenntartható fejlődés pedagógiájában erre a két pillérre is érdemes hangsúlyt fektetni. Sok osztály helyezte középpontba a szemétszedést, faültetést (1), hiszen ezek azok a tevékenységek, melyek iskolai szinten is előkerültek, volt ehhez kapcsolódóan aktivitás. A diákok által megalkotott produktumok globális/lokális jellege (4) vegyes képet mutat. Nagyjából fele-fele arányban irányították projektmunkájuk fókuszát a helyi, saját közösségi színterükre (osztály, város), és emelik „világszintű” felelősséggé a közösen tervezett projektet. Sokkal inkább a segítő szándék, a ,jótett” van gondolkodásuk középpontjában, a vállalkozói kedv (6) szinte alig kerül fókuszba, amennyiben igen, úgy főként annak érdekében, hogy a saját tervüket finanszírozni tudják, legyen miből adni és segíteni egymásnak. A vállalkozói attitüd megjelenése - kiemelt jelentősége ellenére - elhanyagolható, empirikus kutatásunk arra világít rá, hogy érdemes lehet erőteljesebben beépíteni a tantervbe (D. D. Horváth \& Horváth, 2020).

\section{A jövő generációjának relációja a fenntarthatóság egyes megközelítéseivel} meghatározza egy „későbbi jövo”” generációjának jólétét (Abdullahi, 2010). Ez felelősség, amit fel kell ismernie a diáknak, de erre önállóan nem lesz képes. Fontos, hogy ezt a pedagógusok is tudatosítsák magukban és törekedjenek arra, hogy ezt a gyerekek időben elsajátítsák. Ez arról kell, hogy szóljon, hogy az oktatás szerves elemeként megtanítják, hogy

\footnotetext{
${ }^{10}$ A fenntarthatóság az emberiség jelen szükségleteinek kielégítése, a környezet és a természeti erőforrások jövő generációk számára történő megőrzésével egyidejüleg." (CWSA, 2000) A fenntartható fejlődés pedig ennek megvalósulást jelenti (Gór, 2013).
} 
együtt, egy globális közösség részeként képesnek kell lennünk felelősséget vállalni a Föld jövőjéért (Attila Varga, 2018). A tanítás ugyanakkor nem elég, készség szinten van szükség arra, hogy a gondolataikat ez meghatározza (Hernádi és mtsai., 2008). A cselekvés, az aktív magatartás az, amire ösztönözni kell a diákot, hogy aztán ő maga is képes legyen ezeket az ismereteket-akár cselekvés útján továbbadni. A táblázatból is szembetűnő, hogy ennek térnyerése még minimális, fejlesztése kifejezetten szükséges. Fontos, hogy a foglalkozás ne egy egyszeri, külső kutatók által hozott programként jelenjen csak meg az iskola életében, hanem épüljenek be a mindennapi pedagógiai gyakorlatba, ahol az ötletelést követheti a tervezés és a megvalósítás szakasza. Erre a következő fejezetben bemutatásra kerülő kiegészítő workshop is tökéletes megerősítésként szolgál. Összegezve a fentieket, a designkommunikáció, mint kreatív-tervezői nevelési/oktatási eszköz támogatja az aktív, cselekvő fenntartható fejlődésre nevelés térnyerését a kurrikuláris oktatásban, amennyiben adott egy felkészült pedagógus. Fontos ugyanakkor kiegészíteni, hogy egyéb, társadalmunkat, bolygónkat, de akár a szükebb környezetünket érintő probléma is feldolgozható a foglalkozáson keresztül, megtartva a módszertan dinamikus, cselekvésre ösztönző jellegét, ami a következő fejezetben ugyancsak bizonyításra kerül.

\subsection{Kiegészítő workshop-sorozat és eredményeinek bemutatása}

A kutatási kérdés pontos és teljeskörü megválaszolásához a fentieken túl egy kiegészítő workshop-sorozat is kapcsolódik, ami organikusan alakult, az eredeti kutatási tervben nem is kapott még helyet. Létrejöttét a fentiekben megvalósított foglalkozások tapasztalatai és az elemzés során kapott eredmények indokolták. Fontosnak láttam, hogy a termék, a designkommunikáció workshop oktatásba történő integrálásához megvizsgáljuk, hogy mi történik abban az esetben, ha a szakmában aktívan tevékenykedő pedagógus a saját érintett osztályán keresztül figyeli meg a foglalkozáshoz társított pozitív hatásokat, ami a kutatási kérdés megválaszolásához is közelebb enged. Ezen túlmenően jelentőségét nyomatékosítja, hogy a feltáró jellegü, minden megyét érintő kutatás mellett milyen eredményt hoz, ha több alkalommal valósul meg a kutatás ugyanazzal a közösséggel. A kutatás mintavételi szélessége tehát a 24 megvalósított designkommunikáció workshop és annak eredményei által adott, ez a kiegészítő vizsgálat pedig a kutatás elmélyítését teszi lehetővé, a kutatási kérdésben feltárt lehetséges összefüggéseket egy másik dimenzióban keresi. A kvalitatív módszertan sajátosságaként rögzíthető a kutatási keretek folyamatos alakulása, formálódása, a kiegészítés lehetősége a mélyebb megértés érdekében. 
A termékleírás megköti, hogy csak olyan pedagógus tarthat önállóan designkommunikáció workshopot, aki korábban mind megfigyelőként, mind pedig résztvevőként rendelkezik már tapasztalattal, ezért a kiválasztás során mérlegelni kellett a fenti kritériumok meglétét. Így esett a választás annak a vidéki iskolának az egyik pedagógusára, aki a kutatás kezdeti szakaszától támogatta a munkámat. A választott pedagógus részt vett az első pilot workshopon, melynek tanárok és diákok egyaránt szereplői voltak, továbbá két másik foglalkozás aktív megfigyelőjeként is jelen volt Tapolcán és Alsópáhokon. A kiegészítő workshop-sorozat helyszínét tehát a Tapolcai Bárdos Lajos Általános Iskola Kazinczy Ferenc Tagintézménye biztosította. A vizsgálat egy olyan osztály középpontba állításán keresztül valósult meg, akik a 2019 tavaszán létrehozott pilot kutatásokban már részt vettek. Az akkor hatodik osztályos diákok most már egy továbbtanulás előtt álló nyolcadik osztályt jelentettek, akiknek minimális háttérismeretük és tapasztalatuk már volt a termékről. Ez a helyzet gyakorlatilag a kutatási folytonosságot is mintázza, és az elmélyítés eredményességéhez is hozzájárul. A kiegészítő workshop-sorozat 2021. február-március során 4 alkalommal, egymást hetente/kéthetente követően valósult meg. Az utolsó alkalom még éppen létre tudott jönni a pandémia okán bekövetkező online oktatásra történő átállást megelőző utolsó tanítási napon. A vírushelyzet miatt a teljes önállóság adott volt a pedagógus számára, hiszen külsősként az akkori helyzetben fennálló szabályozások okán nem volt lehetőségem bemenni az iskolába.

A kiegészítő workshop-sorozat során is a több módszertanú kvalitatív kutatás módszertana került alkalmazásra, melynek során az adatfelvétel a korábbiakhoz hasonlóan 3 pillérre épült. Az egyik a foglalkozást tartó pedagógussal készített mélyinterjú a workshopokat követően, a másik a résztvevő megfigyelés eredménye. Itt egy második pedagógus bevonása is megtörtént, aki aktív megfigyelöként mind a négy foglalkozást végig követte, és a már jól ismert megfigyelési szempontok alapján készítette el az elemzés alapját képező kutatói reflexiót. A harmadik pillér pedig nem más, mint a diákok által minden workshop végén elkészített reflexió. A reflexió a szubjektív vélemény kifejtése mellett egy asszociációs feladatot is tartalmazott, melynek során a kommunikáció az együttmüködés és a kreatív kifejezés kapcsán kellett leírniuk az első gondolatot, ami az eszükbe jut. Az eredmények ismertetése a fenti mintavételek elemzése alapján valósul, meg összegezve mind a négy foglalkozás kimenetét és tanulságait. 


\subsubsection{A workshop tematikája}

A tematika a jövő köré szerveződik, mert a kutatás alanyai 8. osztályos diákok, akik továbbtanulás előtt állnak, így gondolataikat meghatározza a jövő kérdése. Ahogy a termékleírás során is megfogalmaztam fontos, hogy olyan tematika köré szerveződjön a foglalkozás, mely vagy nem igényel háttértudást, vagy közel azonos ismeretet feltételez a résztvevő diákoktól. Fontos továbbá, hogy egy nyílt problémamegoldó (Dorst, 2011) helyzet elé állítsa a tanulókat. A fentieket figyelembe véve az első workshop tematikája a „Tökéletes iskola", a feladat pedig megtervezni a jövő gyerekei számára egy iskolát. A második workshop az „Osztálymeló” fantázianevet kapta. A wikinomikus együttmüködés során tervezniük kell egy foglalkozást, melyben az osztályuk a legjobb lehet, amire a leginkább alkalmas és amiben együtt ki tudnak teljesedni. A harmadik foglalkozás az „Álommunkahely” téma köré épül, a diákoknak meg kell tervezni egy általuk tökéletesnek vélt munkahely minden apró részletét. A negyedik workshop témája egyre inkább közelít a saját közösségük jövőjéhez. A záró foglalkozásban arra kerestek válaszokat és feltételezett megoldást a gyerekek, hogy hogyan tehetnék jobbá saját osztályközösségüket.

A témaválasztás kapcsán az ideális és tökéletesség fogalmának alkalmazása magyarázatra szorul. Ideális, tökéletes alapvetően nincs, csak a manipulált percepció teszi azzá. A gyerekek esetében ugyanakkor az idealizálás fontossá válik, ők még hisznek a tökéletesben, a csodákban. Az emberi optimum és a megmagyarázhatatlan tökéletes közötti kapcsolatban tehát a gyerekek még képesek hinni (A. Cosovan, 2009). Erre építve és ennek köszönhetően a tökéletes és ideális fogalmak alkalmazása segítségével kézzelfoghatóvá tehető számukra gondolataik megformálásának célja és lényege.

\subsubsection{Mélyinterjú elemzése és kódolása}

A strukturálatlan mélyinterjú a vizsgált osztály osztályfőnökével a négy foglalkozást követően valósult meg, így együttesen volt lehetőség a foglalkozások elemzésére és a köztük fennálló összefüggések feltárására, a lezajló folyamatok értelmezésére. A mélyinterjú leiratának nyílt kódolási folyamatát követően az axiális kódolási szakaszban 8 kategória került rögzítésre, ami egyúttal az eredmény bemutatásának keretrendszerét is jelenti.

\section{Az osztály}

A pedagógus kiemelten fontosnak tartotta, hogy megismerjem a vizsgált közösséget, akik a magatartásuk, a tanulmányi eredményük és a családi hátterüket érintve is heterogén 
összetételü csoport („Az osztályról azt tudni kell, hogy egy olyan osztály, ahol nem nagyon van szoros kapcsolat a diákok között, sokan vannak periférián.”) A diákok szinte képtelenek az együttmüködésre, arra, hogy egy osztályt jellemző egységben gondolkodjanak, a pedagógus irányítására szorulnak: „Amikor ki kell alakitani egy véleményt az osztályban, akkor nehezen tudnak dülőre jutni. Nekem kell szabályokat hozni, ami alapján a döntés születik." Rossz magaviseletük, és az ehhez társuló közepes tanulmányi eredményük okán hírhedt osztályként pozícionálják őket az iskola falain belül, a legtöbb pedagógus nem tudja őket kezelni. Ez kölcsönös, hiszen az osztályfőnökükön kívül ők sem fogadnak el senkit, mindenkiben a hibát keresik. Osztályfönökükkel szerencséjük van, hiszen az ő higgadt természete és a humor, mint nevelési eszköz bevonása segít a kölcsönös elfogadásban.

\section{Pedagógusból tréner}

Egy pedagógus gyakorlatilag olyan, mint egy színész, folyamatosan szerepben van, a legkritikusabb közönség előtt, az egyetlen különbség az, hogy ez itt nem csak egy elképzelt valóság, hanem maga a színtér a valódi mindennapként rögzíthető. Ebböl kiindulva azt gondoltam, hogy egy ilyen tréneri szerep egy pedagógusnak nem okoz majd különösebb problémát, vagy kihívást, de tévedtem. Az interjú során az osztályfőnök rávilágított, hogy a megszokott hierarchikus viszonyrendszerből átállni egy tréneri szerepbe izgalmat és új feladatot hozott számára („Nekem is ez sok tapasztalatot adott és úgy éreztem, hogy egyre inkább kezdtem én is felnőni a feladathoz”). A kezdeti bizonytalanságot felváltotta a szorongás, hogy vajon mindent jól csinál-e, és szinte azonnal érezte, hogy miben és hogyan kellene fejlődnie (,A következőnél már sok olyan hibát nem követek el, amit most úgy érzem hiba volt.”). Kiváló javaslata volt, hogy készüljön egy pontos útmutató, tanácsokkal, praktikákkal felkészülési segítséggel, ami megkönnyíti azt, hogy ugyanazzal a közösséggel szemben egy egészen eltérő szituációs környezetben egy alapjaiban más viszonyrendszerben támogatni tudja a diákok alkotói kibontakozását. A fejlődés egyértelműen azonosítható volt ahogy haladtak elöre a foglalkozások során (,Sokkal magabiztosabbnak éreztem magam. Sokkal jobb volt, mint az elsö, én is úgy éreztem, hogy felkészültebb vagyok, sokkal jobban tudom koordinálni, kérdésekkel segíteni a folyamatot."). Érdekes azonban, hogy a pedagógus a diákok fejlődését saját személyes fejlődése elé helyezte, vagyis a harmadik alkalommal, amikor a workshop látszólag negatív kimenetet mutatott, akkor nem tudott örülni annak, hogy ő milyen jól teljesített, hiszen a diákok vélt kudarca ezt felülírta. 
Fejlödés

A fejlődés megközelítése tehát három dimenzióban volt tetten érhető. A pedagógus és a diákok egyéni fejlődése, valamint az osztály fejlődési folyamata, mint közösség. Az osztályfőnök kiemelt egyes diákokat, akik hétről hétre eredményesebbek voltak, eddig sosem tapasztalt módon csoportszerepeket vettek magukra, (,4 év alatt ezt a kisfiút így nem láttam. Hogy ö érveljen részt vegyen, úgy vegyen részt, hogy ö az egyik hajtóerö és motor."), a hétköznapokban visszahúzódó diákok kerültek a workshop során az osztály élére (,Kifejezetten látható volt, ahogy az új helyzet az egyén új, vagy eddig rejtett oldalának kibontakozásához járul hozzá és tartja fent az aktivitást hétröl hétre”). Az első két workshop a közösség szintjén is érezhető fejlődést mutatott: „amit az elöző workshop során elfogadtak szabályok azt következetesen alkalmazták. Meghallgatták egymást. Fegyelmezték egymást. Nem akarták, hogy tönkretegyék a közös munkát."

\section{Közösségi kudarc, mint eredmény}

A fejlődés a harmadik workshop során megtorpant, a foglalkozás egy kisebb kudarcba és vitába torkollt. A pedagógus ennek okát abban látta, hogy az első két workshop sikerén felbuzdulva még hátrébb lépett, a designkommunikáció módszertanához igazodva még nagyobb teret engedve a tervezői szabadságnak és az osztálynak, ám erre a közösség még nem volt felkészülve. A létrehozott produktum ellenére teljes letargia és szorongás uralkodott el az osztályon. Itt volt egy nagyon fontos lépése a pedagógusnak, nem engedte így lezárni a folyamatot, hanem leültette a diákokat és teret adott a közösségi kudarc kibontakozásának. A workshop eredménye itt nem a foglalkozáson, hanem azt követően realizálódott: „Az osztály életében ez egy jelentös felismerés volt, mert így nyiltan, egymást meghallgatva, érvelve még soha nem mondták el a véleményüket." Szembesítették egymást és megbeszélték közösségi szinten a problémát. Itt kifejezetten nagy jelentősége volt annak a kritériumrendszernek, hogy csak olyan pedagógus tarthatja a workshopot, aki megfelelő designkommunikációs módszertani ismeretekkel is rendelkezik, hiszen így egy látszólag negatív kimenetet a fejlődés irányába fordított.

\section{Érettség a szabadsághoz}

Külön kódként jelenítettem meg azt a gondolatot, ami vélhetően a „közösségi kudarc” jelenségéhez vezetett. Ez pedig nem más, mint az osztályfőnök által megfogalmazott soft készség, az érett, kritikai gondolkodás, ami szükséges ahhoz, hogy értékelni tudja és helyén 
kezelje a diák a kapott szabadságot. A módszertan szabadságot, teret ad a kreativitásnak, ugyanakkor ezzel a szabadsággal meg kell tanítani élni a diákokat, hogy ez valóban egy hajtóerő legyen az egyén és a közösség számára, ne pedig egy gát az együttmüködési folyamatban.

\section{Katarzis}

Az igazi flow élményt a negyedik workshop hozta meg. Az eredetileg három foglalkozással tervezett workshop-sorozat eredményeihez igazodva úgy gondoltam, hogy szükséges egy negyedik alkalom ahhoz, hogy ezt a helyzetet feloldjuk és lehetőséget biztosítsunk a felgyült tapasztalat cselekedetté konvertálódására. A foglalkozás maximálisan hozta a hozzá füzött reményeket, az osztályfőnök elmondása alapján olyan közösségi szellem uralkodott az osztályon, ami még sosem volt tapasztalható. Az eredmény sikere a diákok mellett a pedagógust is megérintette, aki olyannyira átélte a folyamat során a flow élményt, hogy még az interjú alatt is könnybe lábadt a szeme, amikor ehhez a kódkategóriához kapcsolódó témákban mondta el tapasztalatait („A workshop végén, látva az eredményt el kellett fordulnom a diákoktól, mert megkönnyeztem, annyira büszke voltam rájuk").

\section{Kreativitás}

A designkommunikáció workshop a kreativitásra alapoz, és az ehhez kapcsolódó elemek a mélyinterjúban is intenzíven előkerültek. A pedagógus a kreativitás kapcsán két kulcsfogalomra világít rá. Az egyik, hogy a kreativitás elsősorban egyéni szinten volt értelmezhető a foglalkozások alatt. Egyéni szinten pedig két fontos tényező alakította. Az egyik a kommunikációs készség, miszerint: „valahogy azok a gyerekek, akiknek a kommunikációs készségük kiemelkedik a csoportból azok kreativabbnak is tüntek nekem a munkájuk során. Sokkal több ötletet mondtak. Olyan ötleteik voltak, amivel sokkal több értéket adtak a produktumhoz.” A másik ilyen tényező, ami pedig megjelent az az egyéni érdeklődés: „a kreativitás akkor jelent meg szembeötlö formában, amikor olyan téma került elö, ami az adott diákot kifejezetten érdekli." Mindenekelött azonban fontos kiemelni, hogy az egyéni kreativitás kibontakozásához a legnagyobb hajtóerőt a támogató közeg jelenti (,hiába van egy kreatív ember, ha egy olyan közegbe kerül, amelyik ezeket a dolgokat nem támogatja, akkor nem tudnak felszínre törni ezek az ötletek és nem tud úgy elötörni belöle a kreativitás"). 


\section{Kommunikáció, Együttmüködés}

A kommunikáció és együttműködés fogalmi keretrendszerét egy kódként értelmeztem az interjú alapján, mert a pedagógus a foglalkozás kapcsán teljes egységben kezelte a két kifejezést („A megfelelő kommunikáció hiányában képtelenek voltak együttmüködni.”). Egyértelmüen azonosította a fejlődést a közösségi kommunikációban, azonban az egyéni szintủ fejlesztés szükségessége szemet szúrt számára, a foglalkozás felszínre hozta a hiányosságokat („egyéni szinten nagyon sok embernél lehetne ezt fejleszteni, de csoport szinten megint csak azt tudom mondani, hogy javulás volt tapasztalható”). Rávilágított ezzel párhuzamosan saját felelősségére is, a foglalkozás ilyen formában is egy tükröt tartott számára, hogy mennyi mindent tehetne ennek fejlesztése érdekében. („Éreztem a saját felelősségemet is, hogy akár már önmagában a saját kommunikációmmal is mennyit tehetek a fejlödés érdekében.”)

\subsubsection{Résztvevö megfigyelés}

A résztvevő megfigyelés során a foglalkozást tartó osztályfőnök mellett bevonásra került egy másik pedagógus is, aki mind a négy workshop alatt passzív résztvevőként figyelte és rögzítette a folyamatokat az előre egyeztetett megfigyelési szempontok mentén. Korábban ő is részt vett már designkommunikáció workshopon, résztvevőként és megfigyelőként egyaránt, így ismerős volt neki a szituáció, volt összehasonlítási alapja, értette a módszertan lényegét. Nem elhanyagolható, hogy iskolán belül a leginkább nyitott és innovatív szemléletü pedagógusként jellemezhető, aki folyamatosan továbbképzésre jár és az újító pedagógiai módszerek kipróbálása szerves részét képezi a hétköznapi oktatási tevékenységének. A résztvevő megfigyelés eredménye két pedagógus nézőpontjának összegzése mentén kerül tehát bemutatásra.

A megfigyelési szempontok alapvetően a korábban már ismertetett elemekre épültek, kiegészítve néhány olyan egységgel, ami ahhoz kapcsolható, hogy itt a foglalkozás ismétlődő jellege lehetővé tette a folyamatok megfigyelését is. Ide tartozik a fejlödés (10), a közösség erősödése (11), az együttműködés eredményessége (12), a kommunikációs folyamatok (13) és a kreativitás (14), valamint a vállalkozói attitüd (15).

Workshop (1) - 2021.02.05. - „Tökéletes iskola”

Alapvetően a foglalkozások a designkommunikáció módszertanának interaktív bemutatásával kezdődnek, azonban itt a diákok korábban már részt vettek egy ilyen előadáson, 
így egy rövidebb, átfogó, ismétlő bemutatás történt csak a workshop kezdetén. Emlékeztek a diákok (1) („,dizájn-nal kommunikálunk”, „kreativitásról szólt”, „a tervezés eredménye a megvalósitás"), ami már önmagában pozitívumként értelmezhető a workshop tekintetében. A foglalkozást összekapcsolták a korábbi workshop mentorával, azaz velem, többször is várták a megjelenésem (,Hol van Daniella?”, „Mikor jön már Daniella?”), ez is sugallja, hogy egy ilyen folyamat során a tréner szerepe és személyisége mennyire meghatározó lehet a diákoknak.

Az önálló végig gondolása a folyamatnak csak minimális ideig tartotta fent a figyelmet (5), így hamar elkezdtek a véletlenszerüen kialakított kis csoportokban dolgozni. Ez volt a workshop leginkább hatékony eleme (3), ebben a keretben még müködnek (,jó ötleteket hallok $k i$, vitatkoznak, érvelnek”). A csoportoknál látszott, hogy az összetétel nagyon meghatározta az eredményt: „Megfigyelhető volt és csoporton belül látszott, hogy a dominánsabb kisgyerekek mennyire tudták érvényesiteni az akaratukat, azonnal felvállalták a csoportvezető szerepet.”.

A kiscsoportos munkát követően volt egy rövid szünet, majd megkezdődött az osztályszintü együttmüködés. Mindenki nekiállt beszélni és viszonylag rövid idő alatt kitalálták, hogy ez így nem lesz jó, jelentkezésre buzdították egymást (7). Megalkottak olyan a szabályokat, ami egy ilyen kommunikációnál természetes az embernek, nekik mégis újdonság volt (13). Rászóltak egymásra. Fegyelmezték egymást (4). Végigmentek a csoportötleteken, de itt azért fontos megjegyezni, hogy ez inkább tanári irányításra valósult meg, mint önmaguktól. A várt eredményt azonban hozta, hiszen „,nem jellemző rájuk, hogy ilyen beszélgetés alakul ki”. A nagyobb csoportban is jellemzö volt a csoportszerepek azonnali kialakulása (13), elmondható, hogy ugyanazok a gyerekek vették át a vezető szerepet, akik a kis csoportokban is, és a mélyinterjú során tárgyalt kommunikációs készségek terén is ők azok, akiknek ez a soft készségük erős a többiekhez képest.

A létrehozott produktum kapcsán két fontos aspektust szeretnék kiemelni a megfigyelések eredményeiből (9). Az egyik az a tény, hogy a tökéletes iskola a diákok számára fenntartható:” Iskola teteje napelemes legyen”, „Saját energiáját termelje meg az iskola”. A másik pedig, hogy a tökéletes iskolában tanító pedagógusokat miként írják le a diákok: „csak jófej tanár legyen, aki tudja, hogy mi a jó nekünk".

A folyamat során a legnagyobb nehézségek között sorolták fel a pedagógusok, a diákok ráébresztését a motiváció eltérő aspektusaira. Az innovatív módszertan egy nyitott szemléletet is feltételez, amire a diákokat fel kell készíteni és ide tartozik az is, hogy önmagukat képesek legyenek ösztönözni az osztályzatok és intőkön túli mérőszámokkal is, mint az együttműködés öröme vagy az alkotói folyamatban rejlö élmények (12). 
Workshop (2) - 2021.02.12. „Osztálymeló”

A második workshop során a folyamatban volt leginkább megfigyelhető a fejlődés (10). Rutinosabban mozogtak a helyzetben, és látható volt, hogy a passzívabb diákok is aktívabb részeseivé váltak a folyamatnak (3) (,Volt az egyik csoportban egy kisfiú, aki az elsö workshopon nagyon passzív volt, szinte teljesen kivonta magát mindenböl, most pedig nagyon meghatározó volt, és ö lett az egyik vállalkozás vezetöje, holott nem rendelkezik vezetöi képességekkel, viszont annyira magáénak érezte, hogy a többiek elhitték és öt szavazták meg."). Az egyéni munkát követően 4 csoport alakult. A kiscsoportos munka ismételten hatékonynak bizonyult (5), hangosak voltak (4), de külső tanári fegyelmezésre nem volt szükség, ezt koordinálták maguk között a diákok (12). Mikor az osztályfőnök körbe járt a csoportok között, a csoporttagok mindig kinéztek rá, olykor kérdezték, itt is látható volt, hogy megerősítésre szorulnak. Bár már sokkal intenzívebb volt az együttmüködésre irányuló törekvés (12), azért egyik hétről a másikra nem tudják figyelmen kívül hagyni a megszokott hierarchikus viszonyrendszerből adódó mintákat. A csoportösszetétel itt is meghatározta az adott kis csoport munkáját.

A wikinomikus együttmüködést már egy sokkal aktívabb folyamat jellemezte: „annyi ötletük volt, hogy le sem tudták írni mindet”. Használták a táblát, jegyzeteltek lapokra, egy intenzív, alkotói folyamat volt tapasztalható (3), komolyabban vették a feladatot. Ezt eredményezhette az is, hogy a feladatban ők már nem diákok, hanem felnőtt emberek, akik egy közös munkát terveznek, ami befolyásolhatta attitüdjüket is a feladathoz (15). Sokkal több ötlet generálódott (14), és sokkal több gyerek bevonódásával született meg az eredmény. A produktum kapcsán nagyon érdekes, hogy a tervezői folyamat részeként (9) egy tervezőlakberendező vállalkozást hoztak létre, ami kapcsolatba hozható azzal a tervezői szereppel is, amit a designkommunikáció workshop során magukénak tudhatnak (8).

Workshop (3) - 2021.02.19. „Álom munkahely”

A harmadik workshop a másodikhoz hasonlóan az előző alkalom elemzésével, reflektálásával indult. A gyerekek is felismerték a közösség fejlődését (10), aminek hangot is adtak. Egyre inkább látszik, hogy otthonosan mozognak a helyzetben (3), ami még több diák bevonását eredményezi. A kiscsoportos munka remekül zajlott (7), bár a megerősítésre még mindig szükségük volt. A foglalkozást vezető pedagógus ezúttal azonban egy lépéssel hátrébb lépett, így az osztályszintü együttmüködésben önálló teret engedett a diákoknak (5), akik 
azonban erre még nem voltak felkészülve. Az együttmüködési folyamat elindult, azonban néhány diák kibic viselkedése megtörte a folyamatot, felborította a közösséget (4), így a folyamat a katarzis helyett káoszba fulladt (12). Az eredményt nagy nehezen megalkották, de egyértelmü kudarcnak ítélték meg (9).

Ezt követte az osztályszintű megbeszélése a problémának (12) a pedagógus nagyszerü kezdeményezésére, ami finomhangolt az eredményen és a foglalkozás valódi haszna a workshopot követő megbeszélés során realizálódott (9), gyakorlatilag az tekinthető az igazi produktumnak. A két pedagógus és a kutató ennek a folyamatnak a hatására döntött úgy, hogy egy negyedik alkalommal is vizsgálni szeretné, hogy egy ilyen helyzetet követően hogyan értékelik újra a diákok az együttmüködést.

Workshop (4) - 2021.03.05. „Együtt az osztályközösségünkért”

A negyedik workshop teljes meglepetésként érte a diákokat, nem tudtak róla, hogy lesz még egy alkalom. „Nagyon jól indult a foglalkozás, tetszett nekik a feladat”. Ahogy korábban az osztályfönök megfogalmazta az a téma, ami közel áll hozzájuk sokkal inkább megmozgatja a fantáziájukat és kreativitást szül (14), ez be is bizonyosodott a workshop során, számtalan jó ötlet született, amit a különböző csoportok is elismertek egymásról (,,minden csoportnak jó ötletei vannak, csak össze kellene írni”). Kimutatható volt a harmadik workshopot követö értékelő osztálybeszélgetés (13) hatása is („Valószínü, hogy sokat jelentett a múltkori beszélgetés, mert a csöndesebbek bátrabban szálltak szembe a nagyszájúakkal"). A kis csoportok véletlenszerü megalkotása homogén csoportokat eredményezett a magatartás és a tanulmányi eredmény kapcsán is, ami hatással volt a munka kimenetére (12).

A közösség szintjén is kitapintható volt az az akarat, ami a korábbi kudarc felülírására irányult (12). Az együttmüködést a pedagógus megfigyelések alapján erősítette már önmagában a téma jellege is, ami az osztályközösség jobbá tételére fókuszált, így „,együttműködésben hozták létre azt, hogy hogyan javithatnák a jövőben a közösségüket, és a közösségi szintü kooperációt." Együttmüködésben, azonban nem egyetértésben zajlott a munka, ami nem is volt baj, mert az érvekre támaszkodó viták előre lendítették a folyamatokat. A kommunikációjuk is fejlődést mutatott (13).

Produktumként felülírták a házirendet a saját pontjaikkal, amibe minden csoportnak és minden egyénnek beleszólást engedtek (9). A döntésük súlyát aláírásukkal nyomatékosították. Az osztályközösség jobbá tételének házirendi pontjai között erösen jelen volt a kommunikáció javítására irányuló törekvés: „átgondoljuk, amit mondunk”, „,közös beszélgetések”, „,hallgassuk 
meg egymást". Megjelent a designkommunikáció alaptézisei között is helyet kapó egyenrangúság (,legyünk egyenrangúak”) és az egymás iránti tisztelet („,tiszteljük egymást”), valamint az együttmüködés kapott még igen hangsúlyos szerepet: „,tartsunk össze”, „segítsük egymást”, „közös kompromisszumok”, „törödjünk egymással”.

\subsubsection{A diák reflexiók elemzése}

Workshop (1) - 2021.02.05. - „Tökéletes iskola”

A diákok reflexiói az első workshop tükrében, a nyílt kódkategóriák feltárása után a következő főbb elemek mentén értelmezhetők. Jellemezték osztályközösségüket, de sokkal inkább a fejlődés relációjában tették ezt és a foglalkozás eredményeként élték meg a pozitív változásokat, az osztályközösség és az együttmüködés fogalma szorosan összefonódott: „összekovácsolódott, ahhoz képest, hogy milyen szokott lenni”, „szerintem eddig nem foglalkoztunk ennyit egymással”, ,közösségben tudtunk egy jó ötletet feldolgozni, ami a közösséget egybefogta”, „látszott az is, hogy milyen együttmüködöek vagyunk, a végére egy csapat lettünk”, ,ilyen jól még sose láttam együttmüködni az osztályt, végre együtt tudtunk valamit csinálni az osztállyal közösen és kulturáltan”. Negatívumként, munkájuk hátráltatásaként saját magatartásukat rögzítik: „nagy zsivaj és hangzavar, nem értettük meg egymást". A beszélgetés lehetőségét nagyon értékelik, osztályszintü eredményként értelmezik: „tudtunk normálisan beszélgetni az osztálytársaimmal”. A beszélgetéshez szorosan kapcsolódik, azonban sajátos megközelítésben került elő a kommunikáció, aminek a vita, az érvek is szerves részét képezik (,normálisan lehetett veszekedni”, ,,mindenki végighallgatta a másikat, ami úgy kicsit jó érzés volt”, „kicsit vitáztunk, de barátilag”), és a diákok által is megfogalmazásra kerül, amit az osztályfönök is többször érintett az intelligencia és a kommunikáció összefüggése (,intelligencia szükséges hozzá”).

A kreativitás is visszaköszönt a reflexiókban, az alkotással, a képzelettel, az ötletekkel és a fantáziákkal társították, az így címkézett nyílt kódok kerültek összefoglalásra: „az volt a legjobb, amikor összegyúrtuk az ötleteket, ilyenkor elképzelem, hogy nézhet ki ez az alkotás". A kreativitáshoz kapcsolódik, hogy a workshop során a megjelenését a diákok nem hozták összefüggésbe a tanulással, vagyis előkerült a játszva tanulni szemléletmód: ,nem tanultunk, $a$ kreativitásunkat elöhozhattuk". Fontos megemlíteni még az önkifejezést, amit nagyon sok diák érintett (,Sokszor lehetett a saját véleményünket elmondani, mindenki tudott érvényesülni”), méghozzá olyan összefüggésben, hogy az egyéni vélemények teret nyerhettek, majd az így 
létrejött gondolatok összekapcsolása eredményezte a produktumot (,mindenki kimondhatja ahogy elképzelte és ebböl majd a sok ember a végén tud egy jót alkotni”). A létrehozott eredményre büszkék voltak, közös produktumnak értékelték és olyan iskolát alkottak meg, aminek ők is szívesen a diákjai lennének (,,megcsináltuk az ország legjobb iskoláját”, „a végeredmény is szerintem nagyon jó lett, mindenkinek volt egy jó ötlete”, ,sok mindenben a végeredmény best lett, én is járnék oda").

Workshop (2) - 2021.02.12. „Osztálymeló”

A második workshopról készült reflexiók alapján meghatározott kódok a fejlődés kulcskategóriája köré sorakoztak fel. A fejlődés több dimenzióban is teret nyert, az önállóan is kódot formáló kreativitás (,a csoportos tervezésben voltak kreativ ötletek”) az együttmüködés (,,az osztály legnagyobb része közösen, normálisan dolgozott, együtt tudott müködni az osztály”) és a kommunikáció (,„az osztály nagy része végighallgatta a másikat, a végén már a jelentkező szabályt sem kellett betartanunk”) kategóriáihoz kapcsolódóan. Fejlődést realizáltak a gyorsabb haladásban, az együttmüködéshez kapcsolódóan a jobb csapatmunkában (,jobban tudtunk csapatban dolgozni”). A kommunikációjuk pozitív irányú változását sugallta az a felismerés, hogy „könnyebben megegyeztünk egy csomó dologban” és ,jobban meg tudtuk beszélni" a problémát. A kreativitásuk is elkezdett kiteljesedni, saját meglátásuk alapján „sokkal jobb dolgokat mondtak, mint azelött”.

A produktumhoz füződő kapcsolat több szintje is megjelent, az egyszerü teljesítéstől („Alkottunk egy munkát, ami az osztály nagy részének megfelel”) a büszkeségig („A végeredmény nagyon jó lett és büszke vagyok rá"), ugyanakkor abban egyetértés volt, hogy: „megalkottak egy munkát, amit együtt terveztek és összedolgoztak”. Érdekesség, hogy a vállalkozói attitüd is megjelent a kódok között, sokan magukat vállalkozó szerepbe helyezték a munka során („,Ketten folyamatosan beszéltek és nem a vállalkozásról”, „Nehezen, de megalkottunk egy vállalkozást".) Ezt megerősítette a pedagógus mélyinterjúja is, aki elmondta, hogy az osztálymeló tervezése folyamán a diákok előtérbe helyezték a tervezés során is a profitabilitás szempontjait (,legyen az ingatlan a tó partján, mert azt nagyobb haszonnal lehet eladni"). 
Workshop (3) - 2021.02.19. „Álom munkahely”

A mélyinterjú és a résztvevő megfigyelés eredményeinek ismeretében nem meglepő, hogy a diákok reflexiói is tükrözték a workshop negatív kimenetét (,ez volt a három közül a legrosszabb"). A kódkategóriák hasonlóan alakultak, mint az előző két foglalkozás esetében. Kitértek a kreativitás hiányára (,hát ezen az órán nem volt sok”, „ma nem rugaszkodtunk el annyira a lehetöségeinktöl”), az együttmüködés sikertelenségére (,nem tud az osztály együtt dolgozni”, „nagyon nem éreztem jól magam, nem tudtunk együtt dolgozni”) és a kommunikációban megjelenő nehézségekre (,nem tudtunk összedolgozni, mert folyton kiabáltunk”, „, legrosszabb az volt, hogy senki nem hallgatta meg a másikat és nem lehetett közös döntésre jutni”, „,nehezen értettük meg egymás gondolatait”). A kudarc okát négy tényezőben látták. Megjelent annak a néhány embernek a rossz magatartása, akik bomlasztották az együttmüködést („Pár ember szemtelen volt és mindenkinek tönkretették a napját”), felmerült a csoport kimerültsége (,Lehet, hogy belefáradtunk már ebbe”), az érdektelenség (,senkit se érdekelt a végére”) és a feladat, a téma nehézségi foka (,Nehéz volt a feladat, és nem tudtunk közös eredményre jutni”).

Hiába a kiscsoportos munka sikere (,,a külön csoportos munkába volt kreativitás”, ,amíg kisebb csapatokban voltunk jó volt”), az osztályszintű együttmüködés kimenete lett a döntő befolyású, amikor az egész foglalkozás értékelésre került a diákok által.

Workshop (4) - 2021.03.05. „Együtt az osztályközösségünkért”

A negyedik workshop kimenete a diákok nézőpontjából tekintve is egyértelmüen pozitív („ez volt magasan az egyik legjobb foglalkozás”), a reflexiók kicsengése is üdíto,, a szóhasználatuk vidám és sokkal több diák rajzolt vagy írt színes ceruzával a papírra. Ezúttal a feladat kifejezetten elnyerte a tetszésüket (,A feladat nagyon jó volt”, „Ez volt az eddigi legjobb feladat szerintem”). A fejlődést a kommunikáció (,Sokkal jobb volt a kommunikáció, mint a legutóbbi foglalkozáson”) és az együttmüködés (,az együttmüködés elég jó volt és fejlődött benne az osztály”), kapcsán érzékelték leginkább. Az osztályközösség erősödésére is rávilágítottak („ez a foglalkozás egy kicsit talán jobban összehozott minket”). A fejlődést nem egyértelműen az előző workshophoz viszonyították, hanem a négy alkalom relációjában érintették (Az együttmüködés óráról órára jobb lett). Volt olyan kisgyerek, aki egy foglalkozási érzet grafikont is készített a négy alkalom függvényében egy négyes skálán. A produktum sikerét (,Megerőltettük magunkat és jó munkát csináltunk”) az együttmüködés (,,együtt tudtunk 
müködni és meg is lett az eredménye”) és a kommunikáció („,meg tudtuk egymást érteni, ezért is lett jó a végeredmény”) számlájára írták jóvá, azokkal összefüggésben értékelték. A kreativitást a produktummal összekapcsolták. Az, hogy a végén a közösség fejlesztésére irányuló házirendet aláírásukkal megpecsételték egy eredeti és kreatív ötletként maradt meg számukra (,az, hogy aláírtuk a lapot nagyon jó, kreatív ötlet”).

\subsubsection{Eredmények és hozzáadott érték összefoglalása}

Összefésülve az eltérő adatfelvételi módszerek kódkategóriáit, a fejlődés, a kreativitás, a kommunikáció, az együttműködés az osztályközösség, a kudarc és a létrehozott produktum kerül rögzítésre. Ha a négy foglalkozás együttes eredményét tekintjük, akkor a következőként foglalhatjuk össze a legfontosabb konklúziókat. A fejlődés három dimenzióban realizálódik, egyrészt a pedagógus személyes fejlődése az új, tréneri szerepben, az egyes diákok egyéni személyiségében bekövetkező pozitív változás, eddig nem tapasztalt értékek felszínre kerülése, valamint az osztályszintű fejlődési folyamatok. Ez utóbbi leginkább a kommunikáció és az együttműködés kapcsán érhető tetten. Az együttmüködés minősége és az osztályközösség változása közötti kölcsönös és szoros viszony egyértelműen kimutatható. A feltárt problémák, kudarcok a foglalkozáson keresztül lehetőséget teremtettek a változásra és a fejlődésre ott, ahol ezzel a szereplők a designkommunikáció módszertanának ismeretén keresztül élni tudtak. A létrehozott produktumok teret adtak a diákoknak az alkotásra, a kreativitással összekapcsolt új ötletek generálására, a tervezői identitás térnyerésére, melynek során ugyan csak kis mértékben, de a vállalkozói szemléletmód is megjelent, ha a tematika ennek teret hagyott.

A kiegészítő workshop-sorozat egyik fontos célkitűzése volt a 24 állomásos kutatás eredményeihez történő hozzájárulás. Ennélfogva az összefoglalás fontos részeként tartom számon a kapcsolódások és megerősítések, az esetlegesen előkerült új dimenziók feltárását, összefésülését. A fentiek szerint itt is nyomatékos szerepet kapott a (4) fejlődés, a (3) soft készségek fejlődése. Ez utóbbi a foglalkozás ismétlődő jellegéből adódóan még szembe tűnőbb volt, úgy a közösség, mind a pedagógus nézőpontjából. Részben ehhez a kódkategóriához kapcsolódik az (2) osztály, mint közösségben lezajló folyamatok elöremutató jellege is, amit hétről hétre realizált a tréner, a megfigyelő és a résztvevők. A közösség erősödésében a kiegészítő workshop-sorozat során a tervezői, alkotói folyamat, mint a (6) produktumhoz vezető út nagyobb hangsúllyal volt jelen. A korábbiakban definiált 6 dimenziót jelen empirikus kiegészítő kutatás további 2 elemmel bővítette. Itt jelenik meg a (7) kudarc, mint a közösség 
formálásához és a fejlődéshez nagyban hozzájáruló történés, valamint az új téma kapcsán teret nyert a kutatási kérdés kapcsán is megválaszolandó (8) vállalkozói attitüd is.

\subsection{A kutatási kérdések megválaszolása}

Feltáró jellegü kvalitatív kutatásom két nagy egységre bontható. A 24 állomásos designkommunikáció workshop, majd az eredmények kiegészítését, megerősítését, új nézőpontból történő megvilágítását lehetővé tevő 4 állomásos foglalkozás sorozat. Jelen fejezet célja, hogy megválaszolja a disszertációban feltett kutatási kérdéseket. A kérdések megválaszolását a lokációnkénti elemzésekre és az azokat összefoglaló, a mélyebb és a kutatási kérdéseken túlmutató összefüggéseket is feltáró már ismertetett eredményekre alapozom.

A módszertani fejezetben megfogalmazott kutatási kérdés a következő: A designkommunikáció (tervezői kapcsolatteremtés), mint kreatív oktatásmódszertan alkalmazása egy workshopon keresztül hogyan alakítja, milyen módon formálja a részt vevő közösséget (diákok, pedagógusok)? Hogyan járul hozzá a nyílt végü problémamegoldás a vizsgált csoporton belüli kommunikációhoz? Hozzájárulását és befolyását a következő dimenziókban feltételezem: (I) közösségépítés, (II) soft készségek fejlesztése, (III) tervezői, alkotói identitás kialakulása, (IV) vállalkozói kompetencia térnyerése. A rögzített dimenziók által felvetett kérdésekre a következö kutatási alkérdéseken keresztül keresem a választ.

(I): Hogyan segíti a workshop a közösség építését?

(II): Milyen módon, milyen irányba alakítja a workshop a diákok soft készségeit?

(III): Hogyan formálódik, alakul a workshop által a diákok tervezői identitása?

(IV): Hogyan alakítja a workshop a vállalkozói attitüd és kedv megjelenésének intenzitását?

\section{A designkommunikáció módszertan a közösség szereplőit többszinten, és szinteken} belül több irányból formálja. A hierarchikus viszonyrendszer lebontása a pedagógus és a diák között, majd az új alapokra helyezett egyenrangúság a foglalkozás időtartama alatt egy jól kimutatható közeledést biztosít a diák és tanára kapcsolatában. A közeledés ezen túlmenően tetten érhető a diákok között, akik a csoportos és osztályszintủ együttmüködés eredményeként megvalósított közös sikeren keresztül mélyítik el és helyezik új alapokra kapcsolataikat. A tervezői kapcsolatteremtés eredményeként megvalósul tehát a közeledés, mint egy horizontális folyamat, de ezen túlmenően vertikális értelemben is történik előre mozdulás. A fejlődés dimenziói három szinten is tetten érhetők, kifejezetten igaz ez akkor, mikor maga a pedagógus a foglalkozás megvalósítója. Történik egy fejlődés a pedagógus személye kapcsán, akinek egy 
új, eddig ismeretlen szerepben kell helyt állnia. A diákok fejlődése is további két nézőpontból elemezhető. Egyrészt az egyéni fejlődés, másrészt a csoport, mint közösség fejlődése a tervezőialkotói folyamat által.

A designkommunikáció workshop a közösség építését (I) a lehetőségek biztosításával segíti. Lehetőséget ad az osztálynak a közösen eltöltött minőségi időre, ami élményt nyújt számukra. Lehetőséget teremt a beszélgetésre, ami egyértelműen hiánypótló, igényük, szükségük van rá. Lehetőséget biztosít azáltal, hogy a nyílt problémamegoldásra épít, így a megoldáshoz vezető út személyre, a közösségükre szabható, ami segít ahhoz, hogy magukénak érezzék a feladatot. A nyílt problémamegoldási helyzet középpontba helyezésével utat nyit a képzelet, a kreativitás kiteljesítésére. A nagyobb szabadság biztosításával, a konkrét iránymutatás nélkülözésével lehetőséget teremt a diákoknak az önállóságra. Ebben egyrészt fejlődniük szükséges, másrészt így a diákok valóban a saját teljesítményüknek, együttműködésük eredményének könyvelik el a sikert. Ez determinálja a létrehozott produktum és a diákok relációját. A jó középpontba állításán keresztül a diákok számára rávilágít az értékalkotás fontosságára.

A kutatás felhívta a figyelmet a soft készségek egyre növekvő jelentőségére (II). A pedagógusok felismerték az igényt és a felelősséget. Ez egyrészt adódott abból, hogy látva a diákok hiányosságait, a soft készségek fejlesztésének szükségessége nem volt többé megkérdőjelezhető. Másrészt a pedagógusok érzékelték, hogy az életre nevelés, a munka világára történő felkészítés, a megváltozott elvárások megkövetelik ezen készségek oktatásba történő integrálását, függetlenül annak központi szabályozásának hiányától. Hangsúlyt kapott a problémamegoldás (kritikai megközelítés), a kreativitás, a kommunikáció és annak függvényében értelmezett együttmüködés. A kutatás során bizonyításra került, hogy a fent rögzített soft készségekre közvetett vagy közvetlen befolyással van a workshop, különös tekintettel volt ez szembetűnő a kiegészítő workshop során, ahol alkalomról alkalomra kimutatható volt a pozitív irányú változás.

A diákok a tervezői szereppel (III) nagyon hamar azonosultak, az életből vett tervezési folyamatokra építve könnyedén elhelyezkedtek ebben a szerepben. Kezdetben az interaktív prezentáció során még csak az ő életükben megjelenő tervezői feladatok kerültek elő (,megtervezem a napom”, „kitalálom mit veszek fel”, „rajzolok valami szépet”), aztán a foglalkozás második felére ők váltak tervezővé és kapták meg az ezzel járó feladatokat („Tervezöként gondolkodtam és a társaimmal közösen alkottam”). Támogatta az önállóságukat, úgy érezték, hogy felnőttként kell helytállniuk (,Átéreztük, hogy milyen nehézségekkel jár valami újat létrehozni, mire kell figyelni, hogyan kell átgondolni”). A tervezői identitás 
formálása az alkotói (flow) élmény megtapasztalásával teljesedett ki, ami szorosan összekapcsolható a produktum felé megvalósult hozzáállással és a tervezésen keresztül megélt együttmüködés sikerével (,Szerintem jó lett a közös házunk is, amit együtt alkottunk, a saját képzeletünk szerint”').

A vállalkozói attitüd (IV) a vártnál sokkal kisebb mértékben volt jelen, ahogy az a produktumok elemzését taglaló fejezetben is látható. Ez azért is problémás, mert érdemes minél kisebb korban megvalósítani a vállalkozói attitüd expozícióját ahhoz, hogy nagyobb valószínüséggel alakuljon ki vállalkozói hajlandóság (K. Wilson, 2008). Ennek hiánya több dologra is visszavezethető. Egyrészt adódik abból, hogy az iskolában nagyon minimális gazdasági és vállalkozási ismeretet kapnak, így nincs meghatározó mértékben jelen a gondolkodásukban, mely jelenségre ezáltal a kutatás eredménye felhívta a figyelmet. De, ami ennél is fontosabb az a téma. Az otthon, majd az azzal összekapcsolt környezet, annak védelme és fenntartható jellege sokkal inkább megkövetelte a nonprofit jelleget szemben a profitabilitással. A kiegészítő workshop esetében már nagyobb arányban kerültek elő a vállalkozói attitüdhöz kapcsolható fogalmak, ugyanakkor itt sem volt számottevő. A designkommunikáció workshop és nyílt problémamegoldó helyzet adottságai támogathatják a vállalkozói attitüd előtérbe kerülését egy jól irányított témaválasztással, azonban ehhez szükséges az, hogy a hétköznapokban teret kapjon a gazdasági ismeretek tudatos oktatása. A pedagógusok a konstruktív, szabályok betartására építő vállalkozó készségek szocializálásában is kulcsszereplőként vannak jelen, ahogy ezt nemcsak saját empirikus kutatásom, de a szakirodalmi elemzés is megerősíti (Fülöp \& Pressing, 2012).

A kutatási eredményeket egy ábrán keresztül vizualizáltam, melyben látható, hogy az empirikus kutatás mely részein keresztül jutottam el a kutatási kérdések megválaszolásához. Az ábra prezentálja a kutatás fó vonalát meghatározó 24 állomásos workshop eredményeit a kiegészítő workshop során elemzett eredményekkel összehangoltan és azokat kiegészítve. Az empirikus kutatás két fô része, a szakirodalmi elemzés eredményei mellett együttesen járultak hozzá a kutatási kérdések feltárásához. Az elemzés során a kutatási kérdéseken túl további, a kérdésekhez kapcsolódó eredmények is feltárásra kerültek, amit szintén megjelenítettem az ábrában. 
55. ábra: Az empirikus kutatás eredményeinek összegzése

\begin{tabular}{|c|c|}
\hline 24 állomásos foglalkozás & $\begin{array}{l}\text { (1) Keretrendszer (Kapcsolati háló) } \\
\text { [Z. Fodor, 20181 } \\
\text { (2) Osztály, mint közösség } \\
\text { [Igel \& Urquhart, 2012; Turner, 2015] } \\
\text { (3) Életre nevelés: készségek fejlesztése } \\
\text { [Sahlberg, 2009; Dorst, 2011;Zoltayné Paprika \& } \\
\text { Nagy, 2013;Péter-Szarka et al., 2015; Hurrell, 2016; } \\
\text { Succi \& Canovi, 2020] } \\
\text { (4) Fejlődésre törekvés, a fejlödés dimenziói } \\
\text { [Fuchs, 2008] } \\
\text { (5) Hivatásom és felelösségem: pedagógus vagyok } \\
\text { [V. Wilson et al., 2006; Cseke, 2007;Lévai, 2013 ] } \\
\text { (6) A produktum } \\
\text { [Attila Varga, 2018;Hernádi et al., 2008] }\end{array}$ \\
\hline 4 állomásos kiegészítő workshop & $\begin{array}{l}\text { (2) Osztályközösség erősödése } \\
\text { (3) Készségek fejlődése (együttműködés, } \\
\text { kommunikáció) } \\
\text { [Morais \& Azevedo, 2001; Torgyik, 2004] } \\
\text { (4) Fejlödés } 3 \text { dimenziója (pedagógus, diák egyéni } \\
\text { fejlódése, közösség fejlődése) } \\
\text { (6) Produktum és a hozzá vezető út (tervezés, } \\
\text { alkotás) } \\
\text { (7) Kudarc } \\
\text { [Gillespie, 2005] } \\
\text { (8) Vállalkozói attitüd } \\
\text { [K. Wilson, 2008; Fülöp \& Pressing, 2012 ] }\end{array}$ \\
\hline
\end{tabular}

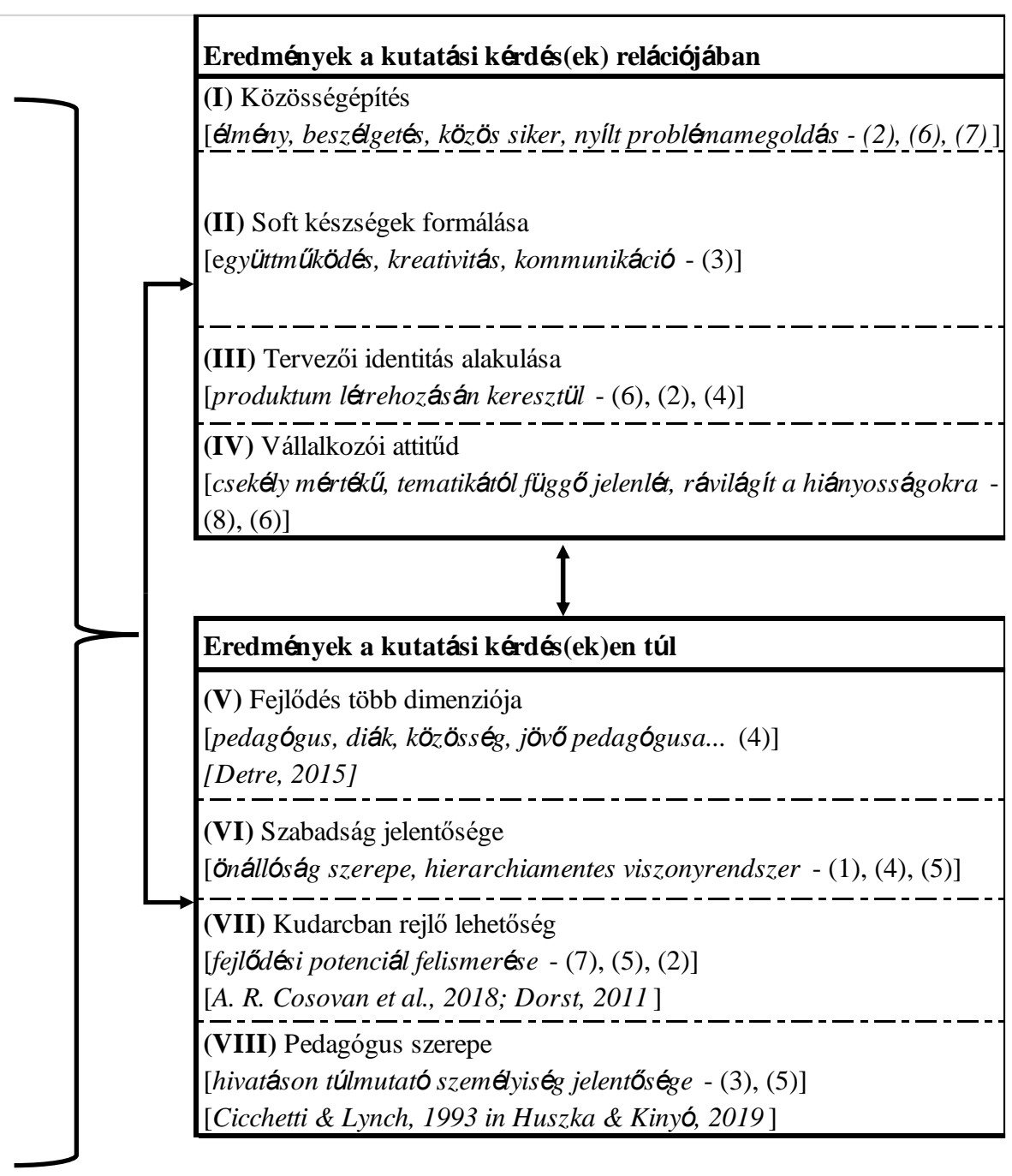




\subsection{A kutatás által nyújtott értékek}

\subsubsection{Akadémiai lenyomat}

Doktori disszertációm tudományos hozzáadott értékét egyrészt a részben hiánypótló szakirodalmi összefoglaló, másrészt az empirikus kutatás eredménye jelenti. Az oktatás legfontosabb szereplőinek hozzáállása, felelőssége és feladata a soft készségek fejlesztésében korábban ilyen összehangoltan, tudományterületeken átívelve nem került még elemzésre. A diákok soft készsége megjelenik, mint output az oktatási oldalon, ezzel párhuzamosan egyre jelentősebb helyet kap a munkáltatói oldalon, ahol a belépési küszöböt jelenti. A szakirodalom áttekintése és az empirikus kutatás eredménye is rávilágít, hogy a pedagógus hozzáállása és személye mennyire kulcsfontosságú, ők jelentik a folyamat motorját, a tudomány és a vállalati gyakorlat között képesek lehetnek megteremteni a párbeszédet, amennyiben erre módszertanilag is felkészülnek.

Az akadémiai lenyomatot tovább erősíti a hazai designkommunikáció módszertan rögzítése a tudományos térben, kapcsolódási pontjainak és legjelentősebb megkülönböztető jegyeinek feltárása egyéb tudományos módszertanok viszonyrendszerében.

Az empirikus kutatás eredményeként tartom számon azt a felismerést, hogy a soft készségek és a vállalkozói attitűd fejlesztésére bizonyítottan szükség van az általános iskolában. A designkommunikáció módszertanban rejlő lehetőségek is bizonyításra kerültek, úgy, mint a módszer pozitív befolyása a tervezői identitás alakulására, vagy az osztályközösség erősítésére, a kreativitás térnyerésére, melyek szintén a dolgozat akadémiai irodalomhoz történő tudományos hozzájárulását feltételezik.

\subsubsection{Gyakorlati eredmények (Oktatás, Vállalat)}

A disszertáció legfontosabb gyakorlati eredménye a létrejött oktatásmódszertani termék. A pedagógusok és az oktatásban érintett szereplök számára egy kézzel fogható értéket teremtettem azáltal, hogy egy olyan módszertant ismerhetnek meg és sajátíthatnak el, ami támogatja őket abban, hogy az iskolai keretrendszeren belül lehetővé váljon a diákok soft készségekeinek tudatos és irányított fejlesztése. Amennyiben a pedagógusok szeretnék elsajátítani a módszertant, úgy a képzéseken keresztül az akadémiai közeghez is közelebb kerülnek, megteremtve így a kapcsolatot különböző tudományterületek és a gyakorlat között, így az interdiszciplinaritás több dimenziója is teret kap. 
Disszertációm a szakirodalmi feldolgozás és az empirikus kutatás azt igazoló eredményein keresztül a gazdasági szereplők számára is értéket képvisel. A pedagógusok által feltárt igény és szükség a soft készségek fejlesztésére vonatkozóan összecseng a szakirodalmi elemzés során megismert, a munkaadók által a jövő munkavállalói felé támasztott követelményekkel. A designkommunikáció workshop egy HÍD-ként jelenhet meg a két szereplő között, lehetőséget teremtve az érdekek még szorosabb összehangolására. A munkavállalók által legfontosabbnak vélt soft készségek oktatásba történő integrálása a saját fejlesztésű workshopon keresztül képes megvalósulni a gyakorlatban. Ahogy az empirikus kutatásom eredményei bizonyították, alkalmazásán keresztül lehetővé válik az együttmüködés gördülékenyebbé tétele a közösség tagjai között, az egyéni és a csoportszintű kommunikáció fejlesztése, valamint katalizálja a kreativitást, támogatja térnyerését.

\subsubsection{Társadalmi hasznosság}

Doktori munkásságom legfontosabb társadalmi hozadéka maga a megvalósított empirikus kutatás folyamata. A mintavétel tudatosan nem az elméleti telítődésig zajlott. Fontosnak tartottam, hogy minden magyarországi megyébe legalább egy iskolába eljussak, és legalább egy osztálynak részvételt biztosítsak egy innovatív és kreatív módszertanra építő foglalkozás élményének átélésére. A pedagógusoktól kapott pozitív visszajelzések és a diákok reflexiói az élmény, a kutató személye és a tanulási/fejlődési folyamat dimenziói mentén rávilágítottak arra, hogy az akadémiai célokon túl valóban realizálódott a kutatás társadalmi hasznossága. A 24 megtartott workshop közel 500 diákhoz juttatta el a designkommunikáció módszertant. Az iskolák közül meghatározó számban voltak jelen olyan intézmények, melyek tanulói nagy számban hátrányos vagy halmozottan hátrányos helyzetü gyerekek, akik számára egy ilyen jellegü tapasztalás egyedi és meghatározó élmény. A designkommunikáció egy empátiára építő szemlélet, ami az objektív jó értékkategóriájára fókuszál. A kutatásom tervezése során is ezt tartottam szem előtt. Elsődleges célként fogalmazódott meg bennem, hogy kutatásom nem lehet csupán öncélú, nem állhat csak a tudomány szolgálatában, hanem társadalmi értéket is teremteni szeretnék általa.

\subsection{A kutatás limitációi}

A kutatás korlátainak összegzése részben kijelöli a jövőbeni kutatási irányokat is. A korlátok feltárása lehetőséget jelent a kutatási eredmények más nézőpontból történő elemzésére 
is a jövőben. Empirikus kutatásom során a fókuszt az oktatás szereplőire helyeztem, és az így kapott eredmények, mint output szolgálhatnak értékes információkkal a vállalati szereplők számára. Az oktatás és gazdaság közötti párbeszéd elmélyítése érdekében azonban fontos lenne feltárni a szakirodalmi elemzésen túl is a vállalati oldalon meghúzódó motivációkat.

A kutatás korlátjaként rögzíthető a Covid-19 okán kialakult pandémiás helyzet is, ami nem tette lehetővé azt, hogy kutatóként személyesen legyek jelen a kiegészítő workshop során. A pedagógus, a gyerekek és a foglalkozás személyes megfigyelése hozzáadott értéket biztosított volna az eredményekhez. Ez egyúttal jelentette azt is, hogy a pedagógusnak lehetősége adódott az önálló munkavégzésre. Az így létrejött egyéni tanulási folyamat feltételezhet egy nehezebb, ám hosszú távon eredményesebb fejlődést és bátorságot a módszer gyakoribb alkalmazására.

A kettős kutatói szerepvállalás ugyancsak értelmezhető korlátként, hiszen egyszerre, egy személyben, megfigyelőként és kutatóként is jelen kellett lenni a folyamatban, ami egy erősen terepmunkához köthető kvalitatív kutatás esetében feltételezhet egy intenzív bevonódást és egy szubjektív szürőt, ami torzíthatja a kutatás eredményeit.

\subsection{Folytatás- a jövő kihívása}

A jövő kihívása számomra gyakorlatilag a jelen disszertációval kezdődik. Doktori tanulmányom céljaként definiáltam egy olyan oktatásmódszertani eszköz létrehozását, mely a pedagógusok bevonásán keresztül integrálható az általános iskolák zárt rendszerébe. A módszer feltárt értékei és az empirikus kutatás során tapasztalt eredmények biztosítják a hátteret ahhoz, hogy megkezdődhessen az oktatási termék széleskörű ismertetése az oktatás legfontosabb szereplőinek megszólításán keresztül. A pandémia által okozott iskolai kényszerszünetek és a digitális oktatásra való átállás a diákok közösségét, a személyes kapcsolatokat beláthatatlan mértékben befolyásolta (de Araújo, Veloso, de Campos Souza, de Azevedo, \& Tarro, 2020; Gupta \& Jawanda, 2020), ami egy újabb érv az együttmüködésre, kommunikációra és a közösség erősítésére fókuszáló módszertanok nagyobb térnyerése mellett.

Ezzel párhuzamosan megkezdődik a vállalati oldalt célzó kutatási térkép elkészítése, az együttműködési hajlandóság feltárása. A kutatási eredmény függvényében megtörténik a jövőben a szereplők összekapcsolása, cselekedeteinek összehangolása egy együttműködő, kreatív és magas szintű kommunikációs készségekkel rendelkező, a munka világára tudatosan felkészített generáció nevelése érdekében. 


\title{
9. ÖSSZEGZÉS
}

\author{
„A képzelet sokkal fontosabb, mint a tudás. \\ A tudás véges. A képzelet felöleli az egész világot.”
}

(Albert Einstein)

Doktori disszertációmat egy kutatói önreflexióval zárom. Tulajdonképpen mi is a célja egy doktori munkának? Lehet ez öncélú? A társadalom, a tudomány vagy a gazdaság szolgálatába kell, hogy álljon? Közel egy év volt, mire a kutatási terv elemei összeálltak egy nagy egésszé. Próbálkozások, zsákutcák, javaslatok, tanulás és fejlődés jellemezte ezt az időszakot. Kvalitatív jellege okán ez a folyamat részeként is tekinthető. Miközben a részek egymásból építkeztek azt mindvégig szem elött tartottam, hogy a létrejött nagy egésszel én valami jót szeretnék tenni. Úgy vélem az akadémiai lét, akárcsak a pedagógus szerep óriási felelősséggel jár. Felelősséggel kell arról dönteni, hogy mi az a téma, az a terület, melynek tanulmányozására éveket szánunk. Számomra jelen doktori disszertáció egy belépőt jelent az akadémiai létbe, ahol a tudományos közösség tagjaként a társadalom és a gazdaság mozgatórugójává is válhatunk. Kutatási kérdéseink megfogalmazásával, annak eredményeivel, a következtetések helyes levonásával és azok megfelelő felhasználásával képesek lehetünk jobbá tenni környezetünk, világunk egy szeletét. Tünhetnének ezek nagy szavaknak, de a tudományos munka (bármely tudományterületen valósuljon is meg) valódi érték. Az értékteremtés példamutatást vonz, ami fokozódó felelősséget jelent és ezzel a tudomány művelőinek tisztában kell lenniük, döntéseiket igenis meg kell, hogy határozza.

A nyitó idézetből kiindulva elgondolkoztam a tudás véges/végtelen mivoltán. Én sokkal inkább úgy vélem, hogy a képzelet az, ami a tudást végtelenné teszi. Ha úgy tetszik a képzelet válik a tudomány motorjává. Doktori tanulmányaim kezdetén úgy éreztem a sötétben tapogatózom. Hasonlóan éreztem magam, mint amit empirikus kutatásom során tapasztaltak a diákok a wikinomikus együttmüködés részeként. Úgy kell ezt elképzelni, mint amikor belelöknek egy sötét verembe, ahonnan meg kell találni a kivezető utat. A designkommunikáció ezt egy olyan túlélési helyzetként definiálja, ahol két opció áll rendelkezésre: vagy elbukjuk a játékot, vagy találunk egy megoldást és kreatívan cselekszünk (A. R. Cosovan és mtsai., 2018). Ez utóbbit választottam. Sok kritika ért azzal kapcsolatban, hogy talán ez túlmutat egy disszertáció küldetésén. Utólag úgy gondolom, hogy jól tettem, hogy nem adtam fel és jól tettem, hogy nem az volt a fontos, hogy ki és mit mond, hanem végig azt tartottam szem előtt, 
hogy ez a kutatás egyszerre szolgálja az oktatási és a tudományos közösség érdekeit, és tegye ezt ne csak a várható eredmény reményében, hanem az odavezető út alatt is.

Hogy megjelent-e a kutatás eredményeként a tudományos értékek mellett a kreativitás, mint a két dimenzióban is alkalmazott designkommunikáció módszertan eszenciája? Csikszenmihályi szerint a kreativitás akkor születik meg, mikor a következő 3 elem interakciója létrejön (A. R. Cosovan és mtsai., 2018; Csíkszentmihályi, 2008). Az egyik az egy szimbolikus szabályokat tartalmazó kultúra, ami a kutatásom során a pedagógusokkal és a diákokkal kialakított fogalmi- és együttmüködési rendszer. A következő ilyen elem az újítók, akik ebbe a szimbolikus rendszerbe innovatív elemeket csempésznek, ahogy esetemben a kutató, a pedagógus és a diákok is tartományokon átívelő, innovatív szereplőkké váltak. A harmadik nélkülözhetetlen elem a kreativitás létrejöttéhez az a szűkebb és tágabb szakértői kör, aki az újítást elismeri. A kutatásba involvált pedagógusok és az érintett oktatási szereplők ezt megtették. A kreativitás teljessé tételéhez azonban szükségem van annak az akadémiai szereplői körnek az elfogadására is, akik látják ebben a lehetőséget, és akik támogatását meglelem, annak érdekében, hogy aztán együtt, közösen a felnövekvő generáció fejlödése érdekében a disszertációmban megválaszolt kérdések, levont következtetések a legjobb úton haladhassanak tovább a tudomány és a társadalom jobbítását prioritásként kezelve. 


\section{IRODALOMJEGYZÉK}

A Nemzeti alaptanterv kiadásáról, bevezetéséről és alkalmazásáról szóló 110/2012. (VI. 4.) Korm. rendelet módosításáról. (2020). Magyar Közlöny, (17), 290-446.

Abdullahi, S. A. (2010). Rethinking global education in the twenty-first century. In Global pedagogies (o. 23-34). Springer. https://doi.org/https://doi.org/10.1007/978-90-4813617-9_2

Altun, S. (2017). The effect of cooperative learning on students' achievement and views on the science and technology course. International Electronic Journal of Elementary Education, 7(3), 451-468.

Amabile, T. M. Creativity and Innovation in Organizations, Harvard Business School Background Note 396-239 (1996). https://doi.org/10.1016/b0-08-043076-7/01418-2

Amabile, T. M., \& Pratt, M. G. (2016). The dynamic componential model of creativity and innovation in organizations: Making progress, making meaning. Research in Organizational Behavior, 36, 157-183.

https://doi.org/https://doi.org/10.1016/j.riob.2016.10.001

Ambrose, D. (2005). Creativity in teaching: Essential knowledge, skills, and dispositions. Creativity across domains: Faces of the muse, 281-298.

Ananiadou, K., \& Claro, M. (2009). 21st Century Skills and Competences for New Millennium Learners in OECD Countries. OECD Education Working Papers.

Anderson, B. (2020). The most in-demand hard and soft skills of 2020. LinkedIn Talent Blog. Elérés forrás https://business.linkedin.com/talent-solutions/blog/trends-andresearch/2020/most-in-demand-hard-and-soft-skills

Anderson, D. R. (2002). Creative teachers: Risk, responsibility, and love. Journal of Education, 183(1), 33-48.

Angyal, Á. (2007). A felismerés és annak 23-féle támogatása. Vezetéstudomány-Budapest Management Review, 38(12), 2-17.

Apicella, C. L., \& Silk, J. B. (2019). The evolution of human cooperation. Current Biology, 29(11), R447-R450.

Arató, F. (2008). Egy konferencia margójára-avagy létezik-e romológia? Iskolakultúra, 18(34), 124-133.

Arató, F. (2010). Egy általános kooperatív modell lehetőségéről. Iskolakultúra, 20(1), 106115. 
Arató, F. (2011). A kooperativ tanulásszervezés egy lehetséges paradigmatikus modellje. Pécsi Tudományegyetem.

Arató, F., \& Varga, A. (2005). A kooperatív hálózat müködése. PTE BTK Neveléstud. INt. Romológia és Nevelésszociológia Tansz.

Archer, W., \& Davison, J. (2008). Graduate employability. The council for industry and Higher Education, 1-20.

Aronowitz, S. (2010). 21st-century skills: Evidence, relevance, and effectiveness. THE Journal. Association of American Colleges and Universities (AAC\&U). The learning all students need for the 21st century.

Aronson, E., \& Blaney, N. S. (1978). C. Sikes, J. and Snapp, M.(1978) The Jigsaw Classroom, Beverly Hills, Calif. Sage Publications.

Aronson, E., \& Bridgeman, D. (1979). Jigsaw Groups and the Desegregated Classroom: In Pursuit of Common Goals. Personality and Social Psychology Bulletin, 5(4), 438-446. https://doi.org/10.1177/014616727900500405

Aspy, D. N., \& Roebuck, F. N. (1974). From humane ideas to humane technology and back again many times. Education, 95(2).

Averianova, I. (2014). Dean, CB, Hubbell, ER, Pitler, H., \& Stone, B. Classroom Instruction that Works. Research-Based Strategies for Increasing Student Achievement. Pearson, 2012. NUCB journal of language culture and communication, 16(1), 67-69.

Balogh, M., Halász, G., Imre, A., Lannert, J., Nagy, M., Palotás, Z., ... Vágó, I. (2000). Jelentés a magyar közoktatásról. Budapest.

Baráth, Á. (2017). A probléma-alapú tanulás esélyei a szociális felsőoktatásban. Párbeszéd: Szociális munka folyóirat, 4(1).

Baráth, T. (2014). Az iskola mint tanuló szervezet.

Barber, M., \& Mourshed, M. (2007). How the world's best-performing schools systems come out on top. McKinsey \& Company.

Barrows, H. S. (1984). A specific problem-based, self-directed learning method designed to teach medical problem-solving skills, and enhance knowledge retention and recall. Tutorials in problem-based learning, 16-32.

Barrows, H. S., \& Tamblyn, R. M. (1980). Problem-based learning: An approach to medical education. Buckingham: Springer Publishing Company.

Bartus, T., \& Róbert, P. (2019). Pályakezdő diplomások. Az első állástalálás képzési területi különbségei és az oktatási intézmény hatása . Educatio, 28(4), 783-802. https://doi.org/10.1556/2063.28.2019.4.9 
Bauer, A., Berács, J., \& Kenesei, Z. (2007). Marketing alapismeretek. Aula Kiadó.

Baxter, P., \& Jack, S. (2008). Qualitative case study methodology: Study design and implementation for novice researchers. The qualitative report, 13(4), 544-559.

Becze, O. (2011). Lépésről lépésre-egy pedagógiai újítás elterjedése. Educatio, 20(3), 432441.

Beghetto, R. A. (2006). Creative justice? The relationship between prospective teachers' prior schooling experiences and perceived importance of promoting student creativity. The Journal of Creative Behavior, 40(3), 149-162.

Beghetto, R. A. (2010). Creativity in the classroom. In The Cambridge handbook of creativity. (o. 447-463). New York, NY, US: Cambridge University Press. https://doi.org/10.1017/CBO9780511763205.027

Beghetto, R. A. (2014). Creative mortification: An initial exploration. Psychology of Aesthetics, Creativity, and the Arts, 8(3), 266.

Beke, M. (2001). Tanuló szervezet avagy hogyan tudunk megfelelni a XXI. század kihívásainak. Vezetéstudomány-Management and Business Journal, 32(7-8), 41-47.

Bencsik, A., Horváth-Csikós, G., \& Juhász, T. (2017). Az Y és a Z generációval szembeni elöítéletek a munkahelyen. Taylor, 9(2), 121-128.

Bencsik, A., \& Machova, R. (2016). Knowledge sharing problems from the viewpoint of intergeneration management. ICMLG2016-4th International Conferenceon Management, Leadership and Governance: ICMLG2016, 42.

Benkler, Y. (2006). The wealth of networks: How social production transforms markets and freedom. Yale University Press. https://doi.org/https://doi.org/10.1017/S2071832200005162

Besenyei, L. (2016). A generáció váltás forradalma. Opus et Educatio, 3(4).

Bettenhausen, S. (2002). Students as teachers. Kappa Delta Pi Record, 38(4), 188-190.

Biró, Z. H. (2009). A magyar neveléstudományi kommunikáció szereplői. Tudományszociológiai elemzés a központi pedagógiai folyóiratok szerzőiről (19972006). Iskolakultúra, 19(3-4), 74-100.

Boden, M. A. (1998). Creativity and artificial intelligence. Artificial Intelligence, 103(1-2), 347-356. https://doi.org/10.1093/acprof:oso/9780199836963.003.0012

Bodóczky, I. (2012). Kis könyv a vizuális müvészeti nevelésröl. Vizuális és Környezetkultúra Fejlesztéséért Alapítvány.

Bodorkós, B. (2010). Társadalmi részvétel a fenntartható vidékfejlesztésben: a részvételi akciókutatás lehetőségei. Doktori értekezés. Gödöllő. https://szie. hu/file/tti/archivum .... 
Bognár, G. (2016). Inter és multidiszciplináris tehetséggondozás. Opus et Educatio, 2(4).

Boland, R., \& Collopy, F. (2004). Managing as designing. Stanford business books Stanford, CA.

Bonebright, D. A. (2010). 40 years of storming: a historical review of Tuckman's model of small group development. Human Resource Development International, 13(1), 111-120.

Bonwell, C. C., \& Eison, J. A. (1991). Active Learning: Creating Excitement in the Classroom. 1991 ASHE-ERIC Higher Education Reports. ERIC.

Boud, D., \& Feletti, G. (1998). The challenge of problem-based learning. Psychology Press.

Boydell, K., Gladstone, B. M., Volpe, T., Allemang, B., \& Stasiulis, E. (2012). The production and dissemination of knowledge: A scoping review of arts-based health research. In Forum Qualitative Sozialforschung/Forum: Qualitative Social Research (Köt. 13).

Bramwell, G., Reilly, R. C., Lilly, F. R., Kronish, N., \& Chennabathni, R. (2011). Creative teachers. Roeper Review, 33(4), 228-238.

Bronfenbrenner, U. (1979). The ecology of human development. Harvard university press.

Brown, T. (2008). Design thinking. Harvard business review, 86(6), 84.

Brown, T. (2009). Change by design: How design thinking creates new alternatives for business and society. Collins Business.

Buchanan, R. (1992). Wicked problems in design thinking. Design issues, 8(2), 5-21.

Buchs, C., Filippou, D., Pulfrey, C., \& Volpé, Y. (2017). Challenges for cooperative learning implementation: reports from elementary school teachers. Journal of Education for Teaching, 43(3), 296-306. https://doi.org/10.1080/02607476.2017.1321673

Buda, M., \& Péter-Szarka, S. (2014). Kreativitás és azon túl... A kreatív klíma mint lehetőség a 21. századi iskola számára. Iskolakultúra, 14(3), 33-40.

Buda, M., \& Péter-Szarka, S. (2015). A kreatív klíma: új irány az iskolai klíma és a konfliktuskezelés kutatásában. Iskolakultúra, 25(9), 3-17.

Budai, I. (2004). „,.. szakmai identitásában megerősödve lépjen ki a gyakorlatba...” Esély, 1, $61-79$.

Bús, E. (2015). Problémaközpontúság és tanítási módszerek vizsgálata általános és középiskolai pedagógusok körében.

Buzan, T. (2006). Mind mapping: kick-start your creativity and transform your life. Essex: BBC Active.[Viitattu 15.12. 201]. Saatavana: http://www. google. fi/books.

Ceglédi, E. (2009). A csoportmunka hatása az iskolai teljesítményre. Iskolakultúra, 19(5-6), 95-106. 
Chen, C. S. (2002). Self-regulated learning strategies and regulated learning strategies and achievement in an introduction to information systems course. Information technology, learning, and performance journal, 20(1), 11-25.

Cicchetti, D., \& Lynch, M. (1993). Toward an ecological/transactional model of community violence and child maltreatment: Consequences for children's development. Psychiatry, 56(1), 96-118.

Cinque, M. (2016). "Lost in translation”. Soft skills development in European countries. Tuning Journal for Higher Education, 3(2), 389-427.

Cohen-Schotanus, J., Muijtjens, A. M. M., Schönrock-Adema, J., Geertsma, J., \& Van Der Vleuten, C. P. M. (2008). Effects of conventional and problem-based learning on clinical and general competencies and career development. Medical education, 42(3), 256-265.

Cole, A. L., \& Knowles, J. G. (2001). Lives in context: The art of life history research. Rowman Altamira.

Cosovan, A. (2009). DISCO. Co\&Co Communication. Budapest: CO\&CO Communication. Cosovan, A., \& Horváth, D. (2016). Emóció-Ráció: Tervezés-Vezetés: Designkommunikáció. Vezetéstudomány-Budapest Management Review, 47(3), 36-45. Cosovan, A. R. (2015). A közhely fenntartható identitása. German Kinga (szerk): Sustainable Identities-Fenntartható identitások. Budapest: Velencei Biennálé Nemzeti Biztosi Iroda, Ludwig Múzeum, 94-99.

Cosovan, A. R., Horváth, D., \& Mitev Ariel, Z. (2018). A designkommunikáció antropológiai megközelítése. Replika, 106(1-2), 233-245.

Craft, A. (2001). Little c creativity. Creativity in education, 45.

Cremin, T. (2001). Creative teachers and creative teaching. Creativity in primary education, 11(1), 36-46.

Crimmins-Crocker, J. (2018). Including creativity in primary school teaching and learning programmes : Teachers 'pedago gical practice and the influence of school leadership.

Cruz, F. J. F., \& Díaz, M. J. F. (2016). Generation z's teachers and their digital skills. Comunicar. Media Education Research Journal, 24(1).

Csapó, B. (2005). A Magyar Pedagógia feladata a neveléstudomány fejlesztésében. Iskolakultúra, 4.

Csapó, B. (2007). A tanári tudás szerepe az oktatási rendszer fejlesztésében. Új Pedagógiai Szemle, 57(3-4), 11-23. Elérés forrás http://publicatio.bibl.uszeged.hu/id/eprint/11646\%0A

Csapó, B. (2011). Az oktatás tudományos hátterének fejlődése. Magyar Tudomány, 172(9), 
1065-1076.

Csapó, B. (2018). A nemzetközi felmérések eredményei-következtetések a magyar közoktatás fejlesztésének megalapozásához. Előadás az MTA KEB-T-Tudok által szervezett konferencián.

Csapó, B. (2020). Bevezetés: neveléstudományi kutatás és a tudományos eredmények alkalmazása Introduction: Educational Research and the Application of Scientific Results. Magyar Tudomány, 181, 3-10. https://doi.org/10.1556/2065.181.2020.1.1

Csapó, B., Csíkos, C., Korom, E., Molnár, G., \& Vidákovich, T. (2017). Neveléstudományi kutatás és kutatóképzés. Magyar Tudomány, 178, 1339-1351. https://doi.org/10.1556/2065.178.2017.11.2

Cseke, V. (2007). Tanári személyiség a közoktatásban és a felnőttoktatásban. A Pécsi Tudományegyetem Felnőttképzési és Emberi Erőforrás Fejlesztési Karának periodikája VIII. évfolyam 1. szám 2007. május, 37.

Csíkos, C. (2010). Problémaalapú tanulás és matematikai nevelés. Iskolakultúra, (12), 52-60.

Csíkos, C. (2020). A neveléstudomány kutatásmódszertanának alapjai. ELTE Eötvös K.

Csíkszentmihályi, M. (1988). Motivation and creativity: Toward a synthesis of structural and energistic approaches to cognition. New Ideas in Psychology, 6(2), 159-176. https://doi.org/https://doi.org/10.1016/0732-118X(88)90001-3

Csíkszentmihályi, M. (2001). Flow: az áramlat, a tökéletes élmény pszichológiája. Akadémiai.

Csíkszentmihályi, M. (2008). Kreativitás-A flow és a felfedezés, avagy a találékonyság pszichológiája. Budapest: Akadémiai Kiadó.

Csíkszentmihályi, M. (2010). Az áramlat: a tökéletes élmény pszichológiája. Akadémiai Kiadó.

Csíkszentmihályi, M. (2018). Kreativitás - A flow és a felfedezés, avagy a találékonyság pszichológiája. Budapest: Akadémiai Kiadó.

Csíkszentmihályi, M., Rathunde, K. R., Whalen, S., Wong, M., \& Halmos, M. (2010). Tehetséges gyerekek: flow az iskolában. Nyitott Könyvmühely.

Csillag, S. (2016). A kooperatív akciókutatás elmélete és gyakorlata. Prosperitas, 3(2), 3662.

Csobanka, Z. E. (2016). The Z generation. Acta Educationis Generalis, 6(2), 63-76.

D. Molnár, É. (2019). Nevelhet-e a neveléstudomány? A neveléstudomány az elvárások össztüzében. https://doi.org/10.31176/apertura.2019.14.3.7

de Araújo, L. A., Veloso, C. F., de Campos Souza, M., de Azevedo, J. M. C., \& Tarro, G. 
(2020). The potential impact of the COVID-19 pandemic on child growth and development: a systematic review. Jornal de Pediatria.

De Corte, E. (2001). Az Iskolai Tanulás: a Legfrissebb Eredmények És a Legfontosabb Tennivalók. Magyar Pedagógia, 101(4), 413-434.

De Graaf, E., \& Kolmos, A. (2003). Characteristics of problem-based learning. International Journal of Engineering Education, 19(5), 657-662.

Deering, P. D., \& Meloth, M. S. (1993). A descriptive study of naturally occurring discussion in cooperative learning groups. The Journal of Classroom Interaction, 7-13.

DeHaan, R. L. (2009). Teaching Creativity and Inventive Problem Solving in Science. CBELife Sciences Education, 8(3), 172-181. https://doi.org/10.1187/cbe.08-12-0081

Deloitte Access Economics. (2017). Soft skills for business success. DeakinCo.

Demeter, K. (2013). Az egész életen át tartó tanuláshoz szükséges kulcskompetenciák. Demeter Kinga (szerk.) A kompetencia. Kihívások és értelmezések. Budapest.

Demeter, M. (2015). Felismerés, megismerés, elismerés. Socio. hu Társadalomtudományi Szemle, (3), 126-151.

Derecskei, A., \& Zoltayné Paprika, Z. Vitás kreativitás - szakirodalmi áttekintés a kreativitás fogalmáról (2012).

Detre, Z. (2015). Kreativitás és neuropedagógia. Training, 13(3), 4.

Devedzic, V., Tomic, B., Jovanovic, J., Kelly, M., Milikic, N., Dimitrijevic, S., ... Sevarac, Z. (2018). Metrics for students' soft skills. Applied Measurement in Education, 31(4), 283296.

Dewey, J. (1923). Democracy and education: An introduction to the philosophy of education. Macmillan.

Ding, M., Li, X., Piccolo, D., \& Kulm, G. (2007). Teacher interventions in cooperativelearning mathematics classes. The journal of educational research, 100(3), 162-175.

Dorst, K. (2011). The core of 'design thinking'and its application. Design studies, 32(6), 521532. https://doi.org/https://doi.org/10.1016/j.destud.2011.07.006

Duch, B. J. (1996). Problem-Based Learning in Physics: The Power of Students Teaching Students. Journal of College Science Teaching, 15(5), 326-329.

DuFour, R. (2004). Schools as learning communities. Educational leadership, 61(8), 6-11.

Dúll, A. (2017). Épített környezet és pszichológia: a lokalitásélmény környezetpszichológiai vizsgálatai. ELTE PPK.

Dúll, A., Somogyi, K., Hülber, A., Brózik, P., \& Szabó, J. (2018). A szociofizikai önállóság első színtere: építészhallgatók és térlaikus egyetemi hallgatók mentális 
térképábrázolásainak összehasonlítása. Magyar Pszichológiai Szemle, 73(1), 83-110. Ersoy, E., \& Başer, N. (2014). The Effects of Problem-based Learning Method in Higher Education on Creative Thinking. Procedia - Social and Behavioral Sciences, 116, 34943498. https://doi.org/10.1016/j.sbspro.2014.01.790

Falck, O., \& Woessmann, L. (2013). School competition and students' entrepreneurial intentions: International evidence using historical Catholic roots of private schooling. Small Business Economics, 40(2), 459-478. https://doi.org/10.1007/s11187-011-9390-z

Fazekas, Á., Halász, G., \& Horváth, L. (2018). Innovációk és innovációs folyamatok a magyar oktatási rendszerben. Educatio, 27(2), 247-264. https://doi.org/10.1556/2063.27.2018.2.7

Fazekas, K. (2018). nem-kognitív készségek hiánya a munkaerőpiacon. Magyar Tudomány, 179(1), 24-36.

Ferincz, A., \& Szabó, Z. R. (2012). Z generáció hatása a munkáltató szervezetekre. Munkaügyi Szemle, 56(2), 88-92.

Ferrari, A., Cachia, R., \& Punie, Y. Innovation and Creativity in Education and Training in the EU Member States: Fostering Creative Learning and Supporting Innovative Teaching (2009). Elérés forrás http://www.jrc.ec.europa.eu/\%0Ahttps://www.researchgate.net/publication/265996963_I nnovation_and_Creativity_in_Education_and_Training_in_the_EU_Member_States_Fos tering_Creative_Learning_and_Supporting_Innovative_Teaching_Literature_review_on _Innovation_an

Fielding, N. G. (2012). The diverse worlds and research practices of qualitative software. In Forum: Qualitative Social Research (Köt. 13). FQS: Forum Qualitative Social Research. Finkle, S. L., \& Torp, L. L. (1995). Introductory documents. Available from the Center for Problem-Based Learning, Illinois Math and Science Academy, 1500, 60506-61000.

Fodor, L. (2015). A kreatív személyiség. Letöltés: http://docplayer. hu/5933702-Akreativszemelyiseg-dr-fodor-laszlo ....

Fodor, Z. (2018). A teljeskörü nevelés lehetőségei : Kutatási eredmények elemzése pályakezdőknek a tanórán kívüli tanulói tevékenységek szervezéséhez, azaz a csengőszó rejtett üzenete. Paideia, 6(1), 113-126. https://doi.org/10.33034/paideia.2018.6.1.113

Fodorné Tóth, K. (2018). E- learning trendek és kérdések. Opus et Educatio, 5(1), 123-131.

Frey, N., Fisher, D., \& Everlove, S. (2009). Productive group work: How to engage students, build teamwork, and promote understanding. ASCD.

Friedman, K. (2003). Theory construction in design research: criteria: approaches, and 
methods. Design studies, 24(6), 507-522.

Fryer, M. (2009). Promoting 21. creativity in education and the role of measurement. Measuring creativity, 327.

Fuchs, C. (2008). Don Tapscott \& Anthony D. Williams: Wikinomics: How Mass Collaboration Changes Everything. International Journal of Communication, 2, 11.

Fullan, M. (2013). Commentary: The new pedagogy: Students and teachers as learning partners. Learning landscapes, 6(2), 23-29.

Furlong, J. (2013). Education-An Anatomy of the Discipline: Rescuing the university project? Routledge.

Fülöp, M., \& Pressing, Z. (2012). Pedagógusok nézetei az iskola szerepéről a versengésre és vállalkozásra való felkészítésben. Iskolakultúra, 22(3), 44-63.

Fürjné Nyeste, E. (2017). A 21. századi nevelés a tanulók nézeteinek tükrében. képzés és gyakorlat, 15(4), 25-37.

Fűzi, B. (2012). A tanári munka sikerességének vizsgálata a pedagógiai attitüdök, a tanárdiák viszony és az iskolai élmények összefüggésrendszerében. Eötvös Loránd Tudományegyetem, Budapest.

Galambos, R. (2005). Esély a változásra, lehetoség a változtatásra. Kézirat.

Gale, S. F. (2015). Forget Gen Y: Are You Ready for Gen Z. Retrieved from.

Galton, M. J., Simon, B., \& Croll, P. (1980). Inside the primary classroom. Routledge.

Galton, M., \& Williamson, J. (2003). Group work in the primary classroom. Routledge.

Gardner, J. W. (2011). A problémaalapú tanulás. Tanulási stratégiák és útmutató.

Geck, C. (2007). The generation $\mathrm{Z}$ connection: Teaching information literacy to the newest net generation. Toward a 21st-century school library media program, 235, 2007.

Gelei, A. (2002). A szervezeti tanulás interpretatív megközelítése: a szervezetfejlesztés esete. Budapesti Corvinus Egyetem.

Gelei, A. (2006). A szervezet interpretatív megközelítése. Vezetéstudomány, 38, 79-97.

Gibb, S. (2014). Soft skills assessment: Theory development and the research agenda. International journal of lifelong education, 33(4), 455-471.

Gillespie, M. (2005). Student-teacher connection: A place of possibility. Journal of Advanced Nursing, 52(2), 211-219. https://doi.org/10.1111/j.1365-2648.2005.03581.x

Glum, J. (2015). Marketing to Generation Z: Millennials move aside as brands shift focus to under-18 customers. International Business Times.

Golnhofer, E. (2004). Hazai pedagógiai nézetek, 1945-1949. Iskolakultúra.

Gór, A. (2013). A fenntarthatóság és a versenyképesség közös pontjai, kölcsönhatásai. 
Gazdálkodás: Scientific Journal on Agricultural Economics, 57(80-2016-922), 170-180.

Gordon, W., Pál, F., \& Langmaid, R. (1997). Kvalitatív piackutatás: gyakorlati kézikönyv. HVG.

Gőgh, E., \& Kővari, A. (2019). Tanulás önszabályozásának tapasztalatai egy szakgimnáziumban. Journal of Applied Technical and Educational Sciences, 9(2), 7286.

Gralewski, J., \& Karwowski, M. (2018). Are teachers' implicit theories of creativity related to the recognition of their students' creativity? The Journal of Creative Behavior, 52(2), $156-167$.

Grasselli, N. I. (2009). Lehet akciókutatásból doktorálni?-Eszményképek kontra valóság. Vezetéstudomány-Budapest Management Review, 40(4), 65-71.

Guba, E. G., \& Lincoln, Y. S. (1994). Competing paradigms in qualitative research. Handbook of qualitative research, 2(163-194), 105.

Guilford, J P. (1950). Creativity. American Psychologist., 4, 444-454.

Guilford, Joy Paul. (1950). Creativity research: Past, present and future. American psychologist, 5(1), 444-454.

Gupta, S., \& Jawanda, M. K. (2020). The impacts of COVID-19 on children. Acta Paediatrica, 109(11), 2181-2183.

Gyulavári, T., Mitev, A., Neulinger, Á., Neumann-Bódi, E., Simon, J., \& Szűcs, K. (2012). A marketingkutatás alapjai. Aula Kiadó, Budapest.

Halász, G. (2008). Előszó a magyar kiadáshoz. In Fullan, M., Változás és változtatás I. Az oktatási reform mélységének feltárása. Oktatáskutató és Fejlesztő Intézet, Budapest.

Hanushek, E. A., \& Woessmann, L. (2010). The high cost of low educational performance: The long-run economic impact of improving PISA outcomes. ERIC.

Harrison, R. L., \& Reilly, T. M. (2011). Mixed methods designs in marketing research. Qualitative market research: an international journal.

Harsányi, D., \& Szántó, S. (2018). Mérhető a kreativitás?”, avagy a személyiségjegyek és a kreatív teljesítmény közötti összefüggések vizsgálata a gazdasági felsőoktatásban tanulók példáján. Vezetéstudomány-Budapest Management Review, 49(1), 13-18.

Havas, P. (2004). Az akciókutatás és a tanulás fejlesztése. Fenntartható közösségek, 9.

Healy, M., \& Perry, C. (2000). Comprehensive criteria to judge validity and reliability of qualitative research within the realism paradigm. Qualitative market research: An international journal.

Heckman, J. J., Humphries, J. E., \& Kautz, T. (2014). The myth of achievement tests: The 
GED and the role of character in American life. University of Chicago Press.

Heckman, J., Pinto, R., \& Savelyev, P. (2013). Understanding the mechanisms through which an influential early childhood program boosted adult outcomes. American Economic Review, 103(6), 2052-2086.

Hernádi, K., Jenei, A., Kovácsevicsné Tóth, M., Kőpataliné Mászáros, M., Magvasi, Á., \& Vargáné Mező, L. (2008). Útravaló pedagógusoknak az intézményi implementációs folyamatok gyakorlattá válásához. Budapest.

Higgins, J. M. (1996). Escape from the Maze: Increasing Individual and Group Creativity. New Management Pub. Co.

Hills, A., \& Bird, A. (2019). Against Creativity. Philosophy and Phenomenological Research, 99(3), 694-713. https://doi.org/10.1111/phpr.12511

Horng, J., Hong, J., ChanLin, L., Chang, S., \& Chu, H. (2005). Creative teachers and creative teaching strategies. International Journal of Consumer Studies, 29(4), 352-358.

Horváth, A. (1994). Kooperatív technikák, Hatékonyság a nevelésben. OKI Iskolafejlesztési Központ.

Horváth, D., Cosovan, A., Csordás, T., Horváth, D., \& Mitev, A. Z. (2018). Beyond the Scope of Design thinking: DesignCommunication (o. 653-662). Design, Management Institute (DMI) (szerk.) The 21st dmi: Academic Design Management Conference Proceeding Boston, Amerikai Egyesült Államok: Design Management Institute.

Horváth, D., Cosovan, A., Horváth, D., \& Lachin, N. (2018). Tanulás-munka interface. A valós idejü találkozások jelentősége a digitális oktatási környezetben. VezetéstudományBudapest Management Review, 49(12), 67-77.

Horváth, D. D., Cosovan, A., Csordás, T., Horváth, D., \& Mitev, A. Z. (2018). Vállalkozásra fel, gyerekek! - A vállalkozói attitüd fejlesztési lehetőségei gyermekkorban a designkommunikáció módszertanának alkalmazásával. In III. Gazdálkodás és Menedzsment Tudományos Konferencia 2018. Kecskemét: Neumann János Egyetem.

Horváth, D. D., Csordás, T., Horváth, D., \& Cosovan, A. (2020). Úgy, mint a nagyok! Iskolakultúra, 30(4-5), 49-66.

Horváth, D. D., \& Horváth, D. (2020). Fenntartható jövő tervezésére vállalkoztunk. KOVÁSZ, 24.

Horváth, D., \& Mitev, A. (2015). Alternatív kvalitatív kutatási kézikönyv. Alinea.

Horváth, S. (2018). A magyar pedagógus társadalom motiváltsága a jövedelmek alapján= The motivation of educators in Hungary based on earnings. Közép-Európai Közlemények, 11(2), 67-78. 
Howe, N., \& Strauss, W. (2000). Millennials rising: The next great generation. Vintage. Huggins, V., Siraj, J., Dékány, Z., Fekszi, K., \& Szabad, D. (2018). Fenntartható fejlődésre nevelés nemzetközi együttmüködési keretben= Education for sustainable development through international partnerships. Különleges Bánásmód, 4(1), 51-57.

Huitt, W. (2003). Constructivism. Educational psychology interactive, 2006.

Hunt, S. D. (1994). On rethinking marketing: our discipline, our practice, our methods. European Journal of Marketing.

Hurrell, S. A. (2016). Rethinking the soft skills deficit blame game: Employers, skills withdrawal and the reporting of soft skills gaps. Human Relations, 69(3), 605-628.

Huszka, N., \& Kinyó, L. (2019). A tanító és a tanuló közötti kapcsolat vizsgálatának lehetőségei kisiskolás korban. Iskolakultúra, 29(12), 3-13.

Igel, C., \& Urquhart, V. (2012). Generation Z, meet cooperative learning: Properly implemented cooperative learning strategies can increase student engagement and achievement. Middle school journal, 43(4), 16-21.

Illés, A. (2009). A művészetterápia lehetőségei az oktatásban. Új Pedagógiai Szemle, 5, 6.

Imre, A. (2018). Tanórán kívüli tanulás az általános iskolában. Új Pedagógia Szemle, 10, 6477.

Iványi, A. S., \& Hoffer, I. (1999). The role of creativity in innovation. Társadalom és gazdaság Közép- és Kelet-Európában / Society and Economy in Central and Eastern Europe, 21(4), 77-101. Elérés forrás http://www.jstor.org/stable/41468443

Jancsák, C. (2012). Tanárképzésben résztvevő hallgatók értékítéleteinek szerkezete két regionális egyetemen. PhD értekezés. Debrecen: Debreceni Egyetem.

Jánosy, O. (2018). Útmutató a Hatékony Tanulási Környezet Kialakításához. Educatio, 27(2), 347-351. https://doi.org/10.1556/2063.27.2018.2.16

Jarvis, P., \& Parker, S. (2006). Human learning: An holistic approach. Routledge.

John-Steiner, V. (2000). Creative collaboration. Oxford University Press.

John, O. P., \& Srivastava, S. (1999). The Big Five trait taxonomy: History, measurement, and theoretical perspectives. Handbook of personality: Theory and research, 2(1999), 102138.

Johnson, R. T., \& Johnson, D. W. (1987). Learning together and alone: Cooperative, competitive, and individualistic learning. Prentice-Hall, Inc.

Johnson, R. T., \& Johnson, D. W. (2008). Active learning: Cooperation in the classroom. The annual report of educational psychology in Japan, 47, 29-30.

Jordan, P. J., \& Troth, A. (2011). Emotional intelligence and leader member exchange. 
Leadership \& Organization Development Journal.

Juhász, C. (2017). Z generációs hallgatók felsőoktatási motivációjának vizsgálata. KözépEurópai Közlemények, 10(2), 131-141.

Juhász, József, Szőke, I., O.Nagy, G., \& Kovalovszky, M. (Szerk.). (1972). Magyar Értelmezö Kéziszótár (Kilencedik). Budapest: Akadémiai Kiadó.

Juhász, Judit. (2019). Megismerés, élmény és alkotás a mủvészetalapú kutatásokban. Kovász, XXIII.(1-4.), 3-28.

Juhász, P. (2005). Az emberi erőforrás értékelési kérdései. Vezetéstudomány-Budapest Management Review, 36(1), 13-32.

Juhász, V. (2018). A szövegértés-fejlesztési stratégiák hatékonyságáról. Új Pedagógia Szemle, 3-4, 73-89.

K.Nagy, E., \& Pálfi, D. (2017). Paradigmaváltás a pedagógusképzésben? A pedagógusképzés áttekintése a sikeres pályára való felkészítés szempontjából. Új Pedagógiai Szemle, 1-2., 76-83.

K Nagy, E. (2005). A társas interakció mint tudásgyarapító tényező a heterogén osztályokban. Iskolakultúra, 15(5), 16-25.

K Nagy, E. (2012). Több mint csoportmunka. Nemzeti Tankönyvkiadó.

Kagan, S. (2001). Kooperatív tanulás Ökonet Kft. Budapest.

Kapitány, G., \& Kapitány, Á. (2002). Résztvevő megfigyelés a saját társadalomban-korszakok szimbolikája. Jelbeszéd az életünk. Budapest: Osiris, 124-156.

Kaszás, G. (2011). Gondolkogjunk, mert vagyunk! 12 kreatív problémamegoldó módszer. Budapest: HVG könyvek.

Kaszás, G. (2014). Reklámcsinálás A kis adrenalinjáték. Budapest: HVG könyvek.

Kaufmann, G. (2003). What to Measure? A new look at the concept of creativity. Scandinavian Journal of Educational Research, 47(3), 235-251. https://doi.org/10.1080/00313830308604

Kaukko, M., \& Fertig, M. (2016). Linking participatory action research, global education, and social justice: Emerging issues from practice. International Journal of Development Education and Global Learning, 7(3), 24-46.

Kautz, T., Heckman, J. J., Diris, R., Ter Weel, B., \& Borghans, L. (2014). Fostering and measuring skills: Improving cognitive and non-cognitive skills to promote lifetime success. National Bureau of Economic Research.

Kechagias, K. (2011). Teaching and assessing soft skills. MASS Project, September. Keeney, O. (1983). Epistemology. London: McGraw Hill. 
Keller, K. R. I. (2006). Investment in primary, secondary, and higher education and the effects on economic growth. Contemporary Economic Policy, 24(1), 18-34.

Keyser, M. W. (2000). Active learning and cooperative learning: understanding the difference and using both styles effectively. Research Strategies, 17(1), 35-44. https://doi.org/https://doi.org/10.1016/S0734-3310(00)00022-7

Kim, R. (1998). A belső motivációt befolyásoló tényezők és megjelenésük a Montessoripedagógiában. Új pedagógiai szemle, 3, 44-54.

Kiss, V. (2010). Mủvészeti nevelés, mủvészettel nevelés, müvészetterápia. Iskolakultúra, 20(10), 18-31.

Kiss, V. (2017). Művészetalapú módszerek. Szolgálva, nem tündökölve, 189.

Kissné Gera, Á. (2016). Élmények és értékek a kutatásalapú tanulás kipróbálása során. Iskolakultúra, 26(3), 89-100.

Knight, L. (2002). Network learning: Exploring learning by interorganizational networks. Human relations, 55(4), 427-454.

Kock, N. F., McQueen, R. J., \& John, L. S. (1997). Can action research be made more rigorous in a positivist sense? The contribution of an iterative approach. Journal of Systems and Information Technology.

Kocsondi, A. (1982). A tudomány és a filozófia viszonyának értelmezése a pozitivizmus XX. századi iskoláiban. Acta Universitatis de Attila József nominate sectio philosophica, 17.

Kovári, A. (2019). A felnottoktatás 4.0 és az az ipar 4.0 kihívásai az életen át tartó tanulásban. PEDACTA, 9(1), 9-16.

Kozma, T. (2013). Pedagógiából neveléstudomány. Neveléstudomány, 1.

Köves, A., Gáspár, J., \& Matolay, R. (2020). Művészet és társadalomtudomány együttmüködése a posztnormál tudományfelfogás keretein belül: backcasting kutatási eredmények egy interaktív színházi kalandjátékban. Magyar Tudomány, 181(2), 210221.

Krajcsák, Z. (2018). Az alkalmazotti elkötelezettség relatív fontossága a munka megváltozó világában. Vezetéstudomány-Budapest Management Review, 49(2), 38-44.

Krisztina, S., \& Pál, S. Á. (2015). A humántőke minőségének gazdasági növekedésre gyakorolt hatásai az Európai Unióban. Konferencia kötet, 309.

Ladd, G. W., \& Burgess, K. B. (2001). Do relational risks and protective factors moderate the linkages between childhood aggression and early psychological and school adjustment? Child development, 72(5), 1579-1601.

Lajos, V. (2018). Mi az a részvételi akciókutatás (RAK)? Kik azok a részvételi akciókutatók? 
Ötféle élmény és értelmezés (szerkesztett interjú). Kovász, 1, 53-83.

Landau, E. (1974). A kreativitás pszichológiája. (F. Dr. Szakács, Szerk.). Budapest.

Latané, B., Williams, K., \& Harkins, S. (1979). Many hands make light the work: The causes and consequences of social loafing. Journal of personality and social psychology, 37(6), 822.

Lechnitzky, G. (1912). Az alkotó munkára való nevelés: Az intuitív és tudatos alkotás lélektana, törvényei és eszközei. A produktív teremtő munkára való nevelés módszerei és a tanítóképzés. Budapest: Atheneum irodalmi és nyomdai részvénytársulat.

Lesku, K. (2010). A fenntarthatóság mint gyermekfilozófiai probléma. Iskolakultúra, 20(10), 79-84.

Lévai, D. (2013). A digitális állampolgárság és digitális műveltség kompetenciája a pedagógus tevékenységéhez kapcsolódóan. Oktatás-Informatika, 1-2. sz. online.

Levasseur, R. E. (2013). People skills: Developing soft skills-A change management perspective. Interfaces, 43(6), 566-571.

Levin, B. (2000). Putting students at the centre in education reform. Journal of educational change, 1(2), 155-172.

Lewin, K. (1946). Action research and minority problems. Journal of social issues, 2(4), 3446.

Lewin, K. (1951). Field theory in social science: selected theoretical papers (Edited by Dorwin Cartwright.). Harpers.

Liedtka, J. (2015). Perspective: Linking design thinking with innovation outcomes through cognitive bias reduction. Journal of product innovation management, 32(6), 925-938.

Lincoln, Y. S., \& Denzin, N. K. (1994). Handbook of qualitative research. Sage.

Lippke, L., \& Wegener, C. (2014). Everyday innovation - pushing boundaries while maintaining stability. Journal of Workplace Learning, 26, 376-391. https://doi.org/10.1108/JWL-10-2013-0086

Lippman, L. H., Ryberg, R., Carney, R., \& Moore, K. A. (2015). Workforce Connections: Key "soft skills" that foster youth workforce success: toward a consensus across fields. Washington, DC: Child Trends.

List, F., \& Horn, J. (1940). A politikai gazdaságtan nemzeti rendszere. Magyar Közgazdasági Társaság.

Lockwood, T. (2010). Design thinking: Integrating innovation, customer experience, and brand value. Simon and Schuster.

Lucas, R. E. (1989). On the mechanics of economic development. NBER Working Paper, 
(R1176).

Lukovics, M., Udvari, B., \& Nádas, N. (2017). A felelősségteljes innováció és a jövő kutatógenerációja. Vezetéstudomány, 48(8-9), 89-100.

Malhotra, N. K., Peterson, M., \& Kleiser, S. B. (1999). Marketing Research: A State-of-theArt Review and Directions for the Twenty-First Century. Journal of the Academy of Marketing Science, 27(2), 160-183. https://doi.org/10.1177/0092070399272004

Málovics, G., \& Ván, H. (2008). Az ökológiai fenntarthatóság és a regionális versenyképesség összefüggései. Tér és Társadalom, 22(2), 21-40.

Marien, A. (2013). A lakossági elégedettség és a helyben maradást magyarázó tényezők összefüggései. Marketing \& Menedzsment, 47(1), 3-10.

Martin, R., \& Martin, R. L. (2009). The design of business: Why design thinking is the next competitive advantage. Harvard Business Press.

Martinez, R., Gonzalez, C., Campoy, P., García-Sánchez, Á., \& Ortega-Mier, M. (2014). Do classes in cooperative classrooms have a positive influence on creativity and teamwork skills for engineering students. International Journal of Engineering Education, 30(6), 1729-1740.

Mason, B. A., Hajovsky, D. B., McCune, L. A., \& Turek, J. J. (2017). Conflict, closeness, \& academic skills: A longitudinal examination of the teacher-student relationship. School Psychology Review, 46(2), 177-189. https://doi.org/10.17105/SPR-2017-0020.V46-2

Mason, J., \& Tóth, K. (2005). A kvalitatív kutatás. Jószöveg Műhely.

Mátés, G. (2019). Gondolatok a jó és a rossz oktatásról - A pedagógia szerepe a felsőoktatásban. Magyar Rendészet, 19(4), 61-67. https://doi.org/10.32577/mr.2019.4.4

McCrae, R. R., \& Costa, P. T. (1987). Validation of the five-factor model of personality across instruments and observers. Journal of personality and social psychology, 52(1), 81.

McCrindle, M., \& Wolfinger, E. (2010). Az XYZ ábécéje. A nemzedékek meghatározása. Korunk, 3, 13-18.

McGurk, J. (2010). Using the head and heart at work: A business case for soft skills. London: Chartered Institute of Personnel and Development (CIPD). http://www. cipd. co. uk/NR/rdonlyres/18616949-CF66.../HeadandheartguideFINAL. pdf.

McNiff, S. (2008). Art-based research. Handbook of the arts in qualitative research: Perspectives, methodologies, examples, and issues, 29-40.

Mei, X. Y. (2019). Gaps in tourism education and workforce needs: attracting and educating the right people. Current Issues in Tourism, 22(12), 1400-1404. 
Mendoza, K. R. (2018). Engaging Generation Z: A Case Study on Motivating the PostMillennial Traditional College Student in the Classroom. Johnson University.

Mészáros, A. (1998). Az osztály csoportszerkezete és hatékonysága. Iskolakultúra, 8(11), 321.

Mező, K., Mező, F., \& Varga, I. (2019). Kreativitásra ösztönzés a speciál pedagógia szemszögéböl. A Gál Ferenc Föiskola tudományos folyóirata, 12(1), 107.

Mihalkovné Szakács, K. (2014). Vállalkozási ismeretek oktatása vs. vállalkozói kompetenciák fejlesztése. Vezetéstudomány/Budapest Management Review, 45(10).

Mihály, I. (2001). Vállalkozási ismeretek oktatása Európában. Új Pedagógia Szemle, 51(12), $81-89$.

Mitev, A. Z. (2012). Grounded theory, a kvalitatív kutatás klasszikus mérföldköve (Grounded theory, the classic milestone of qualitative research). Vezetéstudomány-Budapest Management Review, 43(1), 17-30.

Molnár, G. (2004). Problémamegoldás és probléma-alapú tanítás. Iskolakultúra, 14(2), 12-19.

Molnár, G. (2005). A probléma-alapú tanítás. Iskolakultúra, 15(10), 31-43. Elérés forrás http://epa.oszk.hu/00000/00011/00097/pdf/iq2005-10.pdf

Molnár, G., Turcsányi-Szabó, M., \& Kárpáti., A. (2019). Az interaktív tanulási környezetektől a módszertani megújuláson át a kreatív önkifejezésig. Új Pedagógiai Szemle, 69(11-12), 53-70. Elérés forrás http://publicatio.bibl.uszeged.hu/18510/1/upsz_2019_11-12_MolnarGy.pdf

Morais, M. F., \& Azevedo, I. (2001). What is a creative teacher and what is a creative pupil? Perceptions of teachers. Procedia-Social and Behavioral Sciences, 12, 330-339.

Morse, J. M. (2003). Principles of mixed methods and multimethod research design. In Tashakkori, A. - Teddlie, C. (szerk.): Handbook of Mixed Methods in Social and Behavioral Research. (o. 189-208). Thousand Oaks: Sage Publications.

Morse, J. M. (2010). Simultaneous and sequential qualitative mixed method designs. Qualitative Inquiry, 16(6), 483-491.

Mortimore, P., Sammons, P., Stoll, L., \& Ecob, R. (1988). School matters. Univ of California Press.

Mumford, M. D. (2003). Where Have We Been, Where Are We Going? Taking Stock in Creativity Research. Creativity Research Journal, 15(2-3), 107-120. https://doi.org/10.1207/s15326934crj152\&3_01

Murphy, P. (2008). Defining pedagogy. Pedagogy and practice: Culture and identities, 2839. 
NACE. (2018). Job Outlook 2019. Elérés forrás

https://www.odu.edu/content/dam/odu/offices/cmc/docs/nace/2019-nace-job-outlooksurvey.pdf

Nagy-Czirok, L. (2017). A természettudományos gondolkodás fejlesztése projektekben. Új Pedagógiai Szemle, 67, 5-6.

Nagy, J. (2000). A kritikus kognitív készségek és képességek kritériumorientált fejlesztése. Új Pedagógiai Szemle, 50, 7-8.

Nagy, K. (2016). Az oktatás gazdasági értékei. Opus et Educatio, 3(3).

Nagy, L. (2010). A kutatásalapú tanulás/tanítás ('inquiry-based learning/teaching', IBL) és a természettudományok tanítása. Iskolakultúra, (12), 31-51.

Németh, A. (2002). A magyar neveléstudomány fejlödéstörténete: nemzetközi tudományfejlődési és recepciós hatások, egyetemi tudománnyá válás, középiskolai tanárképzés. Osiris.

Németh, A. (2013). A neveléstudomány főbb fejlődésmodelljei és tudományos irányzatai. Neveléstudomány: Oktatás Kutatás Innováció, 1(1), 18-63.

Neulinger, Á. (2016). Több-módszertanú és vegyes módszertanú kutatások. Vezetéstudomány-Budapest Management Review, 47(4), 63-66.

O'Connor, W. (2016). Generation Z: How this generation is different from Millennials (what parents need to know). Seattle, WA: Amazon Digital Services.

Oborni, K. (2017). Az interperszonális kapcsolatok szerepe az etnográfiai szervezeti kutatásokban-Egy résztvevői szervezeti kutatás tapasztalatai. Vezetéstudomány-Budapest Management Review, 48(4), 18-27.

OECD. (2019). PISA 2018 insights and interpretations. OECD Publishing, 64. Elérés forrás https://www.oecd.org/pisa/PISA 2018 Insights and Interpretations FINAL PDF.pdf

OECD, P. (2010). The high cost of low educational performance. The long run economic impact of improving PISA outcomes. Programme for International Student Assessment OECD.

Paek, S. H., \& Sumners, S. E. (2019). The indirect effect of teachers' creative mindsets on teaching creativity. The Journal of Creative Behavior, 53(3), 298-311.

Pais, E. R. (2013). Alapvetések a Z generáció tudománykommunikációjához. Foundations for the science communication of Generation Z). Project report. Pécs: University of Pécs.

Pajor, G. (2015). „, Gyorsabban, magasabbra, bátrabban”-de hogyan?: teljesitménymotiváció iskolai környezetben. ELTE Eötvös K.

Pál, E. (2013). A Z generációról... irodalmi áttekintés. Töröcsik M.(szerk): 
Tudománykommunikáció a Z generációnak. http://www. zgeneracio. hu/tanulmanyok,(letöltve: 2018.01. 04.).

Pap-Szigeti, R. (2007). Kooperatív módszerek alkalmazása a felsőoktatásban. Iskolakultúra, $17(1), 56-66$.

Papanek, V. (1971). Design for the real world. New York: Pantheon Books.

Papanek, V., \& Fuller, R. B. (1972). Design for the real world. Thames and Hudson London. Parapatits, Z. (2019). Fenntarthatóság digitális gazdasági és társadalmi környezetben. soe.

Pásztor-Kovács, A. (2015). Kollaboratív problémamegoldó képesség: egy új, integratív elméleti keret. Iskolakultúra, 25(2), 3-16.

Pásztor, A. (2014). Lehetőségek és kihívások a digitális játék alapú tanulásban: egy induktív gondolkodást fejlesztő program hatásvizsgálata. Magyar Pedagógia, 114(4), 281-302.

Pataki, G., \& Vári, A. (2011). Részvétel-akció-kutatás. Magyarországi tapasztalatok a részvételi-, akció-és kooperatív kutatásokból. Budapest: MTA Szociológiai Kutatóintézete.

Patnaik, D. (2009). Wired to care: How companies prosper when they create widespread empathy. Ft Press.

Patrick, B. C., Hisley, J., \& Kempler, T. (2000). “What's everybody so excited about?”: The effects of teacher enthusiasm on student intrinsic motivation and vitality. The Journal of Experimental Education, 68(3), 217-236.

Penuel, W. R., Turner, M. L., Jacobs, J. K., Van Horne, K., \& Sumner, T. (2019). Developing tasks to assess phenomenon-based science learning: Challenges and lessons learned from building proximal transfer tasks. Science Education, 103(6), 1367-1395. https://doi.org/10.1002/sce.21544

Perez, E., Haselberger, D., Oberhuemer, P., Cinque, M., \& Capasso, F. (2010). Mediating Soft Skills at Higher Education Institutions.

Pervez, G., \& Kjell, G. (2011). Kutatásmódszertan az üzleti tanulmányokban. Budapest: Akadémiai Kiadó.

Péter-Szarka, S. (2014). Kreatív klíma-A kreativitást támogató légkör megteremtésének iskolai lehetőségei. Géniusz Mühely sorozat, 3.

Péter-Szarka, S., Tímár, T., \& Balázs, K. (2015). Az iskolai kreatív klíma kérdőív. Alkalmazott Pszichológia, 15(2), 107-132. https://doi.org/10.17627/ALKPSZICH.2015.2.107

Petróczi, G. (2020). A módosított Nemzeti alaptanterv bevezetésével kapcsolatos szakmai teendők. Elérés forrás 
https://www.petroczigabor.hu/cikkek/igazgato_kollegaknak/modositott_nat_bevezetese. html

Petrone, P. (2019). The skills companies need most in 2019-and how to learn them. LinkedInThe Learning Blog, January, 2. Elérés forrás https://learning.linkedin.com/blog/topskills/the-skills-companies-need-most-in-2019--and-how-to-learn-them

Pletka, B. (2007). Educating the Net Generation: How to engage students in the 21 st century. Santa Monica Press.

Prensky, M. (2001). Digital natives, digital immigrants. On the horizon, 9(5).

Racskó, R. (2017). Digitális Atállás Az Oktatásban. Budapest: Gondolat Kiadó. https://doi.org/10.17717/IQKONYV.Racsko.2017

Radó, P. (2017). Az iskola jövője. Budapest: Noran Libro Kft.

Raelin, J. A. (2016). Imagine there are no leaders: Reframing leadership as collaborative agency. Leadership, 12(2), 131-158.

Reason, P., \& Bradbury, H. (2001). Handbook of action research: Participative inquiry and practice. Sage.

Reinke, S. J. (2001). Teachable moments: Teaching teamwork through research. Journal of Public Affairs Education, 7(3), 153-160.

Réti, M., \& Varga, A. (2008). Új tendenciák a fenntarthatóságra nevelésben. Avagy miért kellene egy tininek megmentenie a Földet. Új pedagógiai Szemle, 10, 17-42.

Rinaldi, A. (2009). Science wikinomics. EMBO reports, 10(5), 439-443. https://doi.org/10.1038/embor.2009.79

Ripple, R. E. (1989). Ordinary creativity. Contemporary educational psychology, 14(3), 189202.

Rizza, C., \& Varum, C. A. (2011). Directions in entrepreneurship education in Europe. $X X$ Jornadas de la Asociación de Economía de la Educación.

Robbins, T. L. (1994). Meaningfulness and community in the classroom: The role of teamwork in business education. Journal of Education for Business, 69(6), 312-316.

Roberts, R. D., Martin, J., \& Olaru, G. (2015). A Rosetta Stone for noncognitive skills: Understanding, assessing, and enhancing noncognitive skills in primary and secondary education. New York, NY: Asia Society and ProExam.

Rosenzweig, R. (2006). Can history be open source? Wikipedia and the future of the past. The journal of American history, 93(1), 117-146.

Rudnák, I., Komor, L., \& Józsa, I. (2015). „Multikulturális tréning” külföldi hallgatókat oktatók számára. Studia Mundi-Economica, 2(3), 138-148. 
Runco, M. A., \& Jaeger, G. J. (2012). The Standard Definition of Creativity. Creativity Research Journal, 24(1), 92-96. https://doi.org/10.1080/10400419.2012.650092

Ruth, R. (2008). Creativity in the everyday: Culture, self, and emotions. (R. Ruth, Szerk.), Everyday creativity and new views of human nature: Psychological, social, and spiritual perspectives. https://doi.org/10.1037/11595-013

Ruzsa, R. C. (2018). „Z” generáció fő jellemzői és a várható munkerő-piaci kihívások= Main characteristics of generation $\mathrm{Z}$ and the challenges to come in the labour market. KözépEurópai Közlemények, 11(3), 149-157.

Ryan, A. B. (2006). Post-positivist approaches to research. Researching and Writing your Thesis: a guide for postgraduate students, 12-26.

Ryan, M. P., \& Martens, G. G. (1989). Planning a College Course: A Guidebook for the Graduate Teaching Assistant. Eric.

Rychen, D. S., \& Salganik, L. H. (2000). Definition and selection of key competencies. THE INES COMPENDIUM ((Fourth General Assembly of the OCDE Education Indicators programmme). París: OCDE, 61-73.

S Gubik, A., \& Farkas, S. (2016). A karriermotívumok változásának hatásai a magyarországi hallgatók vállalkozásindítási elképzeléseinek alakulására. Vezetéstudomány-Budapest Management Review, 47(3), 46-55.

Sahlberg, P. (2009). The role of education in 22. promoting creativity: potential barriers and enabling factors. Measuring creativity, 337.

Sallay, H. (1995). Tanári szerepek percepciója: egy általános iskolai felmérés tanulságai. Magyar Pedagógia, 95, 3-4.

Saly, E. (2016). Ökoiskola mint pedagógiai innováció. Tanulmányok a pedagógiai innováció támogatásának lehetöségeiröl, 117.

Sántha, K. (2009). Bevezetés a kvalitatív pedagógiai kutatások gyakorlatába. Budapest, Eötvös Könyvkiadó.

Sántha, K. (2010). A trianguláció és az MTMM-mátrix kapcsolata a pedagógiai kutatásban. Iskolakultúra, 20(7-8), 54-62.

Sántha, K. (2015). Trianguláció a pedagógiai kutatásban. Eötvös József Könyvkiadó.

Sántha, K. (2017). A trianguláció-tipológiák és a MAXQDA kapcsolata a kvalitatív vizsgálatban. Vezetéstudomány-Budapest Management Review, 48(12), 33-40.

Savin-Baden, M. (2000). Problem-based learning in higher education: Untold stories: Untold stories. McGraw-Hill Education (UK).

Schleicher, N. (2007). Kvalitatív kutatási módszerek a társadalomtudományokban. Budapesti 
Kommunikációs és Üzleti Föiskola. Jegyzet.

Schroer, W. J. (2008). Generations X, Y, Z and the others. The Journal of the Household Goods Forwarders Association of America, Inc, 40, 9-11.

Schultz, T. W. (1963). The Economics Value of Education . New York and London. Columbia. University Press.

Schulz, B. (2008). The importance of soft skills: Education beyond academic knowledge.

Schutz, P. A., Chambless, C. B., \& DeCuir, J. T. (2004). Multimethods research. Foundations for research: Methods of inquiry in education and the social sciences, 267-281.

Schwandt, T. A. (1994). Constructivist, interpretivist approaches to human inquiry. Handbook of qualitative research, 1, 118-137.

Seemiller, C., \& Grace, M. (2017). Generation Z: Educating and Engaging the Next Generation of Students. About Campus, 22(3), 21-26. https://doi.org/10.1002/abc.21293

Seikkula-Leino, J. (2011). The implementation of entrepreneurship education through curriculum reform in Finnish comprehensive schools. Journal of Curriculum Studies, 43(1), 69-85. https://doi.org/10.1080/00220270903544685

Serfőző, M. (2005). Az iskola mint szervezet a pedagógusok véleményének tükrében. Magyar Pszichológiai Szemle, 60(1-2), 249-265.

Shatto, B., \& Erwin, K. (2016). Moving on From Millennials: Preparing for Generation Z. The Journal of Continuing Education in Nursing, 47(6), 253-254. https://doi.org/http://dx.doi.org/10.3928/00220124-20160518-05

Sin, C., \& Neave, G. (2016). Employability deconstructed: perceptions of Bologna stakeholders. Studies in Higher Education, 41(8), 1447-1462.

So, K., \& Kang, J. (2014). Curriculum Reform in Korea: Issues and Challenges for Twentyfirst Century Learning. Asia-Pacific Education Researcher, 23(4), 795-803. https://doi.org/10.1007/s40299-013-0161-2

Soland, J., Hamilton, L. S., \& Stecher, B. M. (2013). Measuring 21st century competencies: Guidance for educators.

Sowden, P. T., Pringle, A., \& Gabora, L. (2015). The shifting sands of creative thinking: Connections to dual-process theory. Thinking \& Reasoning, 21(1), 40-60. https://doi.org/10.1080/13546783.2014.885464

Stein, S. G. (2000). Equipped for the future content standards: What adults need to know and be able to do in the 21 st century. National Institute for Literacy.

Steinman, R. B. (2009). Projective techniques in consumer research. International Bulletin of Business Administration, 5(1), 37-45. 
Sternberg, R. J. (2006). The nature of creativity. Creativity research journal, 18(1), 87.

Stevenson, C. E., Kleibeuker, S. W., de Dreu, C. K. W., \& Crone, E. A. (2014). Training creative cognition: adolescence as a flexible period for improving creativity . Frontiers in Human Neuroscience . Elérés forrás https://www.frontiersin.org/article/10.3389/fnhum.2014.00827

Strauss, A., \& Corbin, J. (1994). Grounded theory methodology. Handbook of qualitative research (17. kiad.).

Succi, C., \& Canovi, M. (2020). Soft skills to enhance graduate employability: comparing students and employers' perceptions. Studies in Higher Education, 45(9), 1834-1847.

Sunarto, M. J. (2015). Improving Students Soft Skills Using Thinking Process Profile Based on Personality Types. International Journal of Evaluation and Research in Education, 4(3), 118-129.

Szabó-Szentgróti, G., Gelencsér, M., Szabó-Szentgróti, E., \& Berke, S. (2019). Generációs hatás a munkahelyi konfliktusokban. Vezetéstudomány-Budapest Management Review, 50(4), 77-88.

Szabó, C. M., \& Balázs, L. (2020). Pályakezdőkkel szemben támasztott vállalati elvárások vizsgálata a kimeneti kompetenciák tükrében. Journal of Applied Technical and Educational Sciences, 10(1), 3-18.

Szabó, É. (1999). A „kedves”, az „okos” és a „gonosz”, avagy a kedvelt és a nem kedvelt tanár képének jellemzői. Alkalmazott pszichológia, 1(1), 31-41.

Szarka, E. (é. n.). A kreatív gondolkodás helye és szerepe az óvodapedagógusi munkában.

Szebeni, R. (2010). A kompetencia alapú oktatás pedagógus személyiség háttere.

Székely, C. (2013). Innováció és kreativitás; Innovation and Creativity. Gazdaság és társadalom, 2013(4), 3-18.

Szücs, Z. (2018). Tanítási módszerek fontossága a diákok életében= The importance of teaching methods in the life of pupils. Paideia, 6(1), 215-228.

Takácsné Prof Dr György, K., \& Benedek, A. (2016). Bizalmon alapuló együttmüködés vizsgálata a kis-és középvállalatok körében. Tanulmánykötet-Vállalkozásfejlesztés a XXI. században VI., 379-390.

Tapscott, D., Williams, A. D., \& Garamvölgyi, A. (2007). Wikinómia: hogyan változtat meg mindent a tömeges együttmüködés. HVG.

Tari, A. (2011). Z generáció: klinikai pszichológiai jelenségek és társadalom-lélektani szempontok az információs korban. Tericum.

Tímár, É. (2006). Tantestületi légkörvizsgálat. Iskolakultúra, 16(3), 11-23. 
Torda, Á. (2000). Figyelemfejlesztö Program. Budapest.

Torgyik, J. (2004). Hatékony iskola: együttmüködő iskola. Új Pedagógiai Szemle, 10, 32-40.

Torrance, E. P. (1965). Rewarding Creative Behavior; Experiments in Classroom Creativity.

Torrance, E. P. (1974). Torrance tests of creative thinking: Directions guide and scoring manual. Lexington, MA: Personnel Press. Torrance, EP (1988). The nature of creativity as manifest in its testing. In RJ Sternberg (Ed.), The nature of creativity, 43-73.

Tosifescu, S. (2009). Minőség és kompetencia az oktatásban. Új Pedagógiai Szemle, 59(11), 29-34. Elérés forrás

http://epa.oszk.hu/00000/00035/00137/pdf/EPA00035_uj_pedagogiai_szemle_200911_b eliv.pdf

Tóth, P. (2015). A problémamegoldó gondolkodás fejlesztésének módszertana. Tóth Péter (szerk.): Mühelytanulmányok. BME GTK, Budapest.

Tóth, P. (2017). Tanulóközpontú tanulás és problémamegoldás: a probléma alapú tanulás. Tóth Péter-Hanczvikkel Adrienn-Duchon Jenö (szerk.): Tanulóközpontú oktatás, módszertani megújulás a szakképzésben és a felsőoktatásban. Óbudai Egyetem, Budapest, p79-97.

Törőcsik, M., Szűcs, K., \& Kehl, D. (2014). Generációs gondolkodás-AZ és az Y generáció életstílus csoportjai. Marketing \& Menedzsment, 48(Különszám2), 3-15.

Trencsényi, L. (2000). Elmélet, elméletek a művészetpedagógiákban. Trencsényi László (szerk.): Müvészetpedagógia-Elmélet, tanterv, módszer. Okker Kiadó, Budapest, 7-44.

Turkle, S. (2017). Alone together: Why we expect more from technology and less from each other. Hachette UK.

Turner, A. (2015). Generation Z: Technology and social interest. The journal of individual Psychology, 71(2), 103-113.

Uysal, S. D., \& Pohlmeier, W. (2011). Unemployment duration and personality. Journal of economic psychology, 32(6), 980-992.

Vámos, Á. (2013). A gyakorlat kutatása a neveléstudományban-az akciókutatás. Neveléstudomány: Oktatás-kutatás-innováció. 1. évf. 2. pp. 23, 42.

Van Maanen, J. (2011). Tales of the field: On writing ethnography. University of Chicago Press.

Varga, Aranka. (2015). Az inklúzió szemlélete és gyakorlata. PTE BTK NTI Romológia és Nevelésszociológia Tanszék.

Varga, Attila. (2018). A globális felelősségvállalásra nevelés a magyar iskolákban: keretek, lehetőségek és kihívások. 
Vargas, D. L., Bridgeman, A. M., Schmidt, D. R., Kohl, P. B., Wilcox, B. R., \& Carr, L. D. (2018). Correlation between student collaboration network centrality and academic performance. Physical Review Physics Education Research, 14(2), 20112.

Vastagh, Z. (1999). Kooperatív pedagógiai stratégiák az iskolában I-III. Pécs: JPTE.

Veres, G. (2016). Gondolkodás-és képességfejlesztés: Kihívások és megoldások a SAILS projektben. Iskolakultúra, 26(3), 43-56.

Vilmos, V. (2008). A Nemzeti alaptanterv implementációja.

Walia, C. (2019). A Dynamic Definition of Creativity. Creativity Research Journal, 31(3), 237-247. https://doi.org/10.1080/10400419.2019.1641787

Wey Smola, K., \& Sutton, C. D. (2002). Generational differences: Revisiting generational work values for the new millennium. Journal of Organizational Behavior: The International Journal of Industrial, Occupational and Organizational Psychology and Behavior, 23(4), 363-382.

Wilson, K. (2008). Entrepreneurship Education in Europe. Entrepreneurship and Higher Education, 1-20. Elérés forrás https://www.oecd.org/site/innovationstrategy/42961567.pdf

Wilson, V., Powney, J., Hall, S., \& Davidson, J. (2006). Who wants to be a teacher? The impact of age, disability, ethnicity, gender and sexual orientation on teachers'career aspirations. Scottish Educational Review, 38(1), 92.

Woods, P., \& Jeffrey, B. (1996). Teachable moments: The art of creative teaching in primary schools. Open University Press.

www.oktatas.hu. (é. n.). oktatas.hu. Elérés forrás https://www.oktatas.hu/

Yeo, J. W. (2008). Incorporating Thinking Tools to Enhance Facilitation of Problem-Based Learning.

Zemplén, G. (2006). A tudományos viták reprezentációja a tudományfilozófiában és a tudománytörténetben. Fehér-Zemplén-Binzberger (Szerk), 170-196.

Zétényi, Á. (1998). A hatékony tanár. Iskolakultúra, 10, 68-74.

Žogla, I. (2018). Science of Pedagogy: Theory of Educational Discipline and Practice. Journal of Teacher Education for Sustainability, 20(2), 31-43. https://doi.org/https://doi.org/10.2478/jtes-2018-0013

Zolnai, E., Balogh, E., Barnucz, N., Fónai, M., Hüse, L., Pornói, I., ... Nemes, M. (2016). Lehetőség, kihívás vagy akadály? A közoktatás integrációs feladatai-nemzetközi kitekintés és magyarországi helyzetkép. Különleges Bánásmód, II(2016/2), 5. https://doi.org/10.18458/KB.2016.2.5 
Zoltayné Paprika, Z., \& Nagy, V. (2013). A kreativitás megítélése a munkaerőpiacon (Creativity from view of job market). Vezetéstudomány-Budapest Management Review, 44(6), 2-13. 


\section{MELLÉKLET}

\section{A workshop lebonyolításának forgatókönyve}

1. A tréner bemutatkozik, ismerteti a kutatás célját, a kutatás és a workshop részletes menetét (5-7 perc)

2. Bemutatásra kerül a designkommunikáció módszertant ismertető, kifejezetten a workshopra készített a gyerekeket célzó prezentáció (25 perc)

3. Egyéni feladat ismertetése és megoldása ( 5 perc)

a. „Kérlek gondoljátok végig, hogy szerintetek mi az a legfontosabb probléma, ami a ti otthonotokat érinti, és amire szeretnétek megoldást találni"”

4. Véletlenszerüen 4-5 fős (az osztálylétszámtól függően) csoportba rendeződés (5 perc)

5. Csoportmunka (15-20 perc)

a. „A probléma most lehetöséggé válik. Beszéljétek meg az egyénileg kigondolt problémákat, és válasszatok ki egyet, aminek megoldásával az otthonotok jobbá tételére vállalkoztok. Tervezzétek meg, hogy hogyan történne a megvalósitás"

6. A csoportok egyesével ismertetik a megoldást (önálló szerveződés függvényében) (10 perc)

7. A közösség mindenki egyetértésével kiválasztja a legjobb megoldást és/vagy kialakít egy új legjobbnak vélt megoldást az ötletekből. (15 perc)

a. „Feladatotok, hogy az itt meghallgatott lehetöségekböl kiválasztjátok azt az egyet, amivel jobbá tehetnétek ti magatok az otthonotokat. Fontos, hogy a közösségnek egyöntetüen egyet kell értenie a döntéssel."

8. Megtörténik az ötlet megvalósításának irányába tett gyakorlati kivitelezés (30 perc)

9. A diákok összegzik és bemutatják eredményüket a trénernek, elkészül a megoldás vizualizációja is a produktum részeként (15 perc)

10. A workshop utolsó lépéseként a diákok az „Emlékkönyvbe” összegzik tapasztalataikat. (10 perc)

a. Kérlek írjatok az emlékkönyvembe. Szeretném, ha öszintén leírnátok, hogy hogy éreztétek magatokat. Mi az, ami tetszett, és mi az, ami nem. Írjátok le a saját szerepeteket, mit adtatok ti hozzá a létrejött megoldáshoz.

b. Szeretném, ha leírnátok, hogy a bemutatott designkommunikáció, ha ember lenne akkor milyen ember lenne. Mindent írjatok le, ami csak eszetekbe jut. Részletesen jellemezzétek öt, és a hozzá füzödő kapcsolatotokat.

c. Kérlek rajzoljátok le a kreativitást! 


\section{Pedagógus mélyinterjú kérdések}

\section{Jelen, Személyes kompetenciákra irányuló kérdések}

1. Kérem mutassa be magát, mint pedagógust, az iskolában betöltött helyét, legfontosabb szakmai kompetenciáit!

2. Milyen tanárként jellemezné önmagát a gyerekek nézőpontjából? Milyen jellegü visszajelzéseket kap a diákoktól?

\section{Osztály és Közösség}

3. Milyen a kapcsolata az osztállyal?

4. Milyen különbség van az átlagos és a kreatív tervezői kapcsolatteremtés között?

5. Milyen törekvések vannak arra vonatkozóan, hogy megfelelö közösség formálódjon az osztályban? Ön személy szerint mit tesz ezért?

6. Van hatása (és ha igen, akkor miben) a jó/rossz osztályközösségnek a tanulmányi eredményre?

7. Összességében hogyan jellemezné a jelenleg fennálló osztályközösséget? Milyen erösségek és gyengeségek lelhetők fel?

8. Van csoportmunka az iskolai keretek között? Ha igen, akkor ez milyen formában realizálódik? Kérem említsen konkrét megvalósult példákat is amennyiben voltak.

9. A tanórán a diákok kifejezik önmagukat? Vállalják véleményüket?

\section{A vágyott oktatási intézmény}

10. Hogyan jellemezne egy ön szerint jól müködő iskolát?

11. Kérem írja le, hogy milyen egy Ön szerint ideálisnak vélt diák/pedagógus!

12. Ismeri az új NAT törekvéseit? Ön szerint ez mennyiben járulhat hozzá az idealizált iskola megvalósításához?

\section{Kreativitás}

13. Ön szerint melyik állat lenne a legjobb pedagógus?

14. Ön szerint milyen lenne a kreativitás, ha a meglévő állatok közül kellene azonosítani őt?

15. Kérem, hogy azonosítsa, és mutassa be részletesen, hogy ha a kreativitás egy elképzelt állat lenne, akkor milyen lenne ő? Minél pontosabb leírást adjon róla!

16. Kérem, hogy rajzolja le, vizualizálja, hogy hogyan lehet bevinni a gyakorlatban az osztályterem falain belülre a kreativitásra nevelést?

17. Mit jelent az Ön számára a kreativitás? Hogyan definiálná a kreativitás fogalmát?

18. Miért lehet fontos a kreativitás az oktatásban? Miben van szerepe? 


\section{A workshop során bemutatott designkommunikáció prezentáció}

\section{D王SCO}

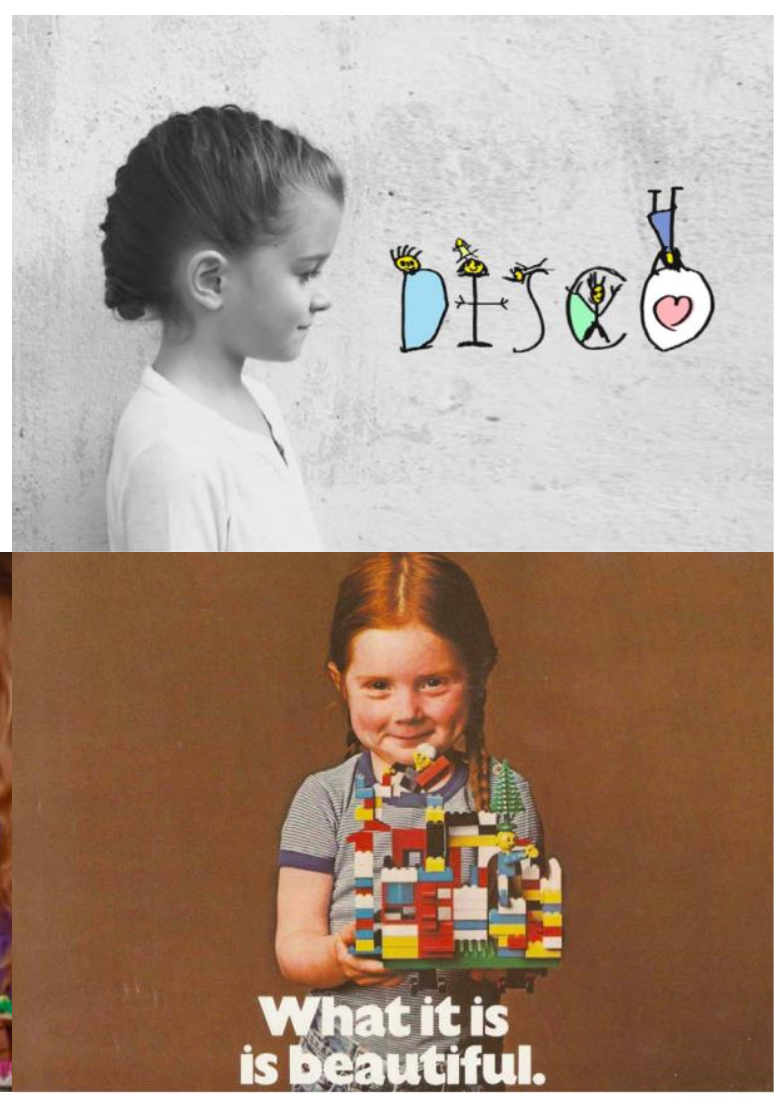

PROBLÉMAMEGOLDÁS

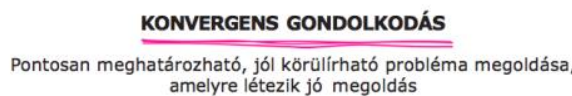

DIVERGENS GONDOLKODÁS Olyan folyamat, amely olyan problémára keresi a legjobb âst, amire nem is biztos, hogy van jó megoldás. Nem csak a megoldast, de a hozza vezető utat is fel kell találni.
PROBLÉMAMEGOLDÁS ÖSSZETEVŐI

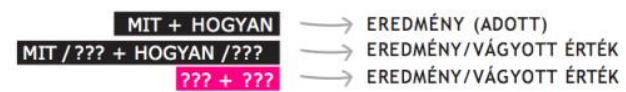

D王CO SZEMLÉLET

Nyilt problémamegoldó helyzetek megértését és megoldását támogatja,
ahol nem állnak rendelkezésre kész módszereḱk és nincsenek viszonytás pontok.

Adott helyzetben eredmény és módszer egymásból következik,

fejlesztésbe integrált kommunikáció valósul meg

miaza D王CO?

design $=$ tervezés, alkotás

kommunikáció $=$ kapcsolatteremtés

nem minden ember designer (?), de minden ember

képes (kreatív) kapcsolatteremtésre

D王CO SZEMLÉLET 


\author{
DESIGN = JÓT CSINÁLNI \\ KOMMUNIKÁCIÓ = JÓTMONDANI
}

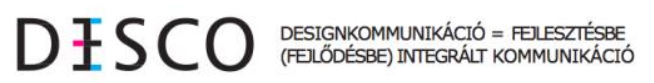

a megfelelö viszonyrendszerben felállitott kérdésfelvetésre a megfelelö viszonyrendszerben felállított kérdésfelvetésre
és mindenki számára elérhető empátára épitő szemlélet
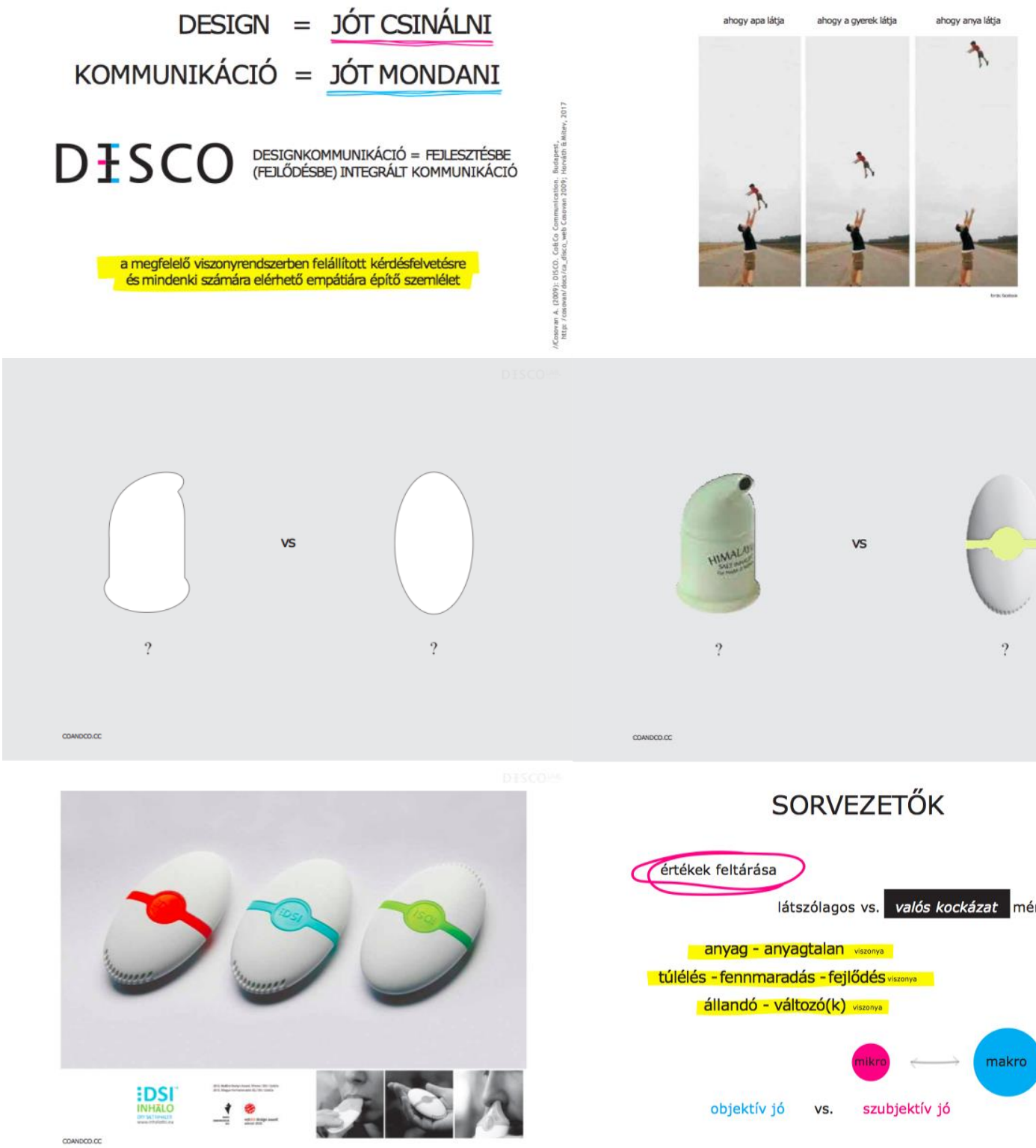

vs

\section{SORVEZETŐK}

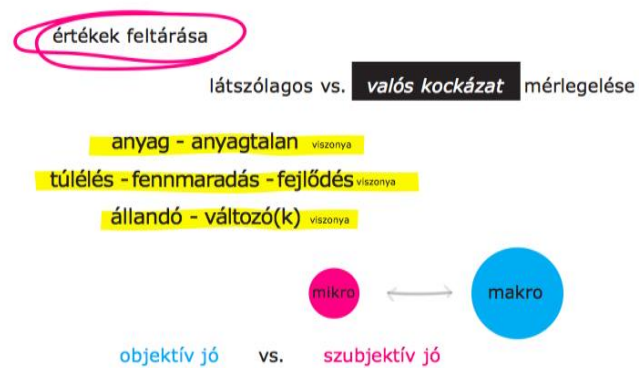

DISCO

köszönjük a figyelmet! 


\section{Hozzájáruló nyilatkozat diákoknak}

Alulírott (születési neve: születési helye, ideje: , anyja neve: szulletesi helye, szóló 2013. évi V. törvény $2: 14$. § (1) bekezdésének ${ }^{1}$, valamint a 2:48. $\S^{2}$ rendelkezéseinek megfelelően, törvényes képviselőként jelen nyilatkozattal egyértelmúen és kifejezetten hozzájárulok, hogy gyermekemről (születési neve: (*), születési helye, ideje: ${ }^{*}$ ), anyja neve: (*)) az alábbi helyen és időben, a Budapesti Corvinus Egyetem szervezésében, a Gazdálkodás Tudományi Kar, Marketing-, Média- és Designkommunikáció Tanszék PHD hallgatója (Horváth Daniella Dominika) által végzett oktatásmódszertani kutatásában részt vegyen valamint a kutatás keretében képmás, hang- és videofelvétel készüljön.

A felvétel készítésének helye: (*) A felvétel készítésének ideje: $\left(^{*}\right)$

Hozzájárulok ahhoz, hogy a gyermekemről készült kép- és videofelvételeket a Budapesti Corvinus Egyetem felhasználja, így különösen, azokat közösségi oldalakon közzé tegye, kisfilm/video anyag készítése során felhasználja.

Megértettem az arra vonatkozó tájékoztatást, hogy a felvételek felhasználásának célja kutatás elemzése, értékelése, az oktatásmódszertani eszköz népszerüsítése, design- és oktatásmódszertan tudományos eredményeinek szélesítése.

Az Európai Parlament és a Tanács (EU) 2016/679 rendelete (a továbbiakban: GDPR) 6. cikk (1) bekezdés a) pontja ${ }^{3}$ alapján kijelentem, hogy a fényképek elkészítéséhez és felhasználásához kapcsolódó adatvédelmi tájékoztató tartalmát teljeskörüen megismertem, hozzájárulok az adatoknak az adatvédelmi tájékoztatóban foglaltak szerinti kezeléséhez.

Tudomásul veszem, hogy hozzájárulásomat bármikor visszavonhatom. A hozzájárulás visszavonása nem érinti a hozzájáruláson alapuló, visszavonás előtti adatkezelés jogszerüségét.

$(*)$

Budapest, 2019. (*) (*)

1 2:14. § (1) A cselekvőképtelen kiskorú jognyilatkozata semmis; nevében a törvényes képviselője jár el.

2 2:48. § (1) Képmás vagy hangfelvétel elkészítéséhez és felhasználásához az érintett személy hozzájárulása szükséges.

3 6. cikk 1) A személyes adatok kezelése kizárólag akkor és annyiban jogszerü, amennyiben legalább az alábbiak egyike teljesül: a) az érintett hozzájárulását adta személyes adatainak egy vagy több konkrét célból történő kezeléséhez. 


\section{Hozzájáruló nyilatkozat pedagógusoknak}

Alulírott (születési neve: , születési helye, ideje: , anyja neve: ) a Polgári Törvénykönyvről szóló 2013. évi V. törvény 2:48. $\S^{1}$ rendelkezésének megfelelően, jelen nyilatkozattal egyértelmúen és kifejezetten hozzájárulok, hogy az alábbi helyen és időben a Budapesti Corvinus Egyetem Gazdálkodás Tudományi Kar szervezésében, a Gazdálkodás Tudományi Kar, Marketing-, Média- és Designkommunikáció Tanszék PHD hallgatója (Horváth Daniella Dominika) által végzett oktatásmódszertani kutatásában rólam képmás és hangfelvétel készüljön.

A felvétel készítésének helye: (*) A felvétel készítésének ideje: (*)

Hozzájárulok ahhoz, hogy rólam készült kép- és videofelvételeket a Budapesti Corvinus Egyetem felhasználja, így különösen, azokat közösségi oldalakon közzé tegye, kisfilm/video anyag készítése során felhasználja.

Megértettem az arra vonatkozó tájékoztatást, hogy a felvételek felhasználásának célja az oktatásmódszertani eszköz népszerüsítése, design- és oktatásmódszertan tudományos eredményeinek szélesítése.

Az Európai Parlament és a Tanács (EU) 2016/679 rendelete (a továbbiakban: GDPR) 6. cikk (1) bekezdés a) pontja ${ }^{2}$ alapján kijelentem, hogy a fényképek elkészítéséhez és felhasználásához kapcsolódó adatvédelmi tájékoztató tartalmát teljeskörüen megismertem, hozzájárulok az adatoknak az adatvédelmi tájékoztatóban foglaltak szerinti kezeléséhez.

Tudomásul veszem, hogy hozzájárulásomat bármikor visszavonhatom. A hozzájárulás visszavonása nem érinti a hozzájáruláson alapuló, visszavonás előtti adatkezelés jogszerüségé.

$(*)$

1 2:48. § (1) Képmás vagy hangfelvétel elkészítéséhez és felhasználásához az érintett személy hozzájárulása szükséges.

2 6. cikk 1) A személyes adatok kezelése kizárólag akkor és annyiban jogszerű, amennyiben legalább az alábbiak egyike teljesül: a) az érintett hozzájárulását adta személyes adatainak egy vagy több konkrét célból történő kezeléséhez. 


\section{A SZERZŐ TÉMÁBAN MEGJELENT PUBLIKÁCIÓI}

\section{Folyóirat cikk:}

1. Horváth, D. D., \& Horváth, D. (2020). Fenntartható jövő tervezésére vállalkoztunk Egy diákok körében végzett, több módszertanú kvalitatív kutatás eredményei a fenntartható fejlödés pedagógiájának nézőpontjából. Kovász, 24, 19.

2. Horváth, D. D., Csordás, T., Horváth, D., \& Cosovan, A. (2020). Úgy, mint a nagyok! Kreatív workshop általános iskolásoknak. Iskolakultúra, 30(4-5), 49-66.

3. Horváth, D. D., \& Bereczky, R. (2020). Gyerekkorban kreatív csoportmunka, felnőttkorban versenyelőny?! A közép-dunántúli régióban megvalósított akciókutatás eredményének bemutatása. Magyar Tudomány, 181 (9), 1216-1227.

4. Horváth, D. D., Mitev, A. Z., \& Korcsmáros, E. (2019). A vállalati innováció dimenzióinak feltárása az értékesítő nézőpontjából. Vezetéstudomány-Budapest Management Review, 50 (10), 26-38.

5. Horváth, D., Cosovan, A., Horváth, D., \& Lachin, N. (2018). Tanulás-munka interface. A valós idejü találkozások jelentősége a digitális oktatási környezetben. Vezetéstudomány-Budapest Management Review, 49(12), 67-77.

6. Horváth, D. D., \& Horváth, D. (2021). Tervező diákok, oktatás, designkommunkáció és egy akciókutatás fenntartható eredménye. Marketing és menedzsment, Tervezett megjelenés: 2021

\section{Előadás és/vagy konferenciakiadványban megjelenő írás:}

\section{Magyar nyelvü}

7. Horváth, D. D. (2020). Akciókutatás az általános iskolában, középpontban a legkisebbek - Egy saját fejlesztésü designkommunikáció workshop eredményeinek ismertetése In: Ercsey, Ida (szerk.) Marketing a digitalizáció korában: Az Egyesület a Marketing Oktatásért és Kutatásért XXVI. Országos konferenciájának előadásai, Győr, Magyarország: Széchenyi István Egyetem, 603-610.

8. Horváth, D. D., \& Horváth, D. (2020). Tervező diákok, oktatás, designkommunikáció és egy akciókutatás fenntartható eredménye, In: Ercsey, Ida (szerk.) Marketing a digitalizáció korában: Az Egyesület a Marketing Oktatásért és Kutatásért XXVI. 
Országos konferenciájának elöadásai, Győr, Magyarország: Széchenyi István Egyetem, 573-581.

9. Horváth, D. D. (2020). Designkommunikáció a határon túl - a csoportmunka, a közös alkotás aktualitása általános iskolás gyerekek körében végzett akciókutatás alapján, In: Horváth, Bálint; Kápolnai, Zsombor; Földi, Péter (szerk.) Közgazdász Doktoranduszok és Kutatók VI. Nemzetközi Téli Konferenciája: Konferenciakötet, Budapest, Magyarország: Doktoranduszok Országos Szövetsége (DOSZ) (2020) 373, 138-147.

10. Horváth, D. D., \& Horváth, D. (2019). Design, kommunikáció, oktatás és gyerekek. Egy akciókutatás bemutatása, fókuszban a Közép-Dunántúli régió, In: Dorkota, Lajos; Matolcsi, Renáta, IV. East-West Cohesion International Scientific Conference: Abstract volume of an international scientific conference, 17-17.

11. Horváth, D. D. (2020). Legyél Te is tervező: Egy általános iskolásokat célzó kreatív oktatásmódszertani eszköz bemutatása, In: Tóth, Alisa - Hankó, Csilla; Sebestyén, Edmond (szerk.), VI. Ifjú Pszichológiai és Neveléstudományi Kutatók Országos Konferenciája ((IPSZILON) - Program és összefoglalók / VI. National Conference of Young Psychological and Pedagogical Researchers - Book of Abstracts, Budapest, Magyarország : Doktoranduszok Országos Szövetsége (DOSZ), 50

12. Horváth, D. D. (2020). Offline kreativitás vs. netgeneráció. Egy innovatív oktatásmódszertani eszköz bemutatása In: Veszelszki, Ágnes; Falyuna, Nóra (szerk.) Tudománykommunikáció 2.0.: Absztraktkötet, Budapest, Magyarország: Budapesti Corvinus Egyetem, 25

13. Horváth, D. D., Cosovan, A., Csordás, T., Horváth, D., \& Mitev, A. (2019). Vállalkozásra fel, gyerekek! - A vállalkozói attitűd fejlesztési lehetőségei gyerekkorban a designkommunikáció módszertanának alkalmazásával, In: Köszegi, Irén Rita (szerk.), III. Gazdálkodás és Menedzsment Tudományos Konferencia: Versenyképesség és innováció, Kecskemét, Magyarország: Neumann János Egyetem Kertészeti és Vidékfejlesztési Kar, 415-421.

14. Horváth, D. D., Horváth, D., Csordás, T., \& Cosovan, A. (2019). Hierarchiamentes övezet az általános iskolában- bemutatkozik a designkommunikáció, mint kreatív oktatásmódszertani eszköz, In: Veres, Zoltán; Sasné, Grósz Annamária; Liska, Fanny (szerk.), Ismerjük a vevőt?: A vásárlás pszichológiája : Az Egyesület $a$ Marketingoktatásért és Kutatásért XXV. Országos konferenciájának elöadásai Veszprém, Magyarország : Pannon Egyetem, 721-729. 
15. Horváth, D. D., \& Horváth, D. (2019). Akik a tervezői csoportot alkotják: Z generáció és a pedagógusk, Hierarchiamentes csoportmunka, mint oktatásmódszertani eszköz az általános iskolában, In: Karlovitz, János Tibor (szerk.) VII. IRI Társadalomtudományi Konferencia, Komárno, Szlovákia: International Research Institute s.r.o., 23.

16. Horváth, D. D., \& Horváth, D. (2019). Akik a tervezői csoportot alkotják, a Z generáció és a pedagógusok: Hierarchiamentes csoportmunka, mint oktatásmódszertani eszköz az általános iskolában In: Karlovitz, János Tibor (szerk.) Tanulmányok a kompetenciákra épülő, fenntartható kulturális és technológiai fejlödés köréböl, Komárno, Szlovákia: International Research Institute s.r.o., 333-342.

17. Horváth, D. D., Korcsmáros, E., \& Mitev, A. Z. (2018). Az innováció értelmezése és dimenziói az értékesítők nézőpontjából, In: Józsa, László; Korcsmáros, Enikő; Seres, Huszárik Erika (szerk.), A hatékony marketing: EMOK 2018 Nemzetközi Tudományos Konferencia konferenciakötete, Komárno, Szlovákia: Selye János Egyetem, 816-827.

18. Horváth, D. D., Horváth, D., Csordás, T., Cosovan, A., \& Mitev, A. (2018). Vállalkozásra fel, Gyerekek! - A vállalkozói attitüd fejlesztési lehetőségei gyermekkorban a designkommunikáció módszertanának alkalmazásával (2018), konferenciaelőadás, III. Gazdálkodás és Menedzsment Tudományos Konferencia, „Versenyképesség és Innováció”, 2018. szeptember 27-28. Kecskemét

19. Horváth, D. D., Horváth, D., Csordás, T., Cosovan, A., \& Mitev, A. (2018). Formabontó oktatás formális keretek között - Lehetőségek a designkommunikáció és a wikinómikus együttműködés találkozásában In: Kanczné, Nagy Katalin; Tóth-Bakos, Anita (szerk.) A Selye János Egyetem 2018-as X. Nemzetközi Tudományos Konferenciájának tanulmánykötete: TANTÁRGYPEDAGÓGIAI SZEKCIÓ, Komárno, Szlovákia: Janos Selye University, 45-54.

20. Cosovan, A., Csordás, T., Horváth, D. D., Horváth, D., \& Mitev, A. (2018). Tervezői helyzetek jelentősége a vezetőképzésben: designkommunikáció és / vagy design thinking, In: Józsa, László; Korcsmáros, Enikő; Seres, Huszárik Erika (szerk.), A hatékony marketing: EMOK 2018 Nemzetközi Tudományos Konferencia konferenciakötete, Komárno, Szlovákia: Selye János Egyetem, 902-914.

\section{Idegen nyelvü}

21. Horváth, D., Cosovan, A., Csordás, T., Horváth, D. D., \& Mitev, A. (2018). Marketing as Designing: Design Methods in Marketing Education - Introduction to 
DesignCommunication, In: Jaromil, Antal; Petr, Král (szerk.), Marketing Challenges, Innovations and Trends in Emerging Markets, 9th EMAC Regional Conference, 12th14th September, 2018, Prague, Czechia Prague, Csehország: University of Economics in Prague, 7.

22. Horváth, D., Cosovan, A., Csordás, T., Horváth, D., \& Mitev, A. Z. (2018). Beyond the Scope of Design thinking: DesignCommunication (pp. 653-662). Design, Management Institute (DMI) (szerk.) The 21st dmi: Academic Design Management Conference

\section{Könyvfejezet, könyvrészlet:}

23. Horváth, D. D. (2018). Design és Oktatás: Egy kreatívan irányított kapcsolatteremtés, In: Csordás, Tamás; Varga, Ákos (szerk.), MMDC terelő: Tanulmányok a marketing-, média- és designkommunikáció területéröl, Budapest, Magyarország: Budapesti Corvinus Egyetem, 113-120.

\section{Egyéb közérdekü publikáció:}

24. Horváth, D. D. (2017). Terméktervezésbe kódolt a hatékony PR, ORIGO.HU: (április 2) Paper: online 